Prepared in cooperation with the U.S. Environmental Protection Agency

\title{
Microphotographs of Cyanobacteria Documenting the Effects of Various Cell-lysis Techniques
}

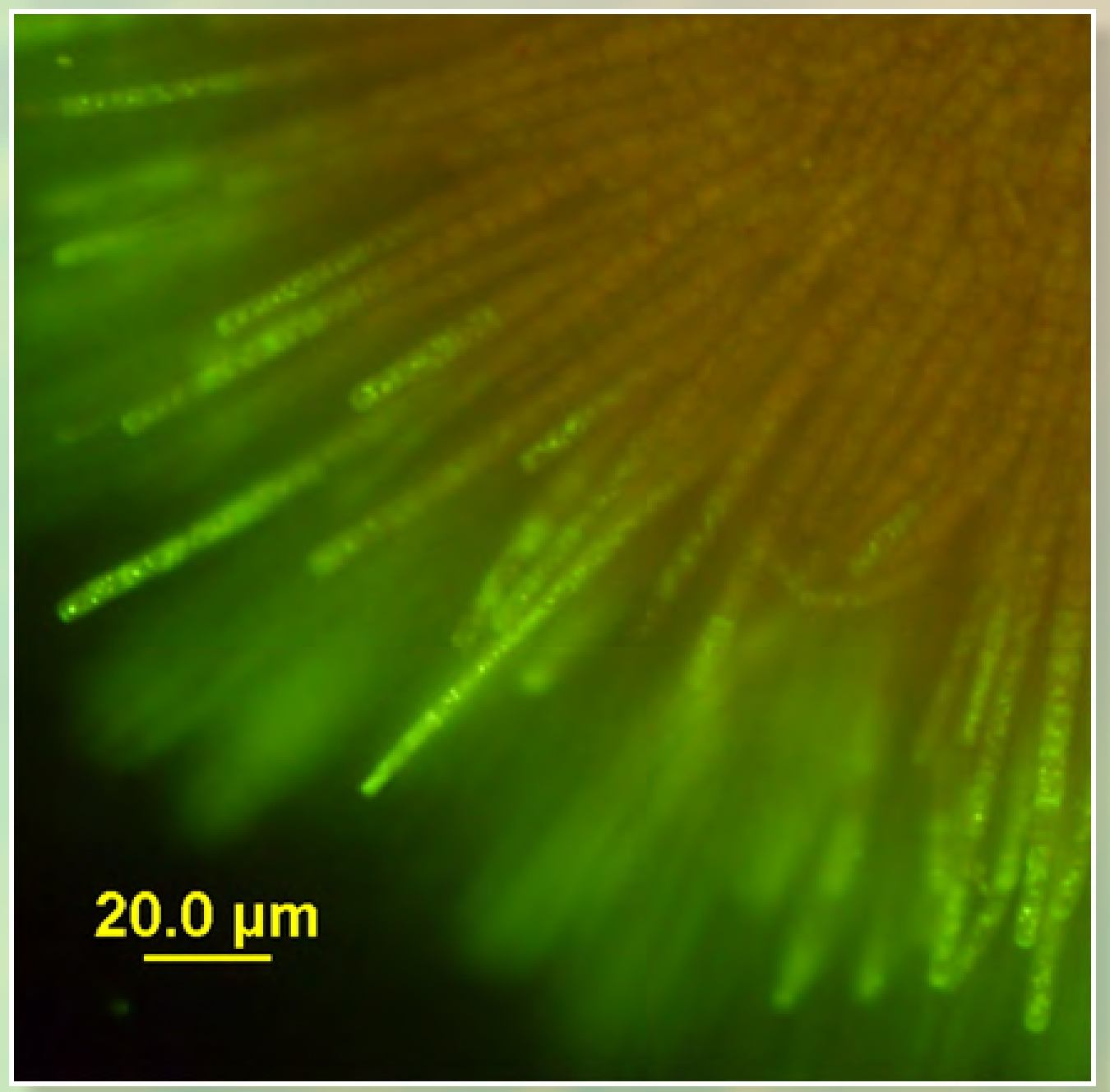

Open-File Report 2010-1289 
Cover: Microphotograph from Upper Klamath Lake, Oregon showing Gloeotrichia echinulata. 


\section{Microphotographs of Cyanobacteria Documenting the Effects of Various Cell-lysis Techniques}

By Barry H. Rosen, Keith A. Loftin, Christopher E. Smith, Rachael F. Lane, and Susan P. Keydel

Prepared in cooperation with the U.S. Environmental Protection Agency

Open-File Report 2010-1289

U.S. Department of the Interior

U.S. Geological Survey 


\section{U.S. Department of the Interior \\ KEN SALAZAR, Secretary}

\section{U.S. Geological Survey \\ Marcia K. McNutt, Director}

\section{U.S. Geological Survey, Reston, Virginia: 2011}

For more information on the USGS - the Federal source for science about the Earth, its natural and living resources, natural hazards, and the environment, visit http://www.usgs.gov or call 1-888-ASK-USGS

For an overview of USGS information products, including maps, imagery, and publications, visit http://www.usgs.gov/pubprod

Any use of trade, product, or firm names is for descriptive purposes only and does not imply endorsement by the U.S. Government.

Although this report is in the public domain, permission must be secured from the individual copyright owners to reproduce any copyrighted materials contained within this report.

Suggested citation:

Rosen, B.H., Loftin, K.A., Smith, C.E., Lane, R.F., and Keydel, S.P., 2010, Microphotographs of cyanobacteria documenting the effects of various cell-lysis techniques: U.S. Geological Survey Open-File Report, 2010-1289, 203 p. 


\section{Contents}

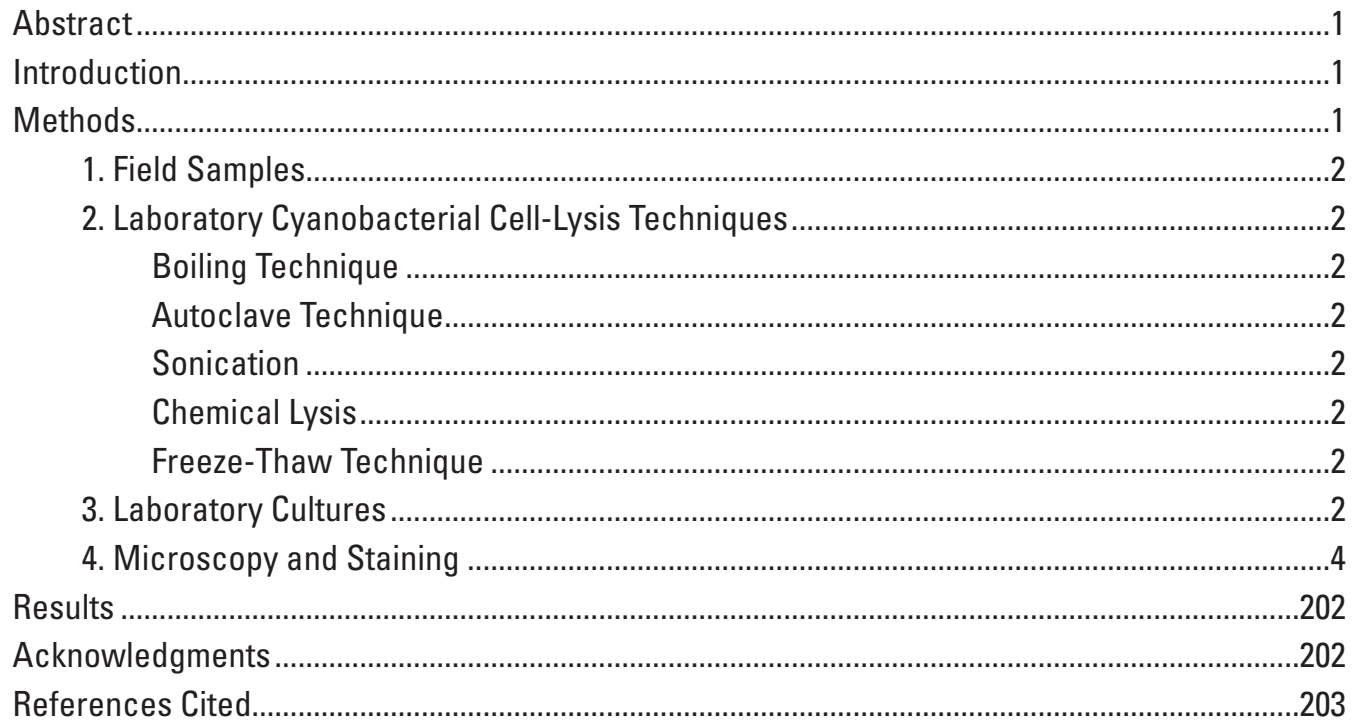

\section{Figures}

1. Microphotograph from Cassidy Lake, WA (10/12/2009). LM-Woronichinia naegeliana, a colonial cyanobacterium with cells in a gelatinous matrix (synonym Coelosphaerium). FITC-a dull reddish color dominates the cells. The scattered bright red cells are eukaryotic algal epiphytes. Syto ${ }^{\circledR}$ greenstain did not penetrate the cell membrane

2. Microphotograph from Cassidy Lake, WA (10/12/2009). LM-Woronichinia naegeliana, cells in a gelatinous matrix. FITC-a yellow-orange color dominates the cells. Sytox ${ }^{\circledR}$ green-stain did not penetrate the cell membrane.....

3. Microphotograph from Cassidy Lake, WA (10/12/2009). LM-Woronichinia naegeliana, cells in a gelatinous matrix. FITC-a yellow-orange color dominates the cells. Sytox ${ }^{\circledR}$ green-stain did not penetrate the cell membrane.

4. Microphotograph from Cassidy Lake, WA (10/12/2009). LM-Likely the remains of a Woronichinia naegeliana colony, with only scattered cells and no colonies. FITC-a yellow color dominates the cells; cell shape distorted because of long photographic exposure time. Syto ${ }^{\circledR}$ green-stain penetrated cell membranes; bright green cells.

5. Microphotograph from Cassidy Lake, WA (10/12/2009). LM-Likely the remains of a Woronichinia naegeliana colony, with only scattered cells and no colonies. FITC-a yellow-orange color dominates the cells; cell shape distorted because of long photographic exposure time. Sytox ${ }^{\circledR}$ green-stain penetrated cell membranes; bright green cells.

6. Microphotograph from Cassidy Lake, WA (10/12/2009). LM-Likely the remains of a degraded colony of Microcystis aeruginosa. FITC-a yellow color dominates the cells of the Microcystis sp.; red cells are likely eukaryotic algae. Sytox ${ }^{\circledR}$ green-stain did not penetrate the cell membrane.... 
7. Microphotograph from Cassidy Lake, WA (10/12/2009). LM-Likely the remains of a Microcystis sp. FITC-a yellow-orange color dominates the cells. Sytox ${ }^{\circledR}$ green-stain did not penetrate the cell membrane

8. Microphotograph from Cassidy Lake, WA (10/12/2009). LM-Likely the remains of a colonial cyanobacterium. FITC-a yellow-orange color dominates the cells. Syto ${ }^{\circledR}$ green-stain did not penetrate the cell membrane

9. Microphotograph from Cassidy Lake, WA (10/12/2009). LM-Likely the remains of a colonial cyanobacterium. FITC-a yellow-orange color dominates the cells. Sytox ${ }^{\circledR}$ green-stain penetrated cell membranes; bright green cells

10. Microphotograph from Cassidy Lake, WA (10/12/2009). LM-A colonial cyanobacterium. FITC-unknown organism; the cells were bright red. Sytox ${ }^{\circledR}$ green-unknown organisms; a single cell was observed and it was intact; stain did not penetrate the cell membrane

11. Microphotograph from Cassidy Lake, WA (10/12/2009). LM-The remains of a colonial cyanobacterium. FITC-a red-orange color dominates the cells. Sytox ${ }^{\circledR}$ green-stain did not penetrated cell membranes of the cyanobacteria.

12. Microphotograph from Cassidy Lake, WA (10/12/2009). LM-The remains of a colonial cyanobacterium. FITC-an orange color dominates the cells. Sytox ${ }^{\circledR}$ green-stain did not penetrate cell membranes of the cyanobacteria.

13. Microphotograph from Cassidy Lake, WA (10/12/2009). LM-The remains of colonial cyanobacteria. FITC-no image or data collected. Sytox ${ }^{\circledR}$ green-stain penetrated the cell membrane of this unknown organism; bright green cell.

14. Microphotograph from Cassidy Lake, WA (10/12/2009). LM-The remains of a colonial cyanobacterium; note, the mucilage that supports the cell remains. FITC-a red-orange color dominates the cells; cell shape distorted because of long photographic exposure time. Sytox ${ }^{\circledR}$ green-stain penetrated the cell membrane of this unknown organism; bright green cell

15. Microphotograph from Spring Lake, CA (8/21/2009). LM-Microcystis aeruginosa colonial cyanobacterium with cells in a gelatinous matrix. FITC-a reddish-orange color dominates the cells. The scattered bright red cells are eukaryotic algal epiphytes. Sytox ${ }^{\circledR}$ green-Woronichinia naegeliana, stain did not penetrate the cell membrane.

16. Microphotograph from Spring Lake, CA (8/21/2009). LM-Microcystis aeruginosa. The same colony was used for all three images. FITC-a yellow color dominates the cells. Syto ${ }^{\circledR}$ green-stain did not penetrate the cell membrane.

17. Microphotograph from Spring Lake, CA (8/21/2009). LM-Woronichinia naegeliana. FITC-a yellow color dominates the cells. Sytox ${ }^{\circledR}$ green- stain did not penetrate the cell membrane.

18. Microphotograph from Spring Lake, CA (8/21/2009). LM-The remains of colonial cyanobacteria; note, the mucilage that supports the cells remains. FITC-a yellow-orange color dominates the cells. Sytox ${ }^{\circledR}$ green-nothing detectable....

19. Microphotograph from Spring Lake, CA (8/21/2009). LM-The remains of a colonial cyanobacterium. FITC-an orange color dominates the cells. Sytox ${ }^{\circledR}$ green-stain penetrated the cell membrane of this unknown organism; bright green cell

20. Microphotograph from Spring Lake, CA (8/21/2009). LM-The remains of a colonial cyanobacterium. FITC-an orange color dominates the cells. Sytox ${ }^{\circledR}$ green-stain penetrated the cell membrane of this unknown organism; bright green cell 
21. Microphotograph from Spring Lake, CA (8/21/2009). LM-The remains of a colonial cyanobacterium. FITC-an orange color dominates the cells. Sytox ${ }^{\circledR}$ green-stain penetrated the cell membrane of this unknown organism; bright green cell

22. Microphotograph from Spring Lake, CA (8/21/2009). LM-The remains of a colonial cyanobacterium. FITC-a yellow-orange color dominates the cells. Sytox ${ }^{\circledR}$ green-stain penetrated the cell membrane of this unknown organism; bright green cell

23. Microphotograph from Spring Lake, CA (8/21/2009). LM-The remains of a colonial cyanobacterium. FITC-a yellow color dominates the cells. Sytox ${ }^{\circledR}$ greenstain penetrated cell membrane of this unknown organism; bright green cell

24. Microphotograph from Spring Lake, CA (8/21/2009). LM-Woronichinia sp., cells in a gelatinous matrix. FITC-an orange color dominates the cells. Sytox ${ }^{\circledR}$ green-stain did not penetrate the cell membrane

25. Microphotograph from Spring Lake, CA (8/21/2009). LM-Likely the remains of Woronichinia sp. FITC-an orange color dominates the cells. Syto ${ }^{\circledR}$ greenstain did not penetrate the cell membranes of the cyanobacteria

26. Microphotograph from Spring Lake, CA (8/21/2009). LM-The remains of a colonial cyanobacterium. FITC-an orange color dominates the cells. Sytox ${ }^{\circledR}$ green-stain did not penetrate the cell membranes of the cyanobacteria

27. Microphotograph from Spring Lake, CA (8/21/2009). LM-The remains of a colonial cyanobacterium. FITC-a yellow color dominates the cells. Sytox ${ }^{\circledR}$ green-stain penetrated the cell membranes; bright green cells.

28. Microphotograph from Spring Lake, CA (8/21/2009). LM-Microcystis wesenbergii, a colonial cyanobacterium. FITC-a yellow color dominates the cells. Sytox ${ }^{\circledR}$ green-stain did not penetrate the cell membranes of the cyanobacteria

29. Microphotograph from Spring Lake, CA (8/21/2009). LM-The remains of a colonial cyanobacterium; the mucilage that supports the cells remains. FITC-a yellow color dominates the cells. Sytox ${ }^{\circledR}$ green-stain did not penetrate the cell membranes of the cyanobacteria, but did stain the bacteria associated with the mucilage

30. Microphotograph from Spring Lake, CA (8/21/2009). LM-The remains of a colonial cyanobacterium; the mucilage that supports the cells remains. FITC-a red color dominates the cells. Sytox ${ }^{\circledR}$ green-stain did not penetrate the cell membranes of the cyanobacteria, but did stain the bacteria associated with the mucilage.

31. Microphotograph from Spring Lake, CA (8/21/2009). LM-The remains of a colonial cyanobacterium. FITC-an orange color dominates the cells. Sytox ${ }^{\circledR}$ green-stain did not penetrate the cell membranes of the cyanobacterium

32. Microphotograph from Blackhawk Lake, IA (8/26/2009). LM-Planktothrix sp., cells in a filament. FITC-an orange color dominates the cells. Sytox ${ }^{\circledR}$ greenstain did not penetrate the cell membrane

33. Microphotograph from Blackhawk Lake, IA (8/26/2009). LM-Planktothrix sp.

FITC-an orange color dominates the cells. Sytox ${ }^{\circledR}$ green-no images obtained

34. Microphotograph from Blackhawk Lake, IA (8/26/2009). LM-Planktothrix sp.

FITC-an orange color dominates the cells. Sytox ${ }^{\circledast}$ green-stain did not penetrate the cell membrane

35. Microphotograph from Blackhawk Lake, IA (8/26/2009). LM-Planktothrix sp.

FITC-an orange color dominates the cells. Sytox ${ }^{\circledR}$ green-stain did not penetrate the cell membrane 
36. Microphotograph from Blackhawk Lake, IA (8/26/2009). LM-Planktothrix sp. FITCan orange color dominates the cells. Sytox ${ }^{\circledR}$ green-stain did not penetrate the cell membrane.

37. Microphotograph from Blackhawk Lake, IA (8/26/2009). LM-Planktothrix sp. FITCan orange color dominates the cells. Sytox ${ }^{\circledR}$ green-stain did penetrate the cell membrane; cells bright green.

38. Microphotograph from Blackhawk Lake, IA (8/26/2009). LM-Planktothrix sp. FITCan orange color dominates the cells. Sytox ${ }^{\circledR}$ green-stain did not penetrate the cell membrane.....

39. Microphotograph from Blackhawk Lake, IA (8/26/2009). LM-Cyanobacterial filamentous. FITC-a yellow-orange color dominates the cells. Sytox ${ }^{\circledR}$ green-stain did penetrate the cell membranes in some of the cells in the filaments.

40. Microphotograph from Blackhawk Lake, IA (8/26/2009). LM-Planktothrix sp. FITCan orange color dominates the cells. Sytox ${ }^{\circledast}$ green-stain did not penetrate the cell membrane.

41. Microphotograph from Blackhawk Lake, IA (8/26/2009). LM-Remains of Planktothrix sp. FITC-an orange-yellow color dominates the cells. Syto ${ }^{\circledR}$ greenstain did not penetrate the cell membrane

42. Microphotograph from Blackhawk Lake, IA (8/26/2009). LM-Remains of unknown organism; no other material observed. FITC-nothing distinguishable as cells. Syto ${ }^{\circledR}$ green-no images obtained

43. Microphotograph from Blackhawk Lake, IA (8/26/2009). LM-Planktothrix sp. FITCan orange color dominates the cells. Sytox ${ }^{\circledR}$ green-stain did penetrate the cell membrane; cells bright green.

44. Microphotograph from Blackhawk Lake, IA (8/26/2009). LM-Planktothrix sp. FITCan orange color dominates the cells. Syto ${ }^{\circledR}$ green-stain did not penetrate the cell membrane, except end cell

45. Microphotograph from Blackhawk Lake, IA (8/26/2009). LM-Remains of a colonial cyanobacterium, likely Microcystis. FITC-a yellow color dominates the cells. Sytox ${ }^{\circledR}$ green-stain did not penetrate the cell membrane

46. Microphotograph from Blackhawk Lake, IA (8/26/2009). LM-Microcystis sp. FITC-a yellow color dominates the cells. Syto ${ }^{\circledR}$ green-stain did not penetrate the cell membrane.

47. Microphotograph from Copco Reservoir, CA (9/10/2009). LM-Microcystis aeruginosa. FITC-an orange color dominates the cells. Sytox ${ }^{\circledR}$ green-stain did penetrate the cell membrane in some of the peripheral cells

48. Microphotograph from Copco Reservoir, CA (9/10/2009). LM-Microcystis aeruginosa. FITC-an orange-red color dominates the cells. Sytox ${ }^{\circledR}$ green-stain did not penetrate the cell membrane

49. Microphotograph from Copco Reservoir, CA (9/10/2009). LM-Microcystis wesenbergii. FITC-an orange-red color dominates the cells. Sytox ${ }^{\circledR}$ green-stain did not penetrate the cell membrane of the cyanobacteria; epiphytic bacteria did stain bright green

50. Microphotograph from Copco Reservoir, CA (9/10/2009). LM-Microcystis wesenbergii. FITC-a yellow color dominates the cells. Syto ${ }^{\circledR}$ green-stain did not penetrate the cell membrane of the cyanobacteria; outer mucilage did stain bright green. 
51. Microphotograph from Copco Reservoir, CA (9/10/2009). LM-Microcystis

wesenbergii. FITC-a yellow color dominates the cells. Syto ${ }^{\circledR}$ green-stain did

not penetrate the cell membrane of the cyanobacteria; outer mucilage did stain

bright green

52. Microphotograph from Copco Reservoir, CA (9/10/2009). LM-Microcystis

wesenbergii. FITC-a yellow color dominates the cells. Sytox ${ }^{\circledR}$ green-stain did

not penetrate the cell membrane of the cyanobacteria; outer mucilage did stain

bright green

53. Microphotograph from Copco Reservoir, CA (9/10/2009). LM-Miscellaneous cyanobacterial filaments and ekaryotic algae. FITC-a yellow-orange color dominates the cells. Sytox ${ }^{\circledR}$ green-stain did penetrate the cell membrane of some of the colonial cyanobacterial cells, but not the unknown cyanobacterial filaments

54. Microphotograph from Copco Reservoir, CA (9/10/2009). LM-Microcystis

aeruginosa. FITC-a red color dominates the cells. Sytox ${ }^{\circledast}$ green-stain did not penetrate the cell membrane .

55. Microphotograph from Copco Reservoir, CA (9/10/2009). LM-Microcystis aeruginosa. FITC-a red color dominates the cells. Sytox ${ }^{\circledast}$ green-stain did not penetrate the cell membrane of the cyanobacteria; epiphytes associated with the outer mucilage did stain bright green

56. Microphotograph from Copco Reservoir, CA (9/10/2009). LM-Microcystis aeruginosa. FITC-an orange color dominates the cells. Sytox ${ }^{\circledR}$ green-stain did not penetrate the cell membrane of the cyanobacteria; outer mucilage and the associated bacterial cells did stain bright green

57. Microphotograph from Copco Reservoir, CA (9/10/2009). LM-Microcystis aeruginosa. FITC-an orange color dominates the cells. Sytox ${ }^{\circledR}$ green-stain did not penetrate the cell membrane of the cyanobacteria; outer mucilage and the associated bacterial cells did stain bright green

58. Microphotograph from Copco Reservoir, CA (9/10/2009). LM-Microcystis aeruginosa. FITC-an orange color dominates the cells. Sytox ${ }^{\circledR}$ green-stain did not penetrate the cell membrane.

59. Microphotograph from Copco Reservoir, CA. LM-Microcystis aeruginosa. FITCMicrocystis aeruginosa-an orange color dominates the cells. Syto ${ }^{\circledR}$ greenMicrocystis wesenbergii. Stain did not penetrate the cell membrane of the cyanobacteria; the associated bacterial cells did stain bright green

60. Microphotograph from Copco Reservoir, CA (9/10/2009). LM-Degraded Microcystis aeruginosa. FITC-a yellow-orange color dominates the cells. Sytox ${ }^{\circledR}$ green-stain did not penetrate the cell membrane of the cyanobacteria.

61. Microphotograph from Grand Lake (Lake St. Mary), OH (7/20/2009). LM-

Planktothrix sp. FITC-an orange color dominates the cells. Sytox ${ }^{\circledR}$ green-stain did not penetrate the cell membrane.

62. Microphotograph from Grand Lake (Lake St. Mary), $\mathrm{OH}$ (7/20/2009). LM-

Planktothrix sp. FITC-an orange color dominates the cells. Sytox ${ }^{\circledR}$ green-stain did not penetrate the cell membrane

63. Microphotograph from Grand Lake (Lake St. Mary), OH (7/20/2009). LM-

Planktothrix sp. FITC-an orange color dominates the cells. Syto ${ }^{\circledast}$ green-stain did not penetrate the cell membrane 
64. Microphotograph from Grand Lake (Lake St. Mary), OH (7/20/2009). LM-

Planktothrix sp. FITC-an orange color dominates the cells. Sytox ${ }^{\circledR}$ green-stain did not penetrate the cell membrane

65. Microphotograph from Grand Lake (Lake St. Mary), $\mathrm{OH}$ (7/20/2009). LM-

Planktothrix sp. FITC-an orange color dominates the cells. Sytox ${ }^{\circledR}$ green-stain did not penetrate the cell membrane

66. Microphotograph from Grand Lake (Lake St. Mary), OH (7/20/2009). LM-

Planktothrix sp. FITC-an orange color dominates the cells. Sytox ${ }^{\circledR}$ green-stain did penetrate the cell membrane, cells bright green

67. Microphotograph from Grand Lake (Lake St. Mary), $\mathrm{OH}$ (7/20/2009). LM-

Planktothrix sp. FITC-an orange color dominates the cells. Sytox ${ }^{\circledR}$ green-stain did penetrate the cell membrane, cells yellow-green.

68. Microphotograph from Grand Lake (Lake St. Mary), $\mathrm{OH}$ (7/20/2009). LMPlanktothrix sp. FITC-an orange color dominates the cells. Sytox ${ }^{\circledR}$ green-stain did penetrate the cell membrane, cells yellow-green.

69. Microphotograph from Grand Lake (Lake St. Mary), $\mathrm{OH}$ (7/20/2009). LM-No image available. FITC-Planktothrix sp.; an orange color dominates the cells. Sytox ${ }^{\circledR}$ green-stain did not penetrate the cell membrane

70. Microphotograph from Grand Lake (Lake St. Mary), OH (7/20/2009). LMPlanktothrix sp. FITC-a red color dominates the cells. Sytox ${ }^{\circledR}$ green-stain did not penetrate the cell membrane.

71. Microphotograph from Grand Lake (Lake St. Mary), OH (7/20/2009). LMFragments of Planktothrix sp. FITC-a red color dominates the cells. Sytox ${ }^{\circledR}$ green-stain did not penetrate the cell membrane

72. Microphotograph from Grand Lake (Lake St. Mary), $\mathrm{OH}$ (7/20/2009). LMNothing recognizable as cells is present

73. Microphotograph from Grand Lake (Lake St. Mary), $\mathrm{OH}$ (7/20/2009). LM-

Planktothrix sp. FITC-an orange-yellow color dominates the cells. Sytox ${ }^{\circledR}$ green-stain did penetrate the cell membrane, cells bright green.

74. Microphotograph from Grand Lake (Lake St. Mary), OH (7/20/2009). LM-

Planktothrix sp. FITC-red dominates the cells; this image is blurred because of the long exposure time. Syto ${ }^{\circledR}$ green-unknown cyanobacterial filament (too thin to be the previous Planktothrix) stain did penetrate the cell membrane, cells bright green

75. Microphotograph from Grand Lake (Lake St. Mary), $\mathrm{OH}$ (7/20/2009). LM-

Planktothrix sp. FITC-an orange color dominates the cells; this image is blurred because of the long exposure time. Sytox ${ }^{\circledR}$ green-too little material to describe effect.

76. Microphotograph from Grand Lake (Lake St. Mary), $\mathrm{OH}$ (7/20/2009). LMLikely the remains of a cyanobacterial colony. FITC-an orange color dominates the few cells present. Sytox ${ }^{\circledR}$ green-too little material to describe effect

77. Microphotograph from Grand Lake (Lake St. Mary), $\mathrm{OH}$ (7/20/2009). LM-

Planktothrix sp. FITC-an orange color dominates the cells; this image is blurred because of the long exposure time. Sytox ${ }^{\circledR}$ green-unknown cyanobacterial colony; stain did not penetrate the majority of the cells in the colony

78. Microphotograph from Grand Lake (Lake St. Mary), $\mathrm{OH}$ (9/15/2009). LM-

Planktothrix sp. FITC-an orange color dominates the cells. Sytox ${ }^{\circledR}$ green-stain did not penetrate the cell membrane 
79. Microphotograph from Grand Lake (Lake St. Mary), OH (9/15/2009). LM-

Planktothrix sp. FITC-an orange color dominates the cells. Sytox ${ }^{\circledR}$ green-stain did not penetrate the cell membrane

80. Microphotograph from Grand Lake (Lake St. Mary), OH (9/15/2009). LM-

Planktothrix sp. FITC-an orange color dominates the cells. Sytox ${ }^{\circledR}$ green-stain did not penetrate the cell membrane

81. Microphotograph from Grand Lake (Lake St. Mary), $\mathrm{OH}$ (9/15/2009). LM-

Planktothrix sp. FITC-an orange color dominates the cells. Sytox ${ }^{\circledR}$ green-stain did penetrate the cell membrane, cells bright green

82. Microphotograph from Grand Lake (Lake St. Mary), $\mathrm{OH}$ (9/15/2009). LM-

Planktothrix sp. FITC-an orange color dominates the cells. Sytox ${ }^{\circledR}$ green-stain did not penetrate the cell membrane

83. Microphotograph from Grand Lake (Lake St. Mary), OH (9/15/2009). LM-

Planktothrix sp. FITC-an orange color dominates the cells. Sytox ${ }^{\circledR}$ green-stain did not penetrate the cell membrane

84. Microphotograph from Grand Lake (Lake St. Mary), $\mathrm{OH}$ (9/15/2009). LM-

Planktothrix sp. FITC-an orange color dominates the cells. Sytox ${ }^{\circledR}$ green-stain did not penetrate the cell membrane

85. Microphotograph from Grand Lake (Lake St. Mary), OH (9/15/2009). LM-A

mixture of cyanobacterial filaments and eukaryotic cells. FITC-an orange color dominates the cells. Sytox ${ }^{\circledR}$ green-stain did penetrate the cell membrane of the uppermost filament in this image.

86. Microphotograph from Grand Lake (Lake St. Mary), OH (9/15/2009). LM-

Planktothrix sp. FITC-a yellow color dominates the cells. Syto ${ }^{\circledR}$ green-stain did penetrate the cell membrane, cells bright green

87. Microphotograph from Grand Lake (Lake St. Mary), $\mathrm{OH}$ (9/15/2009). LM-

Planktothrix sp. FITC-an orange color dominates the cells. Sytox ${ }^{\circledR}$ green-stain did not penetrate the cell membrane

88. Microphotograph from Grand Lake (Lake St. Mary), OH (9/15/2009). LM-

Unknown fragment. FITC-a red color dominates this cell fragment. Syto ${ }^{\circledR}$

green-stain did not penetrate the cell membrane of this Planktothrix filament

89. Microphotograph from Grand Lake (Lake St. Mary), OH (9/15/2009). LM-

Planktothrix sp. FITC-an orange color dominates the cells. Sytox ${ }^{\circledR}$ green-stain

did not penetrate the cell membrane

90. Microphotograph from Grand Lake (Lake St. Mary), OH (9/15/2009). LM-

Unknown cyanobacterial colony fragment. FITC-an orange color dominates

this cell. Sytox ${ }^{\circledR}$ green-stain did not stain the cyanobacterial material; only the eukaryotic cells

91. Microphotograph from Grand Lake (Lake St. Mary), OH (9/15/2009). LM-

Possible unknown cyanobacterial colony fragment. A nematode is evident in this sample (arrow). FITC-an orange color dominates this cell; the bright red cells are diatoms. Sytox ${ }^{\circledR}$ green-stain did not stain the cyanobacterial material; only the bacterial cells

92. Microphotograph from Grand Lake (Lake St. Mary), OH (9/15/2009). LM-

Possible unknown cyanobacterial colony fragment. FITC-an orange color

dominates these cells. Sytox ${ }^{\circledR}$ green-too little material to determine the effect

93. Microphotograph from St. John's River, Jacksonville, FL (7/28/2009). LM-

Microcystis aeruginosa. The small filaments (arrow) are likely the endogloeic cyanobacteria, Pseudoanabaena mucicola (Hindák, 2006). FITC-an orange-red color dominates the cells. Sytox ${ }^{\circledR}$ green-stain did not penetrate the cell membrane. 
94. Microphotograph from St. John's River, Jacksonville, FL (7/28/2009). LM-

Microcystis aeruginosa. Eukaryotic epiphytes are green (arrow). FITC-a red color dominates the cyanobacterial cells. Sytox ${ }^{\circledast}$ green-stain did not penetrate the cell membrane

95. Microphotograph from St. John's River, Jacksonville, FL (7/28/2009). LM-

Microcystis aeruginosa. FITC-a red color dominates the cells. Sytox ${ }^{\circledR}$ green-stain did not penetrate the cell membrane; some of the cyanobacterial epiphytes stained bright green.

96. Microphotograph from St. John's River, Jacksonville, FL (7/28/2009). LM-

Microcystis aeruginosa. FITC-an orange color dominates the cells. Sytox ${ }^{\circledR}$ green-stain did penetrate the cell membrane; bright green cells.

97. Microphotograph from St. John's River, Jacksonville, FL (7/28/2009). LM-

Microcystis aeruginosa. FITC-an orange color dominates the cells. Sytox ${ }^{\circledR}$ green-stain did penetrate the cell membrane; bright green cells.

98. Microphotograph from St. John's River, Jacksonville, FL (7/28/2009). LMLikely the remains of a Microcystis aeruginosa colony. FITC-an orange color dominates the cells. Sytox ${ }^{\circledR}$ green-stain did penetrate the cell membrane; bright green cells

99. Microphotograph from St. John's River, Jacksonville, FL (7/28/2009). LMLikely the remains of a Microcystis aeruginosa colony. FITC-an orange color dominates the cells. Sytox ${ }^{\circledR}$ green-stain did penetrate the cell membrane; bright green cells

100. Microphotograph from St. John's River, Jacksonville, FL (7/28/2009). LMMicrocystis aeruginosa. FITC-a yellow color dominates the cells. Sytox ${ }^{\circledR}$ green-stain did penetrate the cell membrane; bright green cells.

101. Microphotograph from St. John's River, Jacksonville, FL (7/28/2009). LMMicrocystis aeruginosa. FITC-a red color dominates the cells. Sytox ${ }^{\circledR}$ green-stain did not penetrate the cell membrane; epiphytic bacteria bright green

102. Microphotograph from St. John's River, Jacksonville, FL (7/28/2009). LMMicrocystis aeruginosa. FITC-an orange color dominates the cells. Sytox ${ }^{\circledR}$ green-stain did not penetrate the cell membrane; epiphytic bacteria bright green.

103. Microphotograph from St. John's River, Jacksonville, FL (7/28/2009). LMLikely the remains of a Microcystis aeruginosa colony. FITC-an orange color dominates, but cells cannot be distinguished. Syto ${ }^{\circledR}$ green-slight evidence of sheath being stained.

104. Microphotograph from St. John's River, Jacksonville, FL (7/28/2009). LMMicrocystis aeruginosa. FITC-a red color dominates the cells. Syto ${ }^{\circledR}$ greenstain did not penetrate the cell membrane

105. Microphotograph from St. John's River, Jacksonville, FL (7/28/2009). LMMicrocystis aeruginosa. FITC-a red color dominates the cells. Syto ${ }^{\circledR}$ greenstain did penetrate the cell membrane in some of the peripheral cells.

106. Microphotograph from St. John's River, Jacksonville, FL (7/28/2009). LMMicrocystis aeruginosa. FITC-a yellow color dominates the cells. Sytox ${ }^{\circledR}$ greenstain did penetrate the cell membrane in some of the peripheral cells.

107. Microphotograph from St. John's River, Jacksonville, FL (7/28/2009). LMMicrocystis aeruginosa. FITC-a yellow-orange color dominates the cells. Sytox ${ }^{\circledR}$ green-stain did penetrate the cell membrane in some of the peripheral cells. 
108. Microphotograph from St. John's River, Jacksonville, FL (7/28/2009). LM-

Microcystis aeruginosa. FITC-a yellow color dominates the cells. Sytox ${ }^{\circledR}$ green-no image available.

109. Microphotograph from Upper Klamath Lake, OR (8/21/2009). LM-Aphanizomenon flos-aquae filaments. FITC-a yellow-orange color dominates these cells. Sytox ${ }^{\circledR}$ green-no image available.

110. Microphotograph from Upper Klamath Lake, OR (8/21/2009). LM-Aphanizomenon flos-aquae bundle of filaments. FITC-a red-orange color dominates these cells. Sytox ${ }^{\circledast}$ green-stain did not penetrate the cell membrane; sheath and epiphytes stained bright yellow-green.

111. Microphotograph from Upper Klamath Lake, OR (8/21/2009). LM-Aphanizomenon flos-aquae bundle of filaments that appear degraded compared to Control 2. FITC-a red color dominates these cells. Sytox ${ }^{\circledR}$ green-stain did penetrate the cell membrane of some cells; stained bright yellow-green.

112. Microphotograph from Upper Klamath Lake, OR (8/21/2009). LM-Microcystis aeruginosa. FITC-an orange color dominates the cells. Sytox ${ }^{\circledR}$ green- stain did not penetrate the cell membrane of the cyanobacteria; the sheath and epiphytic bacteria (green spots) stained bright green

113. Microphotograph from Upper Klamath Lake, OR (8/21/2009). LM-Gloeotrichia echinulata, a large (note scale bar), colony-forming filamentous cyanobacteria. FITC-an orange color dominates the cells. Syto ${ }^{\circledR}$ green-stained the peripheral filaments, but did not penetrate to the center of this large colony.

114. Microphotograph from Upper Klamath Lake, OR (8/21/2009). LM-No image available. FITC-Gloeotrichia echinulata-an orange color dominates the cells. Syto ${ }^{\circledast}$ green-stained the tips of the filaments, but did not penetrate to the center of the colony

115. Microphotograph from Upper Klamath Lake, OR (8/21/2009). LM-Unknown filamentous cyanobacteria. FITC-no image available. Sytox ${ }^{\circledR}$ green-likely Aphanizomenon flos-aquae filament; stain did penetrate the cell membrane; cells bright green.

116. Microphotograph from Upper Klamath Lake, OR (8/21/2009). LM-Likely Aphanizomenon flos-aquae filament. FITC-an orange color dominates the cells. Sytox ${ }^{\circledR}$ green-stain did penetrate the cell membrane, cells bright green

117. Microphotograph from Upper Klamath Lake, OR (8/21/2009). LM-Gloeotrichia echinulata. FITC-a yellow color dominates the cells. Sytox ${ }^{\circledR}$ green-stained the peripheral filaments, but did not penetrate to the center of this large colony.

118. Microphotograph from Upper Klamath Lake, OR (8/21/2009). Gloeotrichia echinulata. Syto ${ }^{\circledR}$ green-stained the peripheral filaments, but did not penetrate to the center of this large colony.

119. Microphotograph from Upper Klamath Lake, OR (8/21/2009). LM-Gloeotrichia echinulata. FITC-a yellow color dominates the cells. Sytox ${ }^{\circledR}$ green-stained the tips of the filaments, but did not penetrate to the center of this large colony.

120. Microphotograph from Upper Klamath Lake, OR (8/21/2009). LM-Microcystis aeruginosa. FITC-a red color dominates the cells. Sytox ${ }^{\circledast}$ green-stain did not penetrate the cell membrane; green cells were epiphytes attached to the colony .....125

121. Microphotograph from Upper Klamath Lake, OR (8/21/2009). LM-single cell present. FITC and Sytox ${ }^{\circledR}$ green-no data

122. Microphotograph from Upper Klamath Lake, OR (8/21/2009). LM-Aphanizomenon

flos-aquae bundle of filaments. FITC-an orange color dominates these cells. Sytox ${ }^{\circledast}$ green-stain did not penetrate the cell membrane of the main bundle of organisms; a few filaments on the edge stained bright yellow-green .. 
123. Microphotograph from Upper Klamath Lake, OR (8/21/2009). LM-Likely a small fragment of Aphanizomenon flos-aquae. FITC and Sytox ${ }^{\circledR}$ green-no data ..

124. Microphotograph from Upper Klamath Lake, OR (8/21/2009). LM-Microcystis aeruginosa. FITC-a yellow color dominates the cells. Sytox ${ }^{\circledR}$ green-stain did penetrate the cell membrane; cells were bright green.

125. Microphotograph from Klamath River, OR (8/21/2009) (only freeze-thaw material). LM-Microcystis aeruginosa. FITC-a yellow color dominates the cells. Sytox ${ }^{\circledR}$ green-stain did not penetrate the cell membrane

126. Microphotograph from Klamath River, OR (8/21/2009). LM-Microcystis aeruginosa. FITC-a yellow color dominates the cells. Syto ${ }^{\circledR}$ green-stain did not penetrate the cell membrane.

127. Microphotograph from Klamath River, OR (8/21/2009). LM-Microcystis aeruginosa. FITC-a yellow color dominates the cells. Sytox ${ }^{\circledR}$ green-stain did not penetrate the cell membrane of most cells in the colony; some peripheral cells appear bright green

128. Microphotograph from Iron Gate Reservoir, OR (8/25/2009). LM-Microcystis aeruginosa. The small filaments (arrow) are likely the endogloeic cyanobacteria, Pseudoanabaena mucicola (Hindák, 2006). FITC-a red color dominates the cells. Sytox ${ }^{\circledR}$ green-stain did not penetrate the cell membrane

129. Microphotograph from Iron Gate Reservoir, OR (8/25/2009). LM-Microcystis aeruginosa. FITC-a red color dominates the cells. Sytox ${ }^{\circledR}$ green-stain did not penetrate the cell membrane

130. Microphotograph from Iron Gate Reservoir, OR (8/25/2009). LM-Microcystis aeruginosa. FITC-an orange color dominates the cells. Sytox ${ }^{\circledR}$ green-stain did penetrate the cell membrane; cells bright green.

131. Microphotograph from Iron Gate Reservoir, OR (8/25/2009). LM-Possible remains of Microcystis aeruginosa. FITC-an orange color dominates the cells. Sytox ${ }^{\circledast}$ green-stain did penetrate the cell membrane; cell bright green

132. Microphotograph from Iron Gate Reservoir, OR (8/25/2009). LM-Possible remains of Microcystis aeruginosa. FITC-an orange-yellow color dominates the cells. Syto ${ }^{\circledR}$ green-stain did penetrate the cell membrane; cells bright green.

133. Microphotograph from Iron Gate Reservoir, OR (8/25/2009). LM-Possible remains of Microcystis aeruginosa. FITC-an orange-yellow color dominates the cells. Sytox ${ }^{\circledR}$ green-stain did penetrate the cell membrane; cell bright green ..

134. Microphotograph from Iron Gate Reservoir, OR (8/25/2009). LM-Possible remains of Microcystis aeruginosa. FITC-no cyanobacteria cells. Sytox ${ }^{\circledR}$ green-no cyanobacteria cells.

135. Microphotograph from Iron Gate Reservoir, OR (8/25/2009). LM-Possible remains of Microcystis aeruginosa. FITC-an orange-yellow color dominates the cells. Sytox ${ }^{\circledR}$ green-stain did penetrate the cell membrane; cells bright green

136. Microphotograph from Iron Gate Reservoir, OR (8/25/2009). LM-Microcystis aeruginosa. FITC-a red color dominates the cells; orange filaments are cyanobacterial epiphyte. Sytox ${ }^{\circledR}$ green-stain did penetrate the cell membrane; some cells bright green

137. Microphotograph from Iron Gate Reservoir, OR (8/25/2009). LM-Microcystis aeruginosa. FITC-a red color dominates the cells; orange filaments are cyanobacterial epiphyte. Sytox ${ }^{\circledR}$ green-stain did penetrate the cell membrane of the peripheral cells; cells bright green. 
138. Microphotograph from Iron Gate Reservoir, OR (8/25/2009). LM-Microcystis aeruginosa. FITC-a red color dominates the cells; yellow-orange filaments are cyanobacterial epiphyte. Syto ${ }^{\circledast}$ green-stain did penetrate the cell membrane of the peripheral cells and epiphytic bacterial cells that are bright green

139. Microphotograph from Iron Gate Reservoir, OR (8/25/2009). LM-Unknown filamentous cyanobacterium. FITC-an orange color dominates the cells. Sytox ${ }^{\circledR}$ green-cannot be determined...

140. Microphotograph from Iron Gate Reservoir, OR (8/25/2009). LM-Microcystis aeruginosa. FITC-a yellow color dominates the cells. Syto ${ }^{\circledR}$ green-stain did penetrate the cell membrane; cells yellow-green

141. Microphotograph from Iron Gate Reservoir, OR (8/25/2009). LM-Microcystis aeruginosa. FITC-a yellow-orange color dominates the cells. Syto ${ }^{\circledR}$ green-stain did penetrate the cell membrane; cells and the mucilage are green.....

142. Microphotograph from Iron Gate Reservoir, OR (8/25/2009). LM-Microcystis aeruginosa. FITC-a yellow color dominates the cells. Sytox ${ }^{\circledR}$ green-stain did not penetrate the cell membrane.

143. Microphotograph from Pinto Lake, CA (9/22/2009). LM-Microcystis aeruginosa. FITC-a red color dominates the cells; orange filaments are cyanobacterial epiphytes. Syto ${ }^{\circledR}$ green-stain did not penetrate the cell membrane..

144. Microphotograph from Pinto Lake, CA (9/22/2009). LM- Aphanizomenon flos-aquae. FITC-an orange color dominates the cells. Sytox ${ }^{\circledR}$ green-Microcystis aeruginosa; stain did not penetrate the cell membrane.

145. Microphotograph from Pinto Lake, CA (9/22/2009). LM- Aphanizomenon flos-aquae. FITC-an orange color dominates the cells. Sytox ${ }^{\circledR}$ green-stain appears to have penetrated the cell membrane in some cells.

146. Microphotograph from Pinto Lake, CA (9/22/2009). LM-Microcystis aeruginosa. FITC-an orange color dominates the cells. Syto ${ }^{\circledR}$ green-Microcystis wesenbergii-stain did not penetrate the mucilage of the colony; bright green dots are epiphytic bacteria

147. Microphotograph from Pinto Lake, CA (9/22/2009). LM-Microcystis wesenbergii. FITC-a yellow color dominates the cells. Sytox ${ }^{\circledR}$ green-stain did not penetrate the cell membranes.

148. Microphotograph from Pinto Lake, CA (9/22/2009). LM-Microcystis wesenbergii. FITC-a yellow color dominates the cells. Sytox ${ }^{\circledR}$ green-stain did penetrate the mucilaginous cells and the cell membranes; cells bright green.

149. Microphotograph from Pinto Lake, CA (9/22/2009). LM-Microcystis wesenbergii. FITC-a yellow color dominates the cells. Sytox ${ }^{\circledR}$ green-stain did not penetrate the mucilage of the colony; bright green dots are epiphytic bacteria and the mucilage appears to have responded to the stain

150. Microphotograph from Pinto Lake, CA (9/22/2009). LM- Aphanizomenon

flos-aquae. FITC-a yellow color dominates the cells. Sytox ${ }^{\circledast}$ green-stain did not penetrate the cell membrane

151. Microphotograph from Pinto Lake, CA (9/22/2009). LM- Aphanizomenon

flos-aquae. FITC-a yellow color dominates the cells. Sytox ${ }^{\circledR}$ green-stain did penetrate the cell membrane; cells bright green

152. Microphotograph from Pinto Lake, CA (9/22/2009). LM-Microcystis sp. FITC-an orange-red color dominates the cells. Syto ${ }^{\circledR}$ green-stain did not penetrate the mucilage of the colony 
153. Microphotograph from Pinto Lake, CA (9/22/2009). LM-Microcystis wesenbergii. FITC-an orange color dominates the cells. Sytox ${ }^{\circledR}$ green-stain did not penetrate the cell membranes

154. Microphotograph from Pinto Lake, CA (9/22/2009). LM-Microcystis wesenbergii. FITC-an orange-red color dominates the cells. Sytox ${ }^{\circledR}$ green-stain did not penetrate the cell membranes

155. Microphotograph from Pinto Lake, CA (9/22/2009). LM-Microcystis sp. FITC-a yellow color dominates the cells. Syto ${ }^{\circledR}$ green-stain did not penetrate the cell membranes

156. Microphotograph from laboratory culture-Lyngbya DVL 1103B. LM-Lyngbya sp. is a filamentous cyanobacteria with a mucilaginous sheath. FITC-a red color dominates the cells. Yellow is the area of filament splitting (separation discs). Sytox ${ }^{\circledast}$ green-stain was picked up by the sheath but not the cells. Bacteria appear as bright green dots on the sheath

157. Microphotograph from laboratory culture-Lyngbya DVL 1103B. LM-Lyngbya sp. FITC-a yellow color dominates the cells. Sytox ${ }^{\circledR}$ green-stain penetrated, indicating the cell membrane was disrupted. The sheath also picked up the stain

158. Microphotograph from laboratory culture-Lyngbya DVL 1103B. LM-Lyngbya sp. FITC-a yellow-orange color dominates the cells. Sytox ${ }^{\circledR}$ green-stain penetrated some cells, indicating the cell membrane was partially disrupted. The sheath also picked up the stain

159. Microphotograph from laboratory culture-Lyngbya DVL 1103B. LM-Lyngbya sp. FITC-an orange color dominates the cells. Syto ${ }^{\circledR}$ green-stain penetrated, indicating the cell membrane was disrupted. The sheath also picked up the stain

160. Microphotograph from laboratory culture-Lyngbya DVL 1103B. LM-Lyngbya sp. FITC-a yellow-orange color dominates the cells. Sytox ${ }^{\circledR}$ green-stain did not penetrate, indicating the cell membrane was not disrupted. The sheath also picked up the stain

161. Microphotograph from laboratory culture-Lyngbya DVL 1103B. LM-Lyngbya sp. FITC-a yellow color dominates the cells. Sytox ${ }^{\circledR}$ green-stain did penetrate to some extent, indicating the cell membrane was disrupted. The sheath also picked up the stain

162. Microphotograph from laboratory culture-Lyngbya DVL 1103B. LM-Lyngbya sp. FITC-a yellow color dominates the cells. Sytox ${ }^{\circledR}$ green-stain did not penetrate, indicating the cell membrane was not disrupted. The sheath also picked up the stain

163. Microphotograph from laboratory culture-Lyngbya DVL 1103B. LM-Lyngbya sp. Note: the filaments were fragmented. FITC-a red color dominates the cells. Sytox ${ }^{\circledR}$ green-stain did not penetrate, indicating the cell membrane was not disrupted

164. Microphotograph from laboratory culture-Lyngbya DVL 1103B. LM-Lyngbya sp. Note: only a few fragments were found and no material for FITC or Sytox ${ }^{\circledR}$ green.

165. Microphotograph from laboratory culture-Lyngbya DVL 1103B. LM-Lyngbya sp. FITC-a red color dominates the cells. Sytox ${ }^{\circledast}$ green-stain was picked up by a few cells in each filament and the tips of each filament

166. Microphotograph from laboratory culture-Lyngbya DVL 1103B. LM-Lyngbya sp. FITC-a red color dominates the cells. Syto ${ }^{\circledR}$ green-stain was picked up by a few cells in each filament and the tips of each filament 
167. Microphotograph from laboratory culture-Lyngbya DVL 1103B. LM-Lyngbya sp. FITC-a red color dominates the cells. Sytox ${ }^{\circledR}$ green-stain was picked up by a few cells in each filament

168. Microphotograph from laboratory culture-Lyngbya DVL 1103B. LM-Lyngbya sp. Note: the color is dominated by phycocyanin. FITC-a red color dominates the cells. Sytox ${ }^{\circledast}$ green-stain was picked up by the sheath but not the cells .173

169. Microphotograph from laboratory culture-Lyngbya DVL 1103B. LM-Lyngbya sp. FITC-a red color dominates the cells. Note: cellular material appears to clump into particles. Sytox ${ }^{\circledast}$ green-stain was picked up by the sheath but not the cells

170. Microphotograph from laboratory culture-Lyngbya DVL 1103B. LM-Lyngbya sp. FITC-a red color dominates the cells. Note: cellular material appears to clump into particles. Sytox ${ }^{\circledR}$ green-stain was picked up by the sheath but not the cells.

171. Microphotograph from laboratory culture-Phormidium DVL 706A. LM-

Phormidium sp. is a filamentous cyanobacterium which may have a thin, mucilaginous sheath. Some species have no sheath. FITC-a red color dominates the cells. Syto ${ }^{\circledR}$ green-stain was picked up by the extracellular matrix and a few cells. These cultures were not controlled for age; each culture has a mix of filaments that range from actively dividing to senescence. Bacteria appear as bright green dots on the mucilage.

172. Microphotograph from laboratory culture-Phormidium DVL 706A. LM-

Phormidium sp. FITC-an orange color dominates the cells. Sytox ${ }^{\circledR}$ green-stain penetrated, indicating the cell membrane was disrupted; bright green cells. Some of the filaments did not have any cells that stained, or only had some of the cells in the filament that stained

173. Microphotograph from laboratory culture-Phormidium DVL 706A. LM-

Phormidium sp. FITC-a yellow-orange color dominates the cells. Sytox ${ }^{\circledR}$ greenstain penetrated, indicating the cell membrane was disrupted; bright green cells. Some of the filaments did not have any cells that stained, or only had some of the cells in the filament that stained

174. Microphotograph from laboratory culture-Phormidium DVL 706A. LM-

Phormidium sp. FITC-a yellow-orange color dominates the cells. Sytox ${ }^{\circledR}$ greenstain penetrated, indicating the cell membrane was disrupted; bright green cells. Some of the filaments did not have any cells that stained, or only had some of the cells in the filament that stained

175. Microphotograph from laboratory culture-Phormidium DVL 706A. LM-

Phormidium sp. FITC-a yellow-orange color dominates the cells. Sytox ${ }^{\circledR}$ greenstain penetrated, indicating the cell membrane was disrupted; yellow-green cells

176. Microphotograph from laboratory culture-Phormidium DVL 706A. LM-

Phormidium sp. FITC-a yellow-orange color dominates the cells. Sytox ${ }^{\circledR}$ greenstain penetrated, indicating the cell membrane was disrupted; bright green cells

177. Microphotograph from laboratory culture-Phormidium DVL 706A. LM-

Phormidium sp. FITC-a yellow-orange color dominates the cells. Sytox ${ }^{\circledR}$ greenstain penetrated, indicating the cell membrane was disrupted; bright green cells

178. Microphotograph from laboratory culture-Phormidium DVL 706A. LM-

Phormidium sp. FITC-a red color dominates the cells. Sytox ${ }^{\circledR}$ green-stained the sheath but not the cells 
179. Microphotograph from laboratory culture-Phormidium DVL 706A. LM-

Lyngbya sp. Note: the sheath appears to be separated from the cells. FITC-an orange color dominates the cells. Sytox ${ }^{\circledast}$ green-did not penetrate the cells ..... 184

180. Microphotograph from laboratory culture-Phormidium DVL 706A. LMNothing discernable.

181. Microphotograph from laboratory culture-Phormidium DVL 706A. LM-

Phormidium sp. FITC-a red color dominates the cells. Sytox ${ }^{\circledR}$ green-stain penetrated some cells, indicating the cell membrane was disrupted; bright green cells. Some of the filaments only had some of the cells in the filament that stained

182. Microphotograph from laboratory culture-Phormidium DVL 706A. LM-

Phormidium sp. FITC-an orange color dominates the cells. Sytox ${ }^{\circledR}$ green-stain penetrated some cells, indicating the cell membrane was disrupted; bright green cells. Some of the filaments only had some of the cells in the filament that stained

183. Microphotograph from laboratory culture-Phormidium DVL 706A. LM-

Phormidium sp. FITC-a red color dominates the cells. Sytox ${ }^{\circledR}$ green-stain penetrated some cells, indicating the cell membrane was disrupted; bright green cells. Some of the filaments only had some of the cells in the filament that stained

184. Microphotograph from laboratory culture-Phormidium DVL 706A. LM-

Phormidium sp. FITC-a red color dominates the cells. Sytox ${ }^{\circledR}$ green-stain was picked up by the sheath but not the cells

185. Microphotograph from laboratory culture-Phormidium DVL 706A. LM-

Phormidium sp. FITC-a red color dominates the cells. Sytox ${ }^{\circledR}$ green-stain penetrated some cells, indicating the cell membrane was disrupted; bright green cells. Some of the filaments only had some of the cells in the filament that stained

186. Microphotograph from laboratory culture-Phormidium DVL 706A. LM-

Phormidium sp. FITC-a red color dominates the cells. Sytox ${ }^{\circledR}$ green-stain was picked up by the sheath but not the cells

187. Graph showing summary of physical observation of cyanobacterial cell condition, epifluorescent microscopy (FITC), and epifluorescent microscopy in conjunction with the nucleic acid stain Syto ${ }^{\circledR}$ green (Sytox ${ }^{\circledR}$ green staining) as a percentage of the total when results of all environmental samples are combined within each cell-lysis treatment.

\section{Tables}

1. Sample location and taxa of the digital images in this report.....................................

2. Extraction procedures and codes for digital images................................................

3. Sample inventory of digital photomicrographs...

4. Summary of observations compiled from digital microphotographs of multiple cyanobacteria dominated samples exposed to five different cell-y techniques. 


\section{Conversion Factors}

SI to Inch/Pound

\begin{tabular}{lll}
\hline Multiply & By & To obtain \\
\hline & Length & \\
\hline centimeter $(\mathrm{cm})$ & 0.3937 & inch (in.) \\
micrometer $(\mu \mathrm{m})$ & $3.937 \times 10^{-5}$ & inch (in.) \\
meter $(\mathrm{m})$ & 3.281 & foot (ft) \\
\hline & Area & \\
\hline square millimeter $\left(\mathrm{mm}^{2}\right)$ & $1.55 \times 10^{-3}$ & square inch (in2) \\
\hline & Volume & ounce, fluid (fl. oz) \\
\hline liter $(\mathrm{L})$ & 33.82 & pint (pt) \\
liter $(\mathrm{L})$ & 2.113 & quart (qt) \\
liter $(\mathrm{L})$ & 1.057 & gallon (gal) \\
liter $(\mathrm{L})$ & 0.2642 & ounce, avoirdupois $(\mathrm{oz})$ \\
\hline & Mass & pound avoirdupois $(\mathrm{lb})$ \\
\hline gram $(\mathrm{g})$ & 0.03527 & pound per square inch $\left(\mathrm{lb} / \mathrm{in}^{2}\right)$ \\
kilogram $(\mathrm{kg})$ & 2.205 &
\end{tabular}

Temperature in degrees Celsius $\left({ }^{\circ} \mathrm{C}\right)$ may be converted to degrees Fahrenheit $\left({ }^{\circ} \mathrm{F}\right)$ as follows:

$$
{ }^{\circ} \mathrm{F}=\left(1.8 x^{\circ} \mathrm{C}\right)+32
$$

Specific conductance is given in microsiemens per centimeter at 25 degrees Celsius $(\mu \mathrm{S} / \mathrm{cm}$ at $\left.25^{\circ} \mathrm{C}\right)$.

Concentrations of chemical constituents in water are given in parts-per-billion (ppb) which is equivalent to micrograms per liter $(\mu \mathrm{g} / \mathrm{L})$.

\section{Other Abbreviations Used in this Report}

$\begin{array}{ll}\text { ELISA } & \text { Enzyme-linked immunosorbent assay } \\ \text { OGRL } & \text { Organic Geochemistry Research Laboratory, USGS } \\ \text { sp. } & \text { The species of the genus was not determined } \\ \text { USGS } & \text { U.S. Geological Survey } \\ \text { EPA } & \text { U.S. Environmental Protection Agency } \\ \text { psig } & \text { Pounds per square inch gauge } \\ \% & \text { Percentage }\end{array}$





\title{
Microphotographs of Cyanobacteria Documenting the Effects of Various Cell-lysis Techniques
}

\author{
By Barry H. Rosen, Keith A. Loftin, Christopher E. Smith, Rachael F. Lane, and Susan P. Keydel
}

\section{Abstract}

Cyanotoxins are a group of organic compounds biosynthesized intracellularly by many species of cyanobacteria found in surface water. The United States Environmental Protection Agency has listed cyanotoxins on the Safe Drinking Water Act's Contaminant Candidate List 3 for consideration for future regulation to protect public health. Cyanotoxins also pose a risk to humans and other organisms in a variety of other exposure scenarios. Accurate and precise analytical measurements of cyanotoxins are critical to the evaluation of concentrations in surface water to address the human health and ecosystem effects. A common approach to total cyanotoxin measurement involves cell membrane disruption to release the cyanotoxins to the dissolved phase followed by filtration to remove cellular debris. Several methods have been used historically, however no standard protocols exist to ensure this process is consistent between laboratories before the dissolved phase is measured by an analytical technique for cyanotoxin identification and quantitation. No systematic evaluation has been conducted comparing the multiple laboratory sample processing techniques for physical disruption of cell membrane or cyanotoxins recovery. Surface water samples collected from lakes, reservoirs, and rivers containing mixed assemblages of organisms dominated by cyanobacteria, as well as laboratory cultures of species-specific cyanobacteria, were used as part of this study evaluating multiple laboratory cell-lysis techniques in partnership with the U.S. Environmental Protection Agency. Evaluated extraction techniques included boiling, autoclaving, sonication, chemical treatment, and freeze-thaw. Both treated and untreated samples were evaluated for cell membrane integrity microscopically via light, epifluorescence, and epifluorescence in the presence of a DNA stain. The DNA stain, which does not permeate live cells with intact membrane structures, was used as an indicator for cyanotoxin release into the dissolved phase. Of the five techniques, sonication (at 70 percent) was most effective at complete cell destruction while QuikLyse ${ }^{\mathrm{TM}}$ was least effective. Autoclaving, boiling, and sequential freeze-thaw were moderately effective in physical destruction of colonies and filaments.

\section{Introduction}

The purpose of the study is to develop standardized protocols for assessing cyanotoxins in recreational and drinking water. Only one aspect of this overall study is documented for this report; the images captured through microscopy of cells subjected to various extraction (lysing) procedures.

Several species of cyanobacteria have the ability to produce cyanotoxins (toxins) that pose a potential threat to terrestrial and aquatic life, including humans (Chorus and Bartram, 1999). Quantifying these toxins includes the extraction or cell lysis of compounds from within cyanobacterial cells where the toxins are stored; however, the effectiveness of cell lysis is not a simple or well understood procedure (Chorus and Bartram, 1999; Loftin and others, 2008). Cyanobacteria exhibit a great variety of cellular features and morphology, and while these features for example polysaccharide sheath are used to identify these organisms, they also can interfere with the commonly used approaches for extracting compounds. No literature exists, to the authors' knowledge, which demonstrates how colony and filament morphology affects the extraction of cyanotoxins. United States Environmental Protection Agency (USEPA) Region 9 (San Francisco, California) initiated this study, under the Regional Methods Program, which is being conducted by U.S. Geological Survey (USGS), in coordination with USEPA's Office of Science Policy, Office of Research and Development.

\section{Methods}

Two laboratory cultures, each consisting of an isolated cyanobacterial genus, as well as 12 field samples collected from water bodies in six different states during 2009 were used for this research. Grand Lake, Ohio, was sampled twice on two separate dates (July and September). 


\section{Field Samples}

Twelve grab samples of various cyanobacterial cell densities were collected at the air/water interface from the locations listed in table 1 and shipped to the USGS Organic Geochemistry Research Laboratory (OGRL), Kansas Water Science Center for processing. Approximately, 8 liters (L) of sample from each site was composited, mixed, and split from an $8 \mathrm{~L}$ Teflon churn and then lysed by separate techniques and treatment levels at the USGS OGRL (table 2). Lysed and unlysed (control) samples were then shipped overnight on ice in small glass vials, refrigerated on arrival and examined microscopically the following day by the USGS Florida Integrated Science Center (Orlando, Fla.). The lysis or extraction treatments used are listed in table 2, along with the codes used to label each electronic image; a detailed description of the methodology and rationale for extraction procedures will be the subject of a separate publication.

\section{Laboratory Cyanobacterial Cell-Lysis Techniques}

Five different cyanobacterial cell-lysis techniques were used to evaluate effectiveness for disrupting cell membranes: boiling, autoclave, sonication, QuikLyse ${ }^{\mathrm{TM}}$ and freeze-thaw. Approximately, $8 \mathrm{~L}$ of sample from each site was composited, mixed, and split from an $8 \mathrm{~L}$ Teflon churn and then lysed by separate techniques and treatment levels (table 2). All cell lysis techniques had three treatment levels based on time for boiling and autoclave, power for sonication, or repetition for sequential freeze-thaw cycles. QuikLyse ${ }^{\mathrm{TM}}$ (Abraxis, LLC, Warminster, PA., USA) was used at the manufacturer recommended concentration for all samples and, in some cases, two and three times the recommended dose was used for a given sample volume to determine if reagent concentration changed effectiveness.

\section{Boiling Technique}

Fifty milliliter $(\mathrm{mL})$ sample aliquots contained in $123 \mathrm{~mL}$ amber glass, Boston round bottles with caps loosened were placed in boiling reagent water (generated by a ThermoScientific Barnstead Nanopure ${ }^{\circledR}$ Diamond TM TOC Life Science ultrapure water treatment system-Model D11971, conductivity $=5.500$ microsiemens per centimeter $(\mu \mathrm{S} / \mathrm{cm})$, total organic carbon less than 1 part per billion (ppb)) for 5, 15, or 30 minutes before microscopic examination at atmospheric pressure at 296 meters (m) above sea level (Google Earth 5.1, Lawrence, Kans.).

\section{Autoclave Technique}

Fifty milliliter $(\mathrm{mL})$ sample aliquots contained in $123 \mathrm{~mL}$ amber glass, Boston round bottles with caps (Fisher Scientific,
Pittsburgh, PA, USA) loosened were autoclaved (Sterilmatic, Market Forge Industries., Everett, MA, USA) for 5, 15, or 30 minutes (min) at $2.03 \mathrm{kPa}, 120$ degrees Celsius $\left({ }^{\circ} \mathrm{C}\right)$, and a setting of slow before microscopic examination.

\section{Sonication}

Fifteen $\mathrm{mL}$-sample aliquots in $30 \mathrm{~mL}$ amber glass, Boston round bottles were sonicated for 5 min using a Model $102 \mathrm{C}, 0.5$ inch disruptor horn coupled to a 0.125 inch (in) tapered microtip horn (Fisher Scientific, Pittsburgh, PA, USA) connected to a digital ultrasonic dismembrator (Model 500, Fisher Scientific, Pittsburgh, PA, USA) where power was varied from 10, 35, and 70 percent (\%) in separate samples. Samples were incubated for five min in an ice bath before sonication. Samples were sonicated in an ice bath with sample completely immersed below the ice bath surface inside a Branson sonifier sound enclosure (Fisher Scientific, Pittsburgh, Pa., USA). Sample temperature never exceeded $25^{\circ} \mathrm{C}$. The microtip horn was placed directly in the sample and the horn was then cleaned in between samples once with methanol, once with methanol and $0.1 \%$ tetrahydrofuran (with inhibitor), once with reagent water, and finally wiped with a clean Kimwipe ${ }^{\circledR}$ (Fisher Scientific, Pittsburgh, PA, USA).

\section{Chemical Lysis}

The QuikLyse ${ }^{\mathrm{TM}}$ lysis reagents were used as recommended by the manufacturer for the " $1 \mathrm{x}$ treatments" ( $1 \mathrm{x}$ implies that the reagent dosages were used as recommended by manufacturer, Abraxis, LLC, 2008; Loftin and others, 2008). Separate sample aliquots $(1 \mathrm{~mL}$ in a $2-\mathrm{mL}$ amber glass vial) were also subjected to 2 and 3 times ( $2 x$ and $3 x$, respectively) the manufacturer recommended reagent concentrations before microscopic examination.

\section{Freeze-Thaw Technique}

One freeze-thaw cycle consisted of freezing $50 \mathrm{~mL}$ sample aliquot in $123 \mathrm{~mL}$ amber glass Boston round bottles at $20^{\circ} \mathrm{C}$ for as many as 24 hours until frozen solid followed by a thawing step at room temperature (e.g. ranging from 25 to $30^{\circ} \mathrm{C}$ ) for as many as 12 hours (Loftin and others, 2008). Treatment consisted of 1,2, or 3 complete freeze-thaw cycles before microscopic examination.

\section{Laboratory Cultures}

Lyngbya sp. and Phormidium sp. initially were isolated by the Metropolitan Water District of Southern California (Izaguirre and Taylor, 2004) and subsequently maintained by USGS-Florida and were used for this research. The two genera of filamentous cyanobacteria were grown as unialgal cultures in liquid medium using standard culturing techniques (Zimmerman and Rosen, 1992). 
Table 1. Sample location and taxa of the digital images in this report.

[sp., species; CA, California; FL, Florida; IA, Iowa; OH, Ohio; OR, Oregon; St., Saint]

\begin{tabular}{|c|c|c|}
\hline Sample site (sample collection date) & $\begin{array}{c}\text { Cyanobacteria taxa } \\
\text { photographed }\end{array}$ & $\begin{array}{c}\text { Cyanobacterial } \\
\text { morphology }\end{array}$ \\
\hline \multirow[t]{2}{*}{ Cassidy Lake, WA (10/12/2009) } & Woronichinia naegeliana & Colonial \\
\hline & Microcystis sp. & Colonial \\
\hline \multirow[t]{3}{*}{ Spring Lake, CA (8/21/2009) } & Microcystis aeruginosa & Colonial \\
\hline & Microcystis wesenbergii & Colonial \\
\hline & Woronichinia sp. & Colonial \\
\hline \multirow[t]{3}{*}{ Blackhawk Lake, IA (8/26/2009) } & Planktothrix sp. & Filamentous \\
\hline & Filamentous cyanobacteria & Filamentous \\
\hline & Microcystis sp. & Colonial \\
\hline \multirow[t]{3}{*}{ Copco Reservoir, CA (9/10/2009) } & Microcystis wesenbergii & Colonial \\
\hline & Microcystis aeruginosa & Colonial \\
\hline & Filamentous cyanobacteria & Filamentous \\
\hline Grand Lake (Lake St. Mary), OH (7/20/2009) & Planktothrix sp. & Filamentous \\
\hline \multirow[t]{3}{*}{ Grand Lake (Lake St. Mary), OH (9/15/2009) } & Planktothrix sp. & Filamentous \\
\hline & Filamentous cyanobacteria & Filamentous \\
\hline & Colonial cyanobacteria & Colonial \\
\hline St. John's River, Jacksonville, FL (9/15/2009) & Microcystis aeruginosa & Colonial \\
\hline \multirow[t]{3}{*}{ Upper Klamath Lake, OR (8/21/2009) } & Aphanizomenon flos-aquae & Filamentous \\
\hline & Microcystis aeruginosa & Colonial \\
\hline & Gloeotrichia echinulata & $\begin{array}{l}\text { Filamentous } \\
\text { colony }\end{array}$ \\
\hline Klamath River, OR (8/21/2009) & Microcystis aeruginosa & Colonial \\
\hline Iron Gate Reservoir, OR (8/25/2009) & Microcystis sp. & Colonial \\
\hline \multirow[t]{4}{*}{ Pinto Lake, CA (9/22/2009) } & Microcystis sp. & Colonial \\
\hline & Microcystis wesenbergii & Colonial \\
\hline & Aphanizomenon flos-aquae & Filamentous \\
\hline & Planktothrix sp. & Filamentous \\
\hline \multicolumn{3}{|c|}{ Laboratory cultures } \\
\hline Lyngbya DVL 1103B & Lyngbya sp. & Filamentous \\
\hline Phormidium DVL 706A & Phormidium sp. & Filamentous \\
\hline
\end{tabular}


Table 2. Extraction procedures and codes for digital images.

$[\%$, percent; $x$ represents the number of times the recommended dosage was multiplied compared with manufacturer instructions]

\begin{tabular}{|c|c|}
\hline Treatment & Identifier on Image Caption \\
\hline \multicolumn{2}{|c|}{ Control (live material) } \\
\hline Replicate 1 & Control 1 \\
\hline Replicate 2 & Control 2 \\
\hline Replicate 3 & Control 3 \\
\hline \multicolumn{2}{|c|}{ Boiled } \\
\hline 5 minutes & Boiled for 5 minutes \\
\hline 15 minutes & Boiled for 15 minutes \\
\hline 30 minutes & Boiled for 30 minutes \\
\hline \multicolumn{2}{|c|}{ Autoclaved } \\
\hline 5 minutes & Autoclaved for 5 minute \\
\hline 15 minutes & Autoclaved for 15 minute \\
\hline 30 minutes & Autoclaved for 35 minute \\
\hline \multicolumn{2}{|c|}{ Sonicated (5 minutes) } \\
\hline $10 \%$ power & Sonicated at $10 \%$ \\
\hline $35 \%$ power & Sonicated at $35 \%$ \\
\hline $70 \%$ power & Sonicated at $70 \%$ \\
\hline \multicolumn{2}{|c|}{ Freeze-thaw } \\
\hline one cycle & One freeze-thaw cycle \\
\hline two sequential cycles & Two freeze-thaw cycles \\
\hline three sequential cycles & Three freeze-thaw cycles \\
\hline \multicolumn{2}{|c|}{ QuikLyse ${ }^{\mathrm{TM}}$} \\
\hline recommend concentration $(1 \mathrm{x})$ & QuikLyse $^{\mathrm{TM}}-1 \mathrm{x}$ \\
\hline $2 \mathrm{x}$ recommended concentration & QuikLyse $^{\mathrm{TM}}-2 \mathrm{x}$ \\
\hline $3 \mathrm{x}$ recommended concentration & QuikLyse $^{\mathrm{TM}}-3 \mathrm{x}$ \\
\hline
\end{tabular}

\section{Microscopy and Staining}

Samples were placed upright for a minimum of $10 \mathrm{~min}$ before sampling. A plastic disposable pipette was used to withdraw a sub-sample from the bottom of the sample vial and placed on an ethanol-washed glass slide. A number 1, 22 square millimeter $\left(\mathrm{mm}^{2}\right)$ glass cover slip (Thermo Fisher Scientific, USA) was placed over the sample and any excess water was blotted to prevent movement of the cyanobacteria when observed under the microscope.

Samples initially were observed and photographed using differential interference contrast microscopy using an Olympus BX-51 research microscope (Center Valley, Pa., USA) typically at $400 \mathrm{x}$; a 20 micrometer $(\mu \mathrm{m})$ bar is imbedded in most images (image identifying code-LM). The same cells were then examined and photographed under epifluorescent microscopy, with a U-MWB2: WIDE BLUE CUBE, excitation between 450-80 nanometer (nm) and emission above $515 \mathrm{~nm}$ and xenon-X-Cite Series 120Q as the illumination source (image identifying code-FITC). With this configuration, chlorophyll a appears as a deep red color. When other pigments are present, such as phycocyanin and phycoerythrin, the overall appearance of the cells appeared orange-red. Damaged pigments appear yellow. Images for each treatment/microscopic technique combination were captured in digitally and summarized in table 3 . The material on the microscope slide was then stained with 10 microliter $(\mu \mathrm{L})$ Sytox ${ }^{\circledR}$ Green (Invitrogen Corp., Carlsbad, Calif., USA) nucleic acid stain (S7020) (Stock solution: 25 microgram $(\mu \mathrm{g}) / 100 \mathrm{~mL}$ of $100 \%$ reagentgrade ethanol) (image identifying code-Sytox ${ }^{\circledR}$ green). Stain was applied by removing the cover slip, adding the Sytox ${ }^{\circledR}$ green, returning the cover slip, and incubating at 25 to $30^{\circ} \mathrm{C}$ (room temperature) for $5 \mathrm{~min}$. The colonies and cells were then examined and photographed with the same epifluorescent microscope settings as above. If the stain was able to penetrate the cell membrane, as found in many of the treatments, the cells fluoresced a bright green. This was indicative that the cell membrane had lost its integrity. 
Table 3. Sample inventory of digital photomicrographs.

[CA, California; FL, Florida; IA, Iowa; OH, Ohio; OR, Oregon; St., Saint; Boiled and autoclaved were time in minutes; sonicated was percent (\%) of power; freeze-thaw $\mathrm{x}$ indicates how many times the sample was frozen and thawed; and QuikLyse ${ }^{\mathrm{TM}} 1 \mathrm{x}$ indicates the manufacturers recommended concentration, $2 \mathrm{x}$ is twice the concentration and $3 \mathrm{x}$ is three times the recommend concentration; - -, indicates no data]

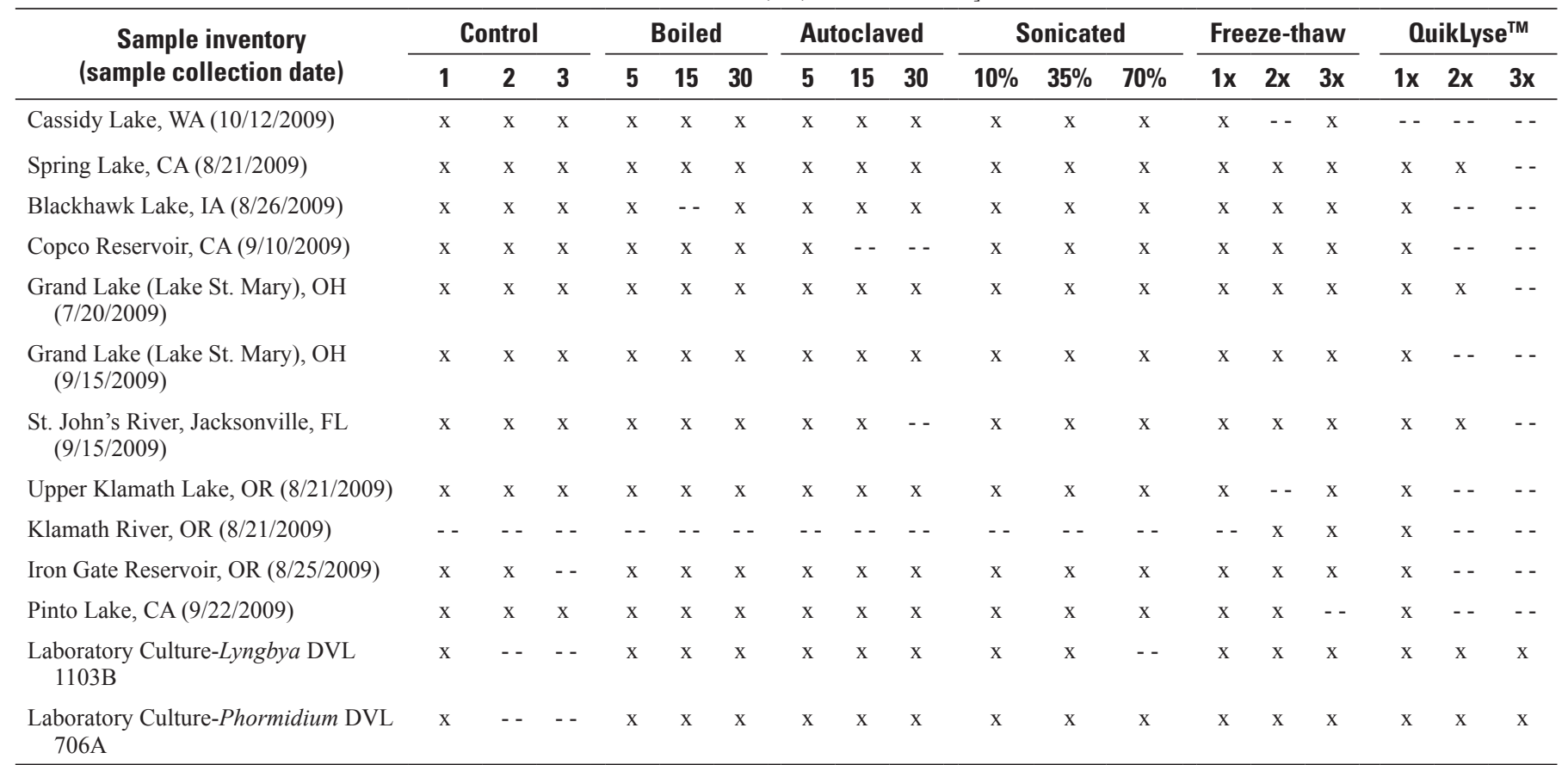

${ }^{1}$ Cyanobacterial morphology defined in Wehr and Sheath, 2003, Van de Hoek and others, 1995.

${ }^{2}$ Lyngbya DVL 1103B and Phormidium DVL 706A are cultures transferred from original samples acquired in study by Izaguirre and Taylor, 2004. 


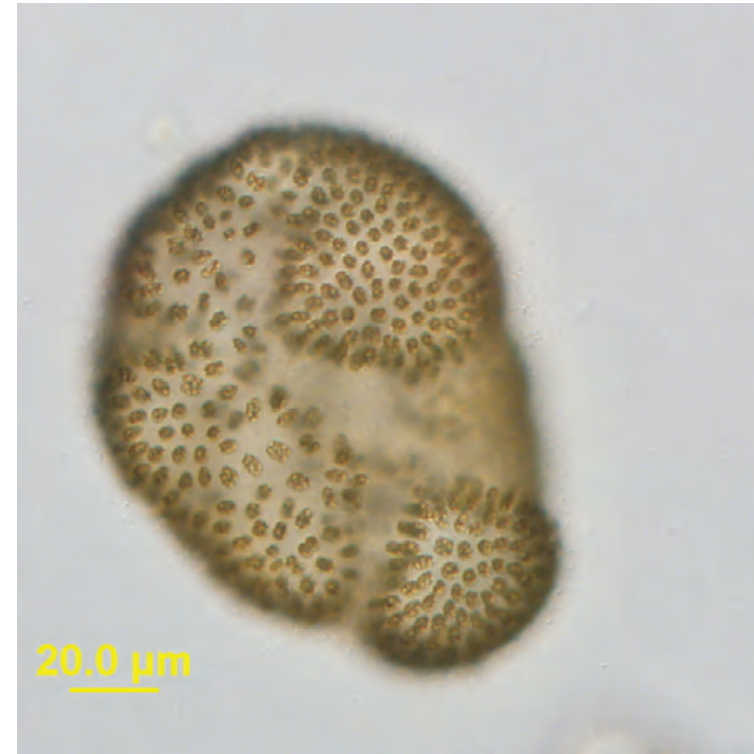

LM

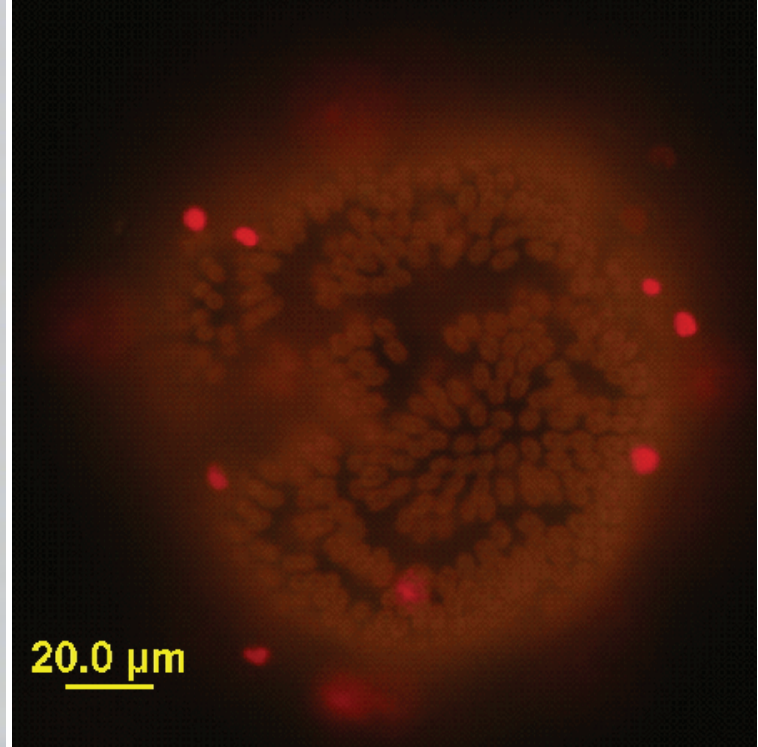

FITC

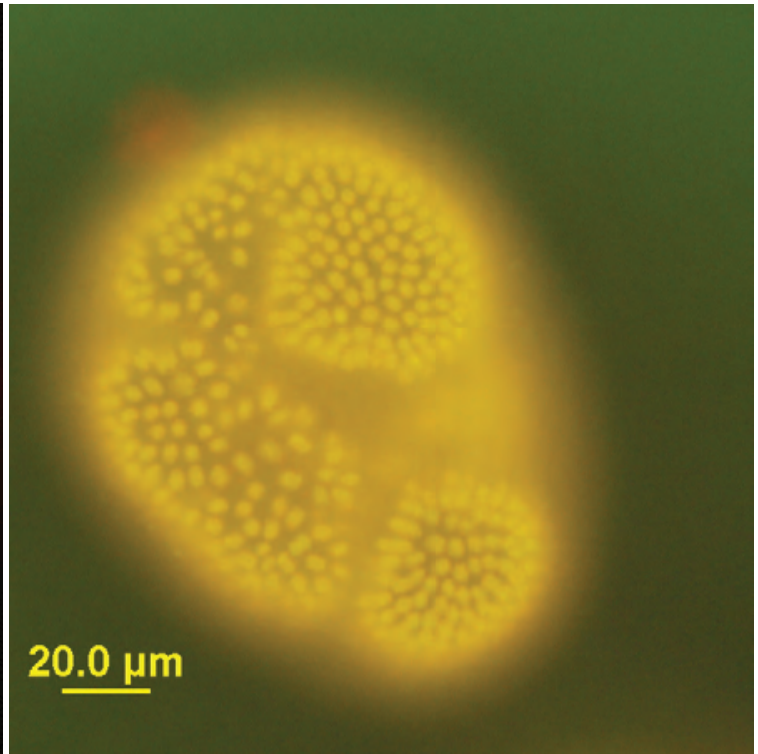

Sytox ${ }^{\circledR}$ green

\section{Control 1}

Figure 1. Cassidy Lake, WA (10/12/2009). LM-Woronichinia naegeliana, a colonial cyanobacterium with cells in a gelatinous matrix (synonym Coelosphaerium). FITC-a dull reddish color dominates the cells. The scattered bright red cells are eukaryotic algal epiphytes. Sytox ${ }^{\circledR}$ green-stain did not penetrate the cell membrane. LM - differential interference contrast microscopy; FITC - epifluorescent microscopy; Sytox ${ }^{\circledR}$ green - epifluorescent microscopy in conjunction with the nucleic acid stain Sytox ${ }^{\circledR}$ green. 


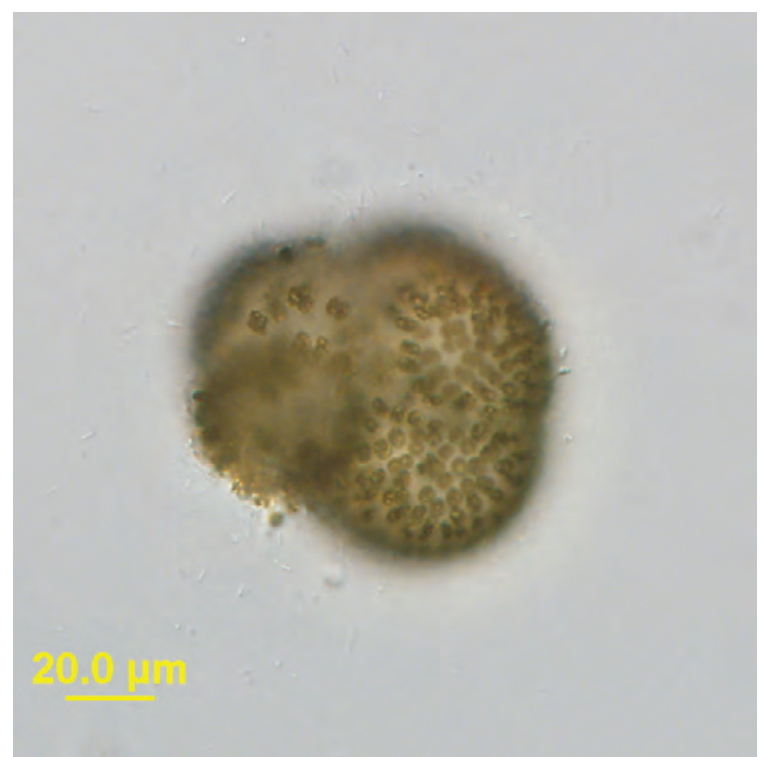

LM

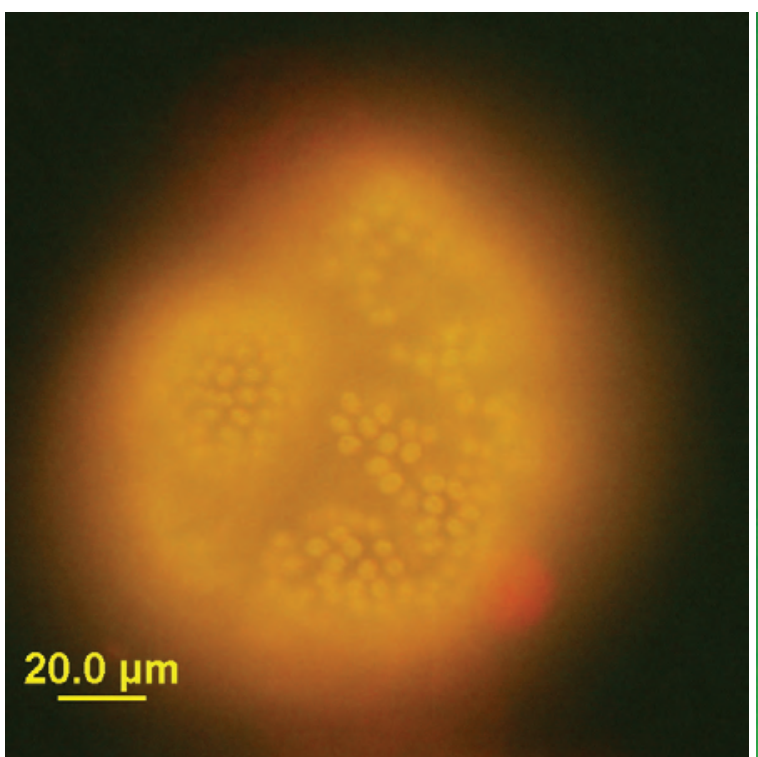

FITC

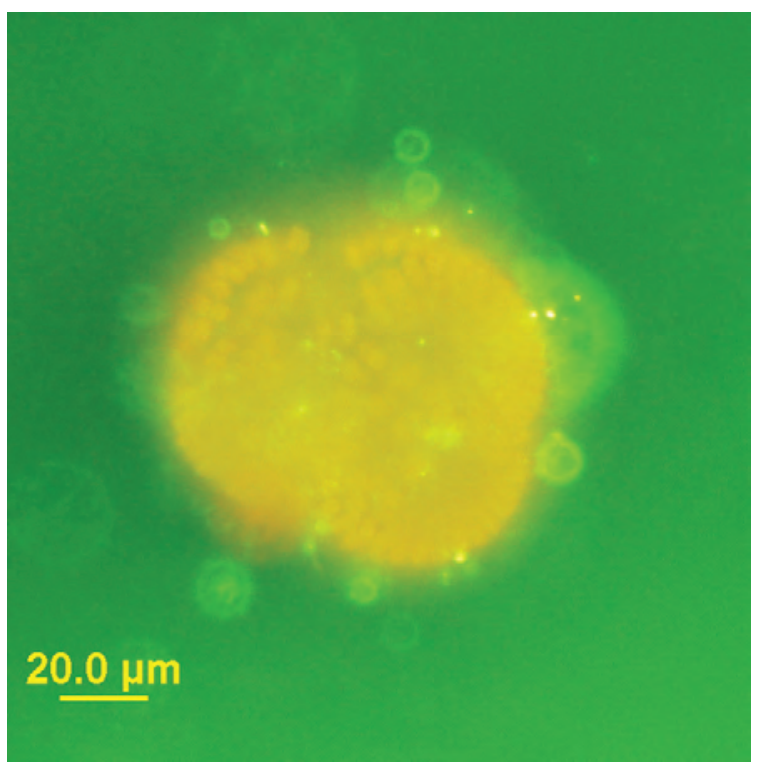

Sytox ${ }^{\circledR}$ green

Control 2

Figure 2. Cassidy Lake, WA (10/12/2009). LM-Woronichinia naegeliana, cells in a gelatinous matrix. FITC-a yellow-orange color dominates the cells. Sytox ${ }^{\circledR}$ green-stain did not penetrate the cell membrane. LM - differential interference contrast microscopy; FITC - epifluorescent microscopy; Sytox ${ }^{\circledR}$ green - epifluorescent microscopy in conjunction with the nucleic acid stain Syto ${ }^{\circledR}$ green. 


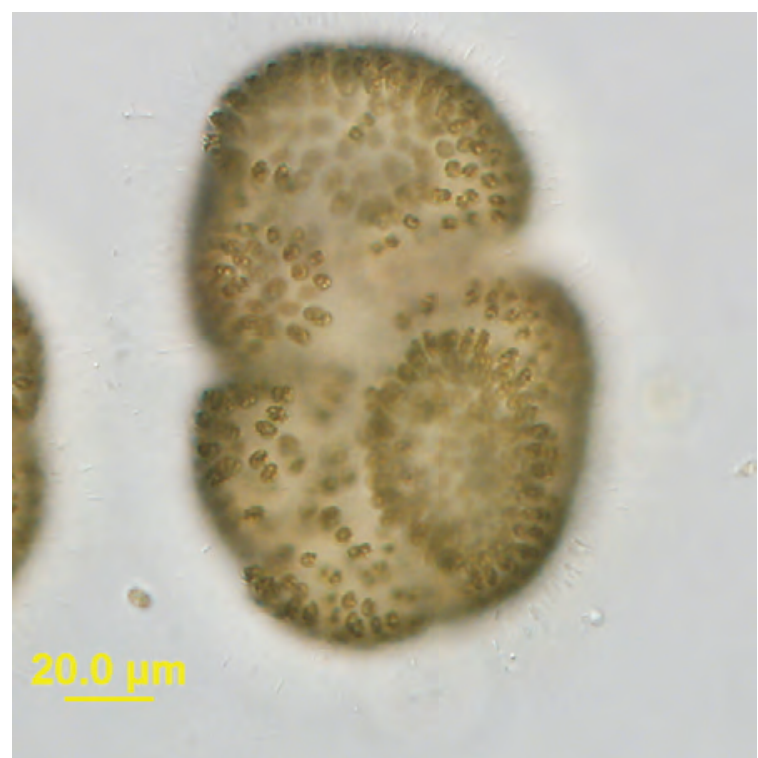

LM

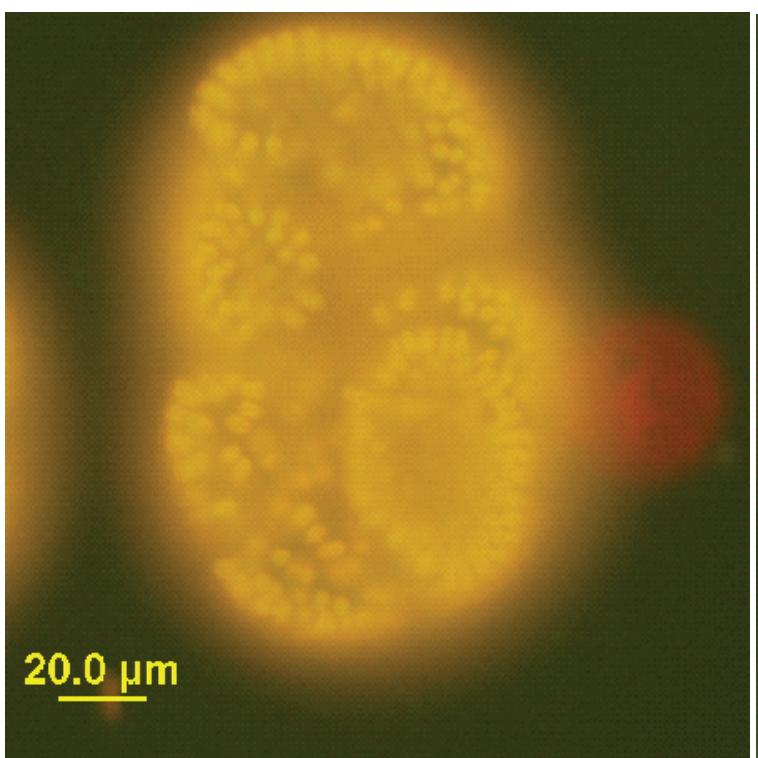

FITC

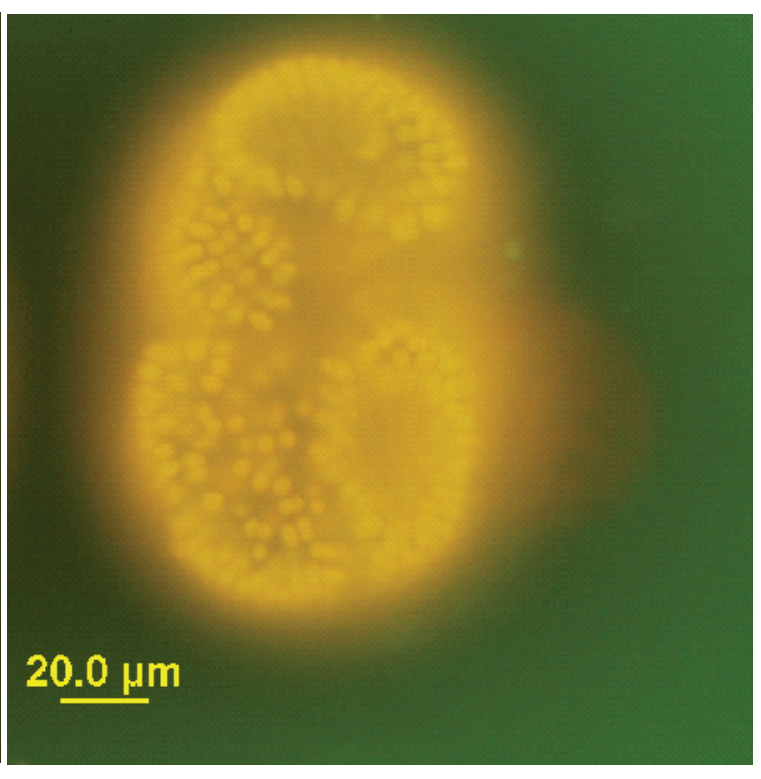

Sytox ${ }^{\circledR}$ green

Control 3

Figure 3. Cassidy Lake, WA (10/12/2009). LM-Woronichinia naegeliana, cells in a gelatinous matrix. FITC-a yellow-orange color dominates the cells. Sytox ${ }^{\circledR}$ green-stain did not penetrate the cell membrane. LM - differential interference contrast microscopy; FITC - epifluorescent microscopy; Sytox ${ }^{\circledR}$ green - epifluorescent microscopy in conjunction with the nucleic acid stain Sytox ${ }^{\circledR}$ green. 


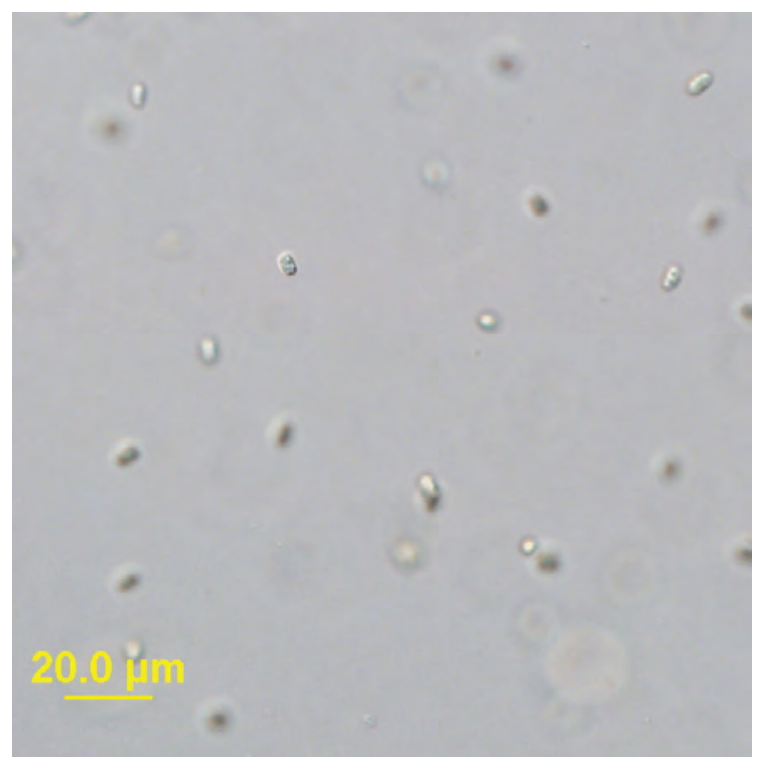

LM

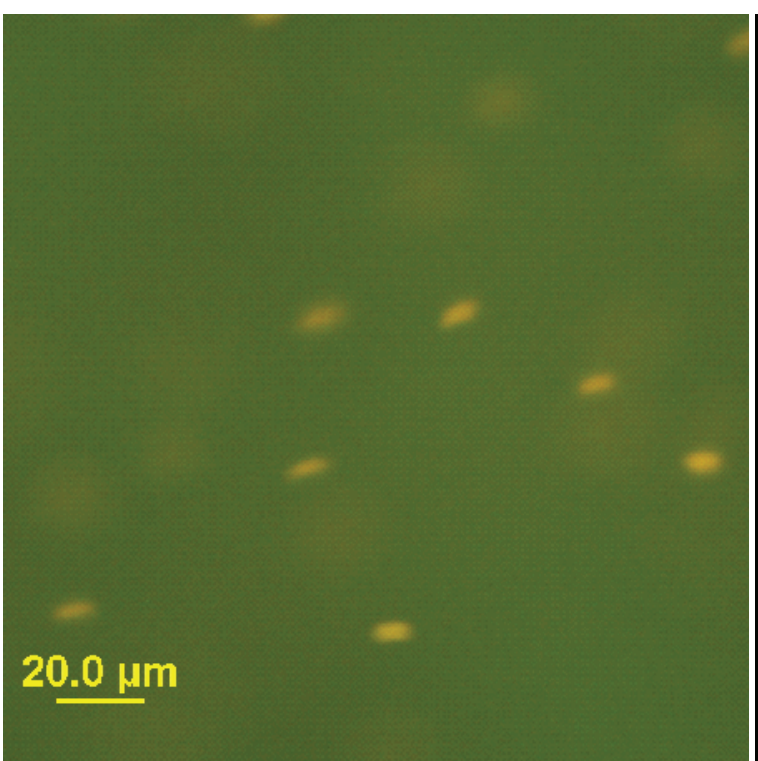

FITC

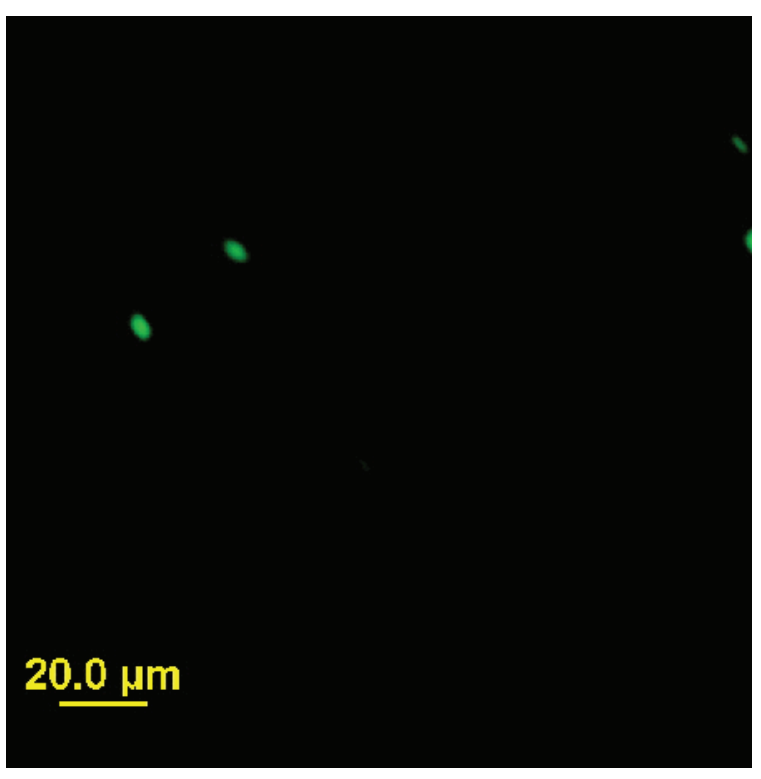

Sytox ${ }^{\circledR}$ green

\section{Boiled for 5 minutes}

Figure 4. Cassidy Lake, WA (10/12/2009). LM-Likely the remains of a Woronichinia naegeliana colony, with only scattered cells and no colonies. FITC-a yellow color dominates the cells; cell shape distorted because of long photographic exposure time. Sytox ${ }^{\circledR}$ green-stain penetrated cell membranes; bright green cells. LM - differential interference contrast microscopy; FITC - epifluorescent microscopy; Sytox ${ }^{\circledR}$ green - epifluorescent microscopy in conjunction with the nucleic acid stain Sytox ${ }^{\circledR}$ green. 


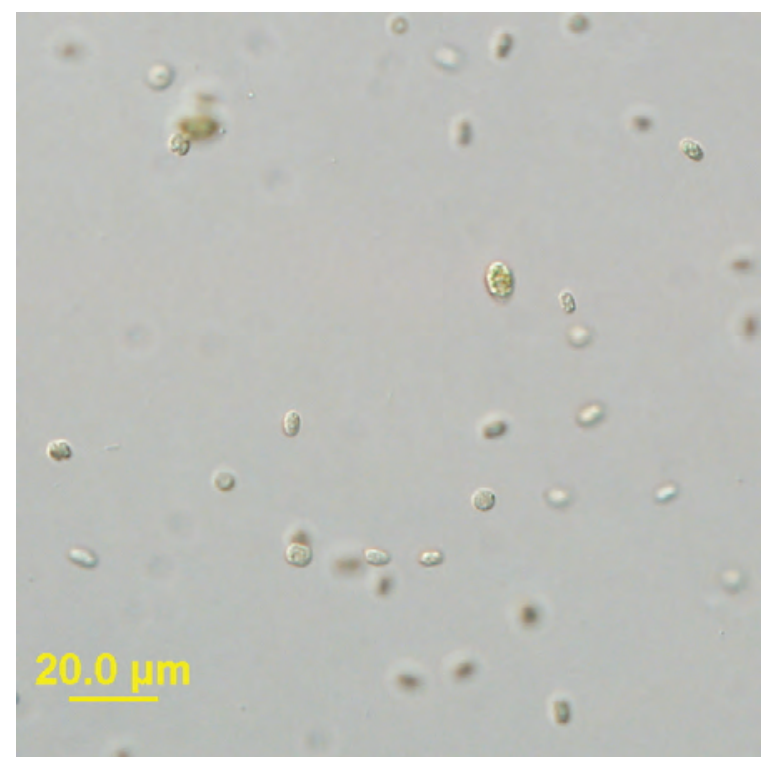

LM

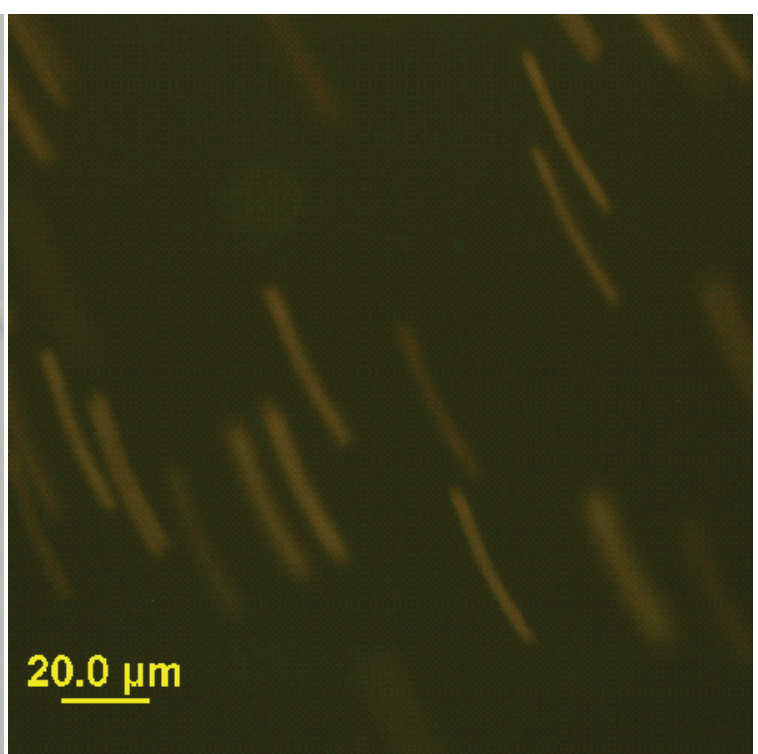

FITC

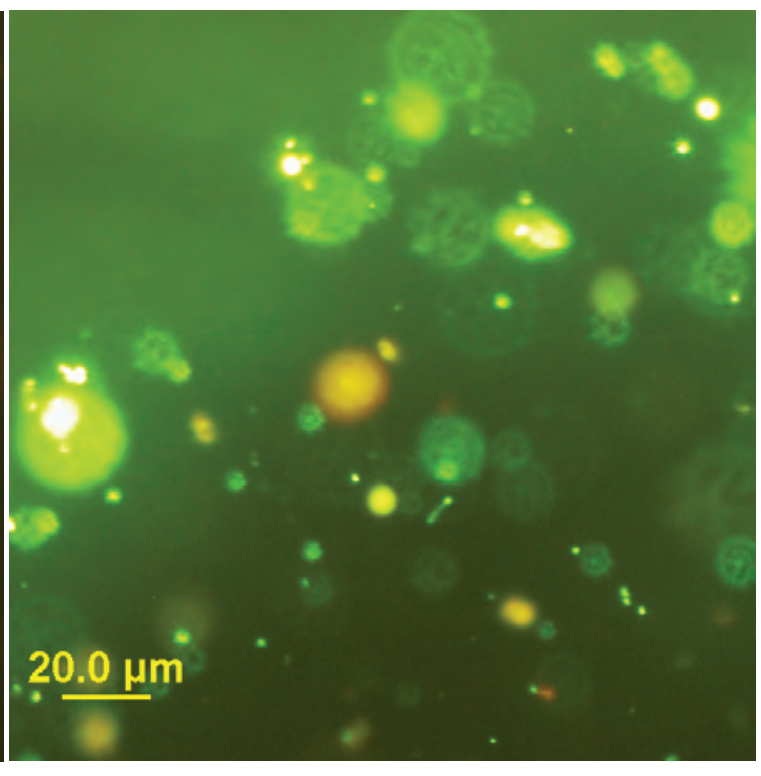

Sytox ${ }^{\circledR}$ green

Boiled for 15 minutes

Figure 5. Cassidy Lake, WA (10/12/2009). LM-Likely the remains of a Woronichinia naegeliana colony, with only scattered cells and no colonies. FITC-a yellow-orange color dominates the cells; cell shape distorted because of long photographic exposure time. Sytox ${ }^{\circledR}$ green-stain penetrated cell membranes; bright green cells. LM differential interference contrast microscopy; FITC - epifluorescent microscopy; Sytox ${ }^{\circledR}$ green - epifluorescent microscopy in conjunction with the nucleic acid stain Sytox ${ }^{\circledR}$ green. 


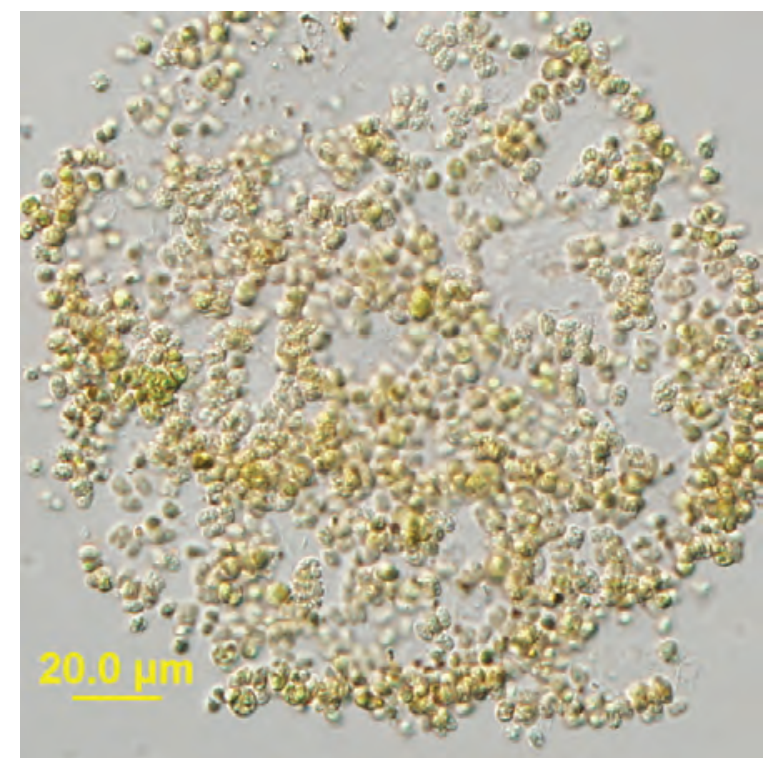

LM

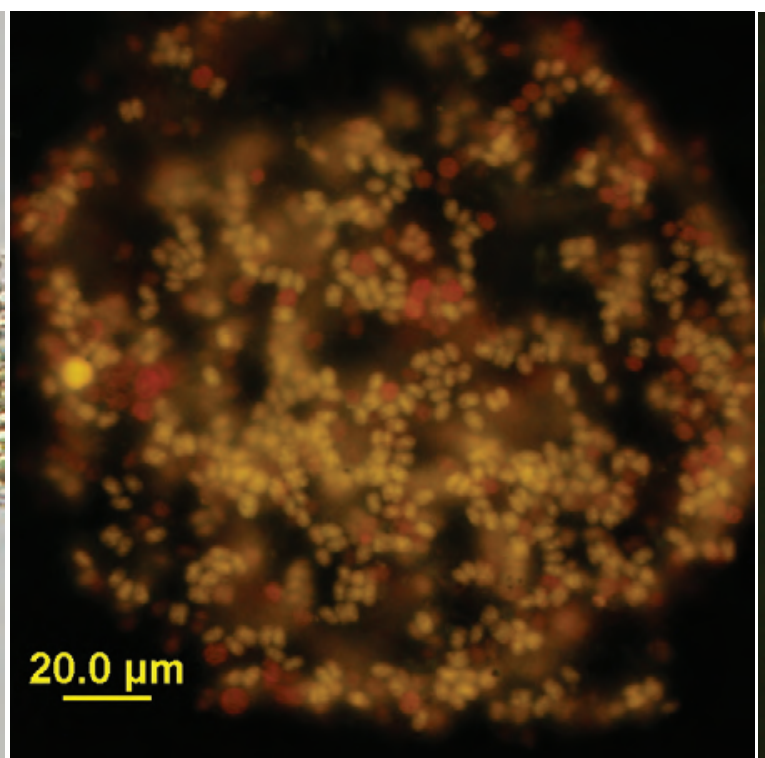

FITC

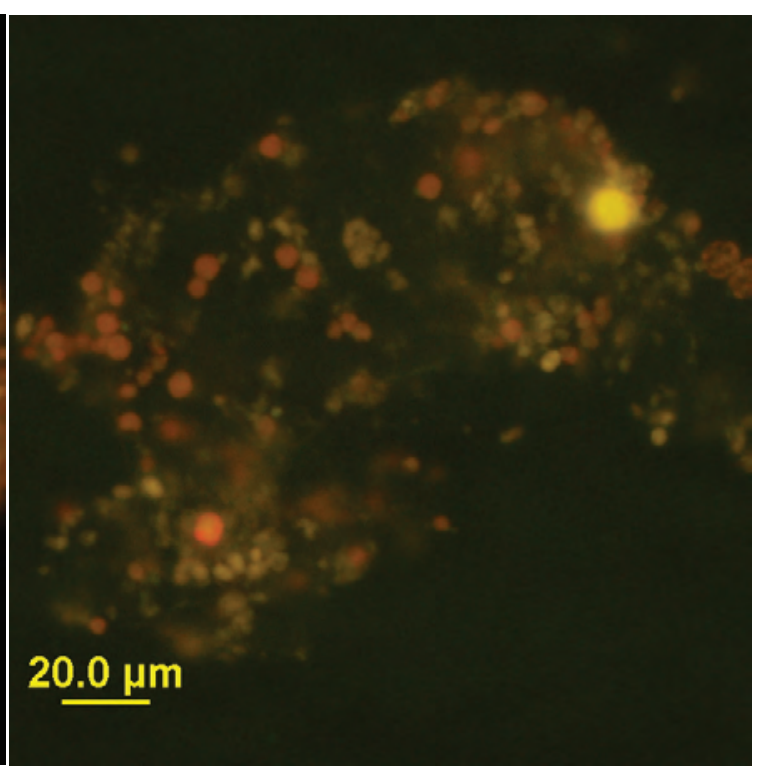

Sytox ${ }^{\circledR}$ green

\section{Boiled for 30 minutes}

Figure 6. Cassidy Lake, WA (10/12/2009). LM-Likely the remains of a degraded colony of Microcystis aeruginosa. FITC-a yellow color dominates the cells of the Microcystis sp.; red cells are likely eukaryotic algae. Syto ${ }^{\circledR}$ green-stain did not penetrate the cell membrane. LM - differential interference contrast microscopy; FITC epifluorescent microscopy; Sytox ${ }^{\circledR}$ green - epifluorescent microscopy in conjunction with the nucleic acid stain Sytox ${ }^{\circledR}$ green. 


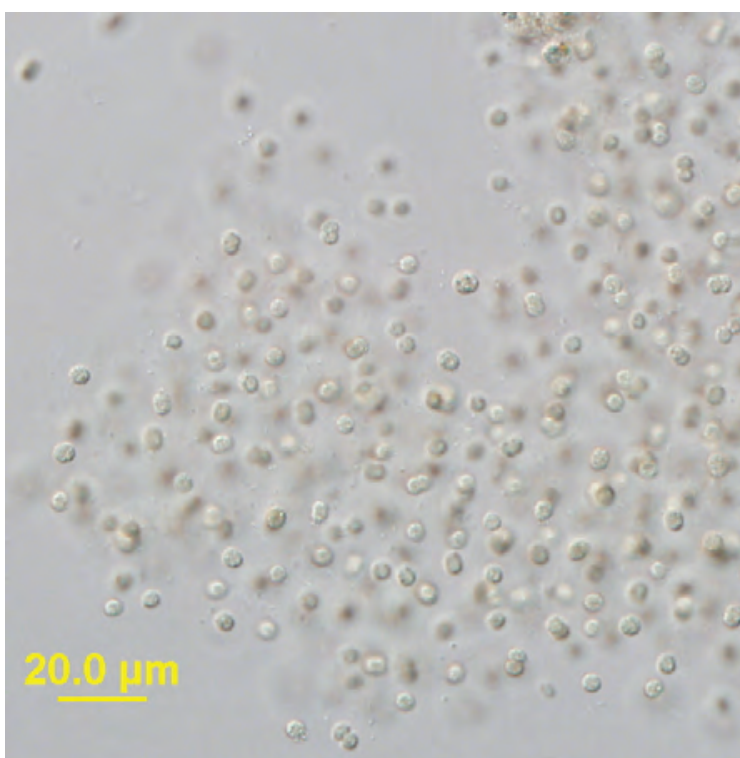

LM

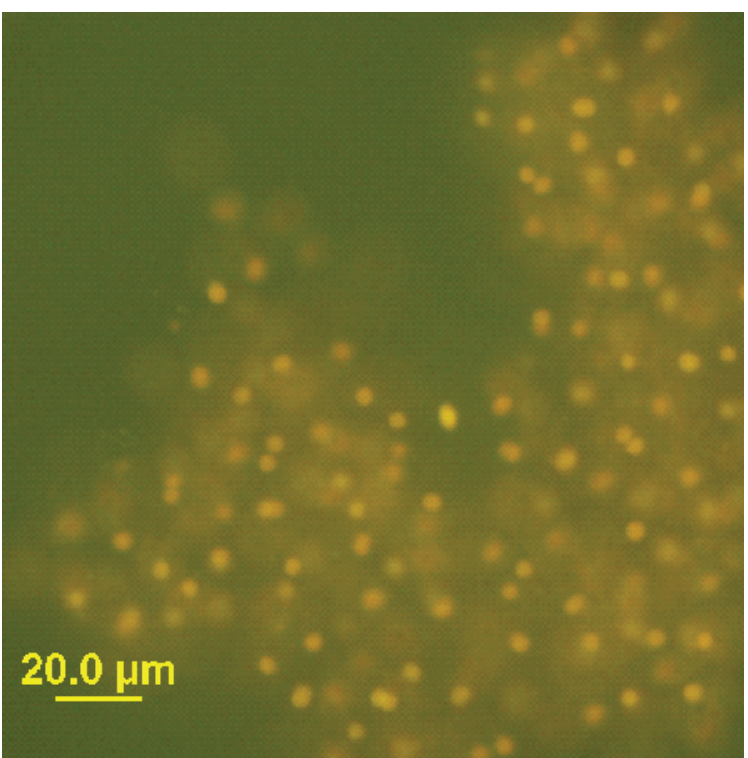

FITC

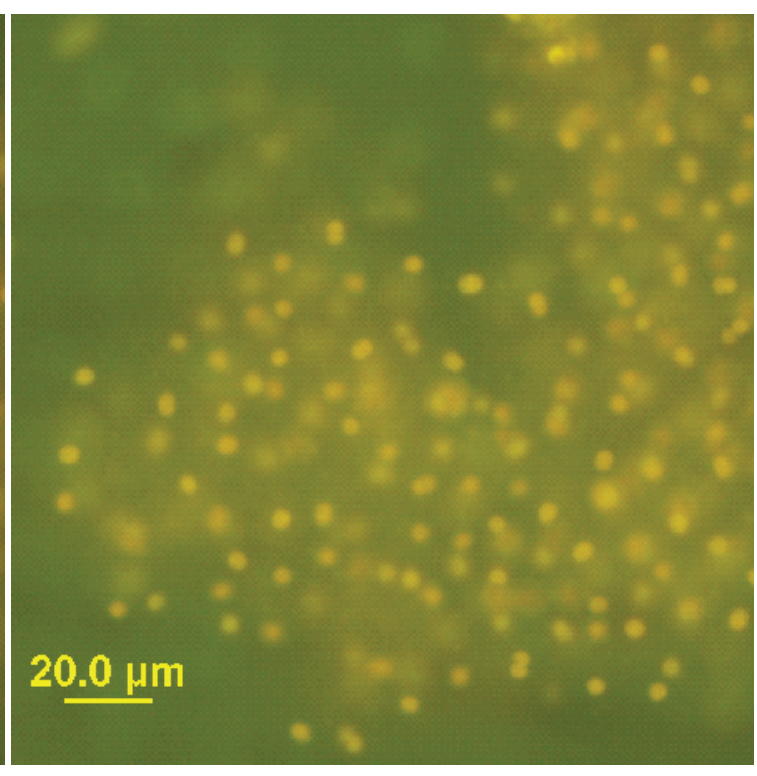

Sytox ${ }^{\circledR}$ green

\section{Autoclaved for 5 minutes}

Figure 7. Cassidy Lake, WA (10/12/2009). LM-Likely the remains of a Microcystis sp. FITC-a yellow-orange color dominates the cells. Sytox ${ }^{\circledR}$ green-stain did not penetrate the cell membrane. LM - differential interference contrast microscopy; FITC - epifluorescent microscopy; Sytox ${ }^{\circledR}$ green - epifluorescent microscopy in conjunction with the nucleic acid stain Sytox ${ }^{\circledR}$ green. 


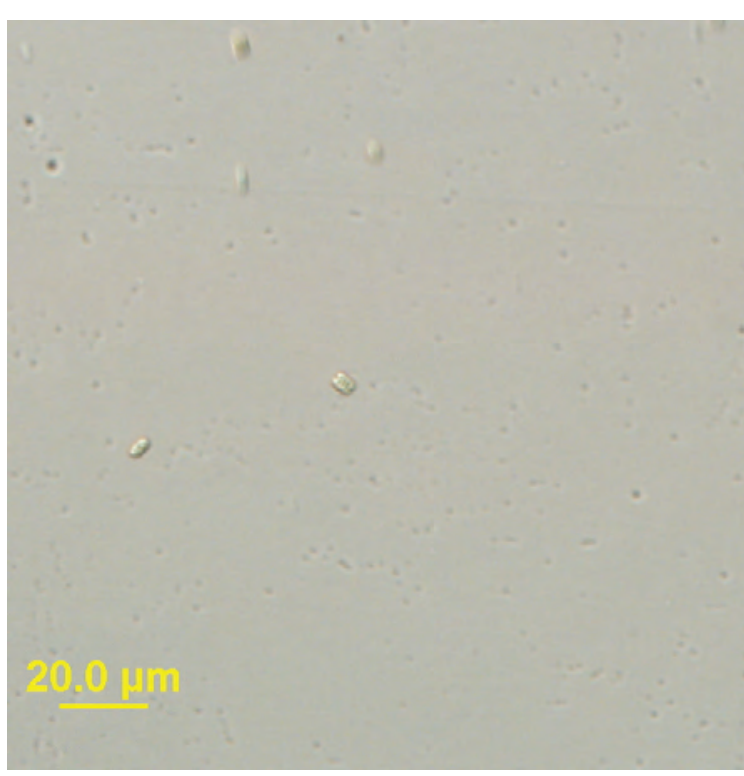

LM

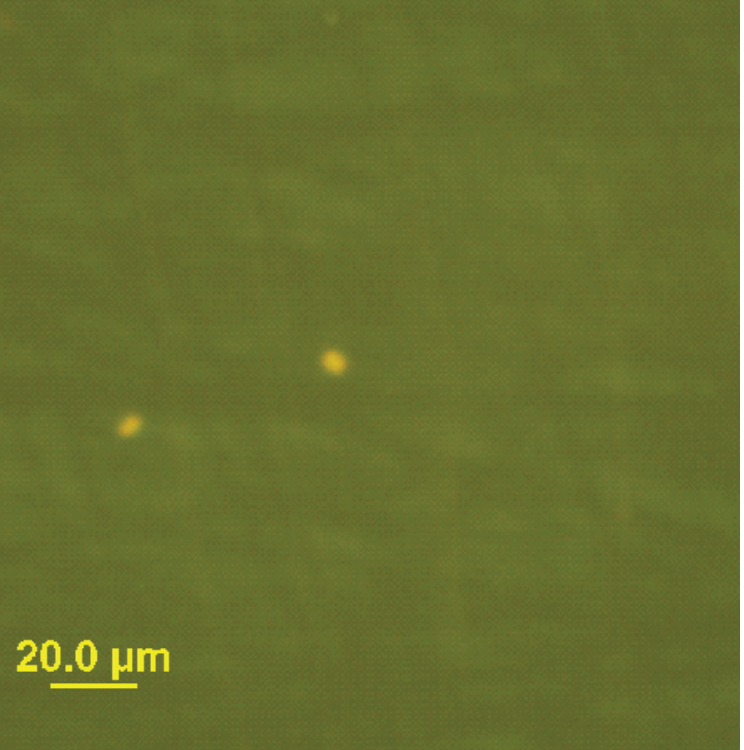

FITC

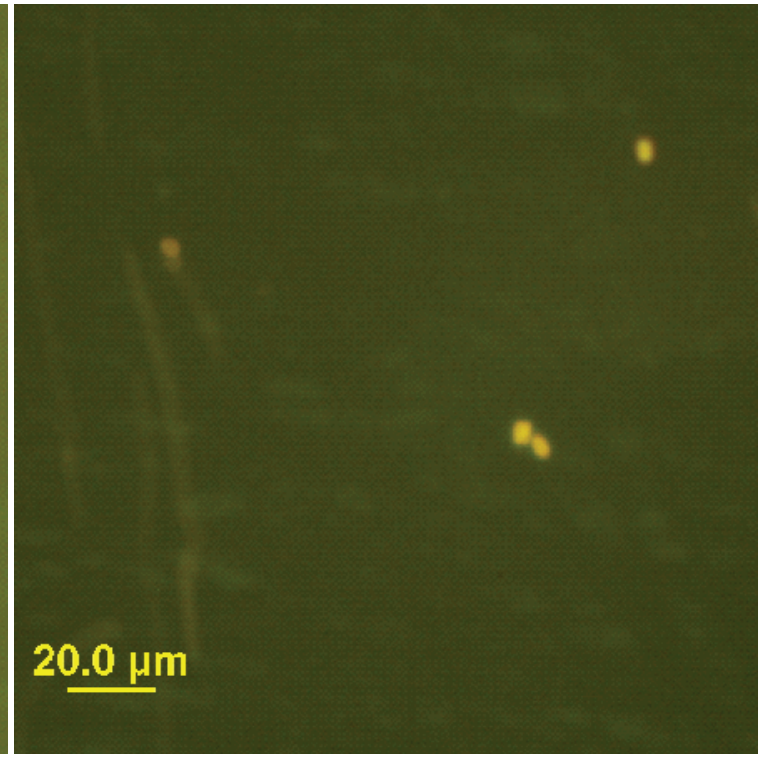

Sytox ${ }^{\circledR}$ green

Autoclaved for 15 minutes

Figure 8. Cassidy Lake, WA (10/12/2009). LM-Likely the remains of a colonial cyanobacterium. FITC-a yellow-orange color dominates the cells. Sytox ${ }^{\circledR}$ green-stain did not penetrate the cell membrane. LM - differential interference contrast microscopy; FITC - epifluorescent microscopy; Sytox ${ }^{\circledR}$ green - epifluorescent microscopy in conjunction with the nucleic acid stain Sytox ${ }^{\oplus}$ green. 


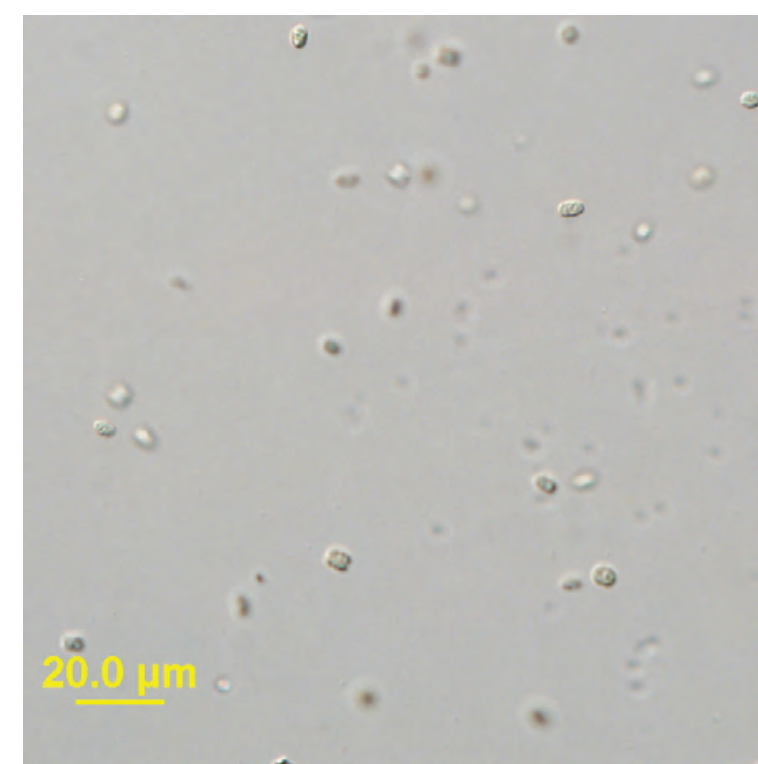

LM

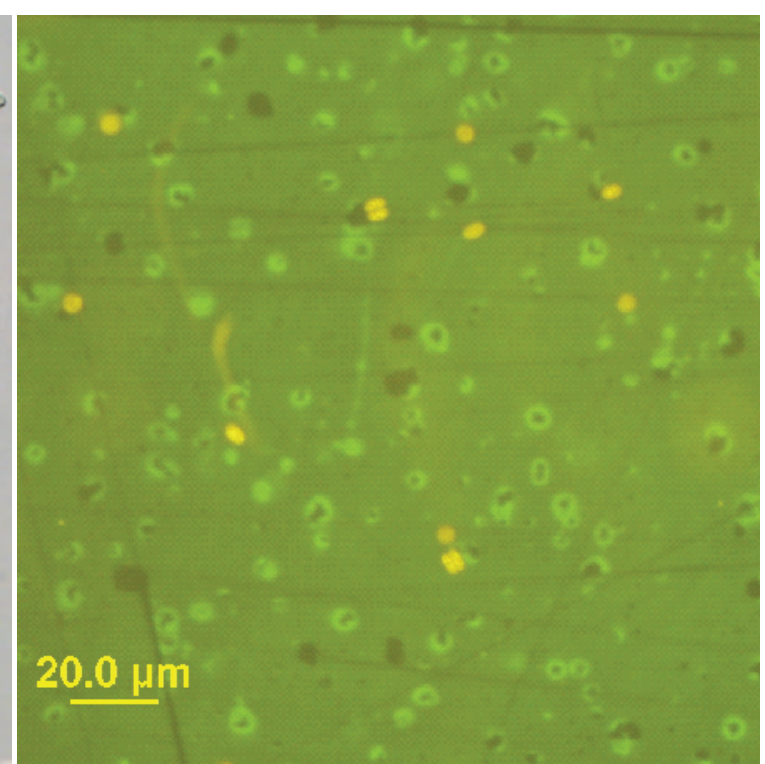

FITC

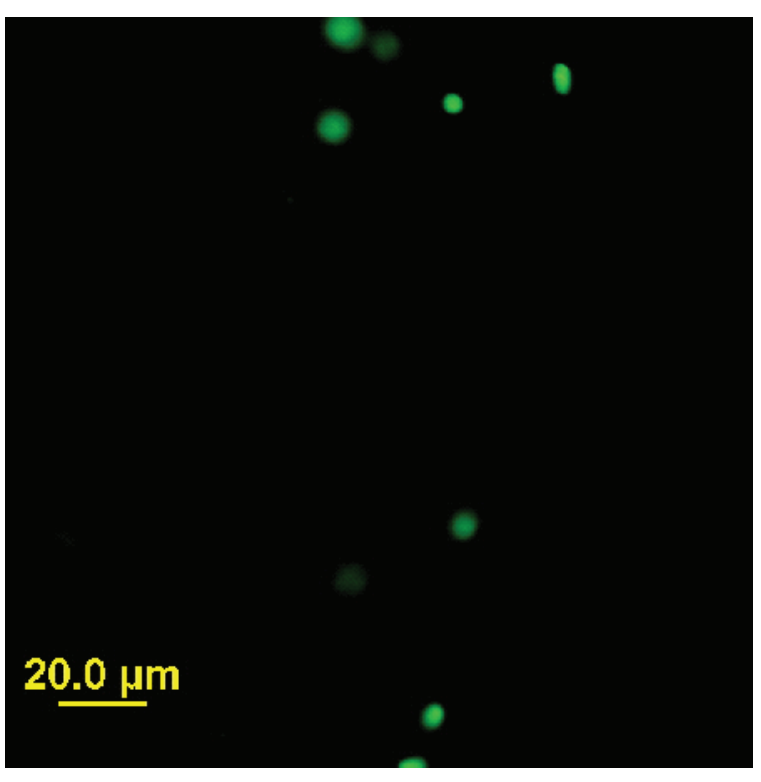

Sytox ${ }^{\circledR}$ green

Autoclaved for 30 minutes

Figure 9. Cassidy Lake, WA (10/12/2009). LM-Likely the remains of a colonial cyanobacterium. FITC-a yellow-orange color dominates the cells. Sytox ${ }^{\circledR}$ green-stain penetrated cell membranes; bright green cells. LM - differential interference contrast microscopy; FITC - epifluorescent microscopy; Sytox ${ }^{\circledR}$ green - epifluorescent microscopy in conjunction with the nucleic acid stain Sytox ${ }^{\circledR}$ green. 


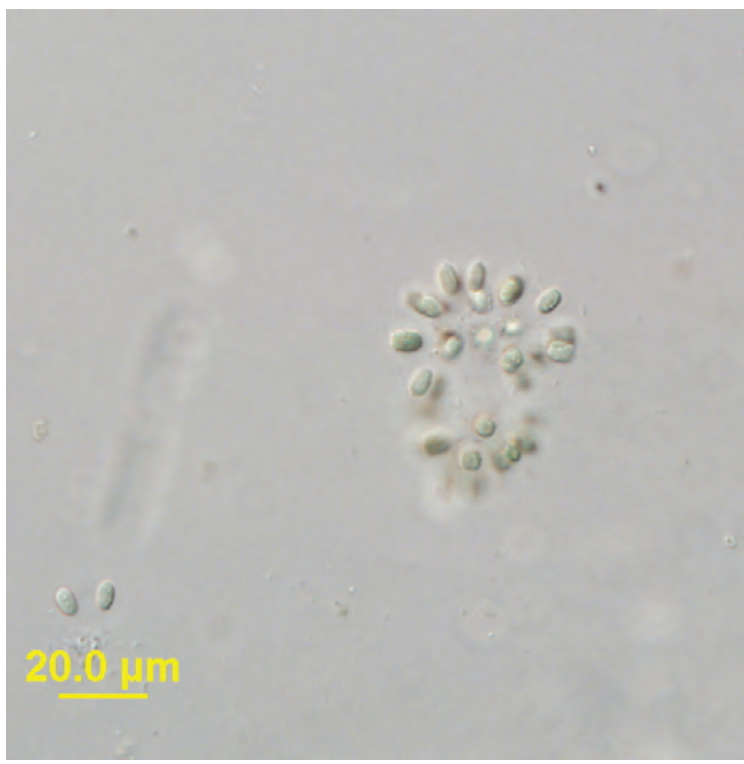

LM

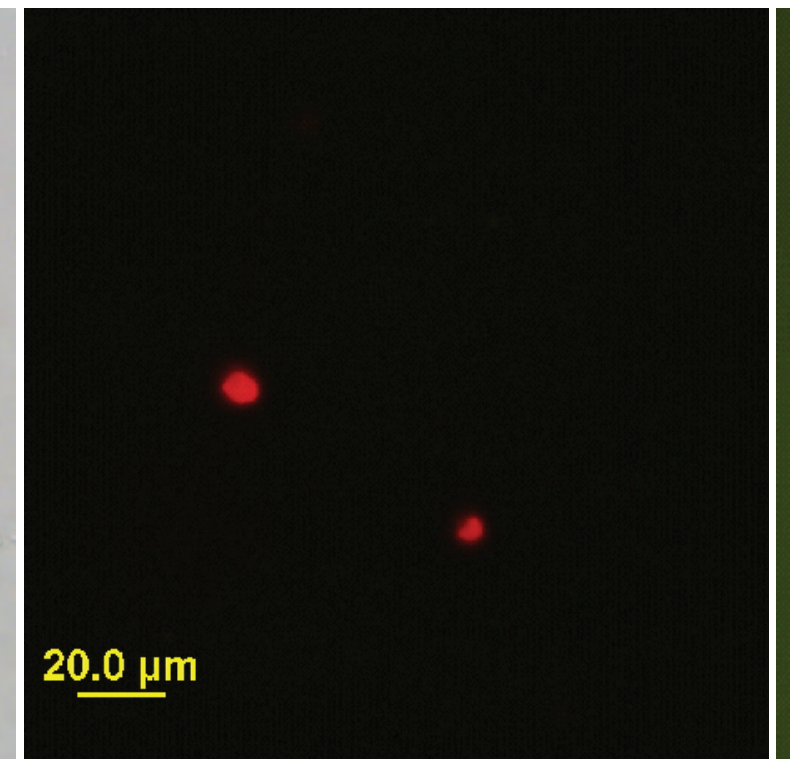

FITC

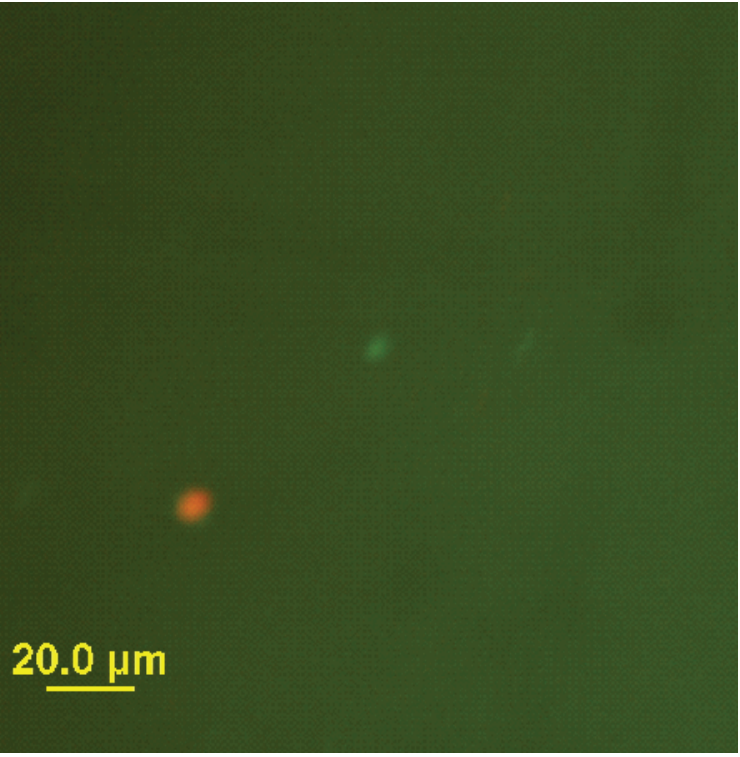

Sytox ${ }^{\circledR}$ green

Sonicated at 10 percent power

Figure 10. Cassidy Lake, WA (10/12/2009). LM-A colonial cyanobacterium. FITC-unknown organism; the cells were bright red. Sytox ${ }^{\circledR}$ green-unknown organisms; a single cell was observed and it was intact; stain did not penetrate the cell membrane. LM - differential interference contrast microscopy; FITC - epifluorescent microscopy; Sytox ${ }^{\circledR}$ green - epifluorescent microscopy in conjunction with the nucleic acid stain Sytox ${ }^{\circledR}$ green. 


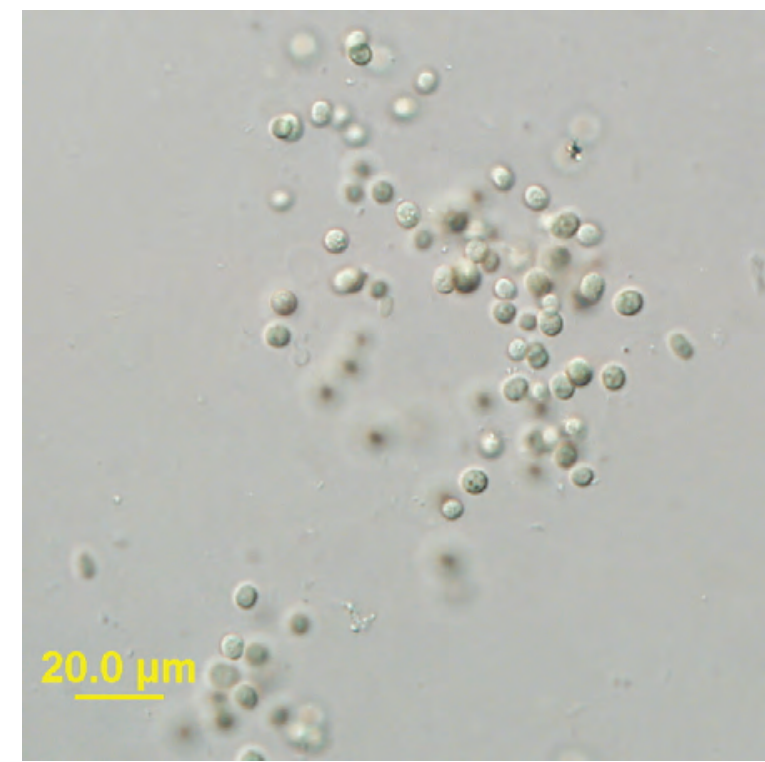

LM

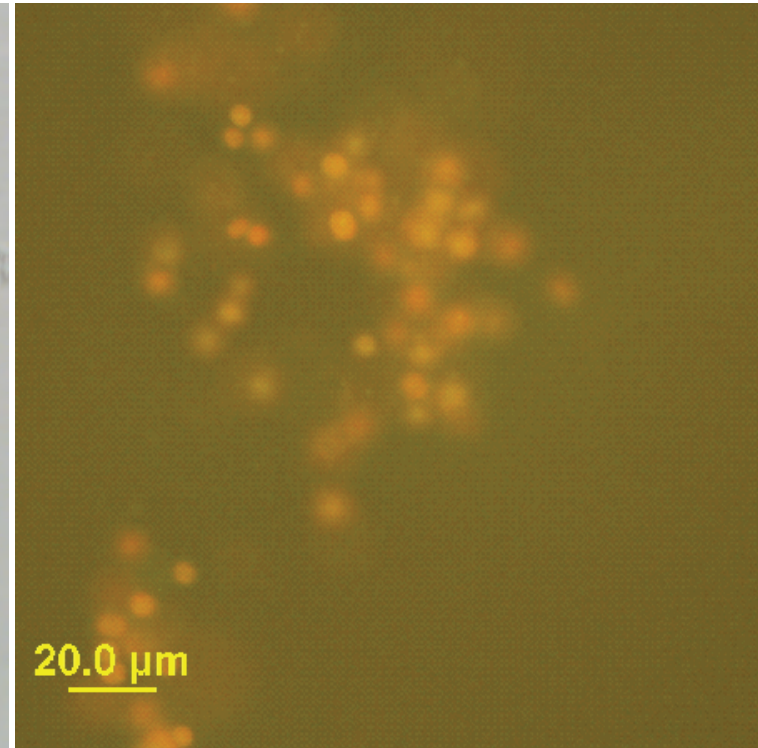

FITC

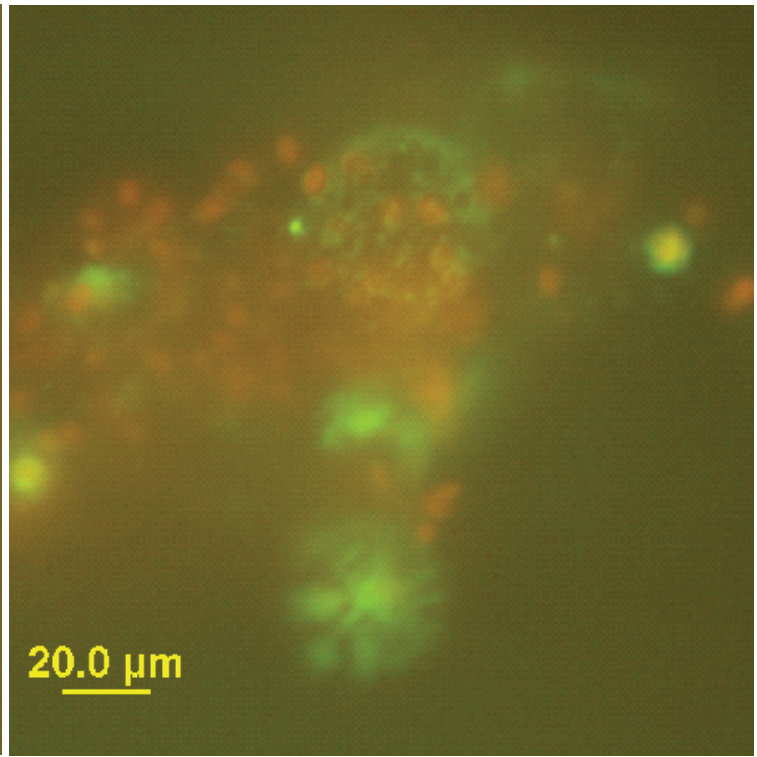

Sytox ${ }^{\circledR}$ green

\section{Sonicated at 35 percent power}

Figure 11. Cassidy Lake, WA (10/12/2009). LM-The remains of a colonial cyanobacterium. FITC-a red-orange color dominates the cells. Sytox ${ }^{\circledR}$ green-stain did not penetrated cell membranes of the cyanobacteria. LM - differential interference contrast microscopy; FITC - epifluorescent microscopy; Sytox ${ }^{\circledR}$ green - epifluorescent microscopy in conjunction with the nucleic acid stain Sytox ${ }^{\circledR}$ green. 


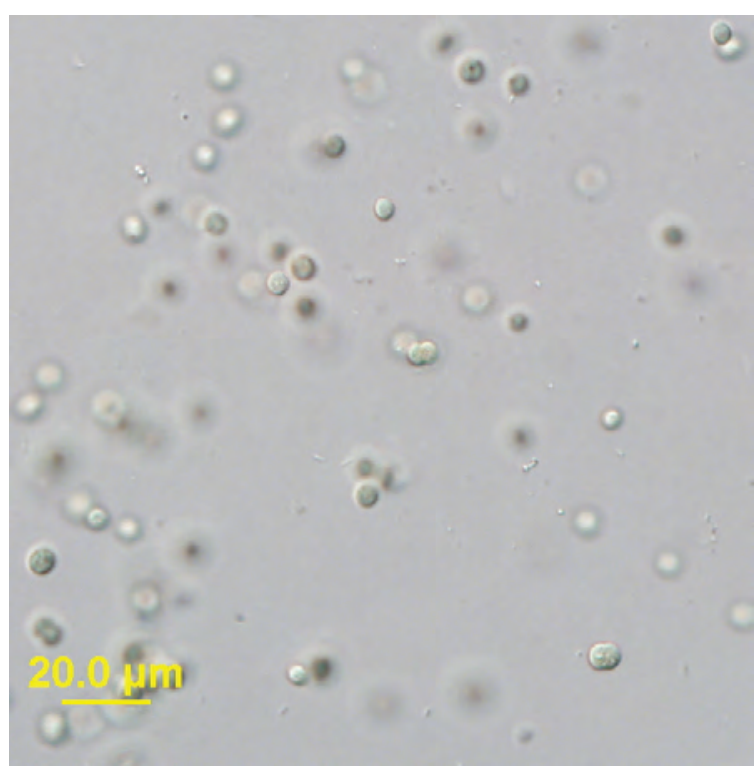

LM

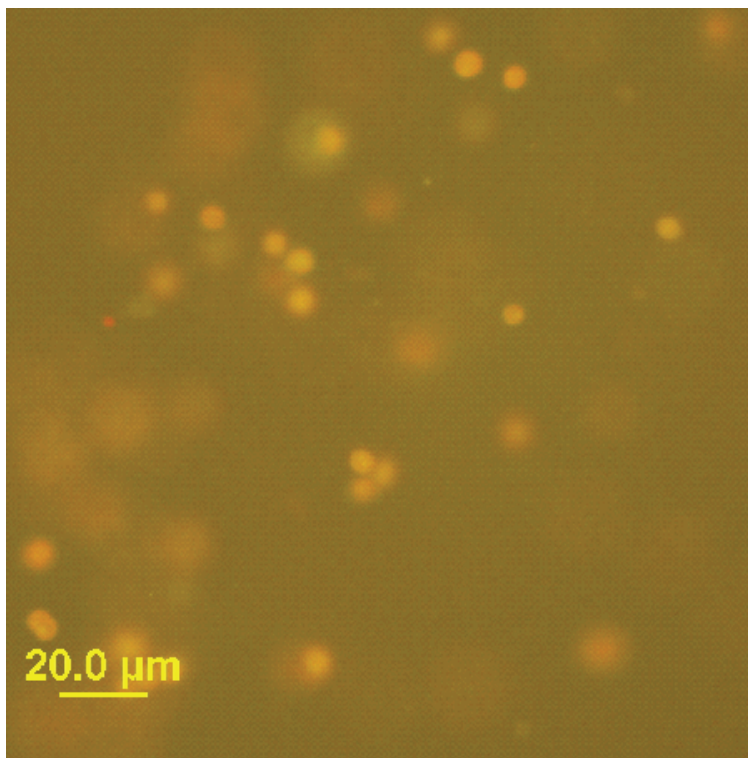

FITC

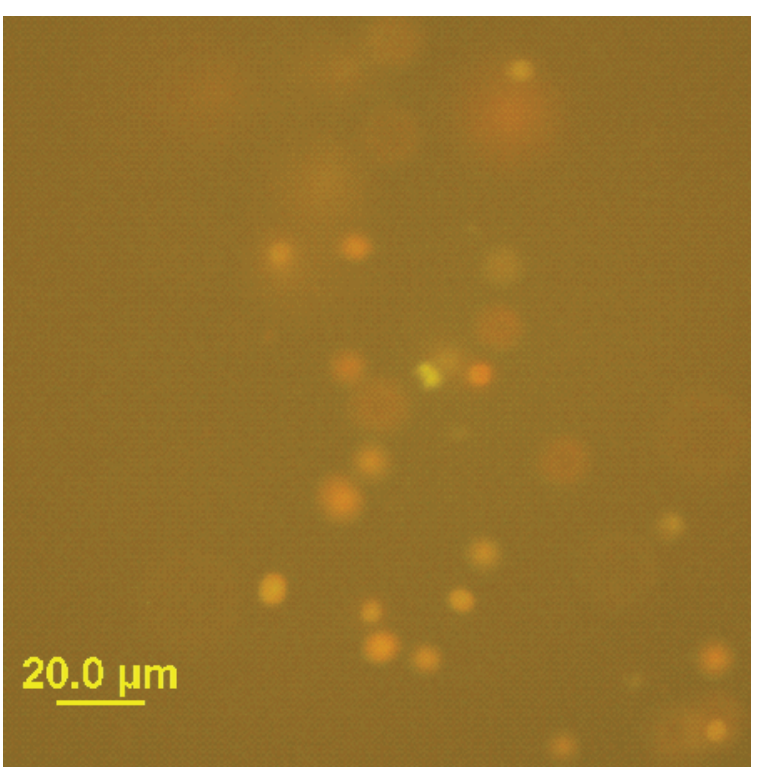

Sytox ${ }^{\circledast}$ green

\section{Sonicated at 70 percent power}

Figure 12. Cassidy Lake, WA (10/12/2009). LM-The remains of a colonial cyanobacterium. FITC-an orange color dominates the cells. Sytox ${ }^{\oplus}$ green-stain did not penetrate cell membranes of the cyanobacteria. LM - differential interference contrast microscopy; FITC - epifluorescent microscopy; Sytox ${ }^{\circledast}$ green - epifluorescent microscopy in conjunction with the nucleic acid stain Sytox ${ }^{\circledast}$ green. 


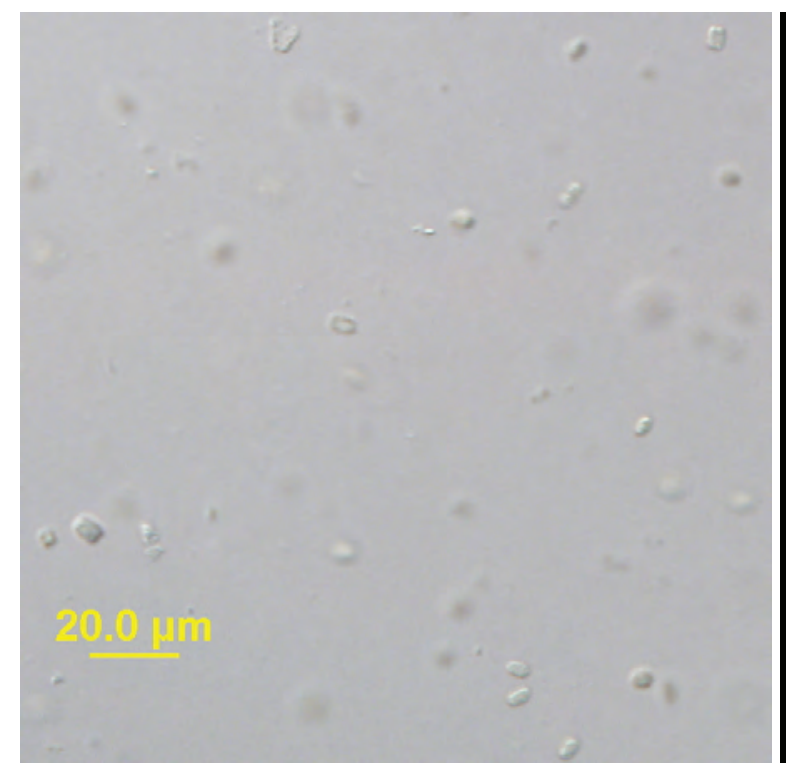

LM

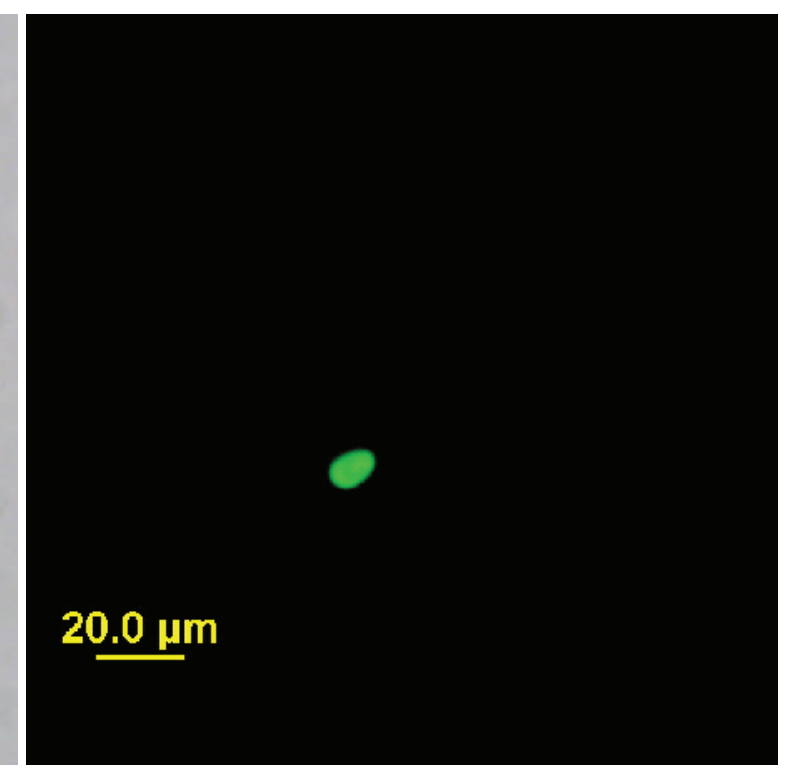

Sytox ${ }^{\circledR}$ green

\section{One freeze-thaw cycle}

Figure 13. Cassidy Lake, WA (10/12/2009). LM-The remains of colonial cyanobacteria. FITC-no image or data collected. Sytox ${ }^{\circledR}$ green-stain penetrated the cell membrane of this unknown organism; bright green cell. LM differential interference contrast microscopy; FITC - epifluorescent microscopy; Sytox ${ }^{\circledR}$ green - epifluorescent microscopy in conjunction with the nucleic acid stain Sytox ${ }^{\circledR}$ green. 


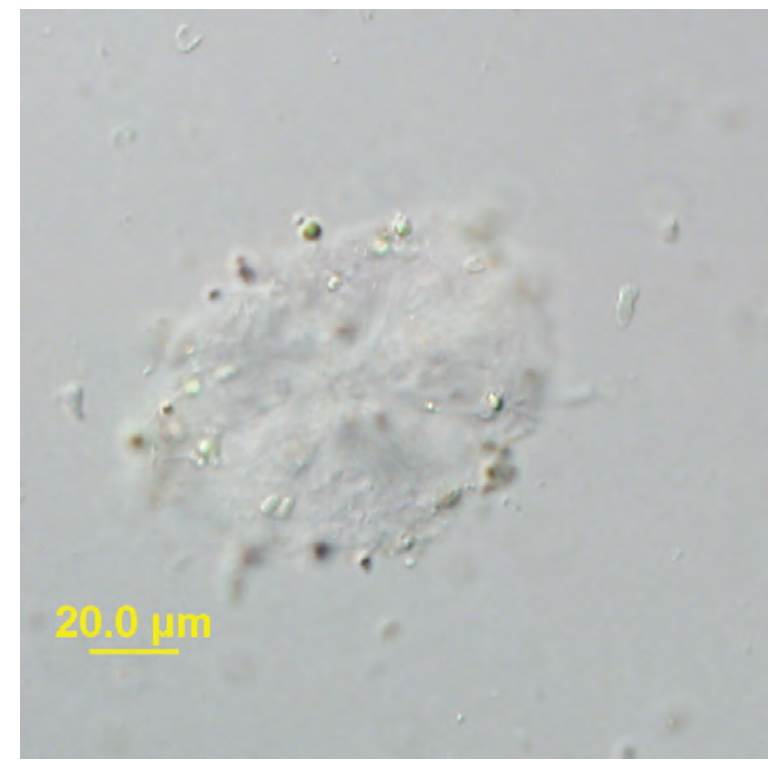

LM

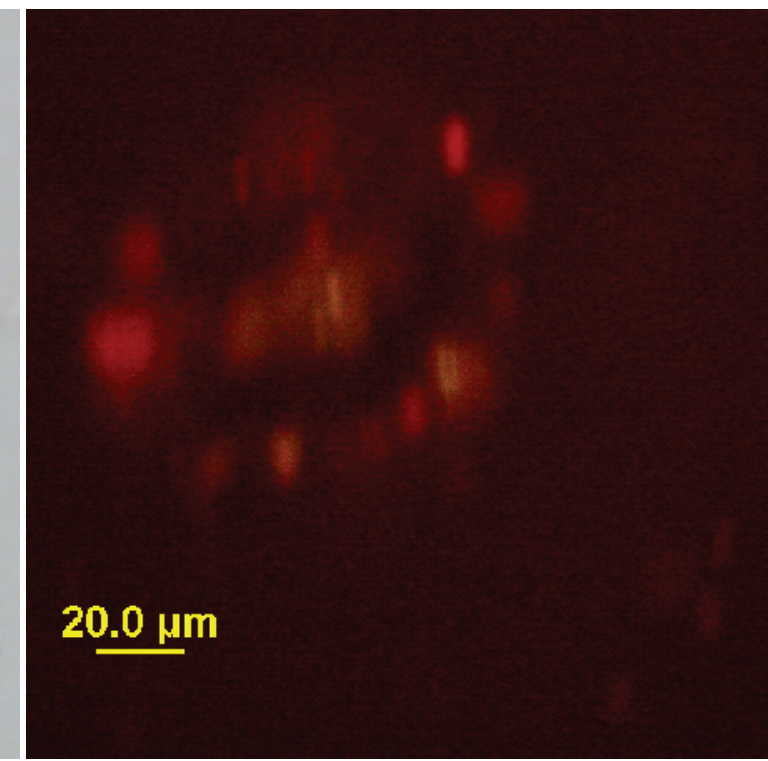

FITC

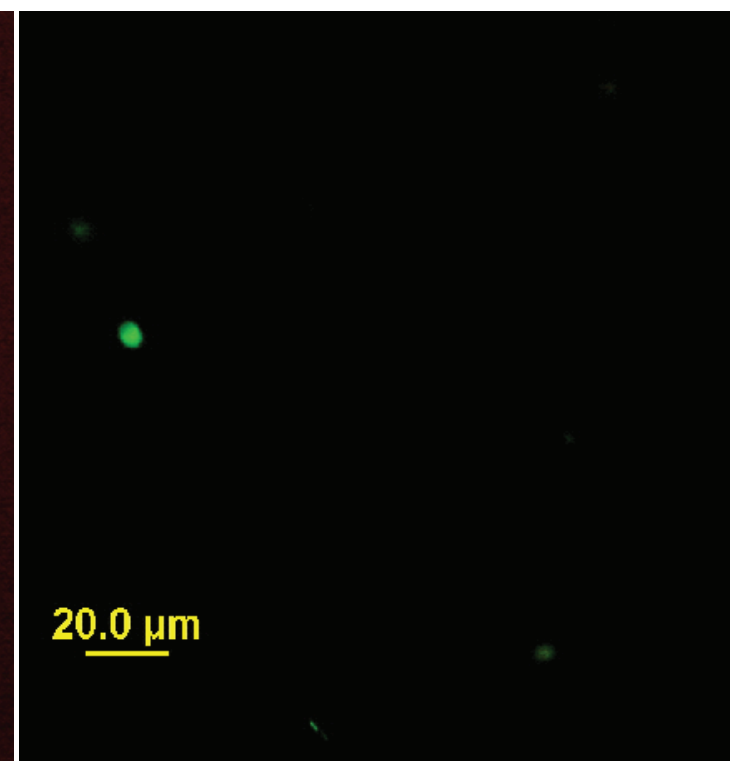

Sytox ${ }^{\circledR}$ green

Three freeze-thaw cycles

Figure 14. Cassidy Lake, WA (10/12/2009). LM-The remains of a colonial cyanobacterium; note, the mucilage that supports the cell remains. FITC-a red-orange color dominates the cells; cell shape distorted because of long photographic exposure time. Sytox ${ }^{\circledR}$ green-stain penetrated the cell membrane of this unknown organism; bright green cell. LM - differential interference contrast microscopy; FITC - epifluorescent microscopy; Sytox ${ }^{\circledR}$ green - epifluorescent microscopy in conjunction with the nucleic acid stain Sytox ${ }^{\circledast}$ green. 


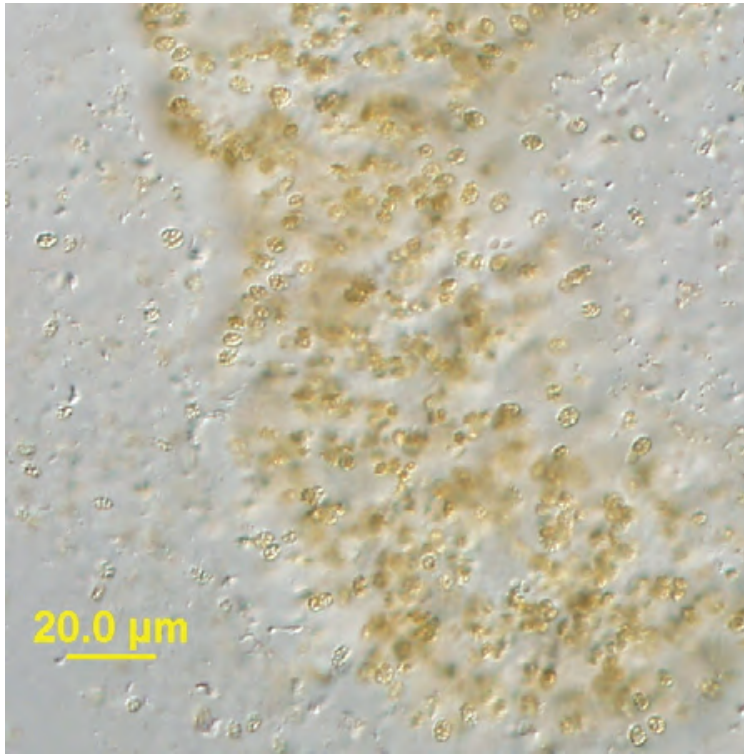

LM

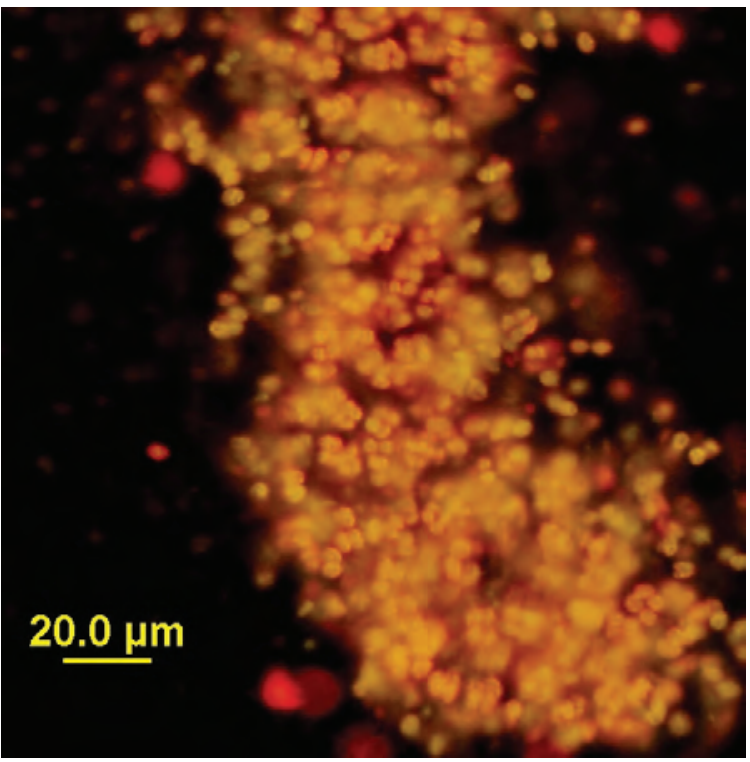

FITC

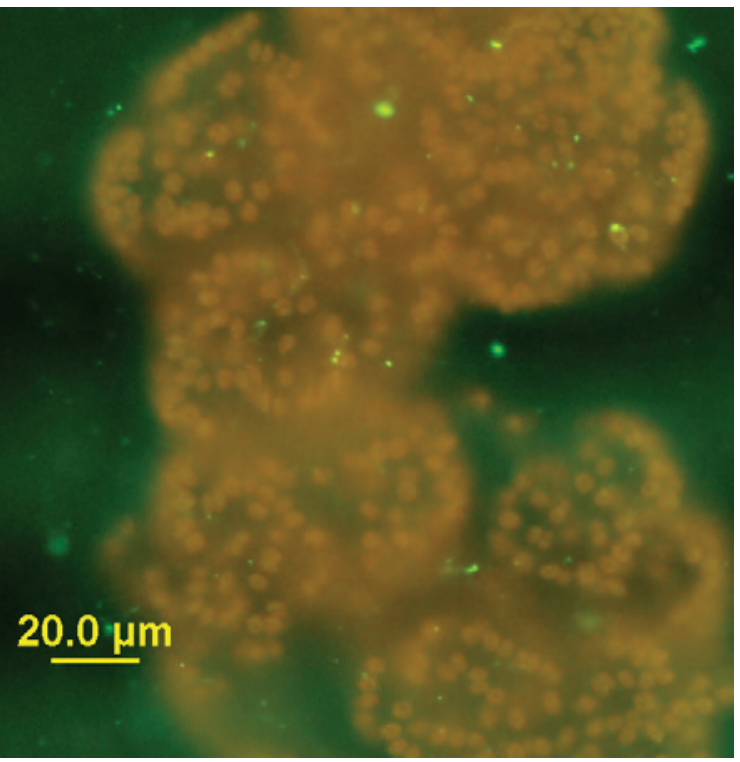

Sytox ${ }^{\circledR}$ green

Control 1

Figure 15. Spring Lake, CA (8/21/2009). LM-Microcystis aeruginosa colonial cyanobacterium with cells in a gelatinous matrix. FITC-a reddish-orange color dominates the cells. The scattered bright red cells are eukaryotic algal epiphytes. Sytox ${ }^{\circledR}$ green-Woronichinia naegeliana, stain did not penetrate the cell membrane. LM - differential interference contrast microscopy; FITC - epifluorescent microscopy; Sytox ${ }^{\circledR}$ green - epifluorescent microscopy in conjunction with the nucleic acid stain Sytox ${ }^{\circledR}$ green 


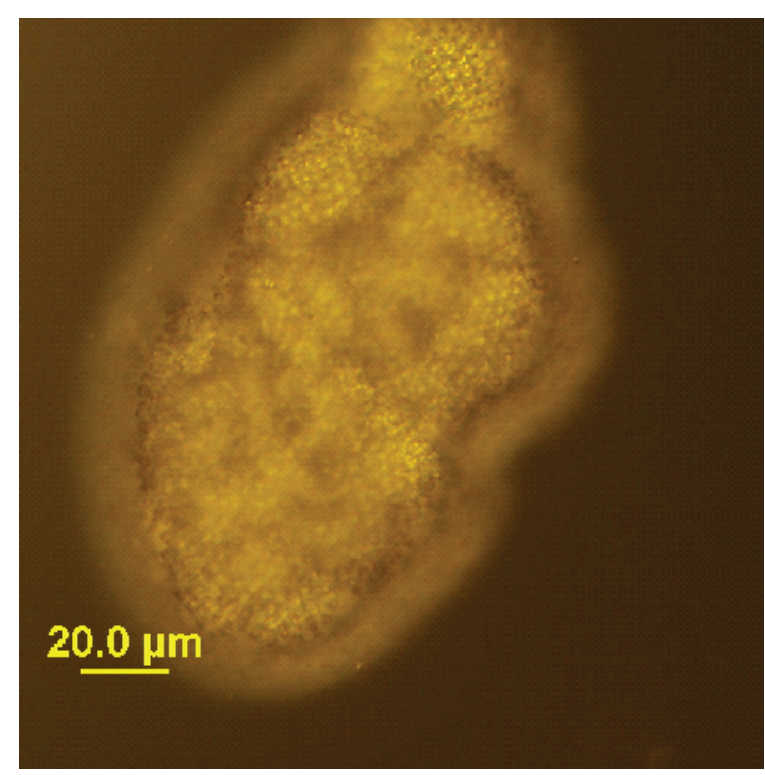

LM

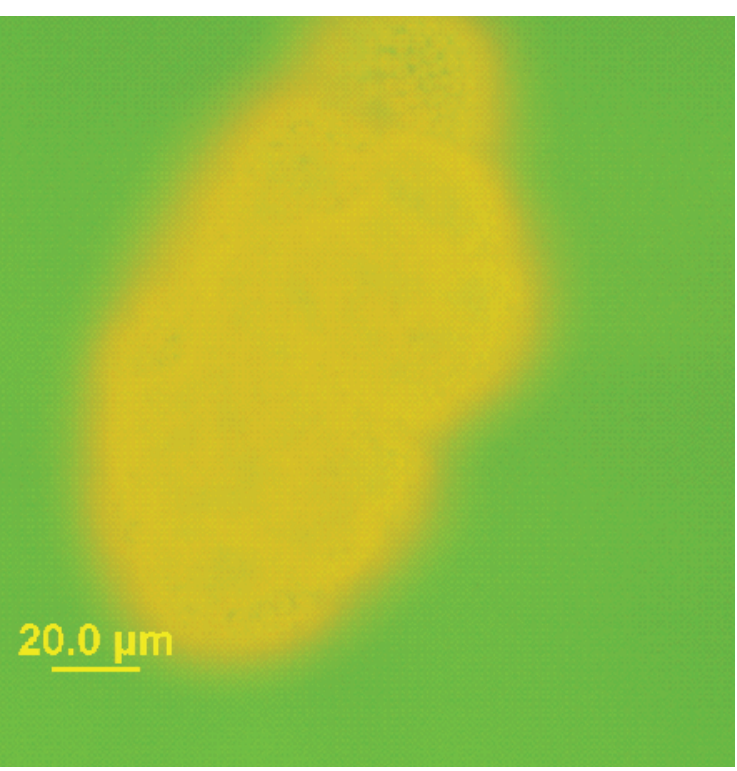

FITC

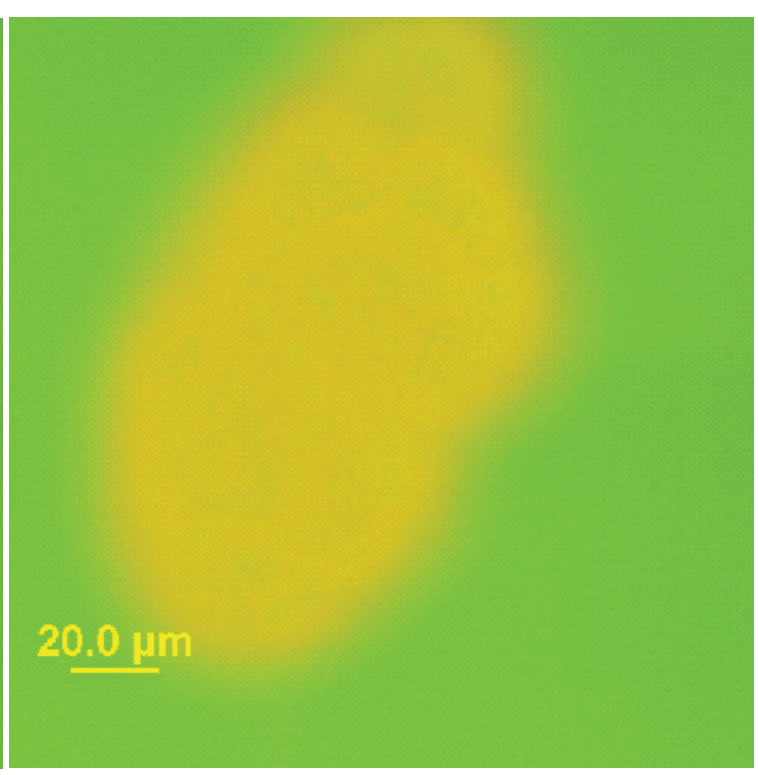

Sytox ${ }^{\circledR}$ green

\section{Control 2}

Figure 16. Spring Lake, CA (8/21/2009). LM-Microcystis aeruginosa. The same colony was used for all three images. FITC-a yellow color dominates the cells. Sytox ${ }^{\circledR}$ green-stain did not penetrate the cell membrane. LM - differential interference contrast microscopy; FITC - epifluorescent microscopy; Sytox ${ }^{\circledR}$ green - epifluorescent microscopy in conjunction with the nucleic acid stain Sytox ${ }^{\circledast}$ green. 


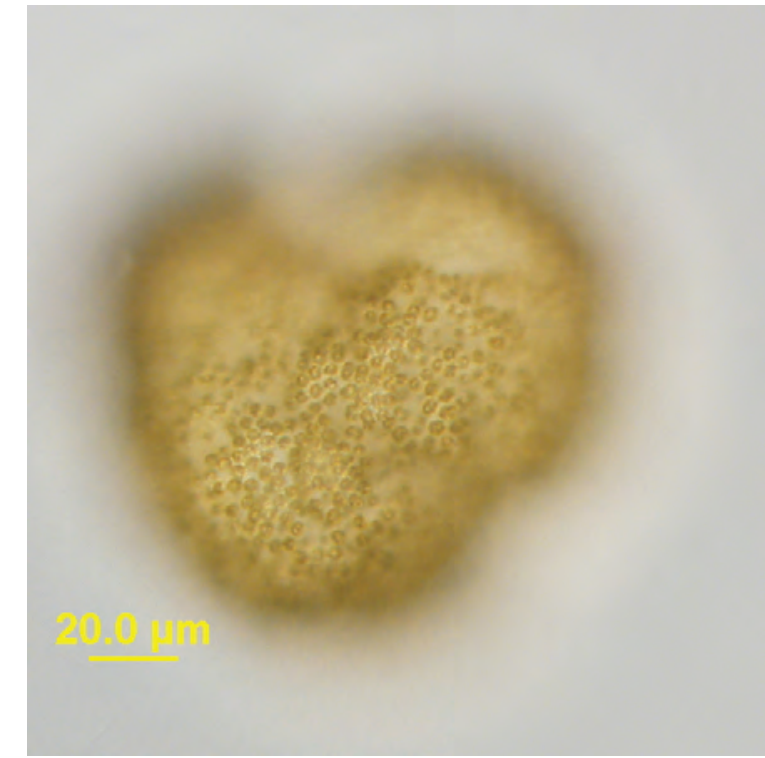

LM

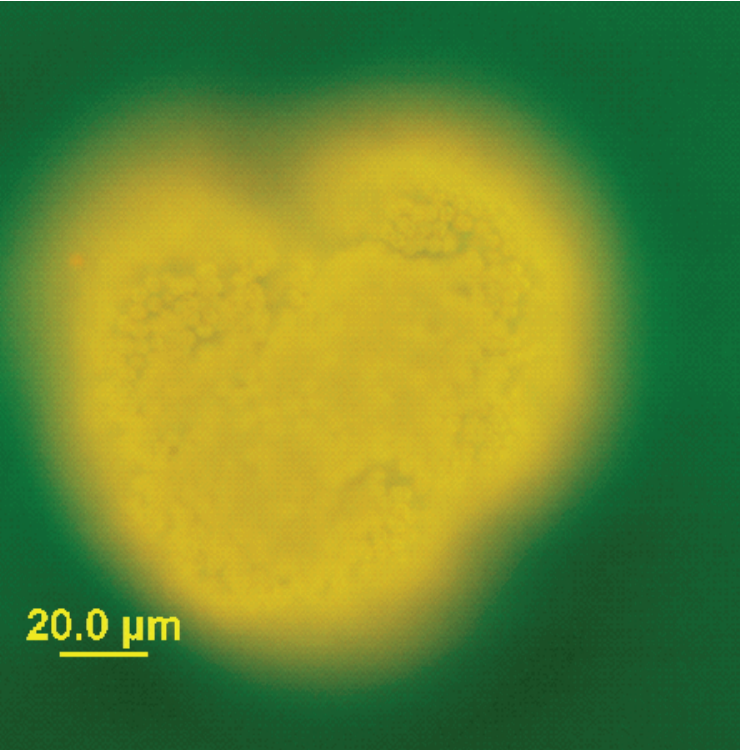

FITC

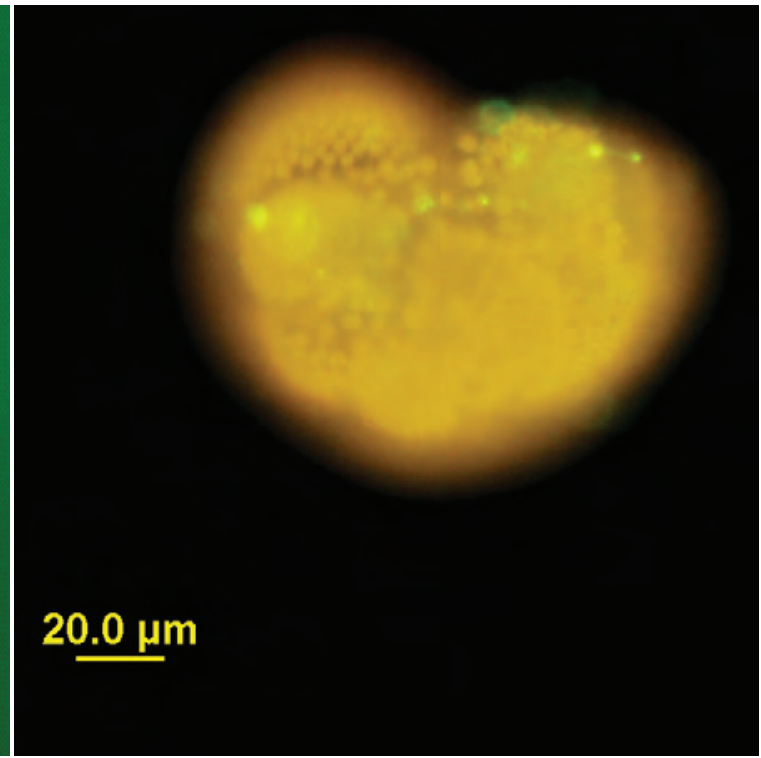

Sytox ${ }^{\circledR}$ green

Control 3

Figure 17. Spring Lake, CA (8/21/2009). LM-Woronichinia naegeliana. FITC-a yellow color dominates the cells. Sytox ${ }^{\circledR}$ green- stain did not penetrate the cell membrane. LM - differential interference contrast microscopy; FITC - epifluorescent microscopy; Sytox ${ }^{\circledR}$ green - epifluorescent microscopy in conjunction with the nucleic acid stain Sytox ${ }^{\circledR}$ green. 


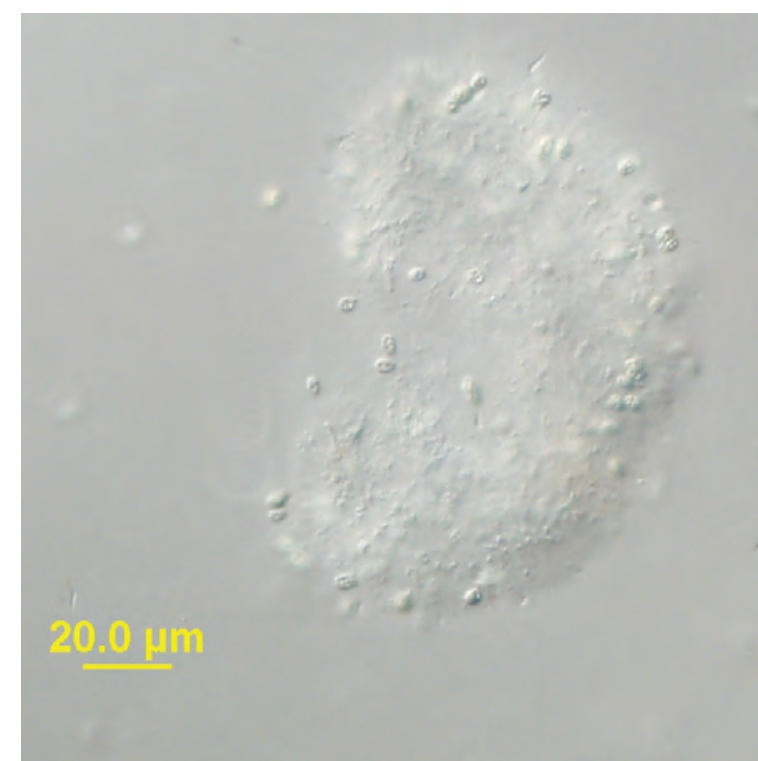

LM

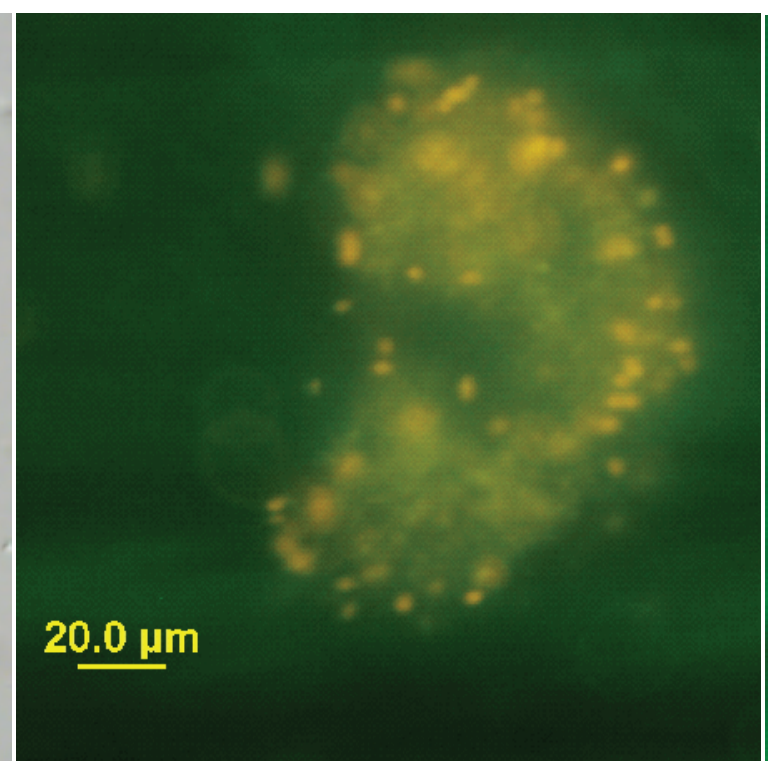

FITC

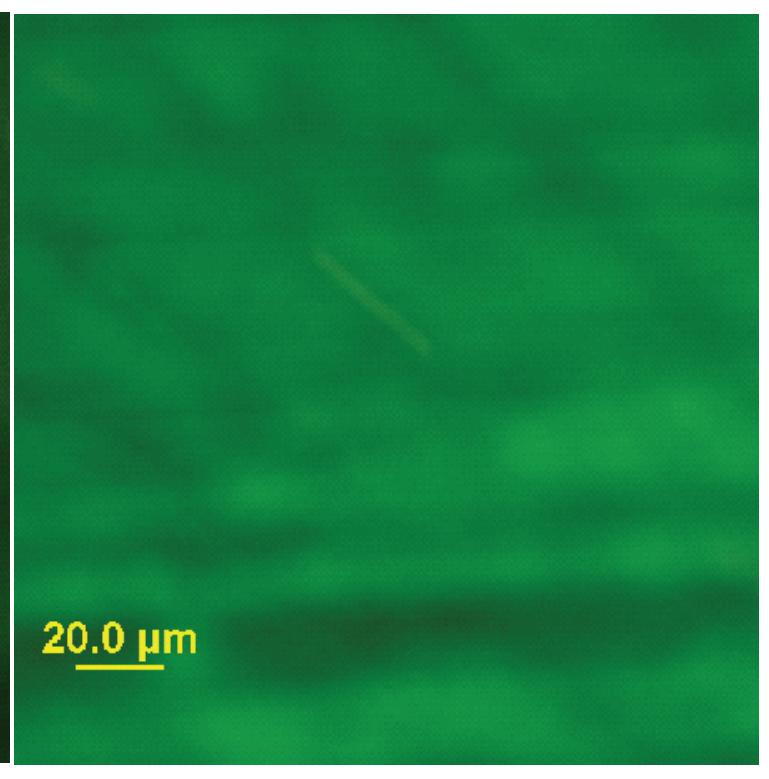

Sytox ${ }^{\circledR}$ green

\section{Boiled for 5 minutes}

Figure 18. Spring Lake, CA (8/21/2009). LM-The remains of colonial cyanobacteria; note, the mucilage that supports the cells remains. FITC-a yellow-orange color dominates the cells. Sytox ${ }^{\oplus}$ green-nothing detectable. LM - differential interference contrast microscopy; FITC - epifluorescent microscopy; Sytox ${ }^{\circledR}$ green - epifluorescent microscopy in conjunction with the nucleic acid stain Sytox ${ }^{\circledR}$ green. 


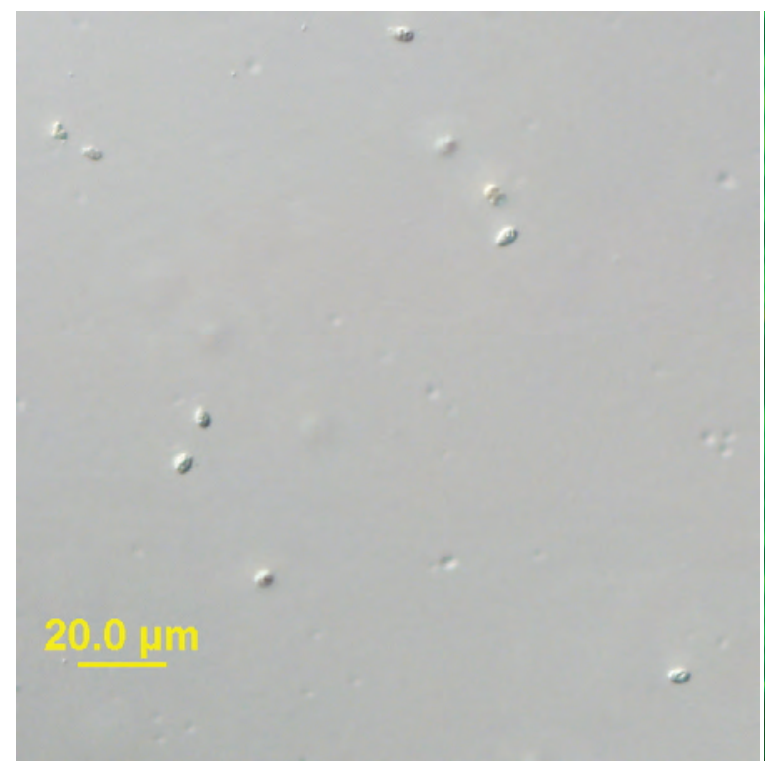

LM

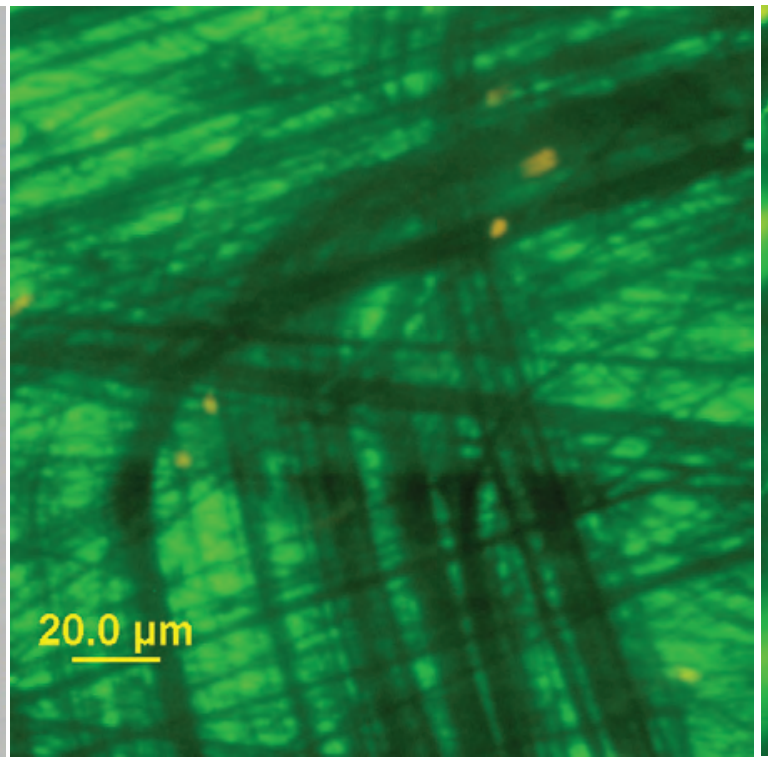

FITC

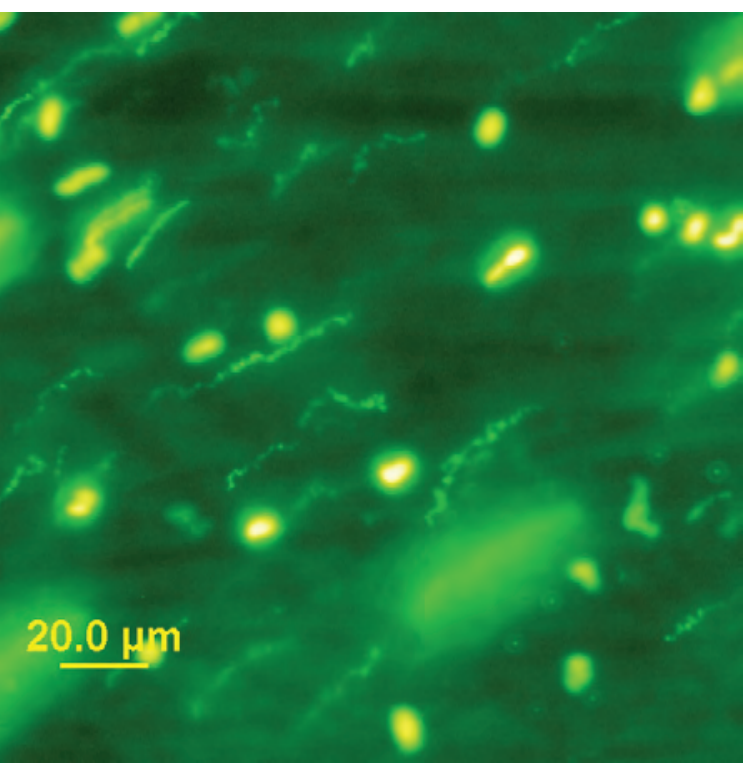

Sytox ${ }^{\circledR}$ green

Boiled for 15 minutes

Figure 19. Spring Lake, CA (8/21/2009). LM-The remains of a colonial cyanobacterium. FITC-an orange color dominates the cells. Sytox ${ }^{\circledR}$ green-stain penetrated the cell membrane of this unknown organism; bright green cell. LM - differential interference contrast microscopy; FITC - epifluorescent microscopy; Sytox ${ }^{\circledR}$ green epifluorescent microscopy in conjunction with the nucleic acid stain Sytox ${ }^{\circledR}$ green. 


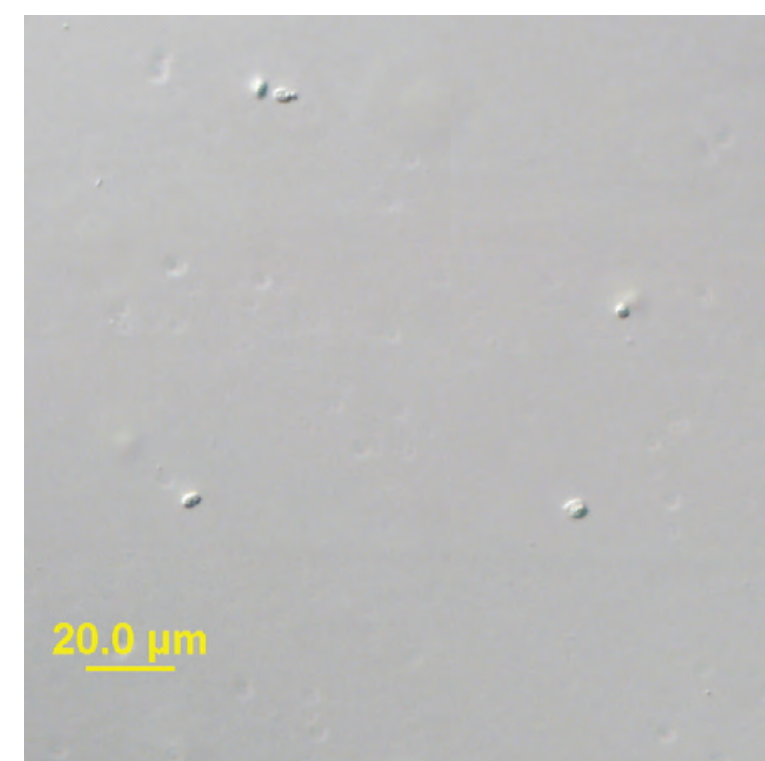

LM

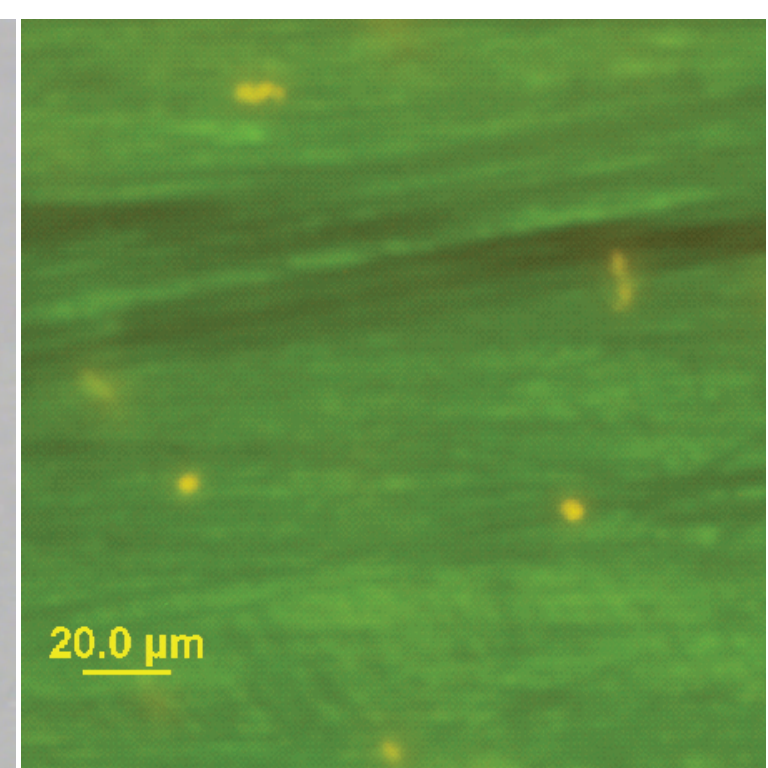

FITC

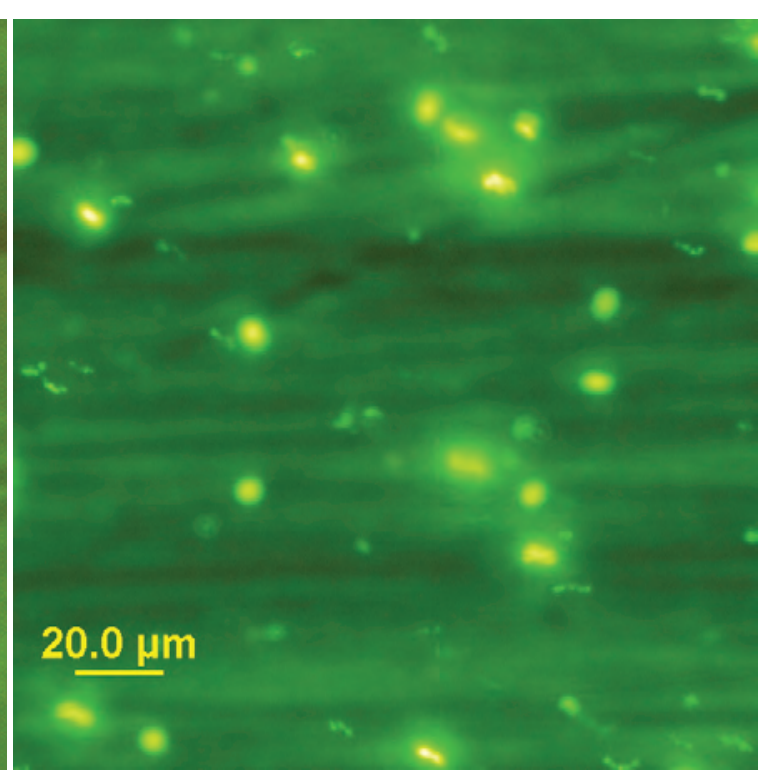

Sytox ${ }^{\circledR}$ green

\section{Boiled for 30 minutes}

Figure 20. Spring Lake, CA (8/21/2009). LM-The remains of a colonial cyanobacterium. FITC-an orange color dominates the cells. Sytox ${ }^{\circledR}$ green-stain penetrated the cell membrane of this unknown organism; bright green cell. LM - differential interference contrast microscopy; FITC - epifluorescent microscopy; Sytox ${ }^{\circledR}$ green epifluorescent microscopy in conjunction with the nucleic acid stain Sytox ${ }^{\circledR}$ green. 


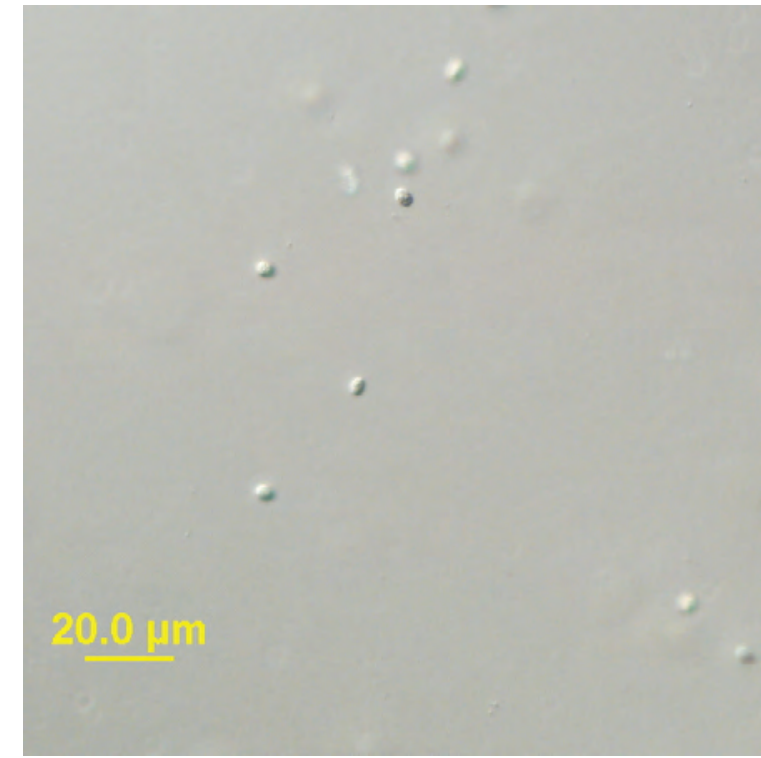

LM

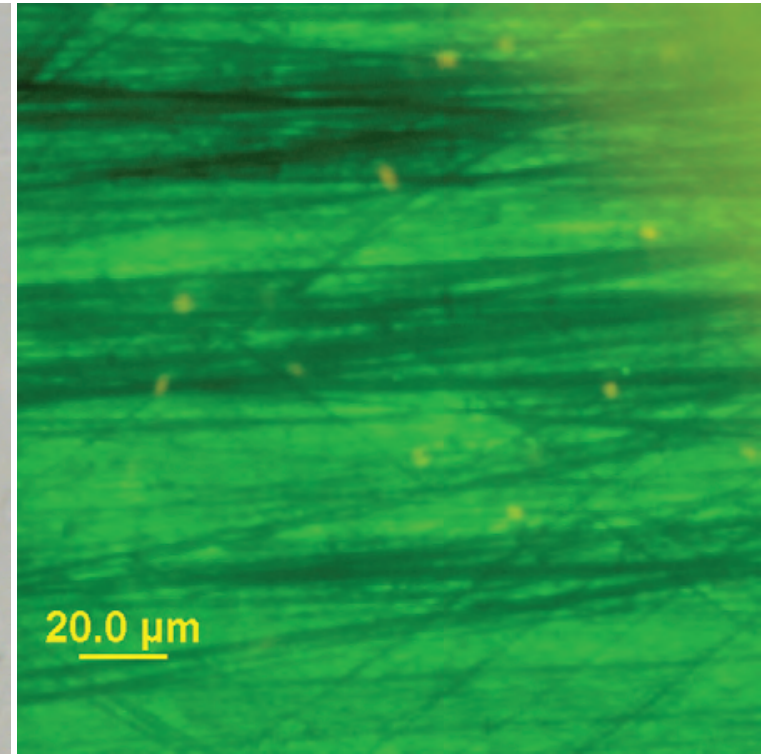

FITC

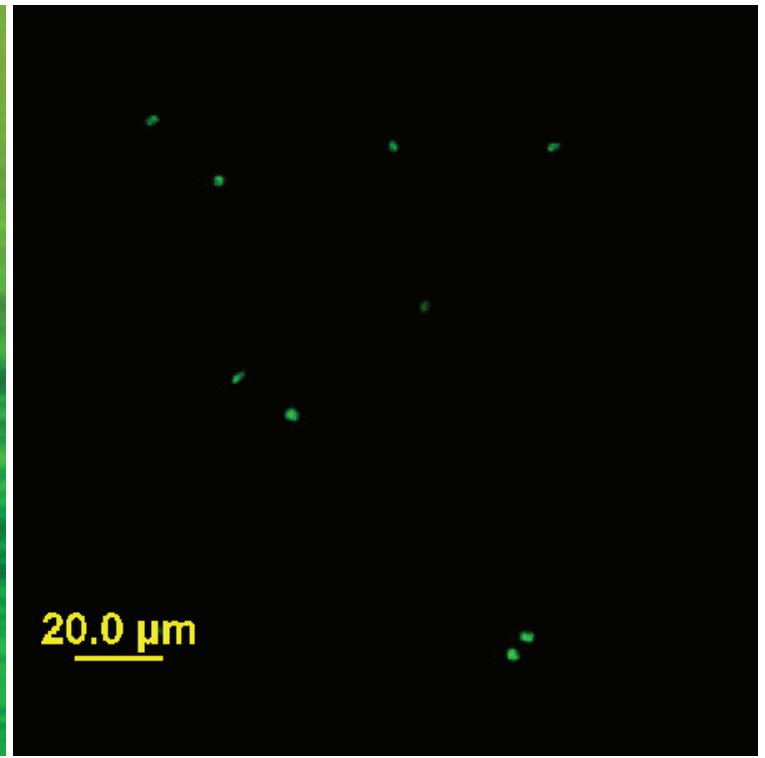

Sytox ${ }^{\circledR}$ green

\section{Autoclaved for 5 minutes}

Figure 21. Spring Lake, CA (8/21/2009). LM-The remains of a colonial cyanobacterium. FITC-an orange color dominates the cells. Sytox ${ }^{\circledR}$ green-stain penetrated the cell membrane of this unknown organism; bright green cell. LM - differential interference contrast microscopy; FITC - epifluorescent microscopy; Sytox ${ }^{\circledR}$ green epifluorescent microscopy in conjunction with the nucleic acid stain Sytox ${ }^{\circledR}$ green. 


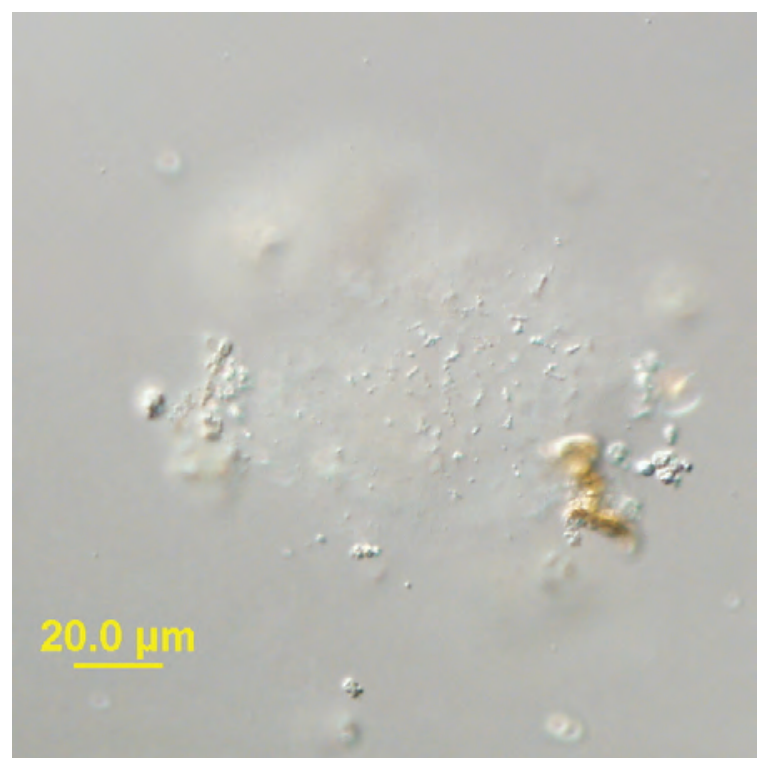

LM

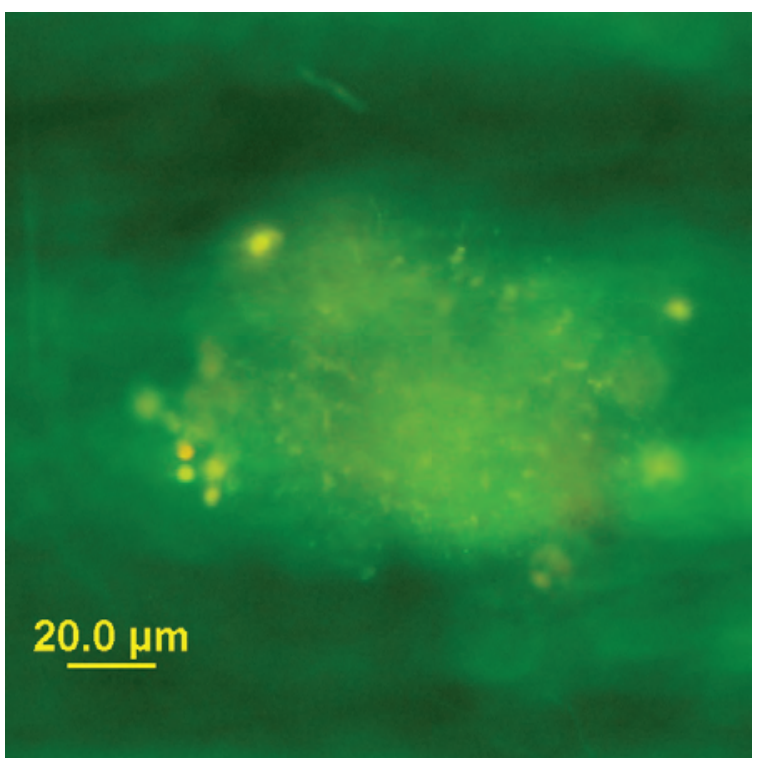

FITC

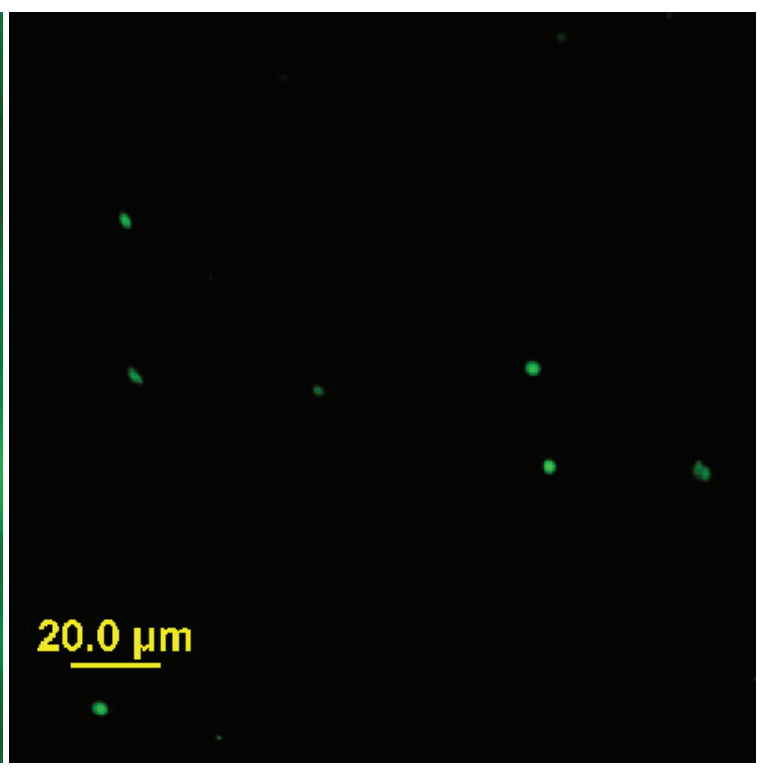

Sytox ${ }^{\circledR}$ green

Autoclaved for 15 minutes

Figure 22. Spring Lake, CA (8/21/2009). LM-The remains of a colonial cyanobacterium. FITC-a yellow-orange color dominates the cells. Sytox ${ }^{\circledR}$ green-stain penetrated the cell membrane of this unknown organism; bright green cell. LM - differential interference contrast microscopy; FITC - epifluorescent microscopy; Sytox ${ }^{\circledR}$ green epifluorescent microscopy in conjunction with the nucleic acid stain Sytox ${ }^{\circledR}$ green. 


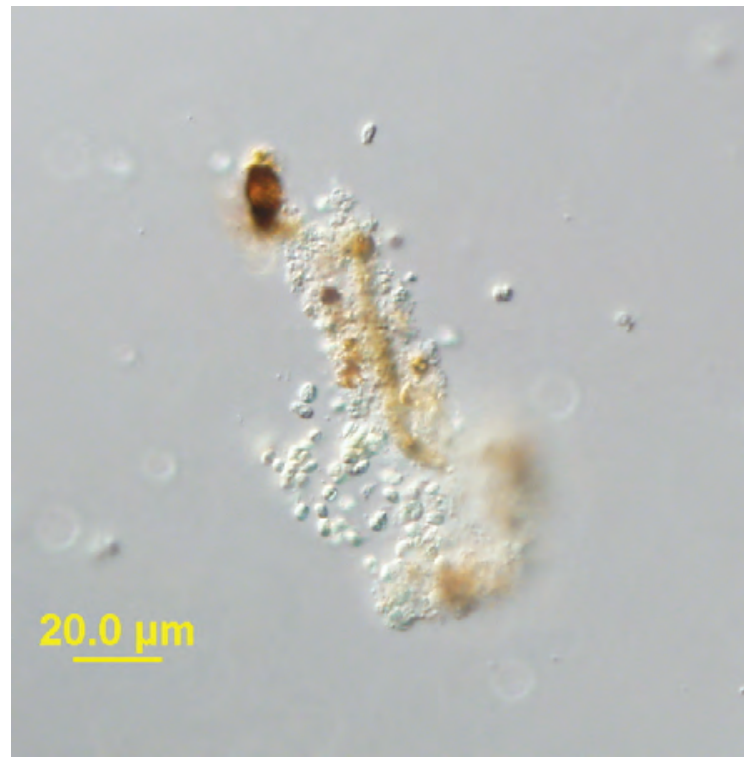

LM

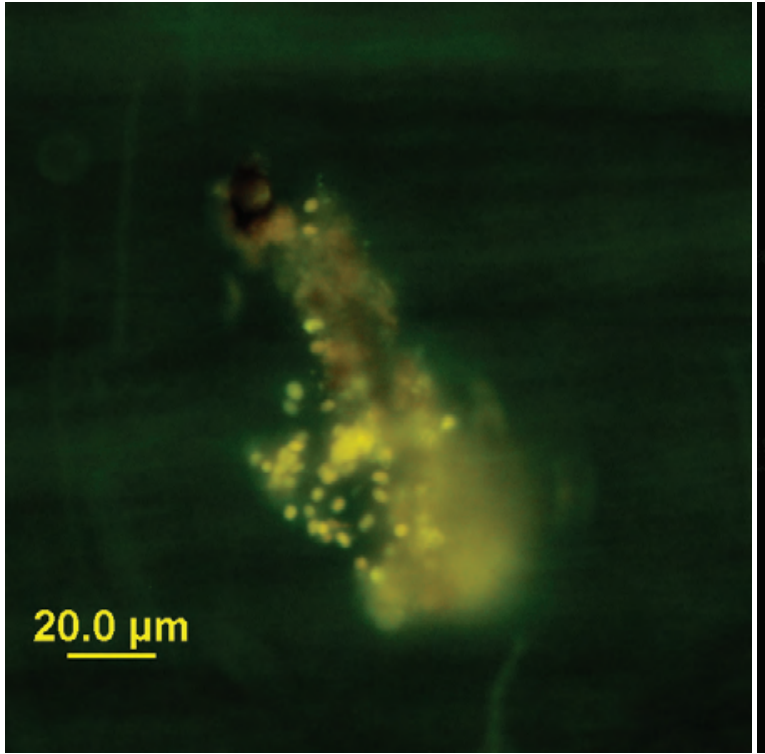

FITC

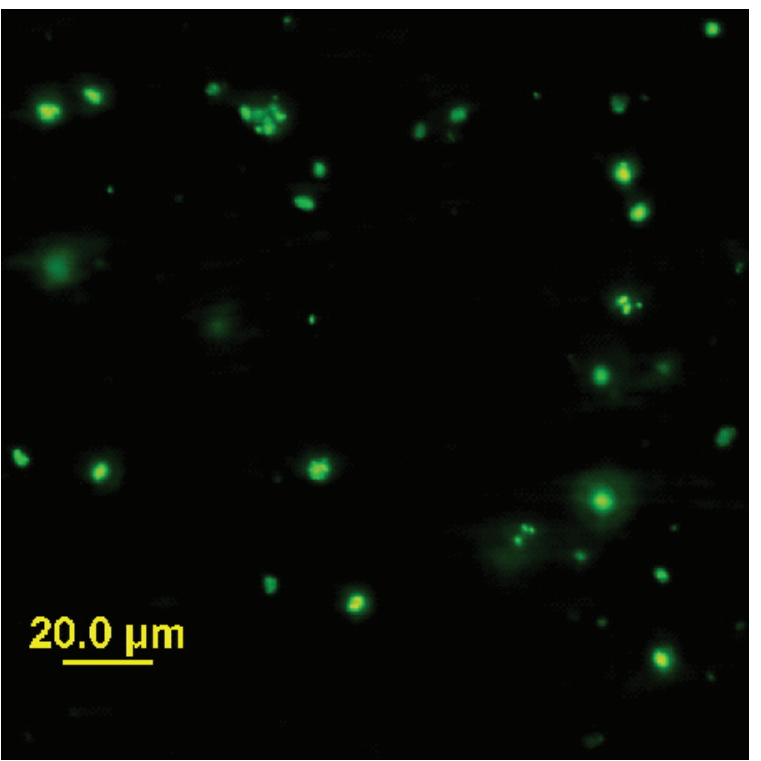

Sytox ${ }^{\circledR}$ green

\section{Autoclaved for 30 minutes}

Figure 23. Spring Lake, CA (8/21/2009). LM-The remains of a colonial cyanobacterium. FITC-a yellow color dominates the cells. Sytox ${ }^{\circledR}$ green-stain penetrated cell membrane of this unknown organism; bright green cell. LM - differential interference contrast microscopy; FITC - epifluorescent microscopy; Sytox ${ }^{\circledR}$ green epifluorescent microscopy in conjunction with the nucleic acid stain Sytox ${ }^{\circledR}$ green. 


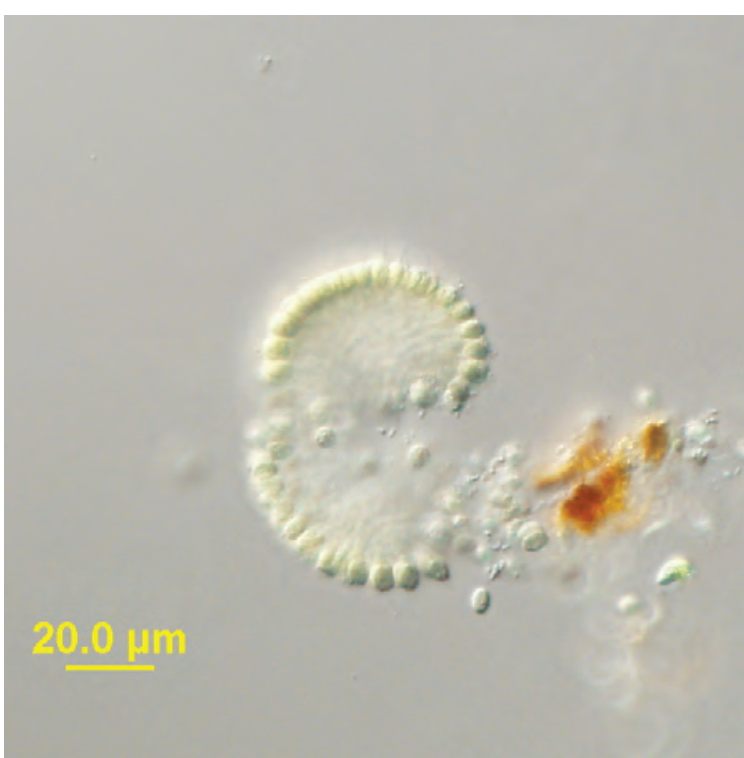

LM

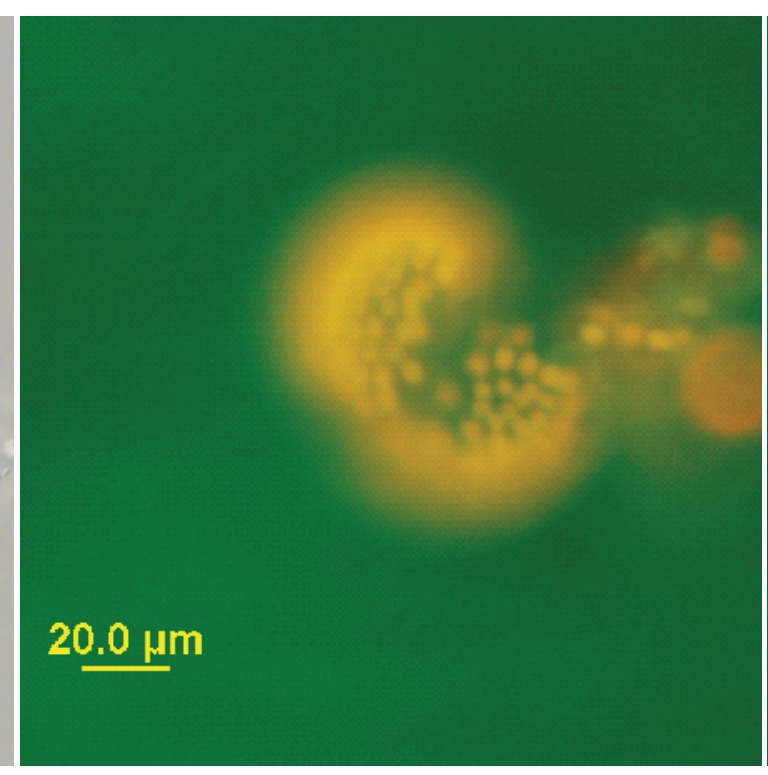

FITC

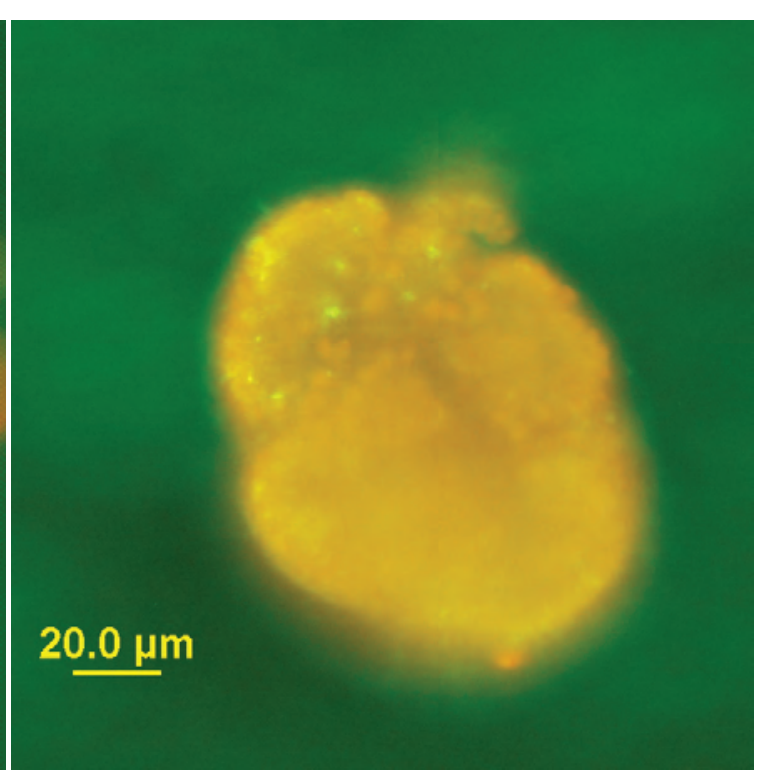

Sytox ${ }^{\circledR}$ green

\section{Sonicated at 10 percent power}

Figure 24. Spring Lake, CA (8/21/2009). LM-Woronichinia sp., cells in a gelatinous matrix. FITC-an orange color dominates the cells. Sytox ${ }^{\oplus}$ green-stain did not penetrate the cell membrane. LM - differential interference contrast microscopy; FITC - epifluorescent microscopy; Syto ${ }^{\circledR}$ green - epifluorescent microscopy in conjunction with the nucleic acid stain Sytox ${ }^{\circledast}$ green. 


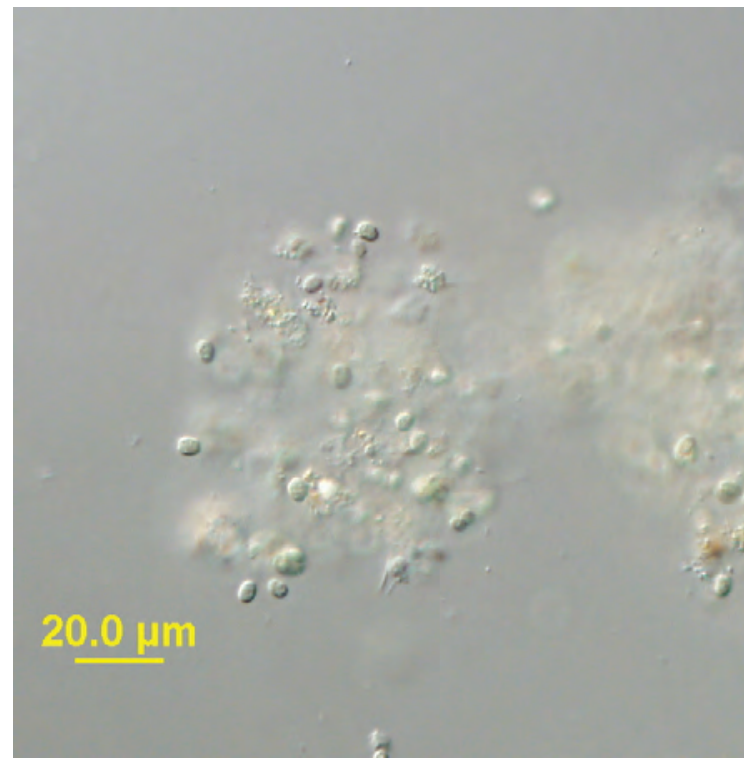

LM

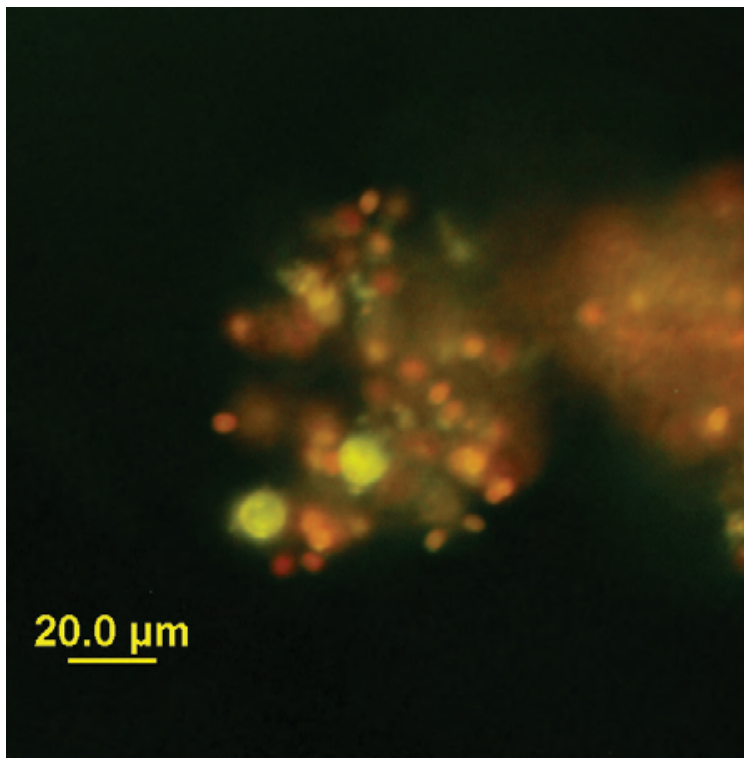

FITC

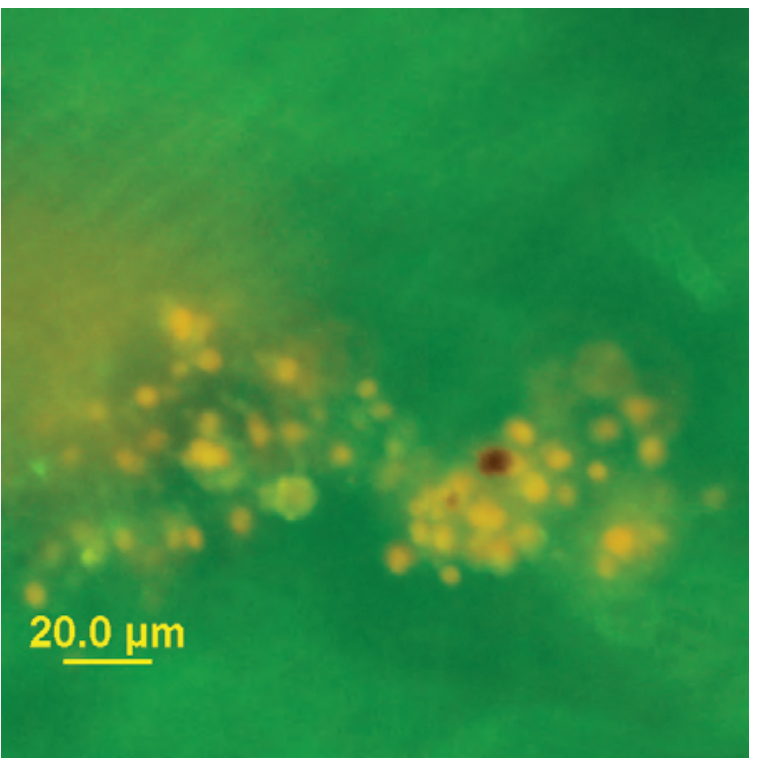

Sytox ${ }^{\circledR}$ green

\section{Sonicated at 35 percent power}

Figure 25. Spring Lake, CA (8/21/2009). LM-Likely the remains of Woronichinia sp. FITC-an orange color dominates the cells. Sytox ${ }^{\circledR}$ green-stain did not penetrate the cell membranes of the cyanobacteria. LM - differential interference contrast microscopy; FITC - epifluorescent microscopy; Sytox ${ }^{\circledast}$ green - epifluorescent microscopy in conjunction with the nucleic acid stain Sytox ${ }^{\circledast}$ green. 


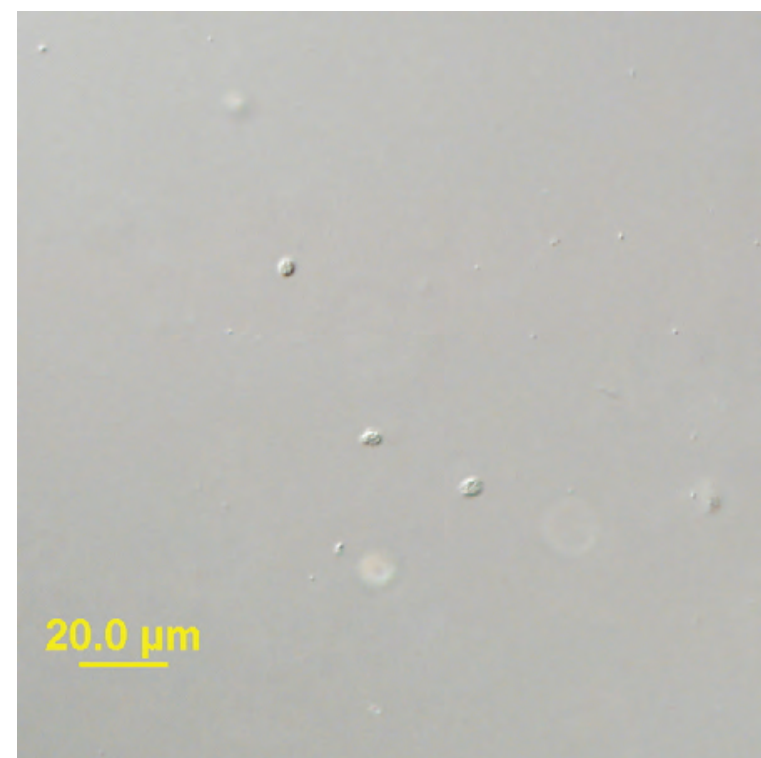

LM

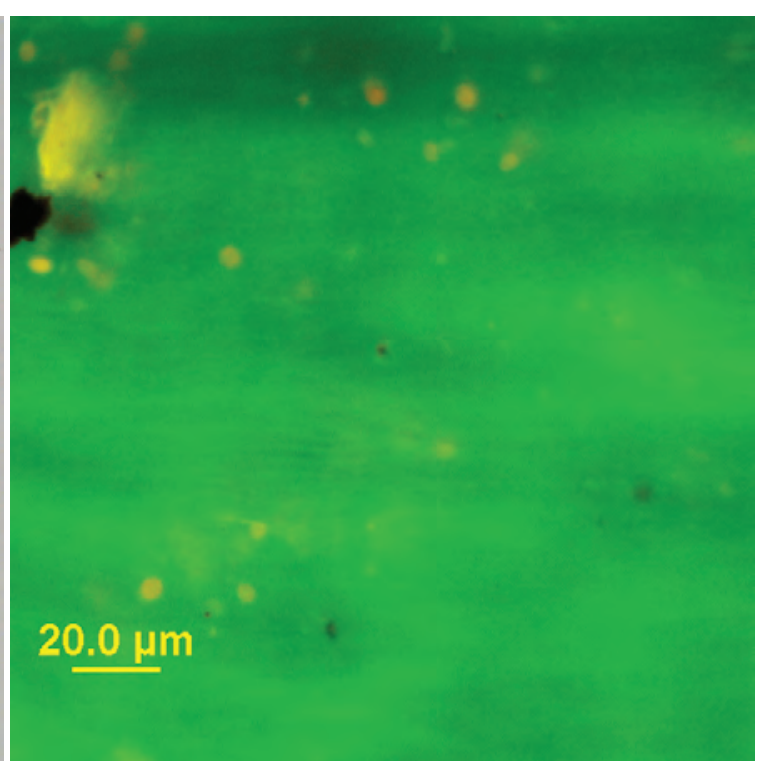

FITC

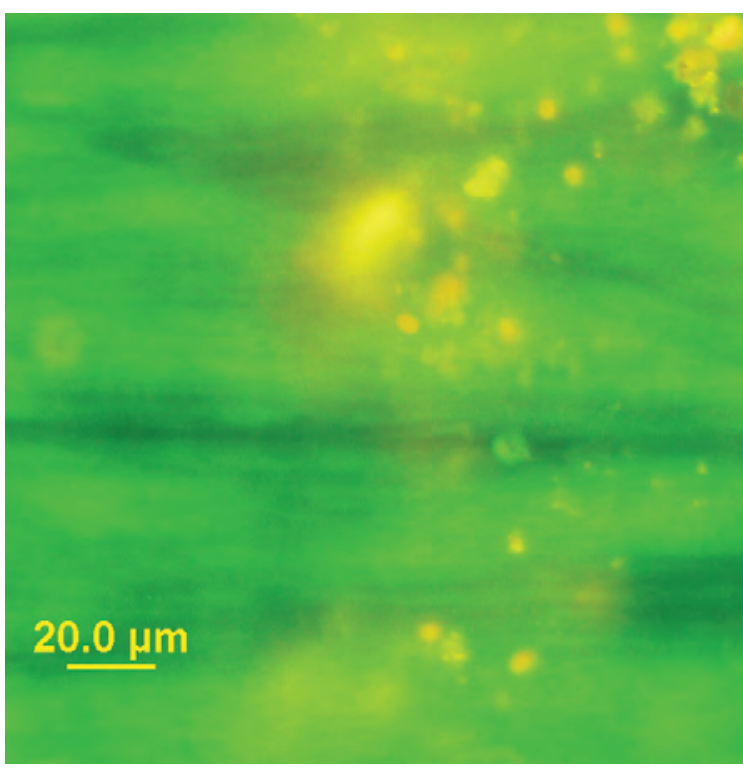

Sytox ${ }^{\circledR}$ green

\section{Sonicated at 70 percent power}

Figure 26. Spring Lake, CA (8/21/2009). LM-The remains of a colonial cyanobacterium. FITC-an orange color dominates the cells. Sytox ${ }^{\circledR}$ green-stain did not penetrate the cell membranes of the cyanobacteria. LM - differential interference contrast microscopy; FITC - epifluorescent microscopy; Sytox ${ }^{\circledast}$ green - epifluorescent microscopy in conjunction with the nucleic acid stain Sytox ${ }^{\circledast}$ green. 


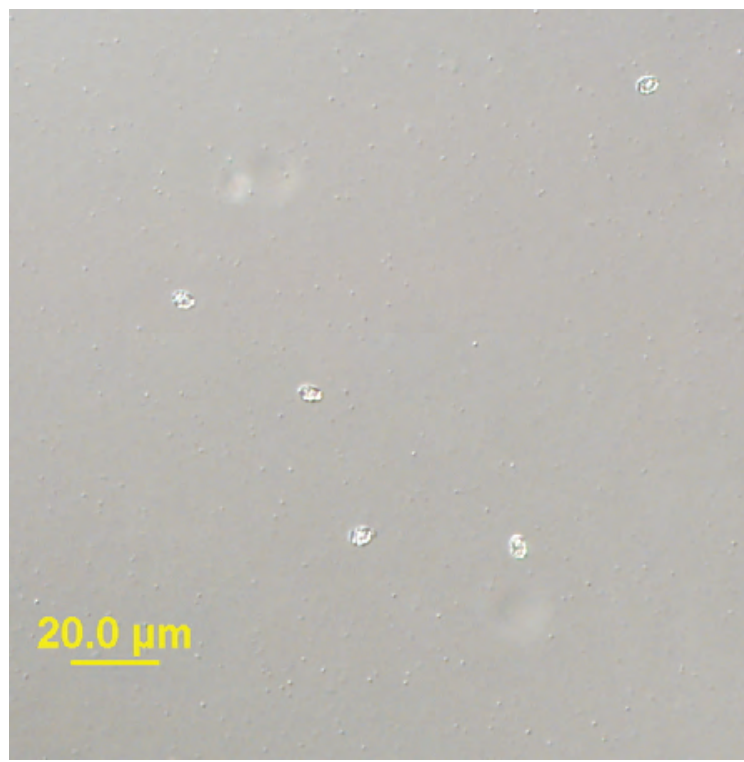

LM

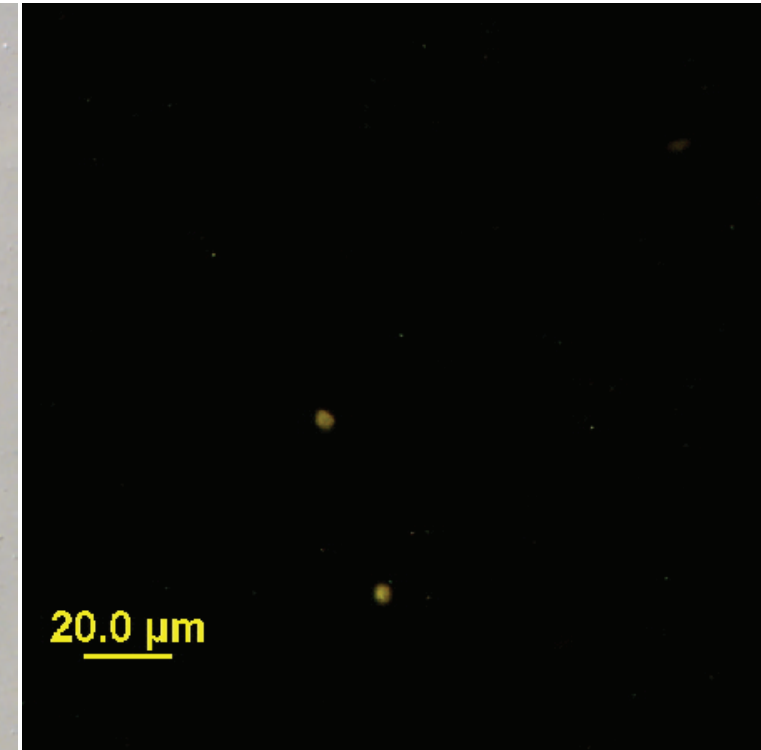

FITC

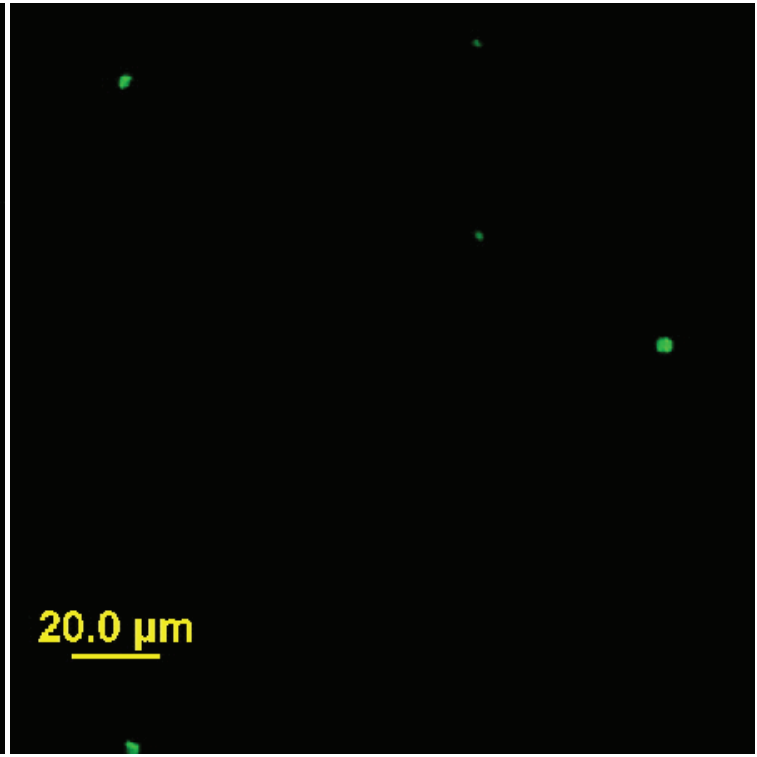

Sytox ${ }^{\circledR}$ green

QuikLyse ${ }^{\mathrm{TM}}-1 \mathrm{x}$

Figure 27. Spring Lake, CA (8/21/2009). LM-The remains of a colonial cyanobacterium. FITC-a yellow color dominates the cells. Sytox ${ }^{\circledR}$ green-stain penetrated the cell membranes; bright green cells. LM - differential interference contrast microscopy; FITC - epifluorescent microscopy; Sytox ${ }^{\circledR}$ green - epifluorescent microscopy in conjunction with the nucleic acid stain Sytox ${ }^{\oplus r e e n . ~}$ 


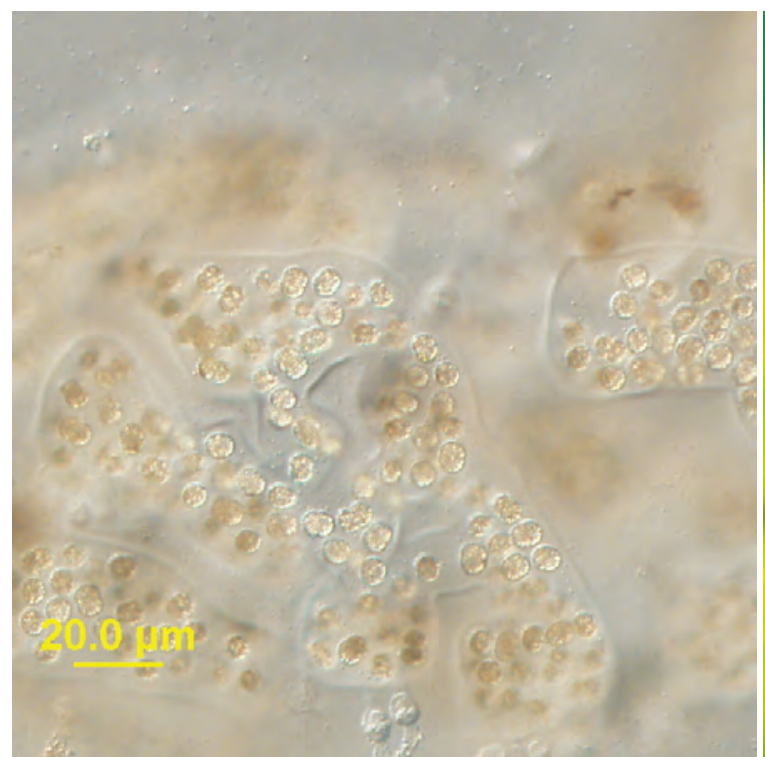

LM

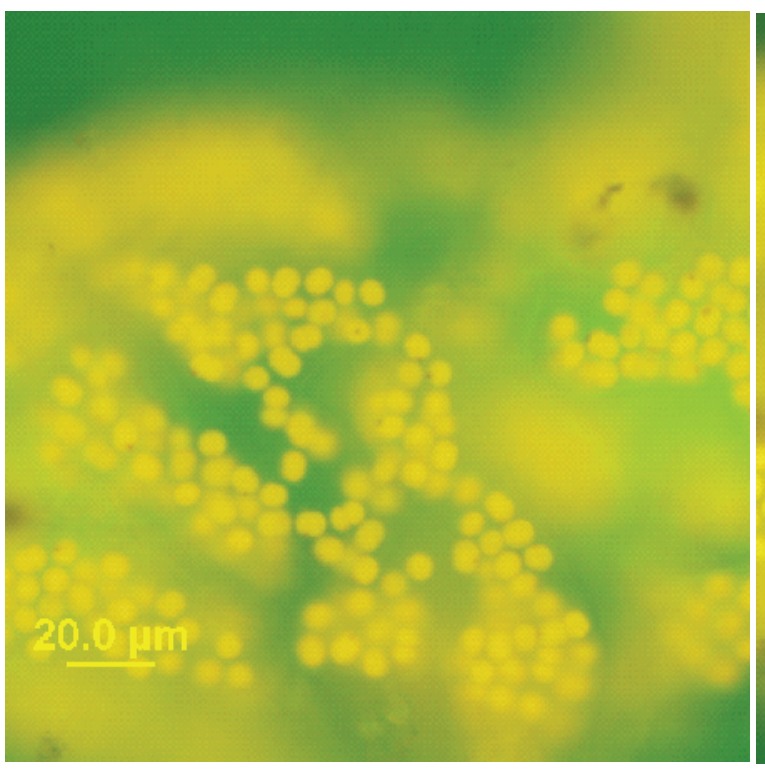

FITC

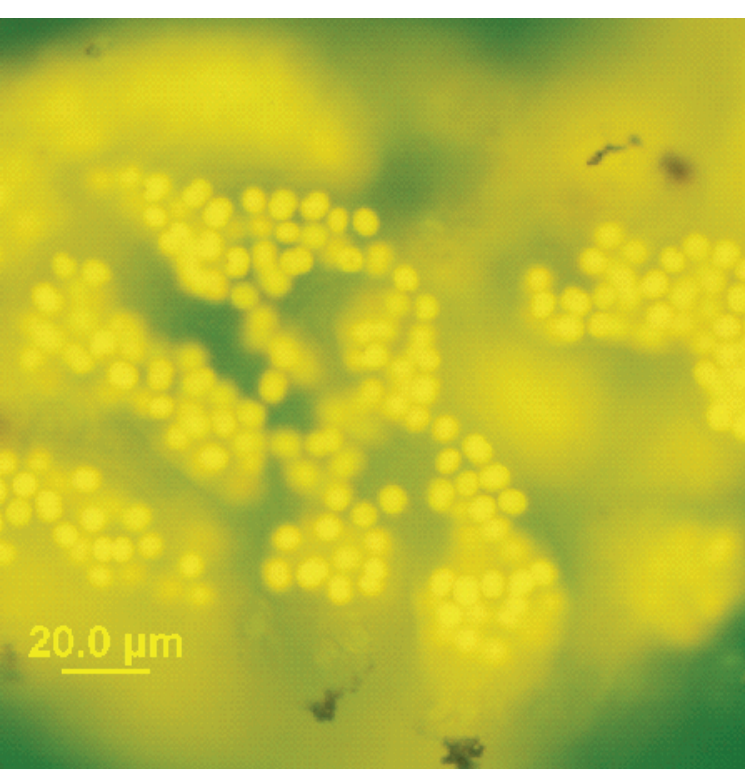

Sytox ${ }^{\circledR}$ green

\section{QuikLyse ${ }^{\mathrm{TM}}-2 \mathrm{x}$}

Figure 28. Spring Lake, CA (8/21/2009). LM-Microcystis wesenbergii, a colonial cyanobacterium. FITC-a yellow color dominates the cells. Sytox ${ }^{\circledR}$ green-stain did not penetrate the cell membranes of the cyanobacteria. LM - differential interference contrast microscopy; FITC - epifluorescent microscopy; Sytox ${ }^{\circledR}$ green - epifluorescent microscopy in conjunction with the nucleic acid stain Sytox ${ }^{\circledR}$ green. 


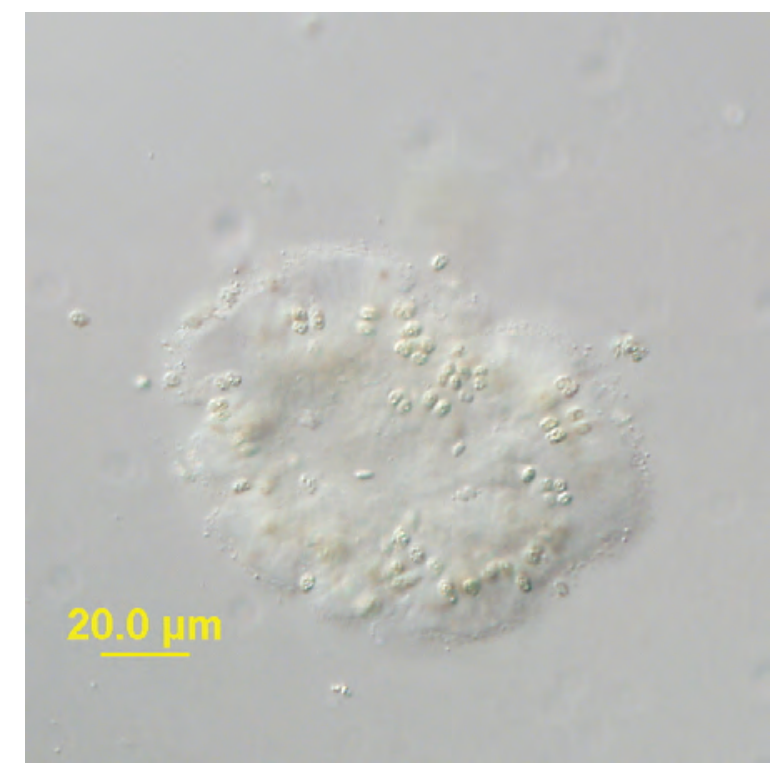

LM

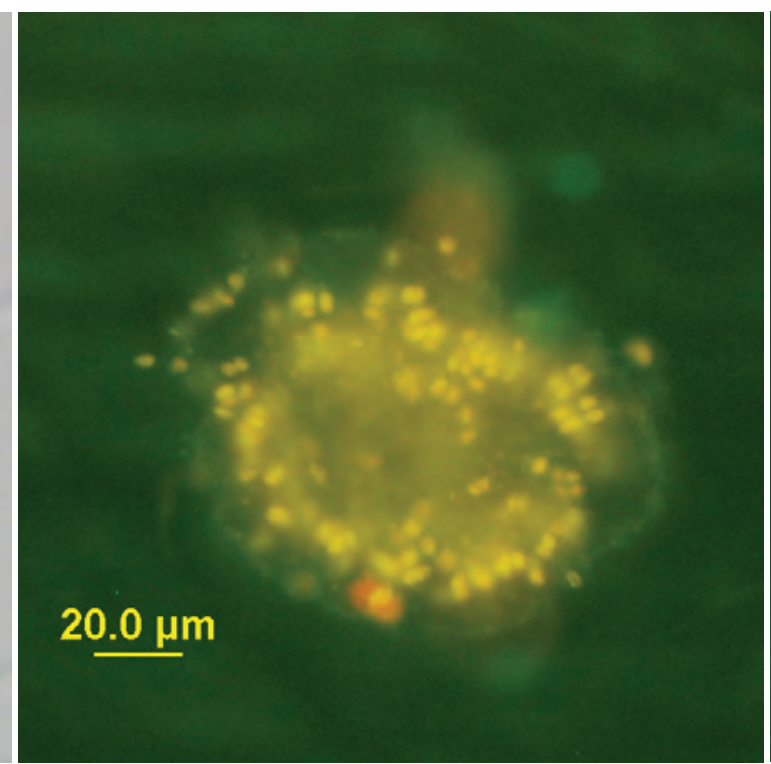

FITC

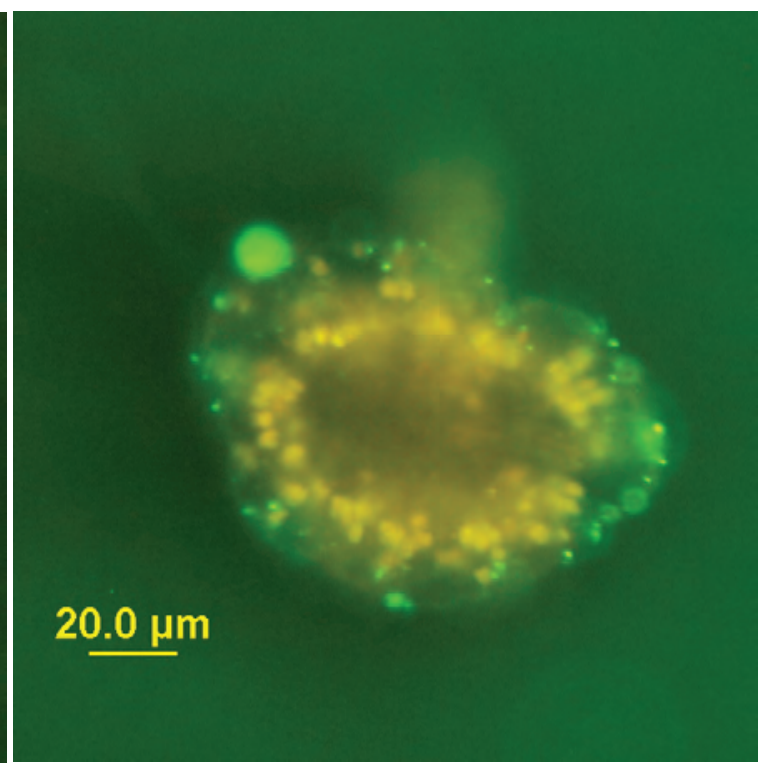

Sytox ${ }^{\circledR}$ green

\section{One freeze-thaw cycle}

Figure 29. Spring Lake, CA (8/21/2009). LM-The remains of a colonial cyanobacterium; the mucilage that supports the cells remains. FITC-a yellow color dominates the cells. Syto ${ }^{\circledast}$ green-stain did not penetrate the cell membranes of the cyanobacteria, but did stain the bacteria associated with the mucilage. LM - differential interference contrast microscopy; FITC - epifluorescent microscopy; Sytox ${ }^{\oplus}$ green - epifluorescent microscopy in conjunction with the nucleic acid stain Sytox ${ }^{\circledR}$ green. 


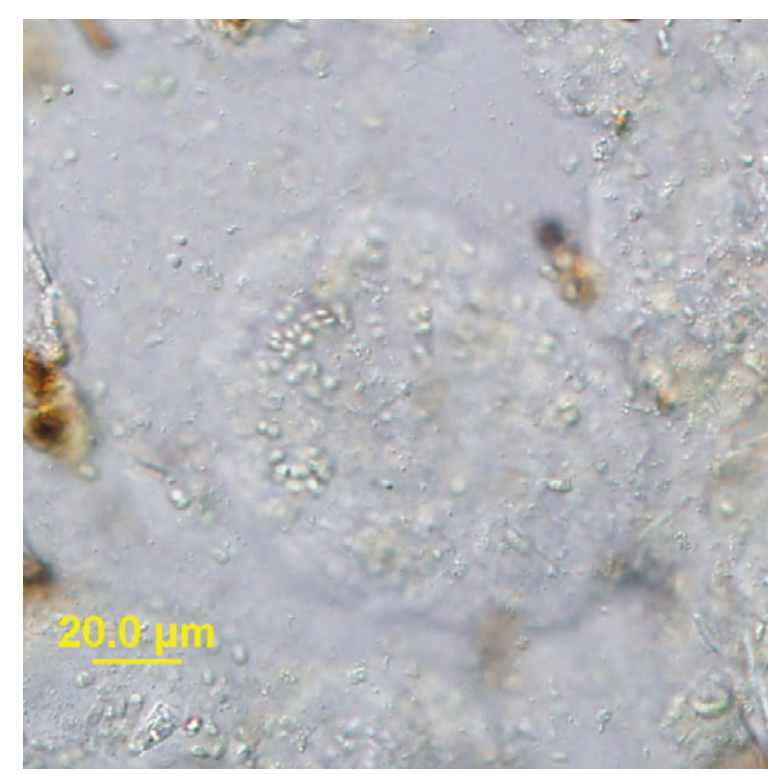

LM

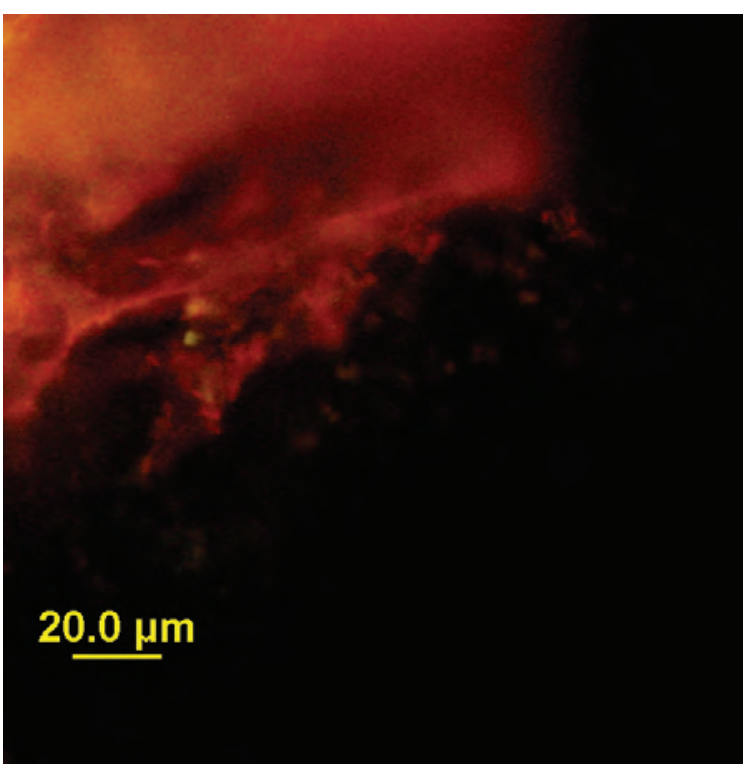

FITC

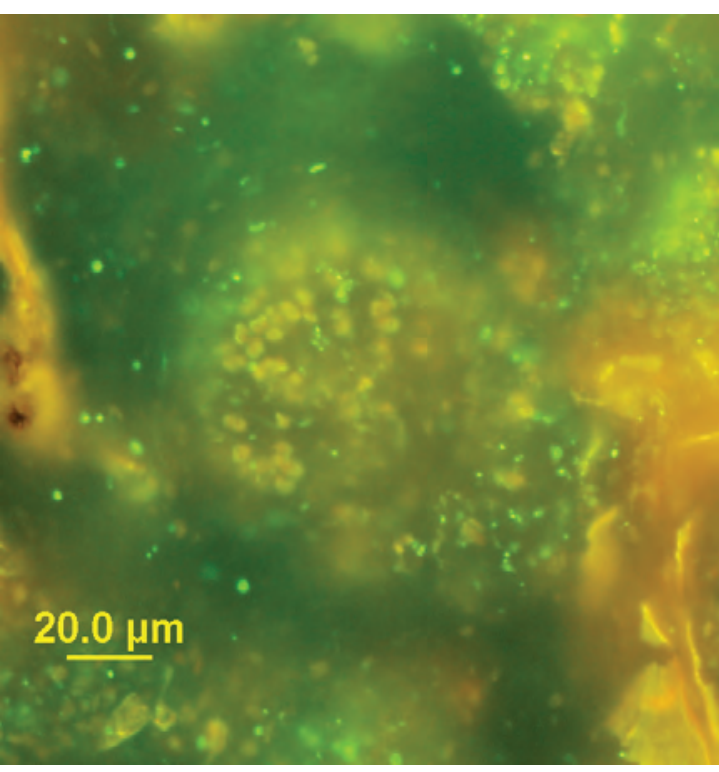

Syto ${ }^{\circledR}$ green

Two freeze-thaw cycles

Figure 30. Spring Lake, CA (8/21/2009). LM-The remains of a colonial cyanobacterium; the mucilage that supports the cells remains. FITC-a red color dominates the cells. Sytox ${ }^{\circledast}$ green-stain did not penetrate the cell membranes of the cyanobacteria, but did stain the bacteria associated with the mucilage. LM - differential interference contrast microscopy; FITC - epifluorescent microscopy; Sytox ${ }^{\circledast}$ green - epifluorescent microscopy in conjunction with the nucleic acid stain Sytox ${ }^{\circledR}$ green. 


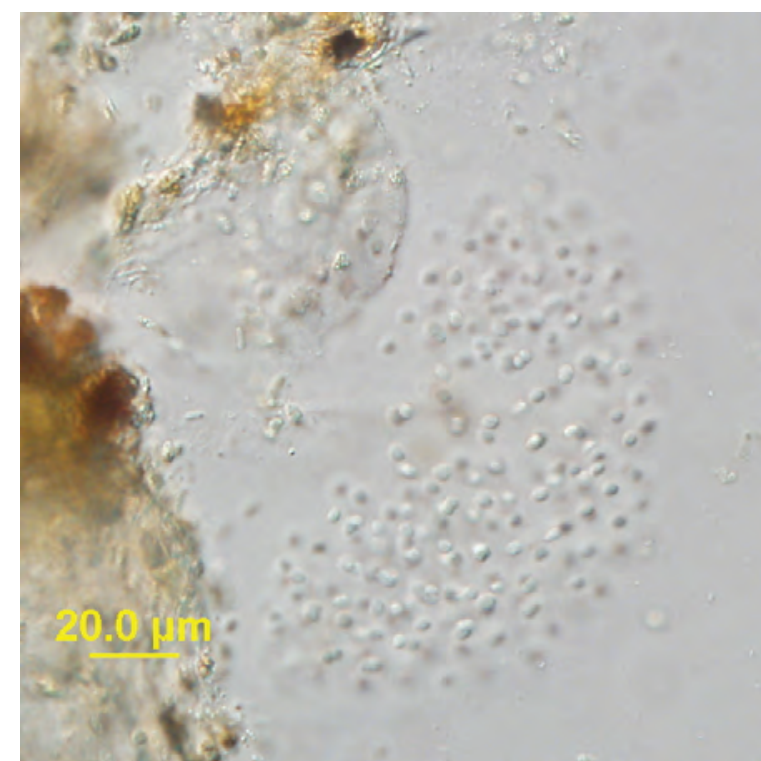

LM

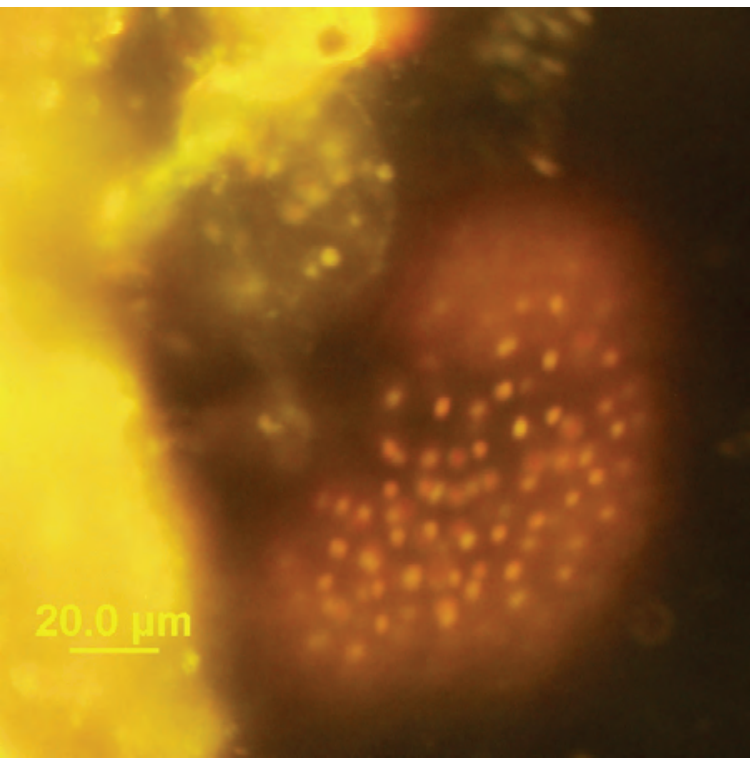

FITC

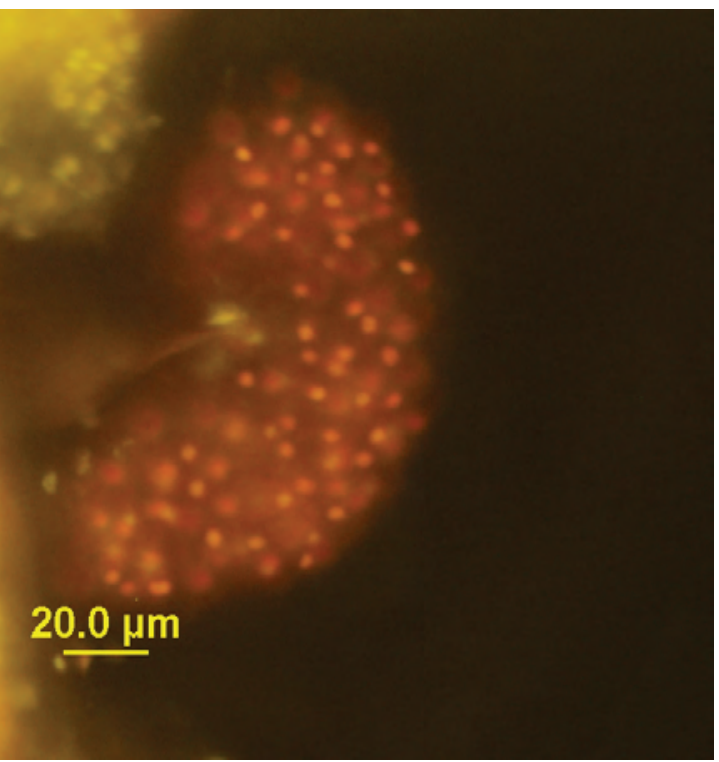

Sytox ${ }^{\circledR}$ green

Three freeze-thaw cycles

Figure 31. Spring Lake, CA (8/21/2009). LM-The remains of a colonial cyanobacterium. FITC-an orange color dominates the cells. Sytox ${ }^{\circledR}$ green-stain did not penetrate the cell membranes of the cyanobacterium. LM - differential interference contrast microscopy; FITC - epifluorescent microscopy; Sytox ${ }^{\circledR}$ green - epifluorescent microscopy in conjunction with the nucleic acid stain Sytox ${ }^{\circledR}$ green. 


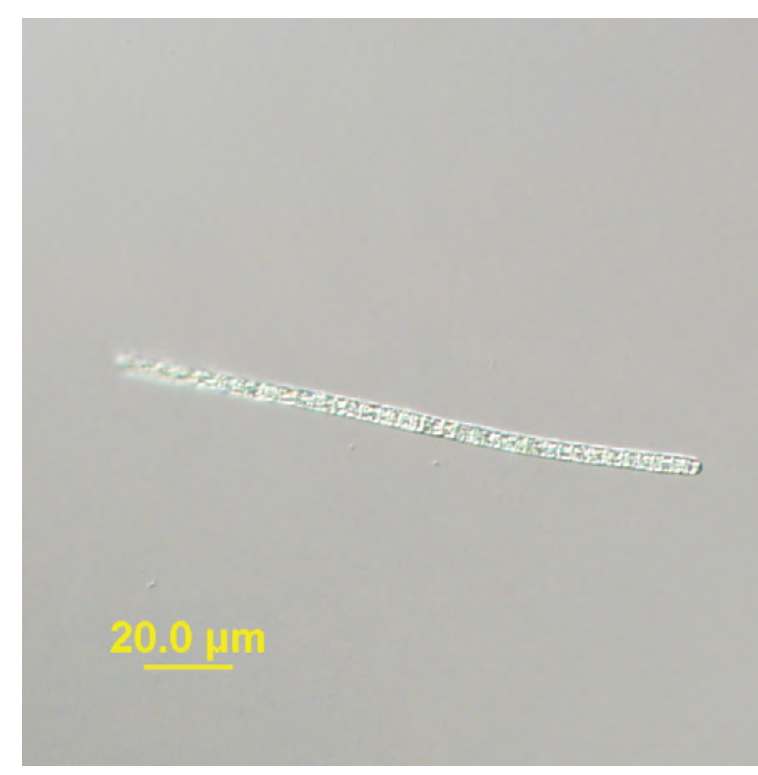

LM

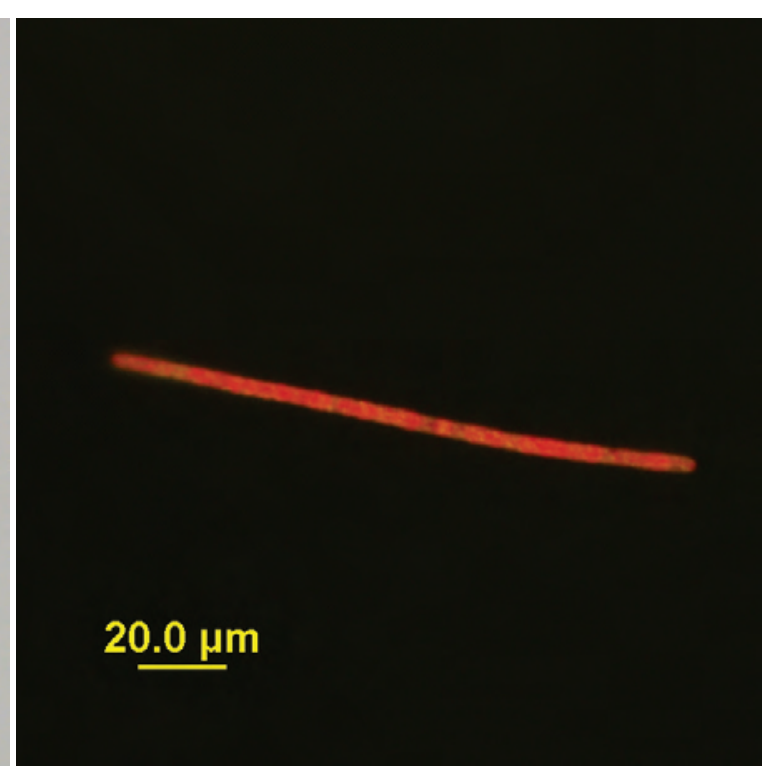

FITC

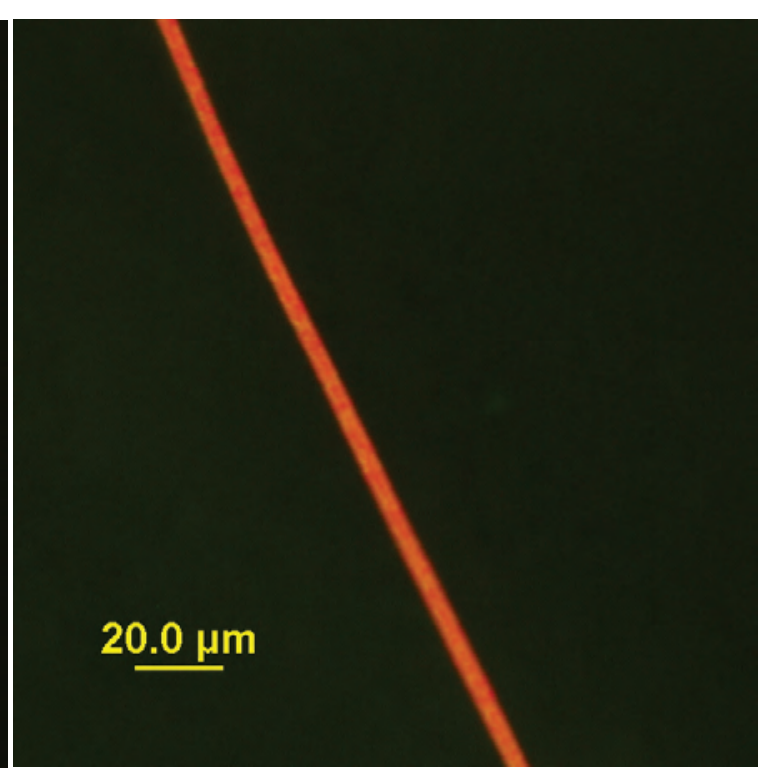

Sytox ${ }^{\circledR}$ green

\section{Control 1}

Figure 32. Blackhawk Lake, IA (8/26/2009). LM-Planktothrix sp., cells in a filament. FITC-an orange color dominates the cells. Sytox ${ }^{\circledR}$ green-stain did not penetrate the cell membrane. LM - differential interference contrast microscopy; FITC - epifluorescent microscopy; Sytox ${ }^{\circledR}$ green - epifluorescent microscopy in conjunction with the nucleic acid stain Sytox ${ }^{\circledR}$ green. 


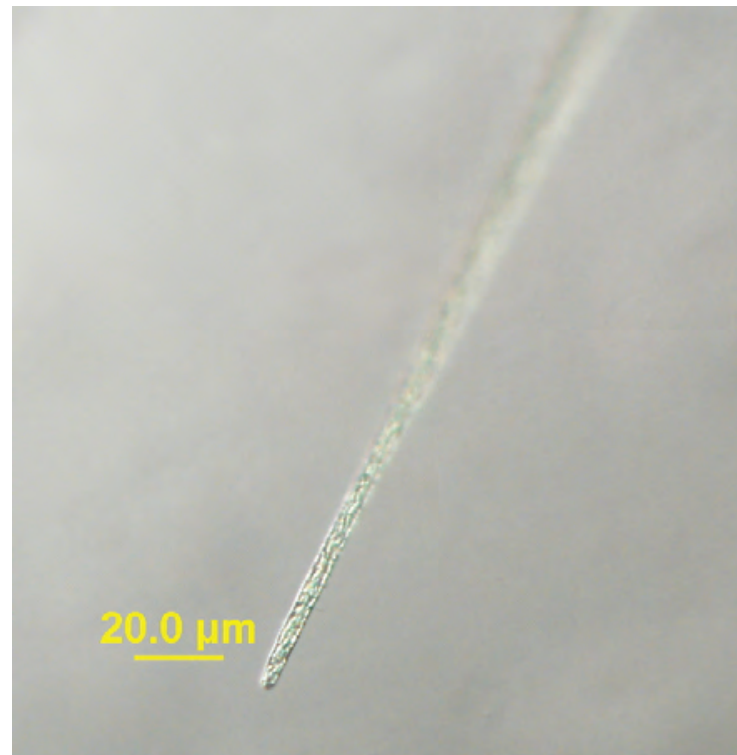

LM

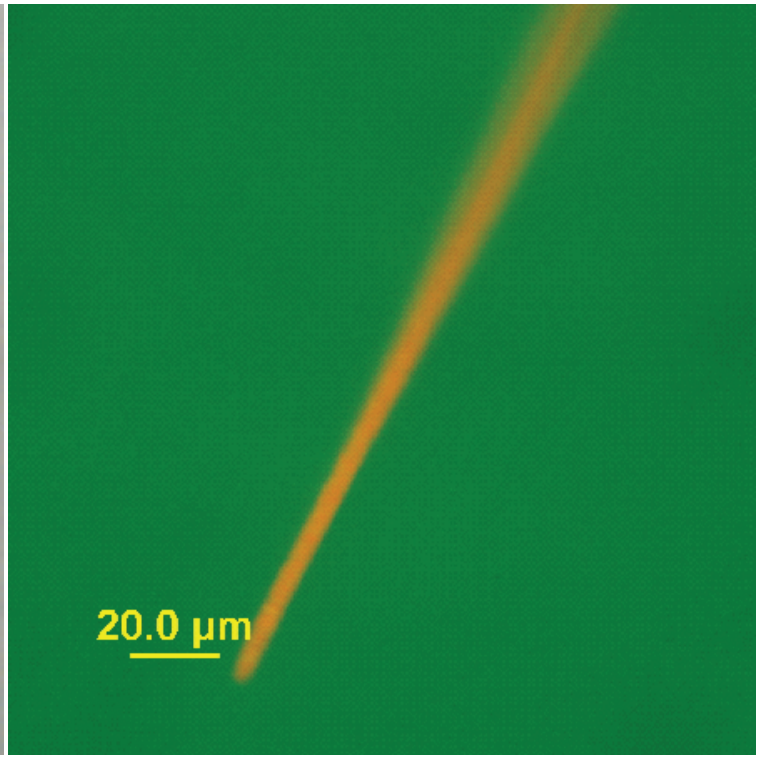

FITC

\section{Control 2}

Figure 33. Blackhawk Lake, IA (8/26/2009). LM-Planktothrix sp. FITC-an orange color dominates the cells. Sytox ${ }^{\circledR}$ green-no images obtained. LM - differential interference contrast microscopy; FITC - epifluorescent microscopy; Sytox ${ }^{\circledR}$ green - epifluorescent microscopy in conjunction with the nucleic acid stain Sytox ${ }^{\circledR}$ green. 


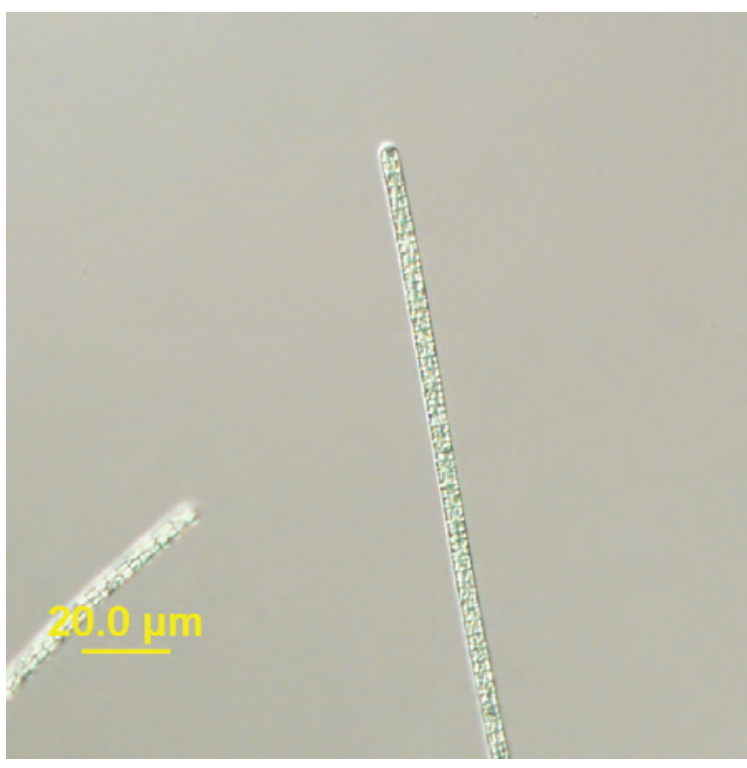

LM

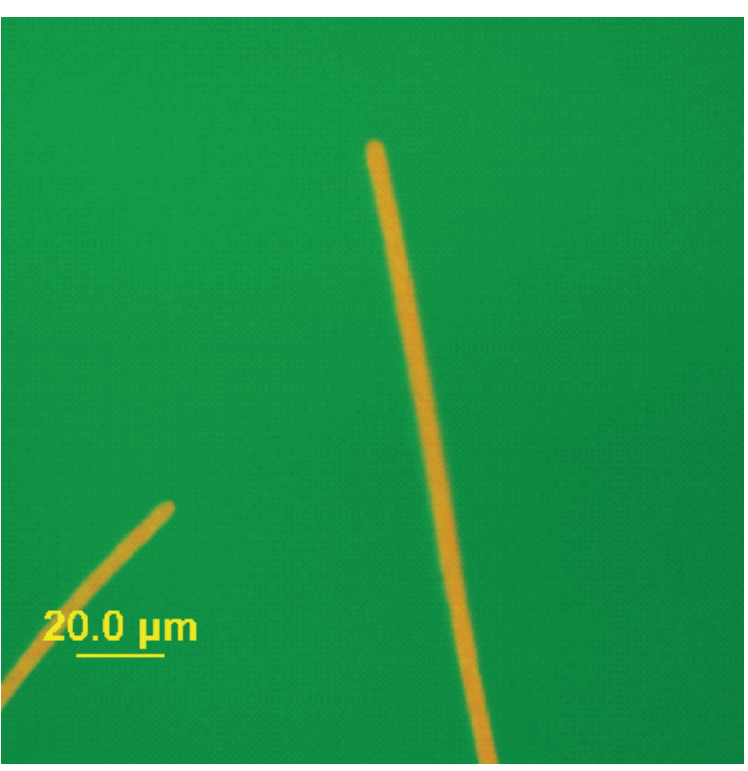

FITC

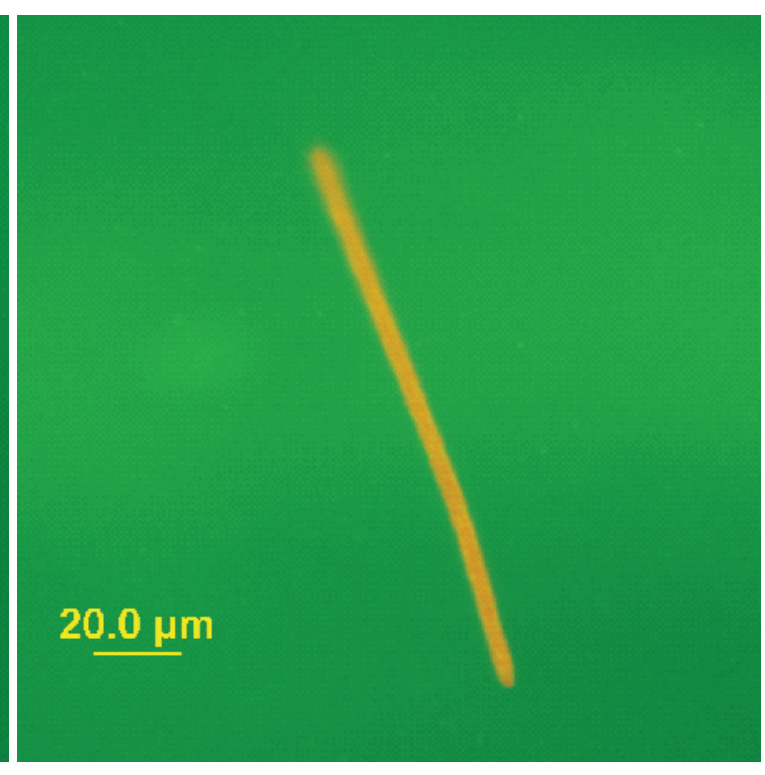

Sytox ${ }^{\circledR}$ green

\section{Control 3}

Figure 34. Blackhawk Lake, IA (8/26/2009). LM-Planktothrix sp. FITC-an orange color dominates the cells. Sytox ${ }^{\circledR}$ green-stain did not penetrate the cell membrane. LM differential interference contrast microscopy; FITC - epifluorescent microscopy; Sytox ${ }^{\circledast}$ green - epifluorescent microscopy in conjunction with the nucleic acid stain Sytox ${ }^{\oplus}$ green. 


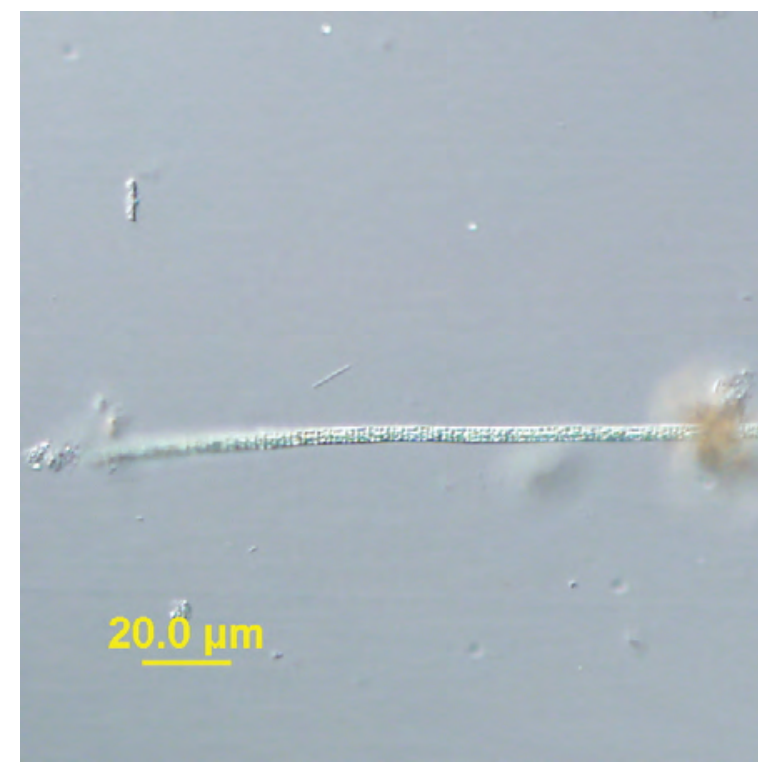

LM

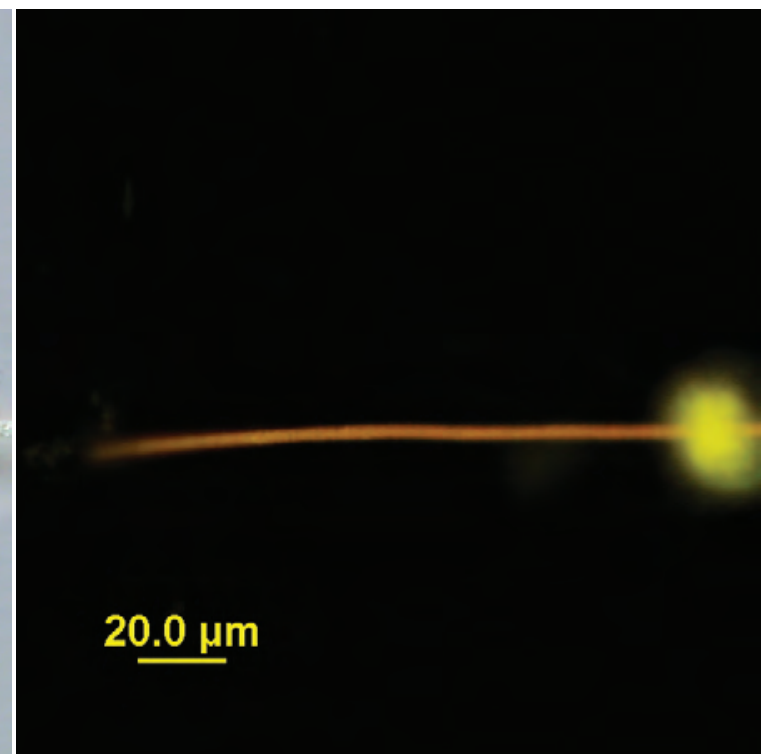

FITC

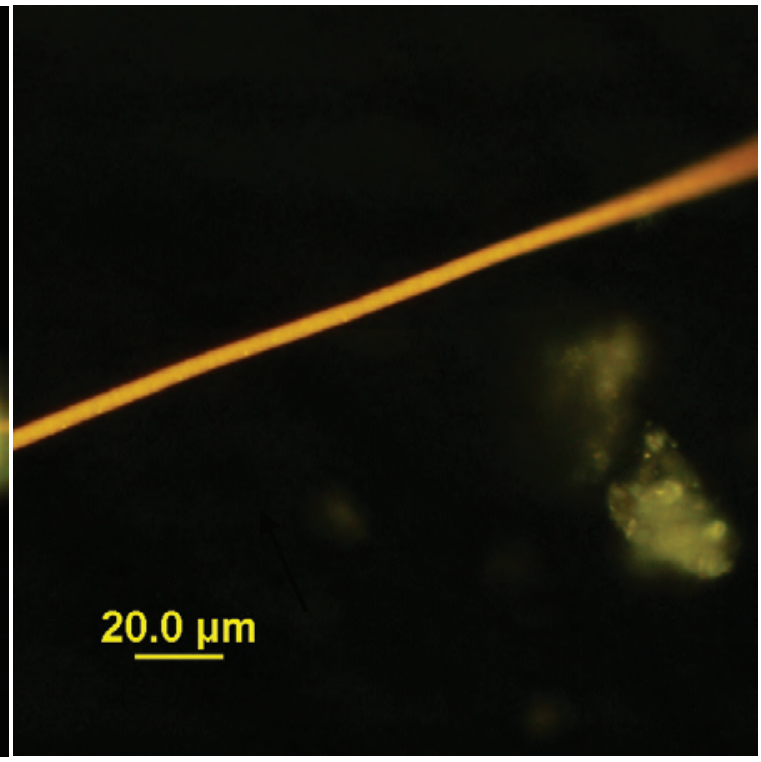

Sytox ${ }^{\circledR}$ green

\section{Boiled for 5 minutes}

Figure 35. Blackhawk Lake, IA (8/26/2009). LM-Planktothrix sp. FITC-an orange color dominates the cells. Sytox ${ }^{\circledR}$ green-stain did not penetrate the cell membrane. LM differential interference contrast microscopy; FITC - epifluorescent microscopy; Sytox ${ }^{\circledR}$ green - epifluorescent microscopy in conjunction with the nucleic acid stain Sytox ${ }^{\circledR}$ green. 


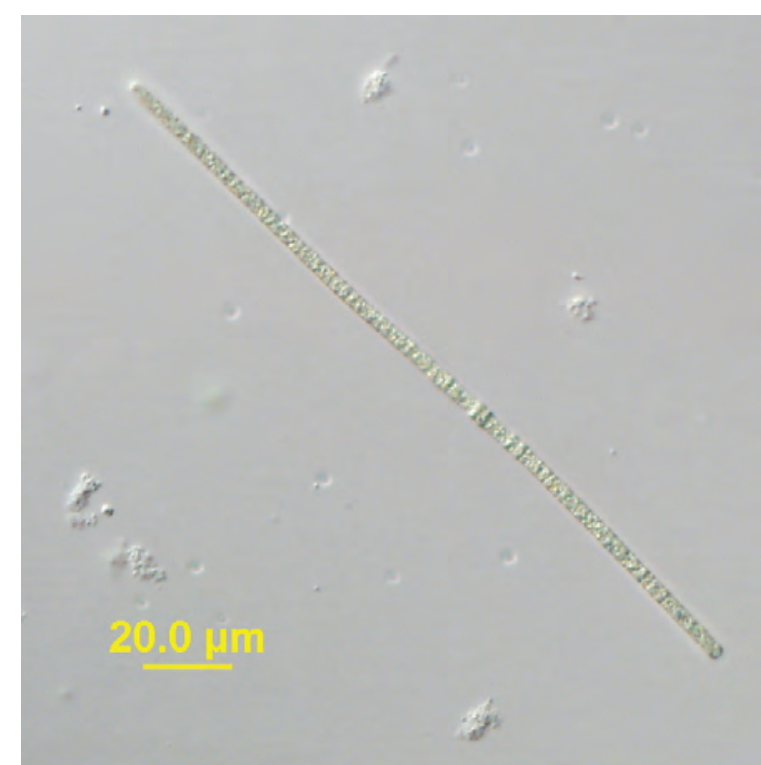

LM

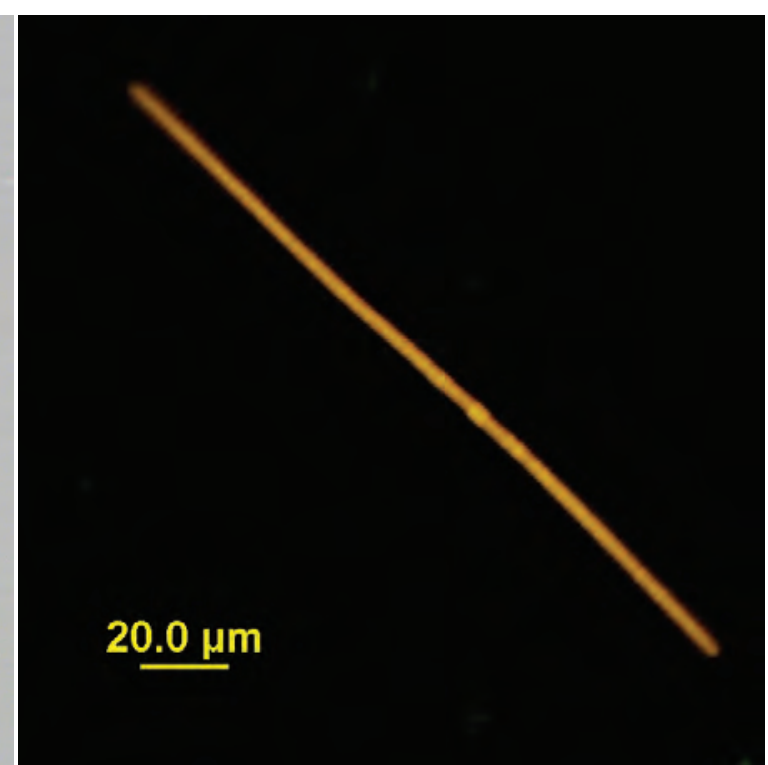

FITC

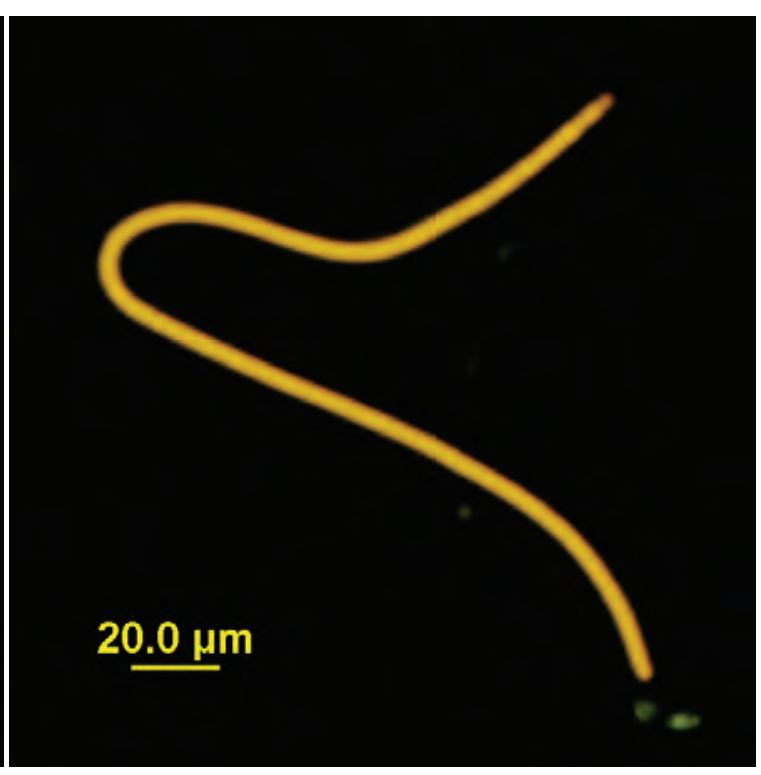

Sytox ${ }^{\circledR}$ green

\section{Boiled for 30 minutes}

Figure 36. Blackhawk Lake, IA (8/26/2009). LM-Planktothrix sp. FITC-an orange color dominates the cells. Sytox ${ }^{\circledR}$ green-stain did not penetrate the cell membrane. LM differential interference contrast microscopy; FITC - epifluorescent microscopy; Sytox ${ }^{\circledast}$ green - epifluorescent microscopy in conjunction with the nucleic acid stain Sytox ${ }^{\circledR}$ green. 


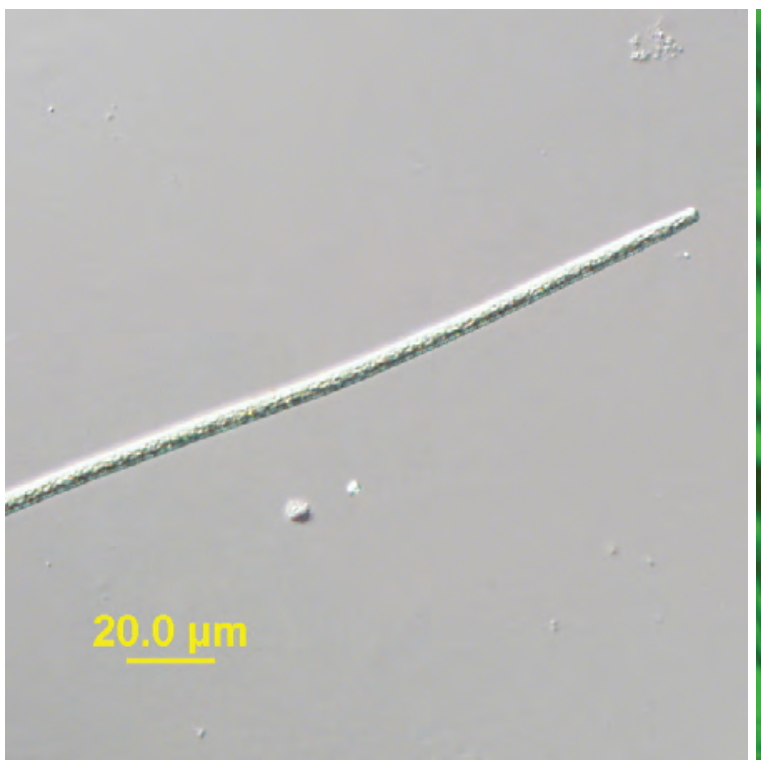

LM

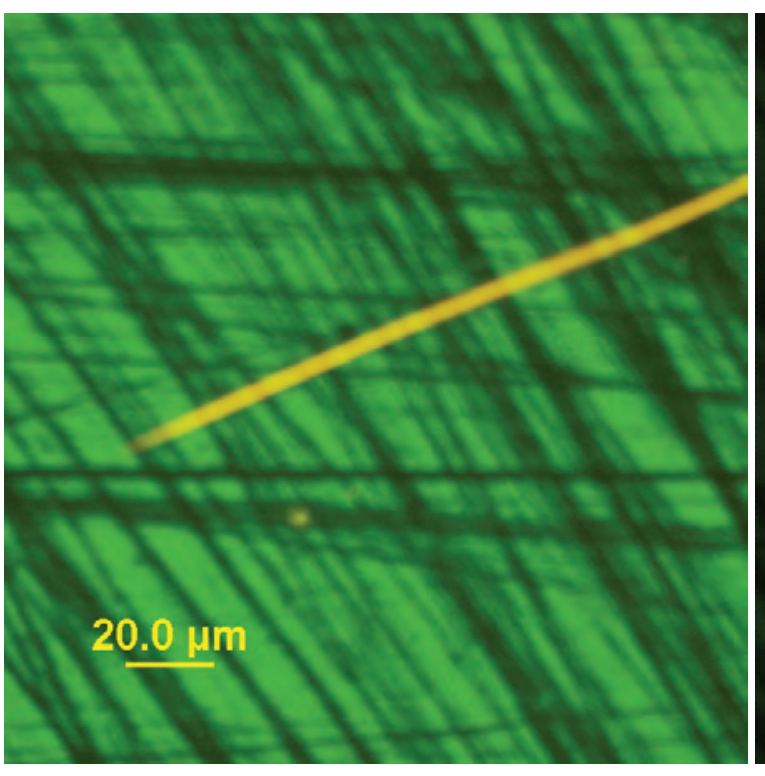

FITC

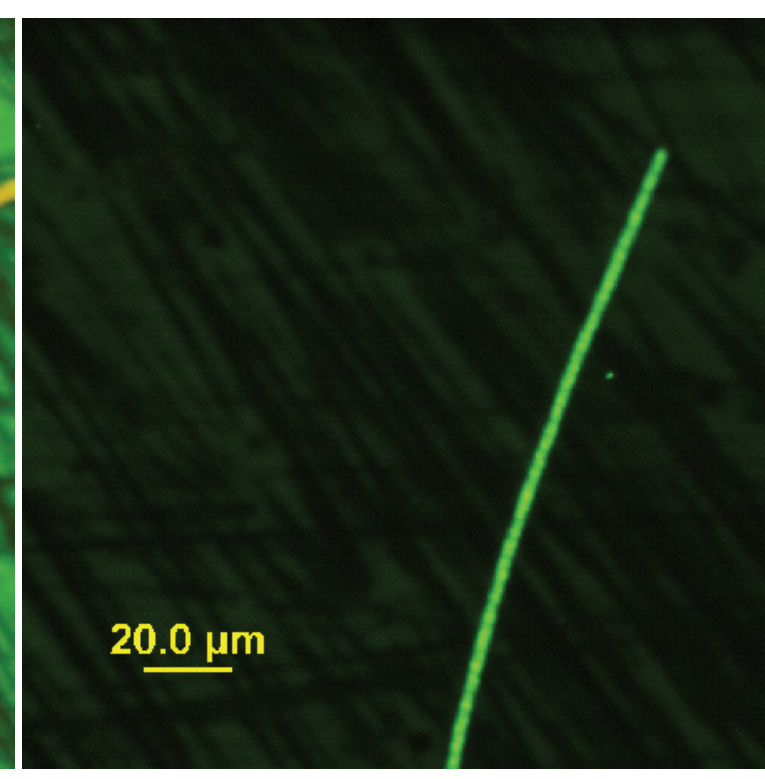

Sytox ${ }^{\circledR}$ green

\section{Autoclaved for 5 minutes}

Figure 37. Blackhawk Lake, IA (8/26/2009). LM-Planktothrix sp. FITC-an orange color dominates the cells. Sytox ${ }^{\circledR}$ green-stain did penetrate the cell membrane; cells bright green . LM - differential interference contrast microscopy; FITC - epifluorescent microscopy; Sytox ${ }^{\circledast}$ green - epifluorescent microscopy in conjunction with the nucleic acid stain Sytox ${ }^{\oplus}$ green. 


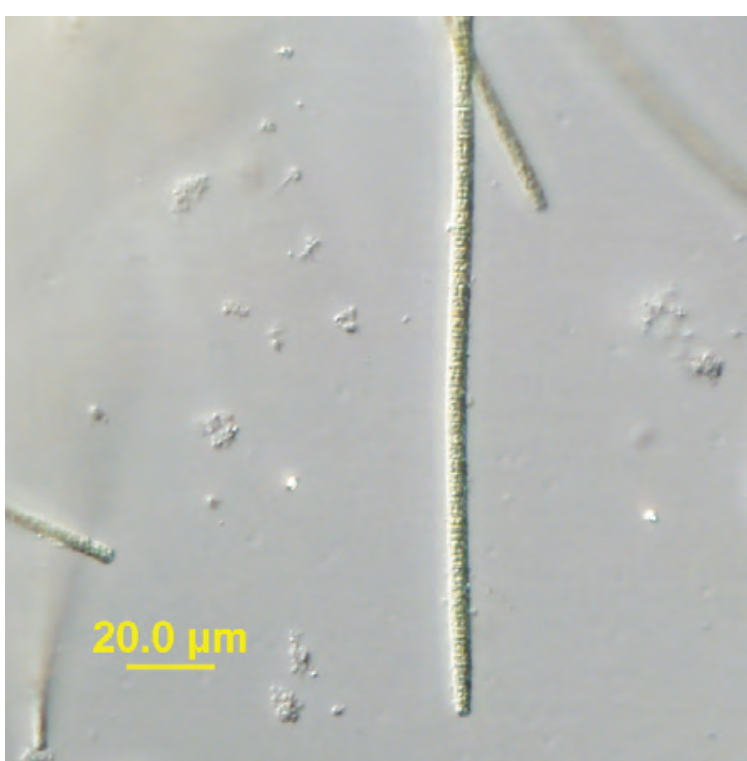

LM

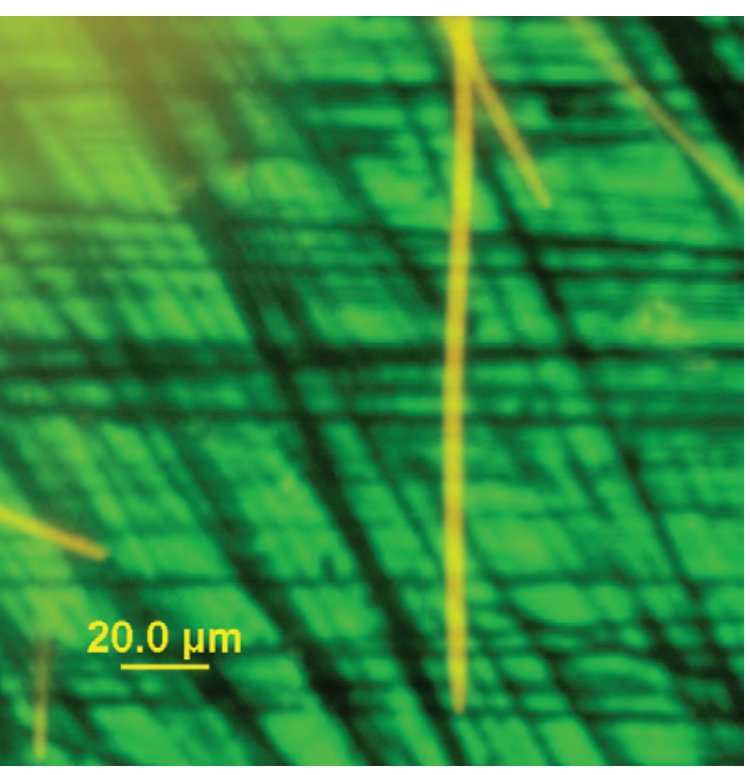

FITC

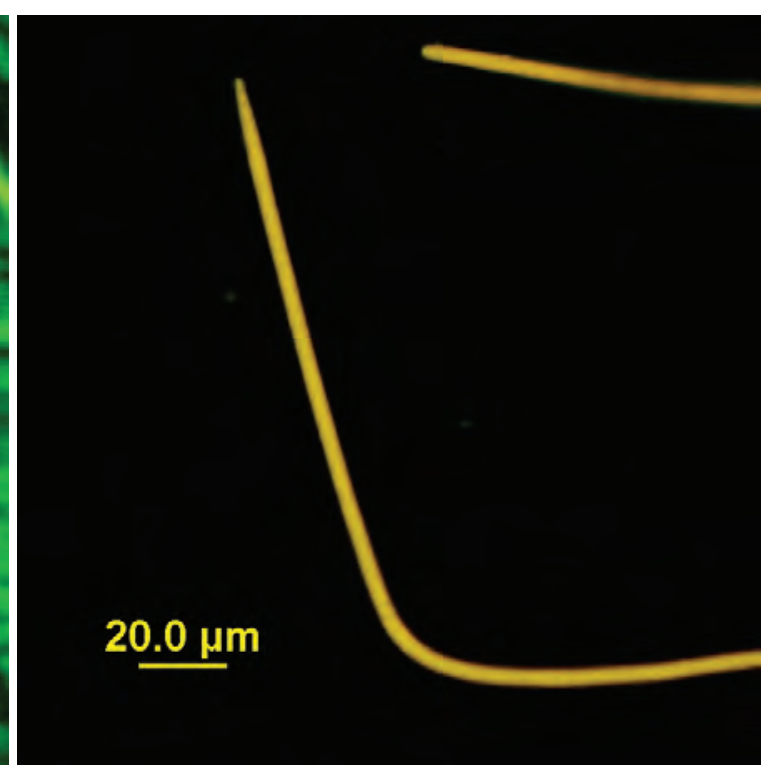

Sytox ${ }^{\circledR}$ green

Autoclaved for 15 minutes

Figure 38. Blackhawk Lake, IA (8/26/2009). LM-Planktothrix sp. FITC-an orange color dominates the cells. Sytox ${ }^{\circledR}$ green-stain did not penetrate the cell membrane. LM differential interference contrast microscopy; FITC - epifluorescent microscopy; Sytox ${ }^{\circledast}$ green - epifluorescent microscopy in conjunction with the nucleic acid stain Sytox ${ }^{\oplus r e e n}$ 


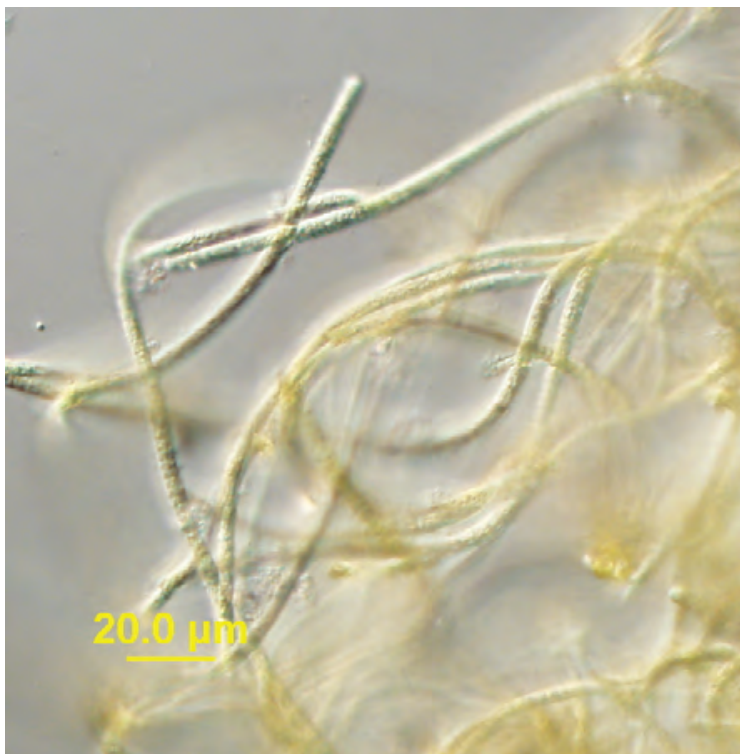

LM

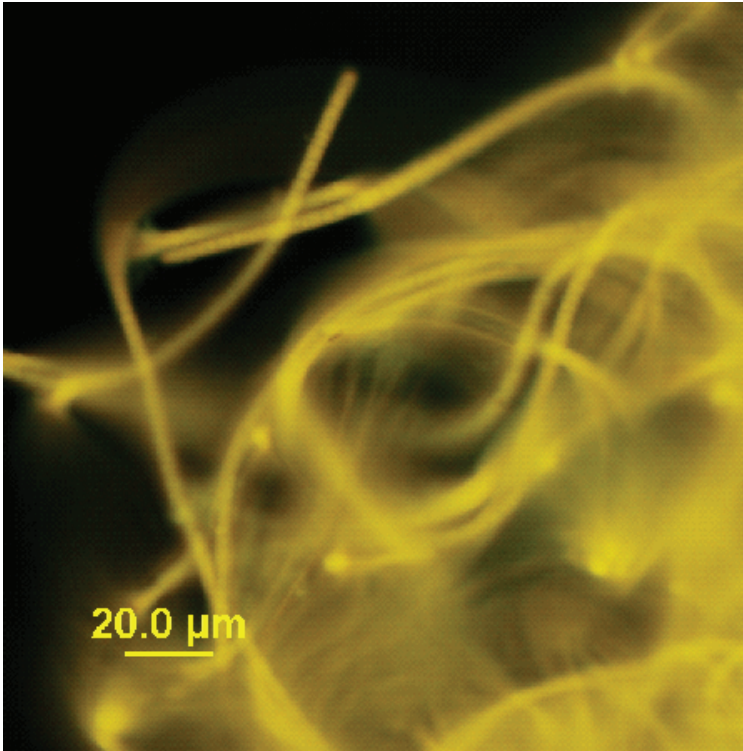

FITC

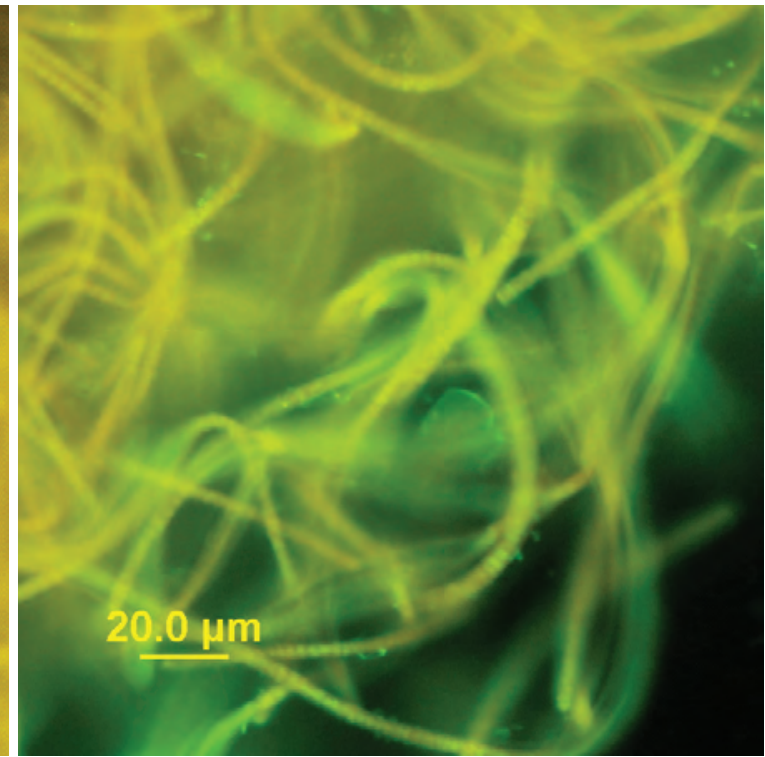

Sytox ${ }^{\circledR}$ green

\section{Autoclaved for 30 minutes}

Figure 39. Blackhawk Lake, IA (8/26/2009). LM-Cyanobacterial filamentous. FITC-a yellow-orange color dominates the cells. Sytox ${ }^{\circledR}$ green-stain did penetrate the cell membranes in some of the cells in the filaments. LM - differential interference contrast microscopy; FITC - epifluorescent microscopy; Sytox ${ }^{\circledR}$ green - epifluorescent microscopy in conjunction with the nucleic acid stain Sytox ${ }^{\circledR}$ green. 


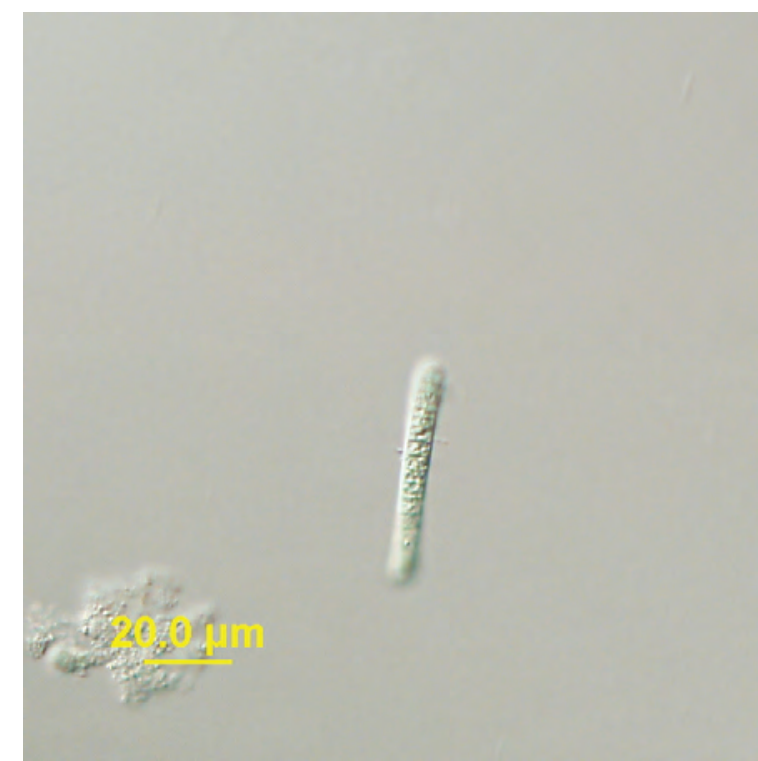

LM

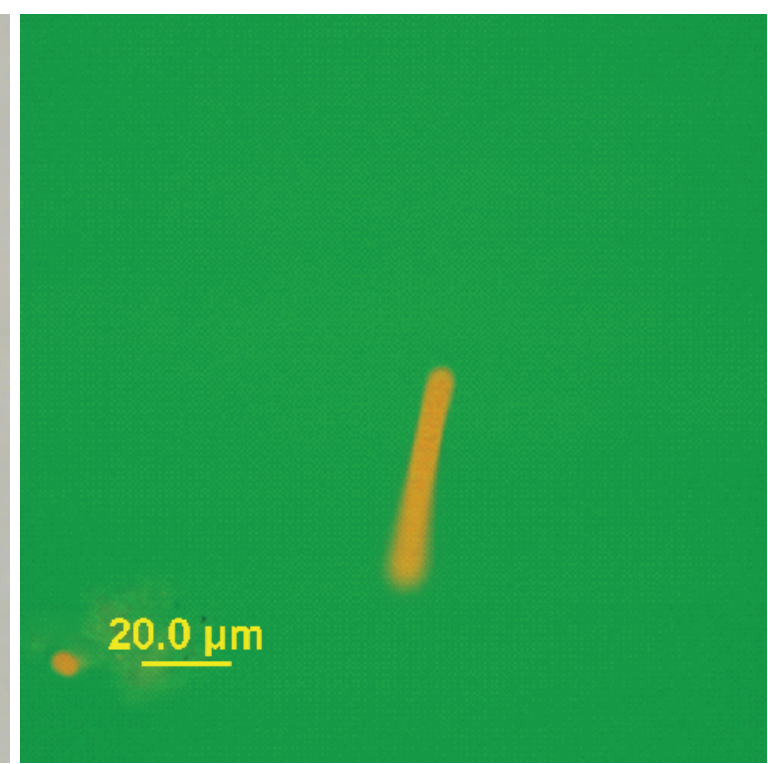

FITC

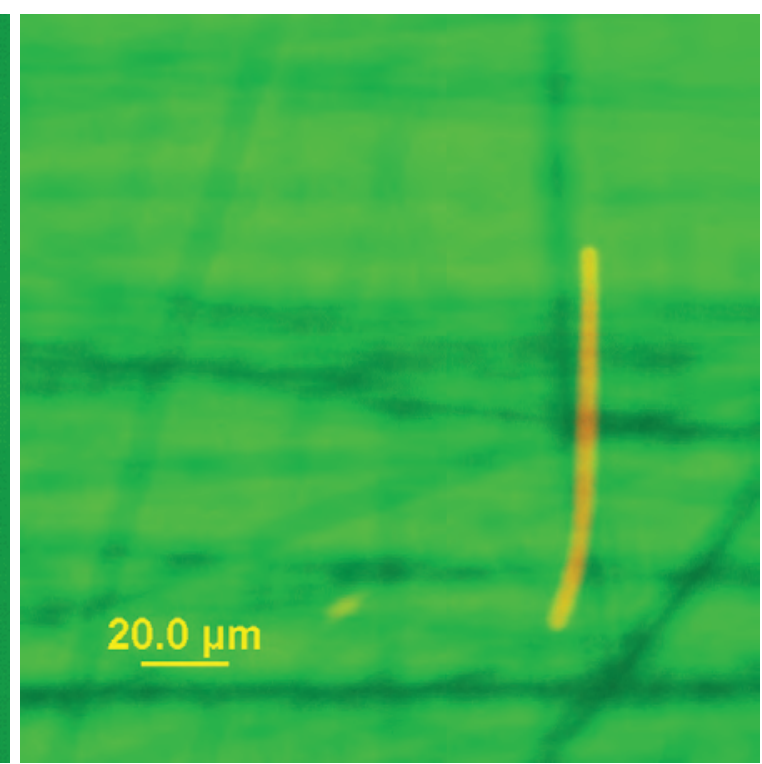

Sytox ${ }^{\circledR}$ green

Sonicated at 10 percent power

Figure 40. Blackhawk Lake, IA (8/26/2009). LM-Planktothrix sp. FITC-an orange color dominates the cells. Sytox ${ }^{\circledR}$ green-stain did not penetrate the cell membrane. LM differential interference contrast microscopy; FITC - epifluorescent microscopy; Sytox ${ }^{\circledast}$ green - epifluorescent microscopy in conjunction with the nucleic acid stain Sytox ${ }^{\circledast}$ green. 


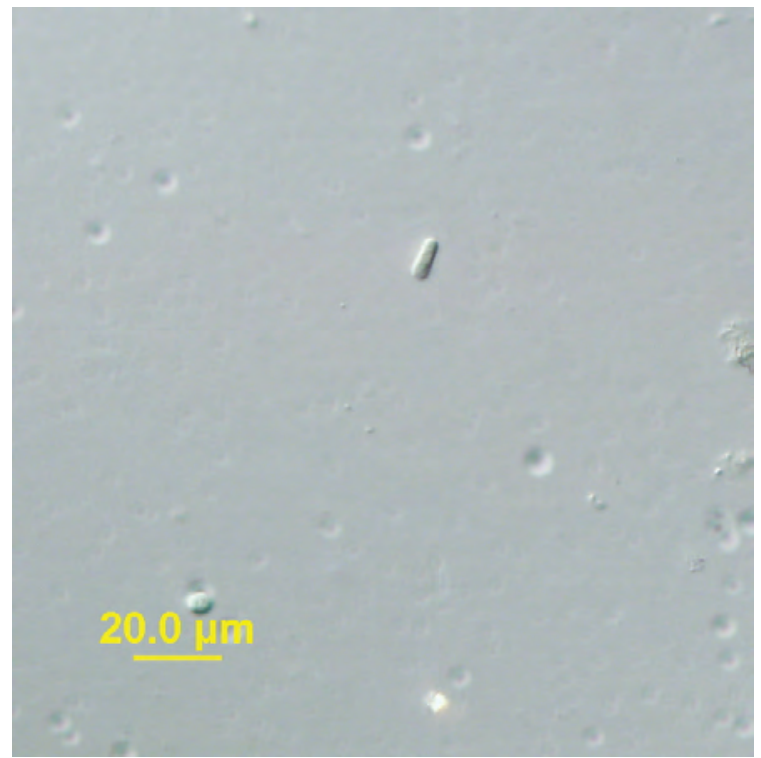

LM

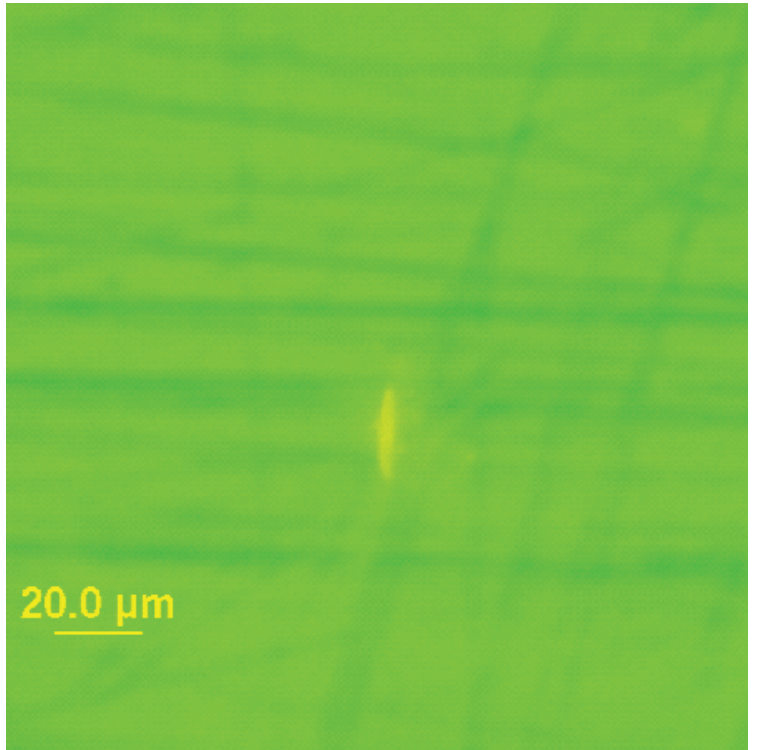

FITC

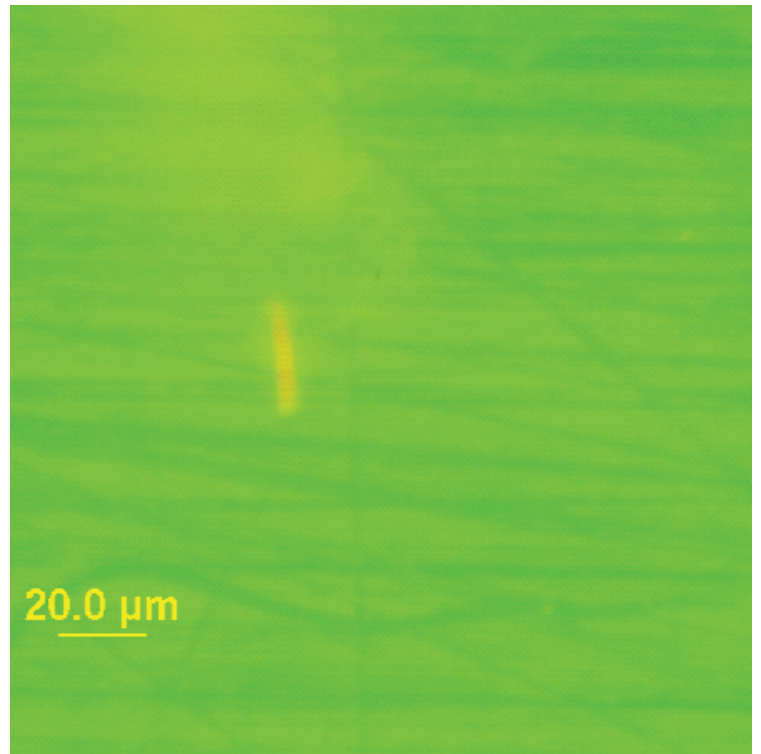

Sytox ${ }^{\circledR}$ green

\section{Sonicated at 35 percent power}

Figure 41. Blackhawk Lake, IA (8/26/2009). LM-Remains of Planktothrix sp. FITC-an orange-yellow color dominates the cells. Sytox ${ }^{\circledR}$ green-stain did not penetrate the cell membrane. LM - differential interference contrast microscopy; FITC - epifluorescent microscopy; Sytox ${ }^{\circledR}$ green - epifluorescent microscopy in conjunction with the nucleic acid stain Syto ${ }^{\circledast}$ green. 


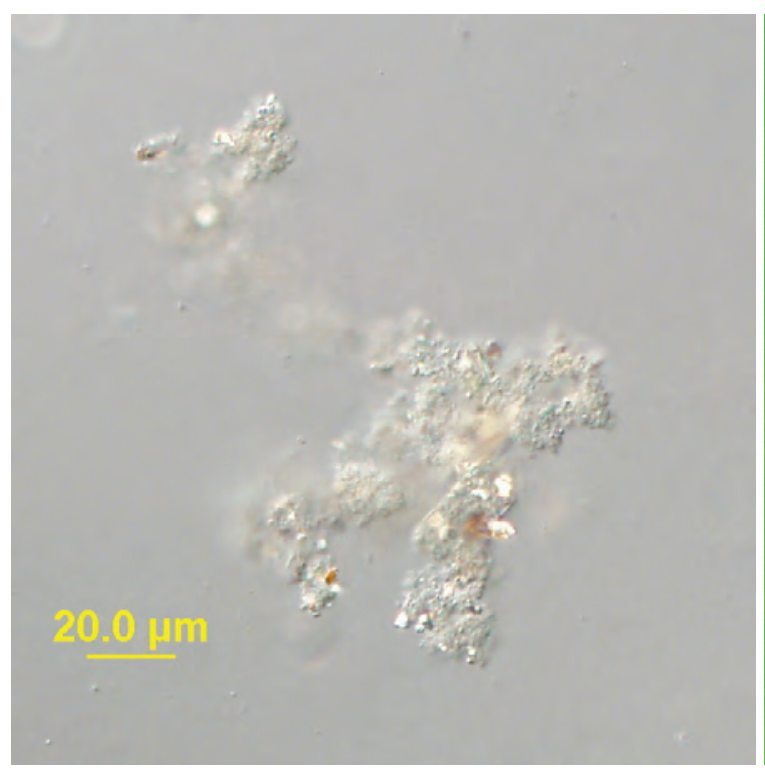

LM

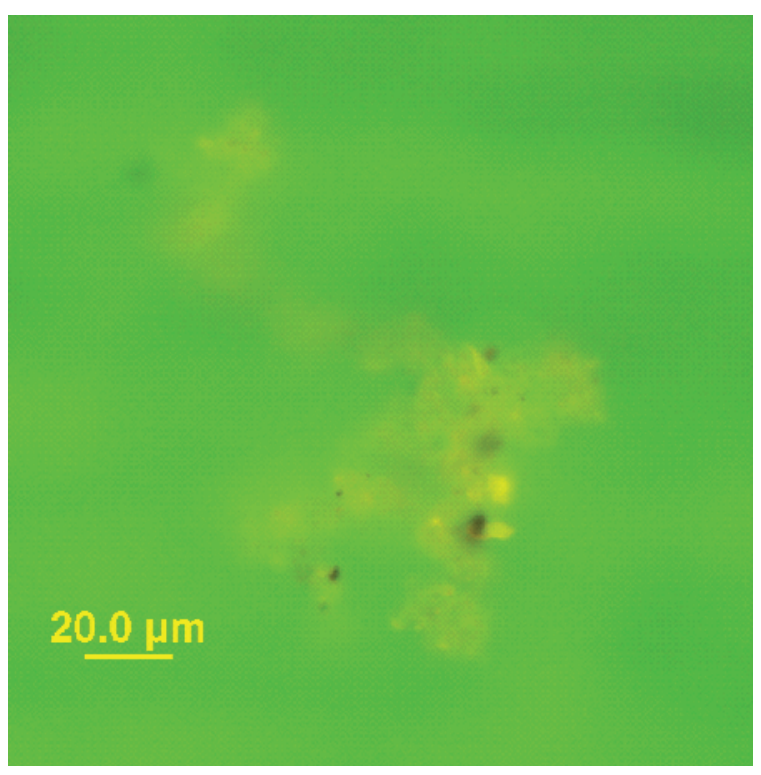

FITC

\section{Sonicated at 70 percent power}

Figure 42. Blackhawk Lake, IA (8/26/2009). LM-Remains of unknown organism; no other material observed.

FITC-nothing distinguishable as cells. Sytox ${ }^{\circledR}$ green-no images obtained. LM - differential interference contrast microscopy; FITC - epifluorescent microscopy; Sytox ${ }^{\circledR}$ green - epifluorescent microscopy in conjunction with the nucleic acid stain Sytox ${ }^{\circledR}$ green. 


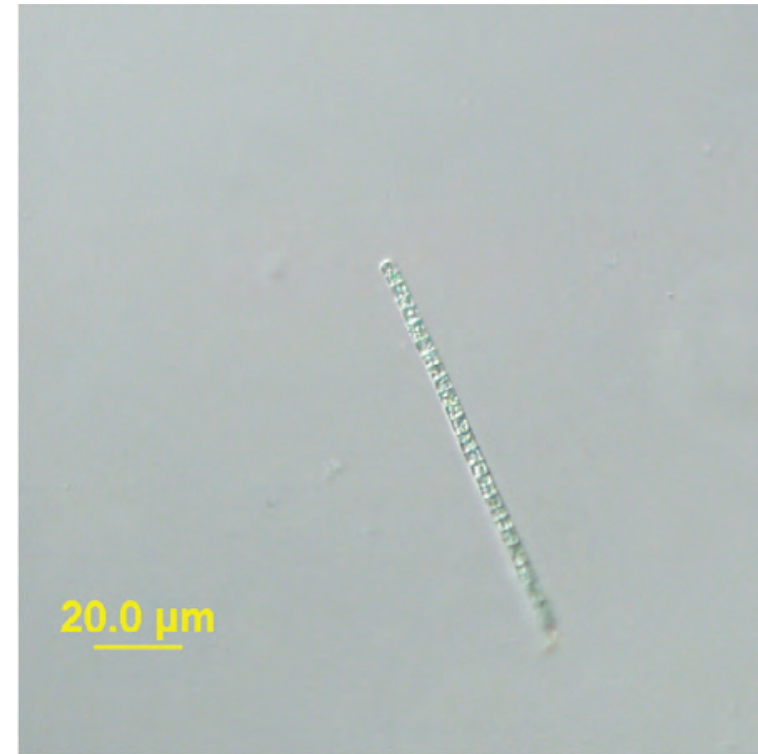

LM

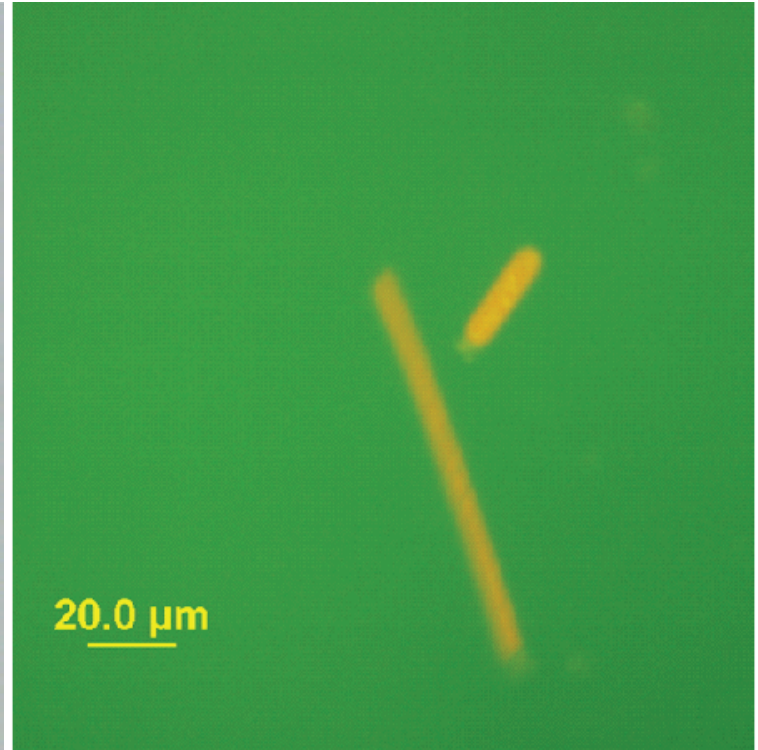

FITC

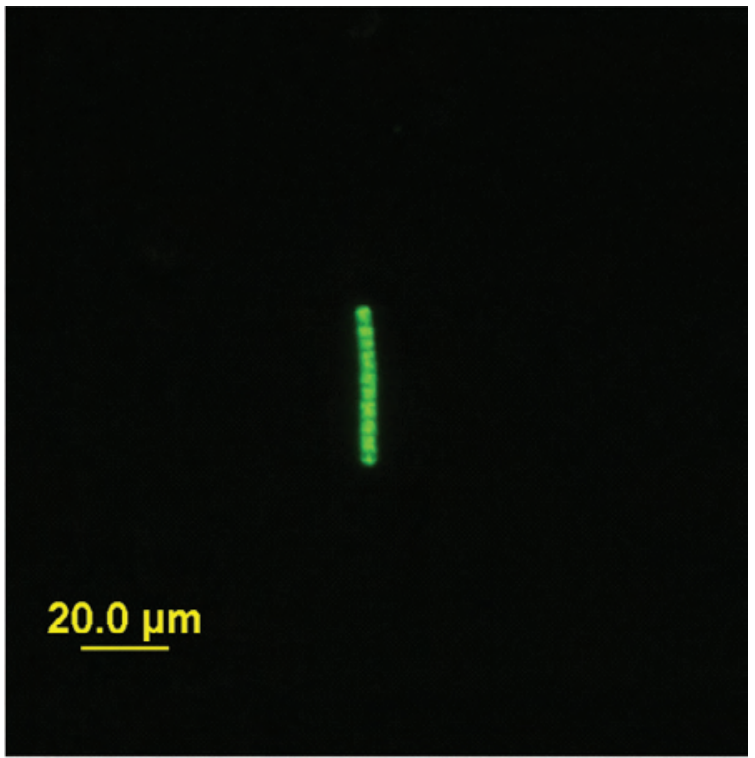

Sytox ${ }^{\circledR}$ green

\section{QuikLyse ${ }^{\mathrm{TM}}-1 \mathrm{x}$}

Figure 43. Blackhawk Lake, IA (8/26/2009). LM-Planktothrix sp. FITC-an orange color dominates the cells. Sytox ${ }^{\oplus}$ green-stain did penetrate the cell membrane; cells bright green. LM - differential interference contrast microscopy; FITC - epifluorescent microscopy; Sytox ${ }^{\circledast}$ green - epifluorescent microscopy in conjunction with the nucleic acid stain Sytox ${ }^{\oplus}$ green. 


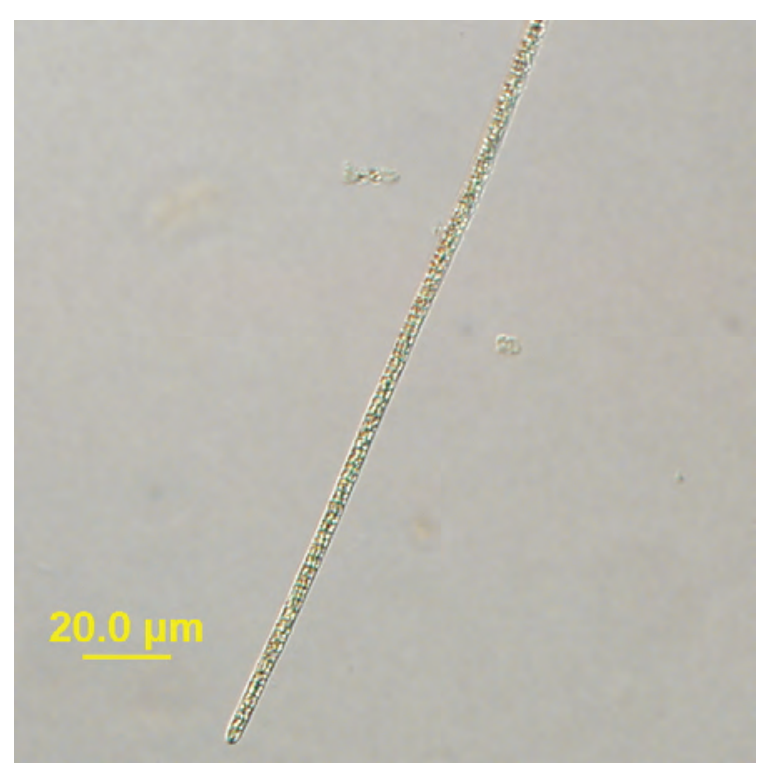

LM

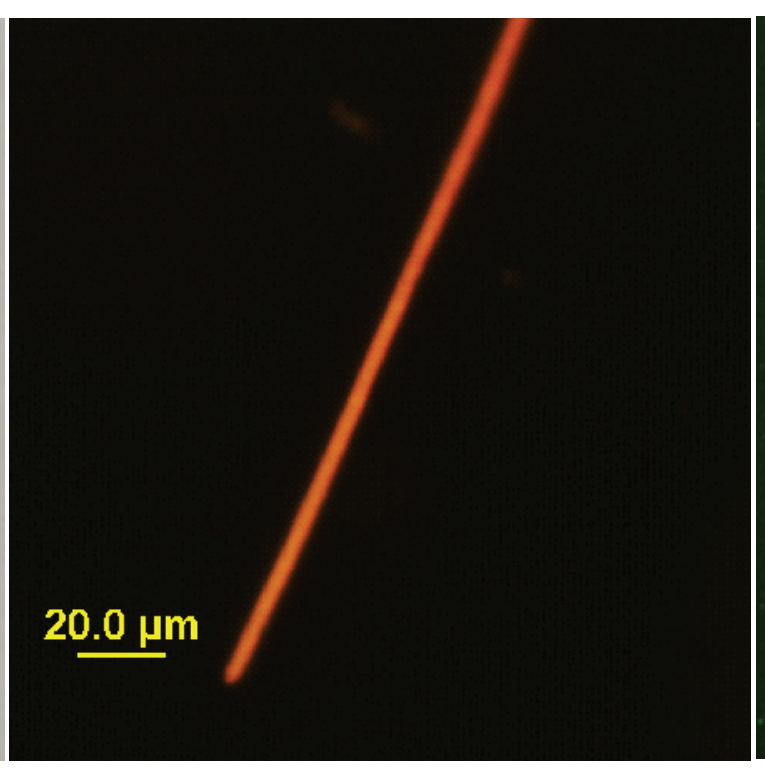

FITC

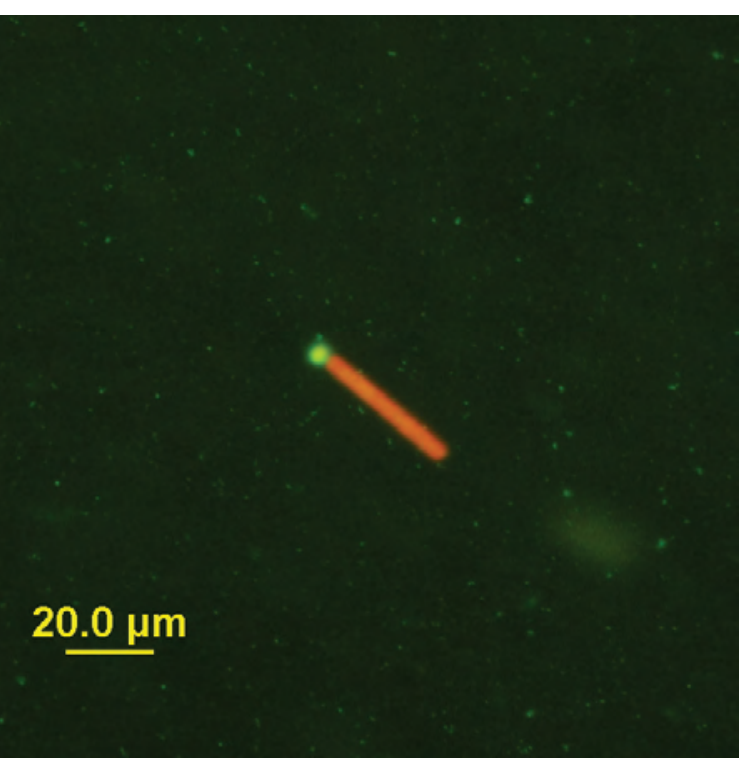

Sytox ${ }^{\circledR}$ green

\section{One freeze-thaw cycle}

Figure 44. Blackhawk Lake, IA (8/26/2009). LM-Planktothrix sp. FITC-an orange color dominates the cells. Sytox ${ }^{\circledast}$ green-stain did not penetrate the cell membrane, except end cell. LM - differential interference contrast microscopy; FITC - epifluorescent microscopy; Sytox ${ }^{\circledast}$ green - epifluorescent microscopy in conjunction with the nucleic acid stain Sytox ${ }^{\circledast}$ green. 


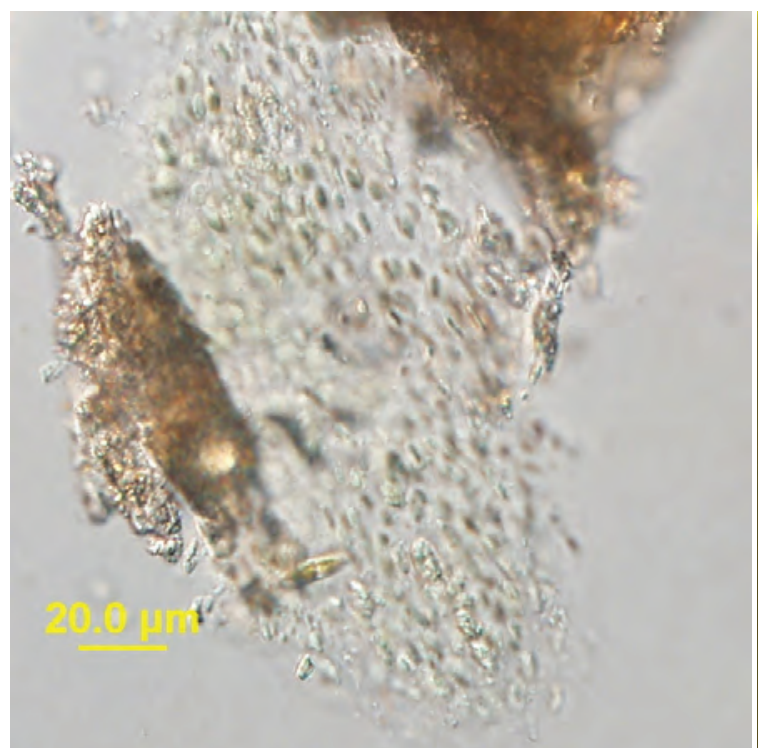

LM

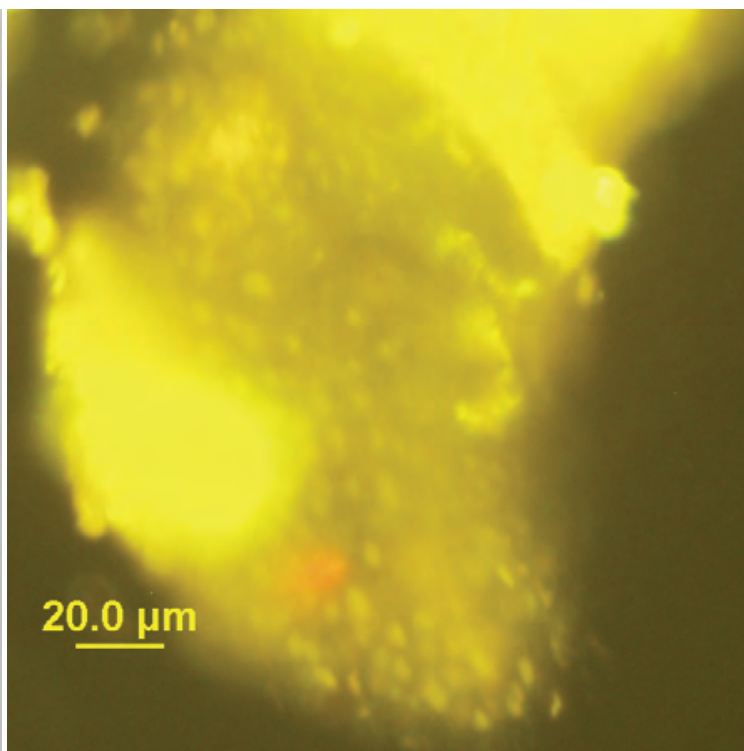

FITC

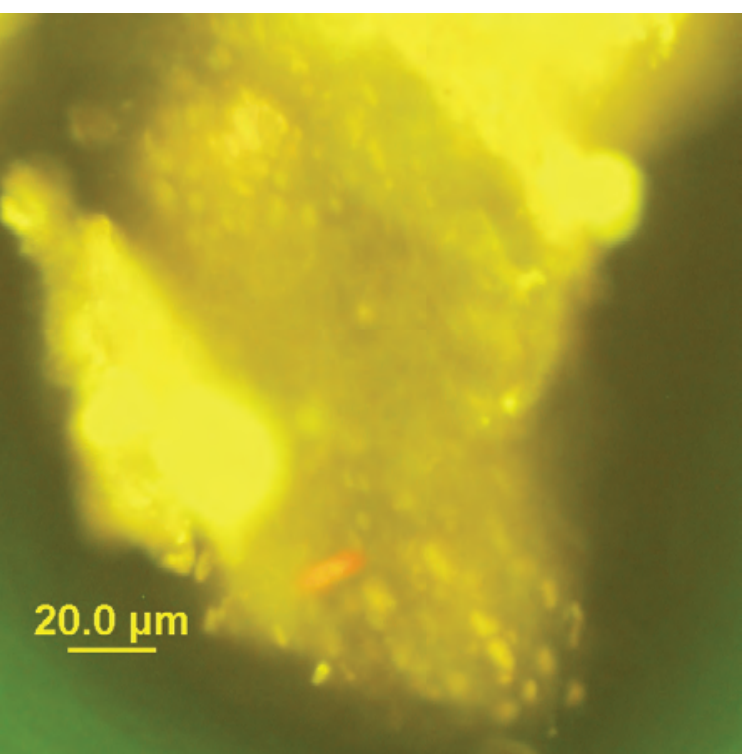

Sytox ${ }^{\circledR}$ green

Two freeze-thaw cycles

Figure 45. Blackhawk Lake, IA (8/26/2009). LM-Remains of a colonial cyanobacterium, likely Microcystis. FITC-a yellow color dominates the cells. Sytox ${ }^{\circledR}$ green-stain did not penetrate the cell membrane. LM - differential interference contrast microscopy; FITC - epifluorescent microscopy; Sytox ${ }^{\circledR}$ green - epifluorescent microscopy in conjunction with the nucleic acid stain Sytox ${ }^{\circledR}$ green. 


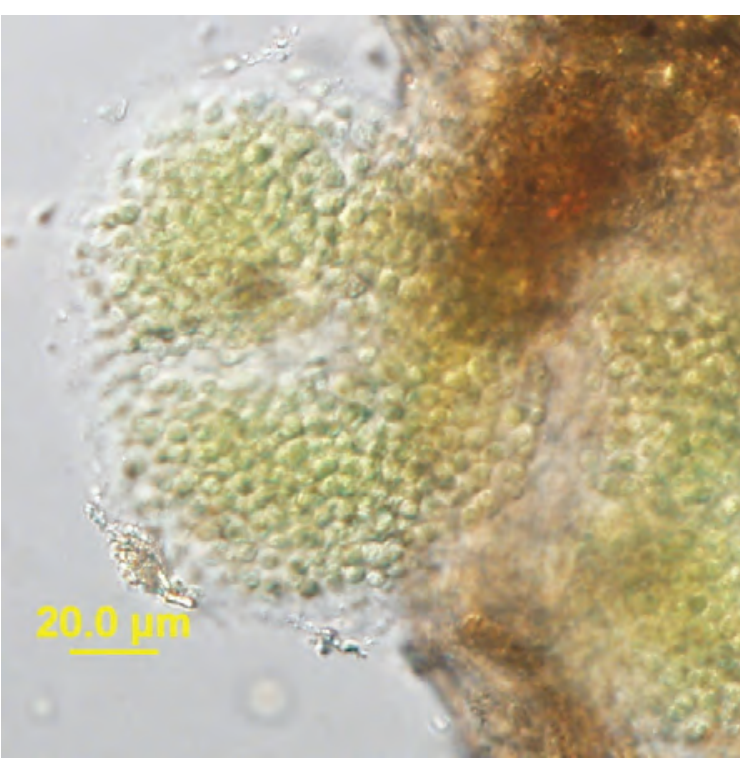

LM

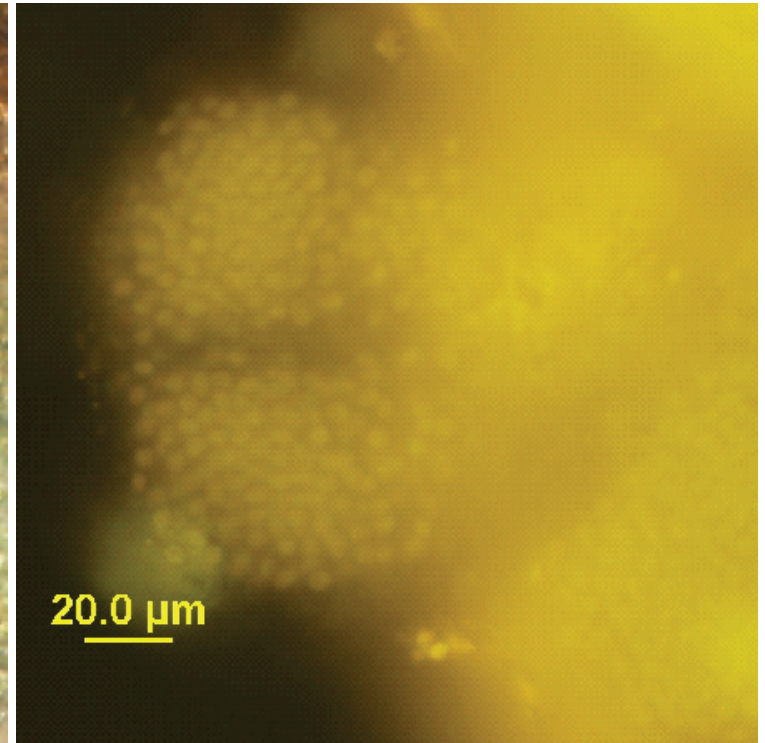

FITC

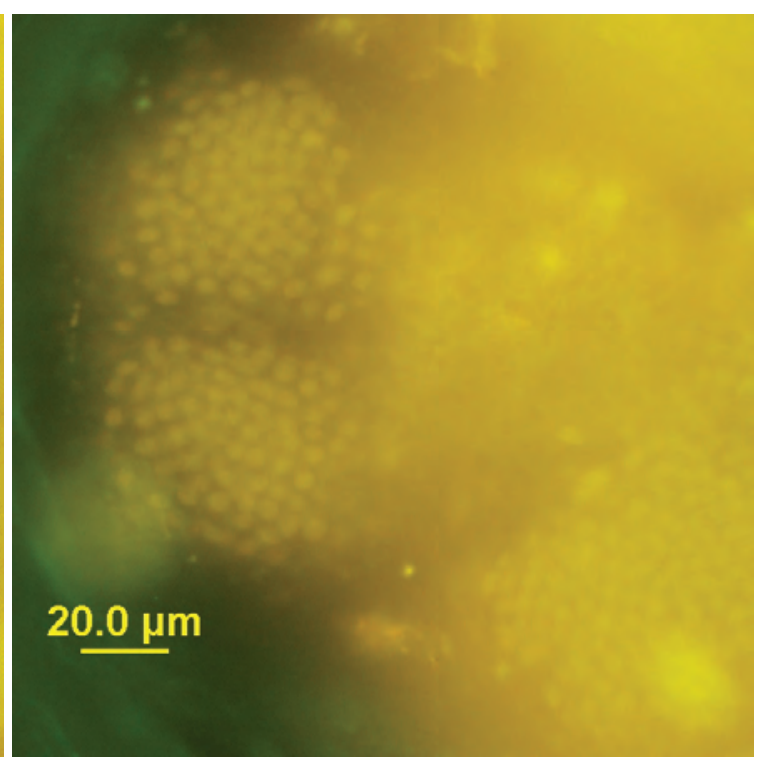

Sytox ${ }^{\circledR}$ green

Three freeze-thaw cycles

Figure 46. Blackhawk Lake, IA (8/26/2009). LM-Microcystis sp. FITC-a yellow color dominates the cells. Sytox ${ }^{\circledR}$ green-stain did not penetrate the cell membrane. LM differential interference contrast microscopy; FITC - epifluorescent microscopy; Sytox ${ }^{\circledast}$ green - epifluorescent microscopy in conjunction with the nucleic acid stain Sytox ${ }^{\circledR}$ green. 


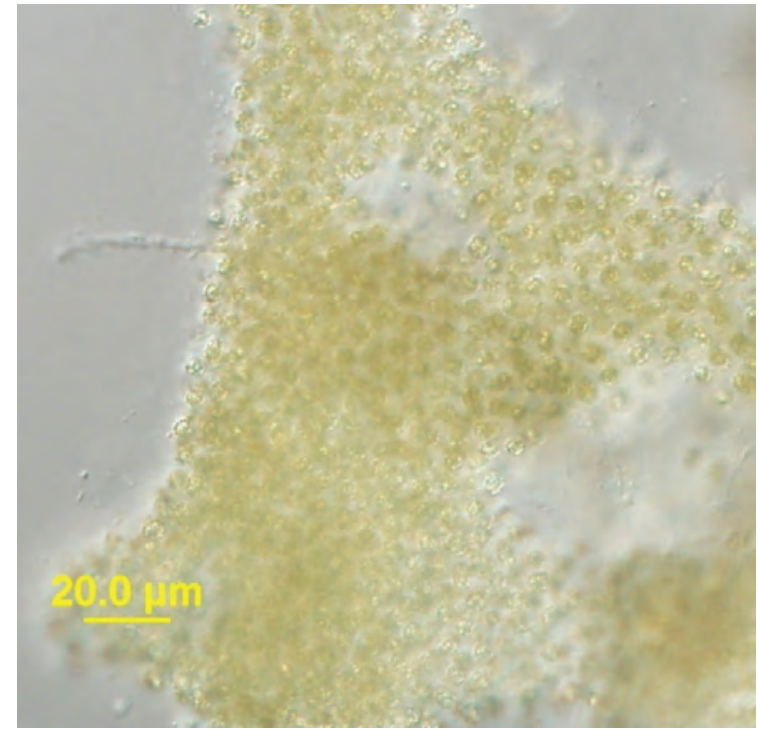

LM

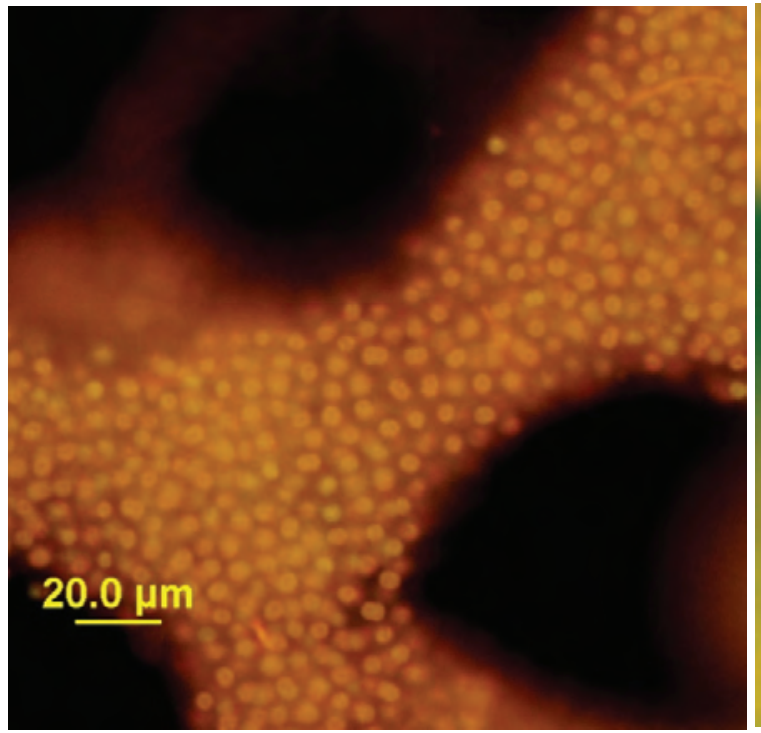

FITC

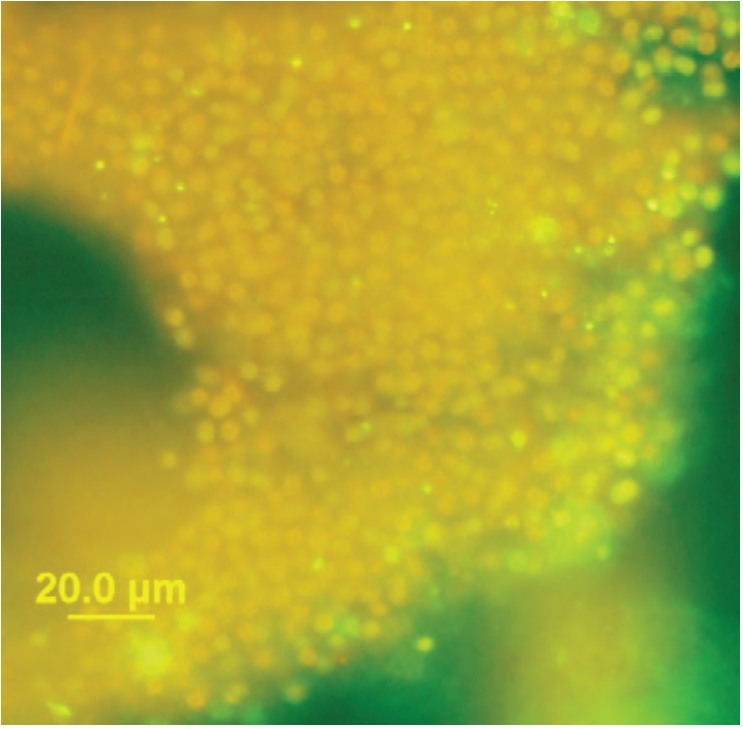

Sytox ${ }^{\circledR}$ green

Control 1

Figure 47. Copco Reservoir, CA (9/10/2009). LM-Microcystis aeruginosa. FITC-an orange color dominates the cells. Sytox ${ }^{\circledR}$ green-stain did penetrate the cell membrane in some of the peripheral cells. LM - differential interference contrast microscopy; FITC - epifluorescent microscopy; Sytox ${ }^{\circledR}$ green - epifluorescent microscopy in conjunction with the nucleic acid stain Sytox ${ }^{\circledR}$ green. 


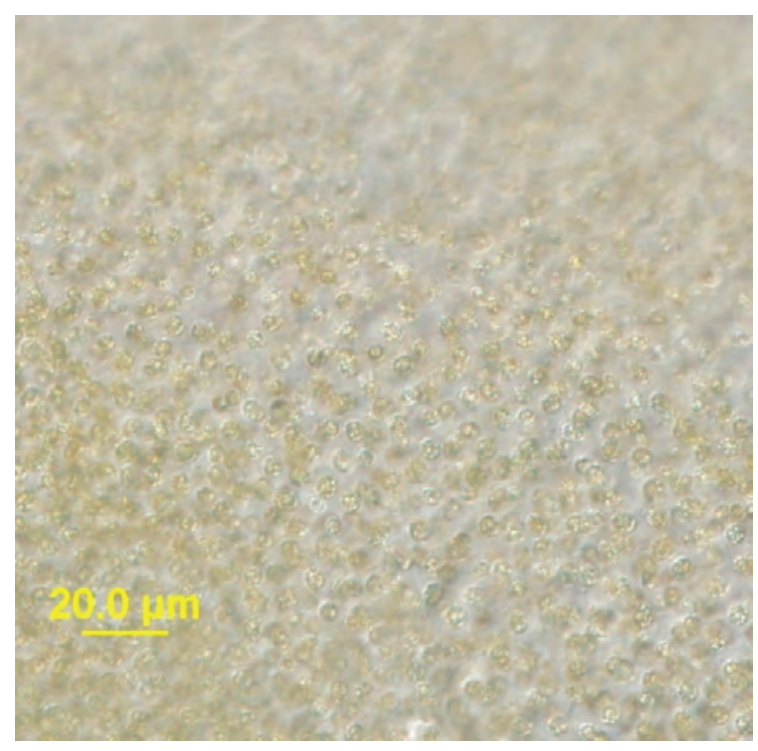

LM

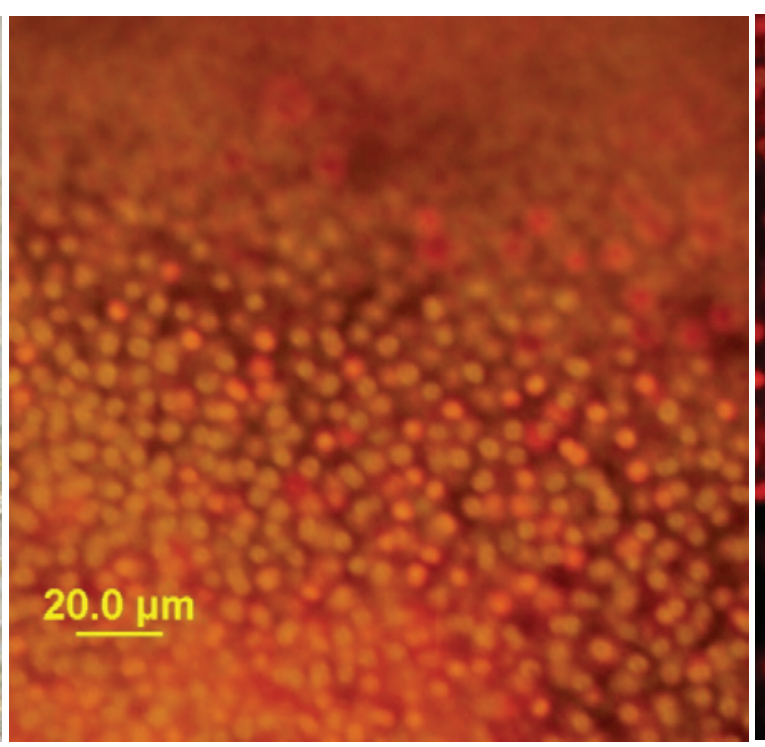

FITC

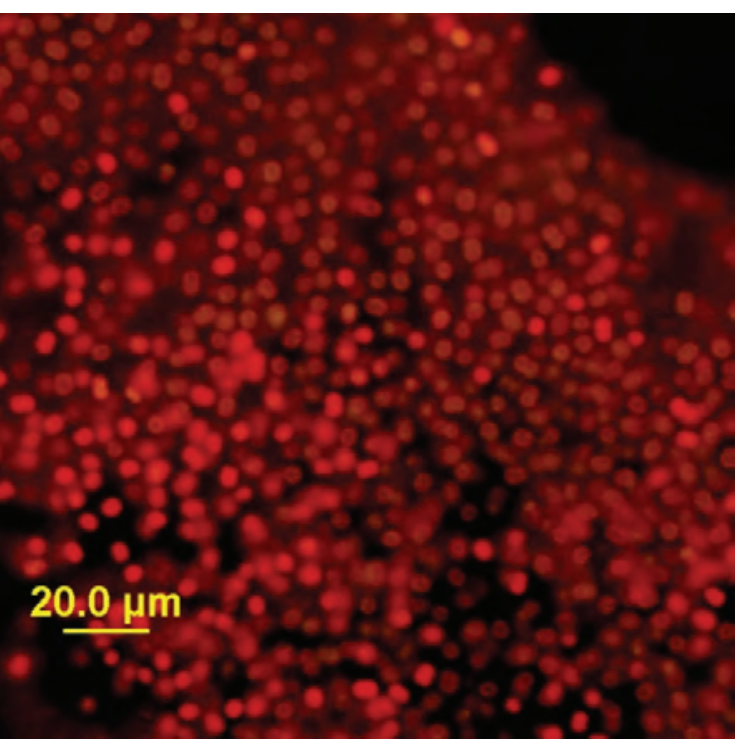

Sytox ${ }^{\circledR}$ green

Control 2

Figure 48. Copco Reservoir, CA (9/10/2009). LM-Microcystis aeruginosa. FITC-an orange-red color dominates the cells. Sytox ${ }^{\oplus}$ green-stain did not penetrate the cell membrane. LM - differential interference contrast microscopy; FITC - epifluorescent microscopy; Sytox ${ }^{\circledR}$ green - epifluorescent microscopy in conjunction with the nucleic acid stain Sytox ${ }^{\circledR}$ green. 


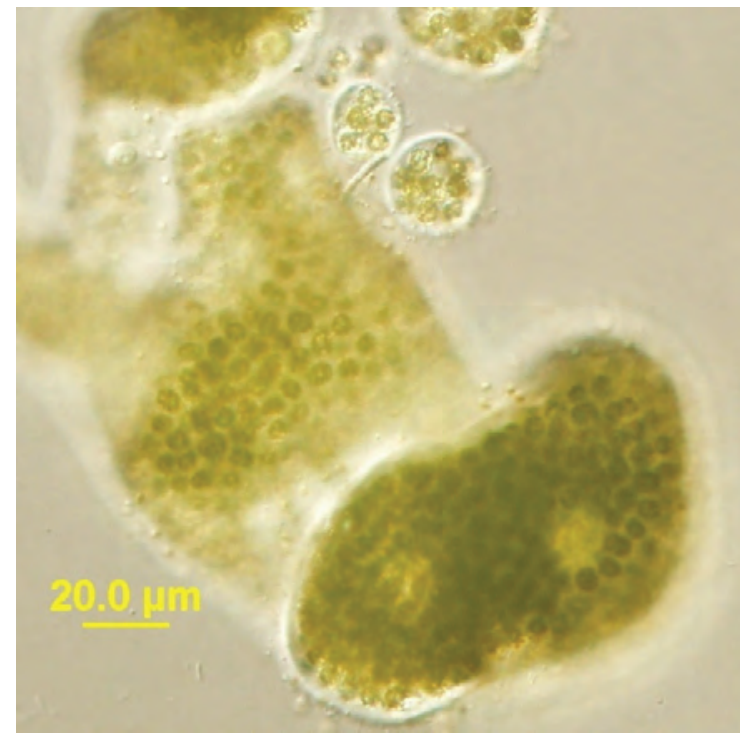

LM

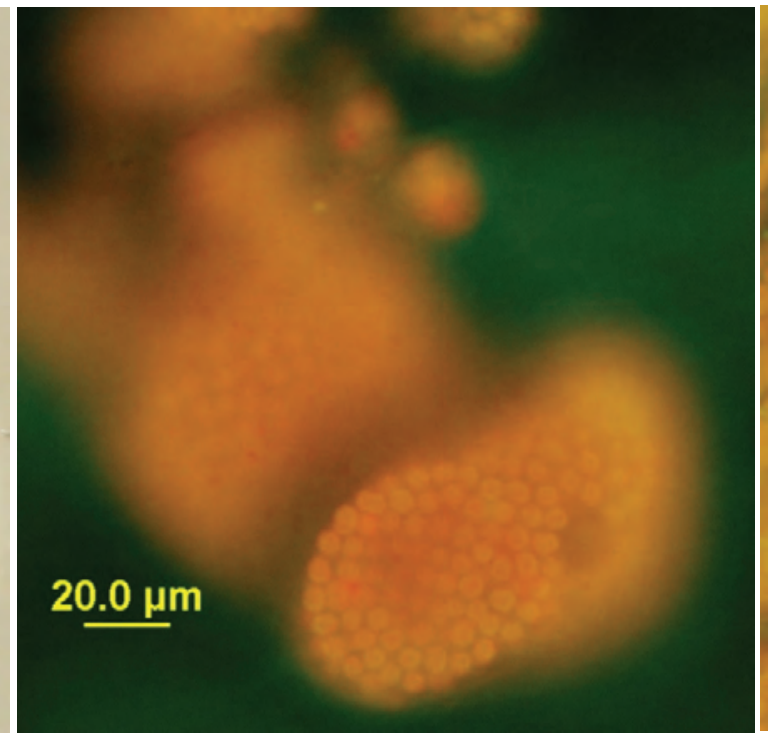

FITC

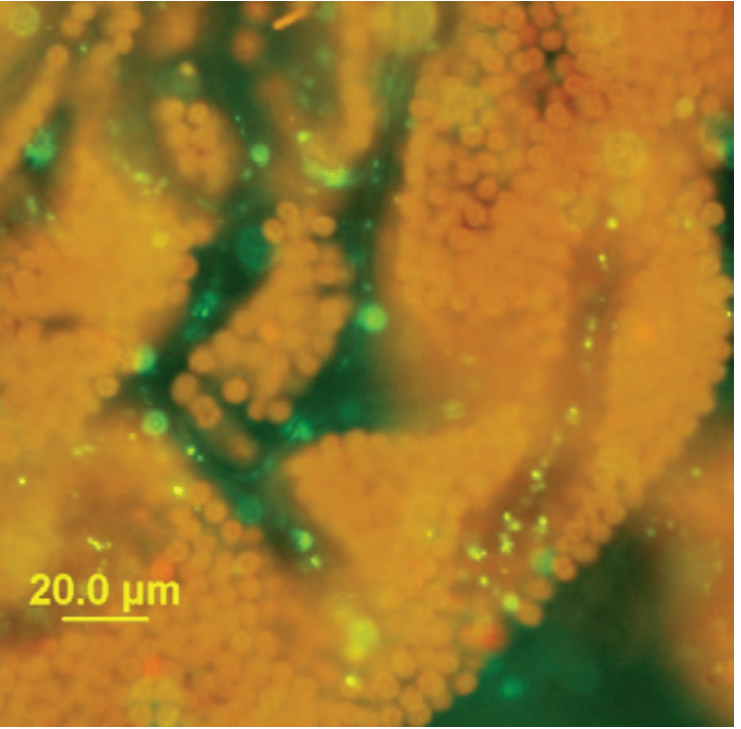

Sytox ${ }^{\circledR}$ green

\section{Control 3}

Figure 49. Copco Reservoir, CA (9/10/2009). LM-Microcystis wesenbergii. FITC-an orange-red color dominates the cells. Sytox ${ }^{\circledR}$ green-stain did not penetrate the cell membrane of the cyanobacteria; epiphytic bacteria did stain bright green. LM - differential interference contrast microscopy; FITC - epifluorescent microscopy; Sytox ${ }^{\circledR}$ green - epifluorescent microscopy in conjunction with the nucleic acid stain Sytox ${ }^{\circledR}$ green. 


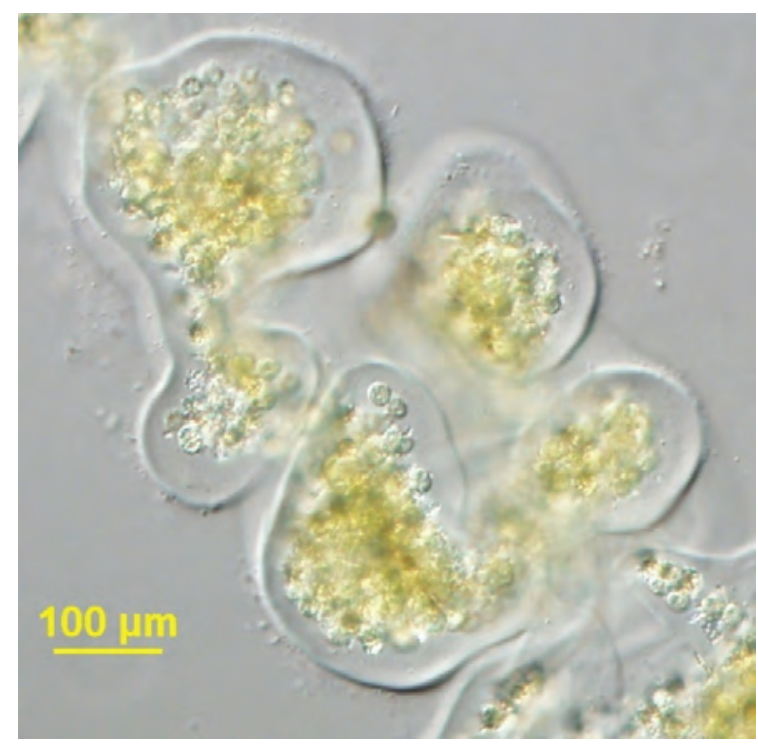

LM

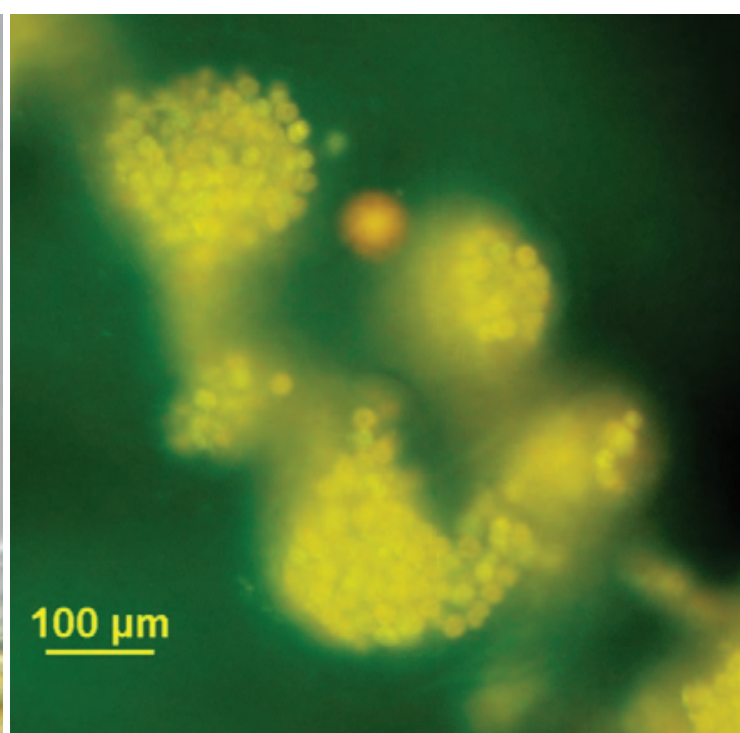

FITC

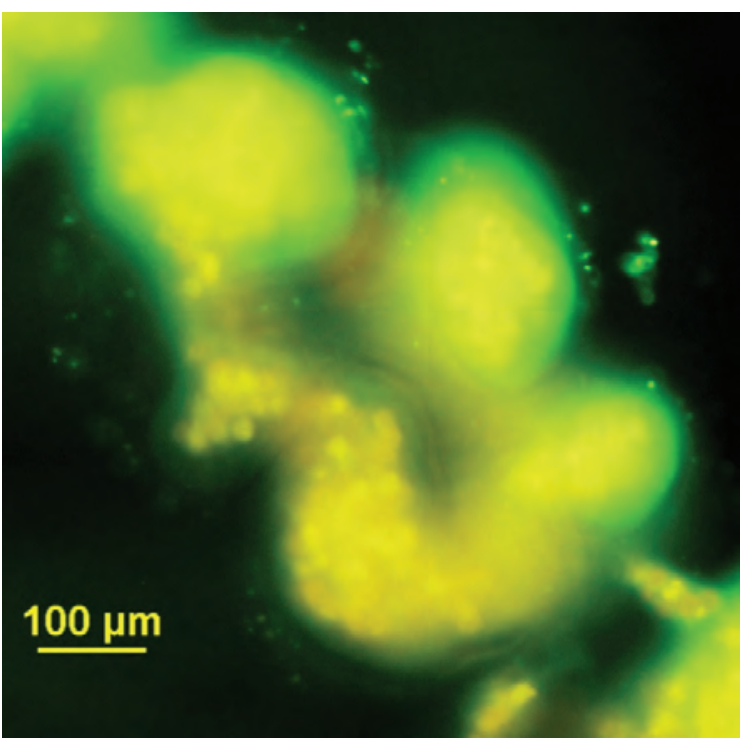

Sytox ${ }^{\circledast r e e n}$

\section{Boiled for 5 minutes}

Figure 50. Copco Reservoir, CA (9/10/2009). LM-Microcystis wesenbergii. FITC-a yellow color dominates the cells. Sytox ${ }^{\circledast}$ green-stain did not penetrate the cell membrane of the cyanobacteria; outer mucilage did stain bright green. LM - differential interference contrast microscopy; FITC - epifluorescent microscopy; Sytox ${ }^{\circledR}$ green epifluorescent microscopy in conjunction with the nucleic acid stain $S y t o x{ }^{\circledast}$ green 


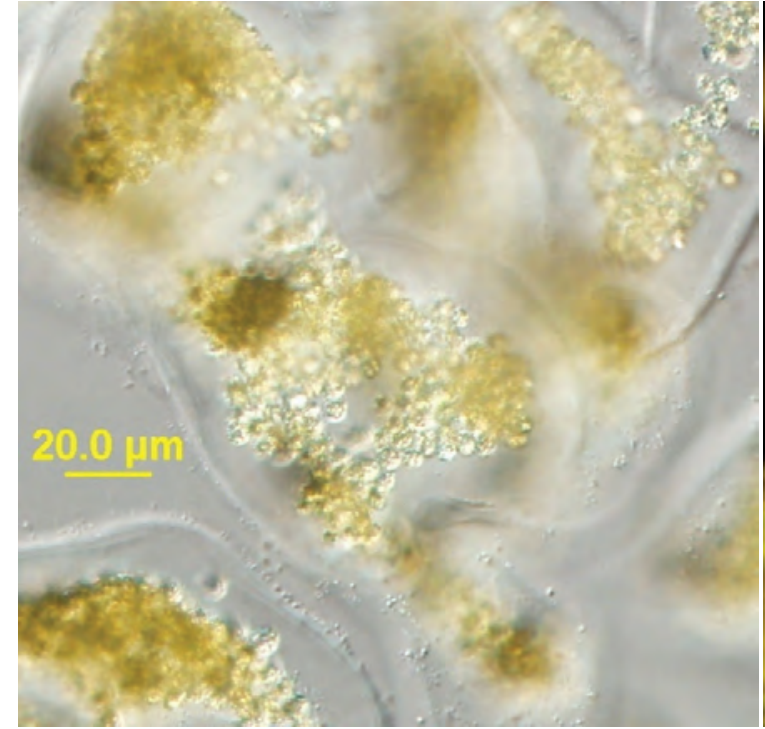

LM

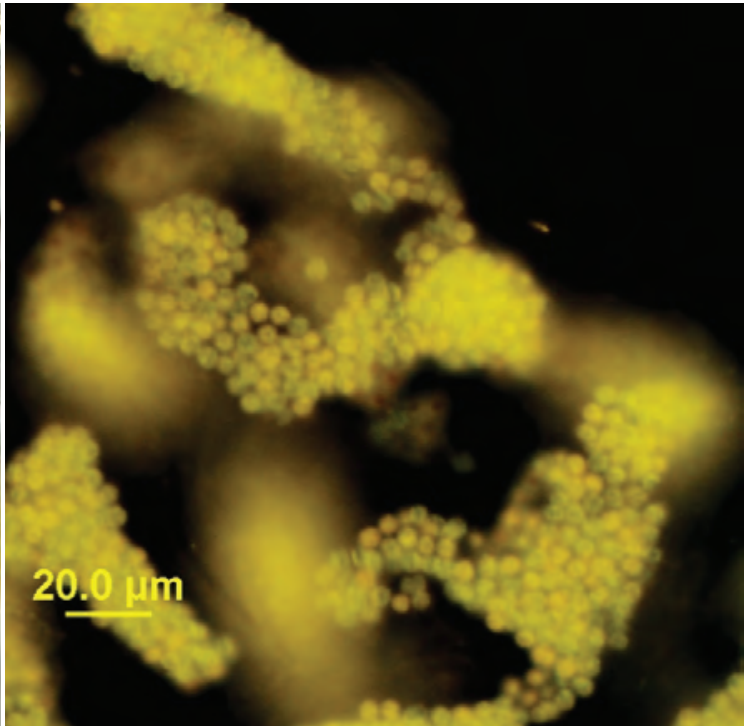

FITC

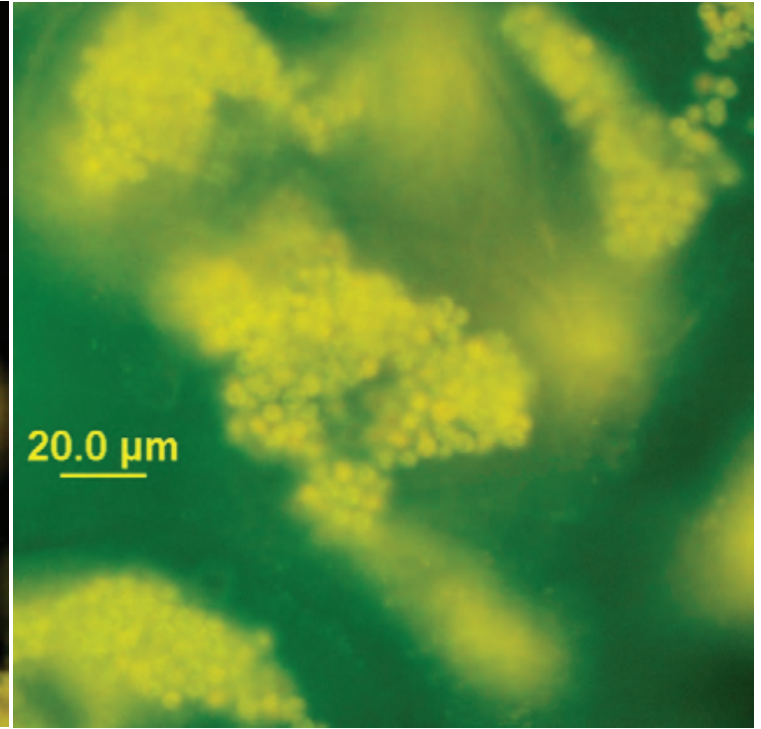

Sytox ${ }^{\circledR}$ green

Boiled for 15 minutes

Figure 51. Copco Reservoir, CA (9/10/2009). LM-Microcystis wesenbergii. FITC-a yellow color dominates the cells. Sytox ${ }^{\circledR}$ green-stain did not penetrate the cell membrane of the cyanobacteria; outer mucilage did stain bright green. LM - differential interference contrast microscopy; FITC - epifluorescent microscopy; Sytox ${ }^{\circledR}$ green epifluorescent microscopy in conjunction with the nucleic acid stain Sytox ${ }^{\circledR}$ green. 


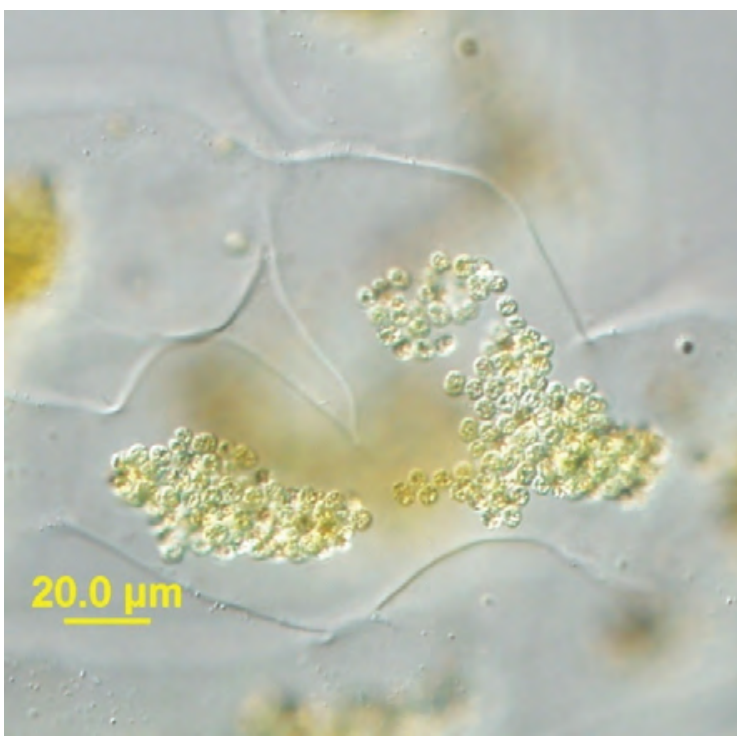

LM

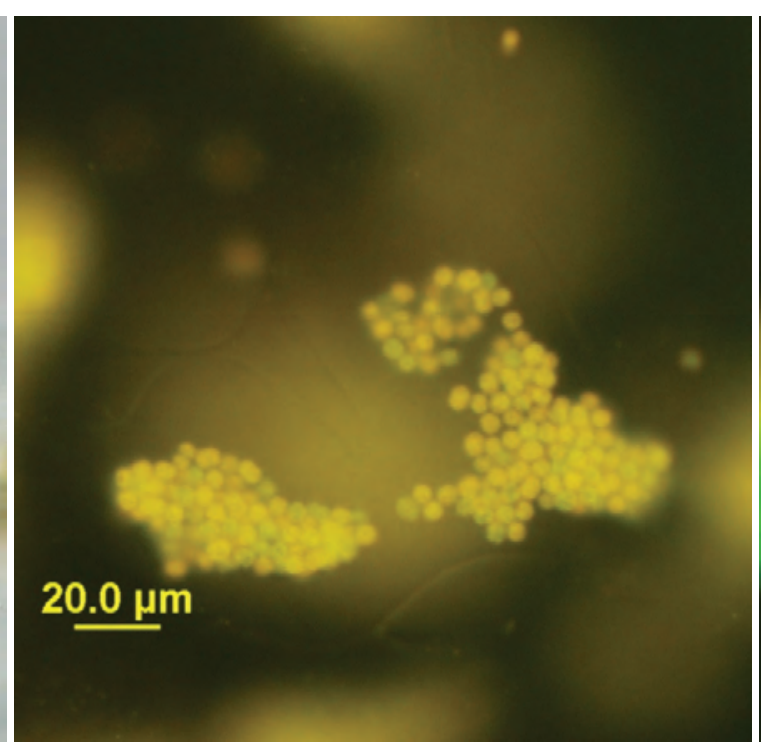

FITC

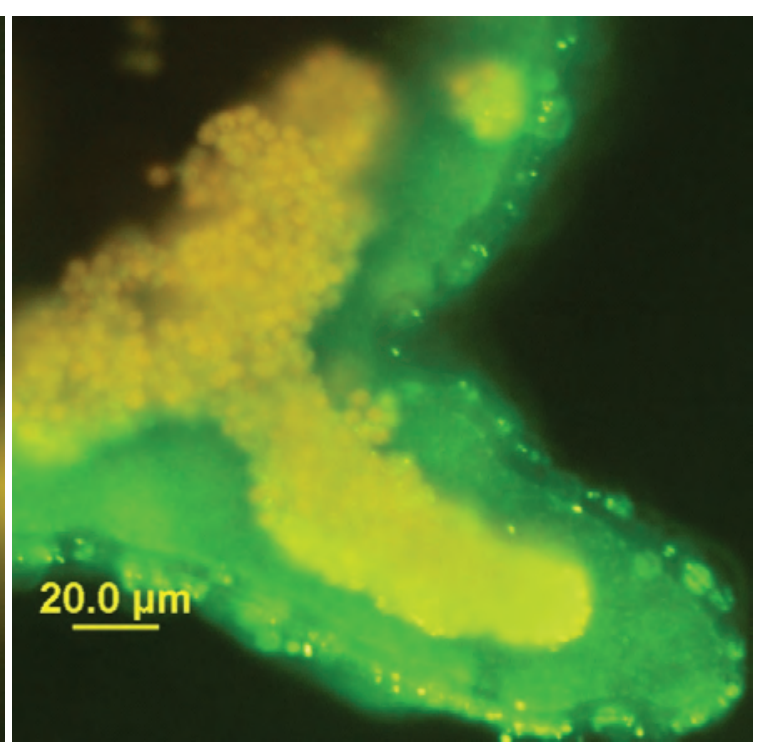

Sytox ${ }^{\circledR}$ green

Boiled for 30 minutes

Figure 52. Copco Reservoir, CA (9/10/2009). LM-Microcystis wesenbergii. FITC-a yellow color dominates the cells. Sytox ${ }^{\circledR}$ green-stain did not penetrate the cell membrane of the cyanobacteria; outer mucilage did stain bright green. LM - differential interference contrast microscopy; FITC - epifluorescent microscopy; Sytox ${ }^{\circledR}$ green epifluorescent microscopy in conjunction with the nucleic acid stain Sytox ${ }^{\circledR}$ green. 


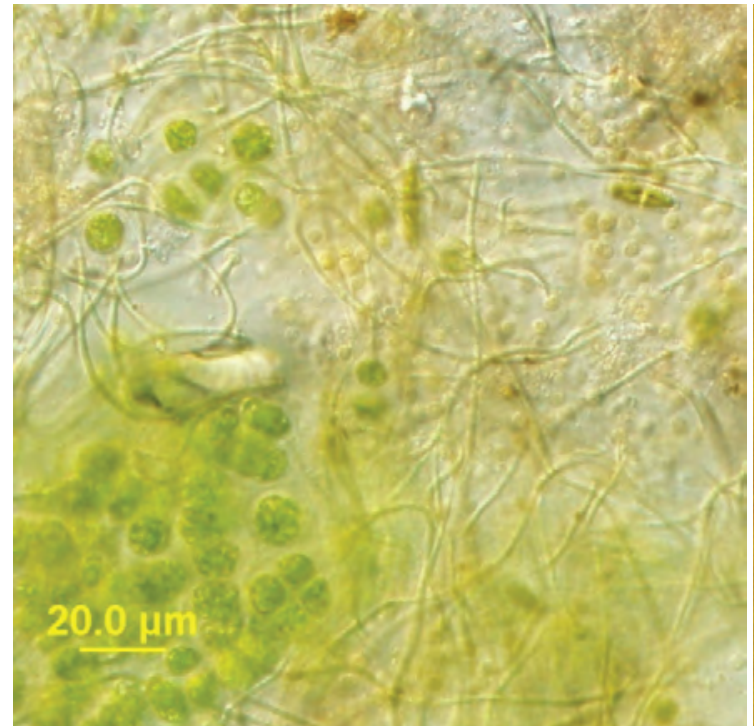

LM

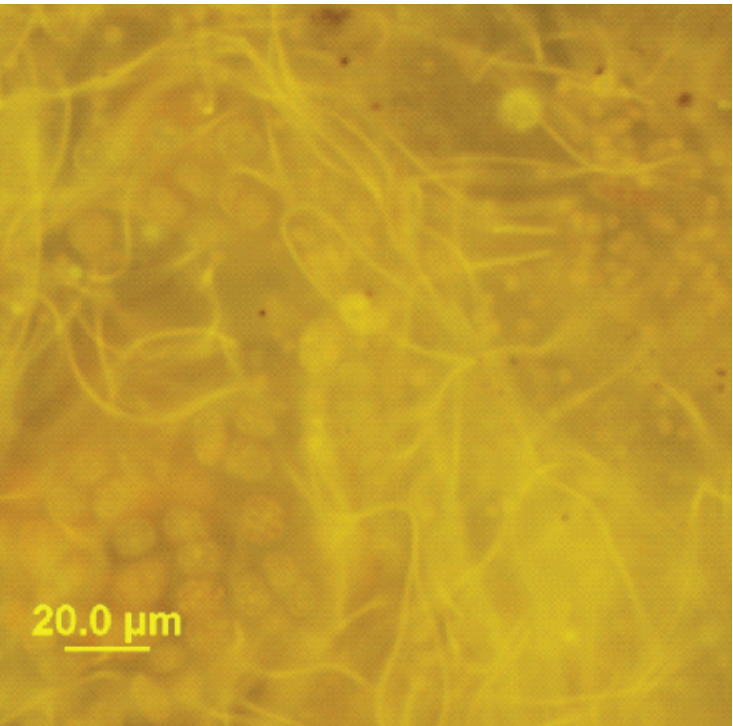

FITC

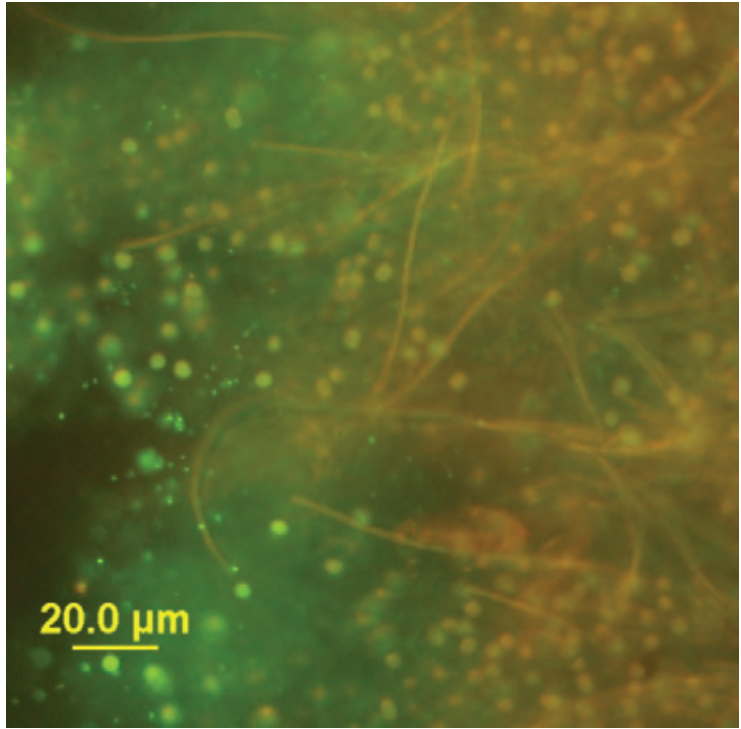

Sytox ${ }^{\circledR}$ green

Autoclaved for 5 minutes

Figure 53. Copco Reservoir, CA (9/10/2009). LM-Miscellaneous cyanobacterial filaments and eukaryotic algae. FITC-a yellow-orange color dominates the cells. Sytox ${ }^{\circledR}$ green-stain did penetrate the cell membrane of some of the colonial cyanobacterial cells, but not the unknown cyanobacterial filaments. LM - differential interference contrast microscopy; FITC - epifluorescent microscopy; Sytox ${ }^{\circledast}$ green - epifluorescent microscopy in conjunction with the nucleic acid stain Sytox ${ }^{\circledR}$ green. 


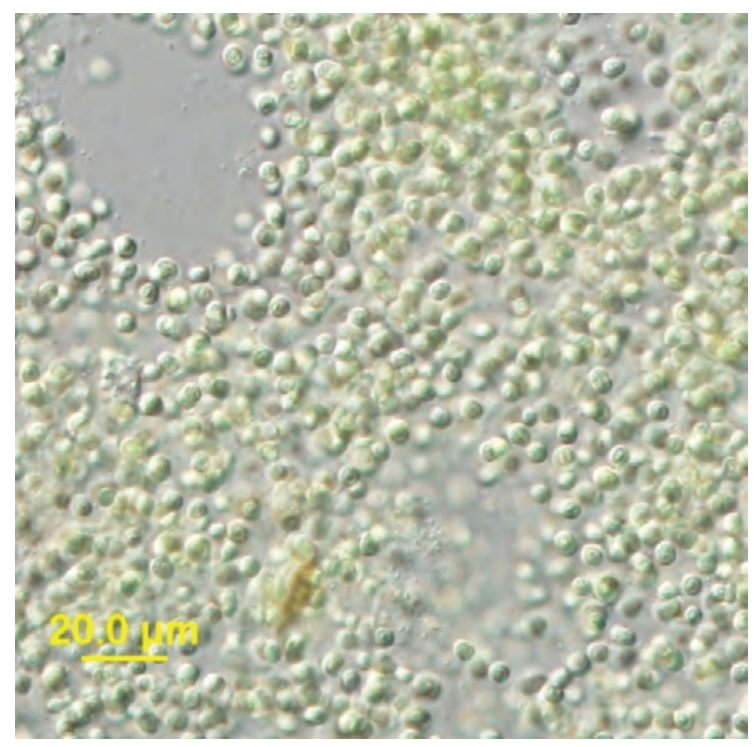

LM

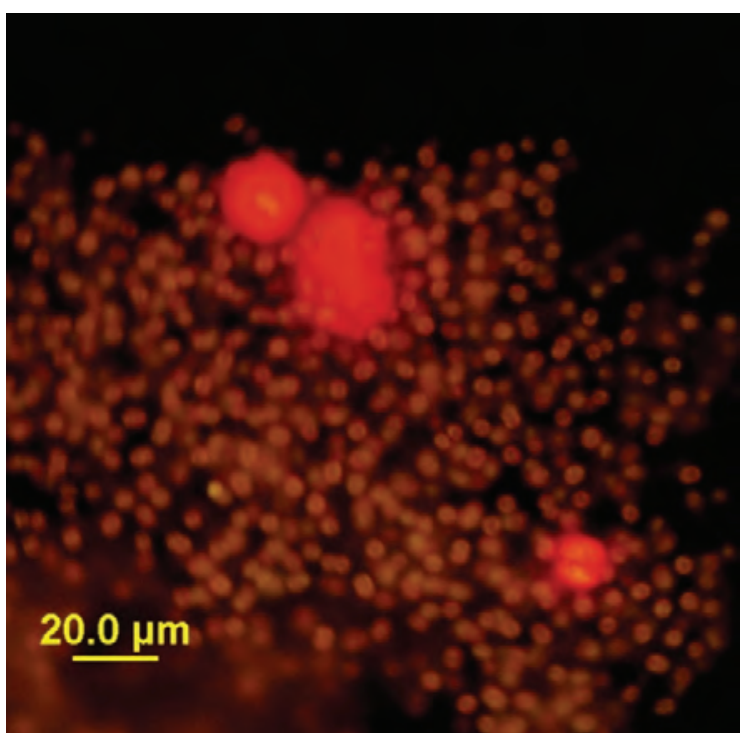

FITC

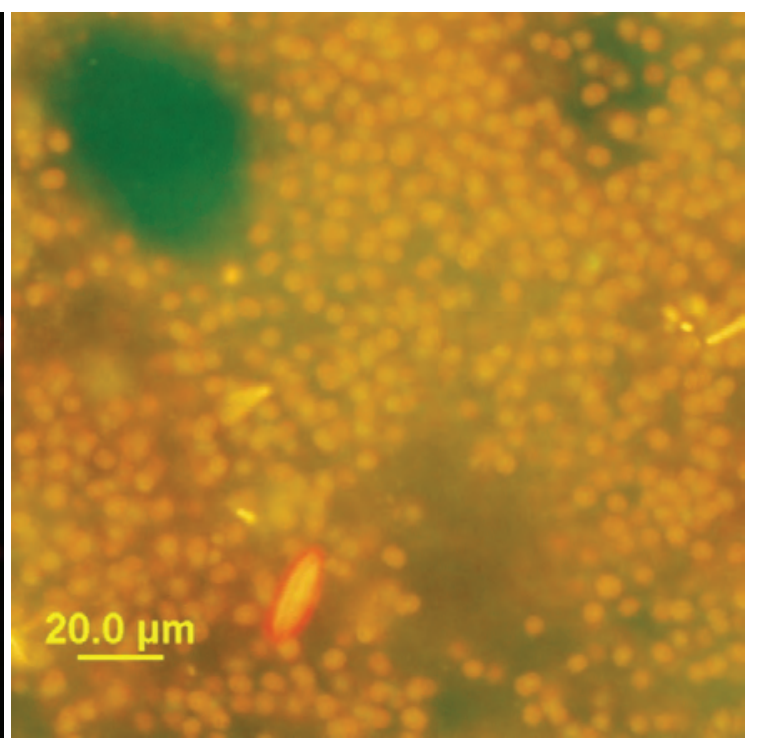

Sytox ${ }^{\circledR}$ green

Sonicated at 10 percent power

Figure 54. Copco Reservoir, CA (9/10/2009). LM-Microcystis aeruginosa. FITC-a red color dominates the cells. Sytox ${ }^{\circledR}$ green-stain did not penetrate the cell membrane. LM - differential interference contrast microscopy; FITC - epifluorescent microscopy; Sytox ${ }^{\circledR}$ green - epifluorescent microscopy in conjunction with the nucleic acid stain Sytox ${ }^{\circledR}$ green. 


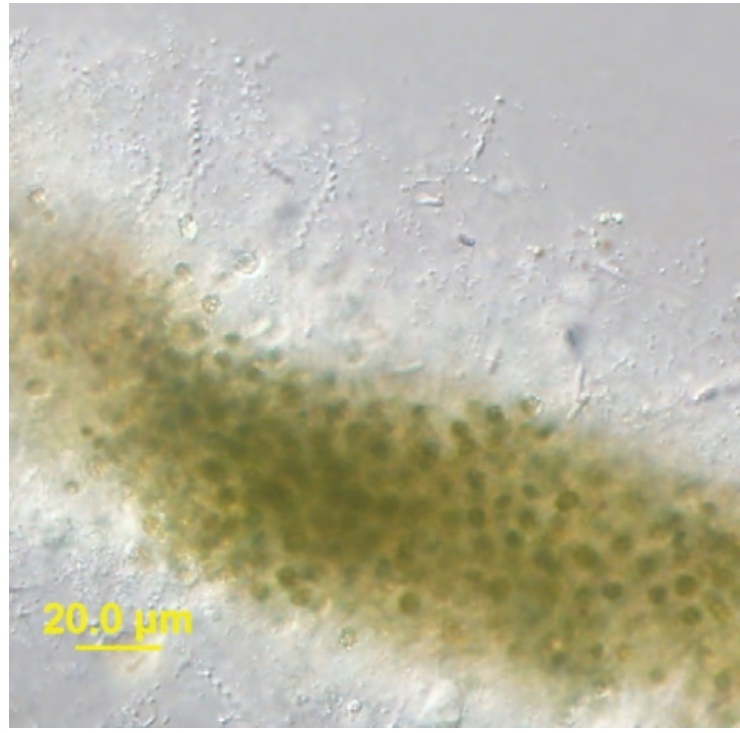

LM

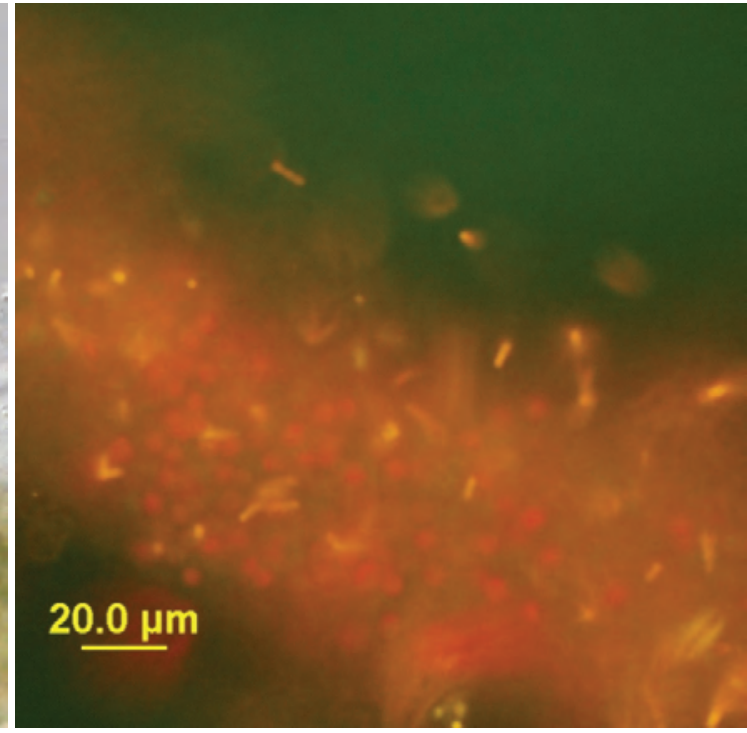

FITC

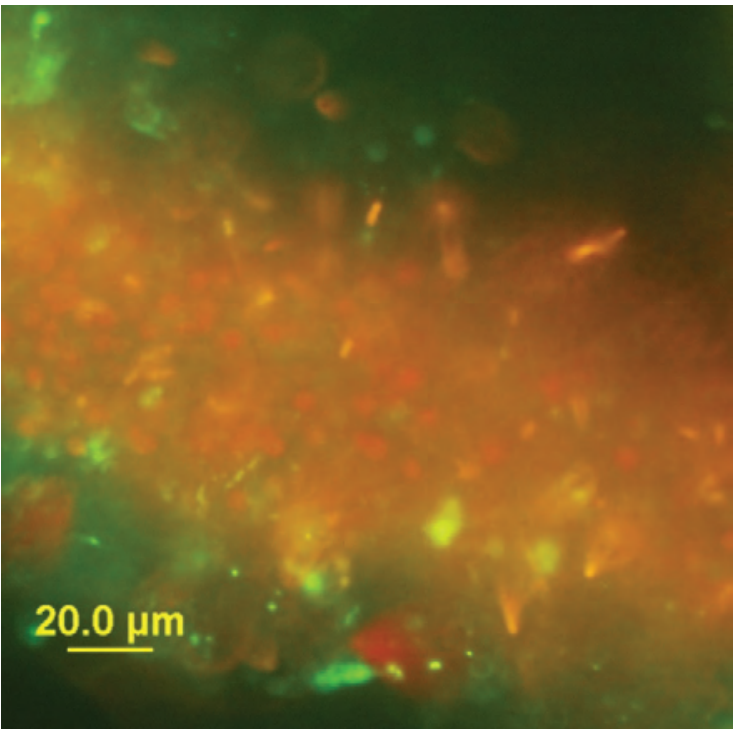

Sytox ${ }^{\circledR}$ green

\section{Sonicated at 35 percent power}

Figure 55. Copco Reservoir, CA (9/10/2009). LM-Microcystis aeruginosa. FITC-a red color dominates the cells. Sytox ${ }^{\circledast}$ green-stain did not penetrate the cell membrane of the cyanobacteria; epiphytes associated with the outer mucilage did stain bright green. LM - differential interference contrast microscopy; FITC - epifluorescent microscopy; Sytox ${ }^{\circledR}$ green - epifluorescent microscopy in conjunction with the nucleic acid stain Sytox ${ }^{\circledast}$ green. 


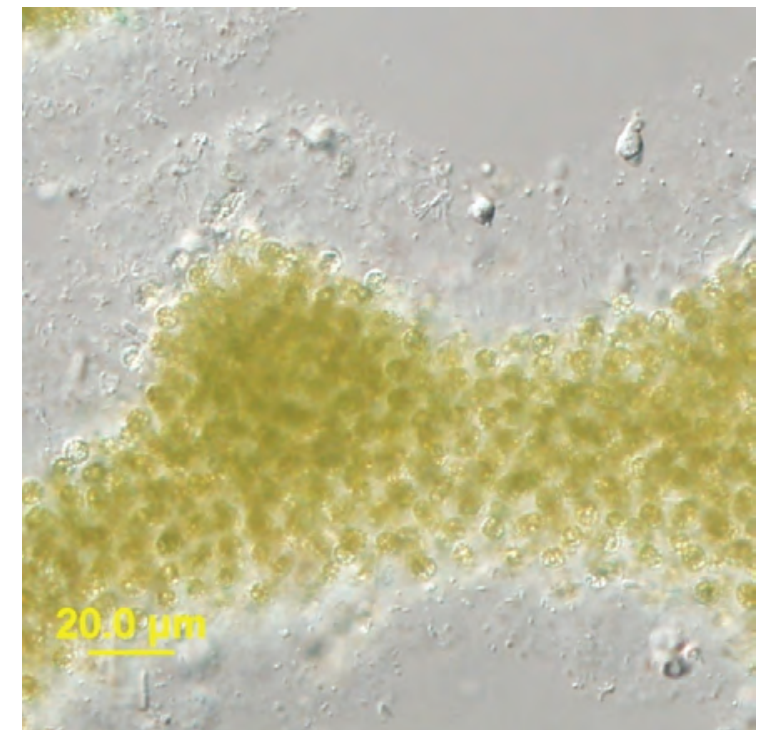

LM

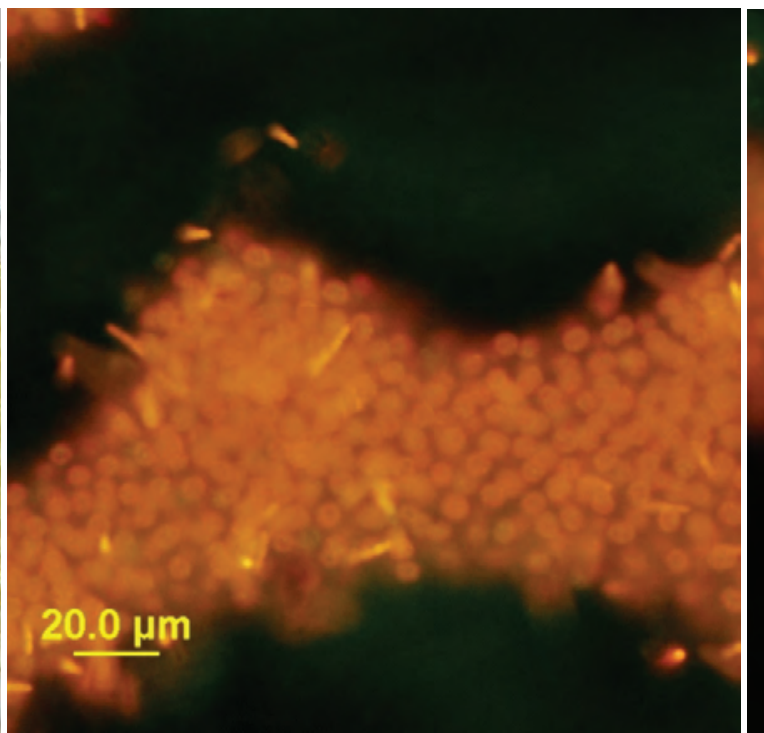

FITC

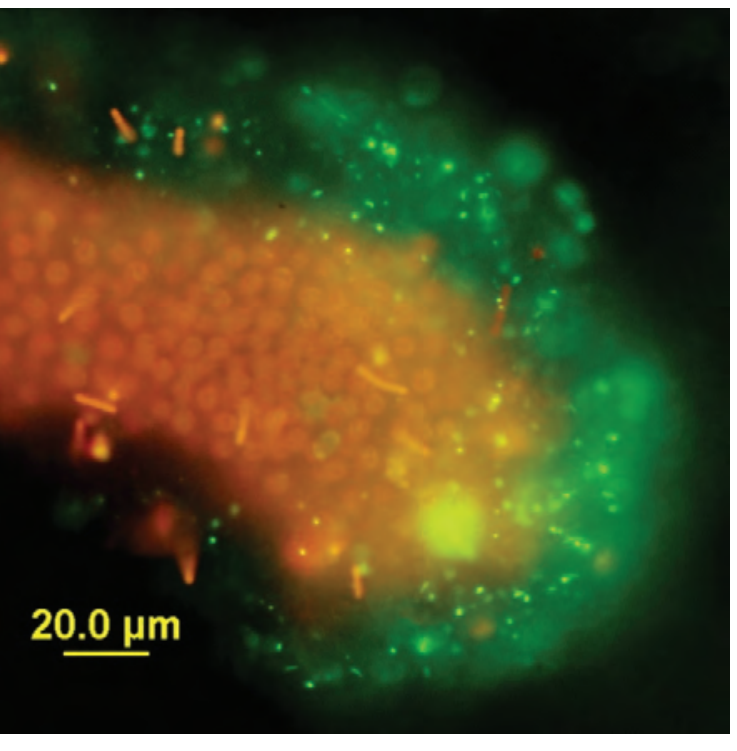

Sytox ${ }^{\circledR}$ green

\section{Sonicated at 70 percent power}

Figure 56. Copco Reservoir, CA (9/10/2009). LM-Microcystis aeruginosa. FITC-an orange color dominates the cells. Sytox ${ }^{\circledR}$ green-stain did not penetrate the cell membrane of the cyanobacteria; outer mucilage and the associated bacterial cells did stain bright green. LM - differential interference contrast microscopy; FITC epifluorescent microscopy; Sytox ${ }^{\circledR}$ green - epifluorescent microscopy in conjunction with the nucleic acid stain Syto ${ }^{\circledR}$ green. 


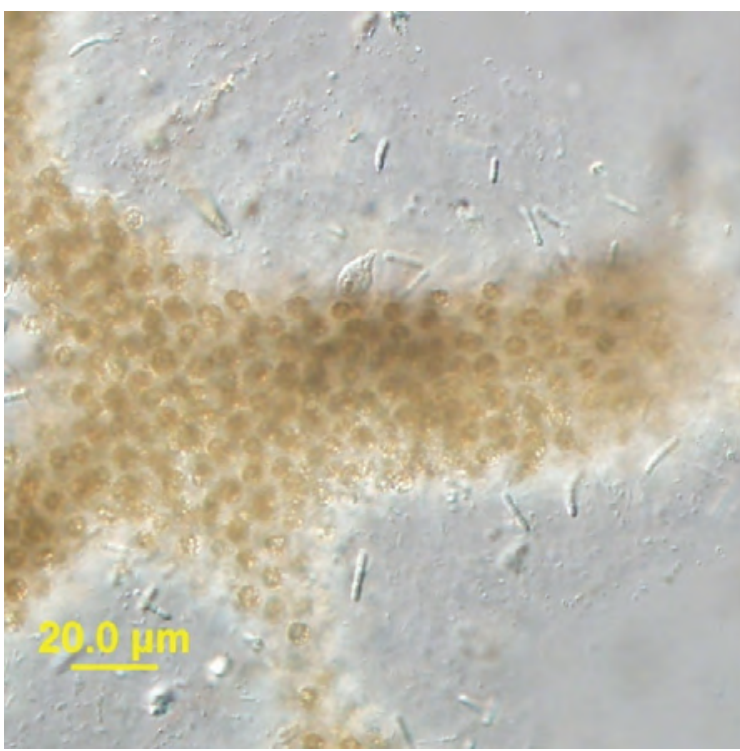

LM

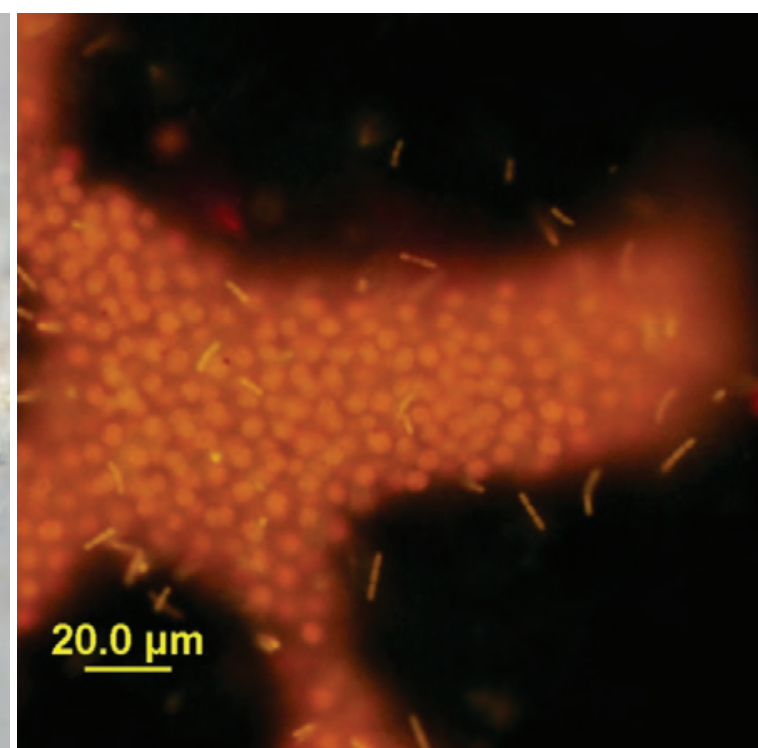

FITC

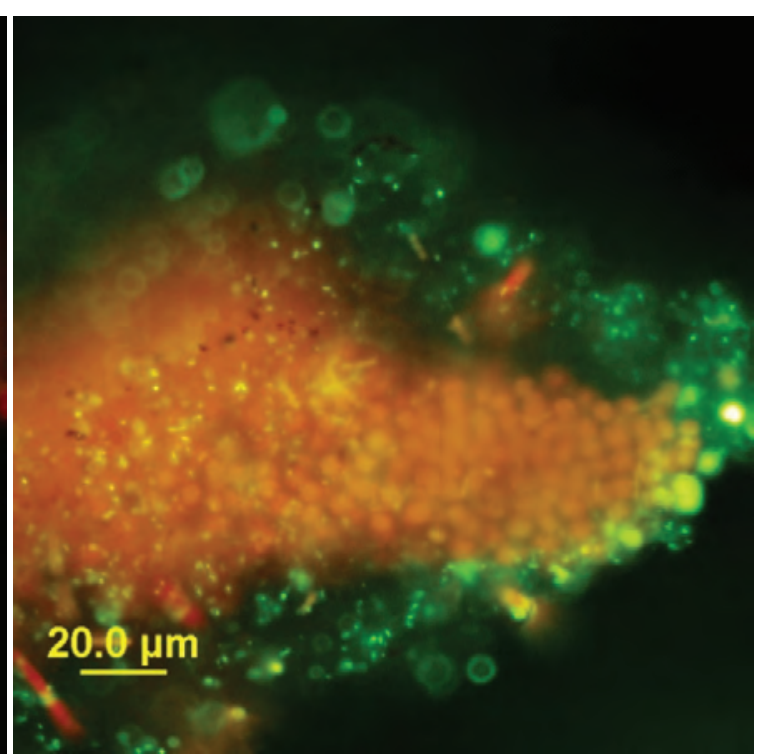

Sytox ${ }^{\circledR}$ green

QuikLyse ${ }^{\mathrm{TM}}-1 \mathrm{x}$

Figure 57. Copco Reservoir, CA (9/10/2009). LM-Microcystis aeruginosa. FITC-an orange color dominates the cells. Sytox ${ }^{\circledR}$ green-stain did not penetrate the cell membrane of the cyanobacteria; outer mucilage and the associated bacterial cells did stain bright green. LM - differential interference contrast microscopy; FITC epifluorescent microscopy; Sytox ${ }^{\circledR}$ green - epifluorescent microscopy in conjunction with the nucleic acid stain Sytox ${ }^{\circledR}$ green. 


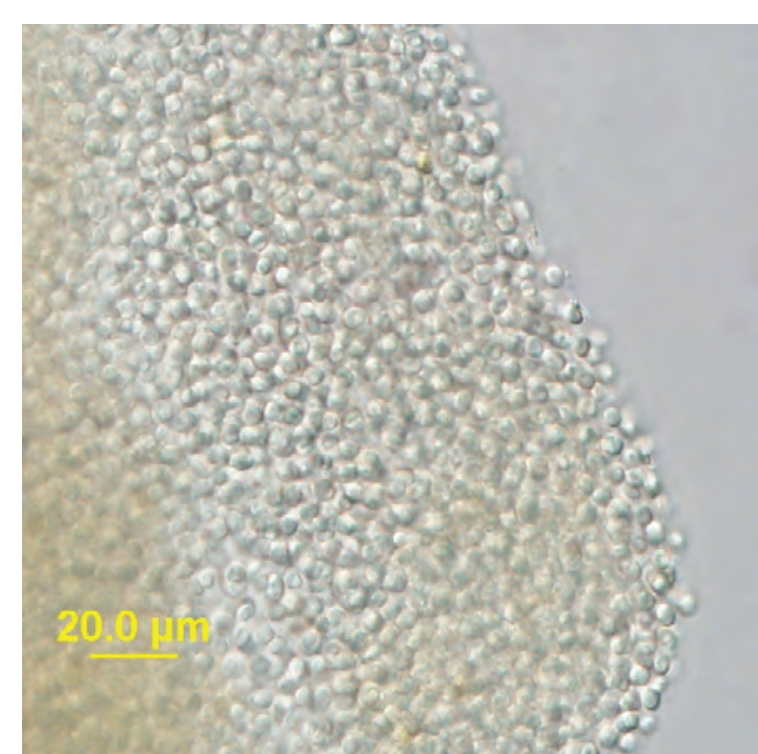

LM

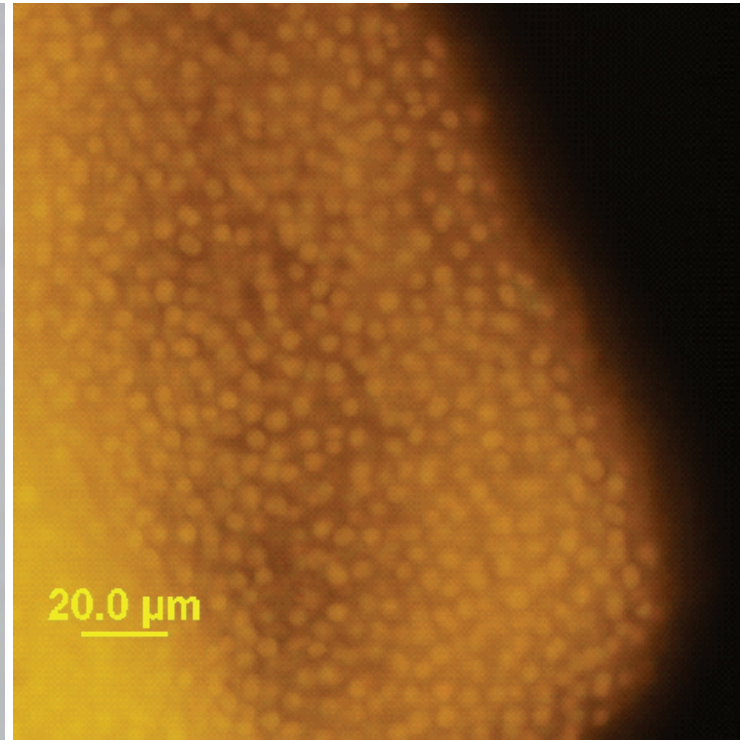

FITC

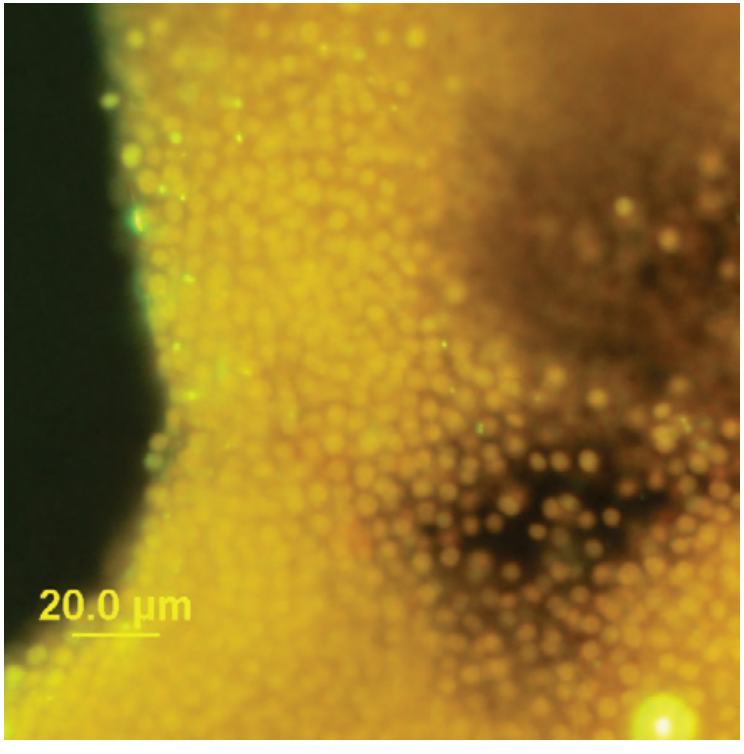

Sytox ${ }^{\circledR}$ green

One freeze-thaw cycle

Figure 58. Copco Reservoir, CA (9/10/2009). LM-Microcystis aeruginosa. FITC-an orange color dominates the cells. Sytox ${ }^{\circledR}$ green-stain did not penetrate the cell membrane. LM - differential interference contrast microscopy; FITC - epifluorescent microscopy; Sytox ${ }^{\circledR}$ green - epifluorescent microscopy in conjunction with the nucleic acid stain Sytox ${ }^{\circledR}$ green. 


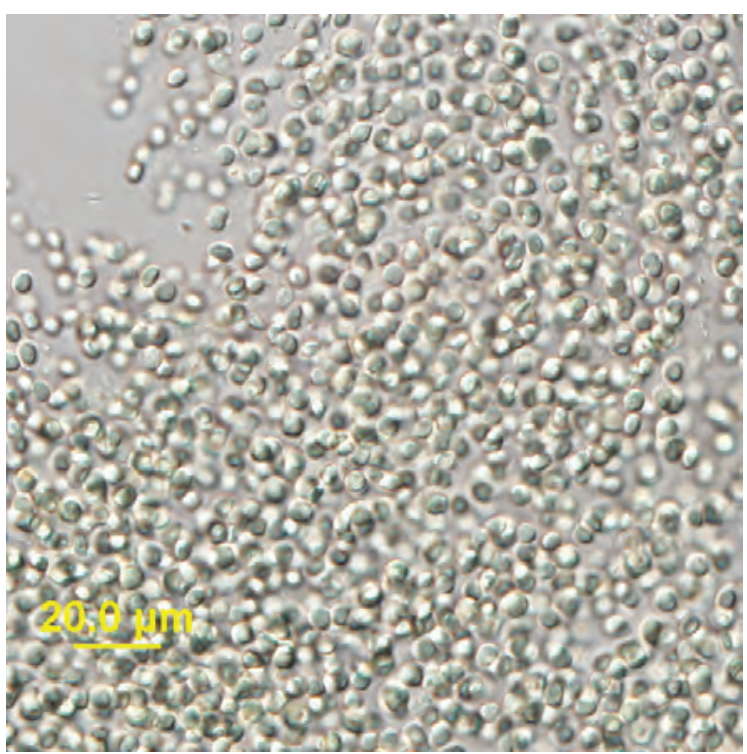

LM

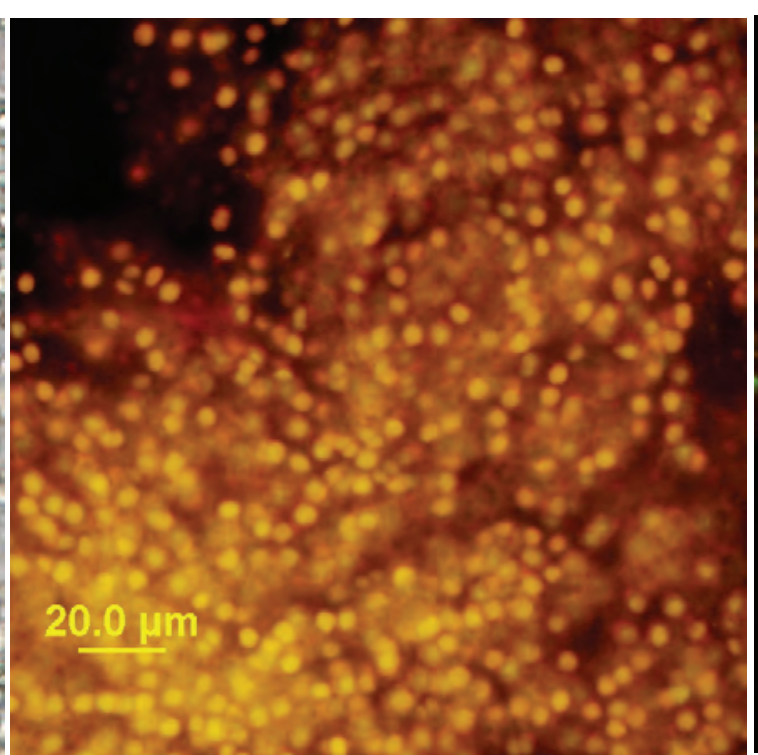

FITC

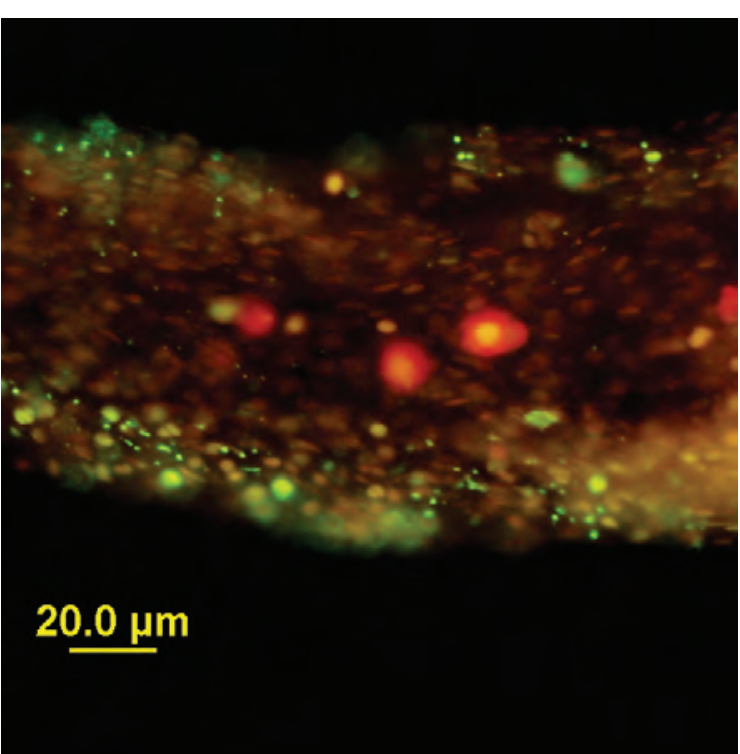

Sytox ${ }^{\circledR}$ green

Two freeze-thaw cycles

Figure 59. Copco Reservoir, CA. LM-Microcystis aeruginosa. FITC-Microcystis aeruginosa-an orange color dominates the cells. Sytox ${ }^{\circledR}$ green-Microcystis wesenbergii. Stain did not penetrate the cell membrane of the cyanobacteria; the associated bacterial cells did stain bright green. LM - differential interference contrast microscopy; FITC - epifluorescent microscopy; Sytox ${ }^{\circledR}$ green - epifluorescent microscopy in conjunction with the nucleic acid stain Sytox ${ }^{\circledast}$ green 


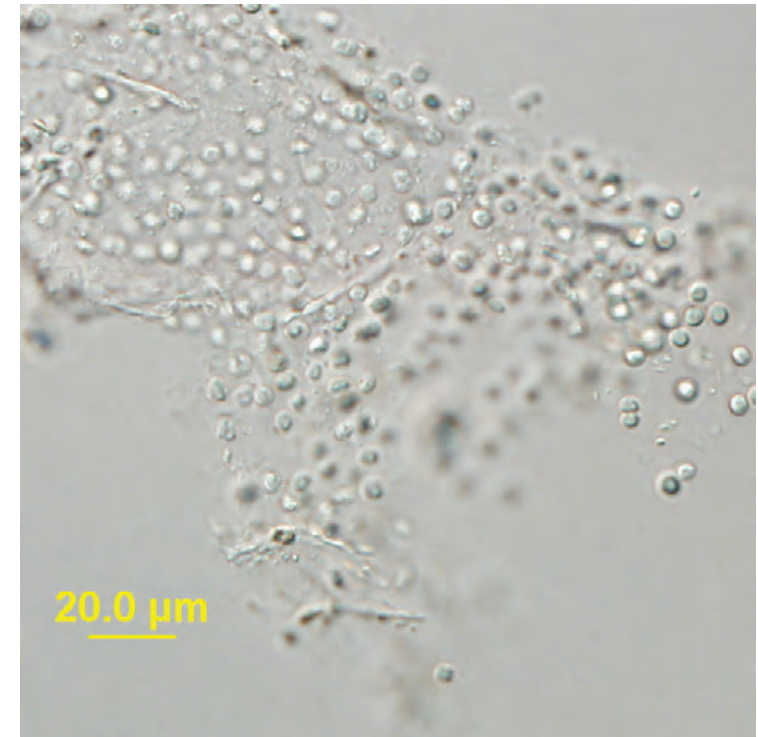

LM

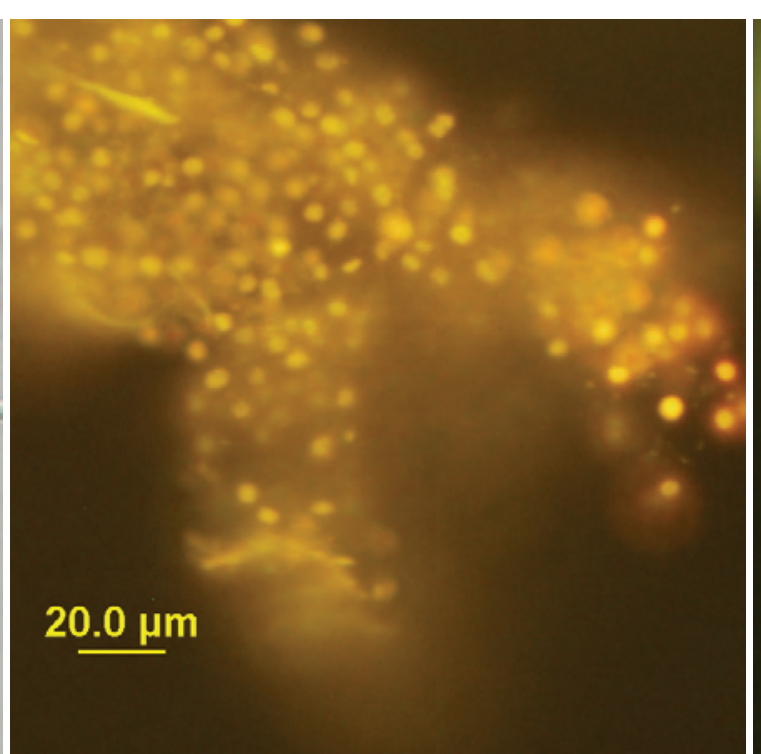

FITC

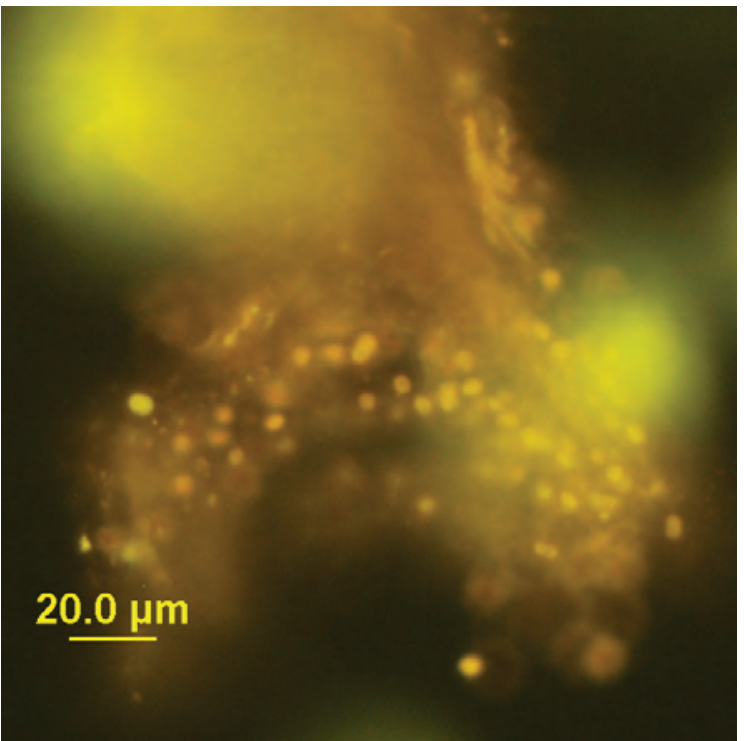

Sytox ${ }^{\circledR}$ green

Three freeze-thaw cycles

Figure 60. Copco Reservoir, CA (9/10/2009). LM-Degraded Microcystis aeruginosa. FITC-a yellow-orange color dominates the cells. Sytox ${ }^{\circledR}$ green-stain did not penetrate the cell membrane of the cyanobacteria. LM - differential interference contrast microscopy; FITC - epifluorescent microscopy; Sytox ${ }^{\circledast}$ green - epifluorescent microscopy in conjunction with the nucleic acid stain Sytox ${ }^{\circledR}$ green. 


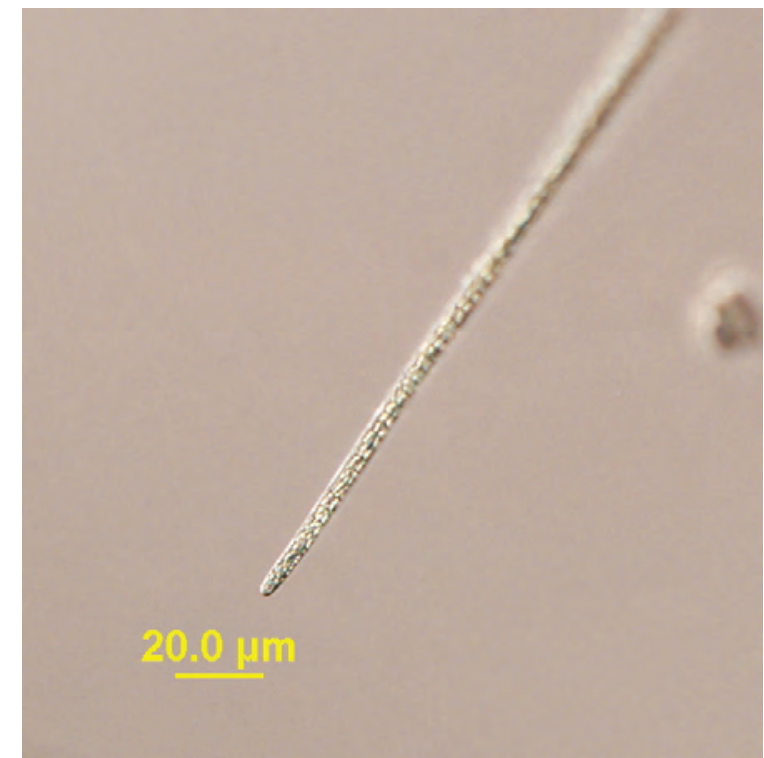

LM

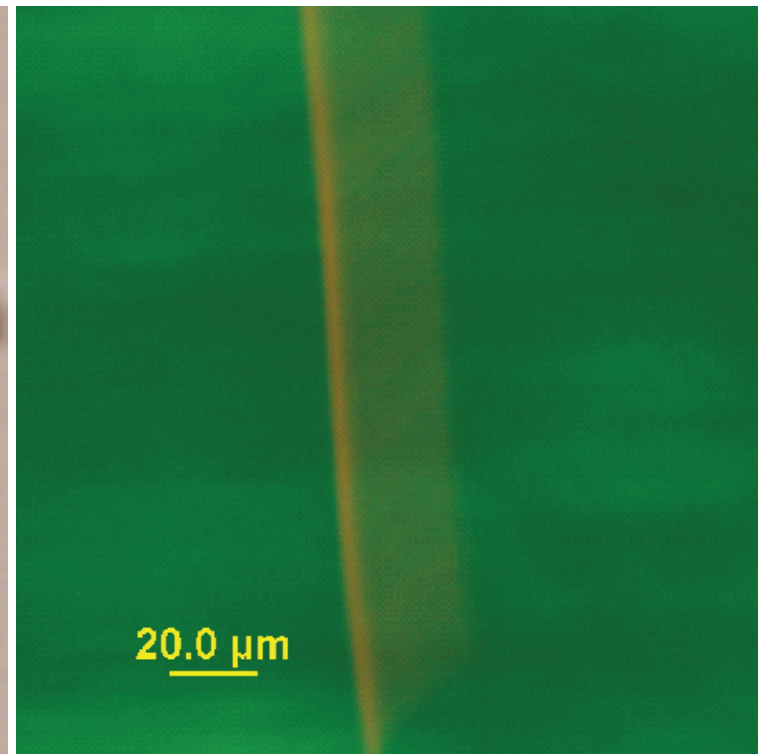

FITC

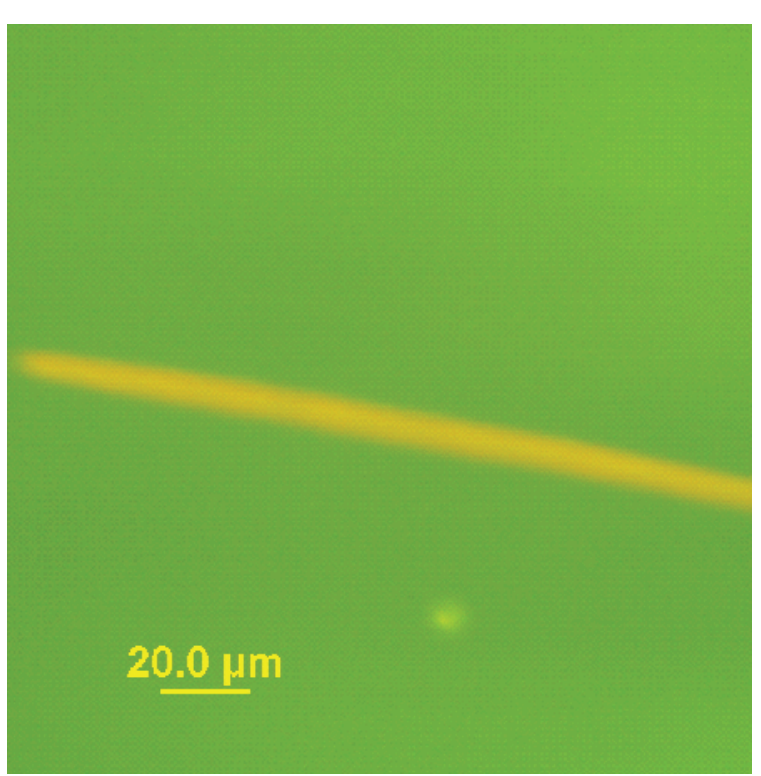

Sytox ${ }^{\circledR}$ green

\section{Control 1}

Figure 61. Grand Lake (Lake St. Mary), $\mathrm{OH}$ (7/20/2009). LM-Planktothrix sp. FITC-an orange color dominates the cells. Sytox ${ }^{\circledR}$ green-stain did not penetrate the cell membrane. LM - differential interference contrast microscopy; FITC - epifluorescent microscopy; Sytox ${ }^{\circledR}$ green - epifluorescent microscopy in conjunction with the nucleic acid stain Sytox ${ }^{\circledR}$ green. 


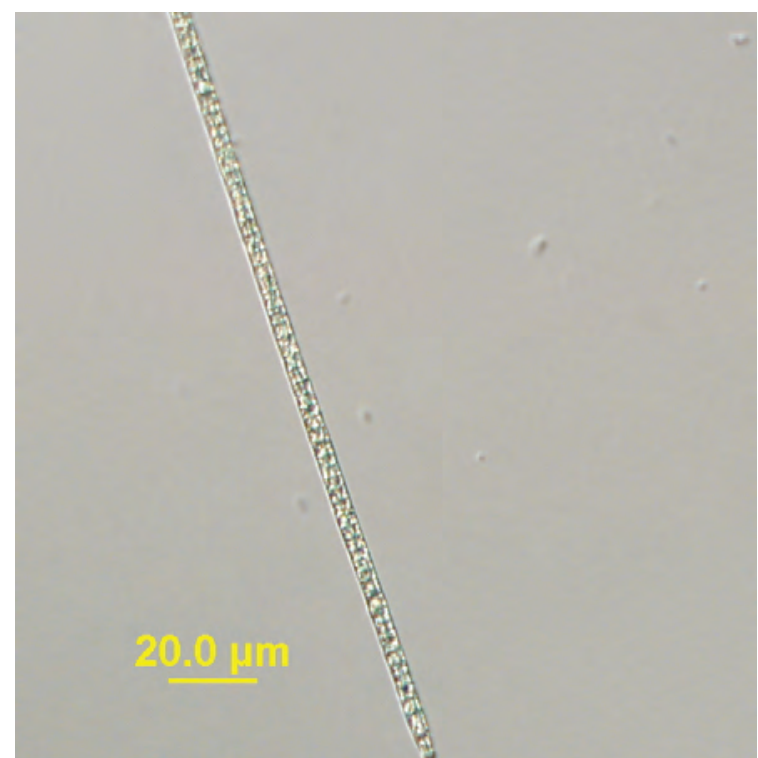

LM

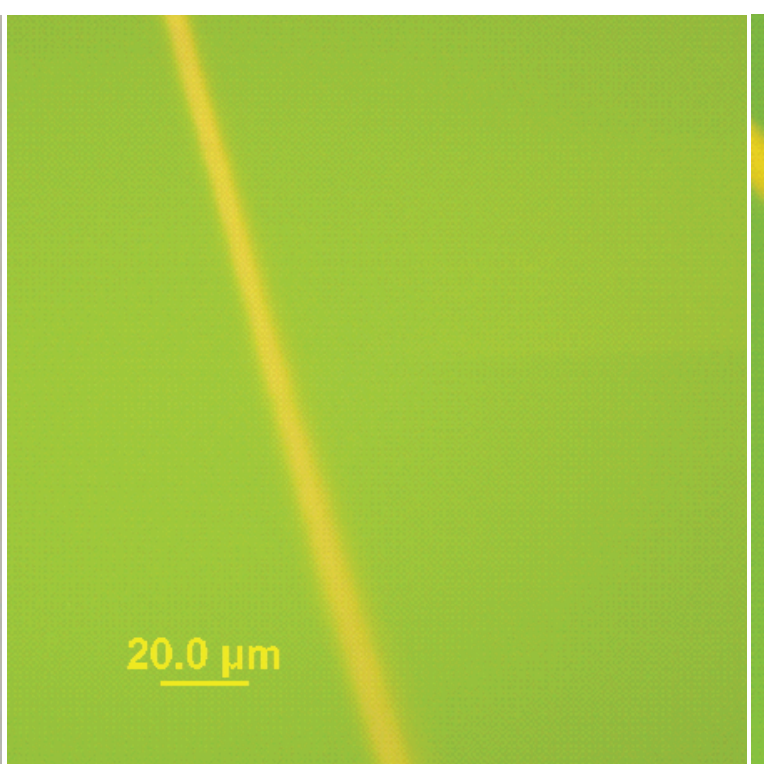

FITC

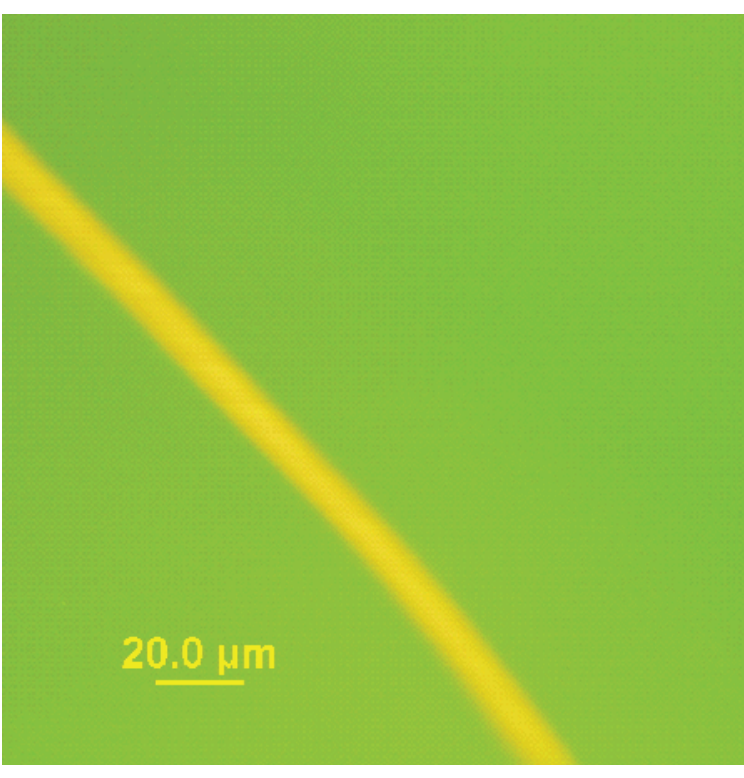

Sytox ${ }^{\circledR}$ green

Control 2

Figure 62. Grand Lake (Lake St. Mary), OH (7/20/2009). LM-Planktothrix sp. FITC-an orange color dominates the cells. Sytox ${ }^{\circledR}$ green-stain did not penetrate the cell membrane. LM - differential interference contrast microscopy; FITC - epifluorescent microscopy; Sytox ${ }^{\circledR}$ green - epifluorescent microscopy in conjunction with the nucleic acid stain Sytox ${ }^{\circledR}$ green. 


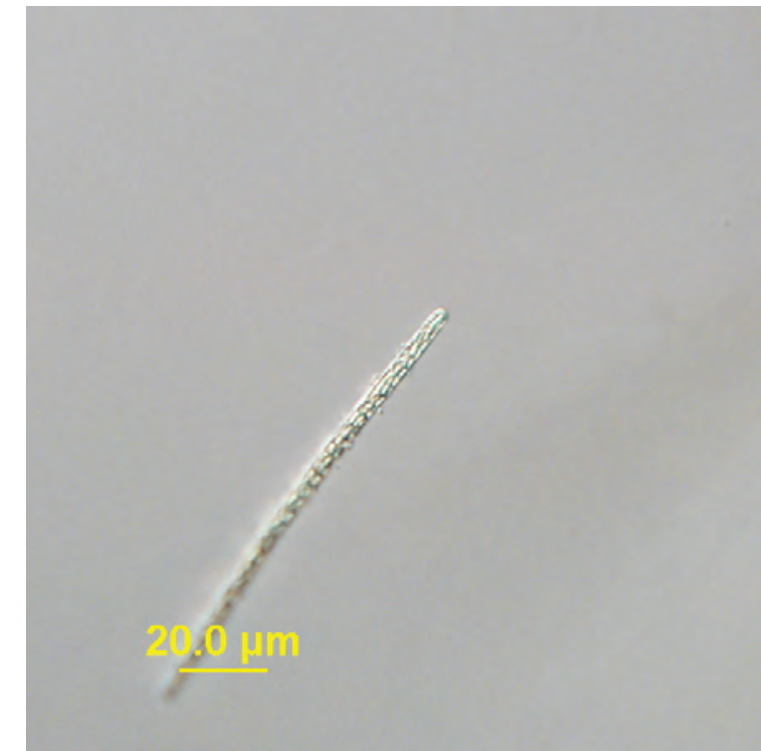

LM

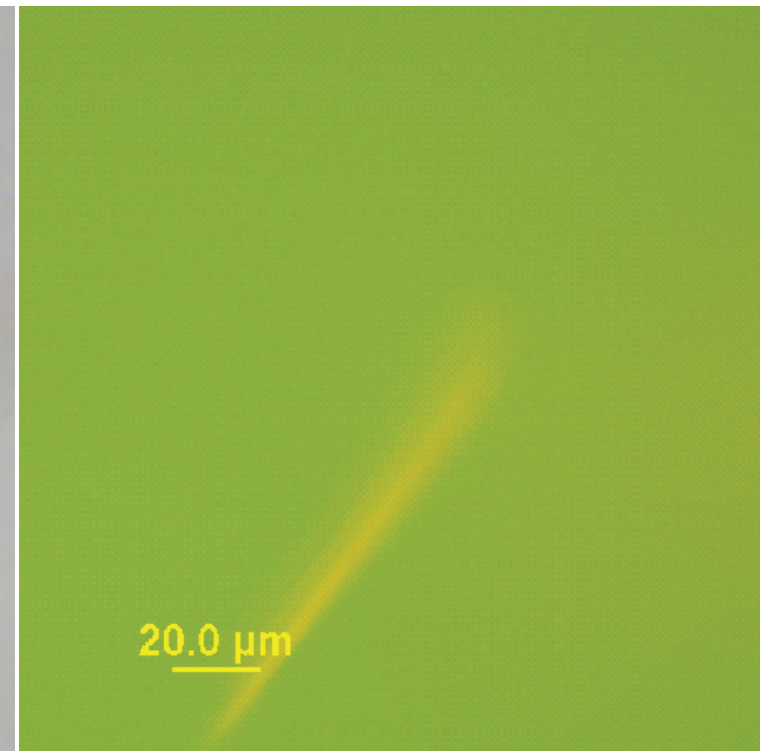

FITC

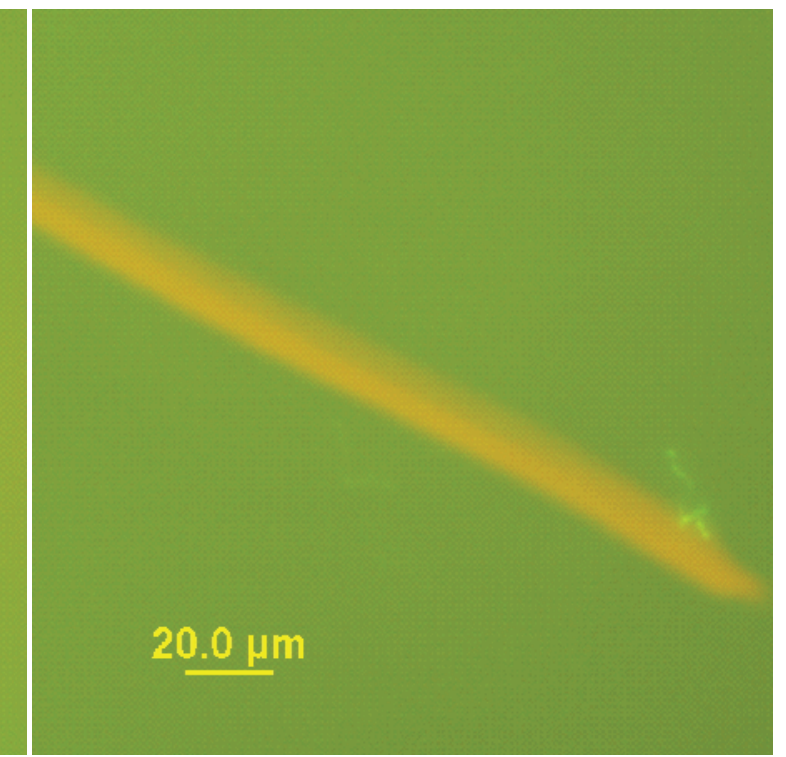

Sytox ${ }^{\circledR}$ green

\section{Control 3}

Figure 63. Grand Lake (Lake St. Mary), $\mathrm{OH}$ (7/20/2009). LM-Planktothrix sp. FITC-an orange color dominates the cells. Sytox ${ }^{\circledR}$ green-stain did not penetrate the cell membrane. LM - differential interference contrast microscopy; FITC - epifluorescent microscopy; Sytox ${ }^{\circledR}$ green - epifluorescent microscopy in conjunction with the nucleic acid stain Sytox ${ }^{\circledR}$ green. 


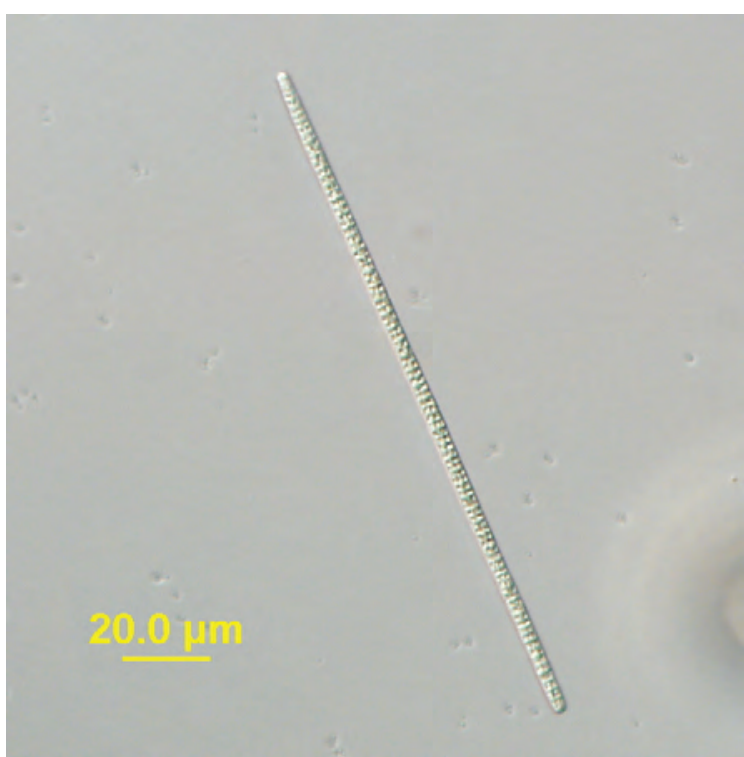

LM

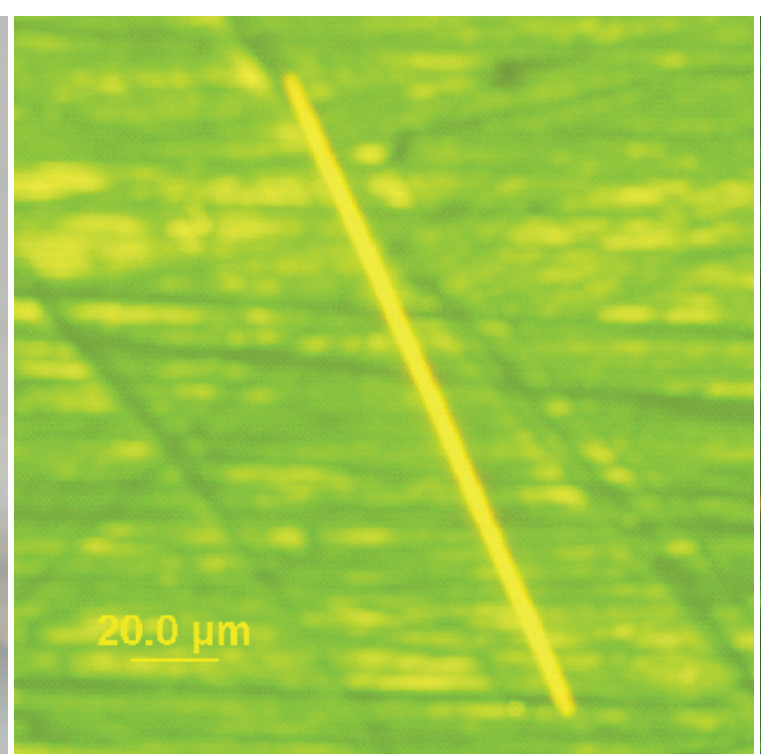

FITC

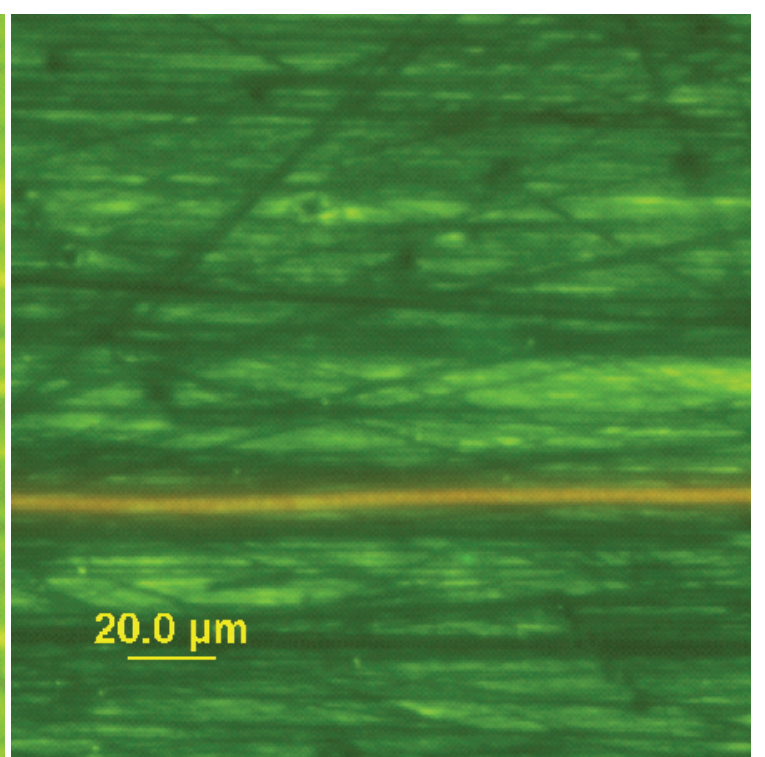

Sytox ${ }^{\circledR}$ green

\section{Boiled for 5 minutes}

Figure 64. Grand Lake (Lake St. Mary), OH (7/20/2009). LM-Planktothrix sp. FITC-an orange color dominates the cells. Sytox ${ }^{\circledR}$ green-stain did not penetrate the cell membrane. LM - differential interference contrast microscopy; FITC - epifluorescent microscopy; Sytox ${ }^{\circledast}$ green - epifluorescent microscopy in conjunction with the nucleic acid stain Sytox ${ }^{\circledR}$ green. 


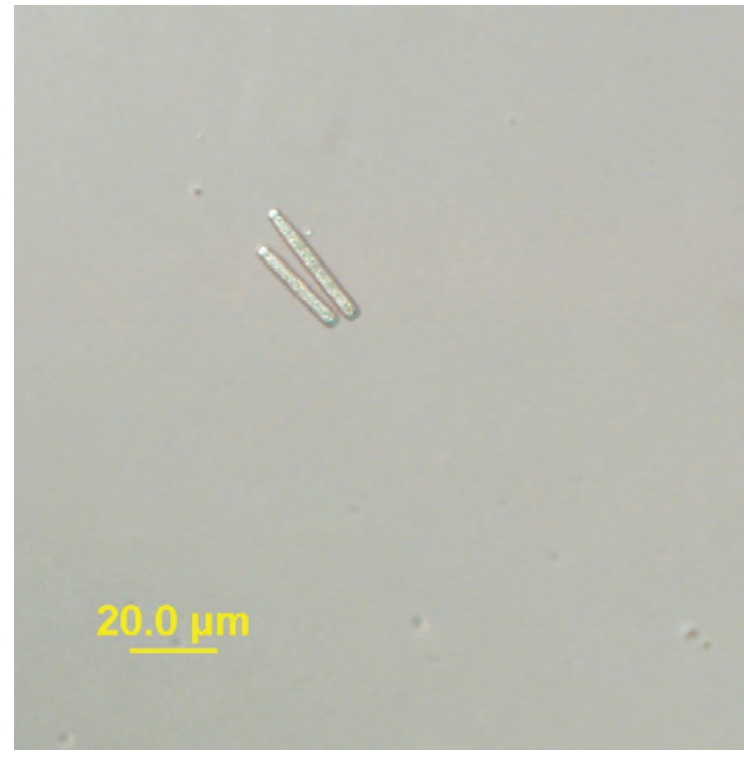

LM

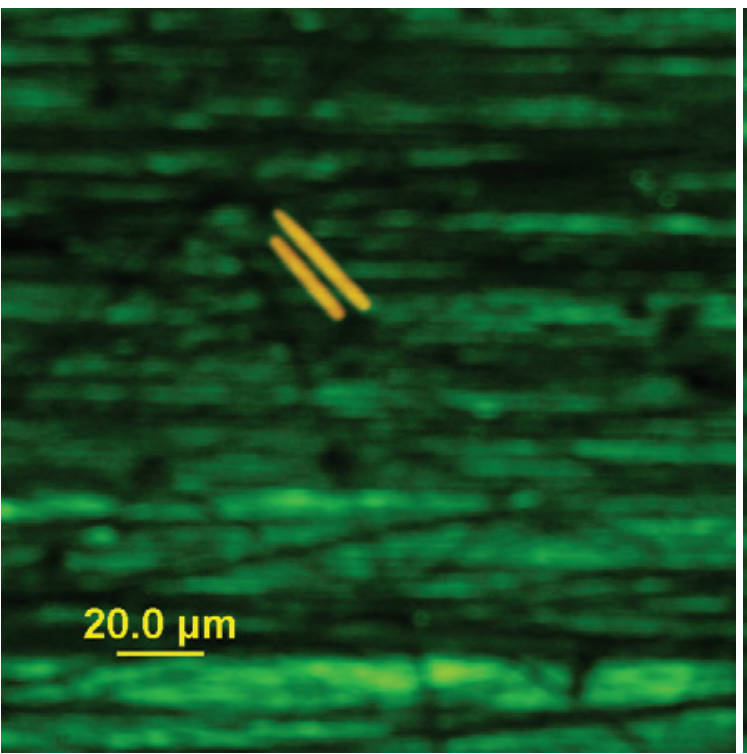

FITC

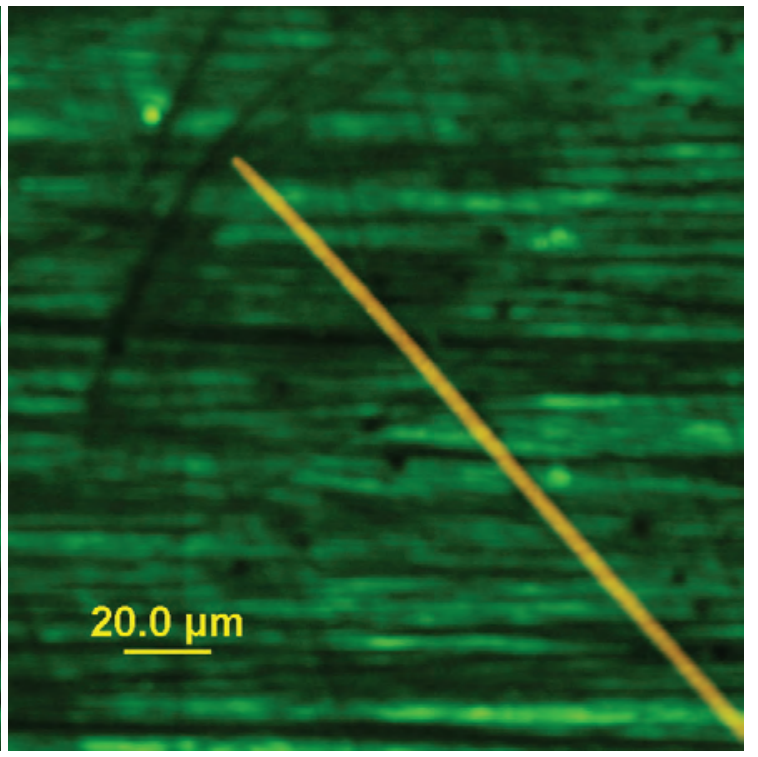

Sytox ${ }^{\circledR}$ green

Boiled for 15 minutes

Figure 65. Grand Lake (Lake St. Mary), $\mathrm{OH}$ (7/20/2009). LM-Planktothrix sp. FITC-an orange color dominates the cells. Sytox ${ }^{\circledR}$ green-stain did not penetrate the cell membrane. LM - differential interference contrast microscopy; FITC - epifluorescent microscopy; Sytox ${ }^{\circledast}$ green - epifluorescent microscopy in conjunction with the nucleic acid stain Sytox ${ }^{\circledast}$ green. 


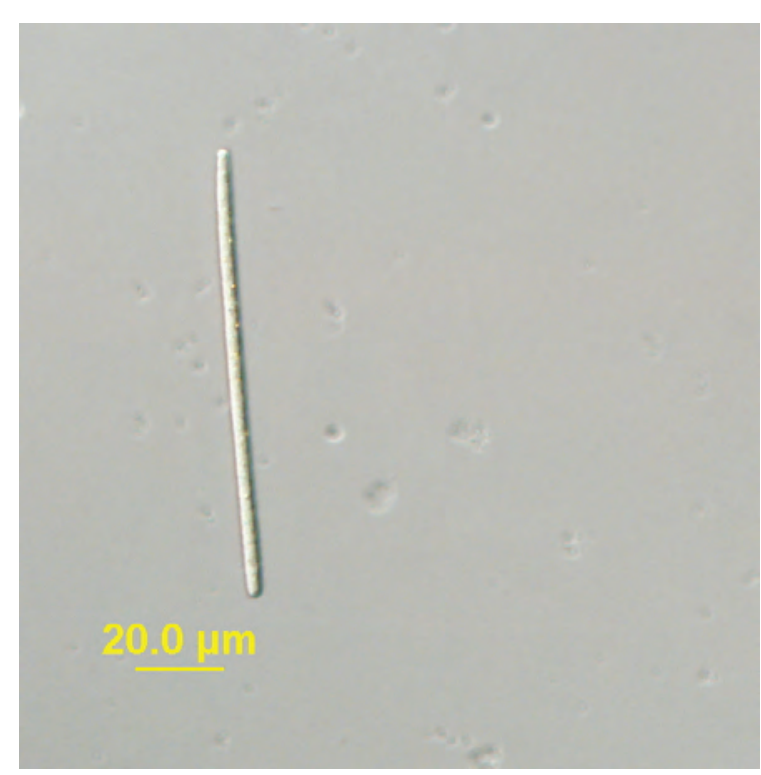

LM

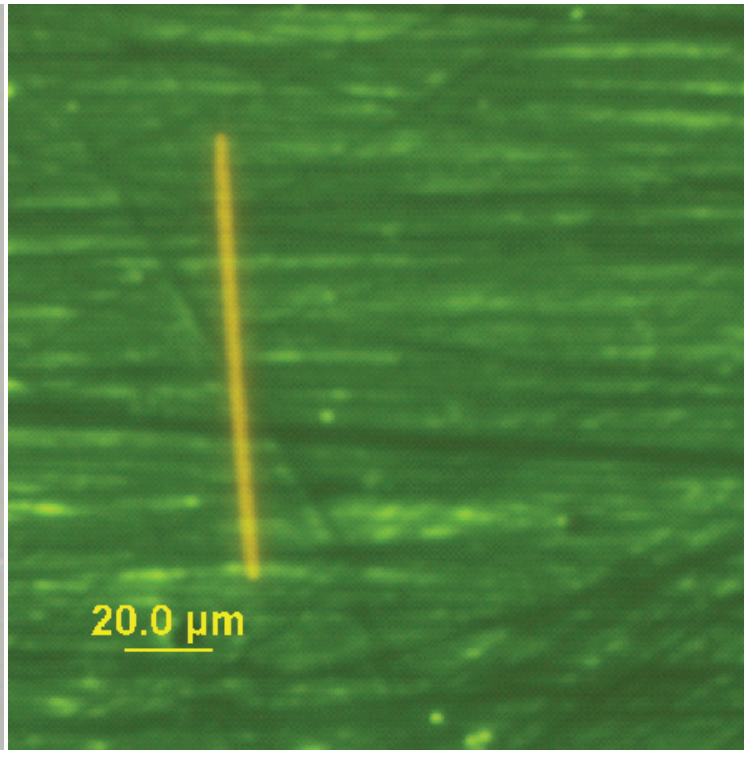

FITC

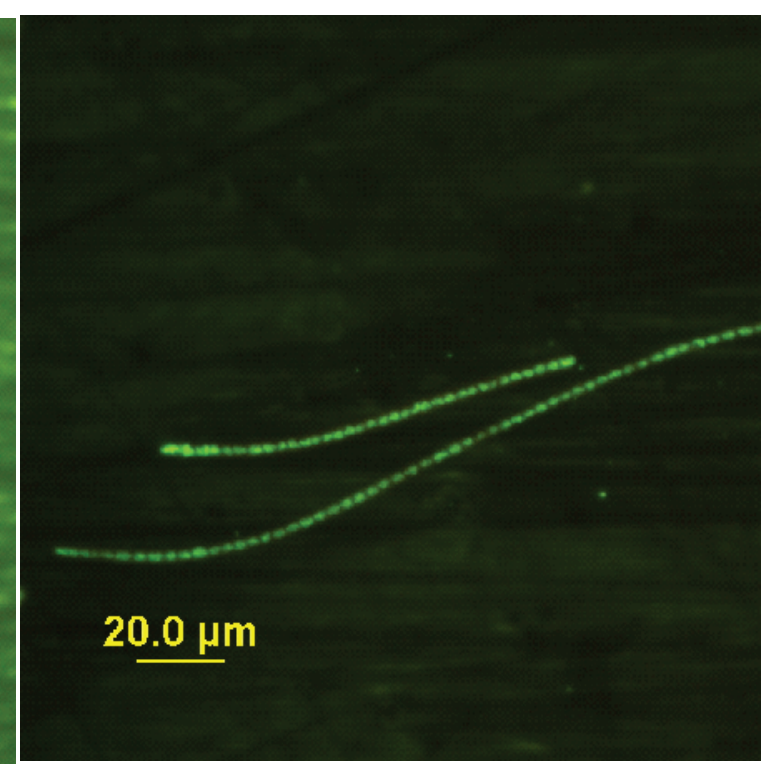

Sytox ${ }^{\circledR}$ green

Boiled for 30 minutes

Figure 66. Grand Lake (Lake St. Mary), $\mathrm{OH}$ (7/20/2009). LM-Planktothrix sp. FITC-an orange color dominates the cells. Sytox ${ }^{\circledR}$ green-stain did penetrate the cell membrane, cells bright green. LM - differential interference contrast microscopy; FITC - epifluorescent microscopy; Sytox ${ }^{\circledR}$ green - epifluorescent microscopy in conjunction with the nucleic acid stain Sytox ${ }^{\circledR}$ green. 


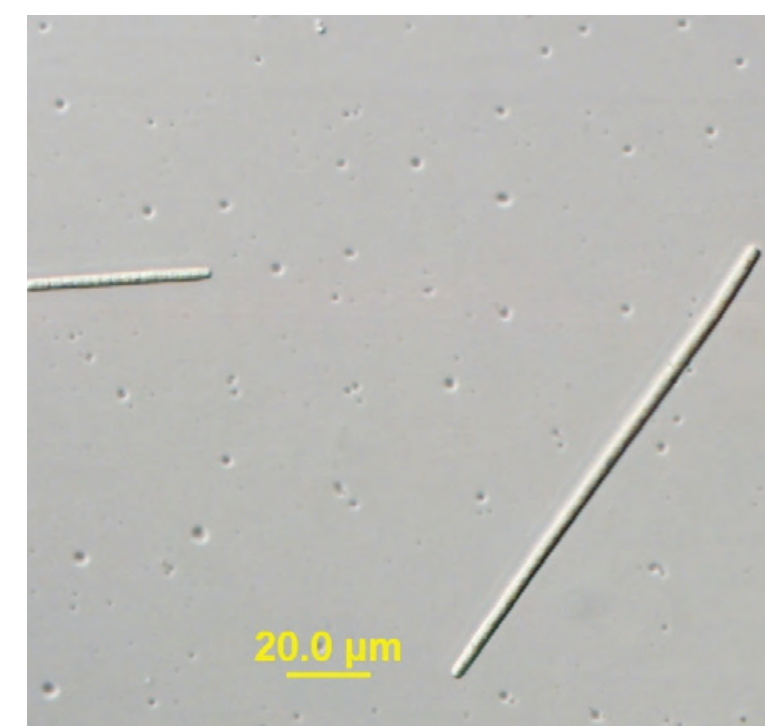

LM

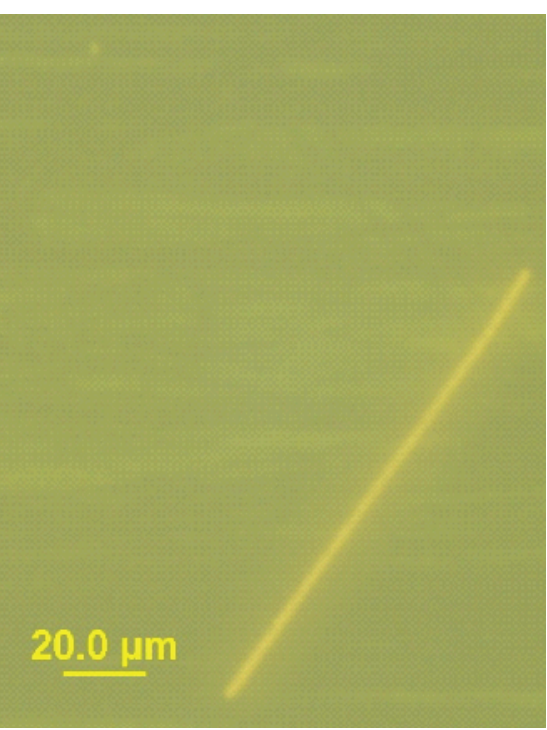

FITC

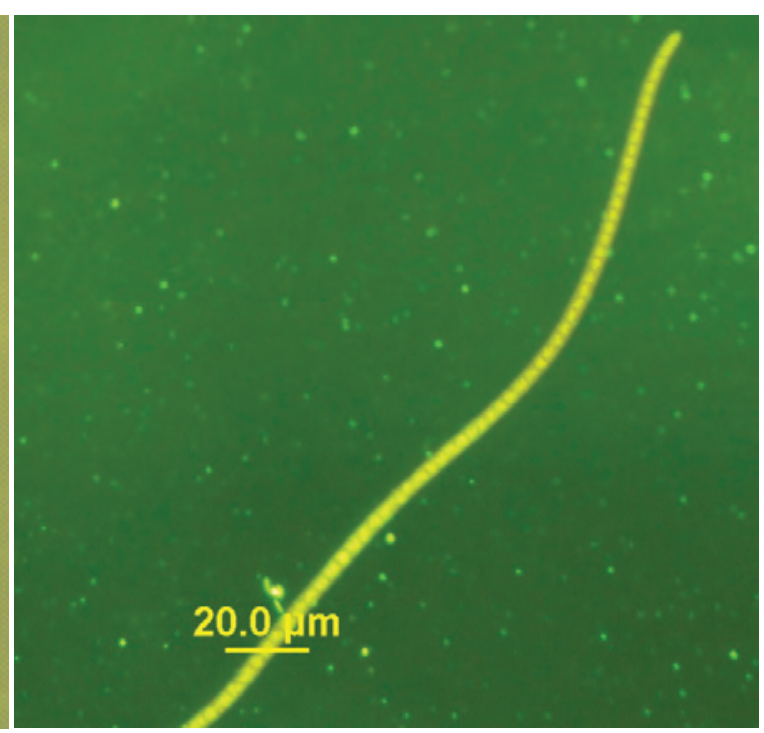

Sytox ${ }^{\circledR}$ green

Autoclaved for 5 minutes

Figure 67. Grand Lake (Lake St. Mary), $\mathrm{OH}$ (7/20/2009). LM-Planktothrix sp. FITC-an orange color dominates the cells. Sytox ${ }^{\circledR}$ green-stain did penetrate the cell membrane, cells yellow-green. LM - differential interference contrast microscopy; FITC - epifluorescent microscopy; Sytox ${ }^{\circledast}$ green - epifluorescent microscopy in conjunction with the nucleic acid stain Syto ${ }^{\circledast}$ green. 


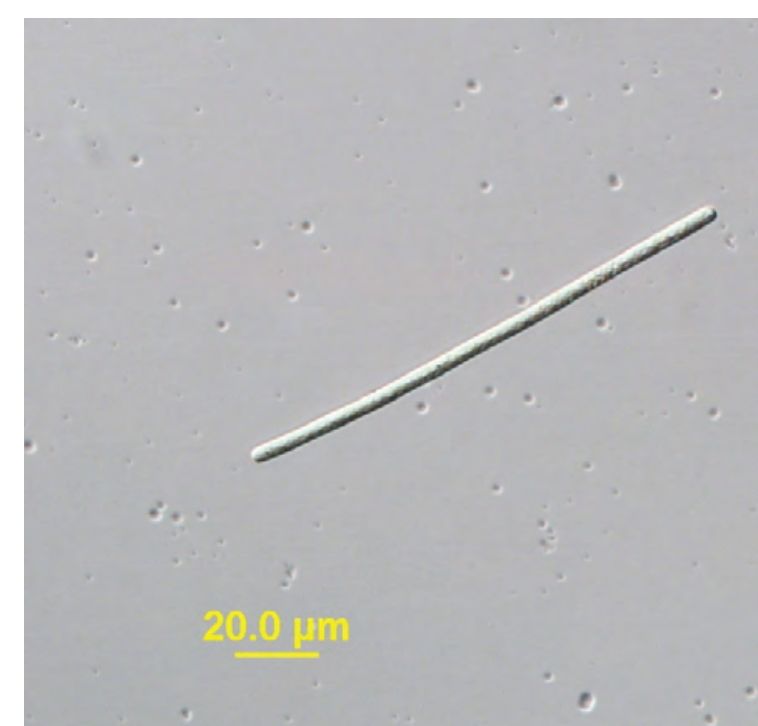

LM

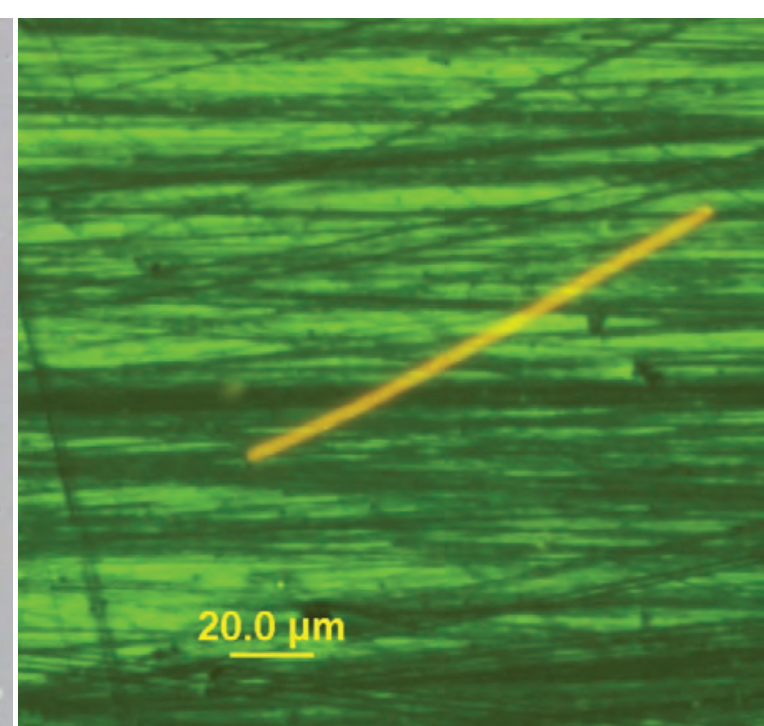

FITC

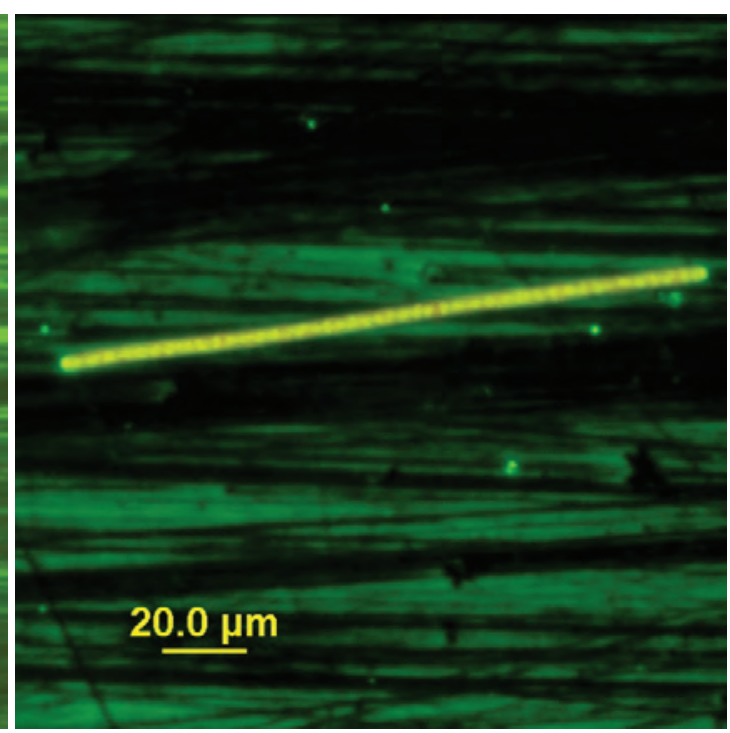

Sytox ${ }^{\circledR}$ green

\section{Autoclaved for 15 minutes}

Figure 68. Grand Lake (Lake St. Mary), $\mathrm{OH}$ (7/20/2009). LM-Planktothrix sp. FITC-an orange color dominates the cells. Sytox ${ }^{\circledR}$ green-stain did penetrate the cell membrane, cells yellow-green. LM - differential interference contrast microscopy; FITC - epifluorescent microscopy; Sytox ${ }^{\circledast}$ green - epifluorescent microscopy in conjunction with the nucleic acid stain Syto ${ }^{\oplus}$ green. 


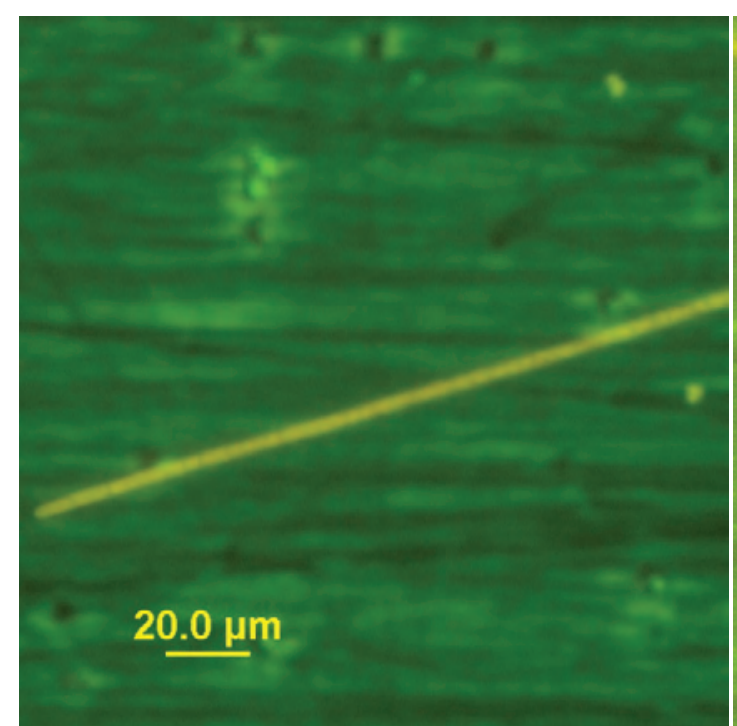

FITC

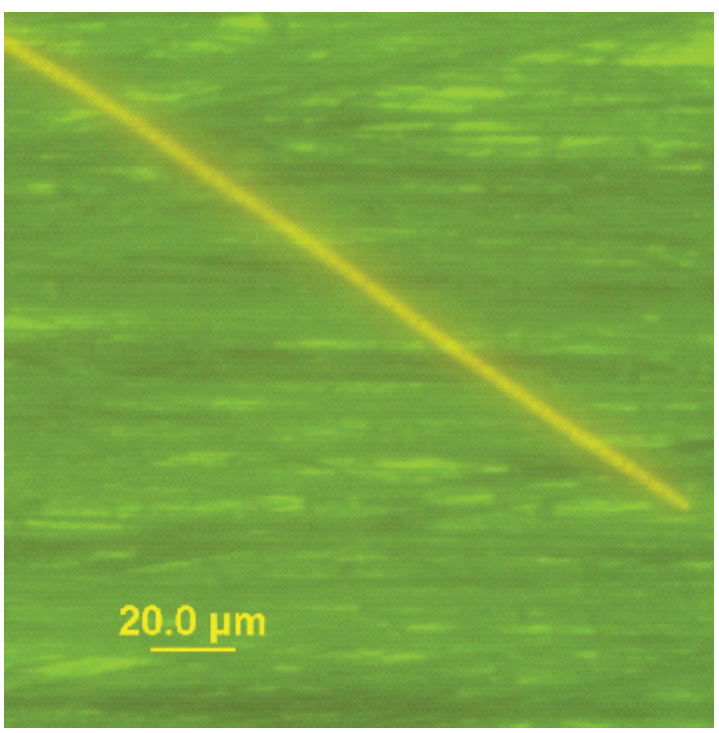

Sytox ${ }^{\circledast}$ green

Autoclaved for 30 minutes

Figure 69. Grand Lake (Lake St. Mary), OH (7/20/2009). LM-No image available. FITC-Planktothrix sp.; an orange color dominates the cells. Sytox ${ }^{\oplus}$ green-stain did not penetrate the cell membrane. LM - differential interference contrast microscopy; FITC - epifluorescent microscopy; Sytox ${ }^{\circledR}$ green - epifluorescent microscopy in conjunction with the nucleic acid stain Sytox ${ }^{\circledR}$ green. 


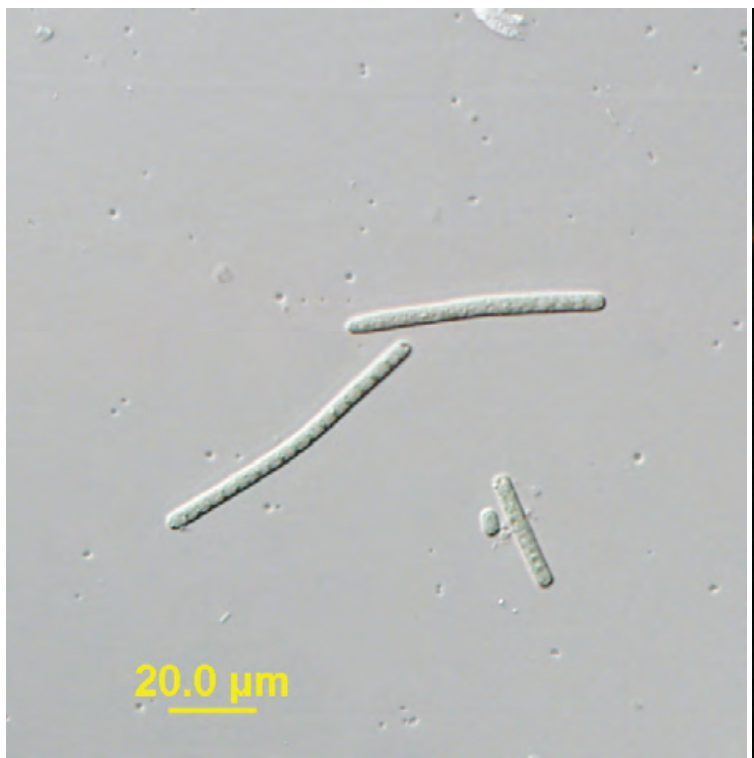

LM

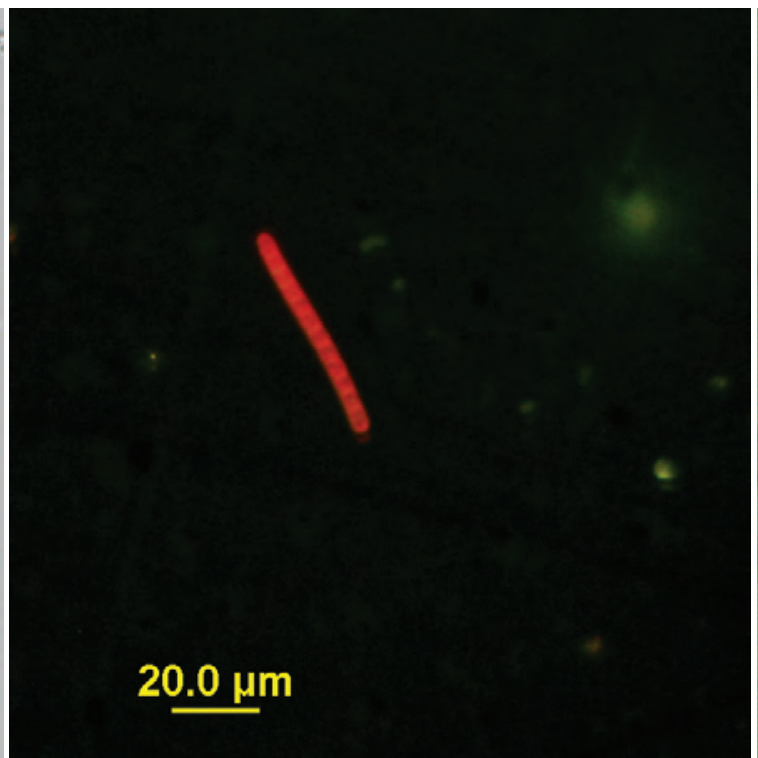

FITC

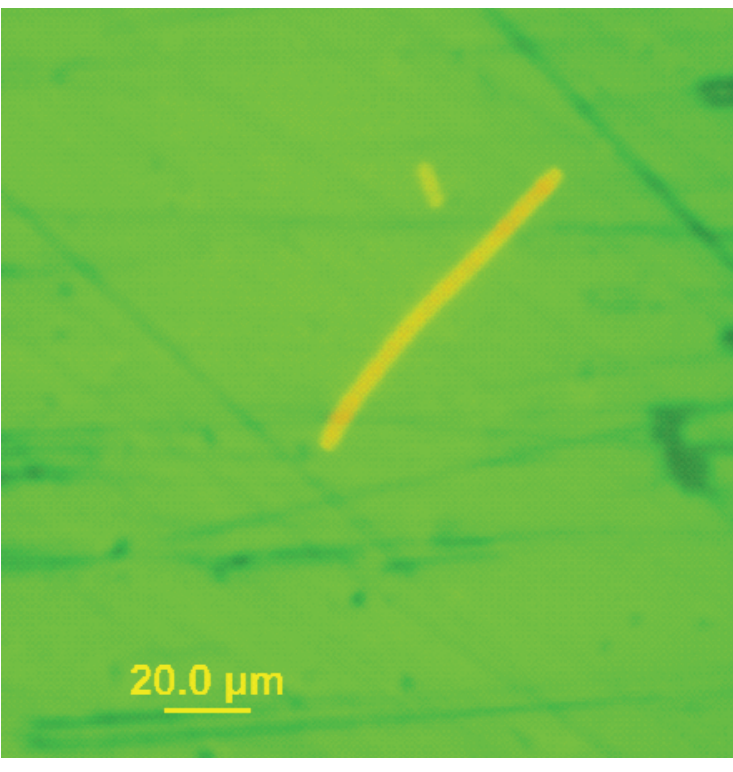

Sytox ${ }^{\circledR}$ green

\section{Sonicated at 10 percent power}

Figure 70. Grand Lake (Lake St. Mary), $\mathrm{OH}$ (7/20/2009). LM-Planktothrix sp. FITC-a red color dominates the cells. Sytox ${ }^{\circledR}$ green-stain did not penetrate the cell membrane. LM - differential interference contrast microscopy; FITC - epifluorescent microscopy; Sytox ${ }^{\circledR}$ green - epifluorescent microscopy in conjunction with the nucleic acid stain Sytox ${ }^{\circledR}$ green. 


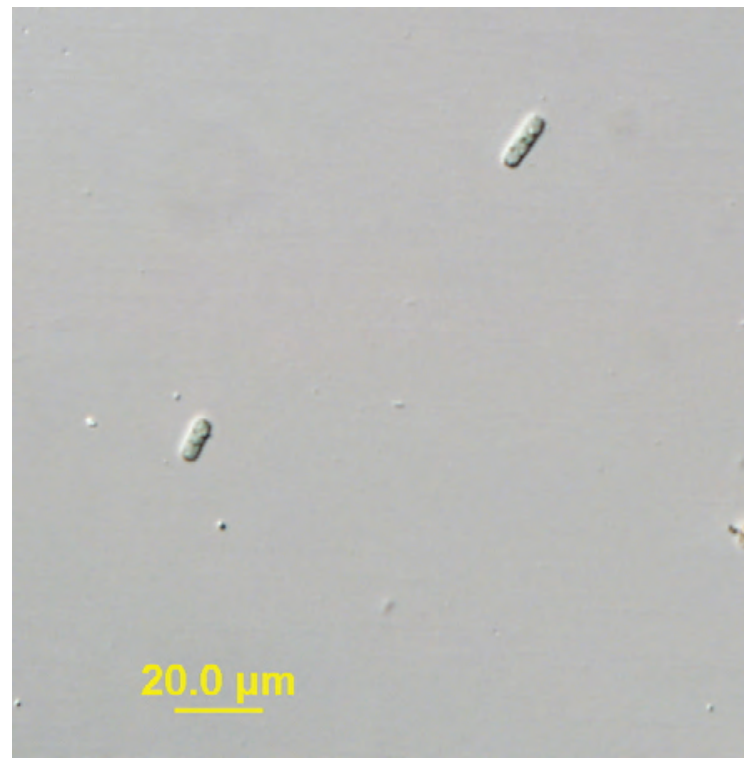

LM

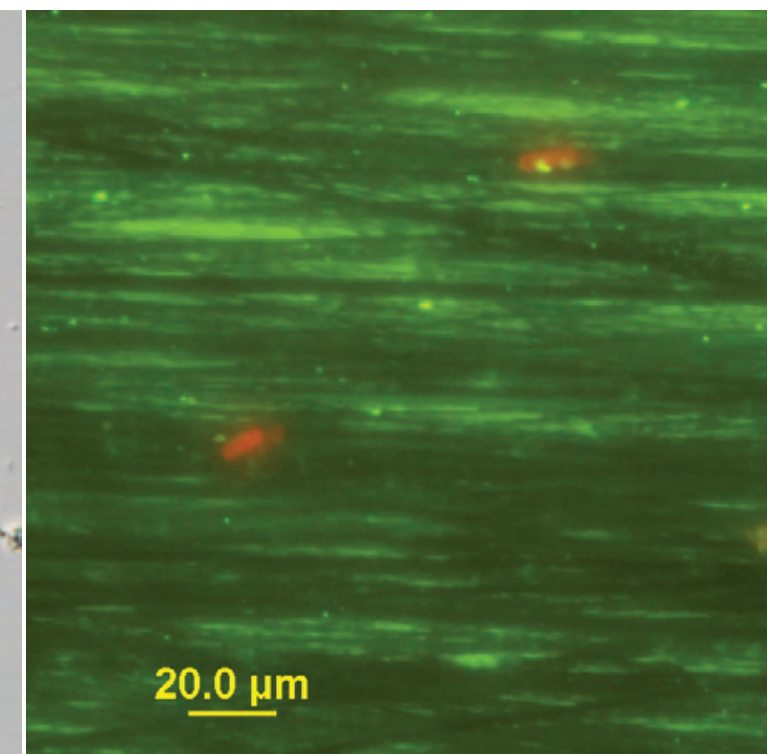

FITC

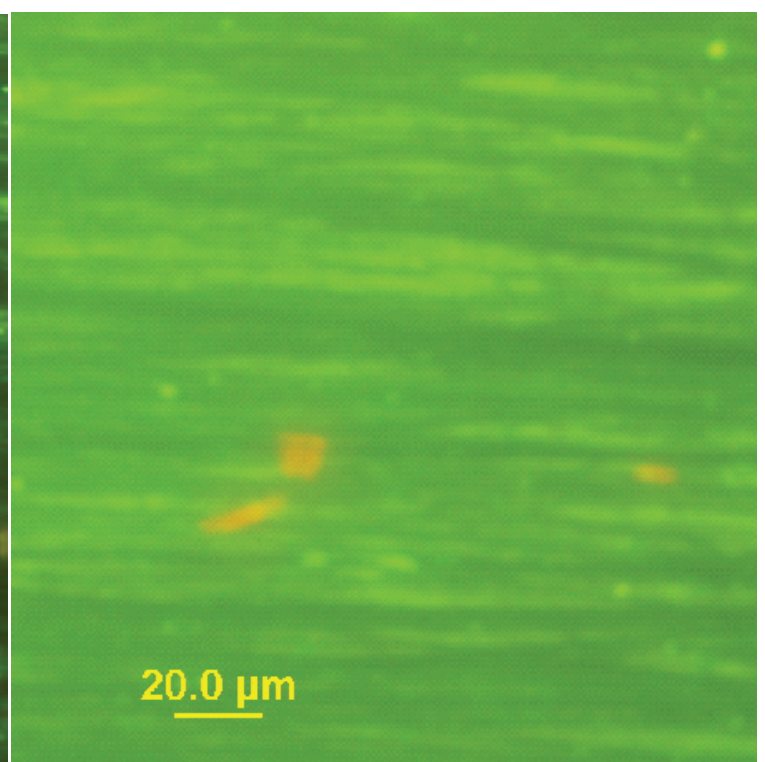

Sytox ${ }^{\circledR}$ green

\section{Sonicated at 35 percent power}

Figure 71. Grand Lake (Lake St. Mary), $\mathrm{OH} \mathrm{(7/20/2009).} \mathrm{LM-Fragments} \mathrm{of} \mathrm{Planktothrix} \mathrm{sp.} \mathrm{FITC-a} \mathrm{red} \mathrm{color} \mathrm{dominates} \mathrm{the} \mathrm{cells.} \mathrm{Sytox}{ }^{\oplus}$ green-stain did not penetrate the cell membrane. LM - differential interference contrast microscopy; FITC - epifluorescent microscopy; Sytox ${ }^{\oplus}$ green - epifluorescent microscopy in conjunction with the nucleic acid stain Sytox ${ }^{\circledast}$ green. 


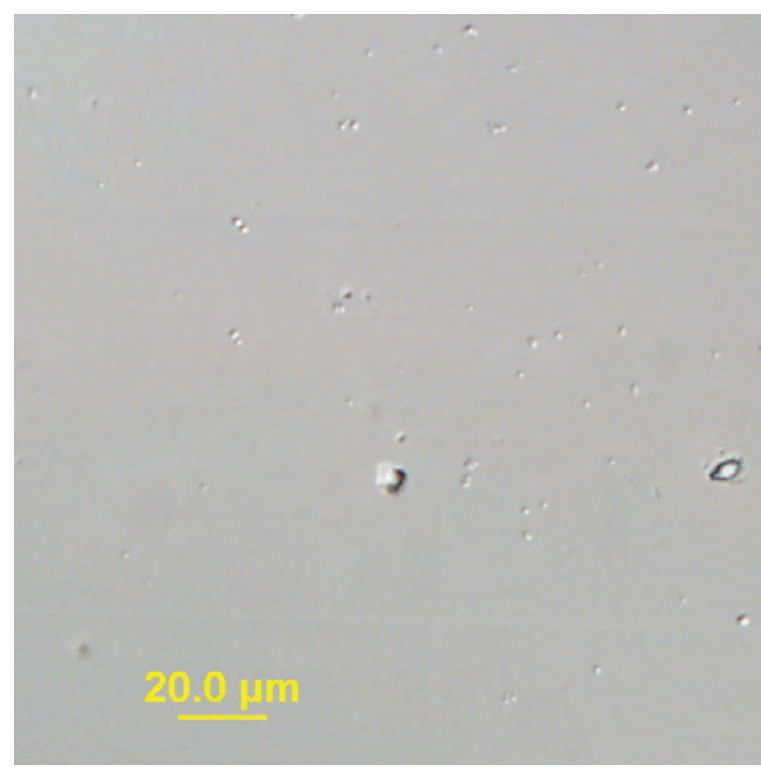

LM

Sonicated at 70 percent power

Figure 72. Grand Lake (Lake St. Mary), $\mathrm{OH}(7 / 20 / 2009)$.

LM-Nothing recognizable as cells is present. LM -

differential interference contrast microscopy; FITC -

epifluorescent microscopy; Sytox ${ }^{\circledast}$ green - epifluorescent

microscopy in conjunction with the nucleic acid stain

Sytox ${ }^{\oplus r e e n . ~}$ 


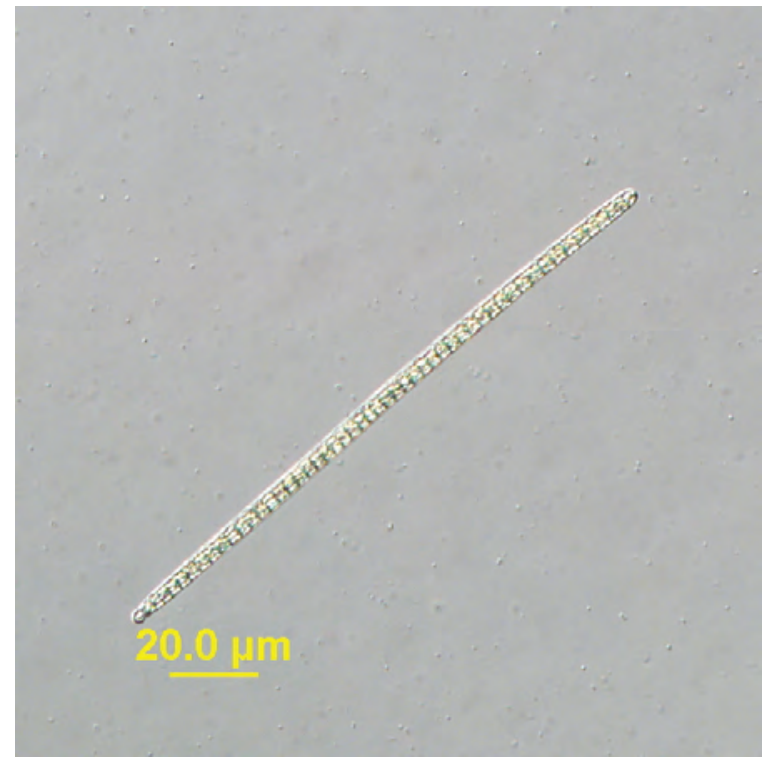

LM

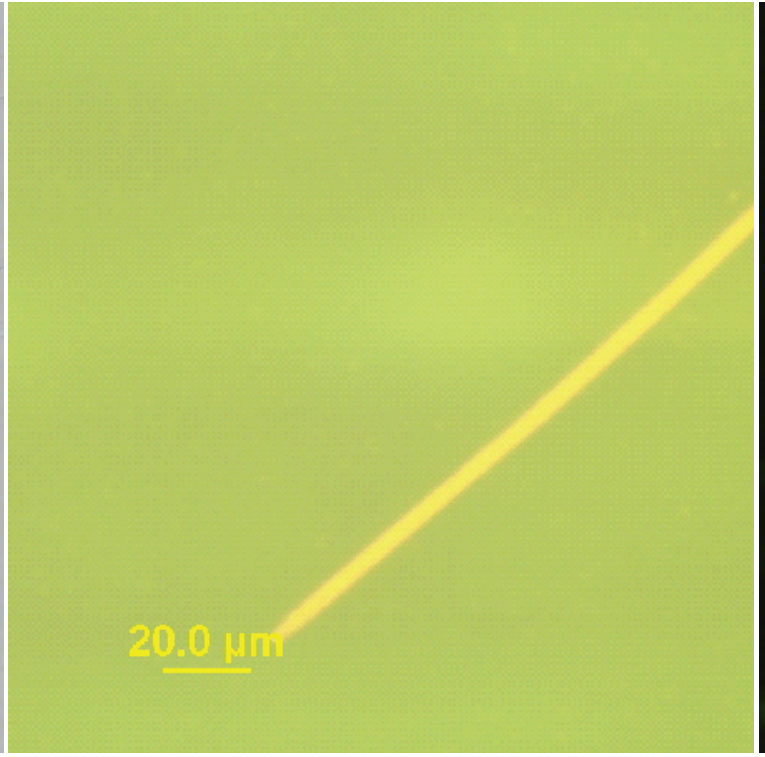

FITC

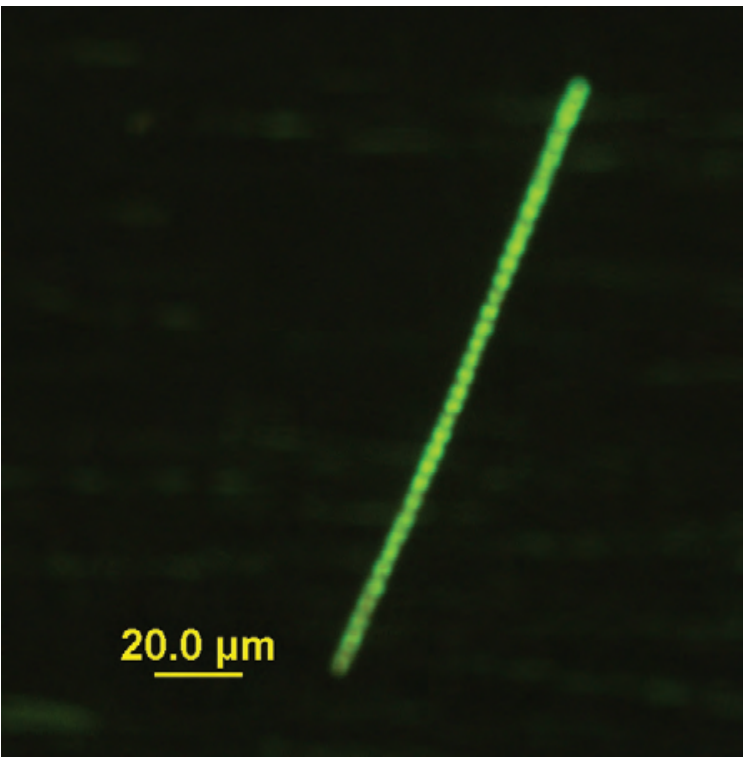

Sytox ${ }^{\circledR}$ green

\section{QuikLyse ${ }^{\mathrm{TM}}-1 \mathrm{x}$}

Figure 73. Grand Lake (Lake St. Mary), $\mathrm{OH}$ (7/20/2009). LM-Planktothrix sp. FITC-an orange-yellow color dominates the cells. Sytox ${ }^{\circledR}$ green-stain did penetrate the cell membrane, cells bright green. LM - differential interference contrast microscopy; FITC - epifluorescent microscopy; Sytox ${ }^{\circledast}$ green - epifluorescent microscopy in conjunction with the nucleic acid stain Syto ${ }^{\oplus}$ green. 


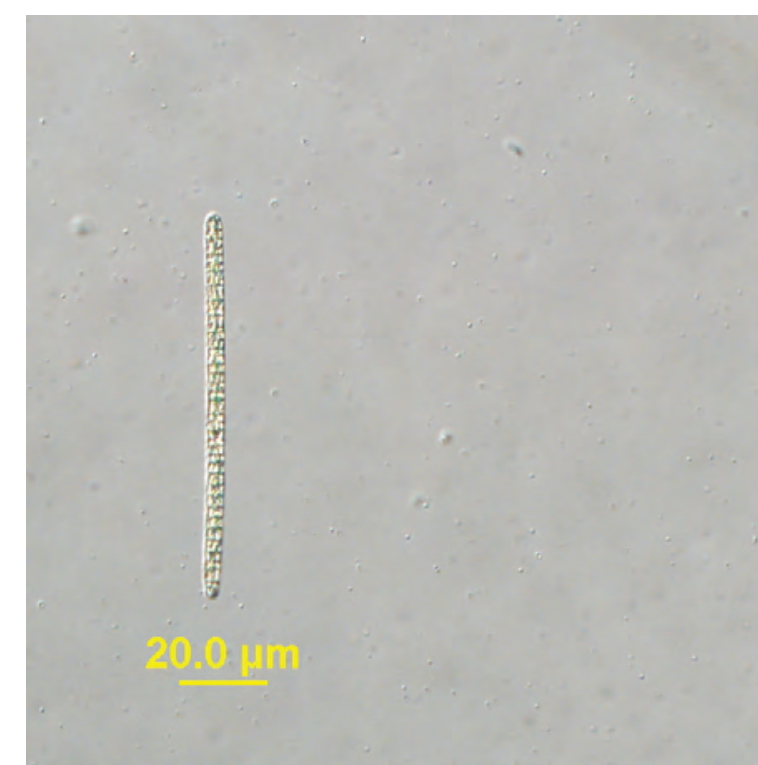

LM

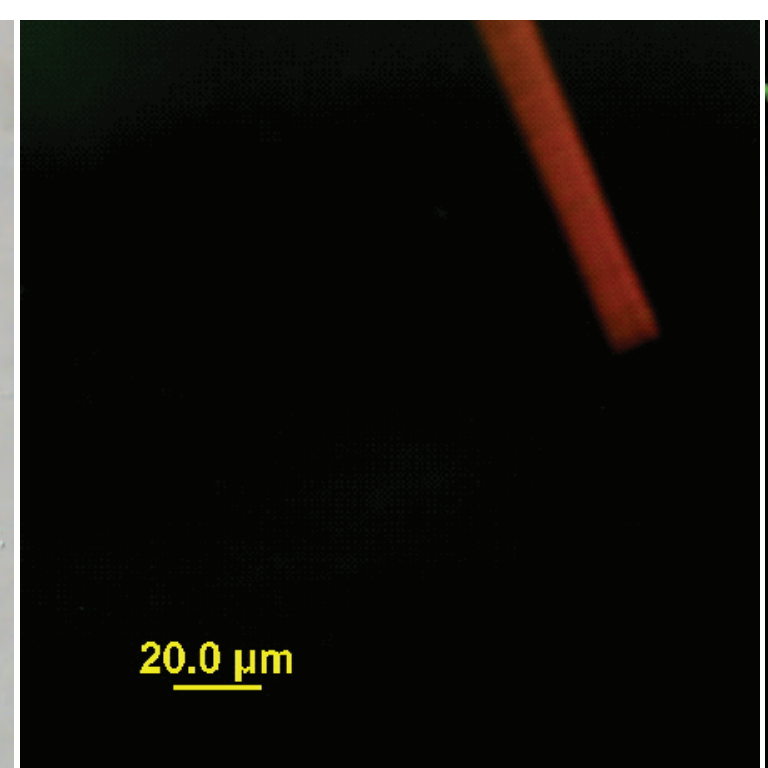

FITC

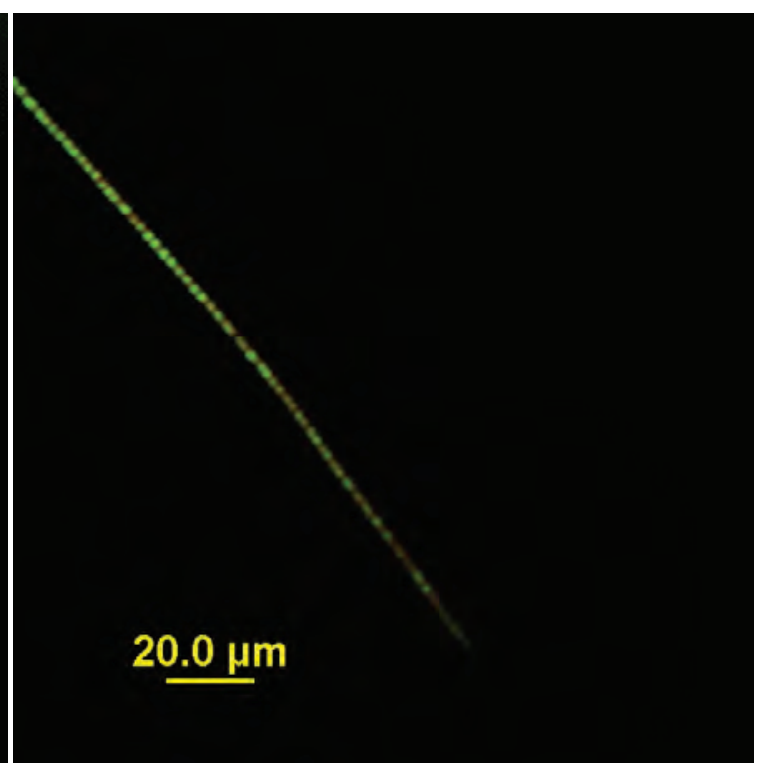

Sytox ${ }^{\circledR}$ green

\section{QuikLyse ${ }^{\mathrm{TM}}-2 \mathrm{x}$}

Figure 74. Grand Lake (Lake St. Mary), $\mathrm{OH} \mathrm{(7/20/2009).} \mathrm{LM-Planktothrix} \mathrm{sp.} \mathrm{FITC-red} \mathrm{dominates} \mathrm{the} \mathrm{cells;} \mathrm{this} \mathrm{image} \mathrm{is} \mathrm{blurred} \mathrm{because} \mathrm{of} \mathrm{the} \mathrm{long} \mathrm{exposure} \mathrm{time.}$ Sytox ${ }^{\circledR}$ green-unknown cyanobacterial filament (too thin to be the previous Planktothrix) stain did penetrate the cell membrane, cells bright green. LM - differential interference contrast microscopy; FITC - epifluorescent microscopy; Sytox ${ }^{\circledR}$ green - epifluorescent microscopy in conjunction with the nucleic acid stain Sytox ${ }^{\circledR}$ green. 


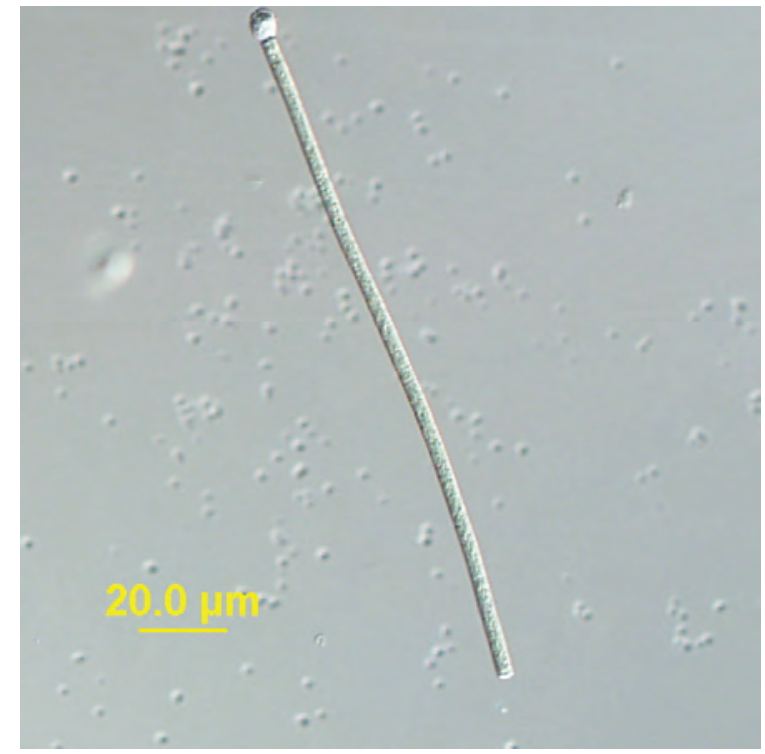

LM

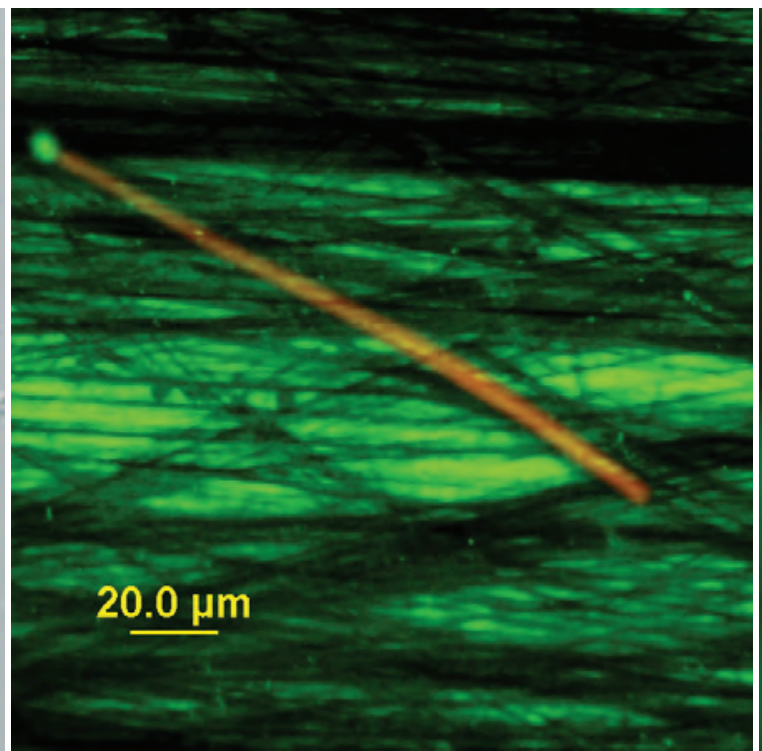

FITC

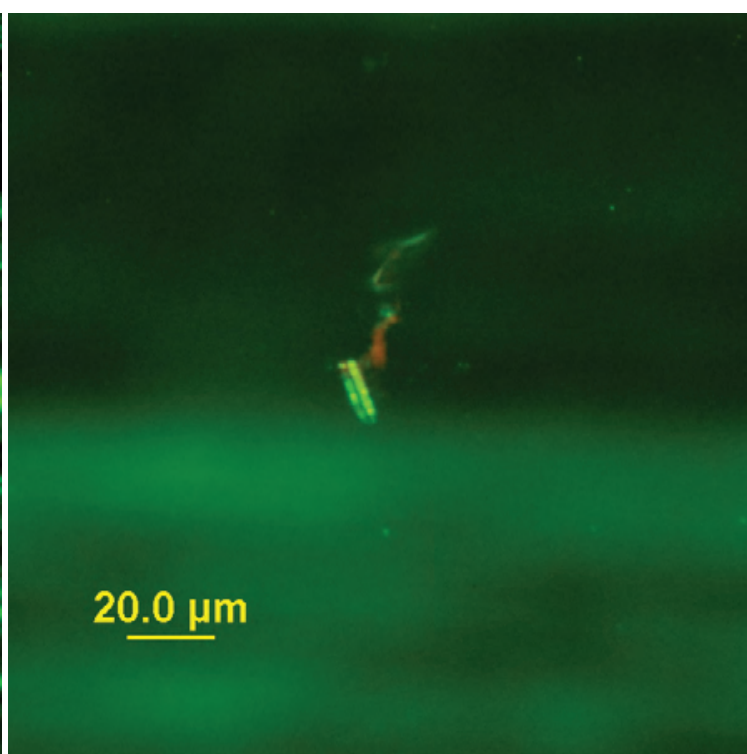

Sytox ${ }^{\circledR}$ green

One freeze-thaw cycle

Figure 75. Grand Lake (Lake St. Mary), $\mathrm{OH}$ (7/20/2009). LM-Planktothrix sp. FITC-an orange color dominates the cells; this image is blurred because of the long exposure time. Sytox ${ }^{\oplus}$ green-too little material to describe effect. LM - differential interference contrast microscopy; FITC - epifluorescent microscopy; Sytox ${ }^{\circledast}$ green epifluorescent microscopy in conjunction with the nucleic acid stain Sytox ${ }^{\circledR}$ green. 


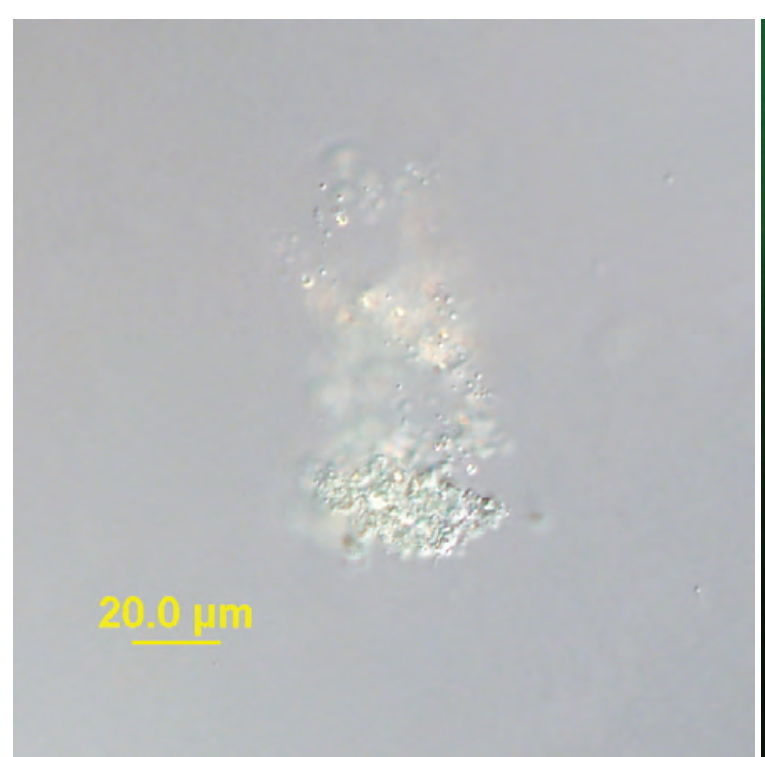

LM

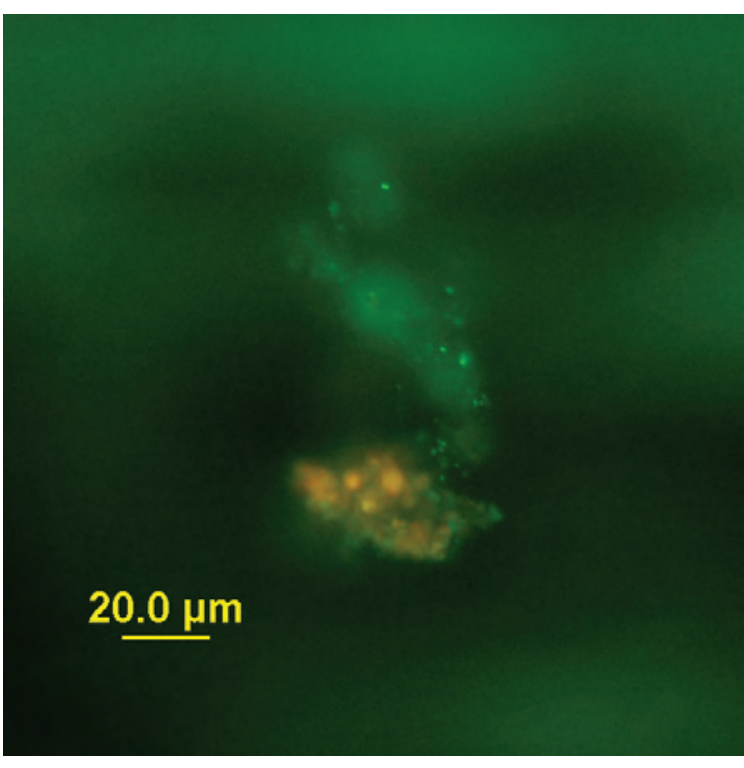

FITC

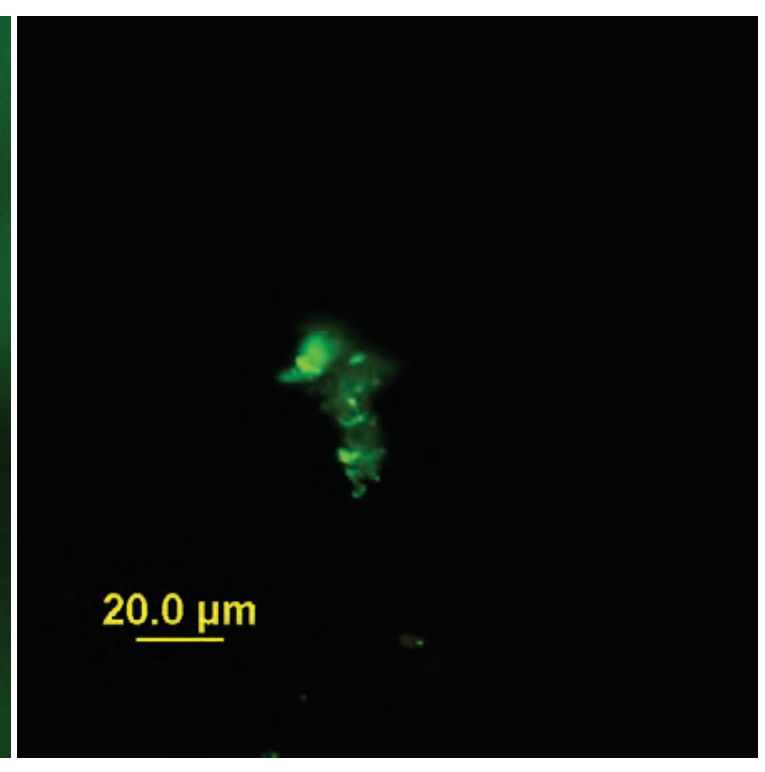

Sytox ${ }^{\circledR}$ green

Two freeze-thaw cycles

Figure 76. Grand Lake (Lake St. Mary), OH (7/20/2009). LM-Likely the remains of a cyanobacterial colony. FITC-an orange color dominates the few cells present.

Sytox ${ }^{\circledR}$ green-too little material to describe effect. LM - differential interference contrast microscopy; FITC - epifluorescent microscopy; Sytox ${ }^{\circledR}$ green - epifluorescent microscopy in conjunction with the nucleic acid stain Sytox ${ }^{\oplus}$ green. 


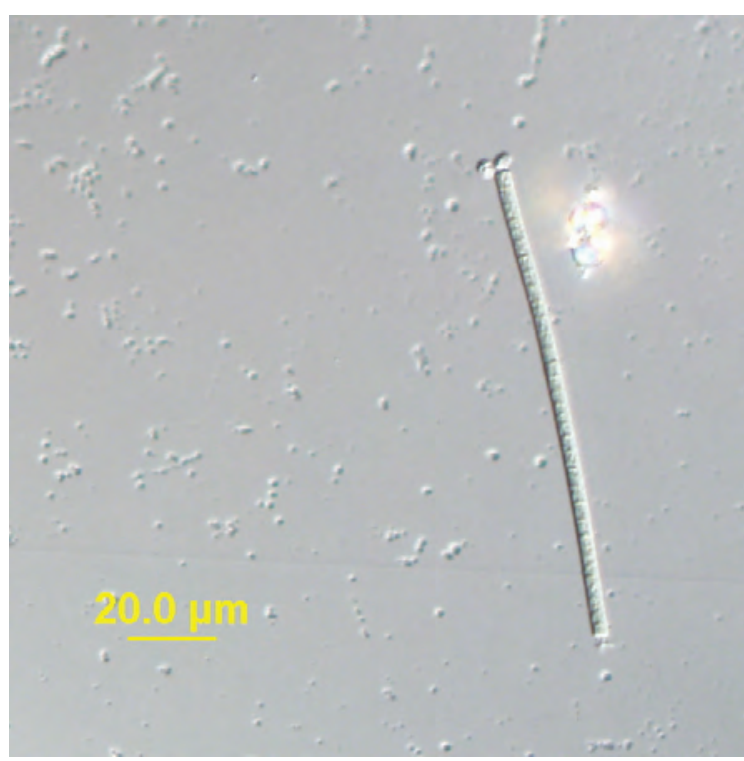

LM

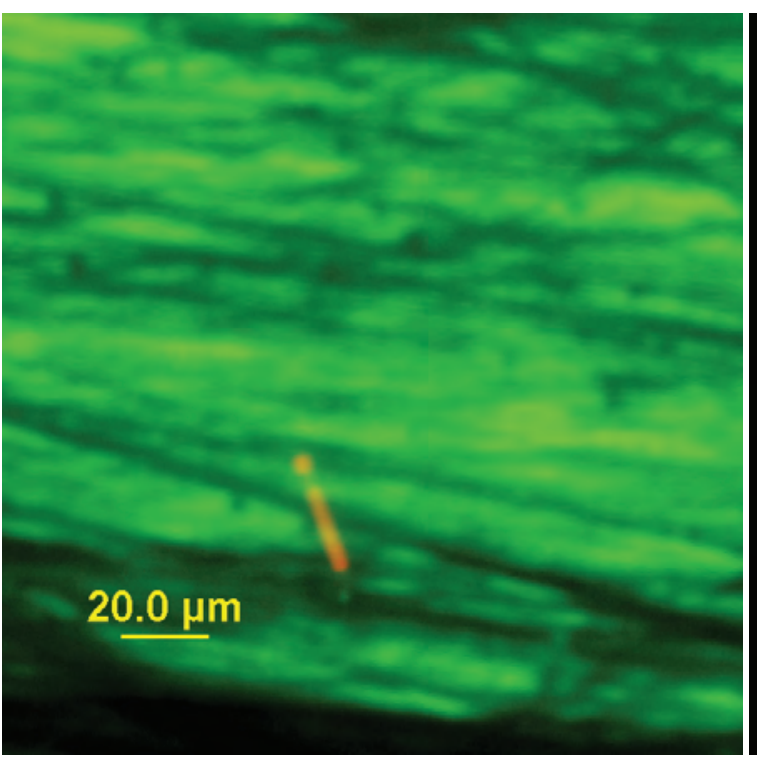

FITC

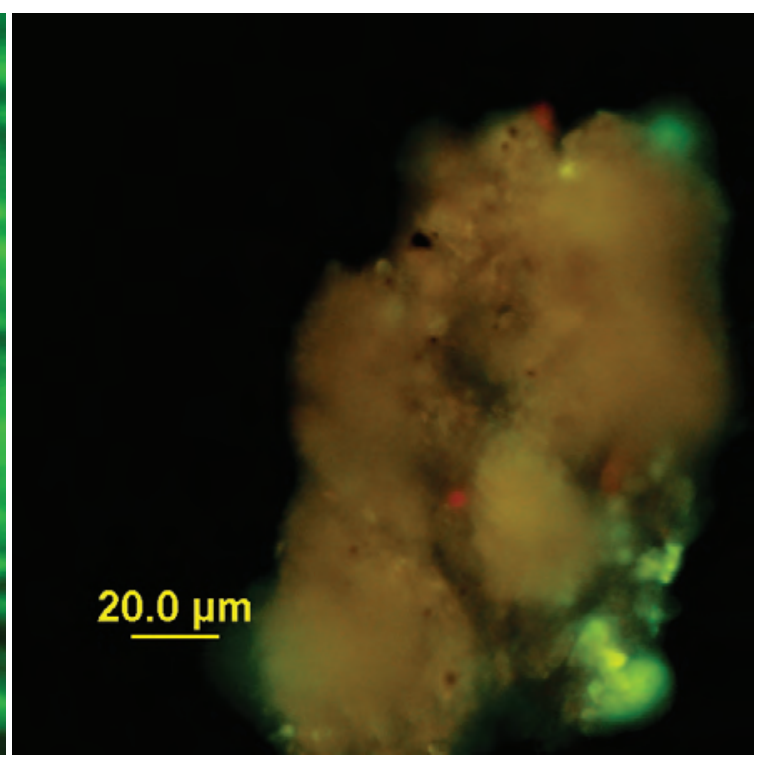

Sytox ${ }^{\circledR}$ green

Three freeze-thaw cycles

Figure 77. Grand Lake (Lake St. Mary), OH (7/20/2009). LM-Planktothrix sp. FITC-an orange color dominates the cells; this image is blurred because of the long exposure time. Sytox ${ }^{\circledast}$ green-unknown cyanobacterial colony; stain did not penetrate the majority of the cells in the colony. LM - differential interference contrast microscopy; FITC - epifluorescent microscopy; Sytox ${ }^{\oplus}$ green - epifluorescent microscopy in conjunction with the nucleic acid stain Sytox ${ }^{\circledR}$ green. 


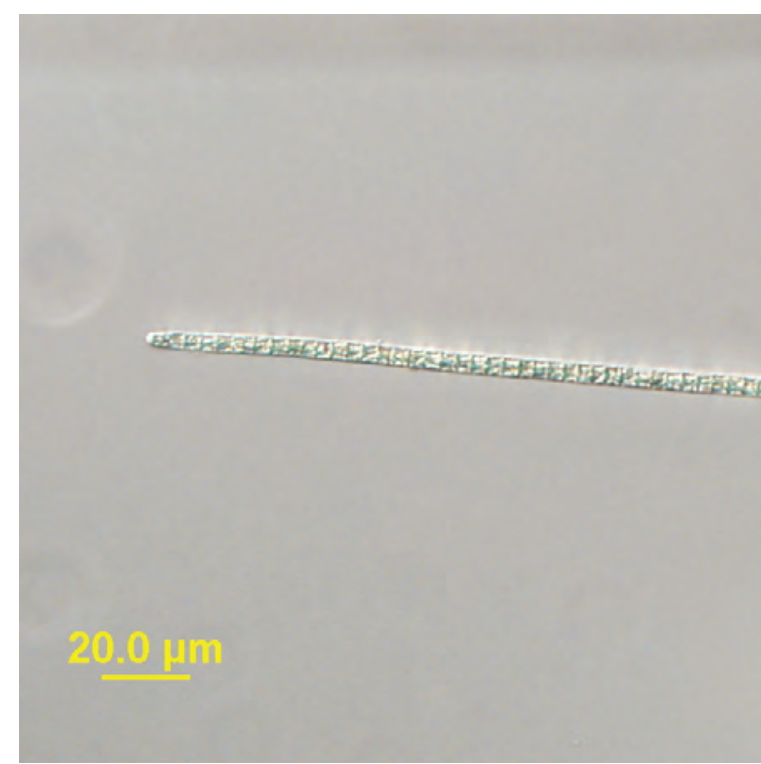

LM

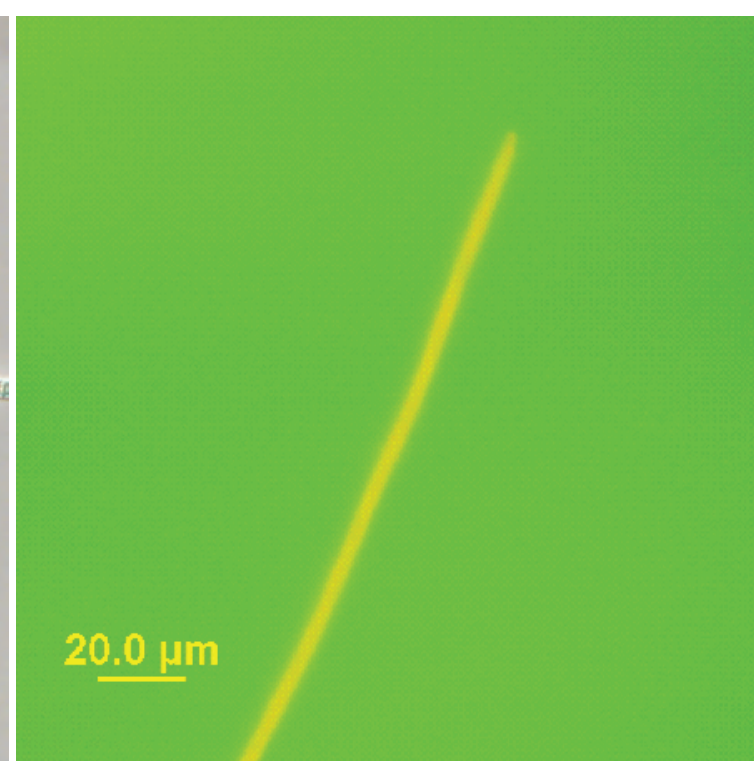

FITC

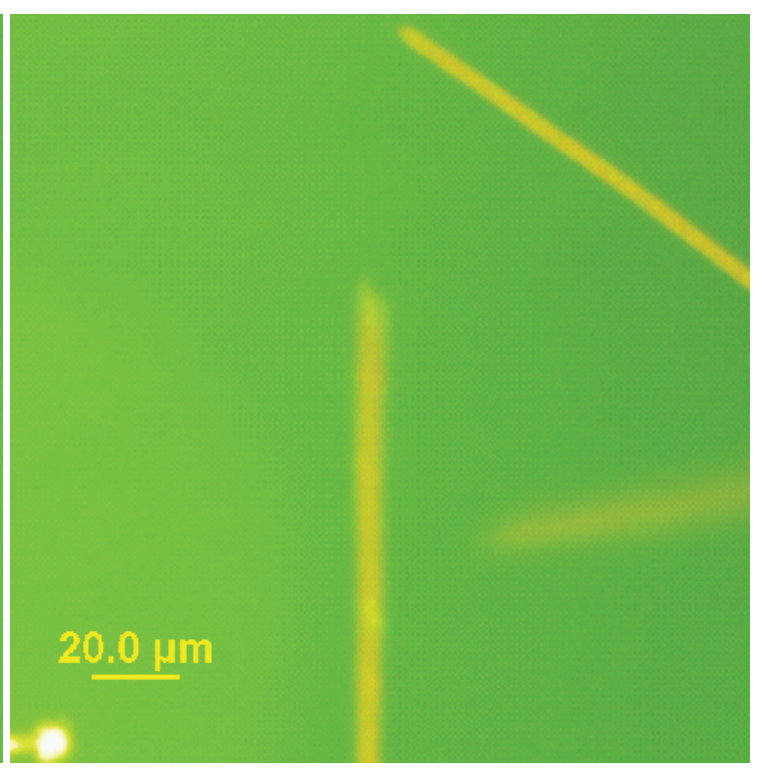

Sytox ${ }^{\circledR}$ green

\section{Control 1}

Figure 78. Grand Lake (Lake St. Mary), OH (9/15/2009). LM-Planktothrix sp. FITC-an orange color dominates the cells. Sytox ${ }^{\circledR}$ green-stain did not penetrate the cell membrane. LM - differential interference contrast microscopy; FITC - epifluorescent microscopy; Sytox ${ }^{\circledast}$ green - epifluorescent microscopy in conjunction with the nucleic acid stain Sytox ${ }^{\circledast}$ green. 


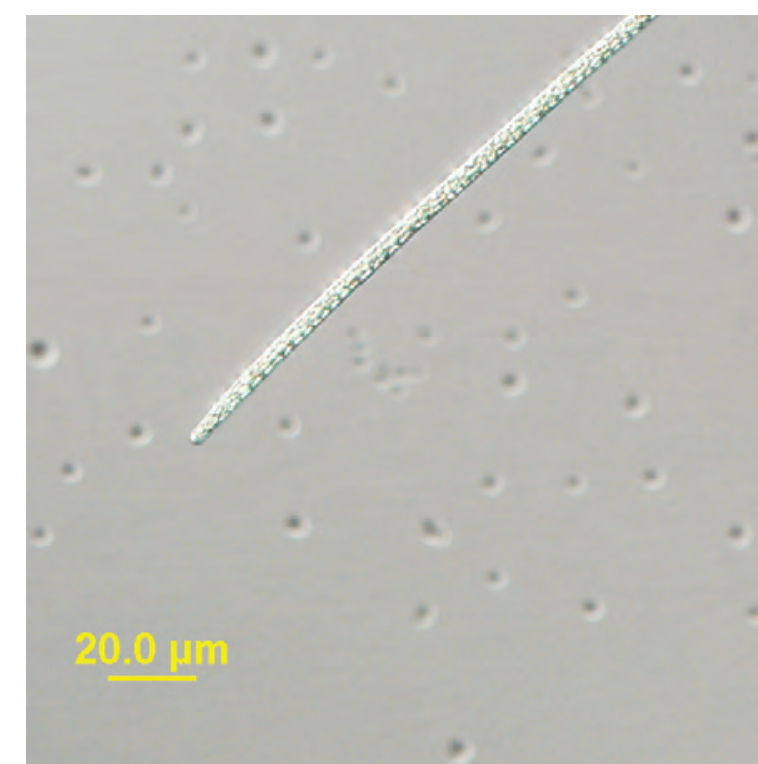

LM

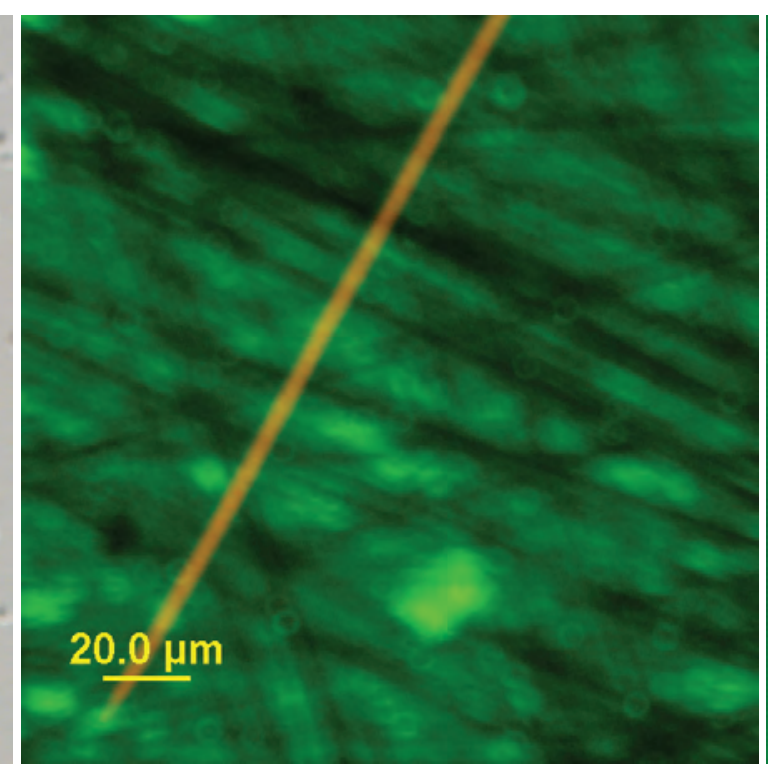

FITC

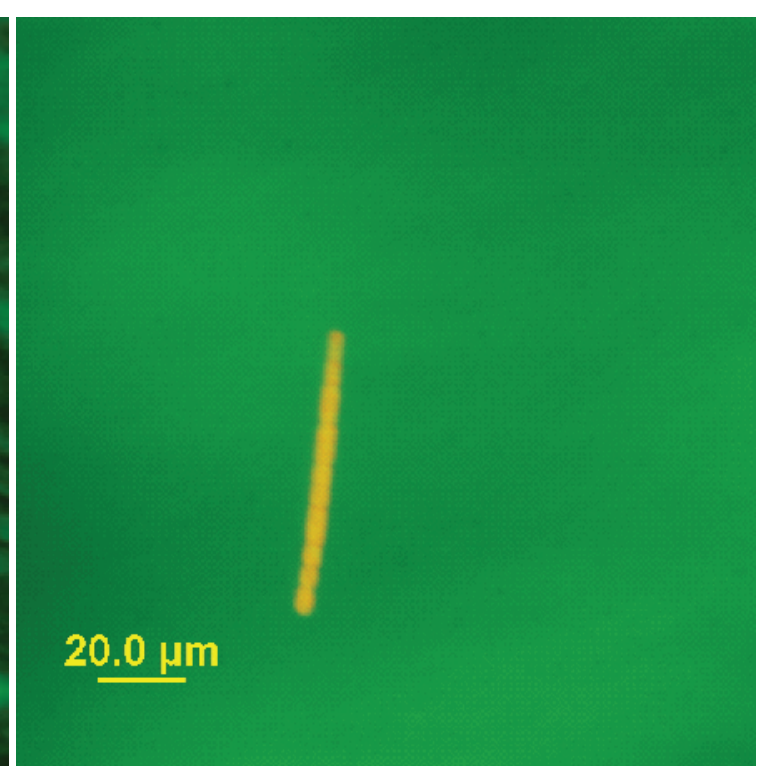

Sytox ${ }^{\circledR}$ green

\section{Control 2}

Figure 79. Grand Lake (Lake St. Mary), $\mathrm{OH}$ (9/15/2009). LM-Planktothrix sp. FITC-an orange color dominates the cells. Sytox ${ }^{\circledR}$ green-stain did not penetrate the cell membrane. LM - differential interference contrast microscopy; FITC - epifluorescent microscopy; Sytox ${ }^{\circledR}$ green - epifluorescent microscopy in conjunction with the nucleic acid stain Sytox ${ }^{\circledR}$ green. 


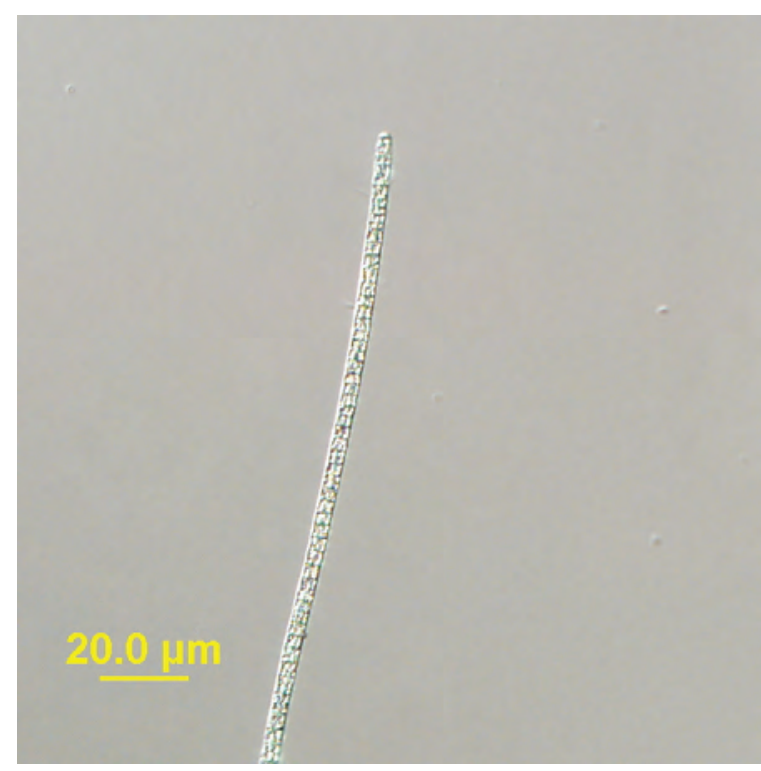

LM

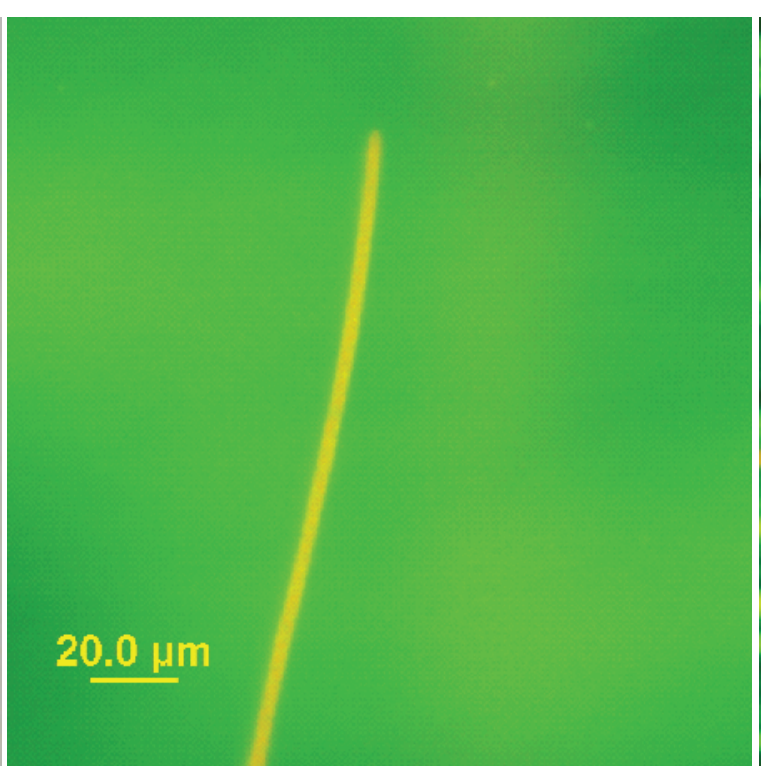

FITC

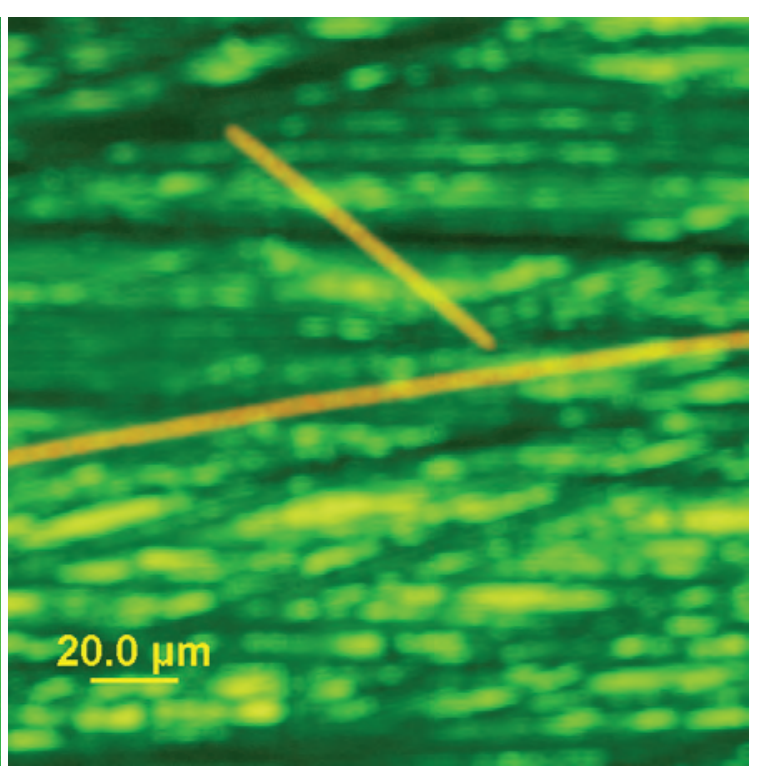

Sytox ${ }^{\circledR}$ green

\section{Control 3}

Figure 80. Grand Lake (Lake St. Mary), OH (9/15/2009). LM-Planktothrix sp. FITC-an orange color dominates the cells. Sytox ${ }^{\oplus}$ green-stain did not penetrate the cell membrane. LM - differential interference contrast microscopy; FITC - epifluorescent microscopy; Sytox ${ }^{\circledast}$ green - epifluorescent microscopy in conjunction with the nucleic acid stain Sytox ${ }^{\circledast}$ green. 


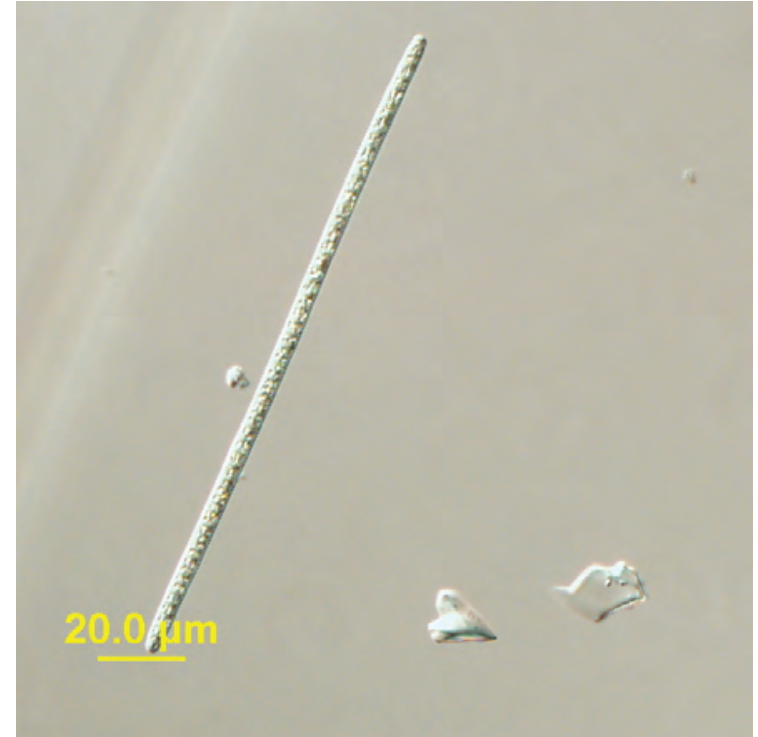

LM

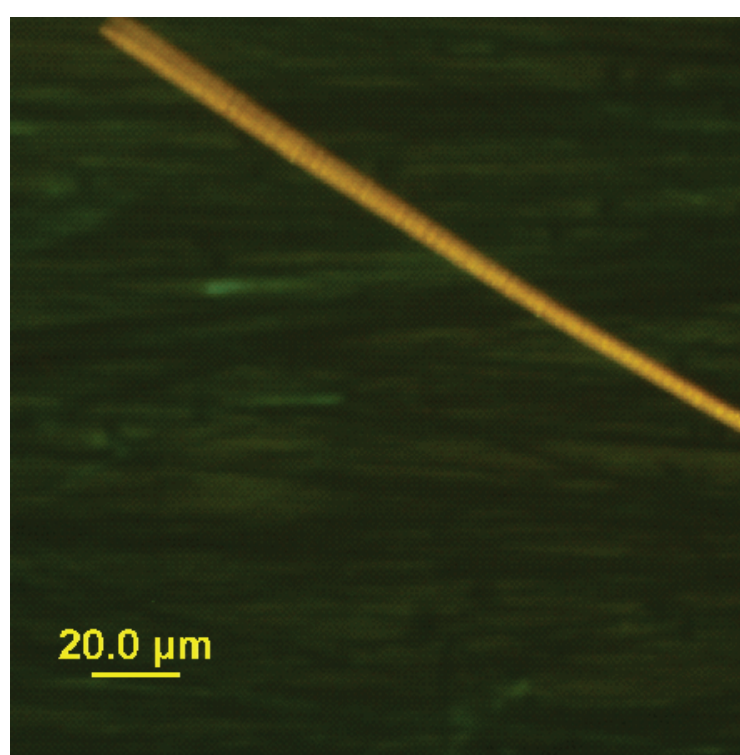

FITC

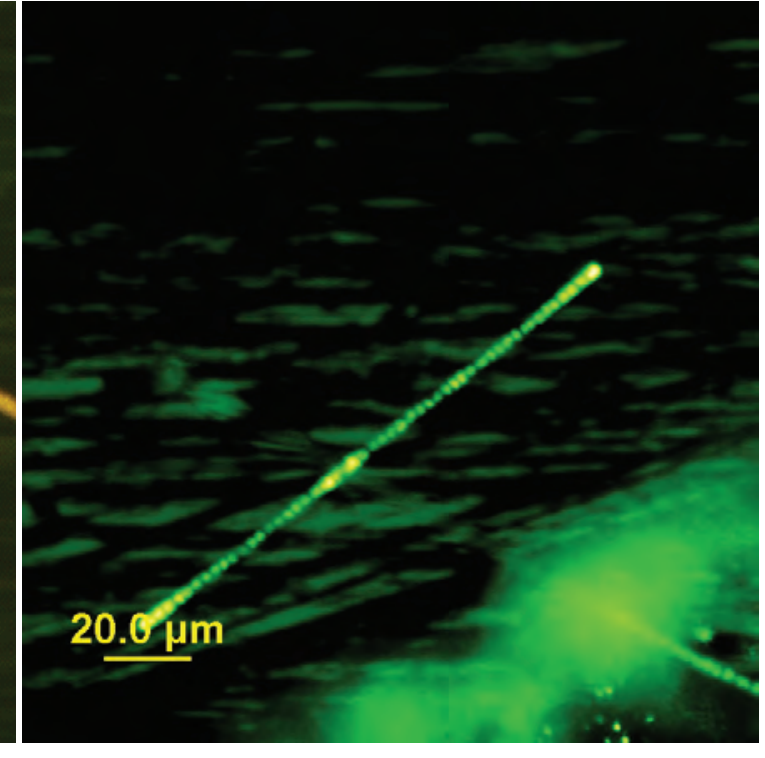

Sytox ${ }^{\circledR}$ green

\section{Boiled for 5 minutes}

Figure 81. Grand Lake (Lake St. Mary), $\mathrm{OH}$ (9/15/2009). LM-Planktothrix sp. FITC-an orange color dominates the cells. Sytox ${ }^{\circledR}$ green-stain did penetrate the cell membrane, cells bright green. LM - differential interference contrast microscopy; FITC - epifluorescent microscopy; Sytox ${ }^{\circledR}$ green - epifluorescent microscopy in conjunction with the nucleic acid stain Sytox ${ }^{\circledR}$ green. 


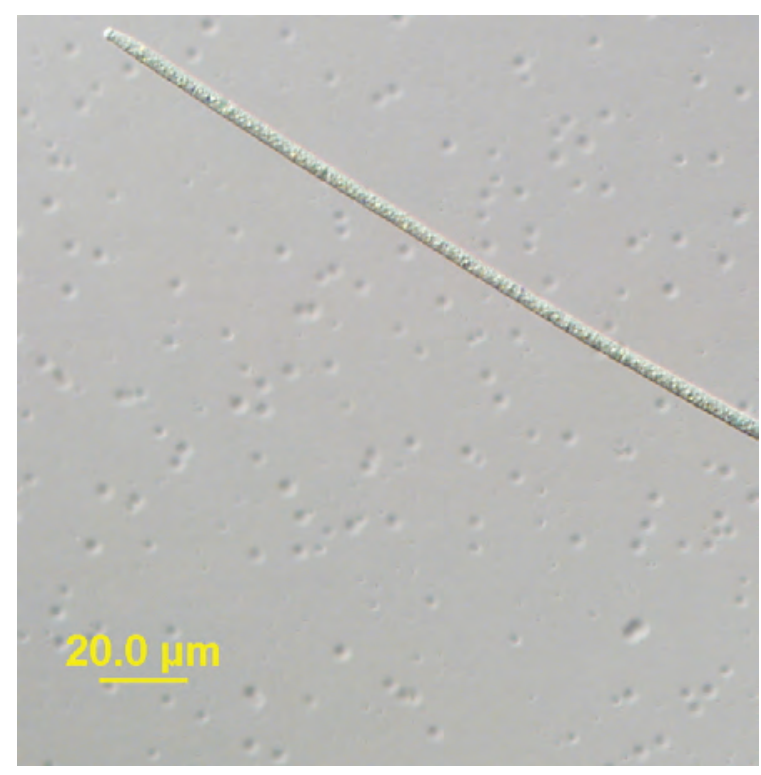

LM

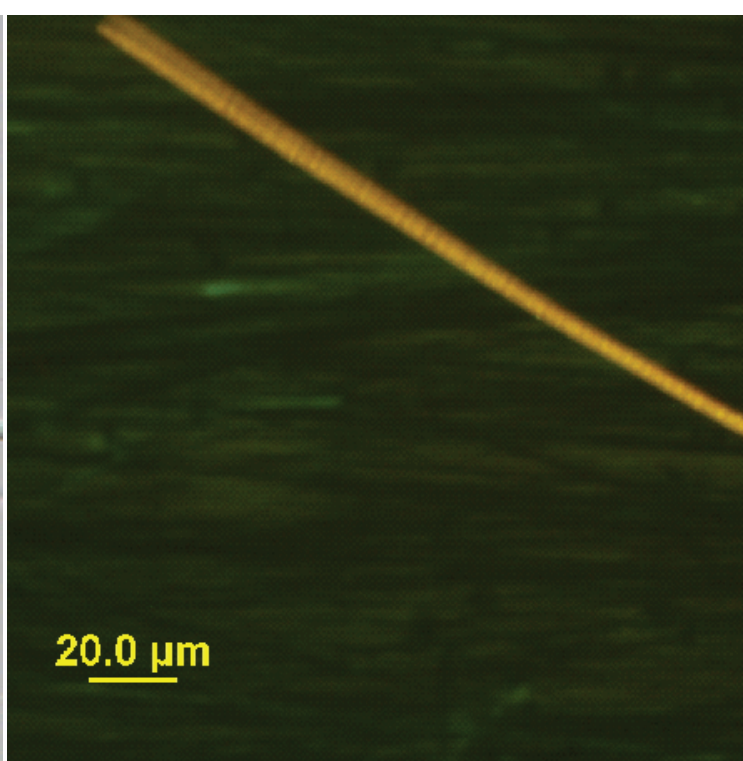

FITC

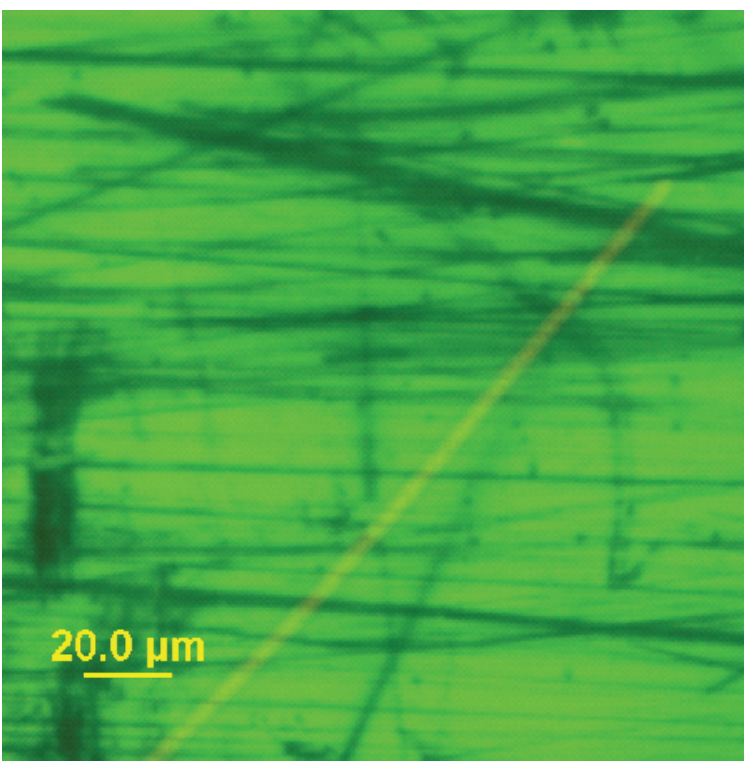

Sytox ${ }^{\circledR}$ green

Boiled for 15 minutes

Figure 82. Grand Lake (Lake St. Mary), OH (9/15/2009). LM-Planktothrix sp. FITC-an orange color dominates the cells. Sytox ${ }^{\circledR}$ green-stain did not penetrate the cell membrane. LM - differential interference contrast microscopy; FITC - epifluorescent microscopy; Sytox ${ }^{\circledR}$ green - epifluorescent microscopy in conjunction with the nucleic acid stain Sytox ${ }^{\circledR}$ green. 


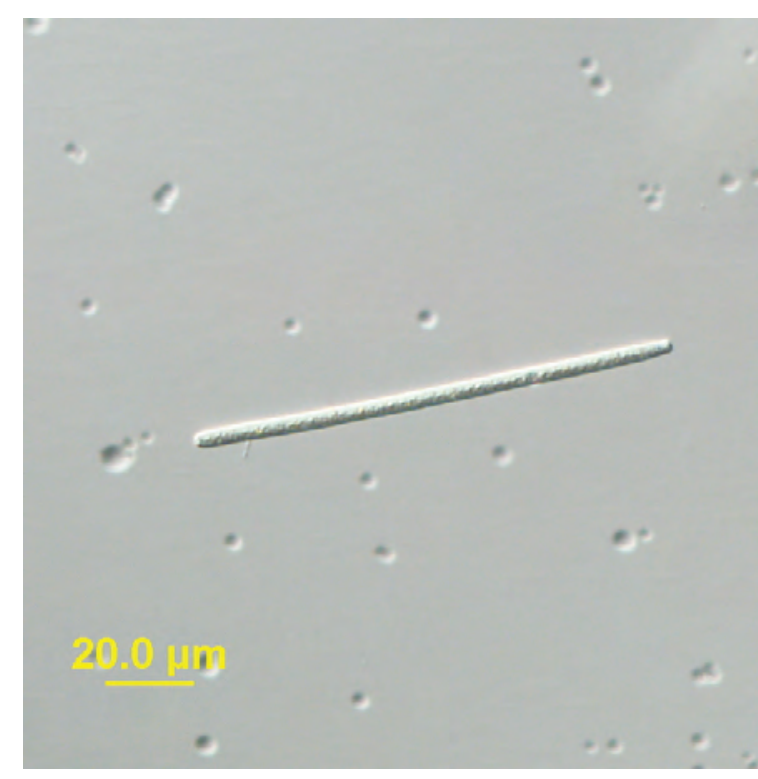

LM

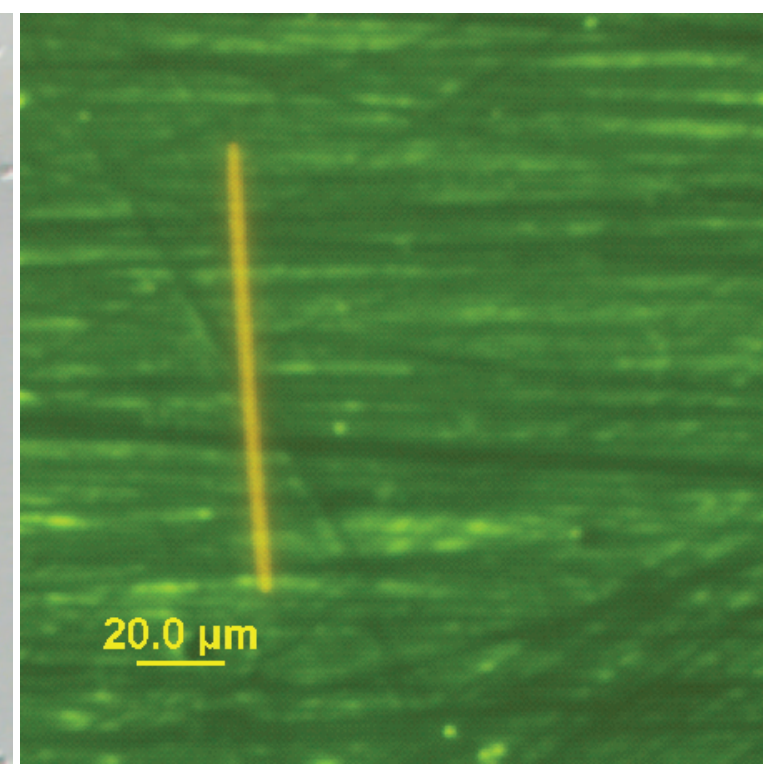

FITC

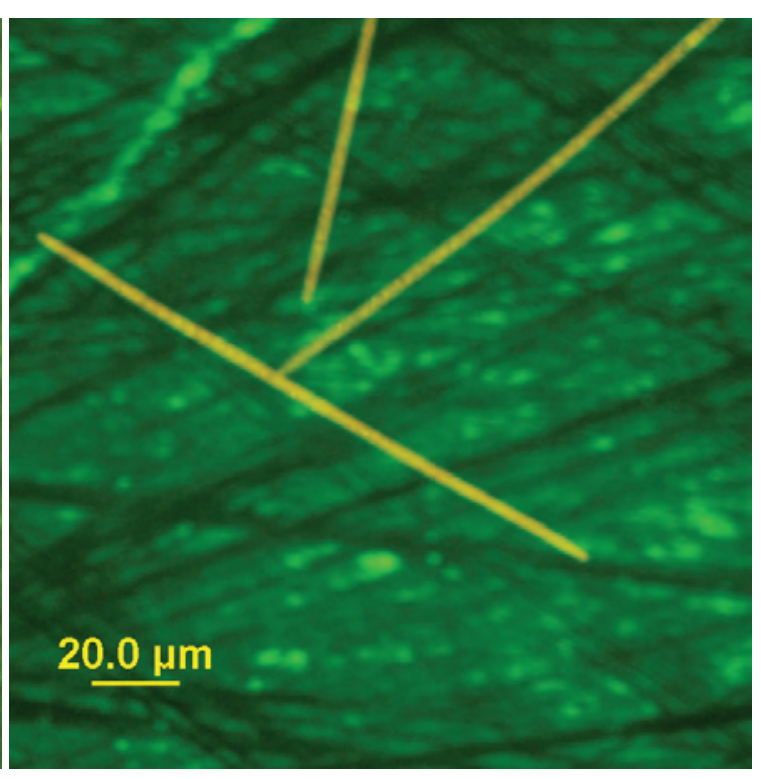

Sytox ${ }^{\circledR}$ green

\section{Boiled for 30 minutes}

Figure 83. Grand Lake (Lake St. Mary), $\mathrm{OH}$ (9/15/2009). LM-Planktothrix sp. FITC-an orange color dominates the cells. Sytox ${ }^{\circledR}$ green-stain did not penetrate the cell membrane. LM - differential interference contrast microscopy; FITC - epifluorescent microscopy; Sytox ${ }^{\circledR}$ green - epifluorescent microscopy in conjunction with the nucleic acid stain Sytox ${ }^{\circledR}$ green. 


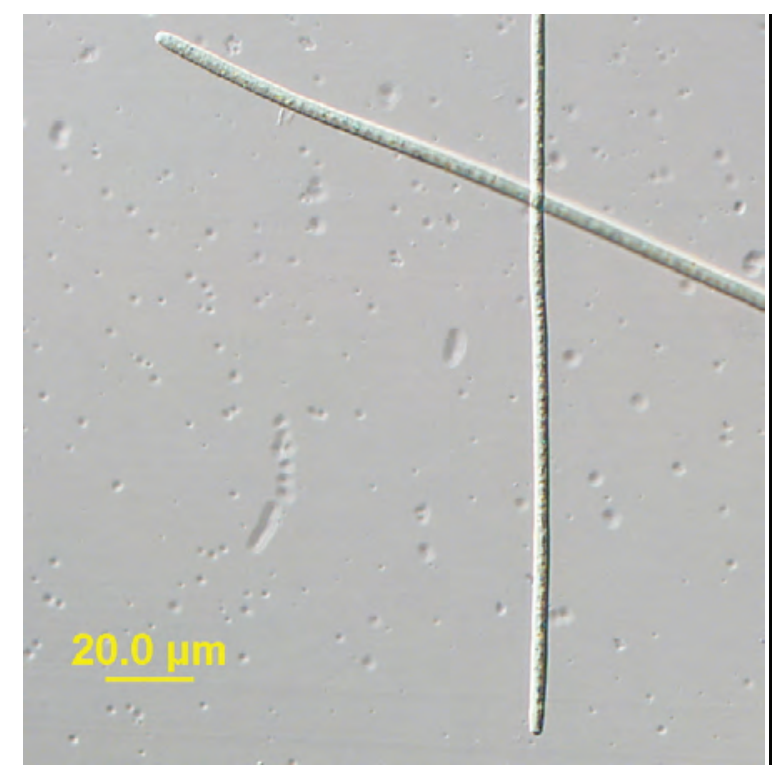

LM

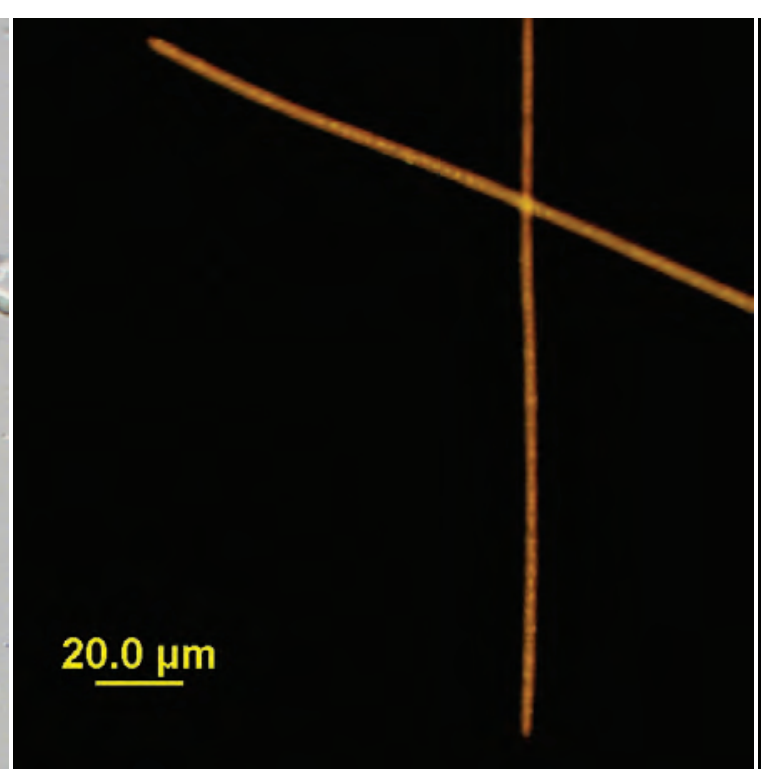

FITC

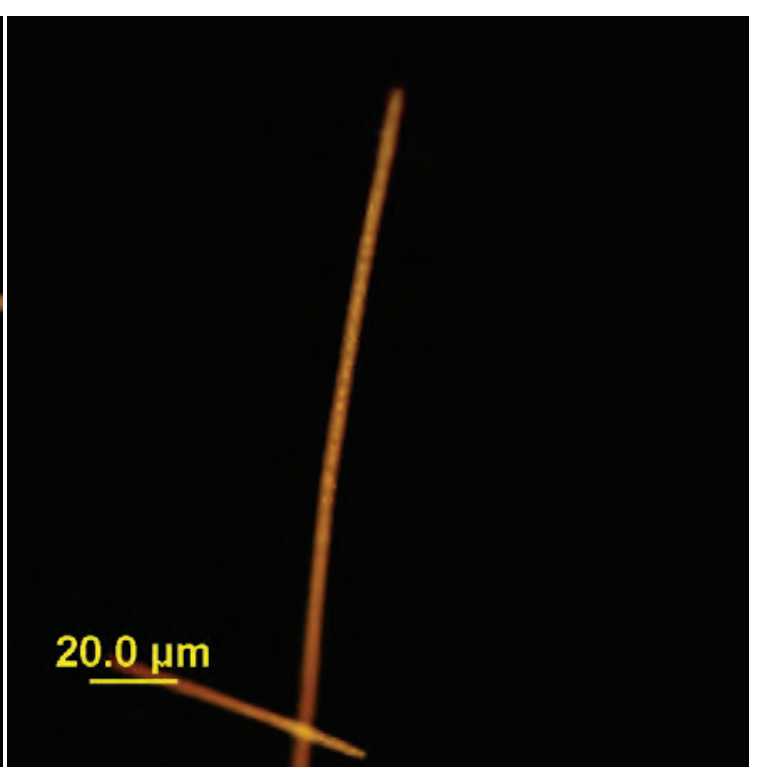

Sytox ${ }^{\circledR}$ green

\section{Autoclaved for 5 minutes}

Figure 84. Grand Lake (Lake St. Mary), OH (9/15/2009). LM-Planktothrix sp. FITC-an orange color dominates the cells. Sytox ${ }^{\circledR}$ green-stain did not penetrate the cell membrane. LM - differential interference contrast microscopy; FITC - epifluorescent microscopy; Sytox ${ }^{\circledR}$ green - epifluorescent microscopy in conjunction with the nucleic acid stain Sytox ${ }^{\circledR}$ green. 


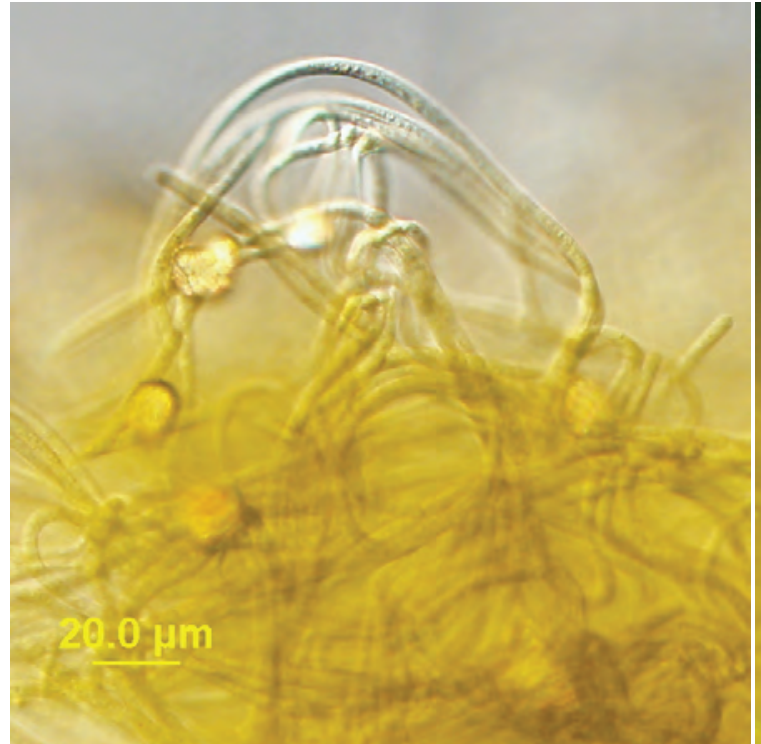

LM

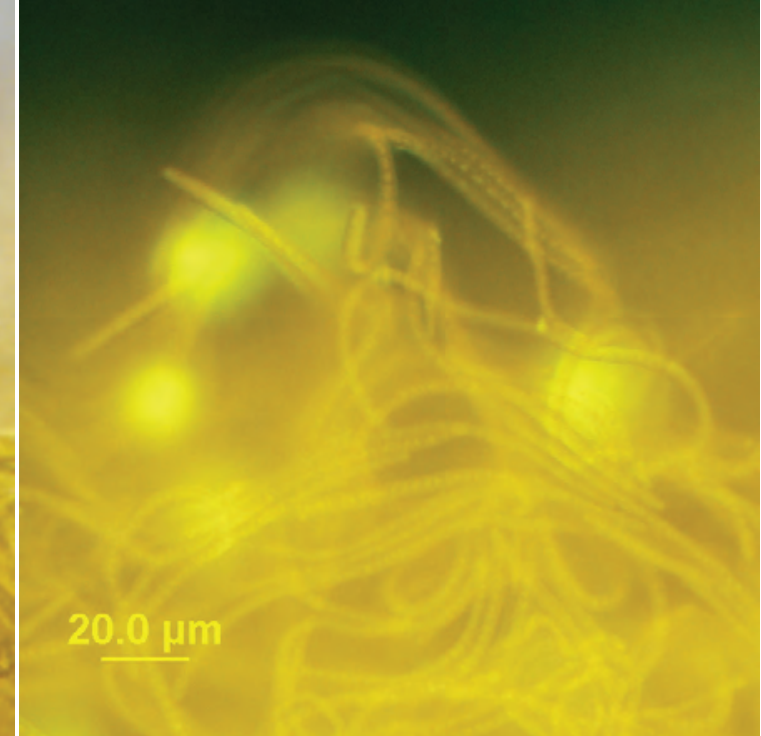

FITC

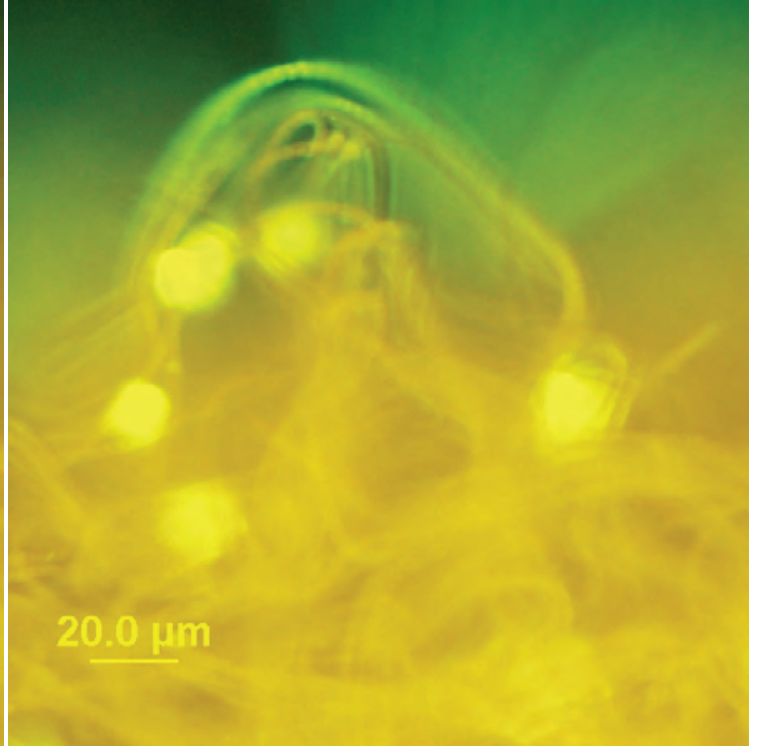

Sytox ${ }^{\circledR}$ green

Autoclaved for 15 minutes

Figure 85. Grand Lake (Lake St. Mary), OH (9/15/2009). LM-A mixture of cyanobacterial filaments and eukaryotic cells. FITC-an orange color dominates the cells. Sytox ${ }^{\circledR}$ green-stain did penetrate the cell membrane of the uppermost filament in this image. LM - differential interference contrast microscopy; FITC - epifluorescent microscopy; Sytox ${ }^{\circledR}$ green - epifluorescent microscopy in conjunction with the nucleic acid stain Sytox ${ }^{\circledR}$ green. 


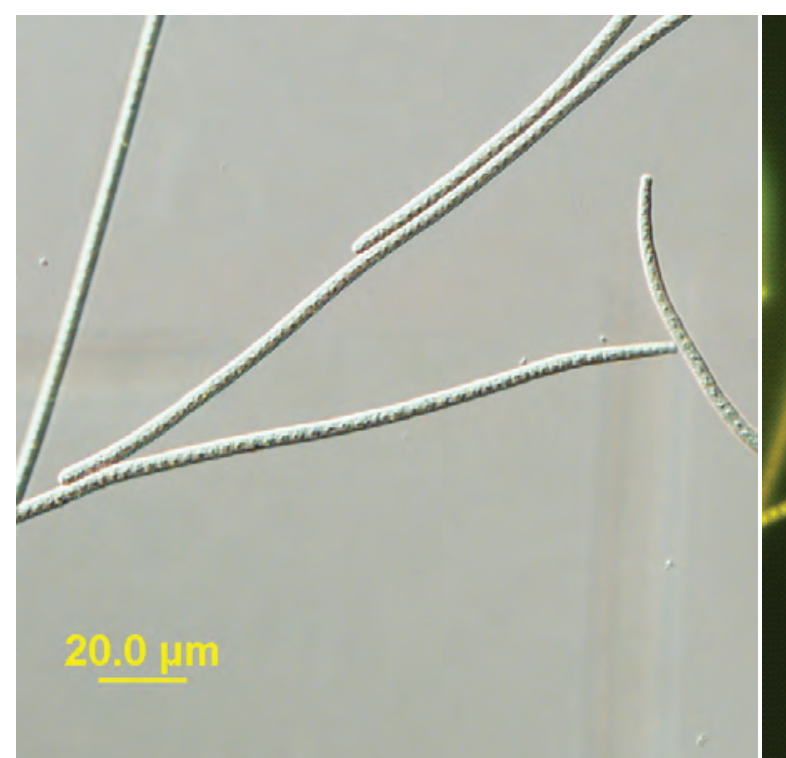

LM

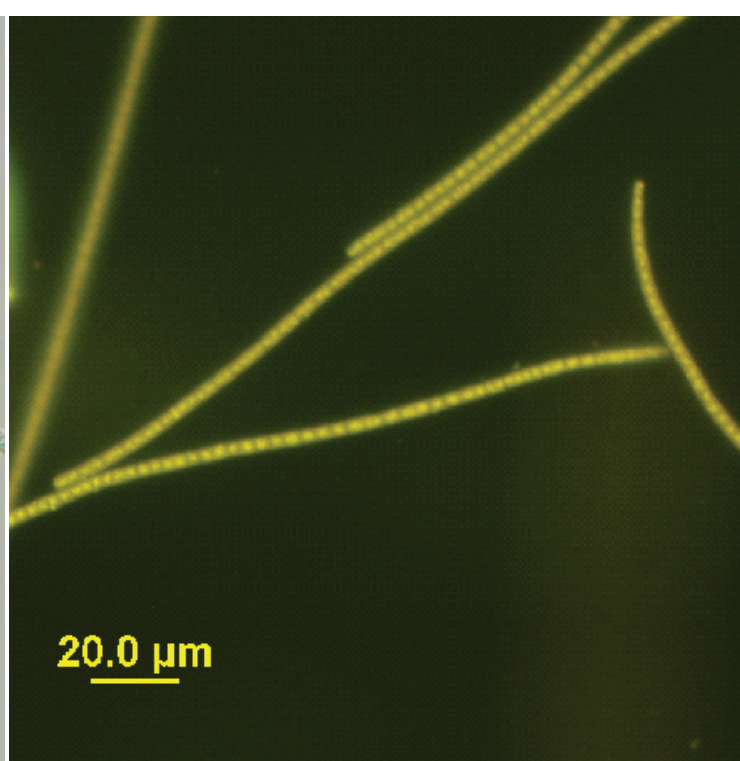

FITC

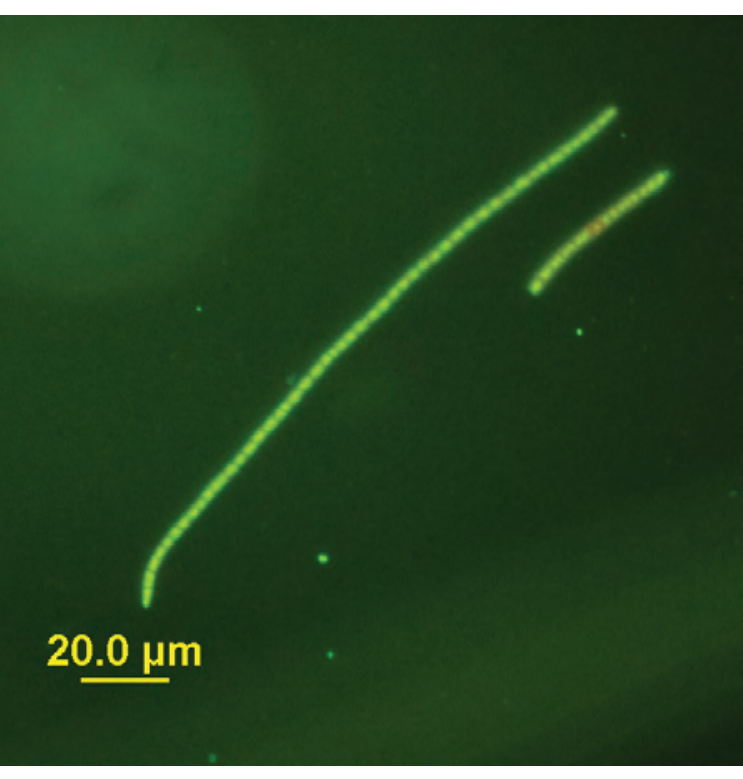

Sytox ${ }^{\circledast r e e n}$

\section{Autoclaved for 30 minutes}

Figure 86. Grand Lake (Lake St. Mary), OH (9/15/2009). LM-Planktothrix sp. FITC-a yellow color dominates the cells. Sytox ${ }^{\oplus}$ green-stain did penetrate the cell membrane, cells bright green. LM - differential interference contrast microscopy; FITC - epifluorescent microscopy; Sytox ${ }^{\circledR}$ green - epifluorescent microscopy in conjunction with the nucleic acid stain Sytox ${ }^{\oplus}$ green. 


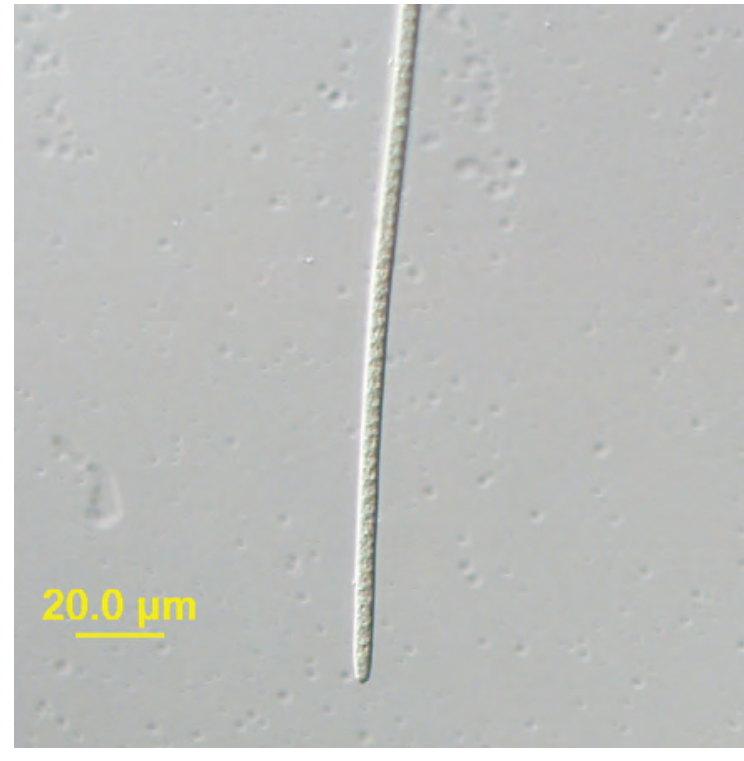

LM

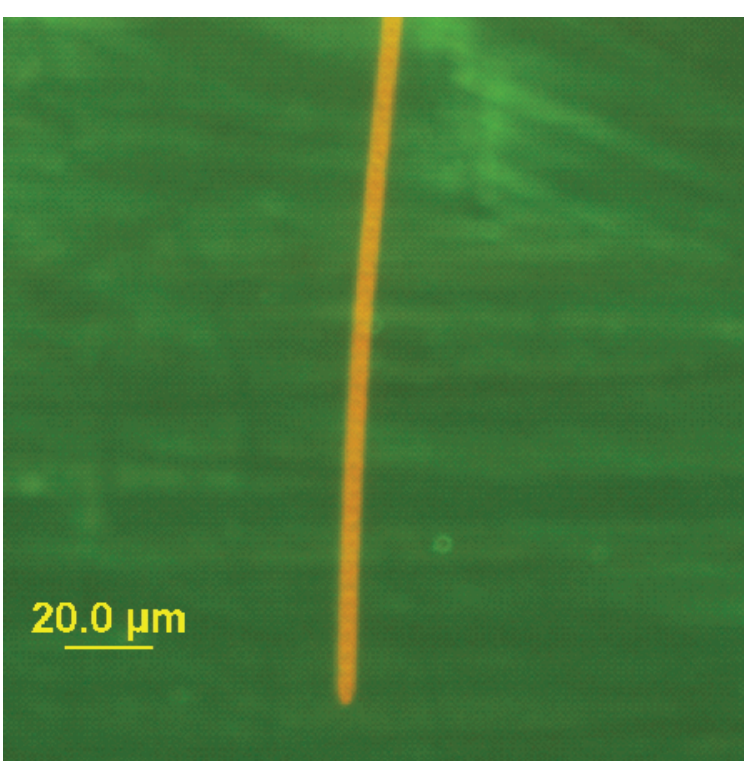

FITC

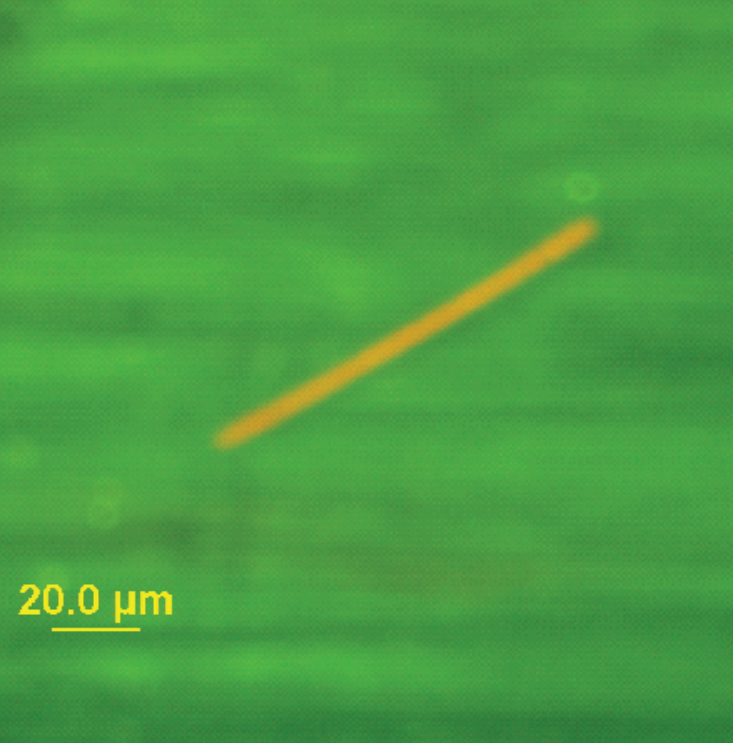

Sytox ${ }^{\circledR}$ green

\section{Sonicated at 10 percent power}

Figure 87. Grand Lake (Lake St. Mary), $\mathrm{OH}$ (9/15/2009). LM-Planktothrix sp. FITC-an orange color dominates the cells. Sytox ${ }^{\circledR}$ green-stain did not penetrate the cell membrane. LM - differential interference contrast microscopy; FITC - epifluorescent microscopy; Sytox ${ }^{\circledR}$ green - epifluorescent microscopy in conjunction with the nucleic acid stain Sytox ${ }^{\circledR}$ green. 


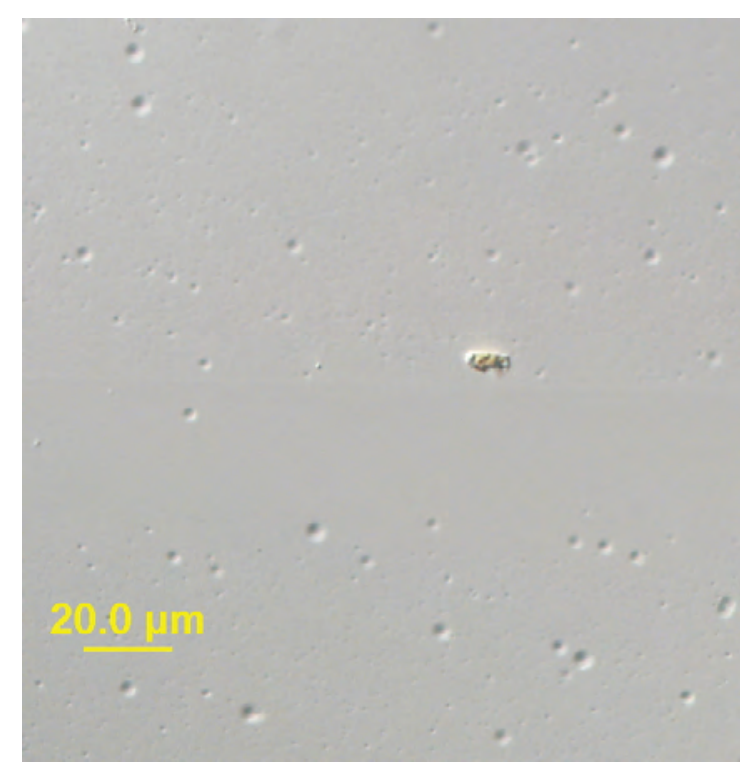

LM

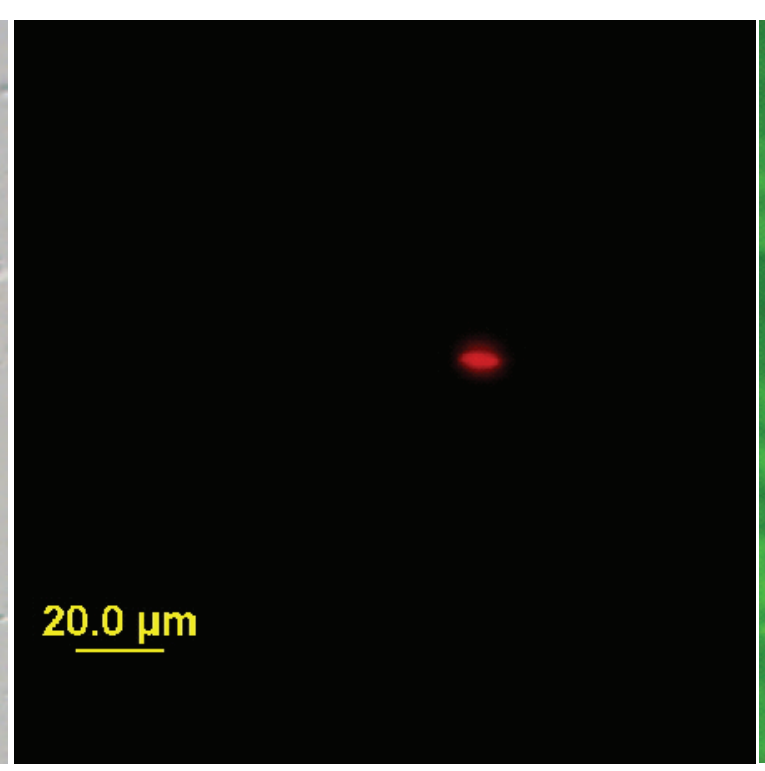

FITC

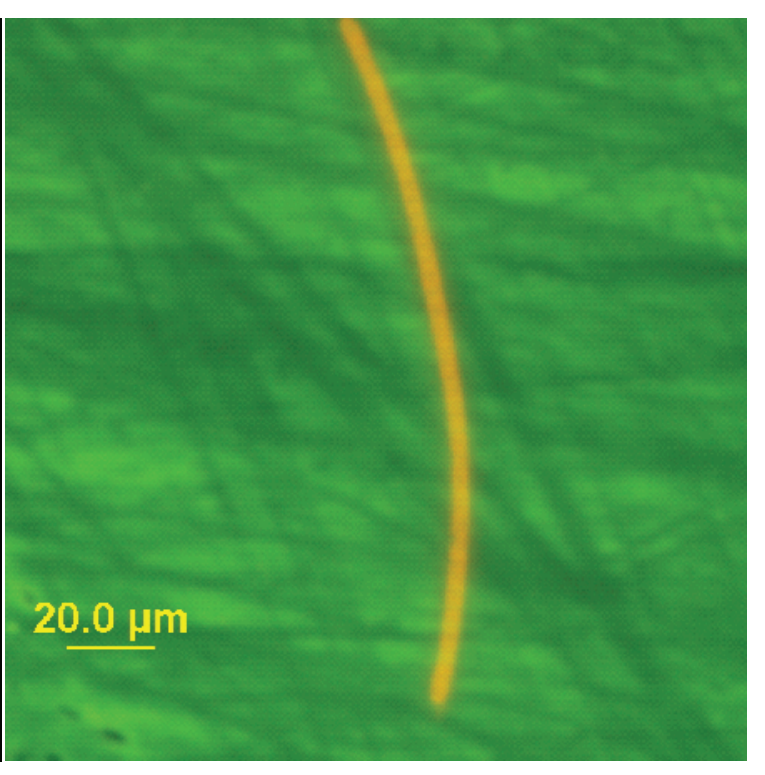

Sytox ${ }^{\circledR}$ green

\section{Sonicated at 35 percent power}

Figure 88. Grand Lake (Lake St. Mary), OH (9/15/2009). LM-Unknown fragment. FITC-a red color dominates this cell fragment. Sytox ${ }^{\circledR}$ green-stain did not penetrate the cell membrane of this Planktothrix filament. LM - differential interference contrast microscopy; FITC - epifluorescent microscopy; Sytox ${ }^{\circledR}$ green - epifluorescent microscopy in conjunction with the nucleic acid stain Syto ${ }^{\circledR}$ green. Note: Sample sonicated at 70 percent power-no cellular material found. 


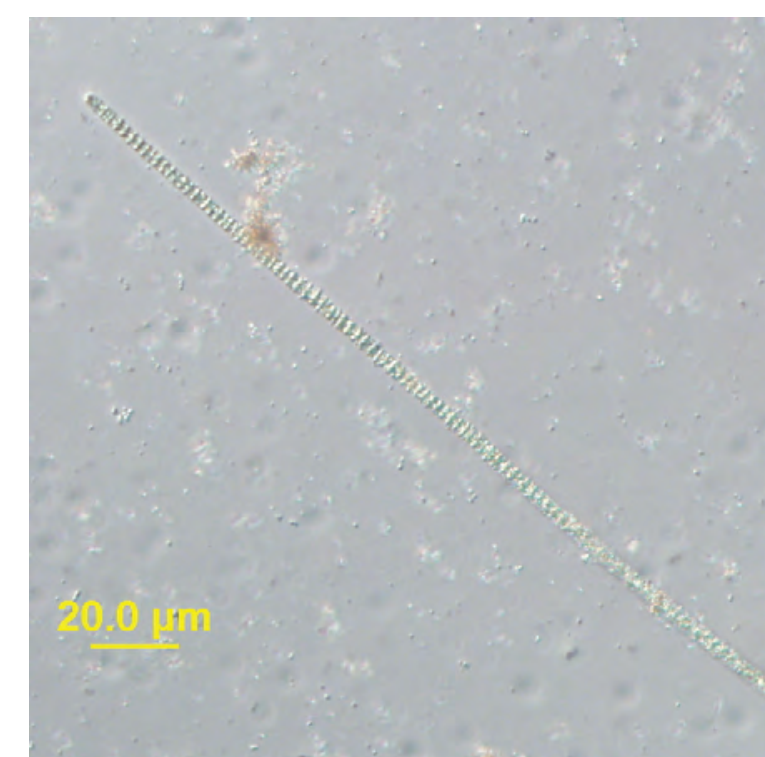

LM

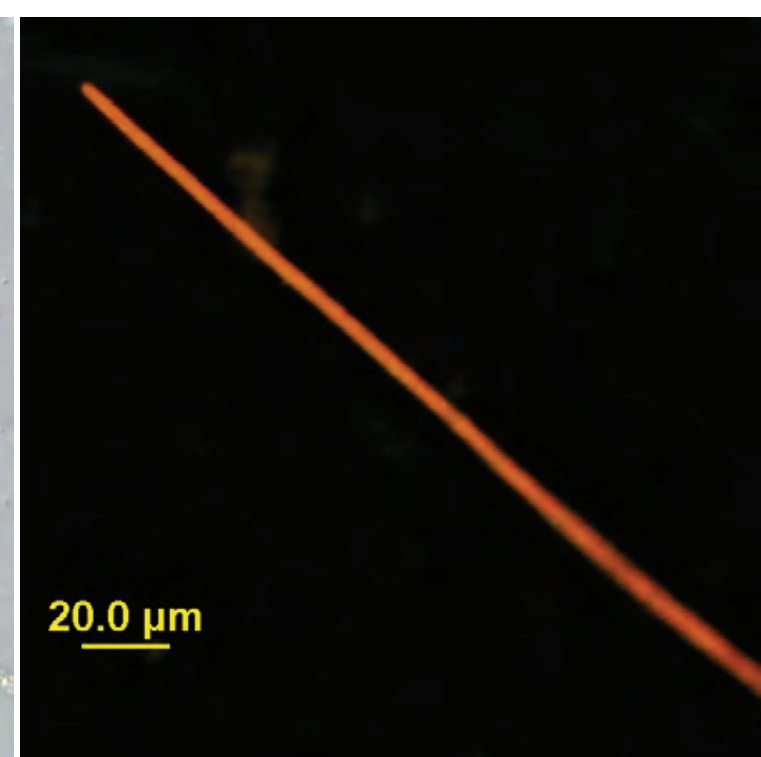

FITC

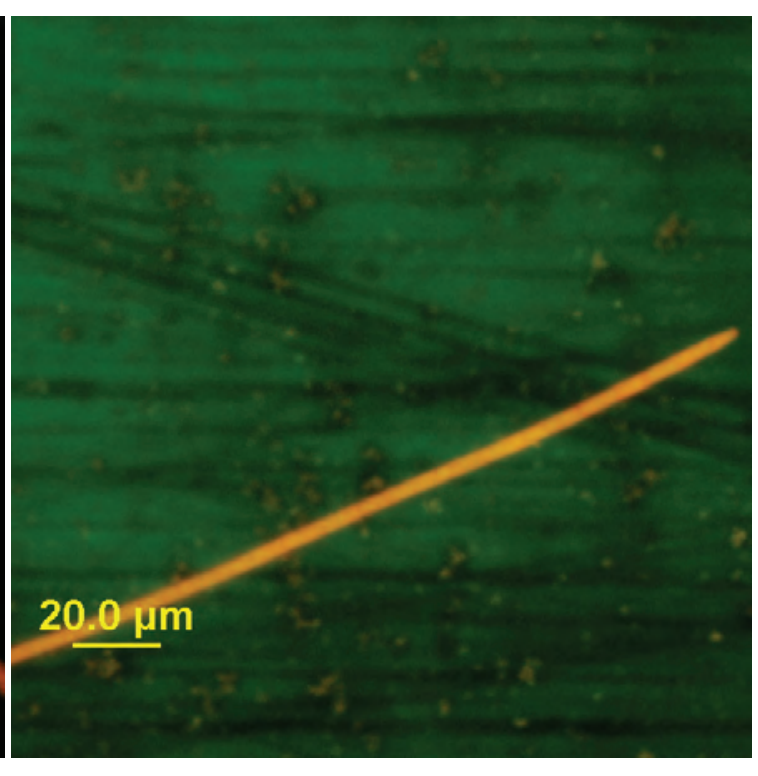

Sytox ${ }^{\circledR}$ green

QuikLyse $\mathrm{TM}^{\mathrm{TM}}-1 \mathrm{x}$

Figure 89. Grand Lake (Lake St. Mary), OH (9/15/2009). LM-Planktothrix sp. FITC-an orange color dominates the cells. Sytox ${ }^{\circledR}$ green-stain did not penetrate the cell membrane. LM - differential interference contrast microscopy; FITC - epifluorescent microscopy; Sytox ${ }^{\circledR}$ green - epifluorescent microscopy in conjunction with the nucleic acid stain Sytox ${ }^{\circledR}$ green. 


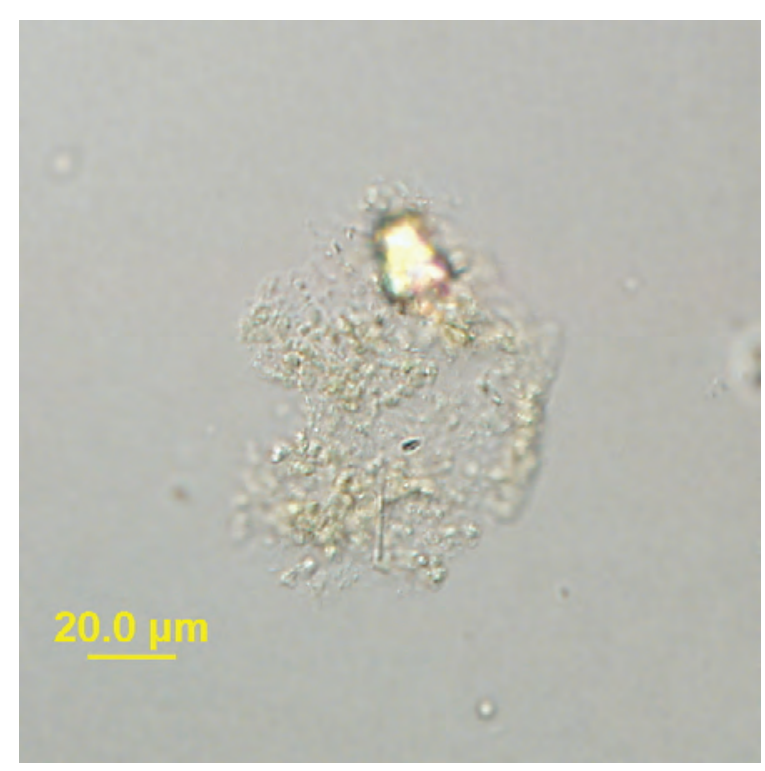

LM

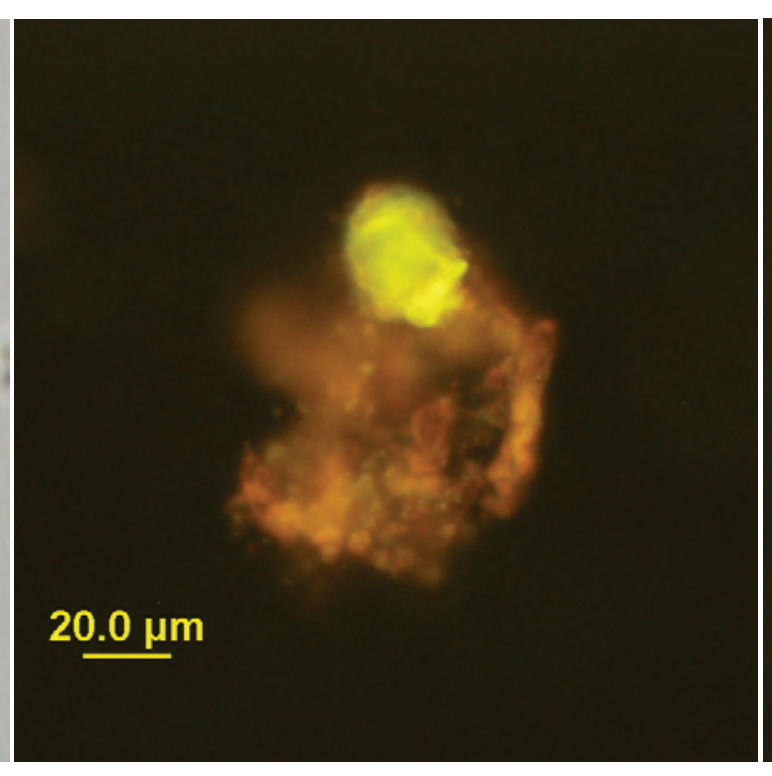

FITC

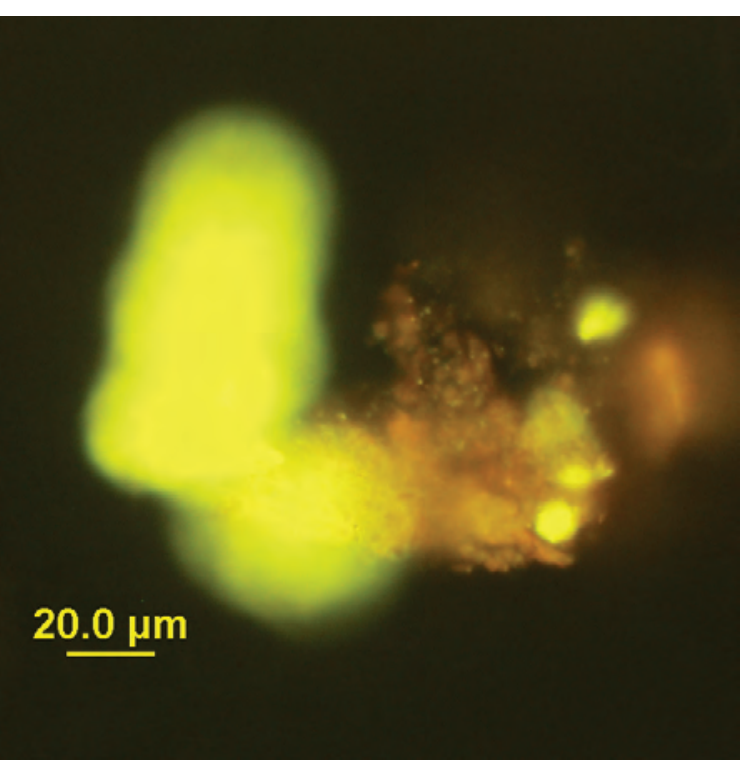

Sytox ${ }^{\circledR}$ green

One freeze-thaw cycle

Figure 90. Grand Lake (Lake St. Mary), OH (9/15/2009). LM-Unknown cyanobacterial colony fragment. FITC-an orange color dominates this cell. Sytox ${ }^{\circledR}$ green-stain did not stain the cyanobacterial material; only the eukaryotic cells. LM - differential interference contrast microscopy; FITC - epifluorescent microscopy; Sytox ${ }^{\circledR}$ green epifluorescent microscopy in conjunction with the nucleic acid stain Sytox ${ }^{\circledR}$ green. 


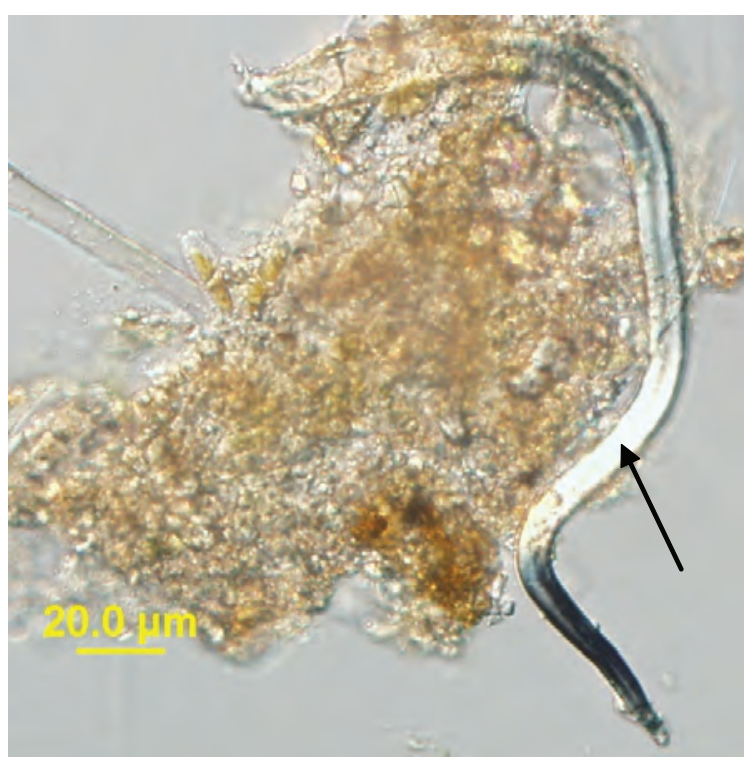

LM

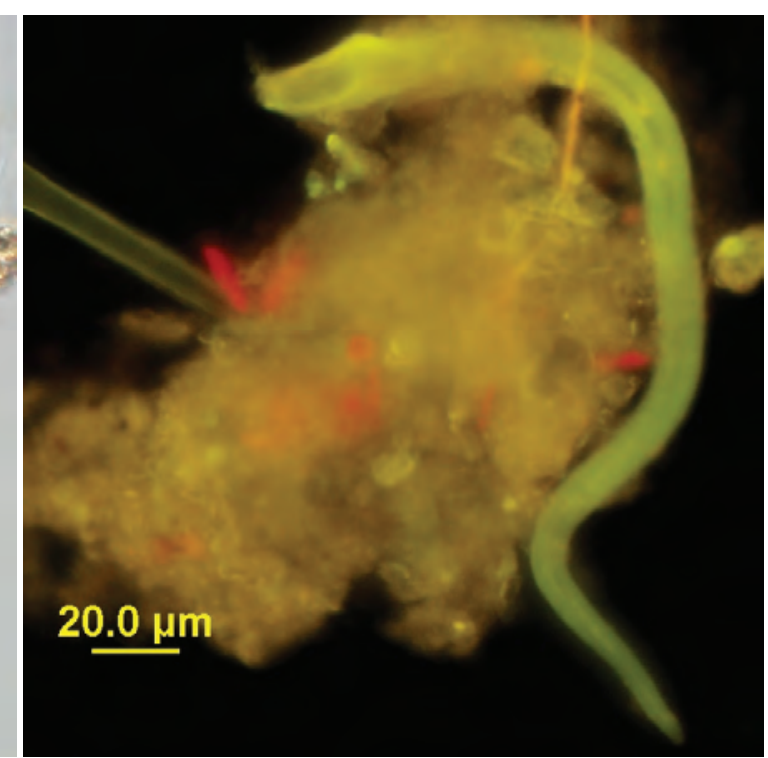

FITC

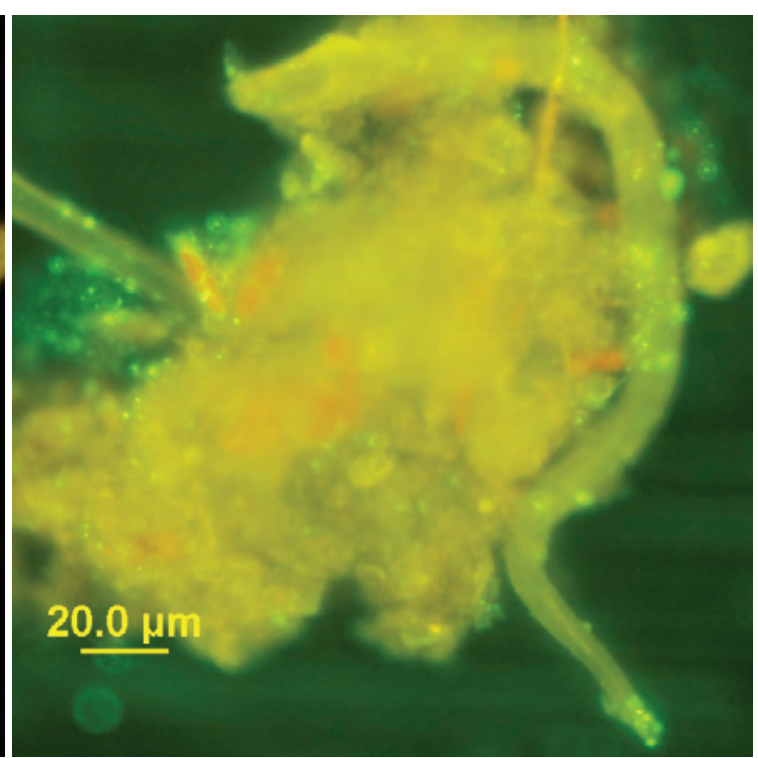

Sytox ${ }^{\circledR}$ green

Two freeze-thaw cycles

Figure 91. Grand Lake (Lake St. Mary), $\mathrm{OH} \mathrm{(9/15/2009).} \mathrm{LM-Possible} \mathrm{unknown} \mathrm{cyanobacterial} \mathrm{colony} \mathrm{fragment.} \mathrm{A} \mathrm{nematode} \mathrm{is} \mathrm{evident} \mathrm{in} \mathrm{this} \mathrm{sample} \mathrm{(arrow).} \mathrm{FITC-an}$ orange color dominates this cell; the bright red cells are diatoms. Sytox ${ }^{\circledR}$ green-stain did not stain the cyanobacterial material; only the bacterial cells. LM - differential interference contrast microscopy; FITC - epifluorescent microscopy; Sytox ${ }^{\circledR}$ green - epifluorescent microscopy in conjunction with the nucleic acid stain Sytox ${ }^{\circledR}$ green. 


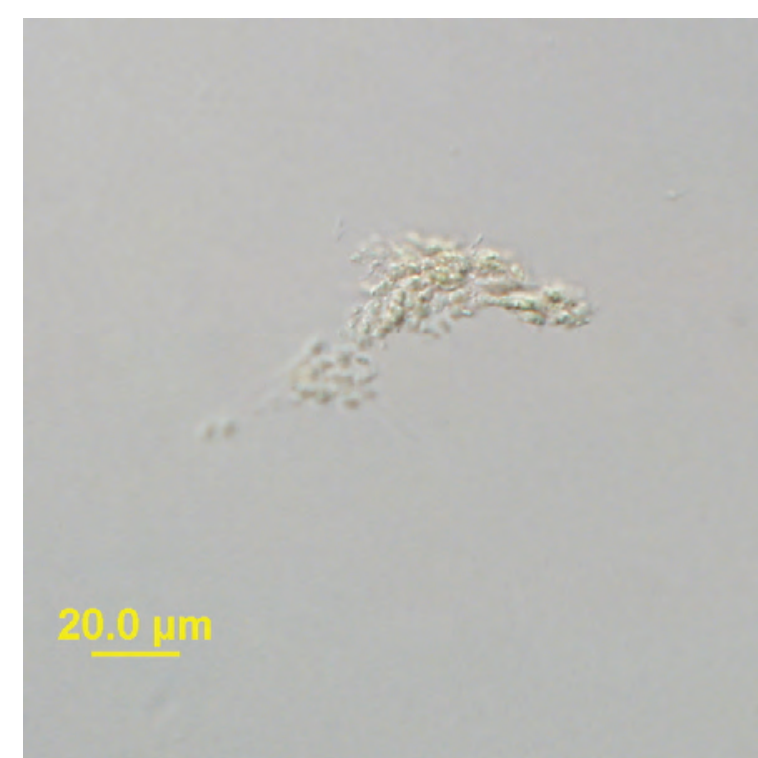

LM

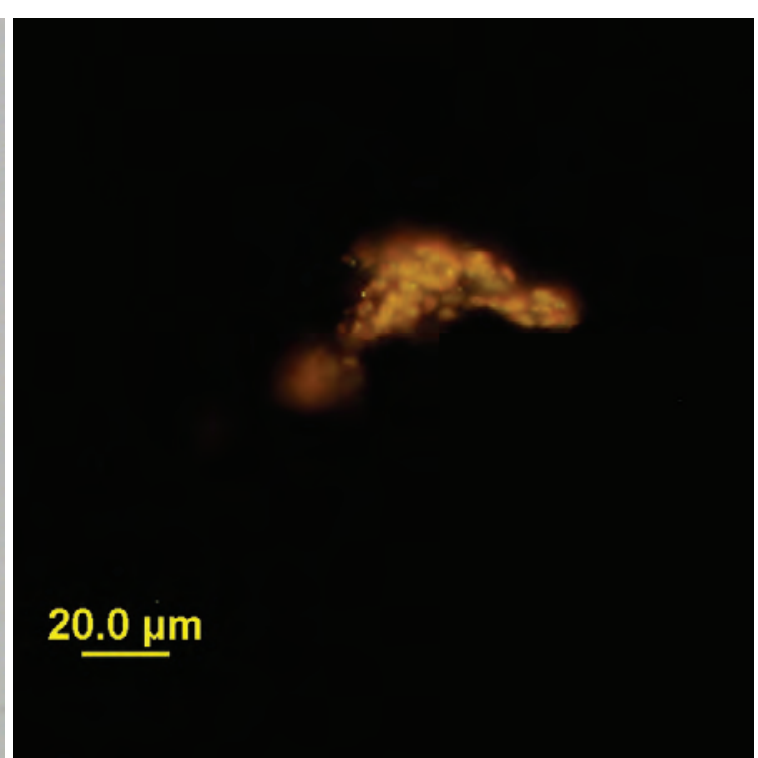

FITC

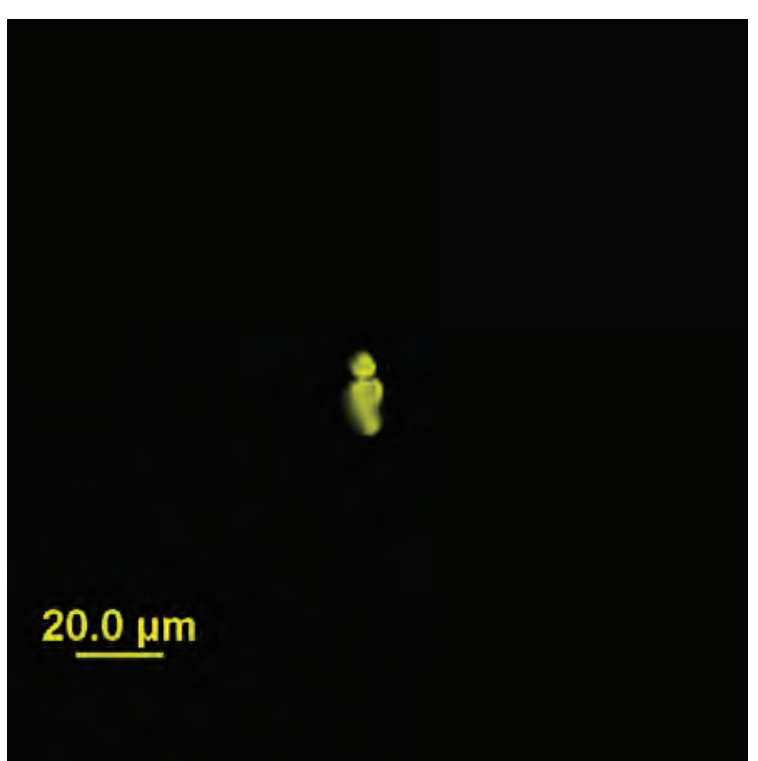

Sytox ${ }^{\circledR}$ green

Three freeze-thaw cycles

Figure 92. Grand Lake (Lake St. Mary), OH (9/15/2009). LM-Possible unknown cyanobacterial colony fragment. FITC-an orange color dominates these cells. Sytox ${ }^{\circledast}$ green-too little material to determine the effect. LM - differential interference contrast microscopy; FITC - epifluorescent microscopy; Sytox ${ }^{\circledR}$ green - epifluorescent microscopy in conjunction with the nucleic acid stain Sytox ${ }^{\circledR}$ green. 


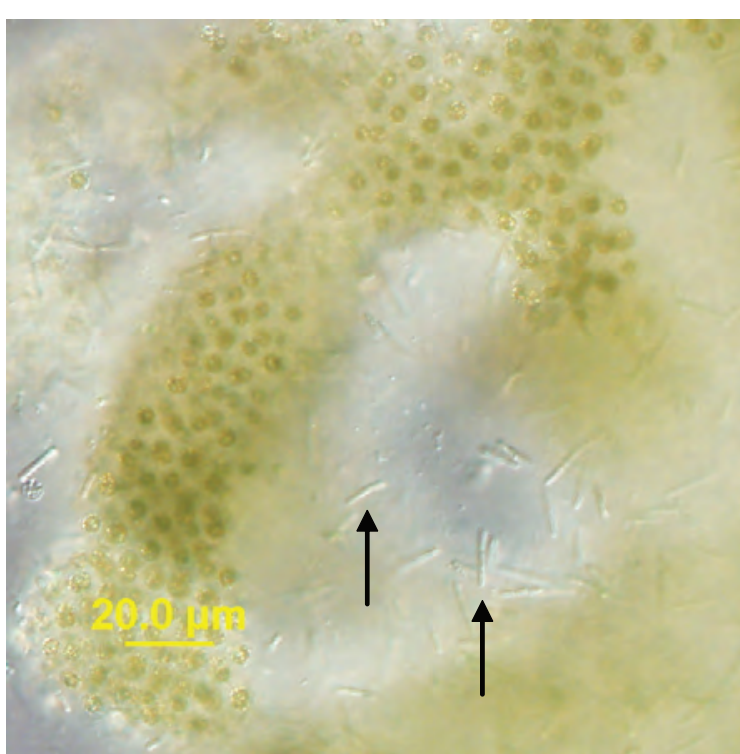

LM

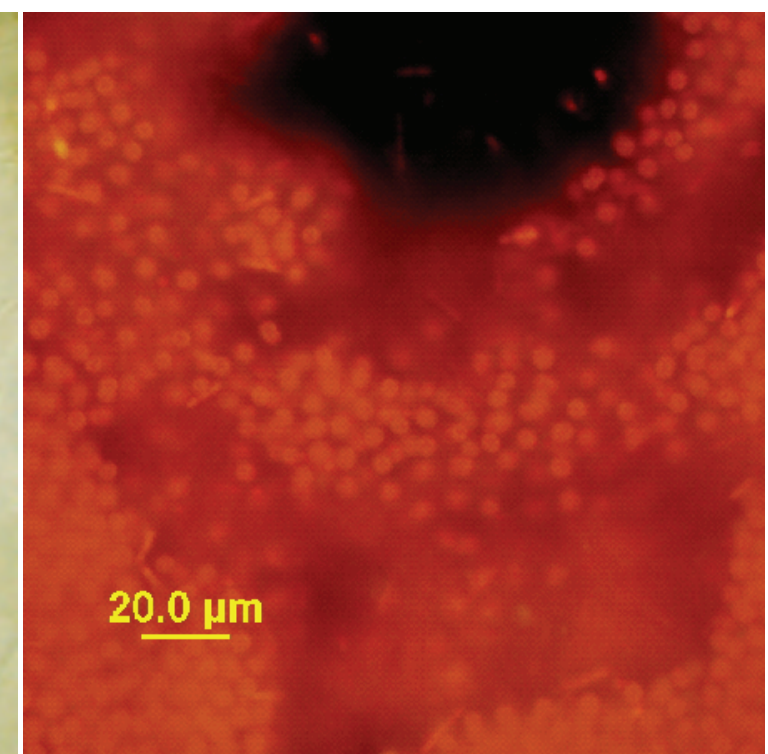

FITC

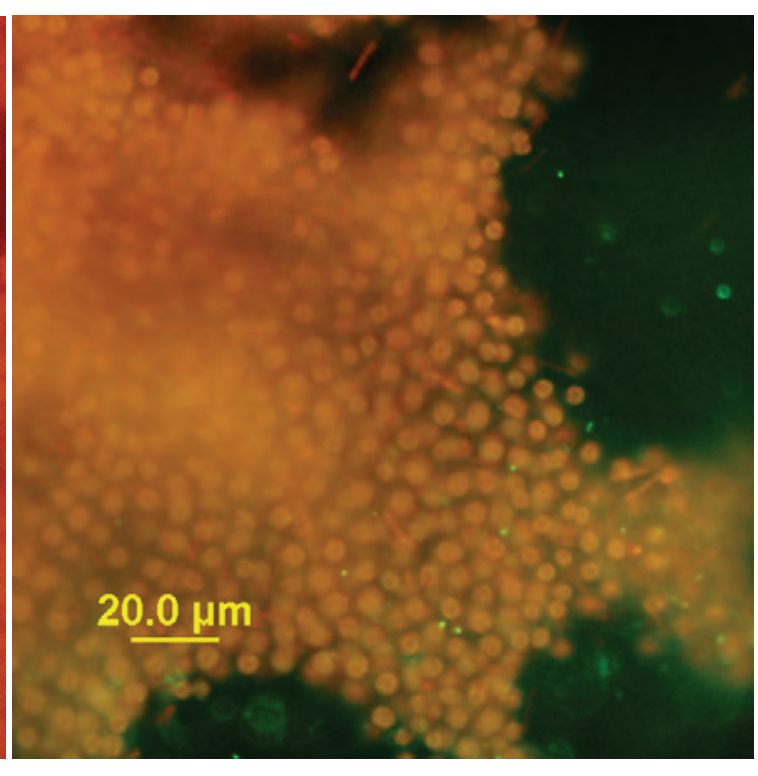

Sytox ${ }^{\circledR}$ green

Control 1

Figure 93. St. John's River, Jacksonville, FL (7/28/2009). LM-Microcystis aeruginosa. The small filaments (arrow) are likely the endogloeic cyanobacteria,

Pseudoanabaena mucicola (Hindák, 2006). FITC-an orange-red color dominates the cells. Sytox ${ }^{\circledR}$ green-stain did not penetrate the cell membrane. LM - differential interference contrast microscopy; FITC - epifluorescent microscopy; Sytox ${ }^{\circledR}$ green - epifluorescent microscopy in conjunction with the nucleic acid stain Sytox ${ }^{\circledR}$ green. 


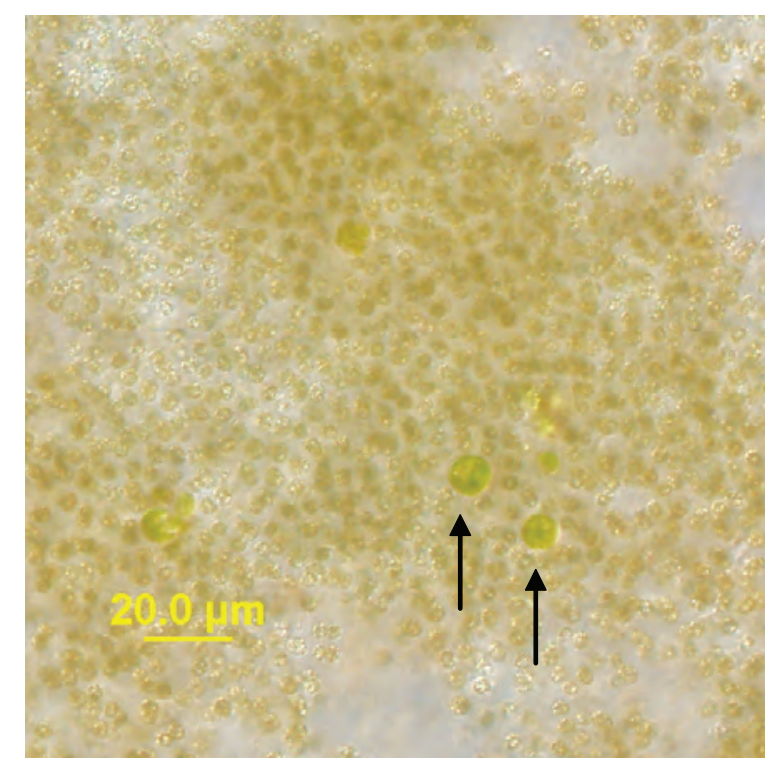

LM

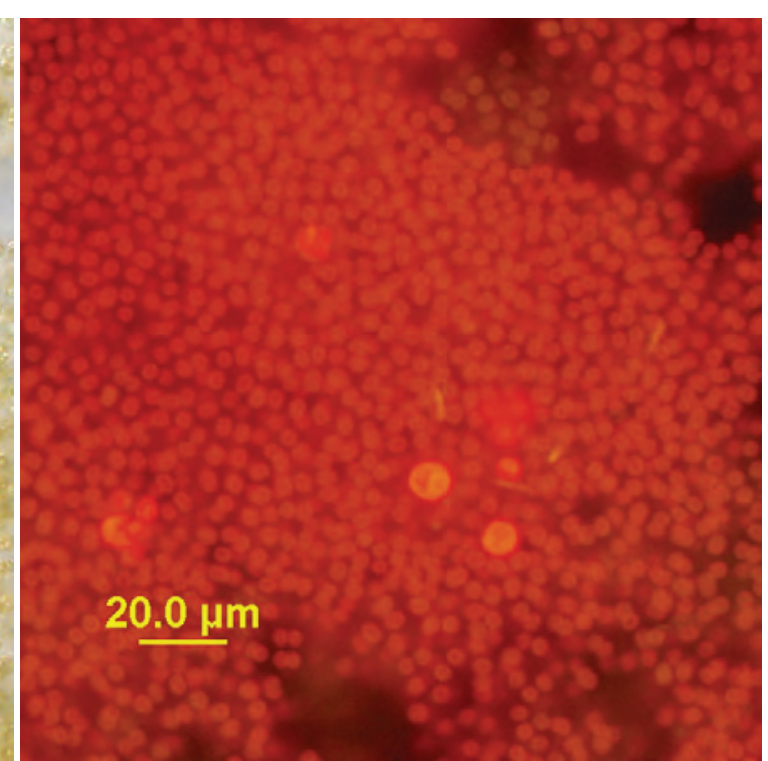

FITC

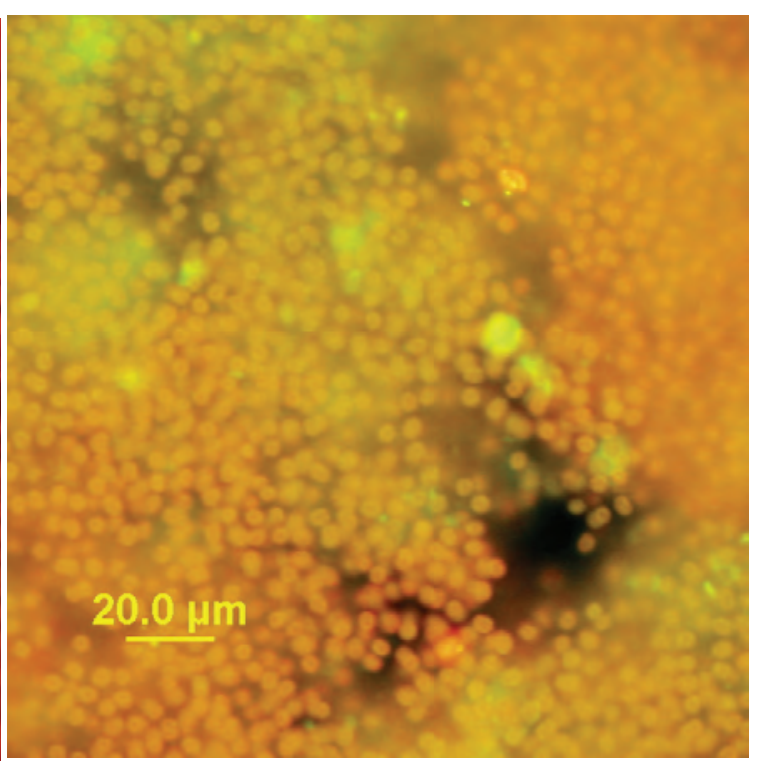

Sytox ${ }^{\circledR}$ green

\section{Control 2}

Figure 94. St. John's River, Jacksonville, FL (7/28/2009). LM-Microcystis aeruginosa. Eukaryotic epiphytes are green (arrow). FITC-a red color dominates the

cyanobacterial cells. Sytox ${ }^{\circledR}$ green-stain did not penetrate the cell membrane. LM - differential interference contrast microscopy; FITC - epifluorescent microscopy; Sytox ${ }^{\circledR}$ green - epifluorescent microscopy in conjunction with the nucleic acid stain Sytox ${ }^{\circledR}$ green. 


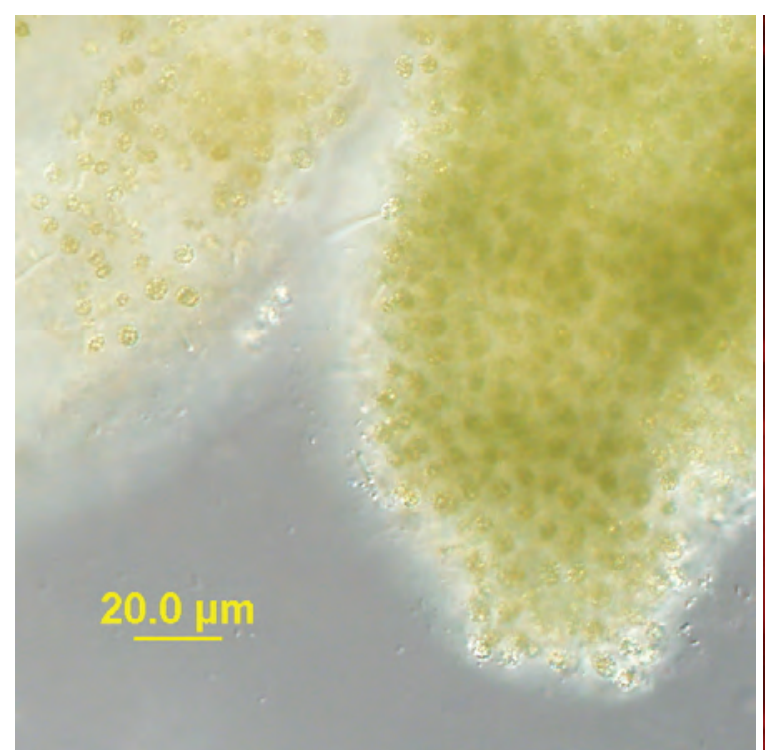

LM

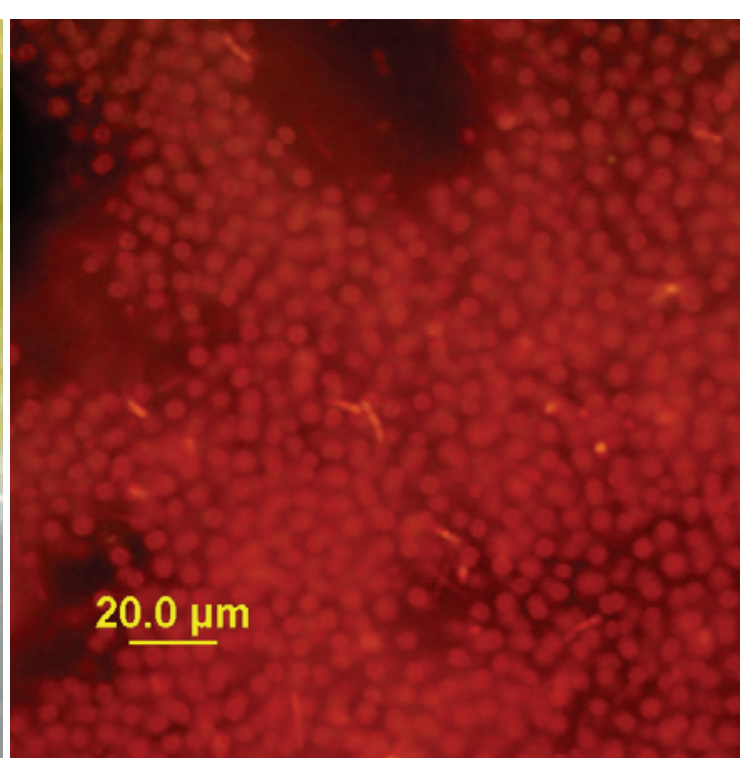

FITC

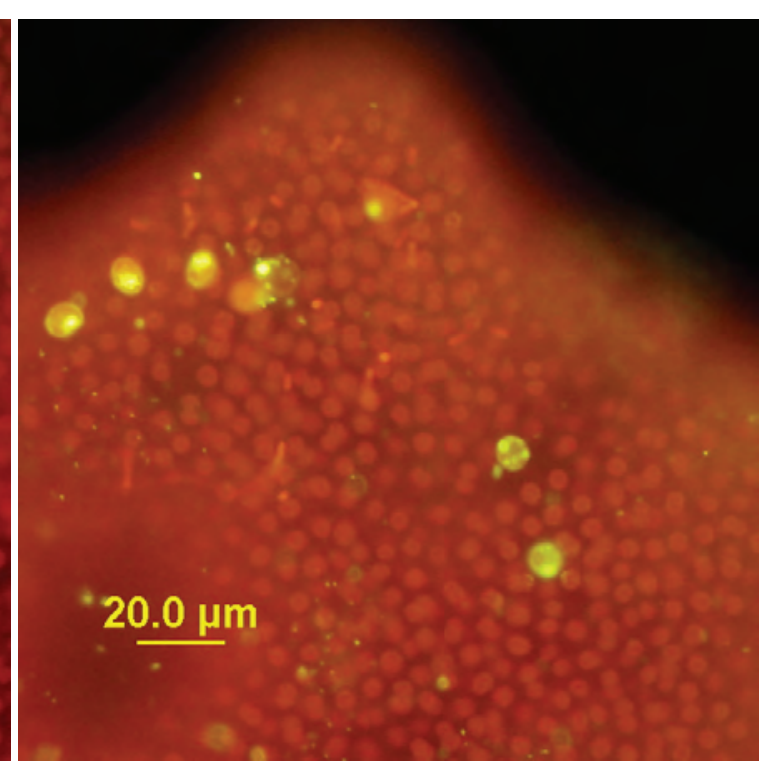

Sytox ${ }^{\circledR}$ green

Control 3

Figure 95. St. John's River, Jacksonville, FL (7/28/2009). LM-Microcystis aeruginosa. FITC-a red color dominates the cells. Sytox ${ }^{\circledR}$ green-stain did not penetrate the cell membrane; some of the cyanobacterial epiphytes stained bright green. LM - differential interference contrast microscopy; FITC - epifluorescent microscopy; Sytox ${ }^{\circledR}$ green - epifluorescent microscopy in conjunction with the nucleic acid stain Sytox ${ }^{\circledR}$ green. 


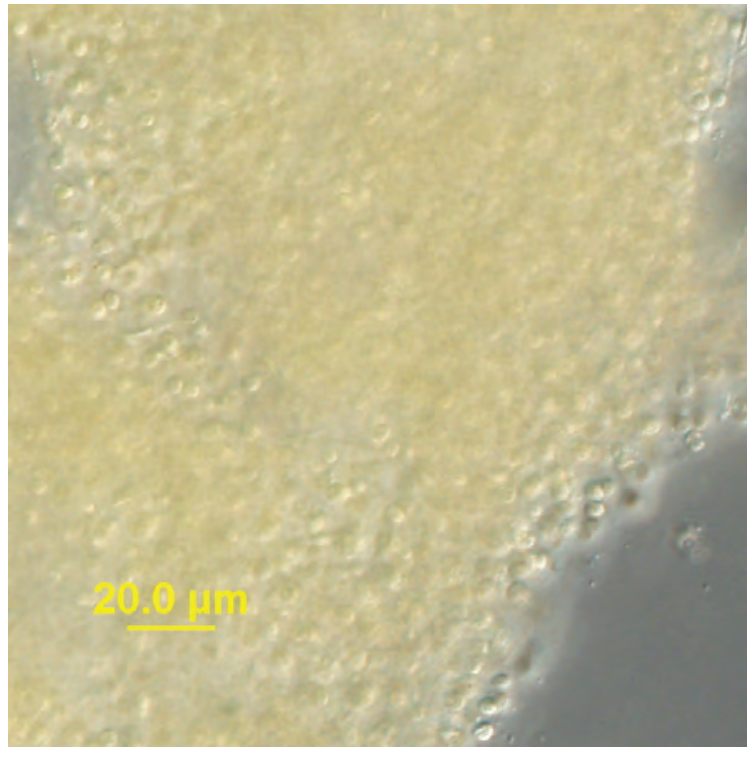

LM

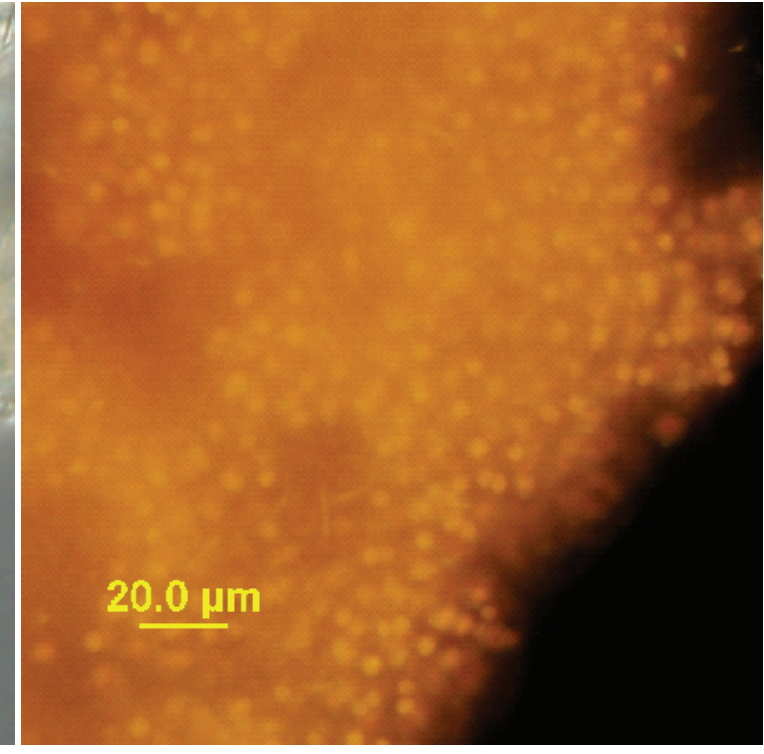

FITC

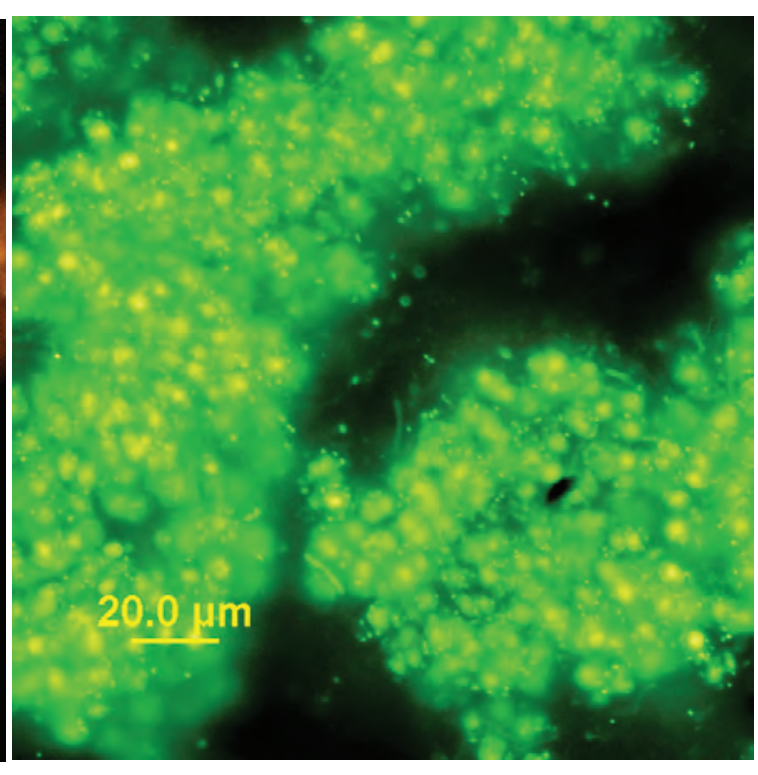

Sytox ${ }^{\circledR}$ green

\section{Boiled for 5 minutes}

Figure 96. St. John's River, Jacksonville, FL (7/28/2009). LM-Microcystis aeruginosa. FITC-an orange color dominates the cells. Sytox ${ }^{\circledR}$ green-stain did penetrate the cell membrane; bright green cells. LM - differential interference contrast microscopy; FITC - epifluorescent microscopy; Sytox ${ }^{\circledR}$ green - epifluorescent microscopy in conjunction with the nucleic acid stain Sytox ${ }^{\circledR}$ green. 


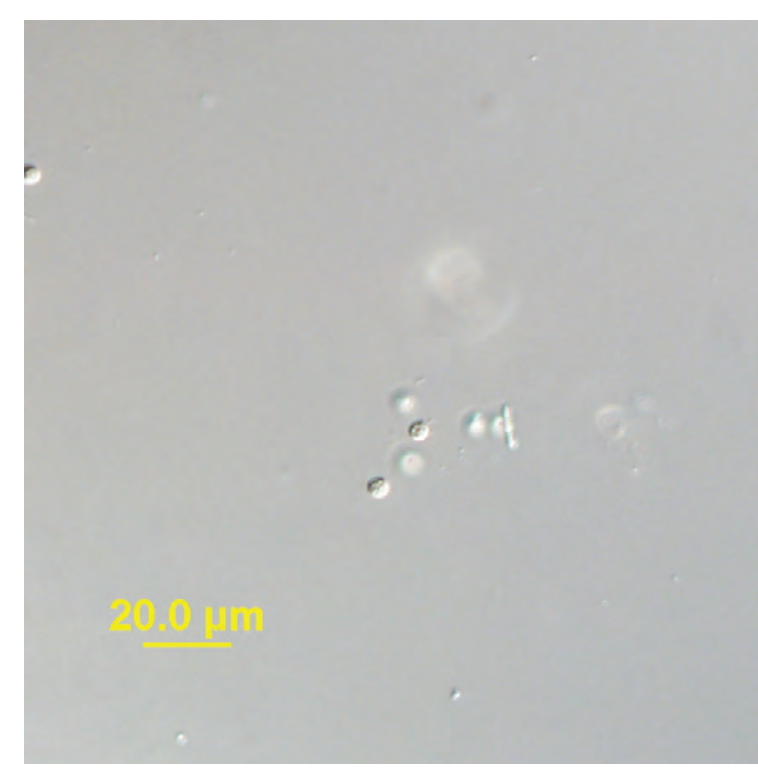

LM

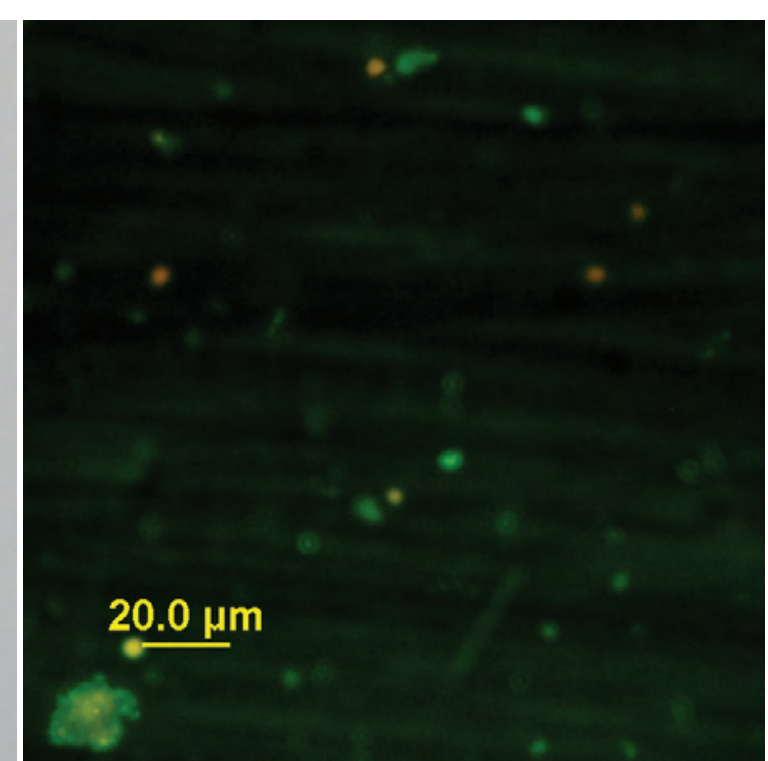

FITC

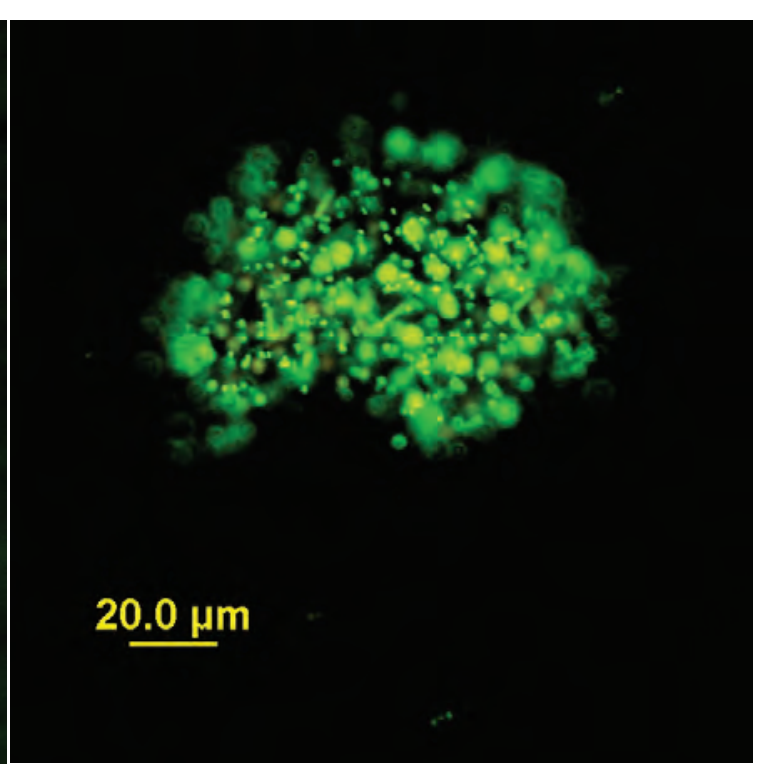

Sytox ${ }^{\circledR}$ green

\section{Boiled for 15 minutes}

Figure 97. St. John's River, Jacksonville, FL (7/28/2009). LM-Microcystis aeruginosa. FITC-an orange color dominates the cells. Sytox ${ }^{\circledR}$ green-stain did penetrate the cell membrane; bright green cells. LM - differential interference contrast microscopy; FITC - epifluorescent microscopy; Sytox ${ }^{\circledR}$ green - epifluorescent microscopy in conjunction with the nucleic acid stain Syto ${ }^{\circledR}$ green. 


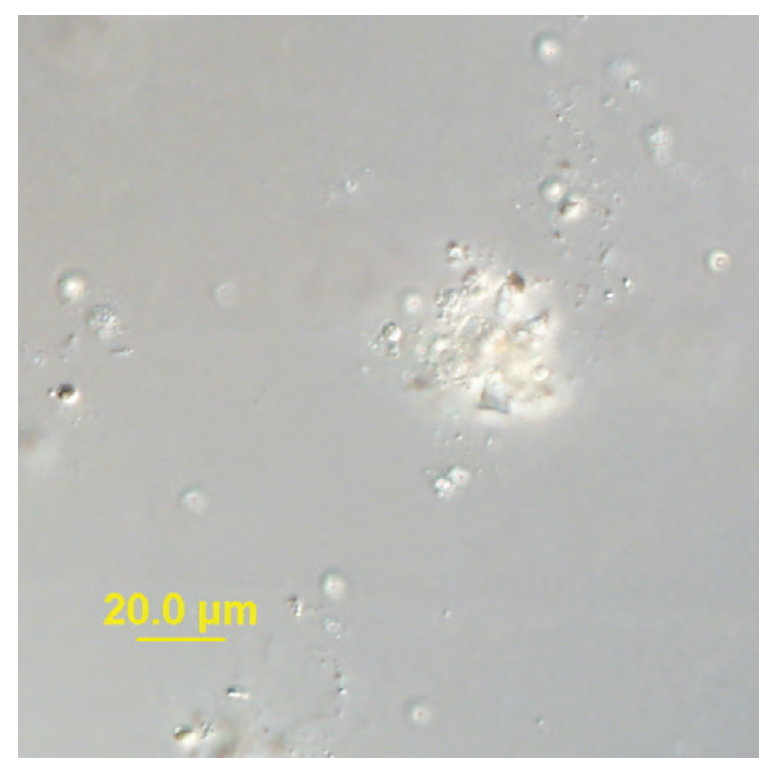

LM

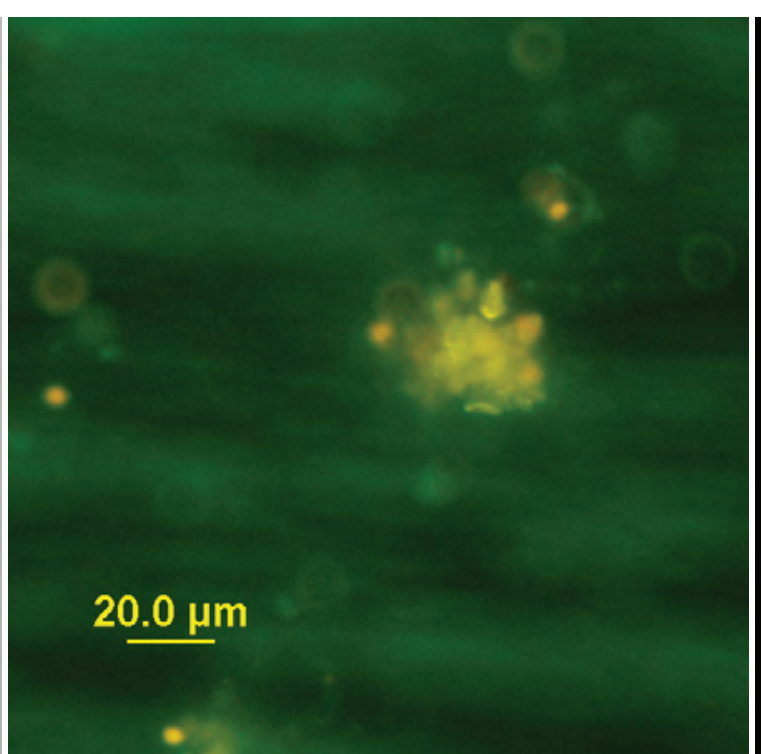

FITC

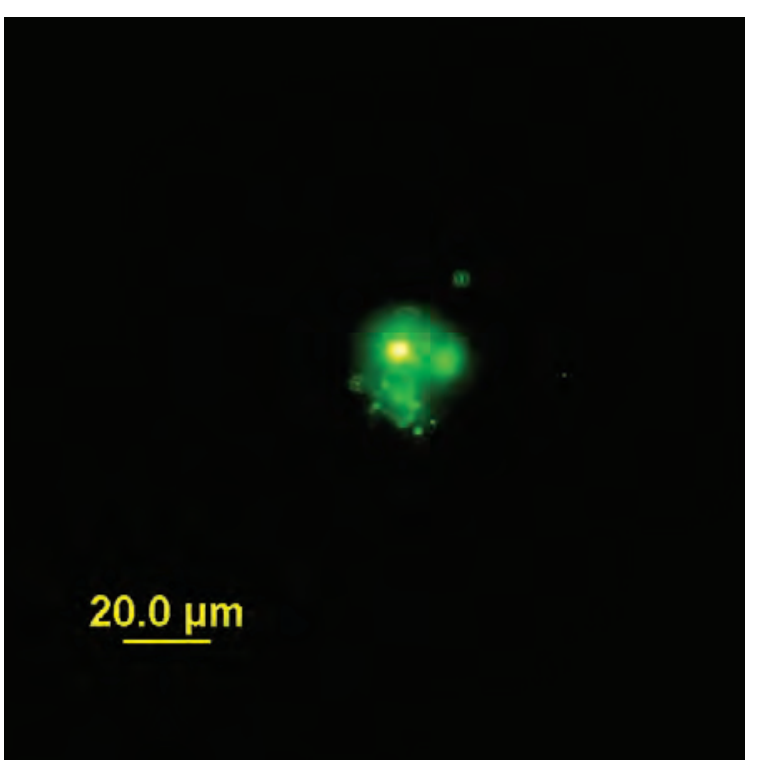

Sytox ${ }^{\circledR}$ green

Boiled for 30 minutes

Figure 98. St. John's River, Jacksonville, FL (7/28/2009). LM-Likely the remains of a Microcystis aeruginosa colony. FITC-an orange color dominates the cells. Sytox ${ }^{\circledR}$ green-stain did penetrate the cell membrane; bright green cells. LM - differential interference contrast microscopy; FITC - epifluorescent microscopy; Sytox ${ }^{\circledR}$ green epifluorescent microscopy in conjunction with the nucleic acid stain Sytox ${ }^{\circledR}$ green. 


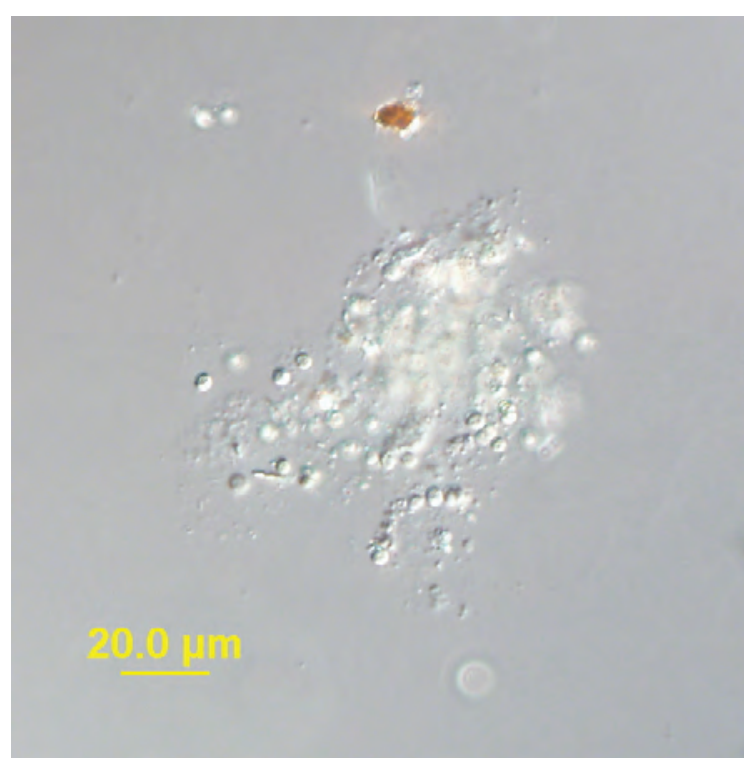

LM

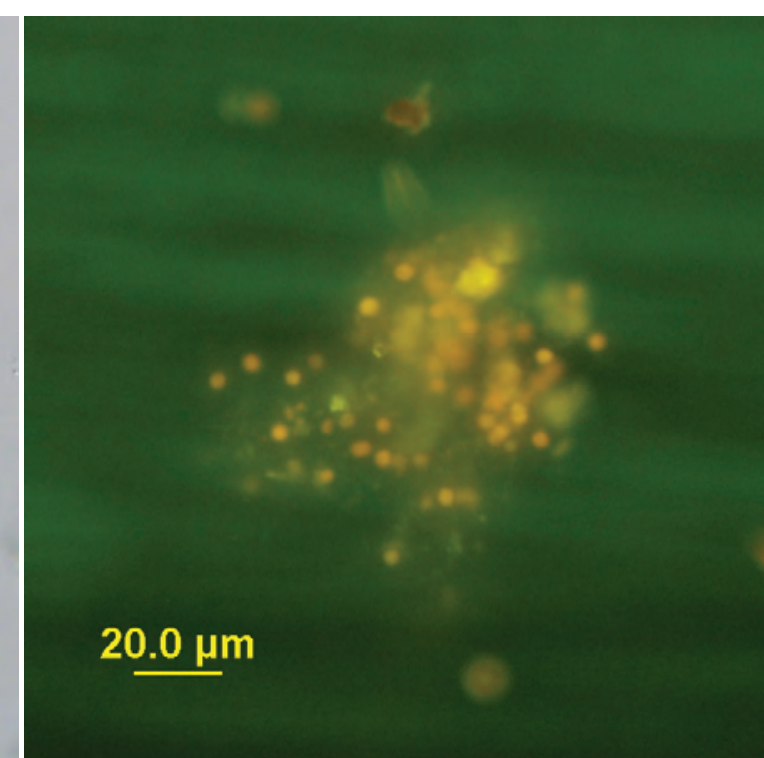

FITC

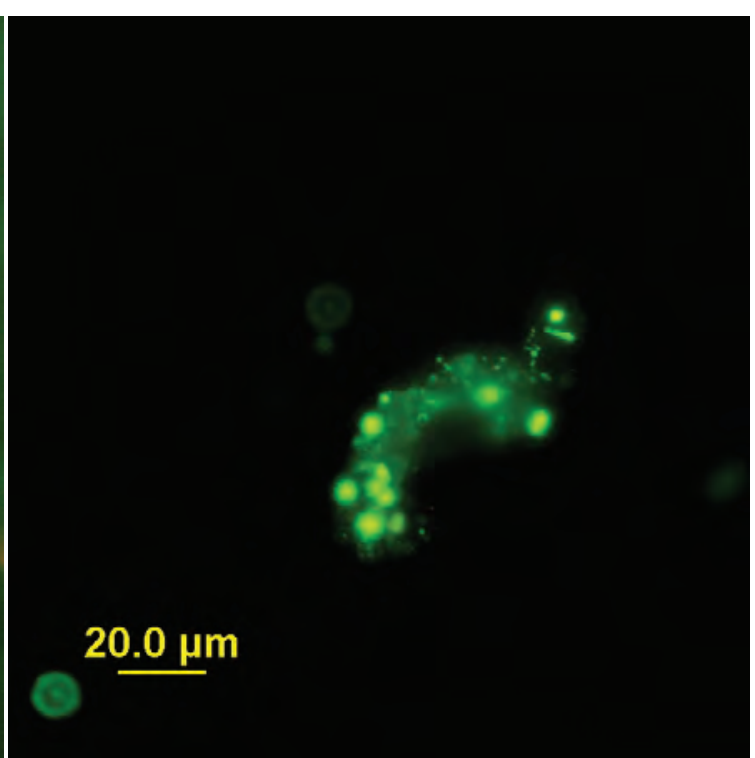

Sytox ${ }^{\circledR}$ green

\section{Autoclaved for 5 minutes}

Figure 99. St. John's River, Jacksonville, FL (7/28/2009). LM-Likely the remains of a Microcystis aeruginosa colony. FITC-an orange color dominates the cells. Sytox ${ }^{\circledR}$ green-stain did penetrate the cell membrane; bright green cells. LM - differential interference contrast microscopy; FITC - epifluorescent microscopy; Sytox ${ }^{\circledR}$ green epifluorescent microscopy in conjunction with the nucleic acid stain Sytox ${ }^{\circledR}$ green. 


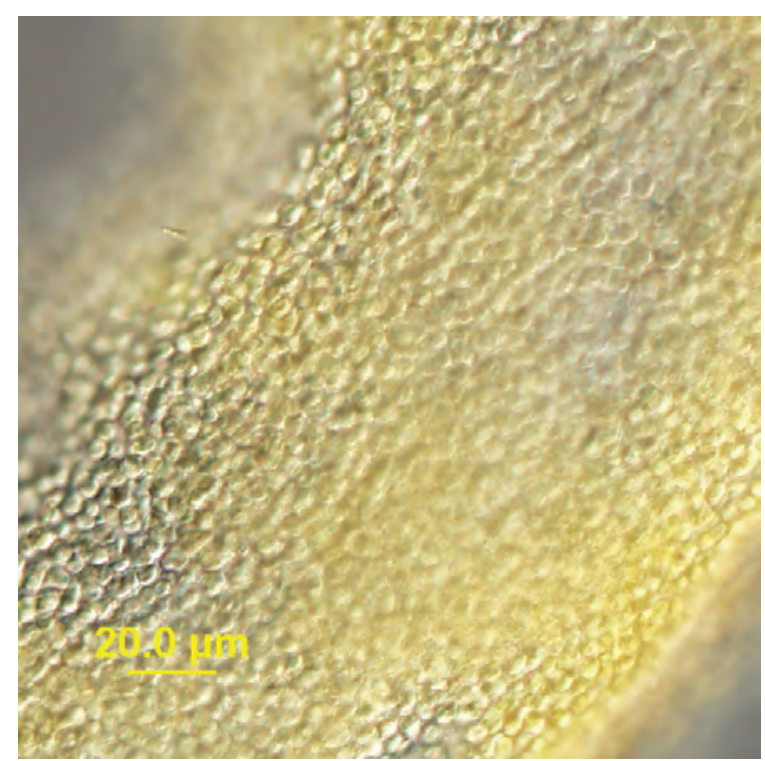

LM

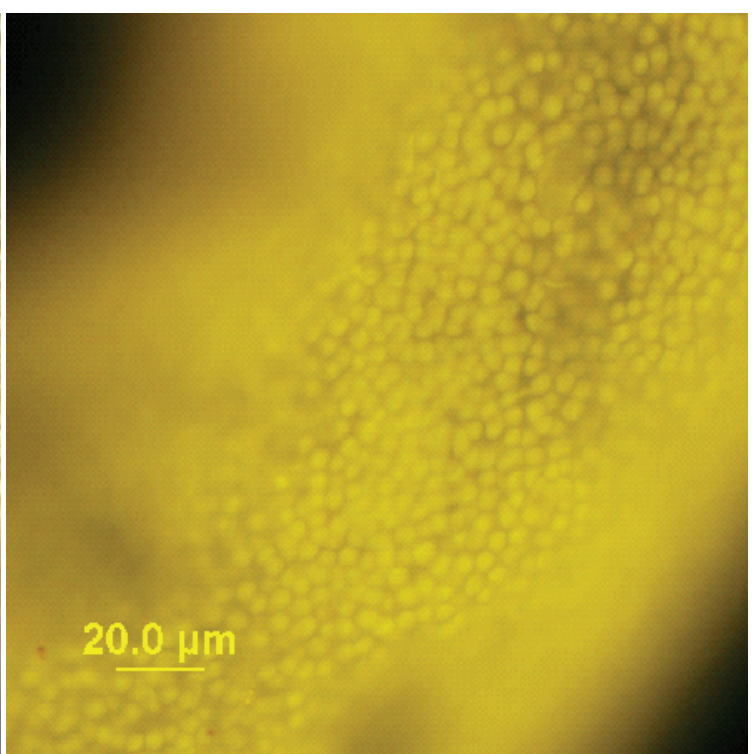

FITC

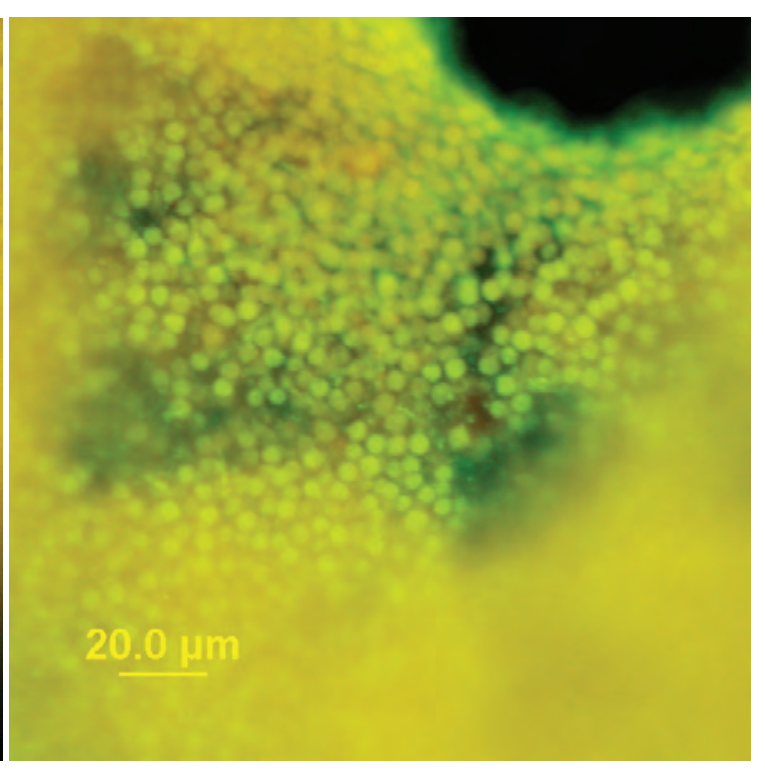

Sytox ${ }^{\circledast r e e n}$

\section{Autoclaved for 15 minutes}

Figure 100. St. John's River, Jacksonville, FL (7/28/2009). LM-Microcystis aeruginosa. FITC-a yellow color dominates the cells. Sytox ${ }^{\circledR}$ green-stain did penetrate the cell membrane; bright green cells. LM - differential interference contrast microscopy; FITC - epifluorescent microscopy; Sytox ${ }^{\circledR}$ green - epifluorescent microscopy in conjunction with the nucleic acid stain Syto ${ }^{\circledR}$ green. Note: No cells were found in the sample autoclaved for 30 minutes. 


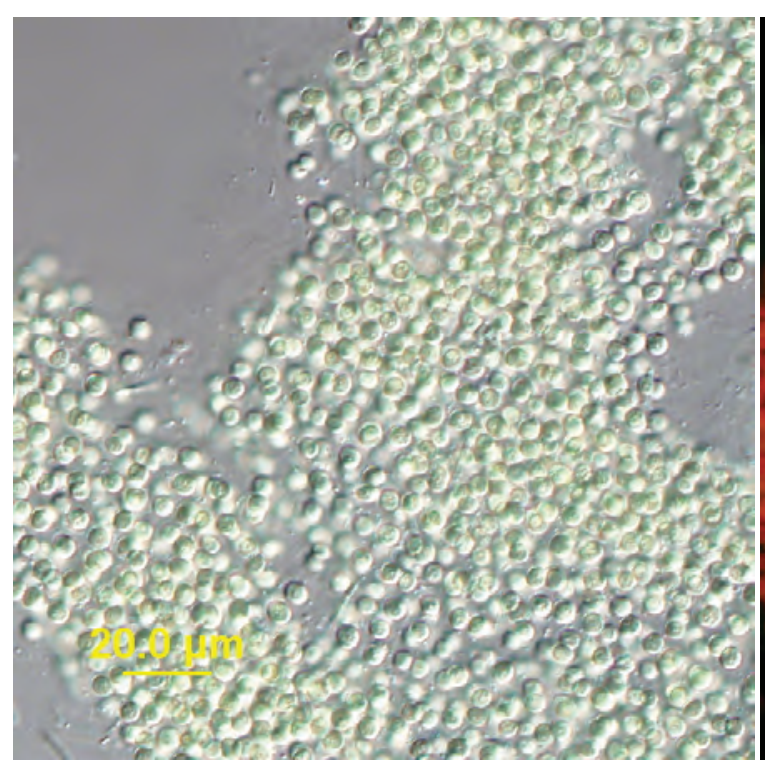

LM

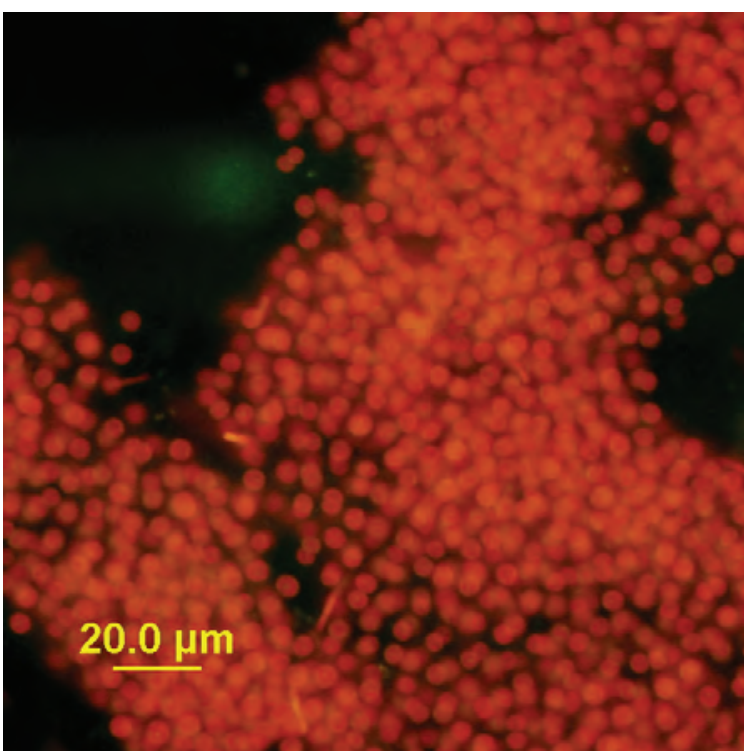

FITC

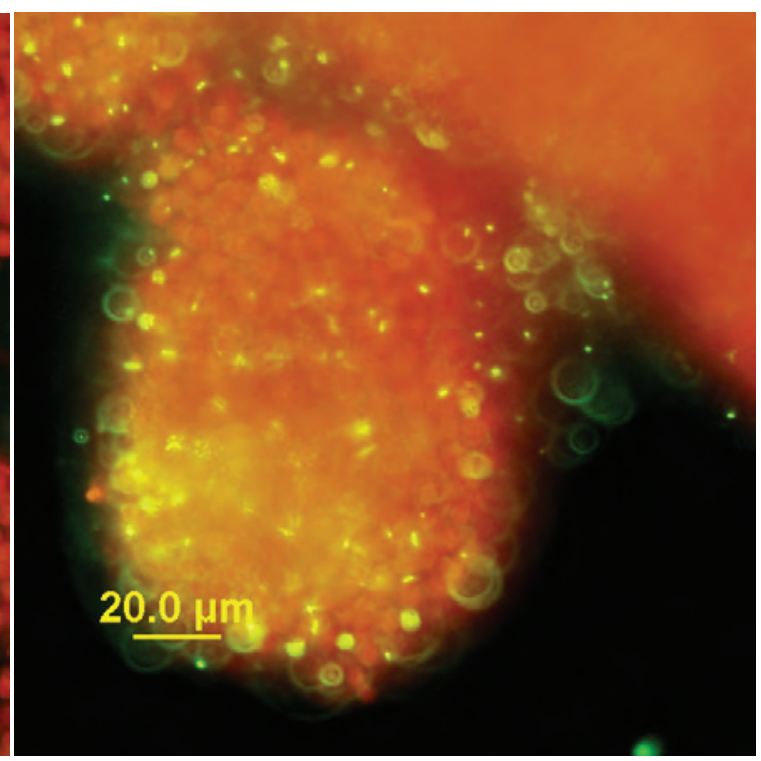

Sytox ${ }^{\circledR}$ green

Sonicated at 10 percent power

Figure 101. St. John's River, Jacksonville, FL (7/28/2009). LM-Microcystis aeruginosa. FITC-a red color dominates the cells. Sytox ${ }^{\circledR}$ green-stain did not penetrate the cell membrane; epiphytic bacteria bright green. LM - differential interference contrast microscopy; FITC - epifluorescent microscopy; Sytox ${ }^{\circledR}$ green - epifluorescent microscopy in conjunction with the nucleic acid stain Sytox ${ }^{\circledR}$ green. 


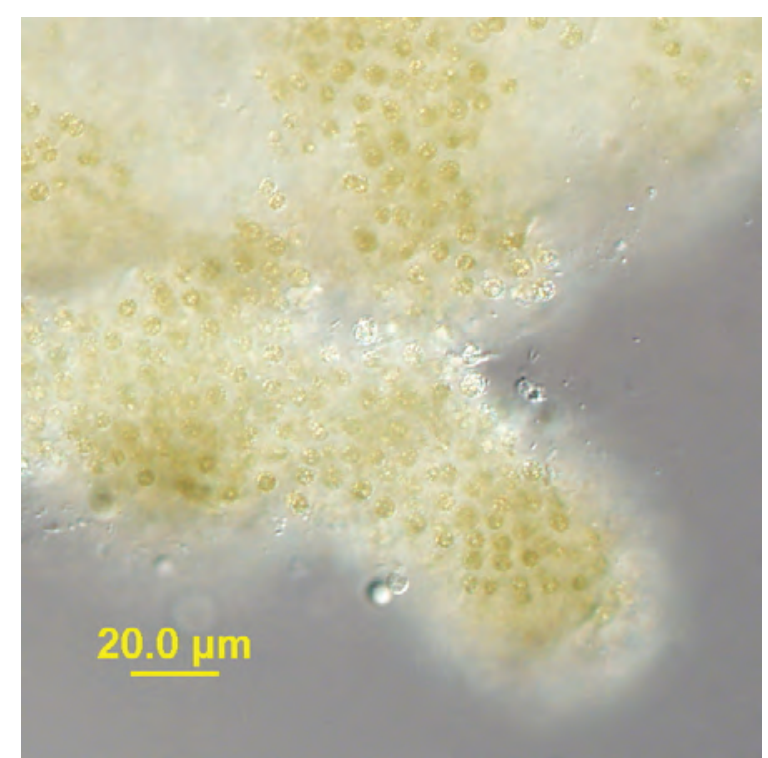

LM

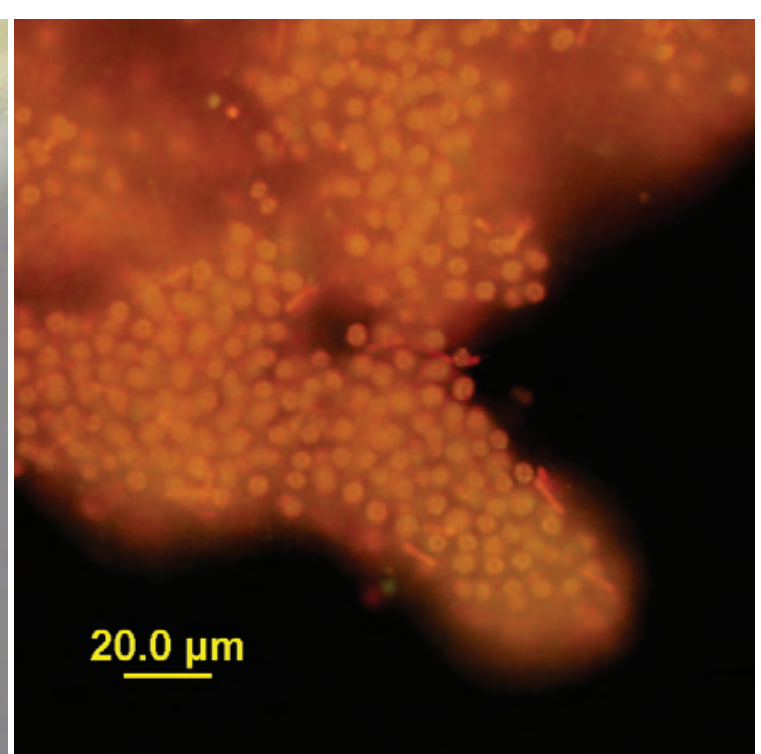

FITC

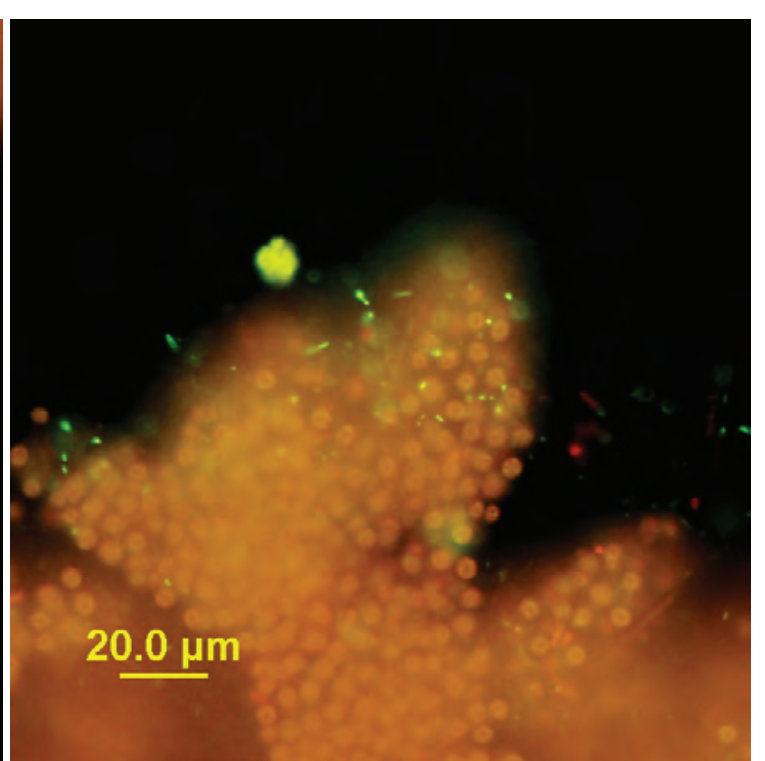

Sytox ${ }^{\circledR}$ green

\section{Sonicated at 35 percent power}

Figure 102. St. John's River, Jacksonville, FL (7/28/2009). LM-Microcystis aeruginosa. FITC-an orange color dominates the cells. Sytox ${ }^{\circledR}$ green-stain did not penetrate the cell membrane; epiphytic bacteria bright green. LM - differential interference contrast microscopy; FITC - epifluorescent microscopy; Sytox ${ }^{\circledR}$ green - epifluorescent microscopy in conjunction with the nucleic acid stain Sytox ${ }^{\circledR}$ green. 


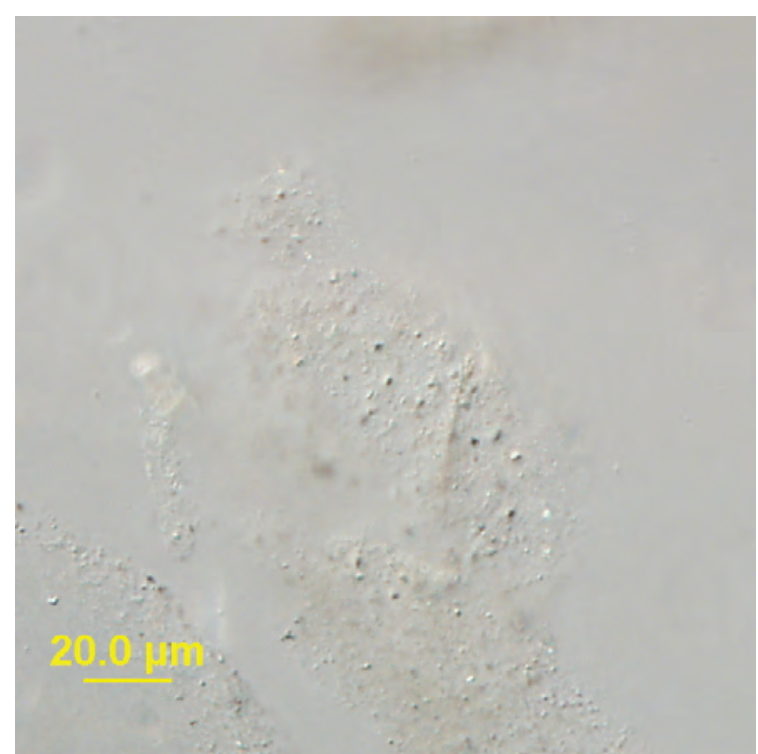

LM

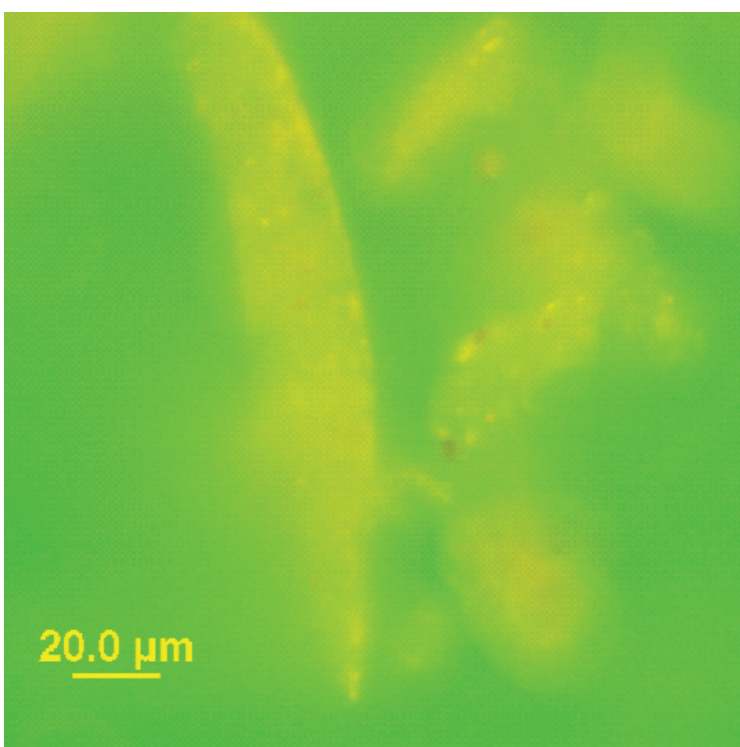

FITC

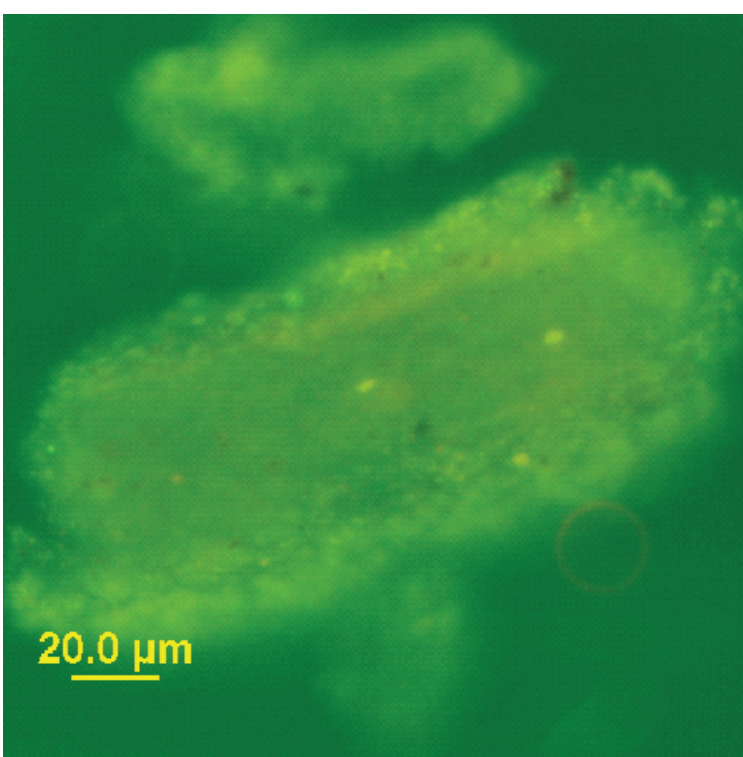

Sytox ${ }^{\circledR}$ green

\section{Sonicated at 70 percent power}

Figure 103. St. John's River, Jacksonville, FL (7/28/2009). LM-Likely the remains of a Microcystis aeruginosa colony. FITC-an orange color dominates, but cells cannot be distinguished. Sytox ${ }^{\circledR}$ green-slight evidence of sheath being stained. LM - differential interference contrast microscopy; FITC - epifluorescent microscopy; Sytox ${ }^{\circledR}$ green - epifluorescent microscopy in conjunction with the nucleic acid stain Sytox ${ }^{\circledR}$ green. 


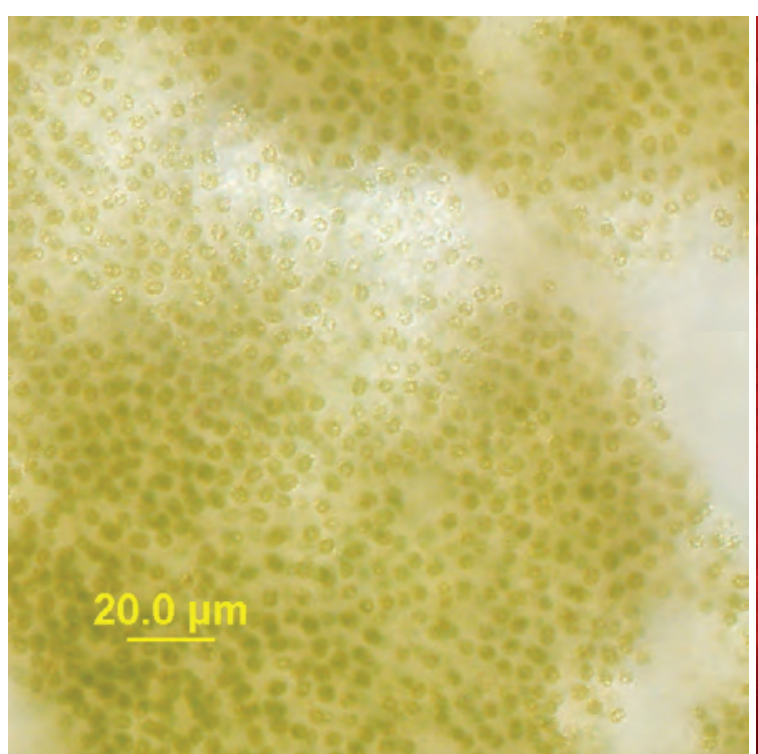

LM

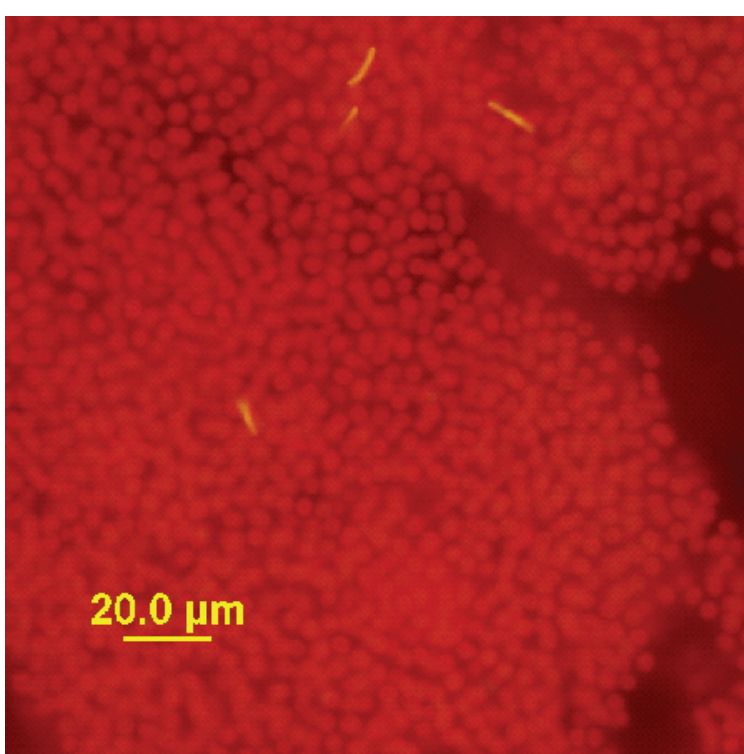

FITC

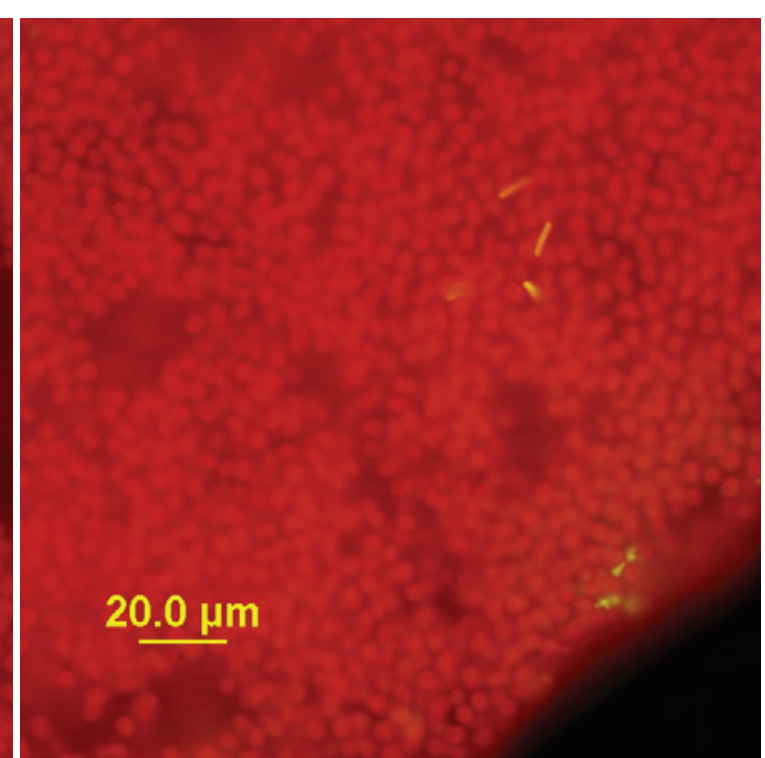

Sytox ${ }^{\circledR}$ green

QuikLyse ${ }^{\mathrm{TM}}-1 \mathrm{x}$

Figure 104. St. John's River, Jacksonville, FL (7/28/2009). LM-Microcystis aeruginosa. FITC-a red color dominates the cells. Sytox ${ }^{\circledR}$ green-stain did not penetrate the cell membrane. LM - differential interference contrast microscopy; FITC - epifluorescent microscopy; Sytox ${ }^{\circledR}$ green - epifluorescent microscopy in conjunction with the nucleic acid stain Sytox ${ }^{\circledR}$ green. 


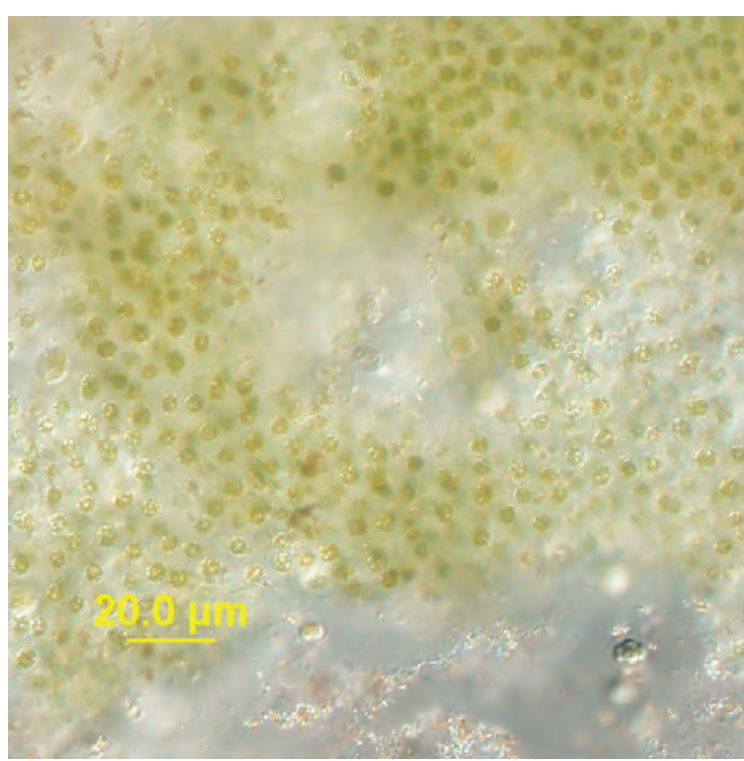

LM

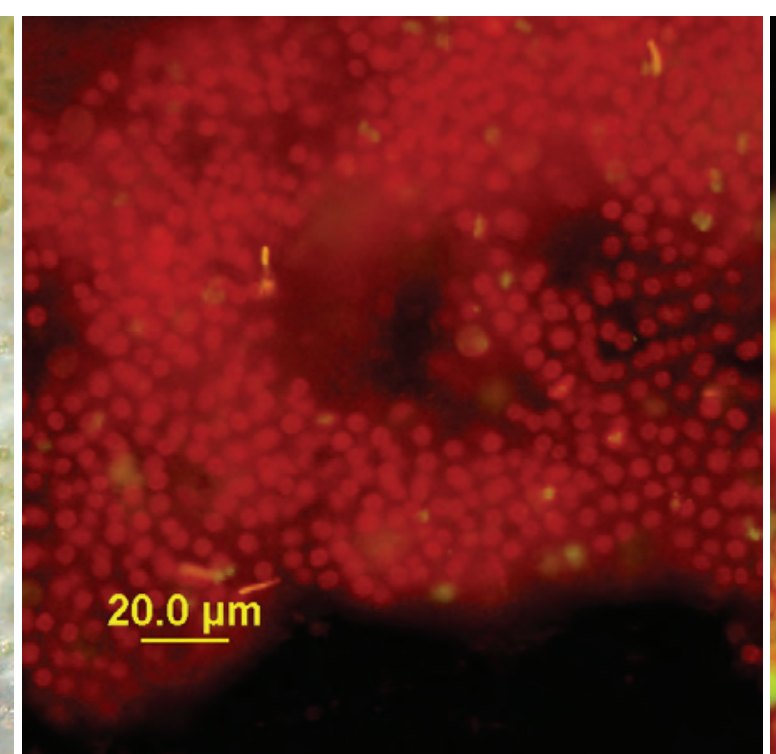

FITC

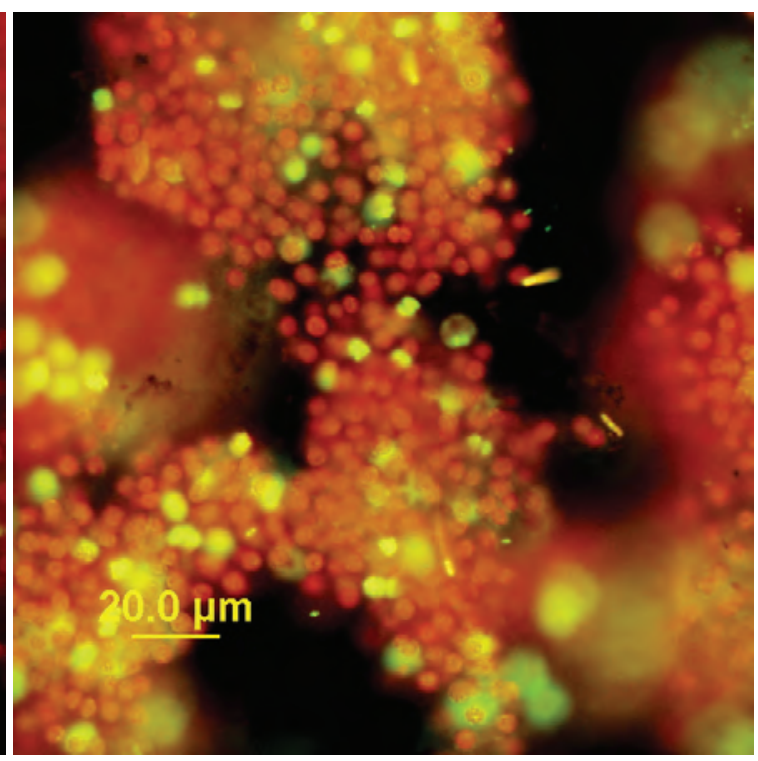

Sytox ${ }^{\circledR}$ green

QuikLyse ${ }^{T M}-2 x$

Figure 105. St. John's River, Jacksonville, FL (7/28/2009). LM-Microcystis aeruginosa. FITC-a red color dominates the cells. Sytox ${ }^{\circledR}$ green-stain did penetrate the cell membrane in some of the peripheral cells. LM - differential interference contrast microscopy; FITC - epifluorescent microscopy; Sytox ${ }^{\circledR}$ green - epifluorescent microscopy in conjunction with the nucleic acid stain Sytox ${ }^{\circledR}$ green. 


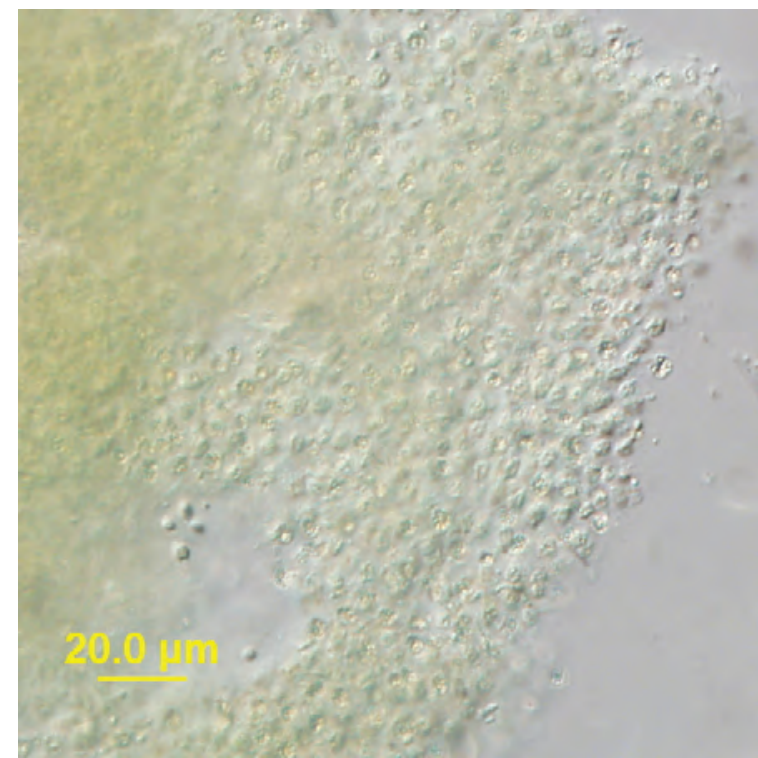

LM

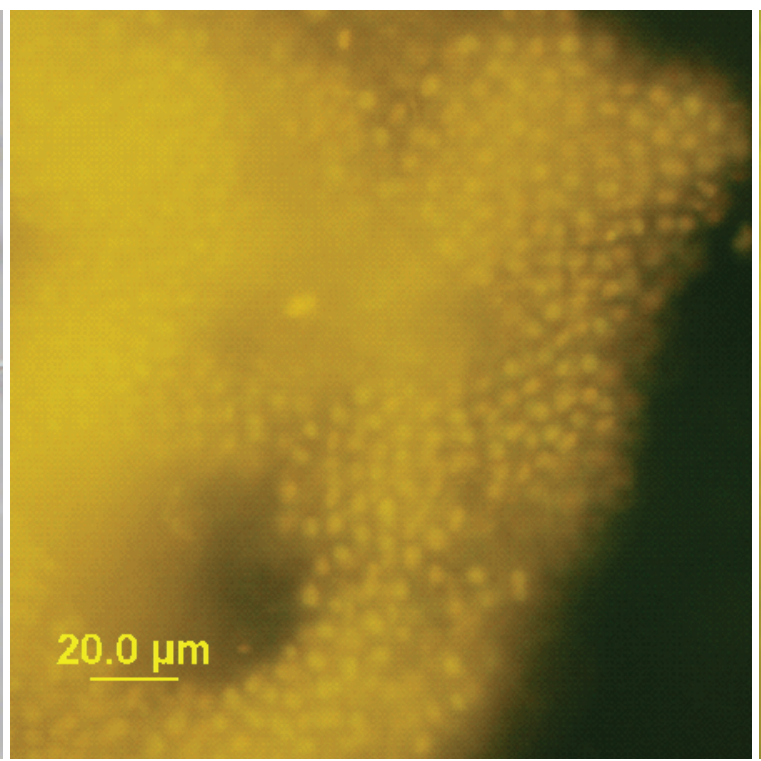

FITC

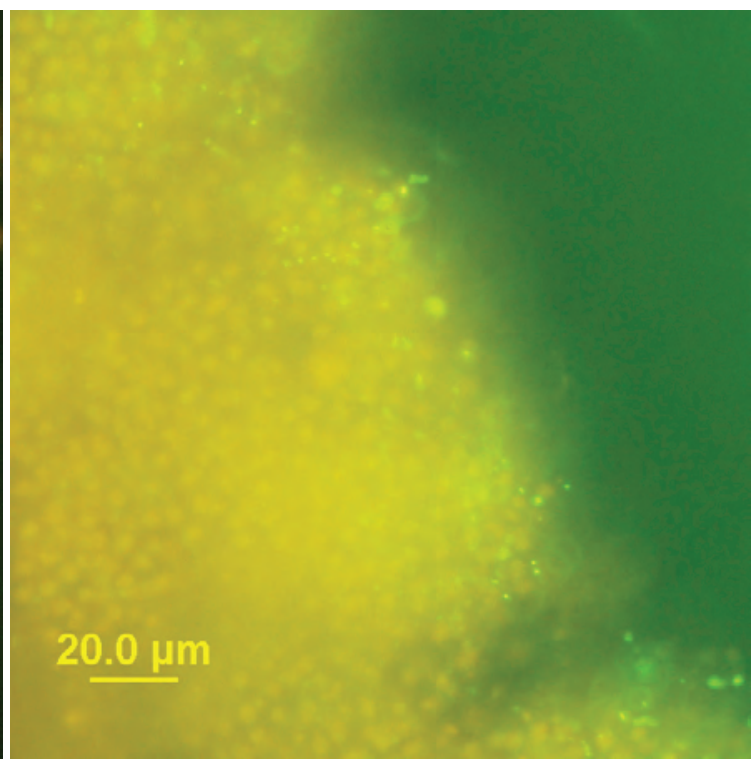

Sytox ${ }^{\circledR}$ green

One freeze-thaw cycle

Figure 106. St. John's River, Jacksonville, FL (7/28/2009). LM-Microcystis aeruginosa. FITC-a yellow color dominates the cells. Sytox ${ }^{\circledR}$ green-stain did penetrate the cell membrane in some of the peripheral cells. LM - differential interference contrast microscopy; FITC - epifluorescent microscopy; Sytox ${ }^{\circledR}$ green - epifluorescent microscopy in conjunction with the nucleic acid stain Sytox ${ }^{\circledR}$ green. 


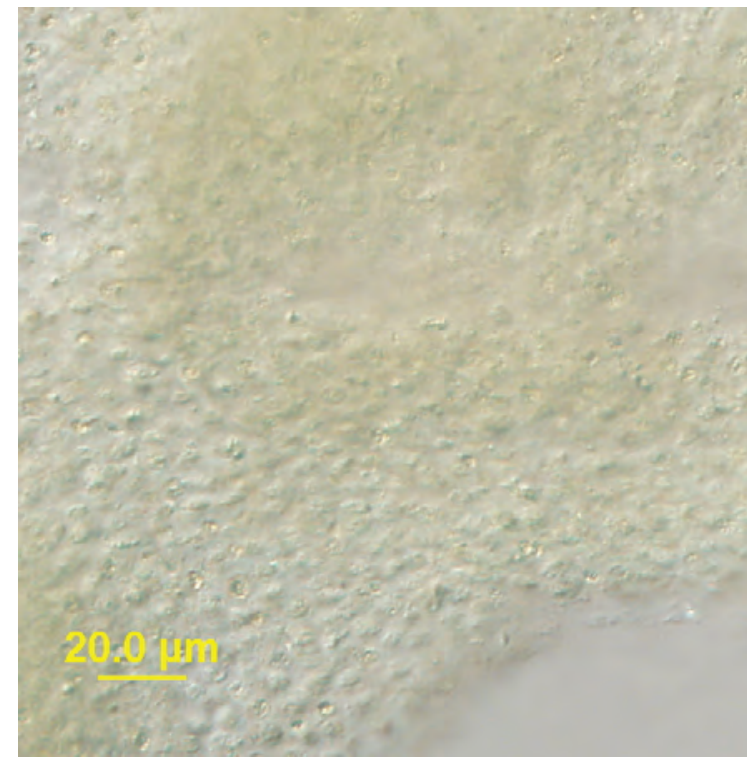

LM

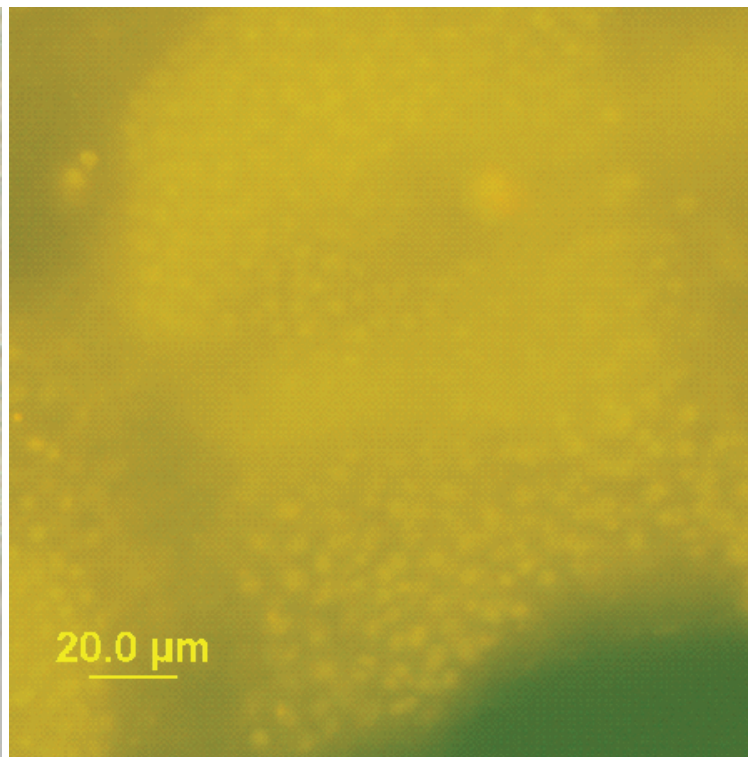

FITC

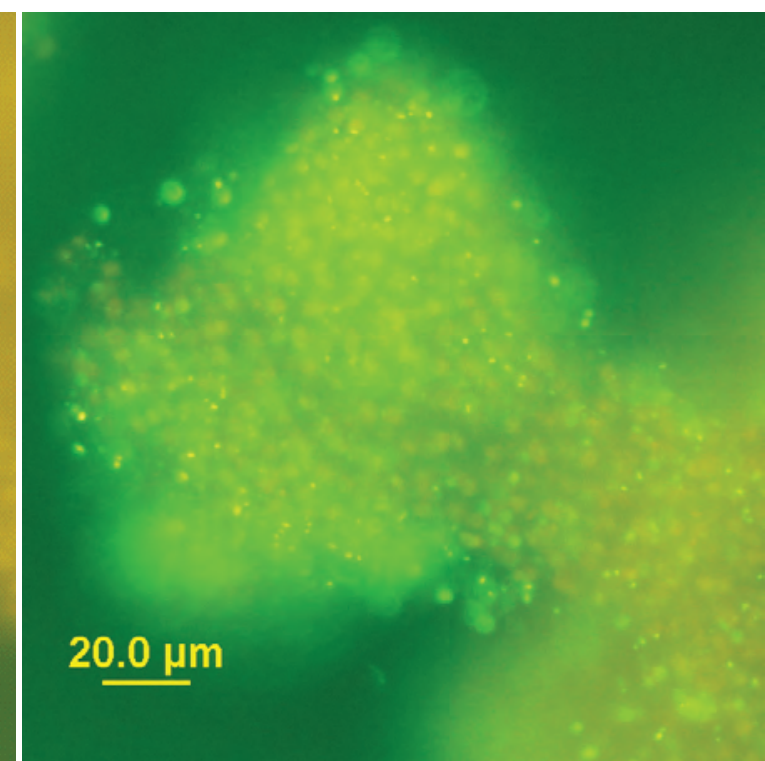

Sytox ${ }^{\circledR}$ green

\section{Two freeze-thaw cycles}

Figure 107. St. John's River, Jacksonville, FL (7/28/2009). LM-Microcystis aeruginosa. FITC-a yellow-orange color dominates the cells. Sytox ${ }^{\circledR}$ green-stain did penetrate the cell membrane in some of the peripheral cells. LM - differential interference contrast microscopy; FITC - epifluorescent microscopy; Sytox ${ }^{\circledR}$ green - epifluorescent microscopy in conjunction with the nucleic acid stain Syto ${ }^{\circledR}$ green. 


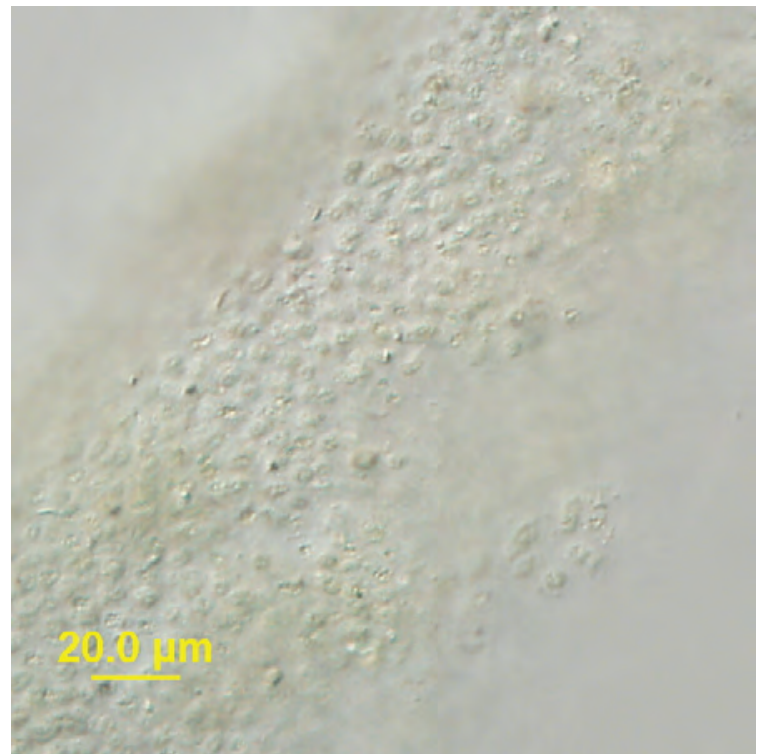

LM

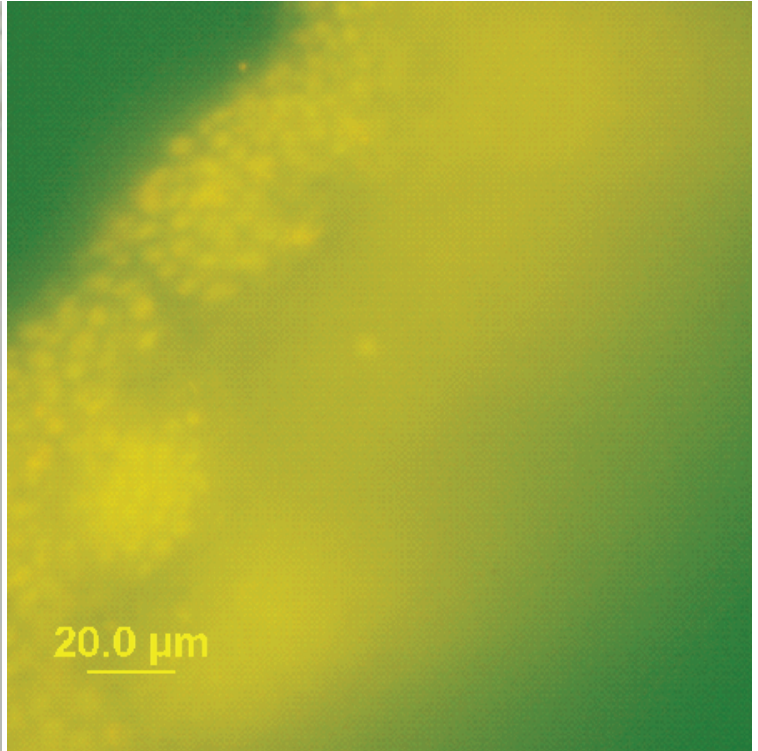

FITC

Three freeze-thaw cycles

Figure 108. St. John's River, Jacksonville, FL (7/28/2009). LM-Microcystis aeruginosa. FITC-a yellow color dominates the cells. Sytox ${ }^{\circledR}$ green-no image available. LM - differential interference contrast microscopy; FITC epifluorescent microscopy; Sytox ${ }^{\circledR}$ green - epifluorescent microscopy in conjunction with the nucleic acid stain Sytox ${ }^{\circledR}$ green. 


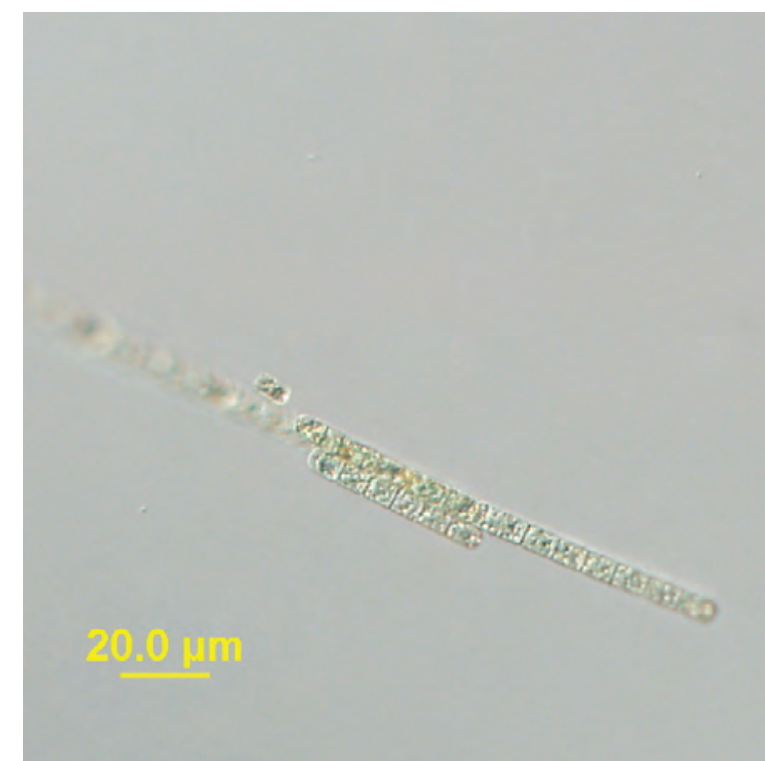

LM

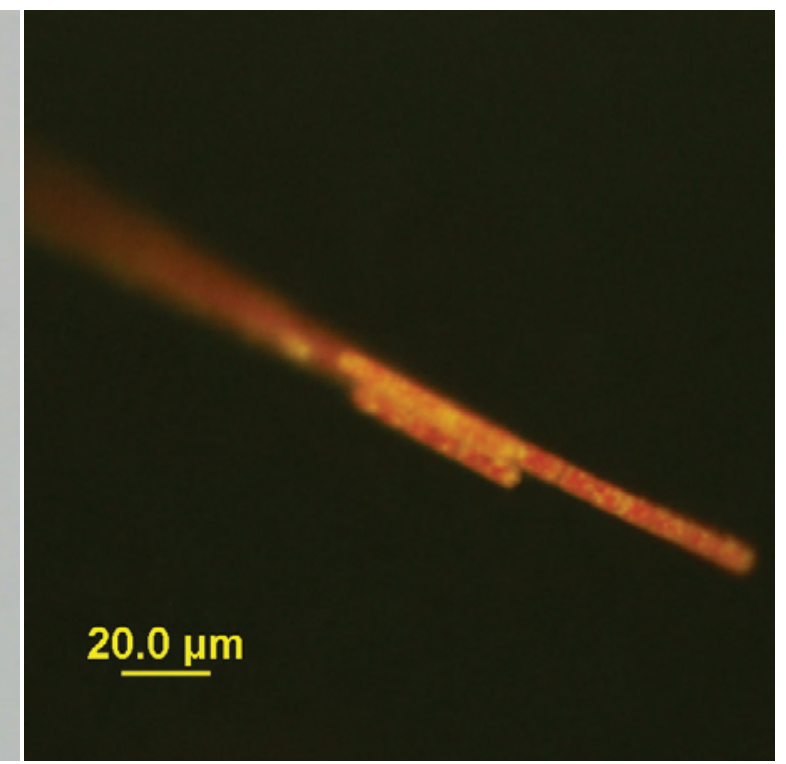

FITC

\section{Control 1}

Figure 109. Upper Klamath Lake, OR (8/21/2009). LM-Aphanizomenon flos-aquae filaments. FITC-a yelloworange color dominates these cells. Sytox ${ }^{\circledast}$ green-no image available. LM - differential interference contrast microscopy; FITC - epifluorescent microscopy; Sytox ${ }^{\oplus}$ green - epifluorescent microscopy in conjunction with the nucleic acid stain Sytox ${ }^{\circledR}$ green. 


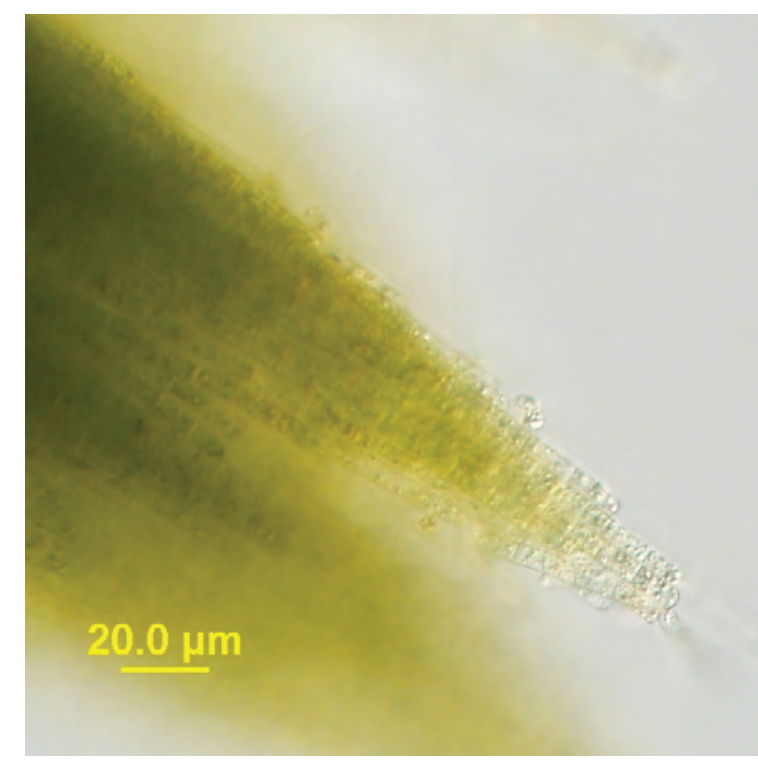

LM

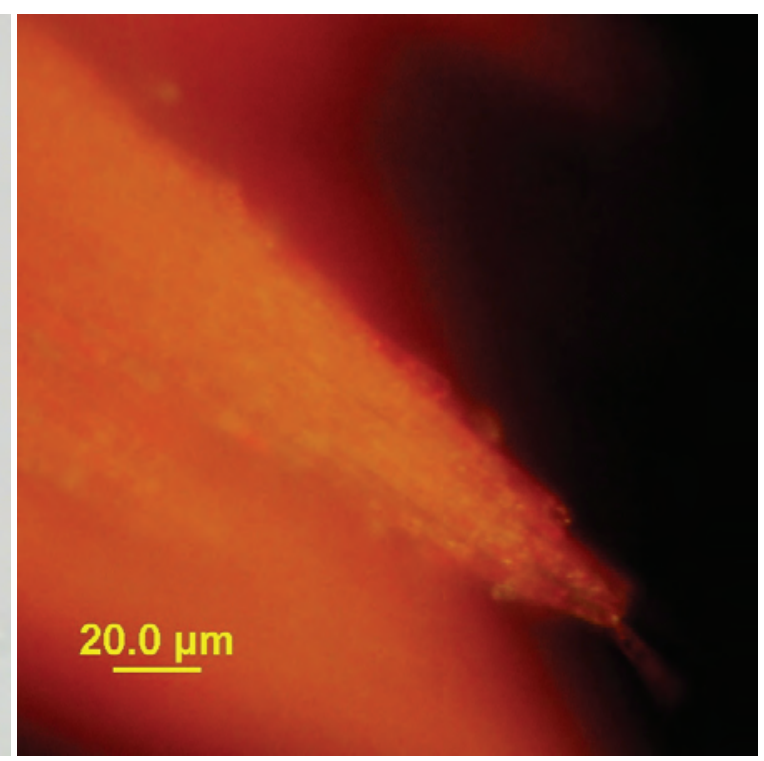

FITC

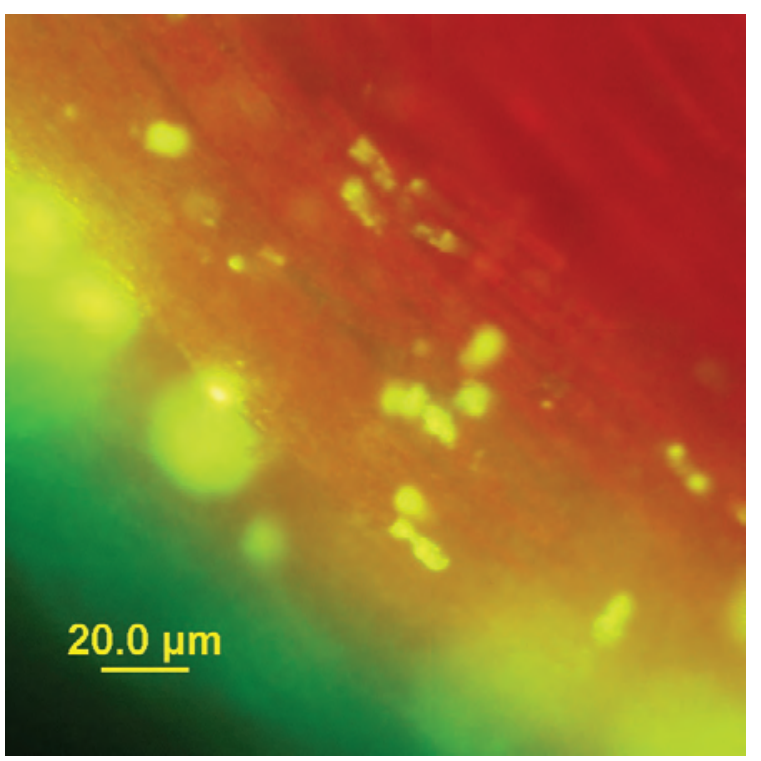

Sytox ${ }^{\circledR}$ green

Control 2

Figure 110. Upper Klamath Lake, OR (8/21/2009). LM-Aphanizomenon flos-aquae bundle of filaments. FITC-a red-orange color dominates these cells. Sytox ${ }^{\circledR}$ greenstain did not penetrate the cell membrane; sheath and epiphytes stained bright yellow-green. LM - differential interference contrast microscopy; FITC - epifluorescent microscopy; Sytox ${ }^{\circledR}$ green - epifluorescent microscopy in conjunction with the nucleic acid stain Sytox ${ }^{\circledR}$ green. 


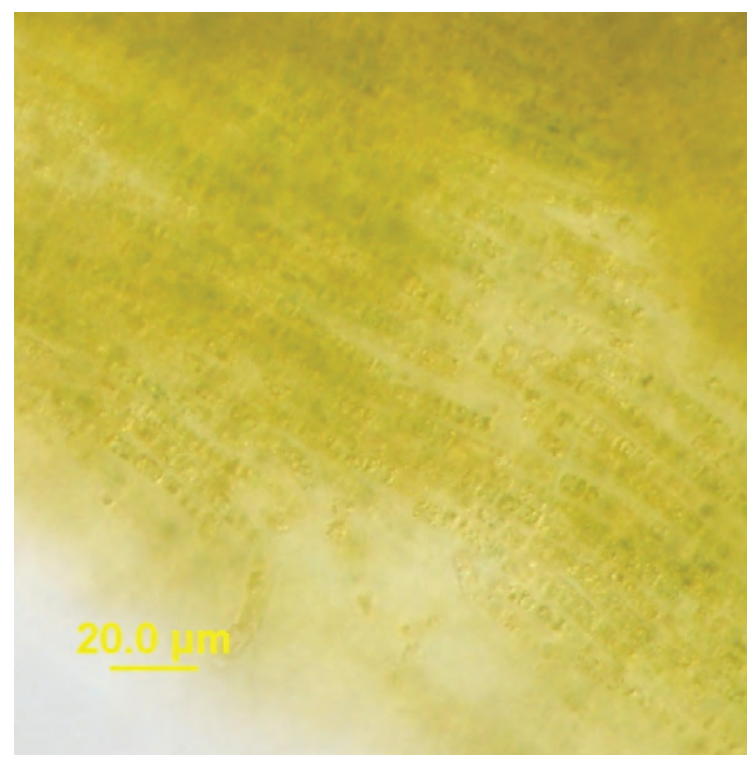

LM

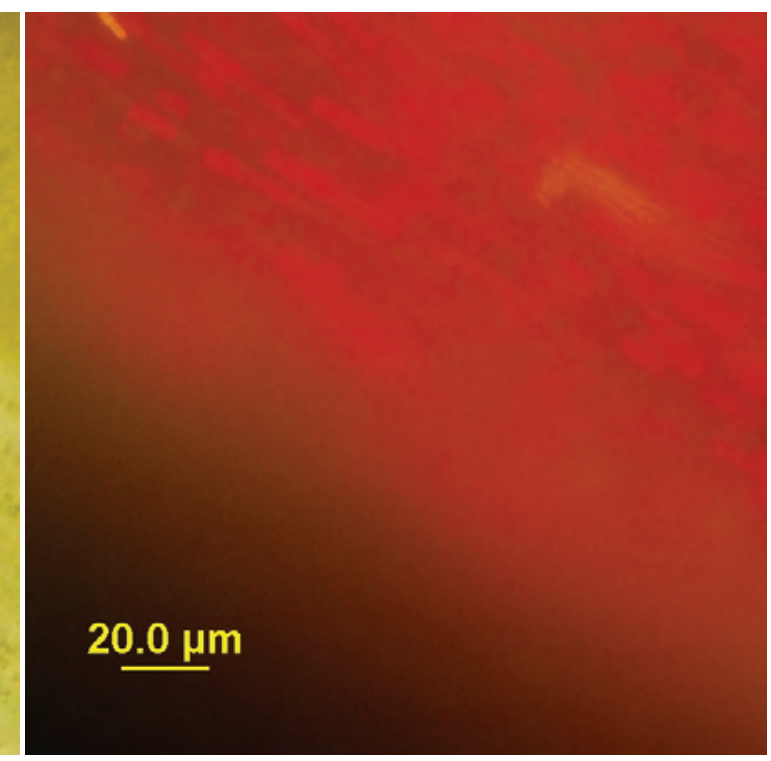

FITC

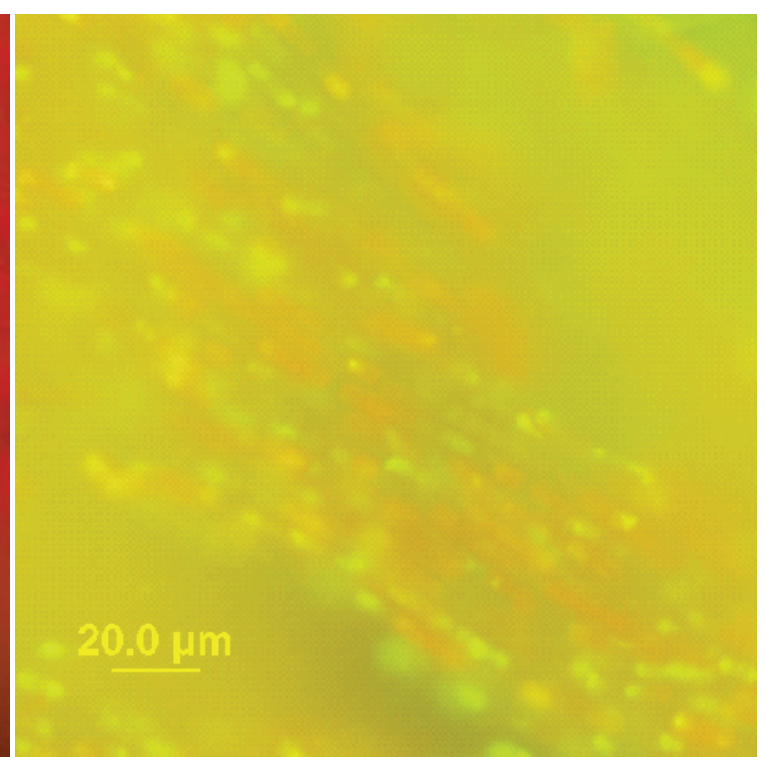

Sytox ${ }^{\circledR}$ green

Control 3

Figure 111. Upper Klamath Lake, OR (8/21/2009). LM-Aphanizomenon flos-aquae bundle of filaments that appear degraded compared to Control 2. FITC-a red color dominates these cells. Sytox ${ }^{\circledR}$ green-stain did penetrate the cell membrane of some cells; stained bright yellow-green. LM - differential interference contrast microscopy; FITC - epifluorescent microscopy; Sytox ${ }^{\circledR}$ green - epifluorescent microscopy in conjunction with the nucleic acid stain Sytox ${ }^{\circledR}$ green. 


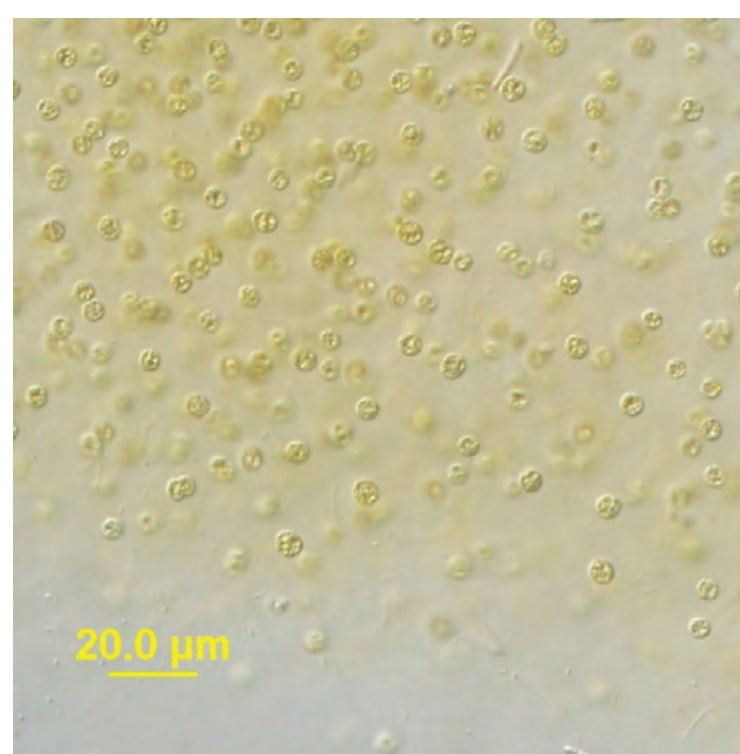

LM

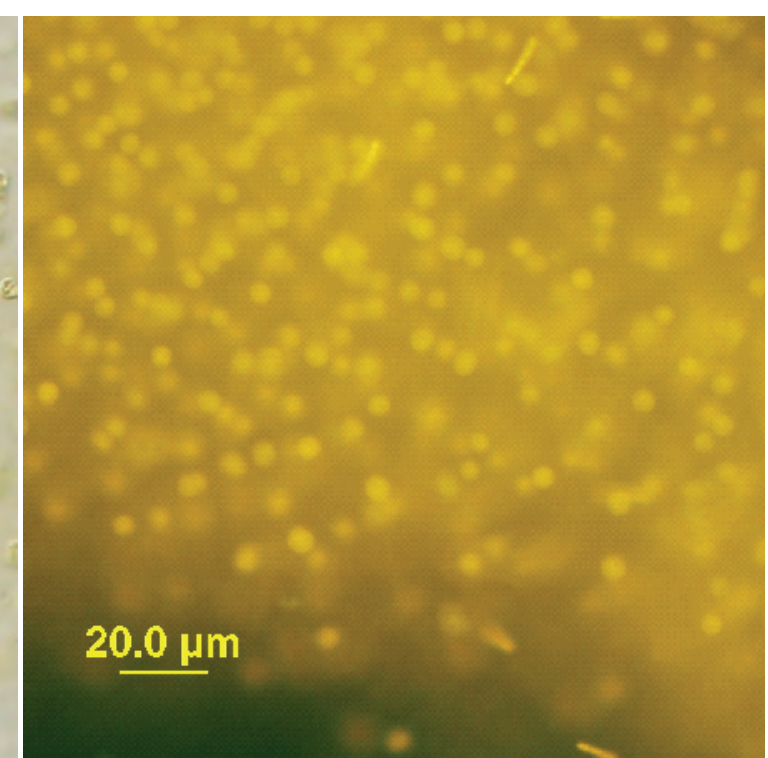

FITC

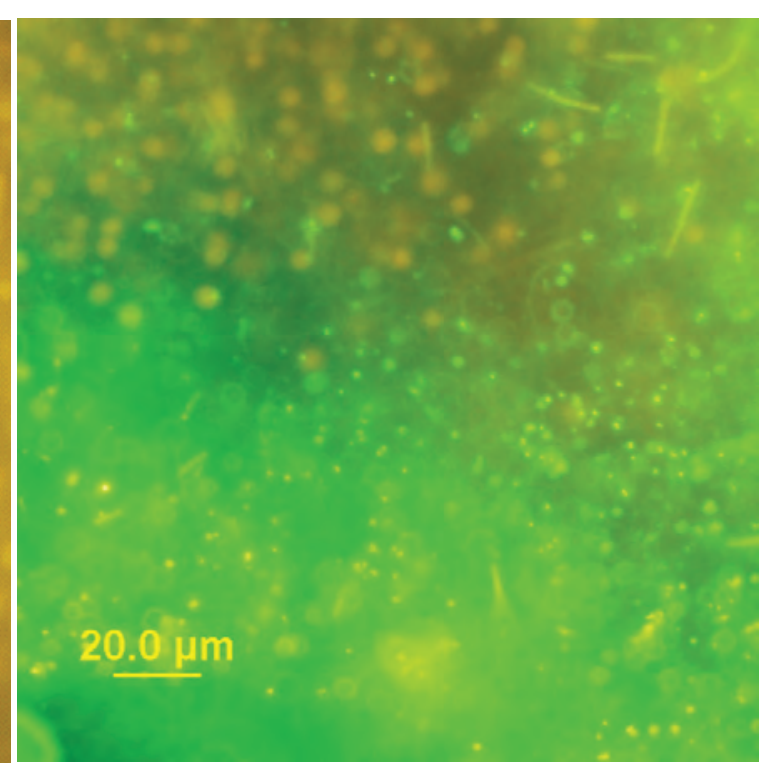

Sytox ${ }^{\circledR}$ green

\section{Boiled for 5 minutes}

Figure 112. Upper Klamath Lake, OR (8/21/2009). LM-Microcystis aeruginosa. FITC-an orange color dominates the cells. Sytox ${ }^{\circledR}$ green- stain did not penetrate the cell membrane of the cyanobacteria; the sheath and epiphytic bacteria (green spots) stained bright green. LM - differential interference contrast microscopy; FITC epifluorescent microscopy; Sytox ${ }^{\circledR}$ green - epifluorescent microscopy in conjunction with the nucleic acid stain Sytox ${ }^{\circledR}$ green. 


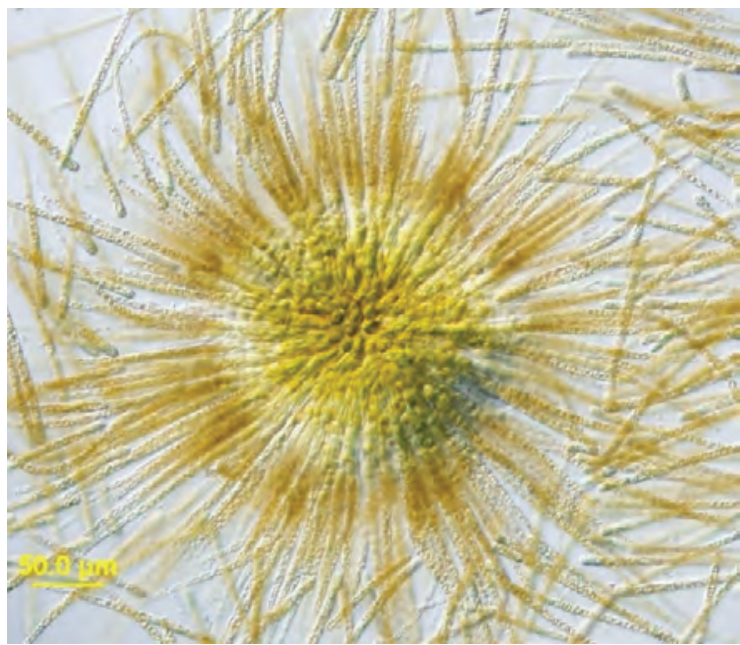

LM

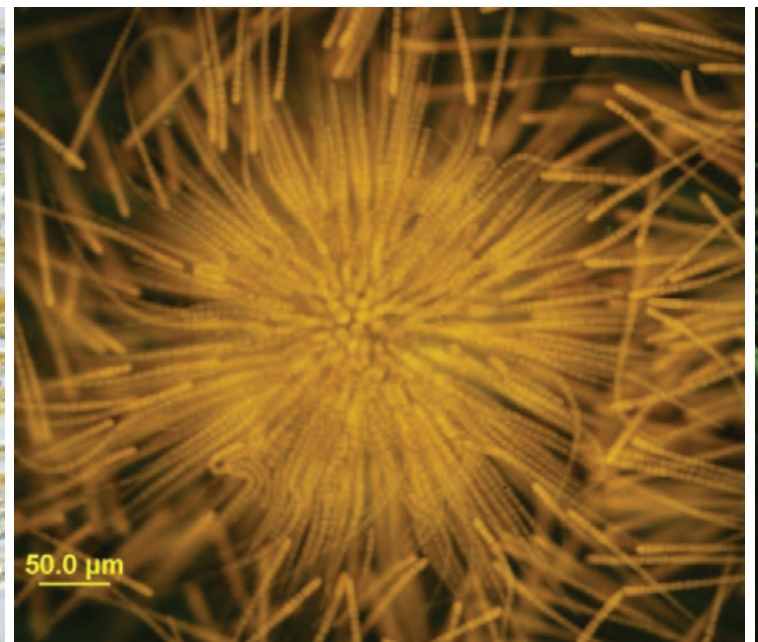

FITC

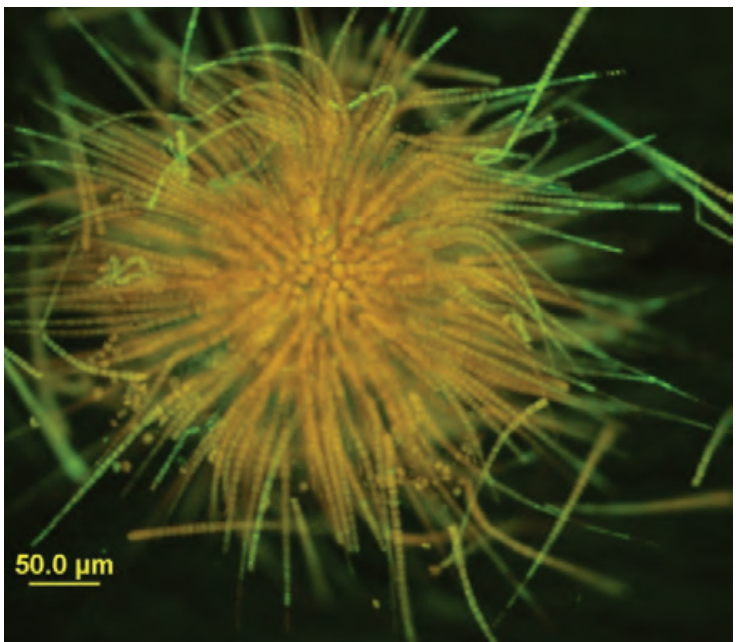

Sytox ${ }^{\circledR}$ green

Boiled for 15 minutes

Figure 113. Upper Klamath Lake, OR (8/21/2009). LM-Gloeotrichia echinulata, a large (note scale bar), colony-forming filamentous cyanobacteria. FITC-an orange color dominates the cells. Syto ${ }^{\circledast}$ green-stained the peripheral filaments, but did not penetrate to the center of this large colony. LM - differential interference contrast microscopy; FITC - epifluorescent microscopy; Syto ${ }^{\circledast}$ green - epifluorescent microscopy in conjunction with the nucleic acid stain Sytox ${ }^{\circledast}$ green. 


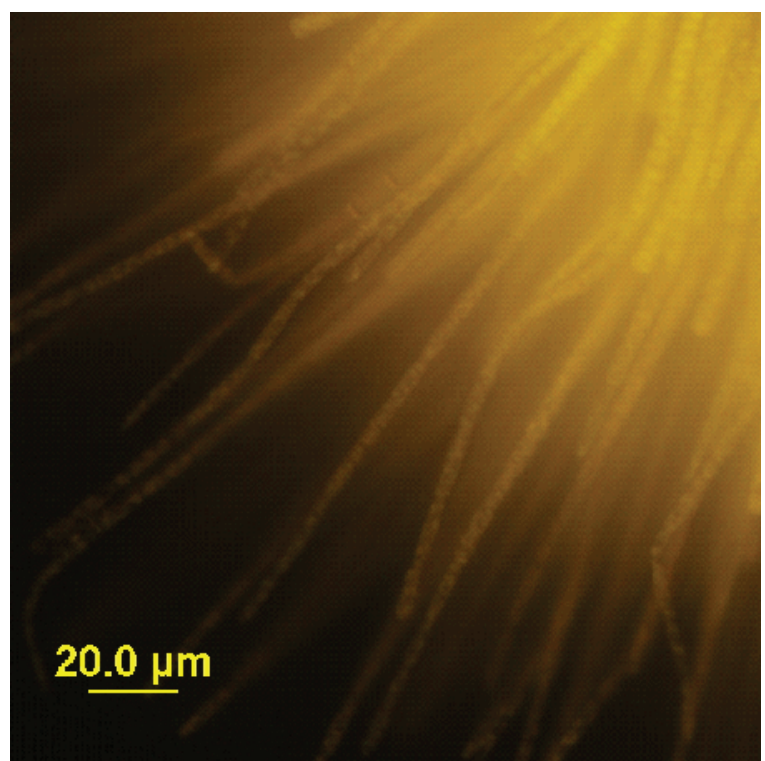

FITC

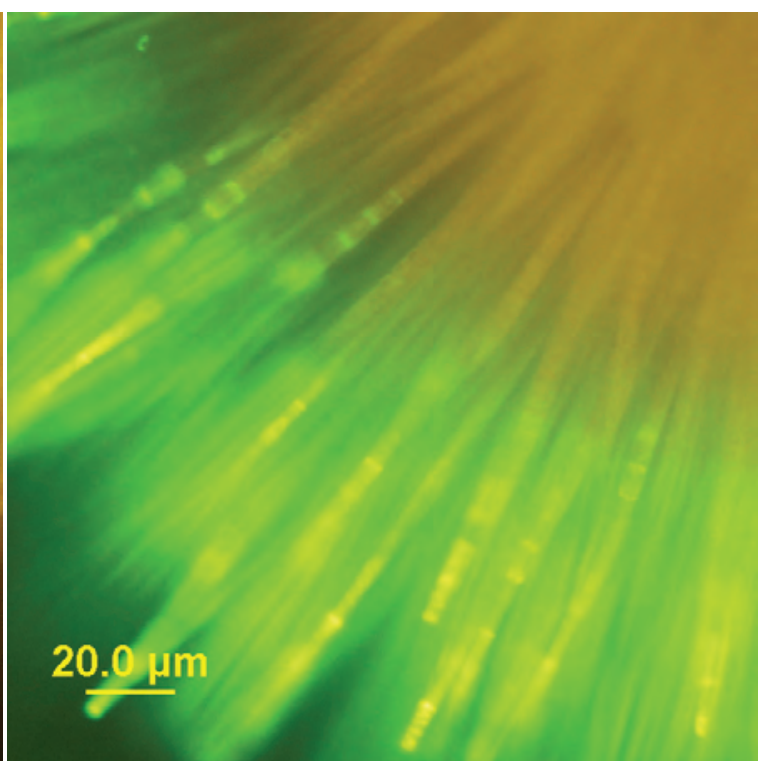

Sytox ${ }^{\circledR}$ green

\section{Boiled for 30 minutes}

Figure 114. Upper Klamath Lake, OR (8/21/2009). LM-No image available. FITC-Gloeotrichia echinulata-an orange color dominates the cells. Sytox ${ }^{\circledR}$ green-stained the tips of the filaments, but did not penetrate to the center of

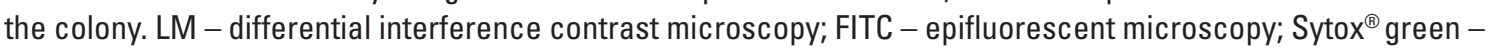
epifluorescent microscopy in conjunction with the nucleic acid stain Sytox ${ }^{\circledR}$ green. 


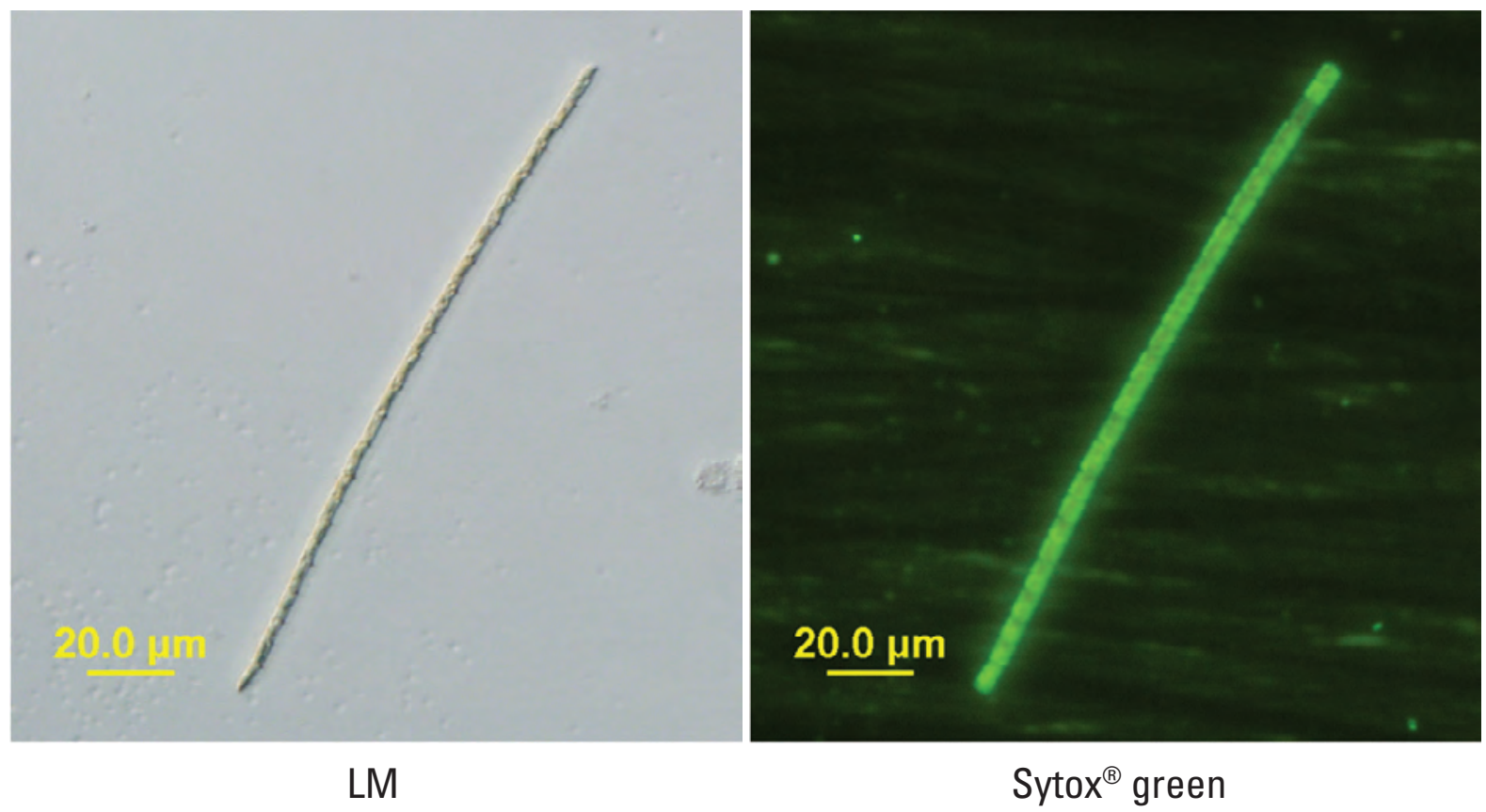

Boiled for 30 minutes

Figure 115. Upper Klamath Lake, OR (8/21/2009). LM-Unknown filamentous cyanobacteria. FITC-no image available. Sytox ${ }^{\circledast}$ green-likely Aphanizomenon flos-aquae filament; stain did penetrate the cell membrane; cells bright green. LM - differential interference contrast microscopy; FITC - epifluorescent microscopy; Sytox ${ }^{\circledR}$ greenepifluorescent microscopy in conjunction with the nucleic acid stain Sytox ${ }^{\circledR}$ green. 


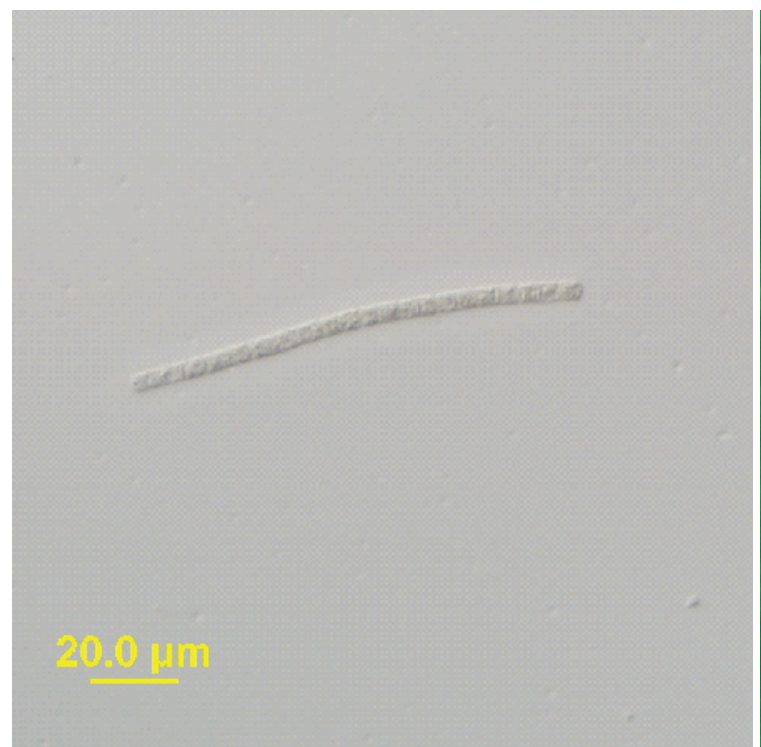

LM

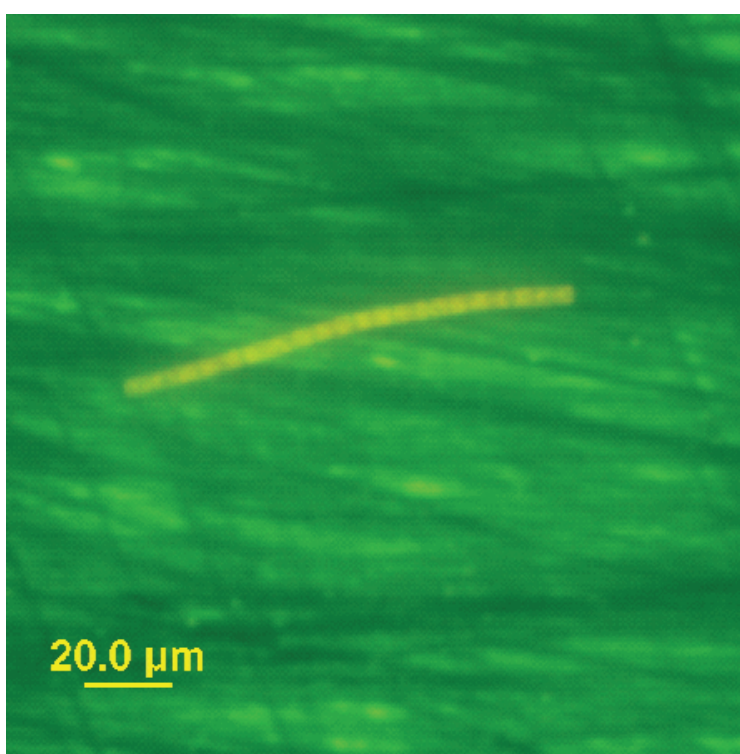

FITC

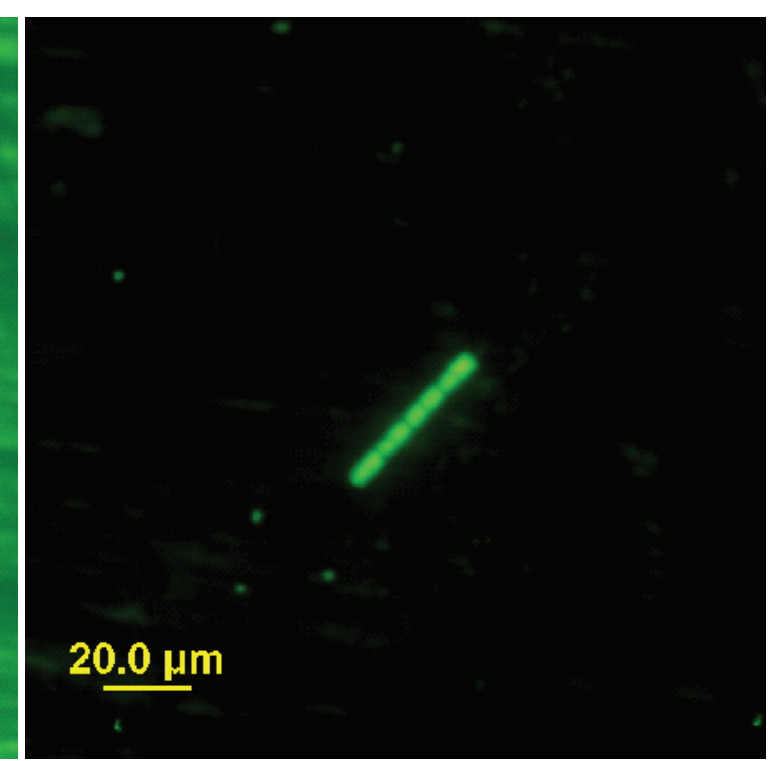

Sytox ${ }^{\circledR}$ green

\section{Autoclaved for 5 minutes}

Figure 116. Upper Klamath Lake, OR (8/21/2009). LM-Likely Aphanizomenon flos-aquae filament. FITC-an orange color dominates the cells. Sytox ${ }^{\circledR}$ green-stain did penetrate the cell membrane, cells bright green. LM - differential interference contrast microscopy; FITC - epifluorescent microscopy; Sytox ${ }^{\circledR}$ green - epifluorescent microscopy in conjunction with the nucleic acid stain Sytox ${ }^{\circledR}$ green. 


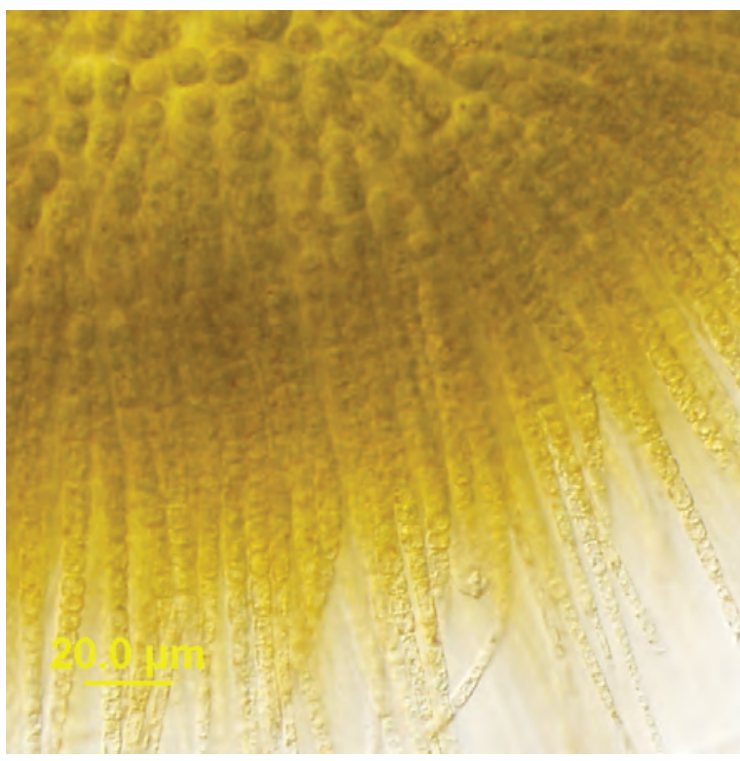

LM

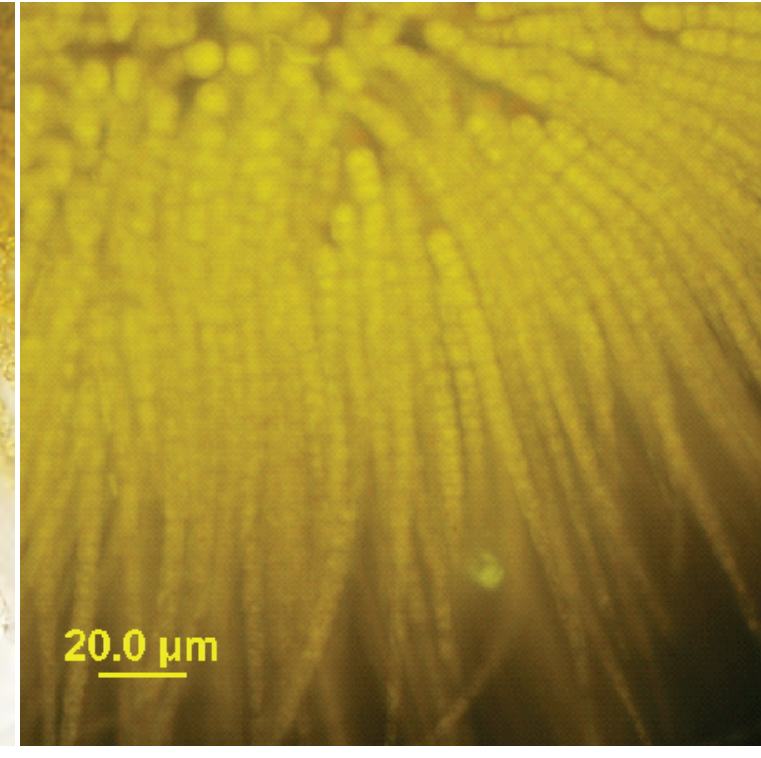

FITC

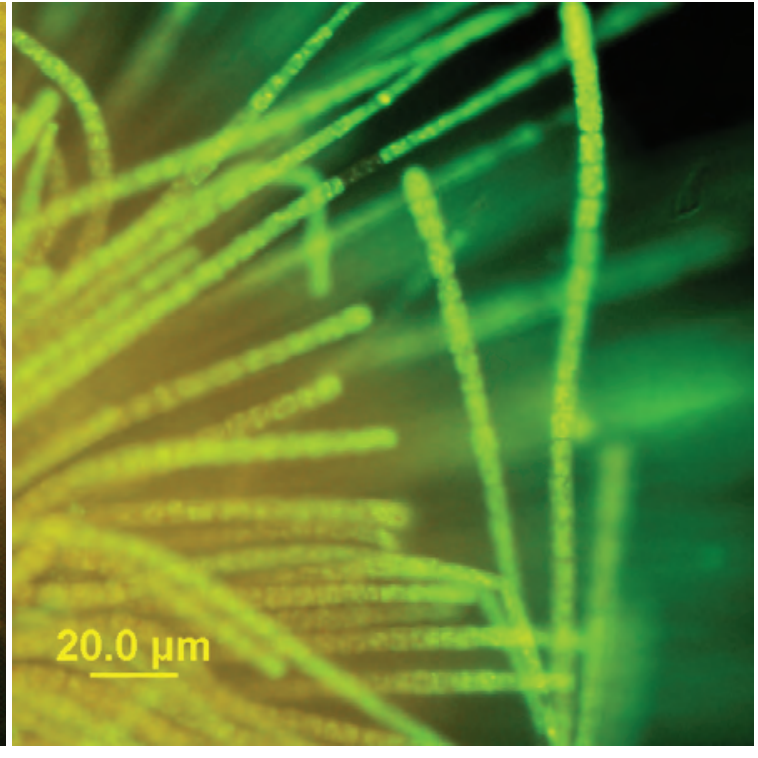

Sytox ${ }^{\circledR}$ green

\section{Autoclaved for 15 minutes}

Figure 117. Upper Klamath Lake, OR (8/21/2009). LM-Gloeotrichia echinulata. FITC-a yellow color dominates the cells. Sytox ${ }^{\circledR}$ green-stained the peripheral filaments, but did not penetrate to the center of this large colony. LM - differential interference contrast microscopy; FITC - epifluorescent microscopy; Sytox ${ }^{\circledR}$ green epifluorescent microscopy in conjunction with the nucleic acid stain Sytox ${ }^{\oplus}$ green. 


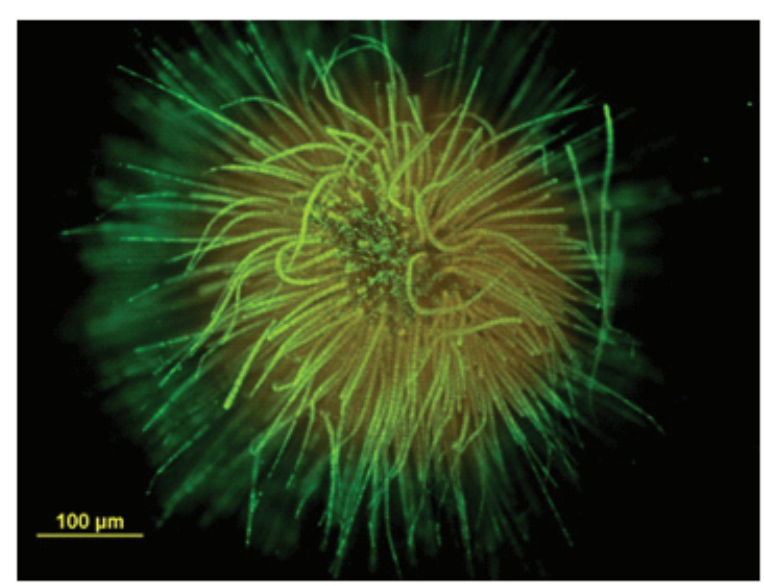

\section{Sytox ${ }^{\circledR}$ green}

Autoclaved for 15 minutes

Figure 118. Upper Klamath Lake, $\mathrm{OR}$ (8/21/2009). Gloeotrichia echinulata. Syto ${ }^{\circledast}$ green-stained the

peripheral filaments, but did not penetrate to the center of this large colony. LM - differential interference

contrast microscopy; FITC - epifluorescent microscopy; Sytox ${ }^{\circledast}$ green - epifluorescent microscopy in conjunction with the nucleic acid stain Sytox ${ }^{\oplus}$ green. 


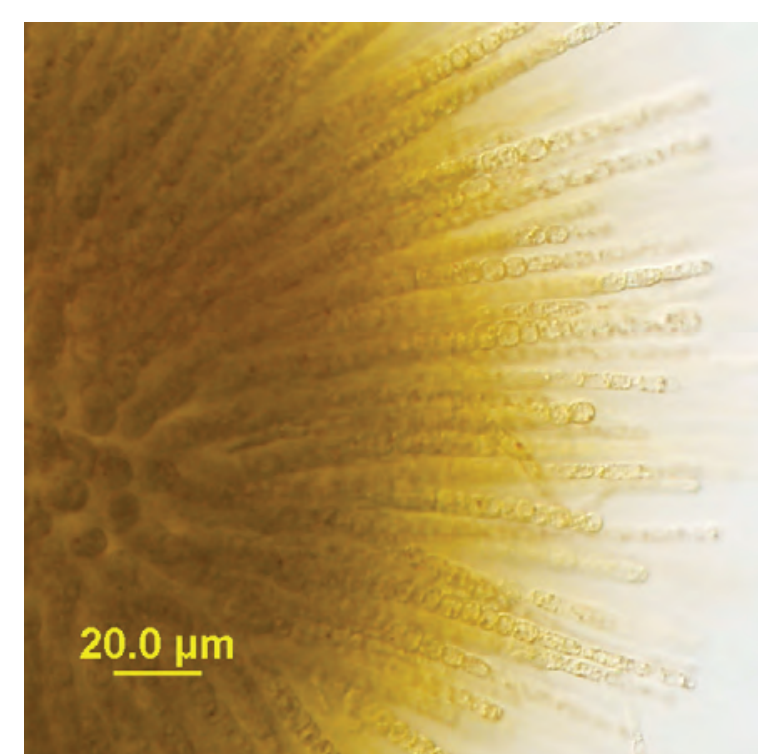

LM

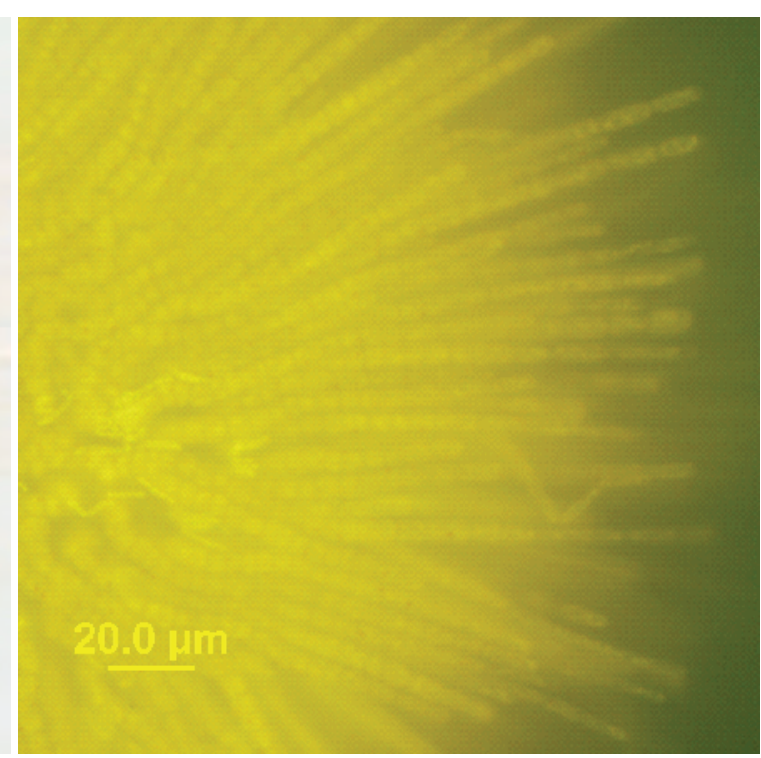

FITC

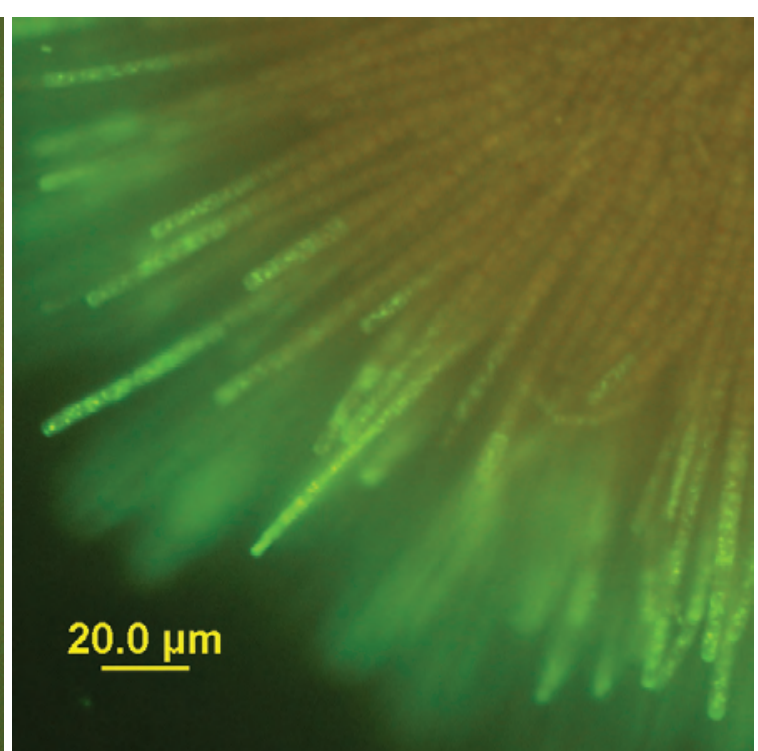

Sytox ${ }^{\circledR}$ green

Autoclaved for 30 minutes

Figure 119. Upper Klamath Lake, OR (8/21/2009). LM-Gloeotrichia echinulata. FITC-a yellow color dominates the cells. Sytox ${ }^{\circledR}$ green-stained the tips of the filaments, but did not penetrate to the center of this large colony. LM - differential interference contrast microscopy; FITC - epifluorescent microscopy; Sytox ${ }^{\circledR}$ green epifluorescent microscopy in conjunction with the nucleic acid stain Sytox ${ }^{\circledR}$ green. 


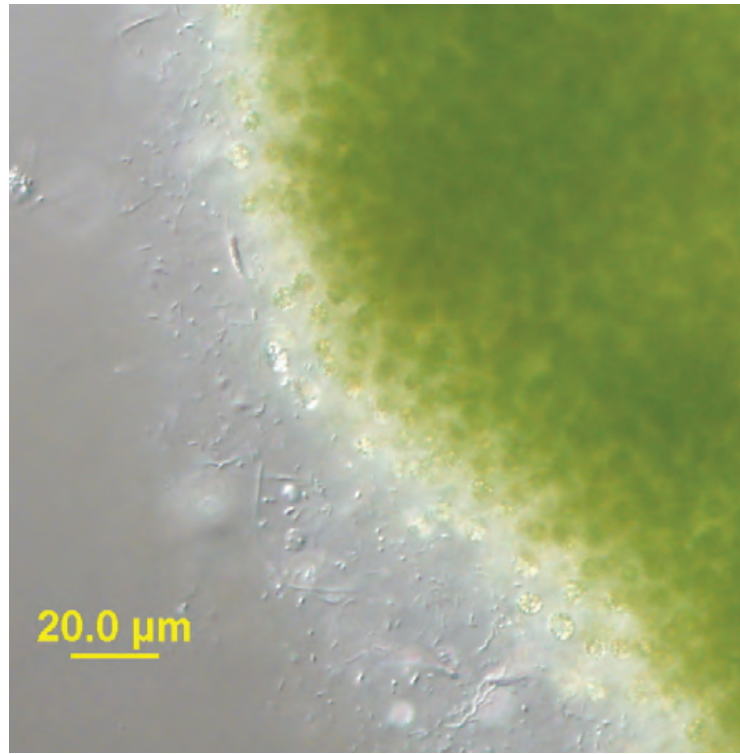

LM

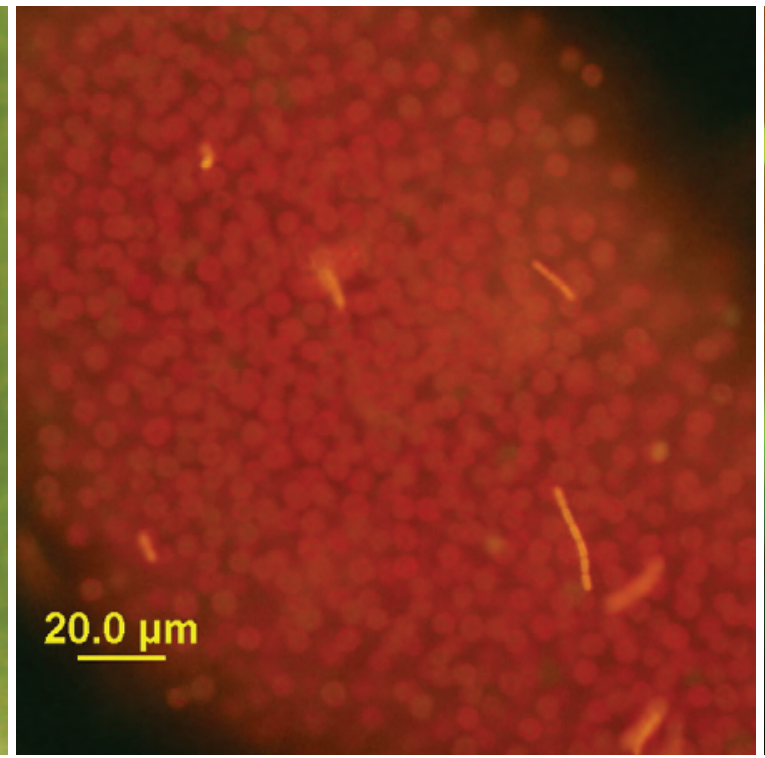

FITC

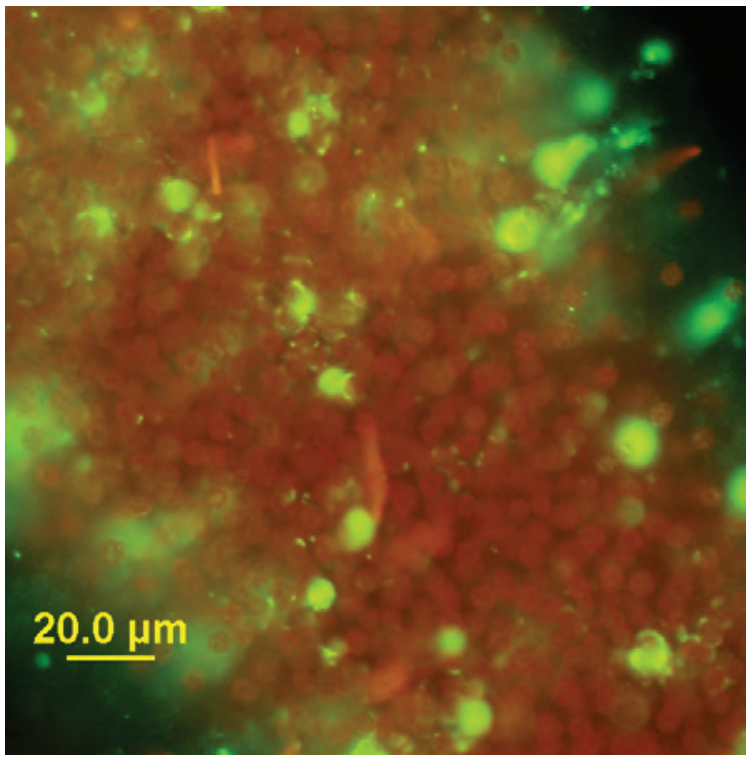

Sytox ${ }^{\circledast}$ green

\section{Sonicated at 10 percent power}

Figure 120. Upper Klamath Lake, OR (8/21/2009). LM-Microcystis aeruginosa. FITC-a red color dominates the cells. Sytox ${ }^{\circledR}$ green-stain did not penetrate the cell membrane; green cells were epiphytes attached to the colony. LM - differential interference contrast microscopy; FITC - epifluorescent microscopy; Sytox ${ }^{\circledR}$ green epifluorescent microscopy in conjunction with the nucleic acid stain Sytox ${ }^{\circledR}$ green. 


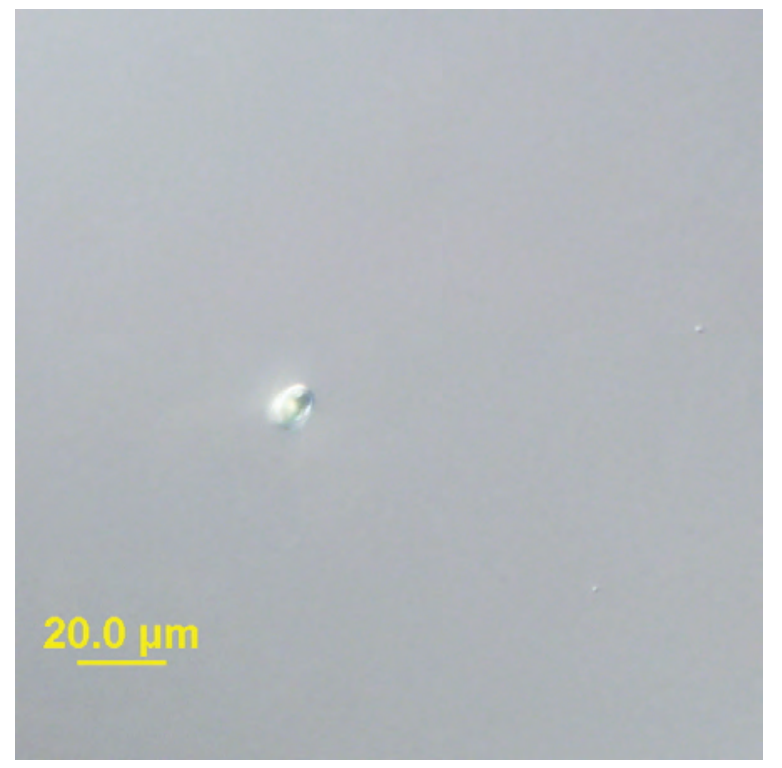

LM

\section{Sonicated at 35 percent power} and 70 percent power

Figure 121. Upper Klamath Lake, $O R$ (8/21/2009).

LM-single cell present. FITC and Syto ${ }^{\circledR}$ green-no data. LM - differential interference contrast microscopy; FITC epifluorescent microscopy; Sytox ${ }^{\circledast}$ green - epifluorescent microscopy in conjunction with the nucleic acid stain Sytox ${ }^{\circledast}$ green. 


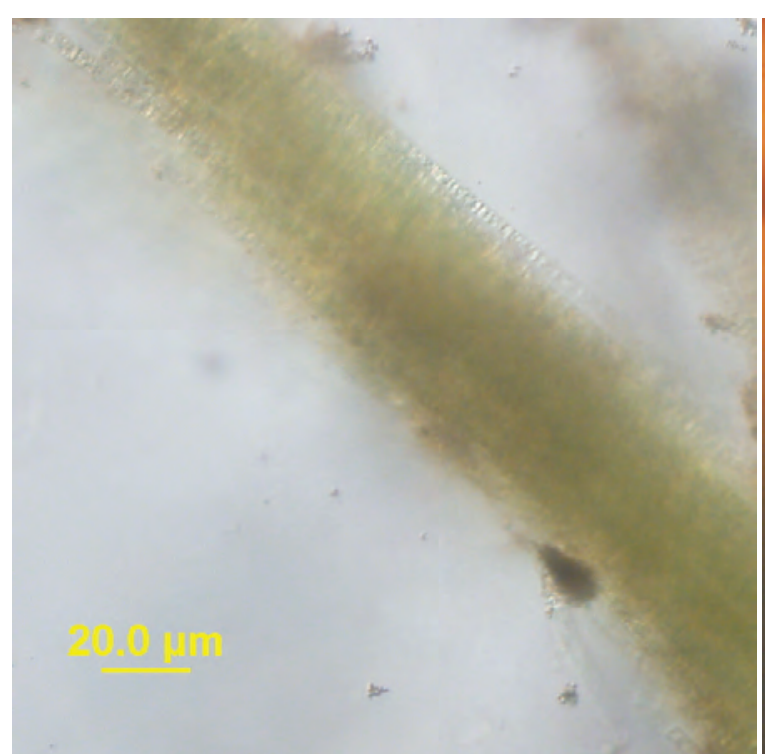

LM

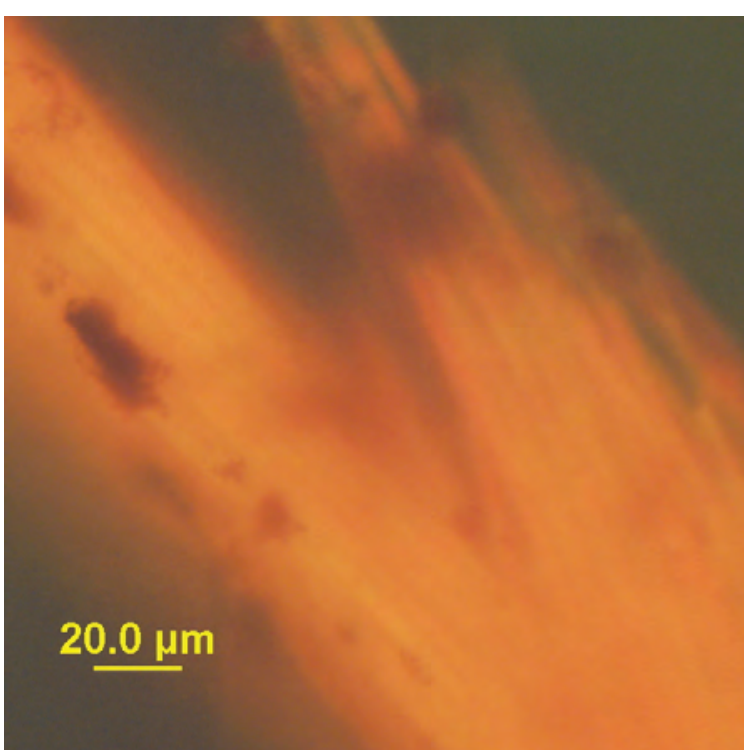

FITC

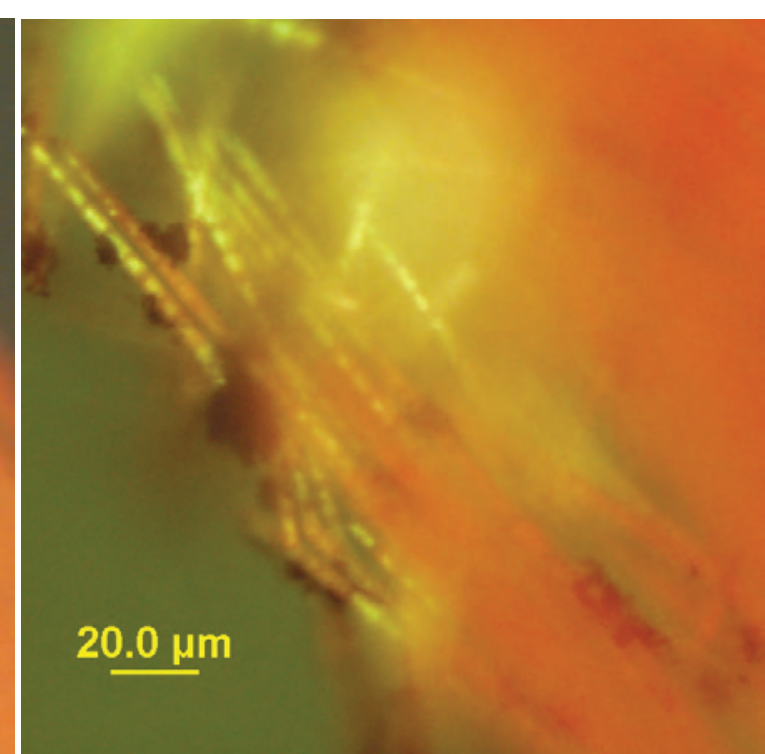

Sytox ${ }^{\circledR}$ green

\section{QuikLyse ${ }^{\mathrm{TM}}-1 \mathrm{x}$}

Figure 122. Upper Klamath Lake, OR (8/21/2009). LM-Aphanizomenon flos-aquae bundle of filaments. FITC-an orange color dominates these cells. Sytox ${ }^{\circledR}$ green-stain did not penetrate the cell membrane of the main bundle of organisms; a few filaments on the edge stained bright yellow-green. LM - differential interference contrast microscopy; FITC - epifluorescent microscopy; Sytox ${ }^{\circledR}$ green - epifluorescent microscopy in conjunction with the nucleic acid stain Sytox ${ }^{\circledR}$ green. 


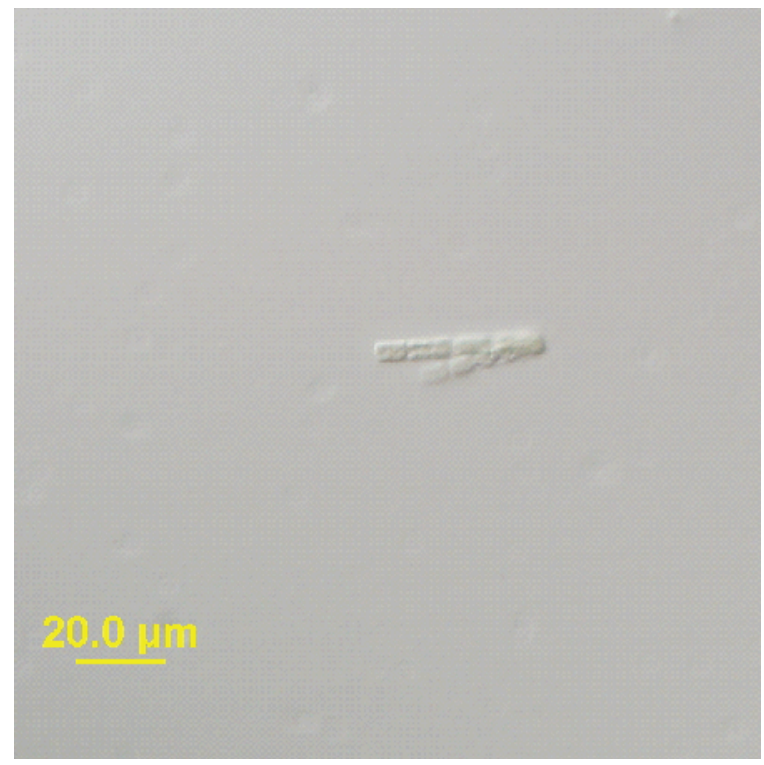

LM

\section{One freeze-thaw cycle}

Figure 123. Upper Klamath Lake, OR (8/21/2009).

LM-Likely a small fragment of Aphanizomenon flos-

aquae. FITC and Syto ${ }^{\circledR}$ green-no data. LM - differential interference contrast microscopy; FITC - epifluorescent microscopy; Sytox ${ }^{\circledR}$ green - epifluorescent microscopy in conjunction with the nucleic acid stain Sytox ${ }^{\circledR}$ green. 


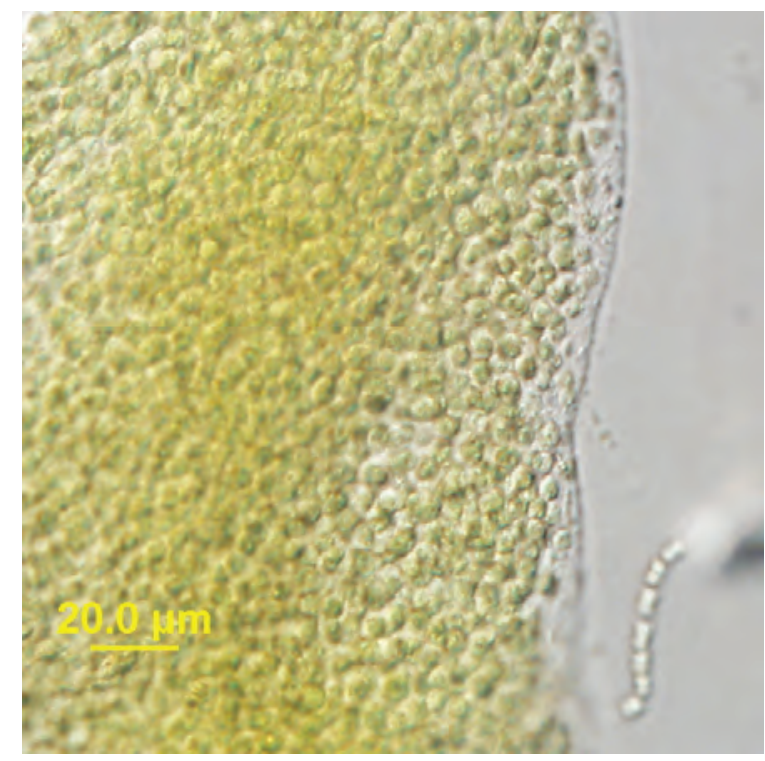

LM

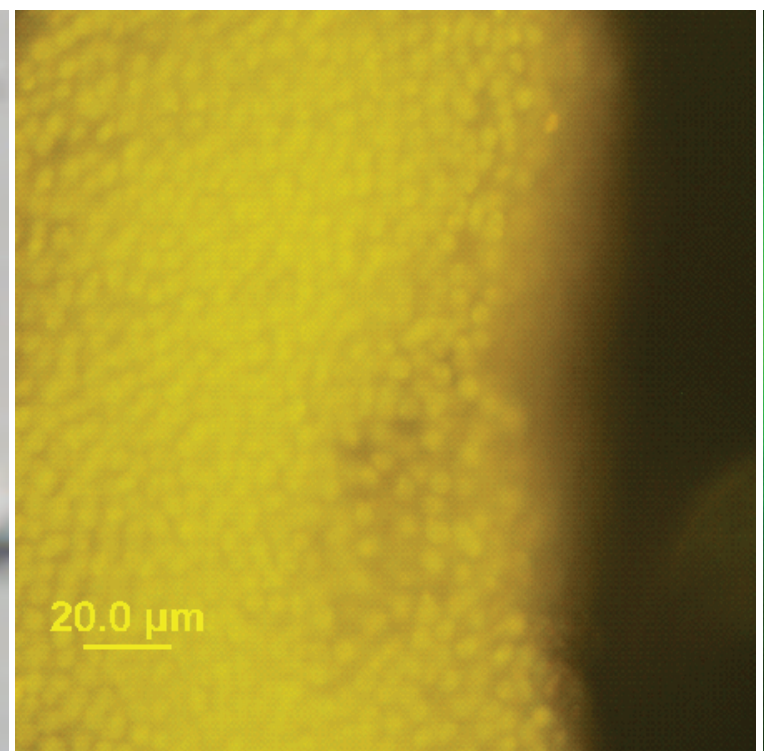

FITC

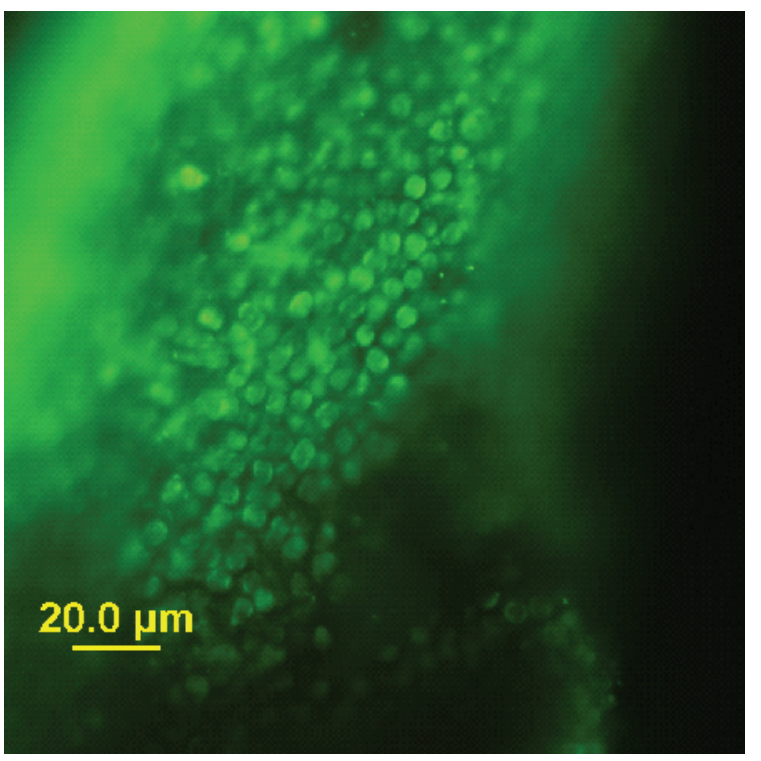

Sytox ${ }^{\circledR}$ green

Three freeze-thaw cycles

Figure 124. Upper Klamath Lake, $0 \mathrm{R}(8 / 21 / 2009)$. LM-Microcystis aeruginosa. FITC-a yellow color dominates the cells. Sytox ${ }^{\circledR}$ green-stain did penetrate the cell membrane; cells were bright green. LM - differential interference contrast microscopy; FITC - epifluorescent microscopy; Sytox ${ }^{\circledR}$ green - epifluorescent microscopy in conjunction with the nucleic acid stain Sytox ${ }^{\circledR}$ green. 


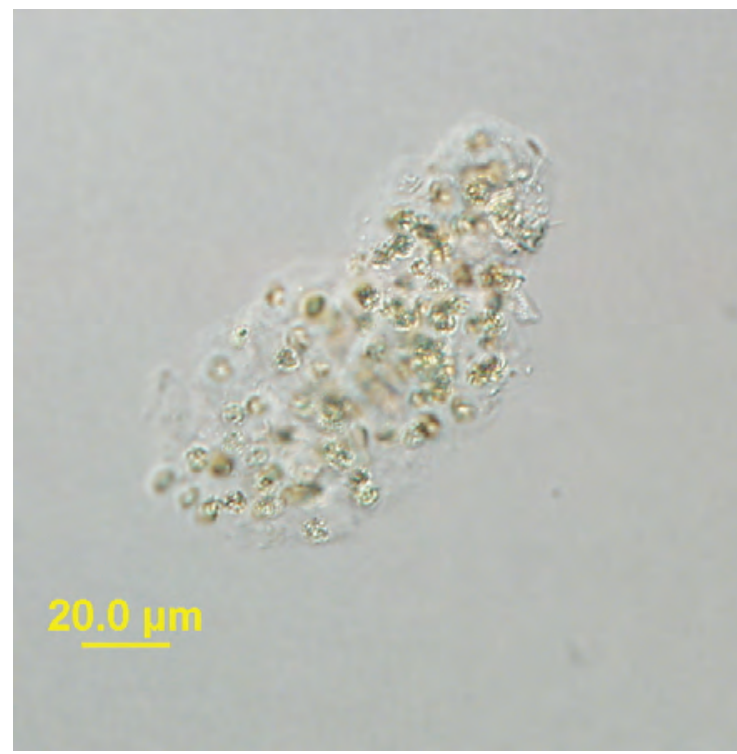

LM

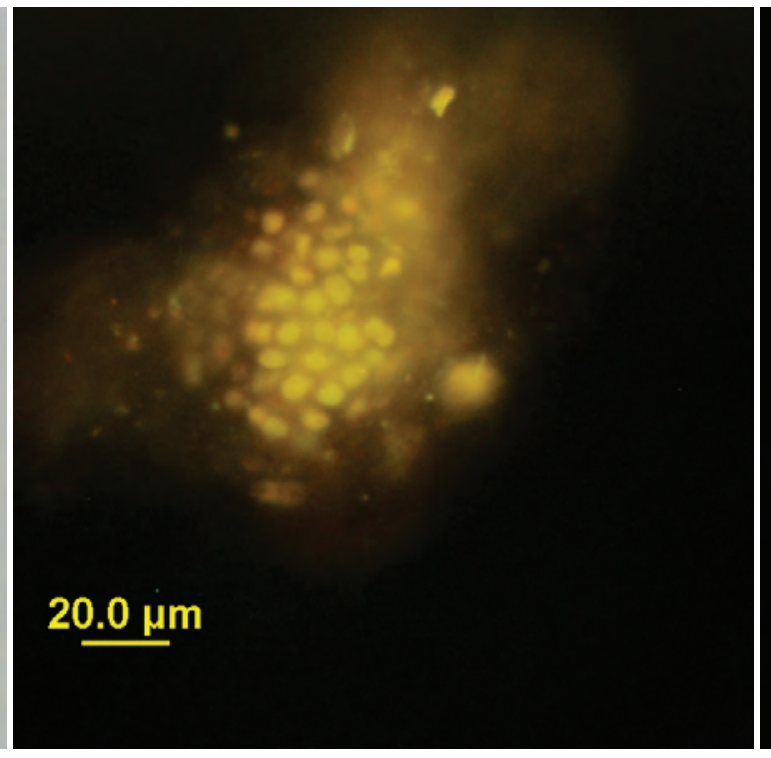

FITC

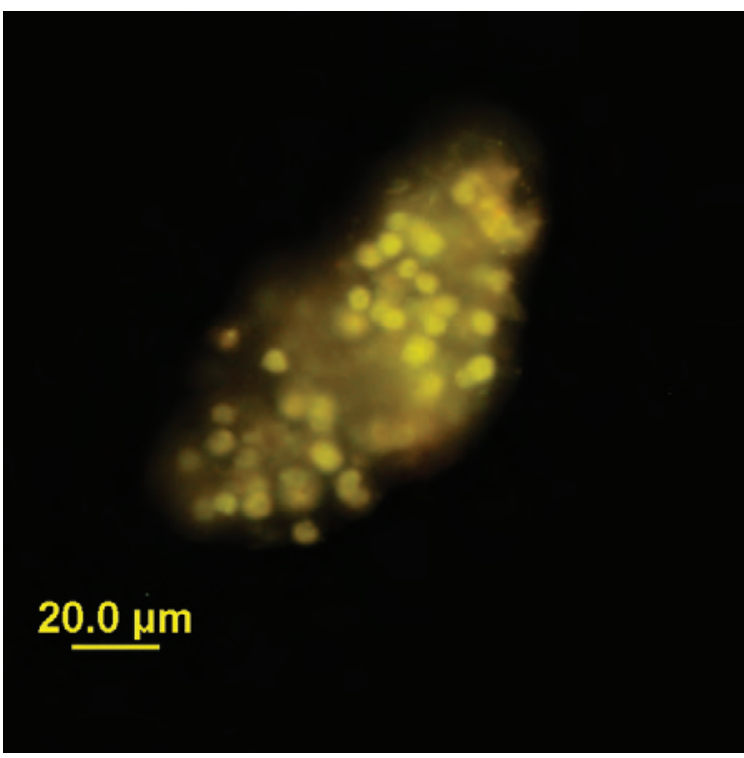

Sytox ${ }^{\circledR}$ green

One freeze-thaw cycle

Figure 125. Klamath River, OR (8/21/2009) (only freeze-thaw material). LM-Microcystis aeruginosa. FITC-a yellow color dominates the cells. Syto ${ }^{\oplus}$ green-stain did not penetrate the cell membrane. LM - differential interference contrast microscopy; FITC - epifluorescent microscopy; Sytox ${ }^{\oplus}$ green - epifluorescent microscopy in conjunction with the nucleic acid stain Sytox ${ }^{\oplus}$ green. 


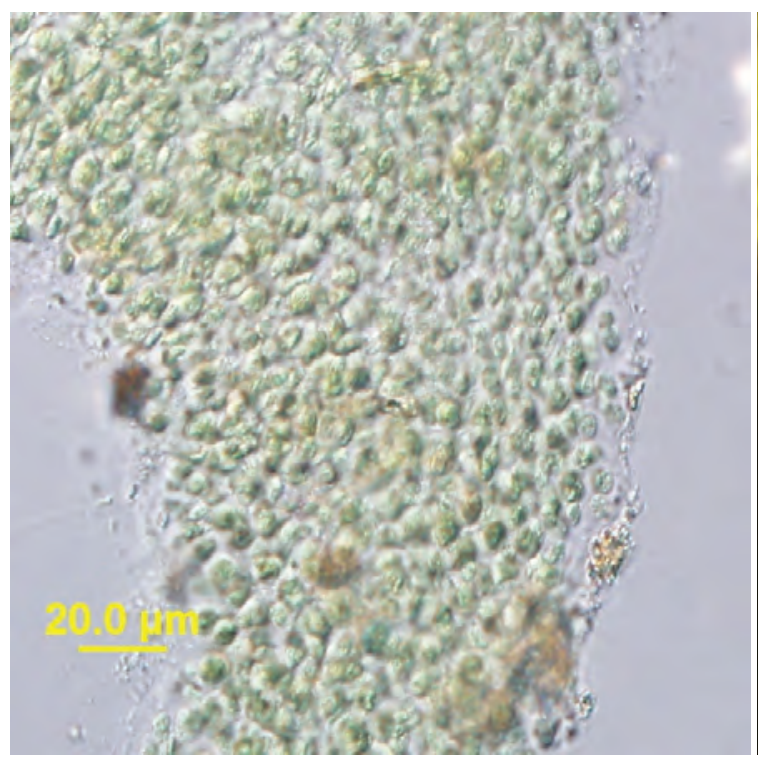

LM

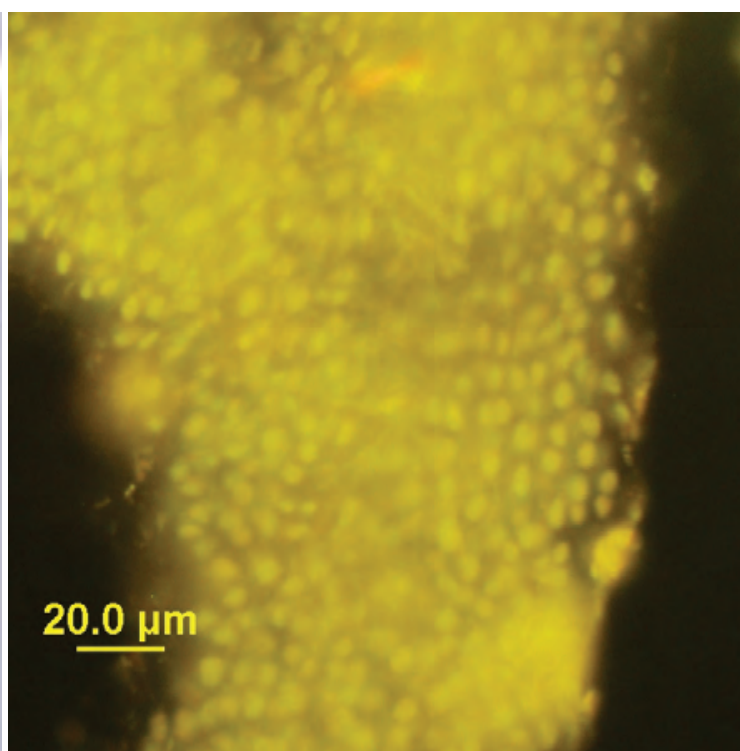

FITC

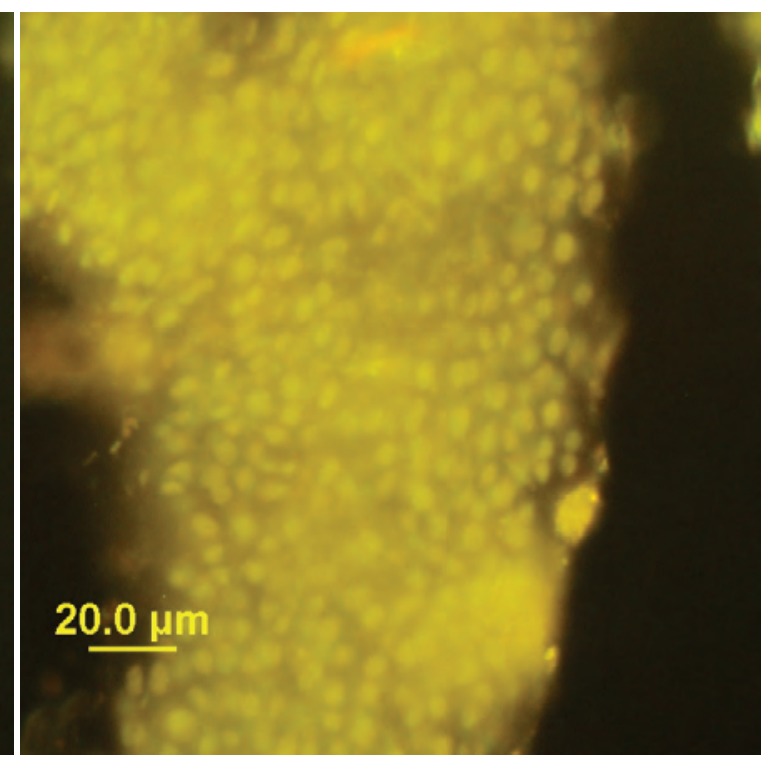

Sytox ${ }^{\circledR}$ green

Two freeze-thaw cycles

Figure 126. Klamath River, OR (8/21/2009). LM-Microcystis aeruginosa. FITC-a yellow color dominates the cells. Sytox ${ }^{\circledR}$ green-stain did not penetrate the cell membrane. LM - differential interference contrast microscopy; FITC - epifluorescent microscopy; Sytox ${ }^{\circledR}$ green - epifluorescent microscopy in conjunction with the nucleic acid stain Sytox ${ }^{\circledR}$ green. 


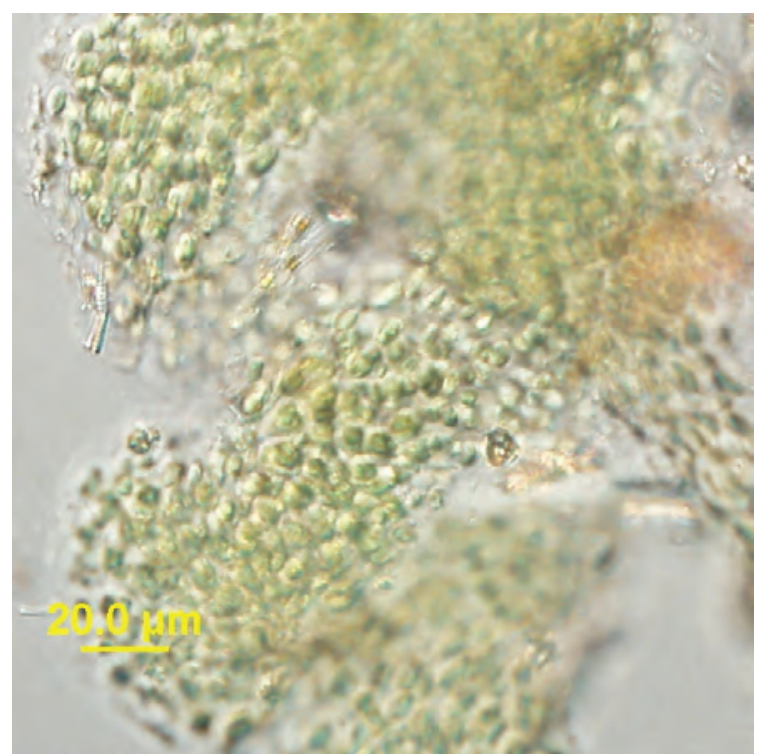

LM

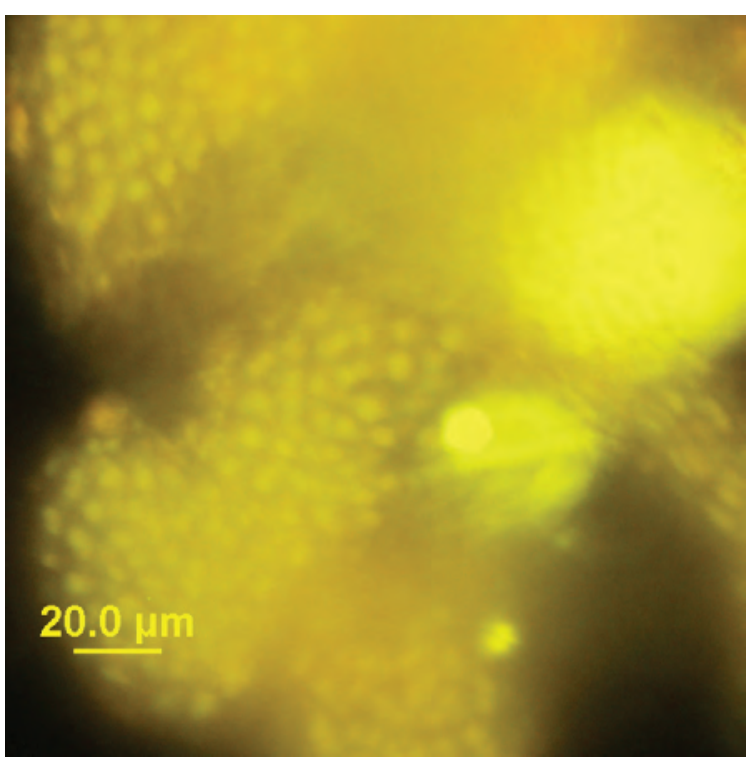

FITC

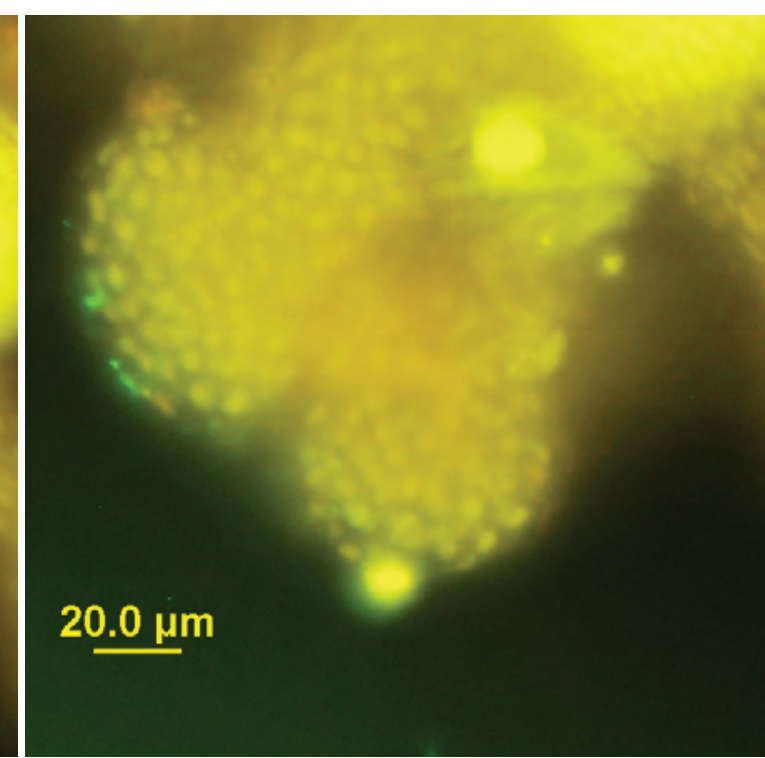

Sytox ${ }^{\circledR}$ green

\section{Three freeze-thaw cycles}

Figure 127. Klamath River, OR (8/21/2009). LM-Microcystis aeruginosa. FITC-a yellow color dominates the cells. Sytox ${ }^{\circledR}$ green-stain did not penetrate the cell membrane of most cells in the colony; some peripheral cells appear bright green. LM - differential interference contrast microscopy; FITC - epifluorescent microscopy; Sytox $^{\oplus}$ green - epifluorescent microscopy in conjunction with the nucleic acid stain Sytox ${ }^{\circledast}$ green. 


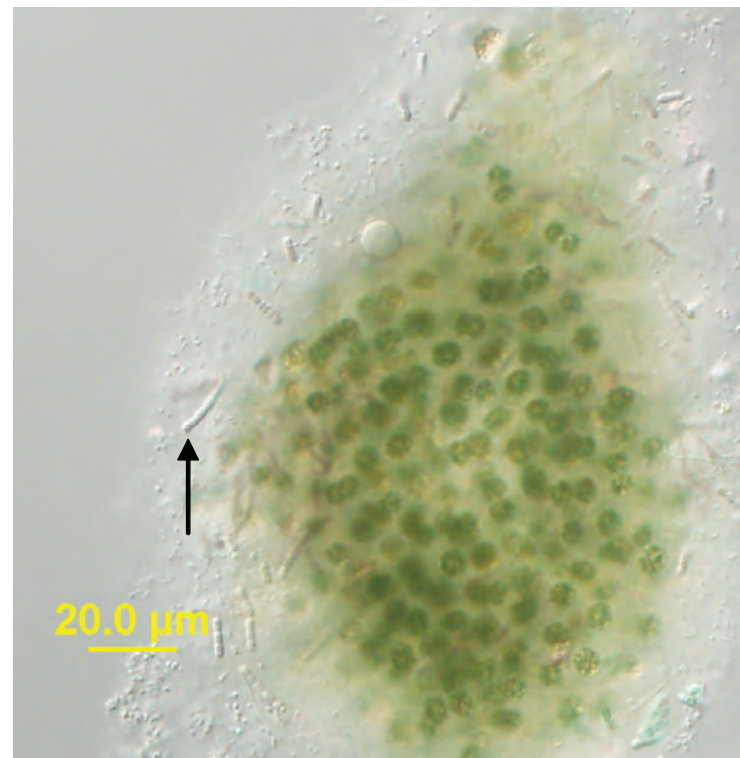

LM

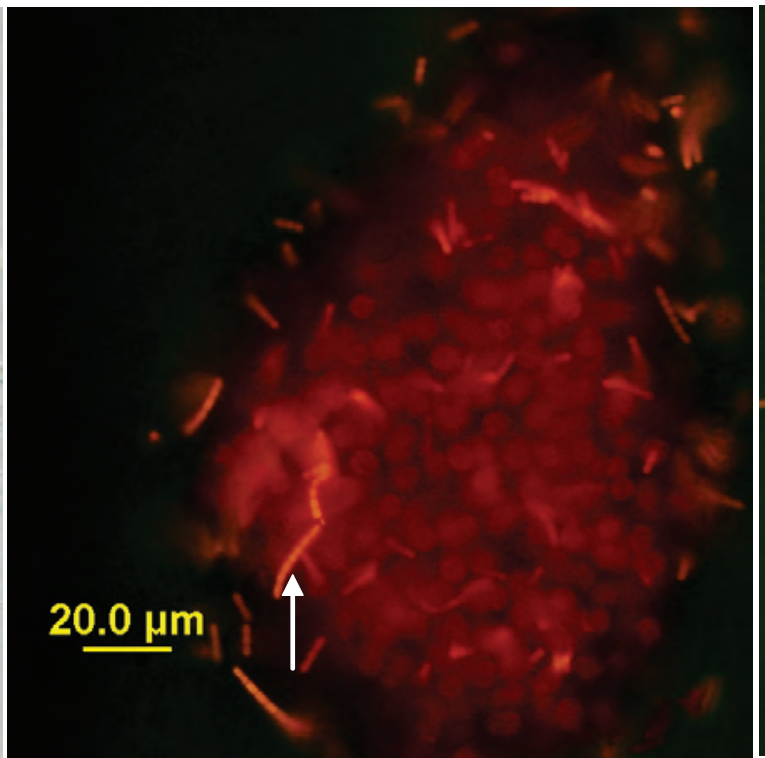

FITC

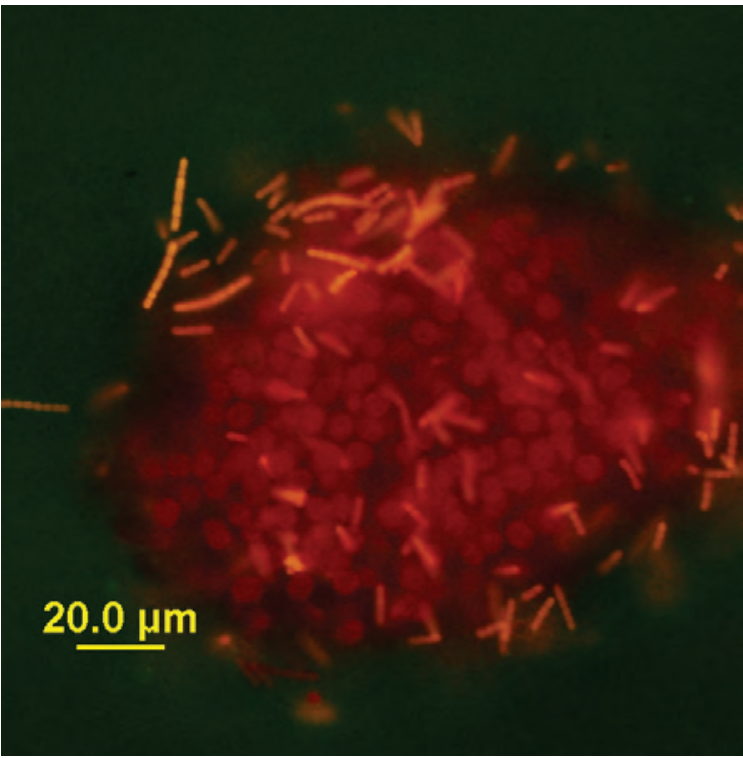

Sytox ${ }^{\circledR}$ green

Control 1

Figure 128. Iron Gate Reservoir, OR (8/25/2009). LM-Microcystis aeruginosa. The small filaments (arrow) are likely the endogloeic cyanobacteria, Pseudoanabaena mucicola (Hindák, 2006). FITC-a red color dominates the cells. Sytox ${ }^{\circledR}$ green-stain did not penetrate the cell membrane. LM - differential interference contrast microscopy; FITC - epifluorescent microscopy; Sytox ${ }^{\circledR}$ green - epifluorescent microscopy in conjunction with the nucleic acid stain Sytox ${ }^{\circledR}$ green. 


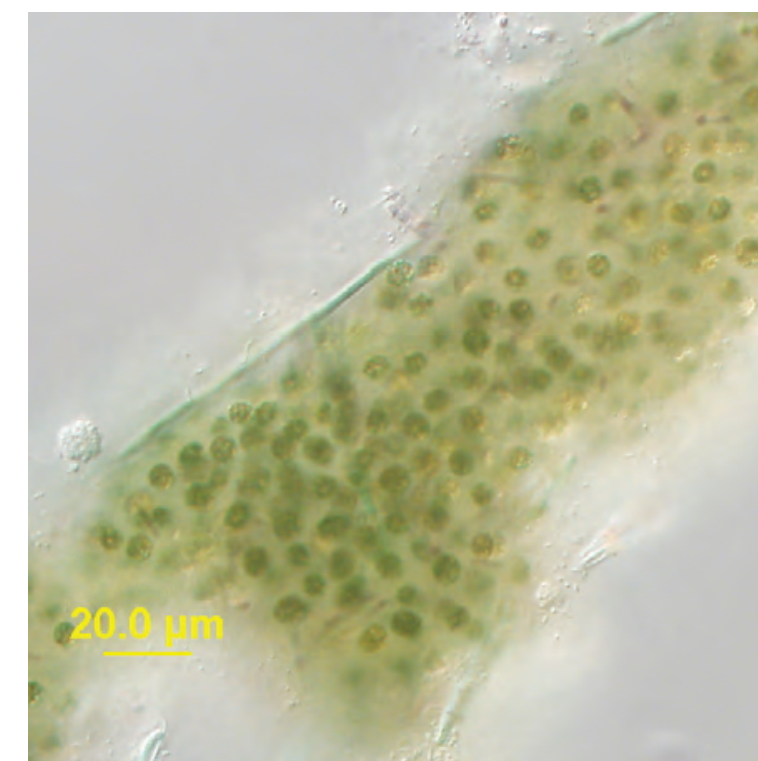

LM

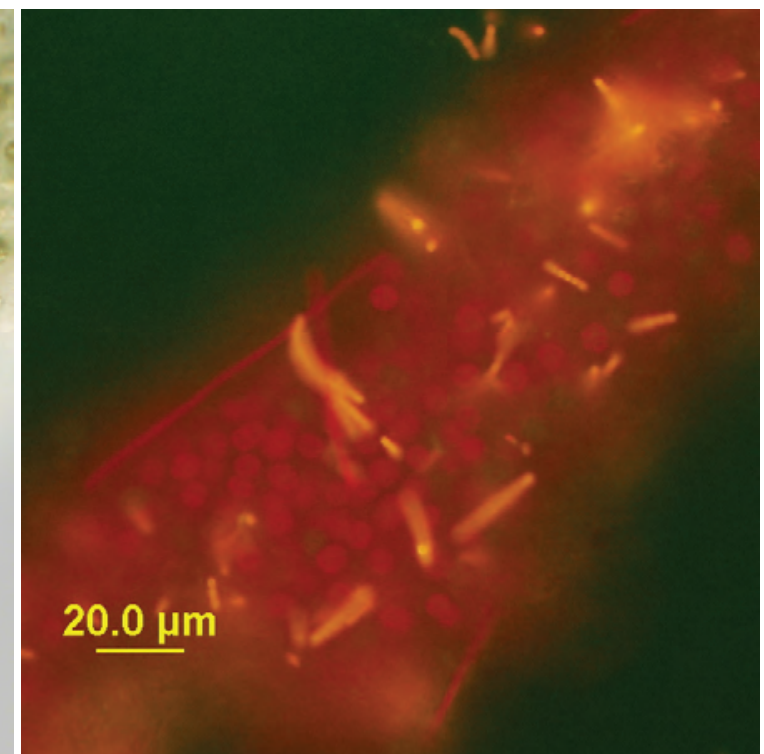

FITC

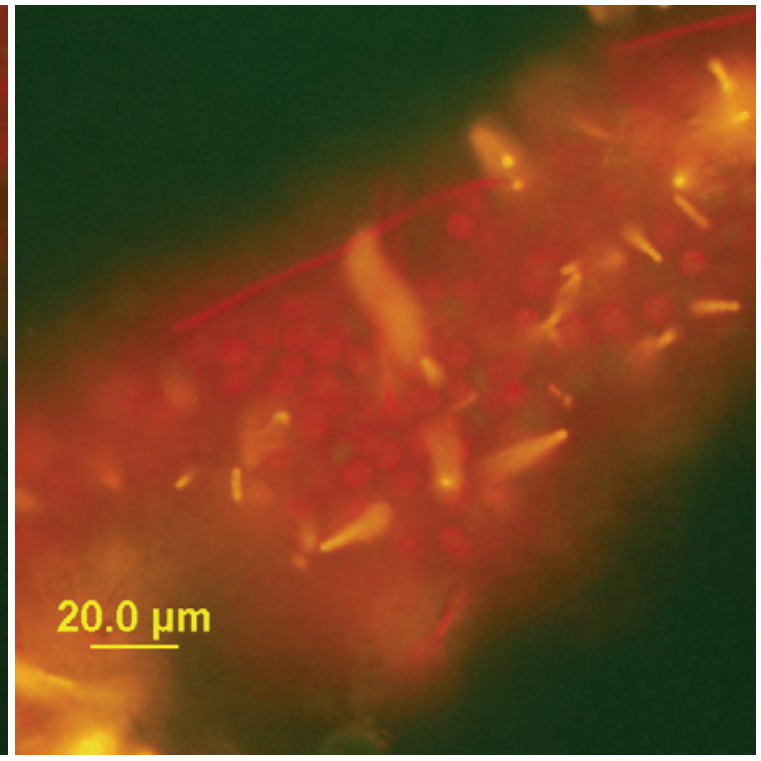

Sytox ${ }^{\circledR}$ green

Control 2

Figure 129. Iron Gate Reservoir, OR (8/25/2009). LM-Microcystis aeruginosa. FITC-a red color dominates the cells. Sytox ${ }^{\circledR}$ green-stain did not penetrate the cell membrane. LM - differential interference contrast microscopy; FITC - epifluorescent microscopy; Sytox ${ }^{\circledR}$ green - epifluorescent microscopy in conjunction with the nucleic acid stain Sytox ${ }^{\oplus}$ green. 


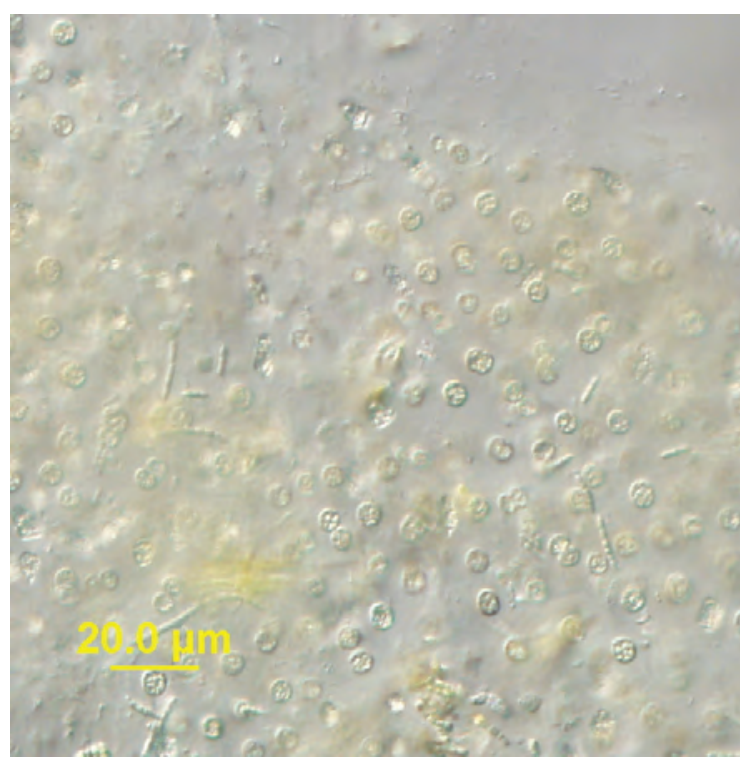

LM

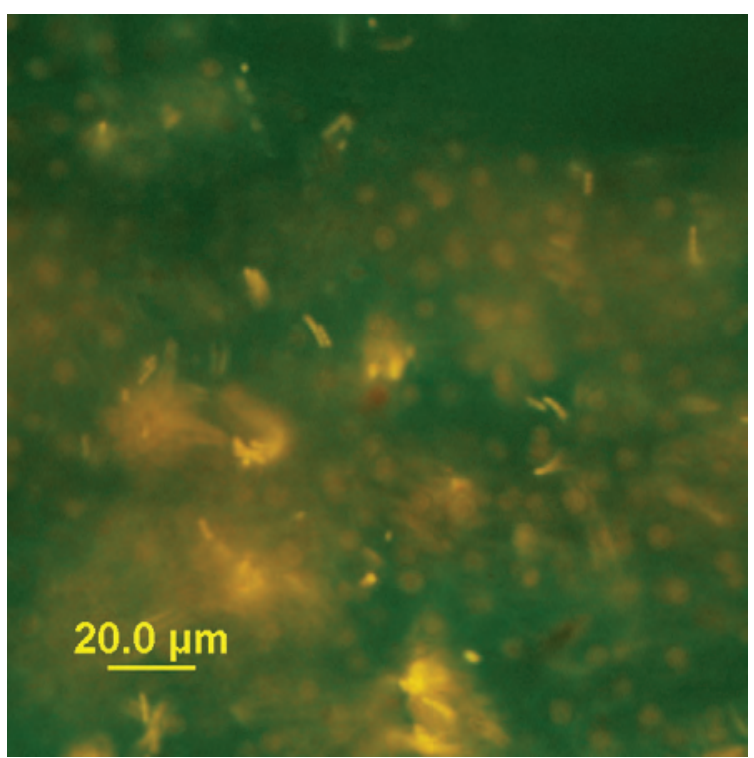

FITC

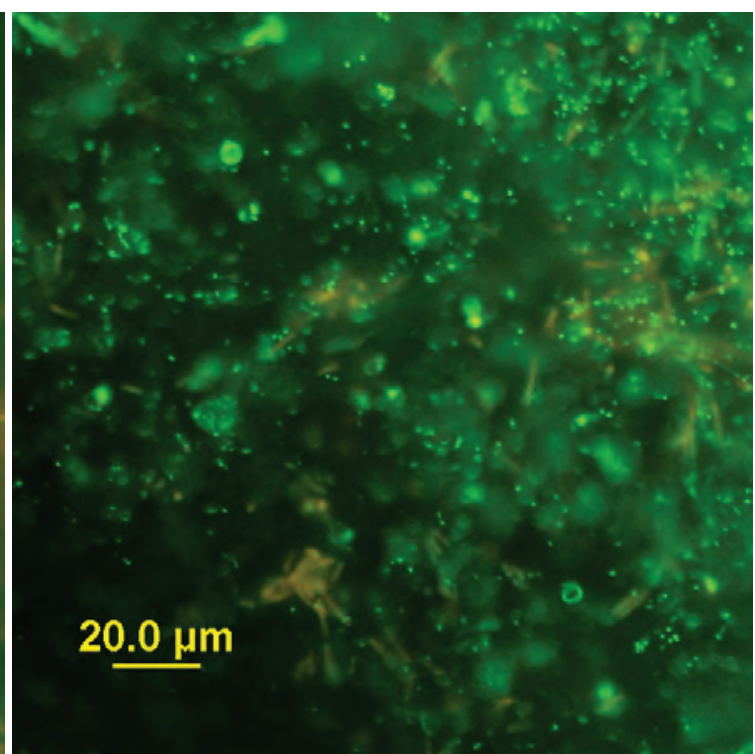

Sytox ${ }^{\circledR}$ green

Boiled for 5 minutes

Figure 130. Iron Gate Reservoir, OR (8/25/2009). LM-Microcystis aeruginosa. FITC-an orange color dominates the cells. Sytox ${ }^{\circledR}$ green-stain did penetrate the cell membrane; cells bright green. LM - differential interference contrast microscopy; FITC - epifluorescent microscopy; Sytox ${ }^{\circledR}$ green - epifluorescent microscopy in conjunction with the nucleic acid stain Sytox ${ }^{\circledR}$ green. 


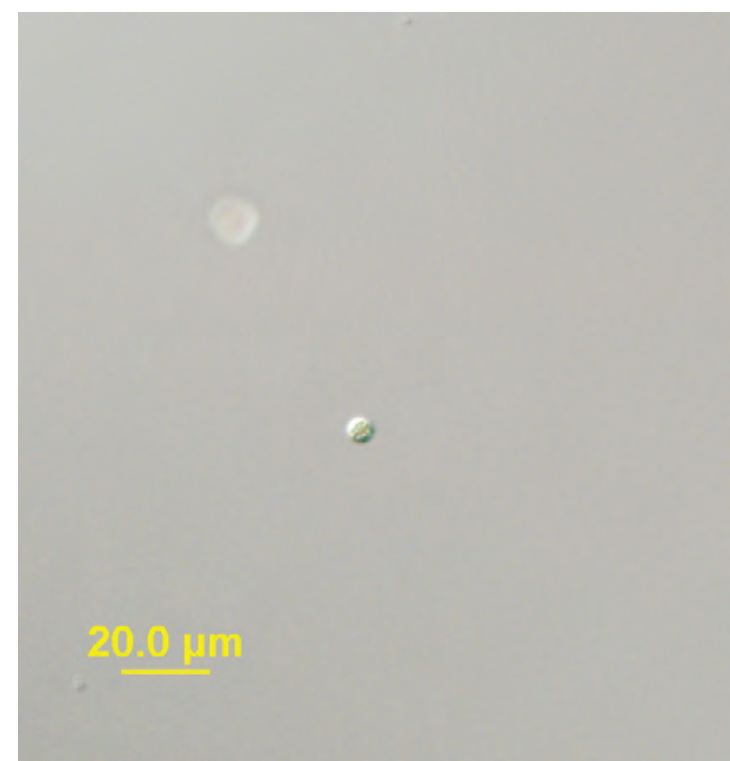

LM

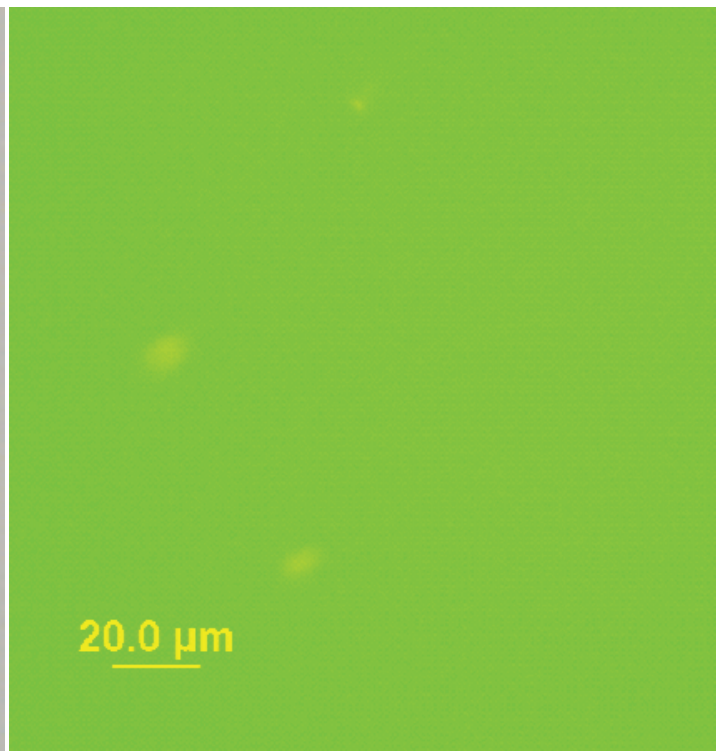

FITC

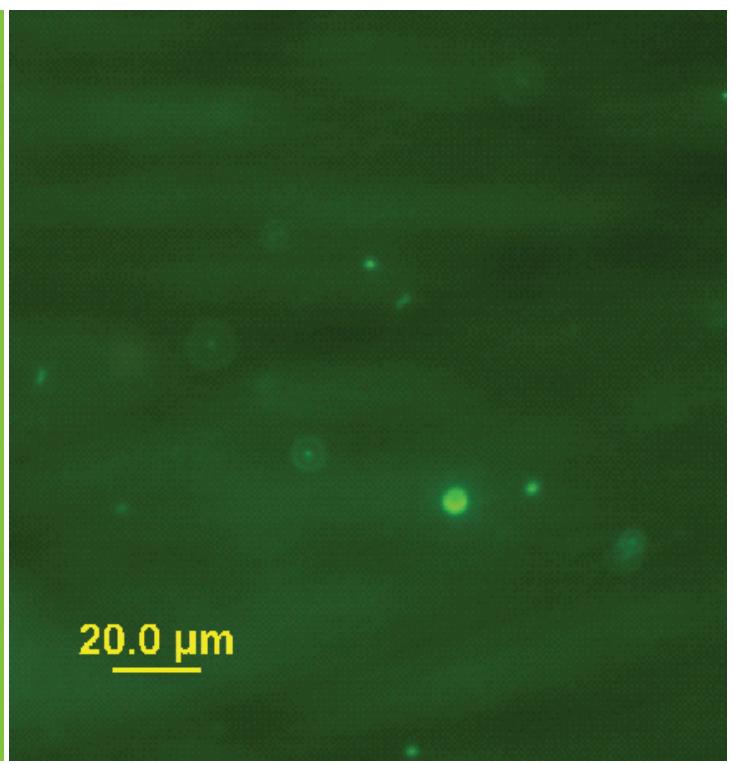

Sytox ${ }^{\circledR}$ green

\section{Boiled for 15 minutes}

Figure 131. Iron Gate Reservoir, $\mathrm{OR}(8 / 25 / 2009)$. LM-Possible remains of Microcystis aeruginosa. FITC-an orange color dominates the cells. Sytox ${ }^{\circledR}$ green-stain did penetrate the cell membrane; cell bright green. LM - differential interference contrast microscopy; FITC - epifluorescent microscopy; Sytox ${ }^{\oplus}$ green - epifluorescent microscopy in conjunction with the nucleic acid stain Sytox ${ }^{\circledR}$ green. 


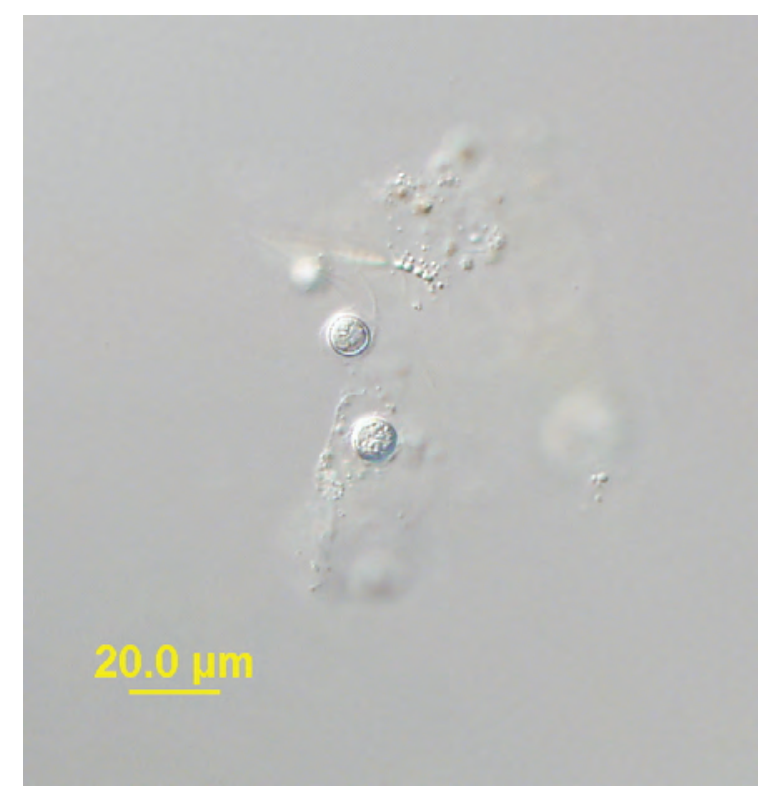

LM

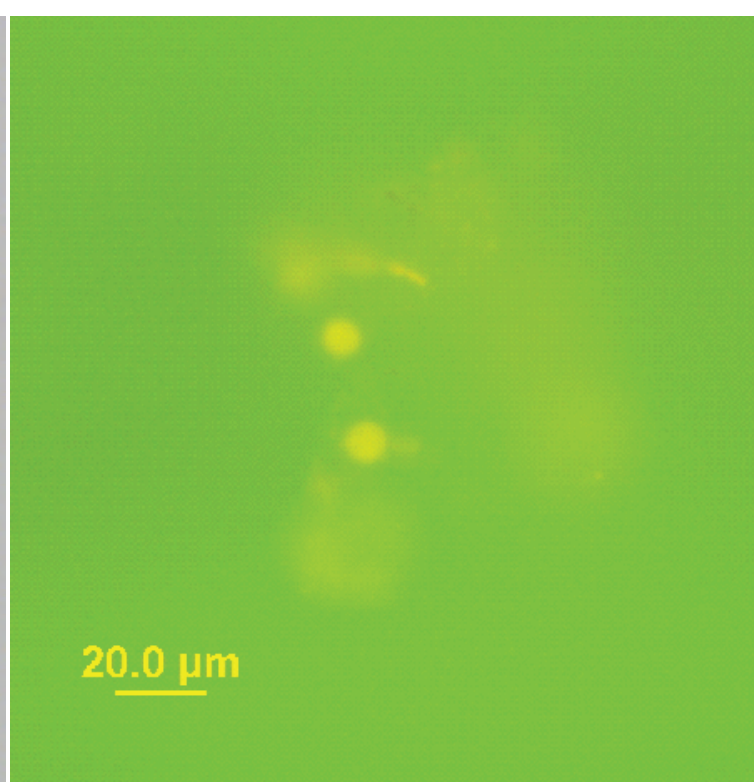

FITC

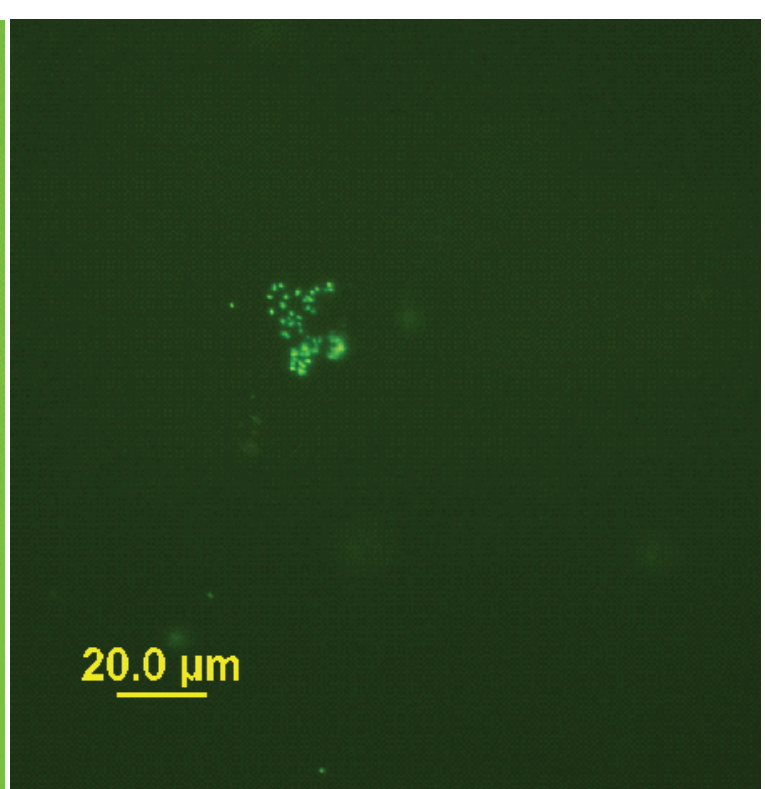

Sytox ${ }^{\circledR}$ green

\section{Boiled for 30 minutes}

Figure 132. Iron Gate Reservoir, OR (8/25/2009). LM-Possible remains of Microcystis aeruginosa. FITC-an orange-yellow color dominates the cells. Sytox ${ }^{\circledR}$ greenstain did penetrate the cell membrane; cells bright green. LM - differential interference contrast microscopy; FITC - epifluorescent microscopy; Sytox ${ }^{\circledR}$ green epifluorescent microscopy in conjunction with the nucleic acid stain Sytox ${ }^{\circledR}$ green. 


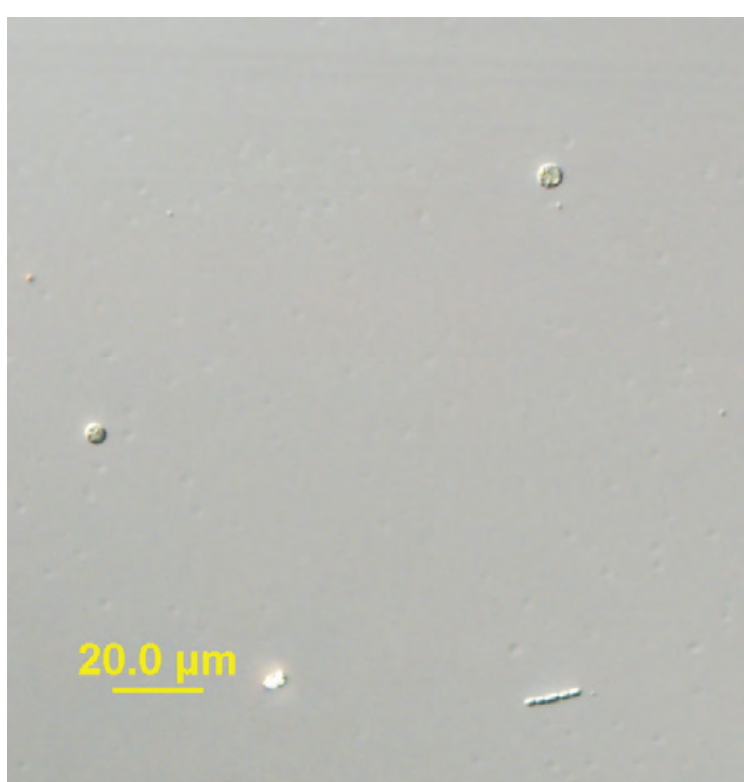

LM

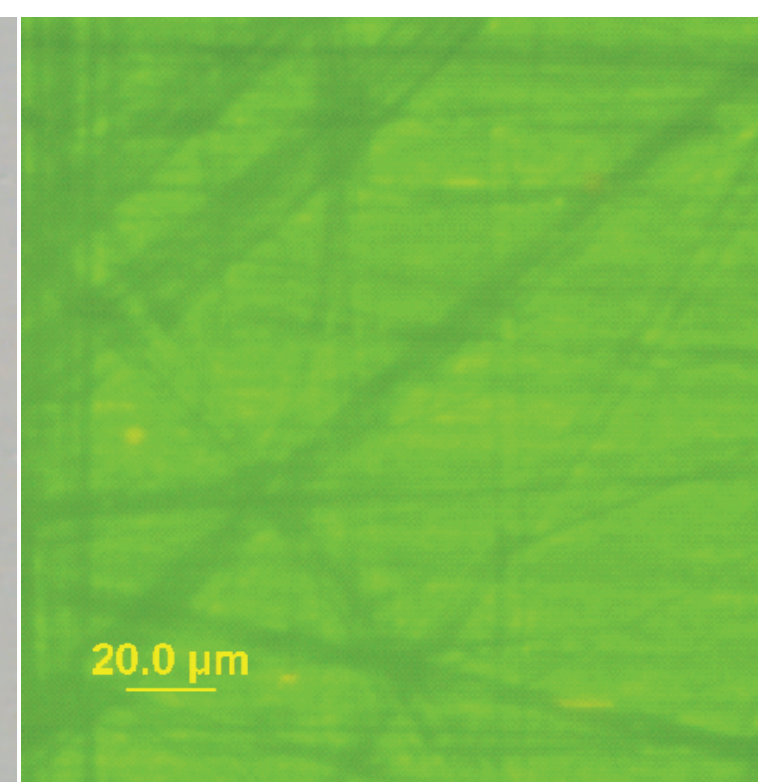

FITC

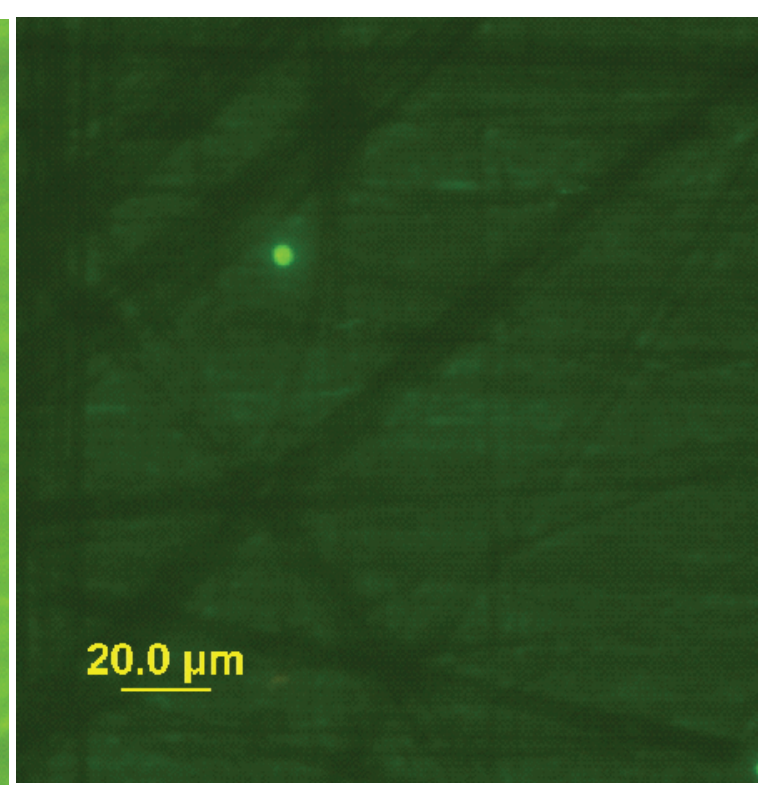

Sytox ${ }^{\circledR}$ green

\section{Autoclaved for 5 minutes}

Figure 133. Iron Gate Reservoir, OR (8/25/2009). LM-Possible remains of Microcystis aeruginosa. FITC-an orange-yellow color dominates the cells. Sytox ${ }^{\circledR}$ greenstain did penetrate the cell membrane; cell bright green. LM - differential interference contrast microscopy; FITC - epifluorescent microscopy; Sytox ${ }^{\circledR}$ green epifluorescent microscopy in conjunction with the nucleic acid stain Sytox ${ }^{\circledR}$ green. 


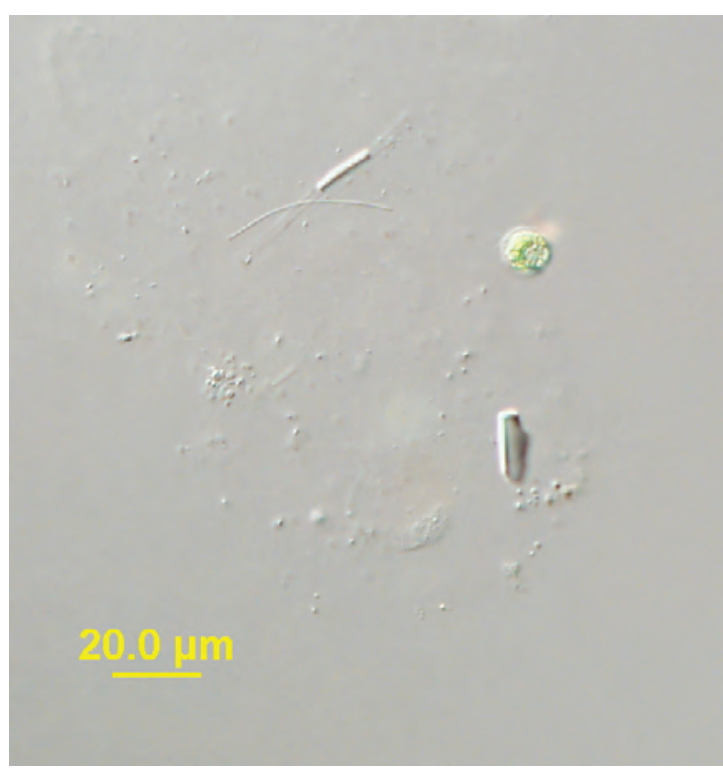

LM

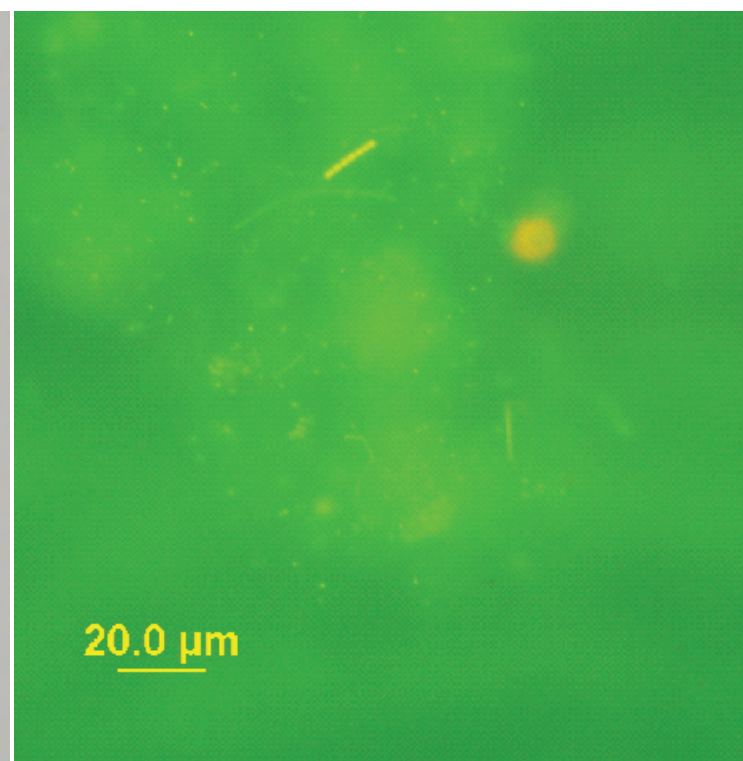

FITC

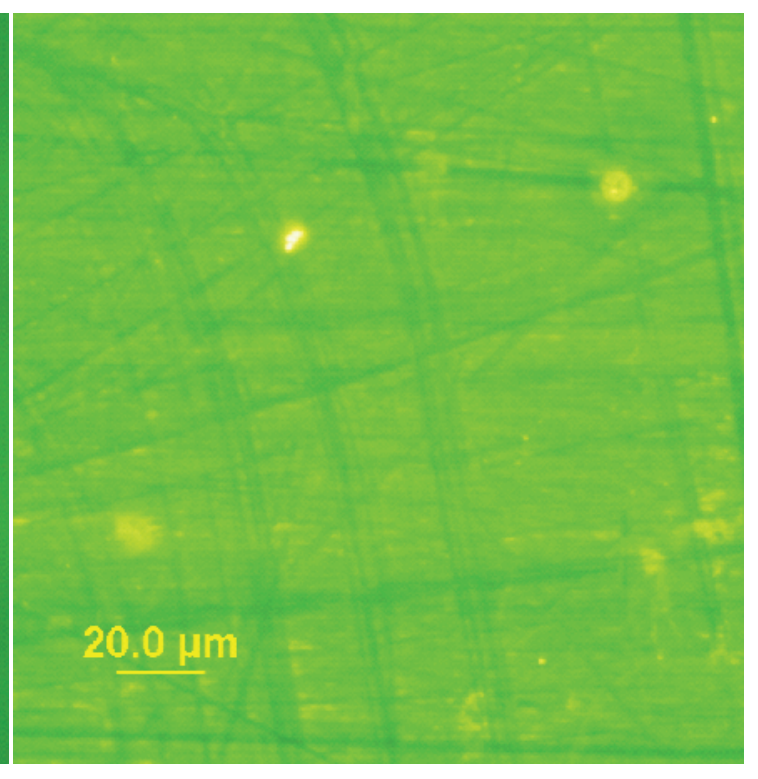

Sytox ${ }^{\circledR}$ green

\section{Autoclaved for 15 minutes}

Figure 134. Iron Gate Reservoir, OR (8/25/2009). LM-Possible remains of Microcystis aeruginosa. FITC-no cyanobacteria cells. Sytox ${ }^{\circledR}$ green-no cyanobacteria cells.

LM - differential interference contrast microscopy; FITC - epifluorescent microscopy; Sytox ${ }^{\circledR}$ green - epifluorescent microscopy in conjunction with the nucleic acid stain Sytox ${ }^{\circledR}$ green. 


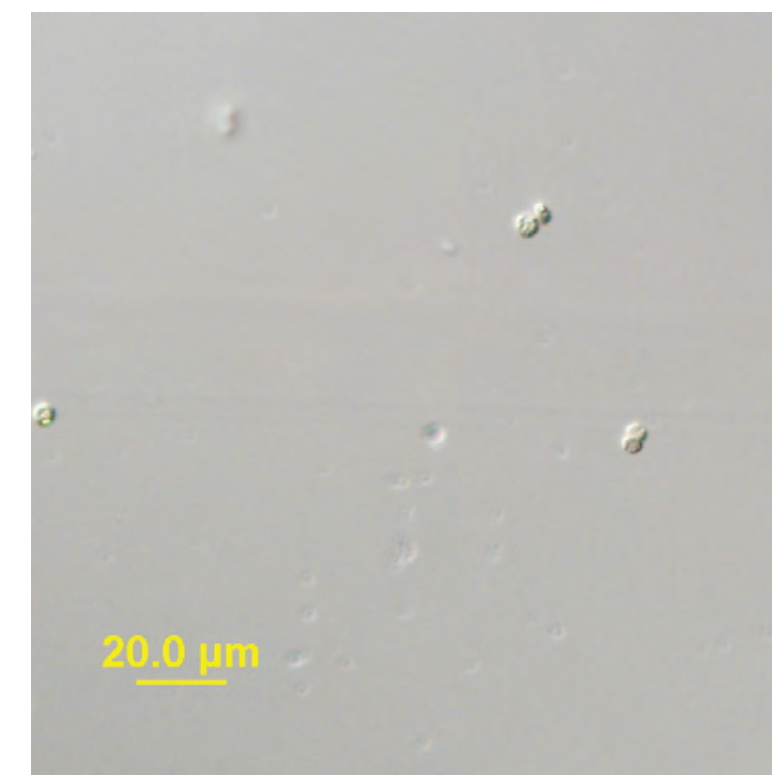

LM

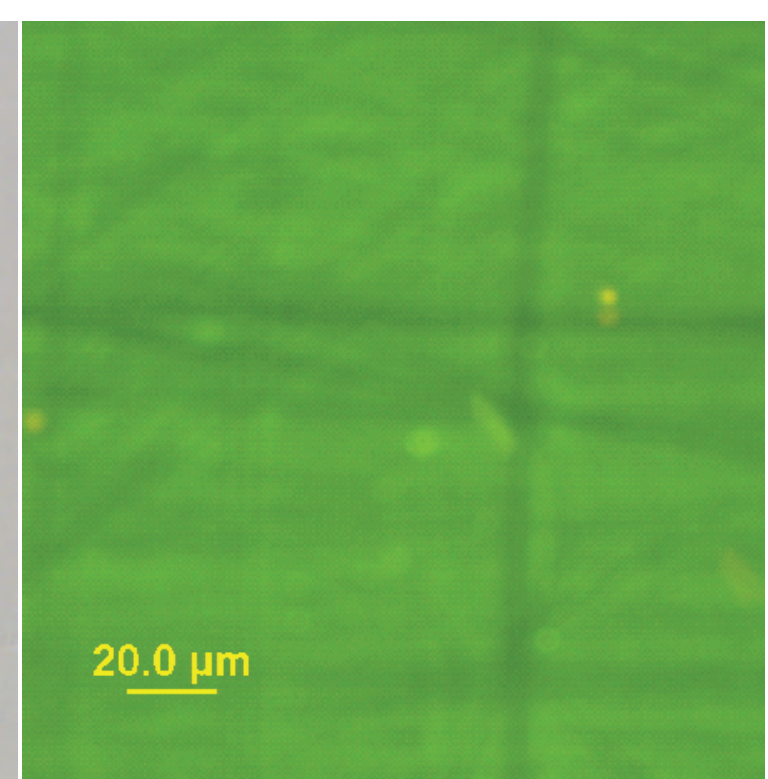

FITC

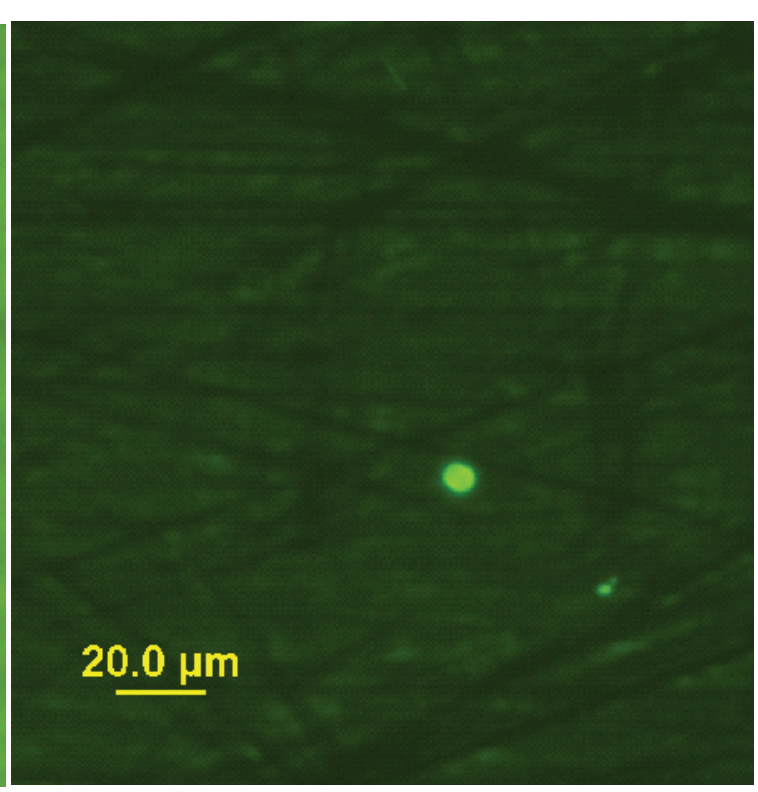

Sytox ${ }^{\circledast}$ green

\section{Autoclaved for 30 minutes}

Figure 135. Iron Gate Reservoir, OR (8/25/2009). LM-Possible remains of Microcystis aeruginosa. FITC-an orange-yellow color dominates the cells. Sytox ${ }^{\circledR}$ greenstain did penetrate the cell membrane; cells bright green. LM - differential interference contrast microscopy; FITC - epifluorescent microscopy; Sytox ${ }^{\circledR}$ green epifluorescent microscopy in conjunction with the nucleic acid stain Sytox ${ }^{\oplus}$ green. 


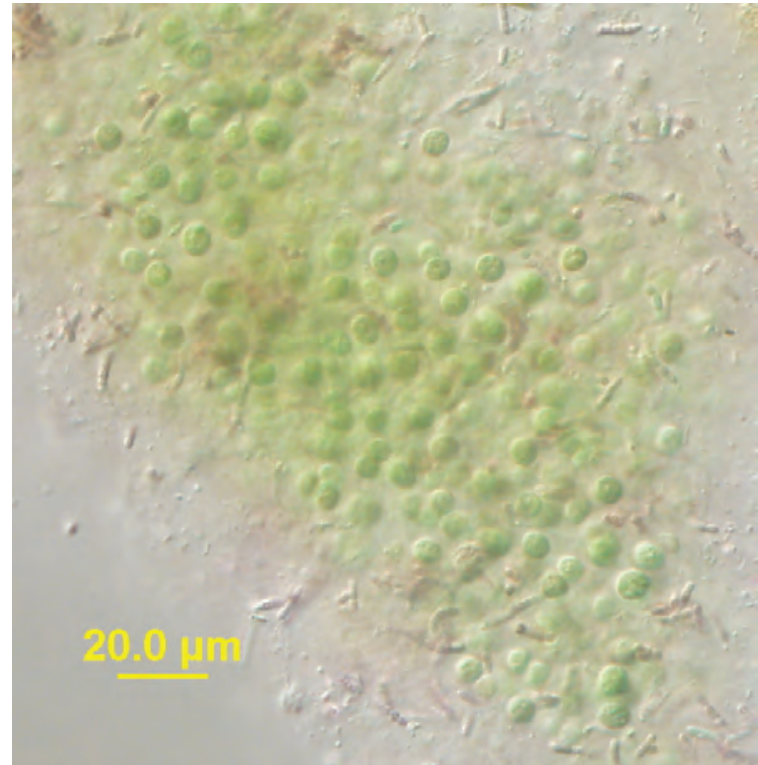

LM

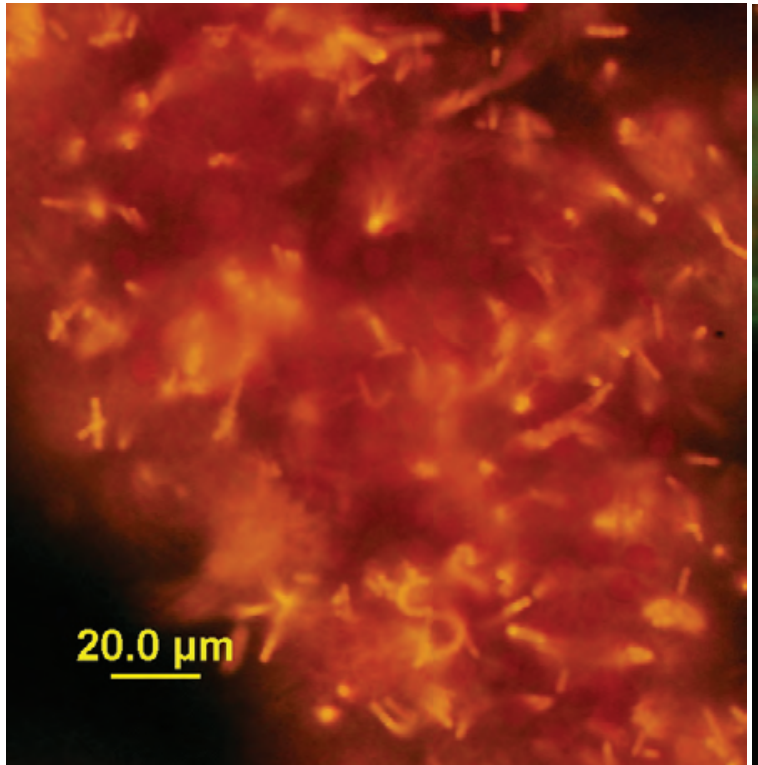

FITC

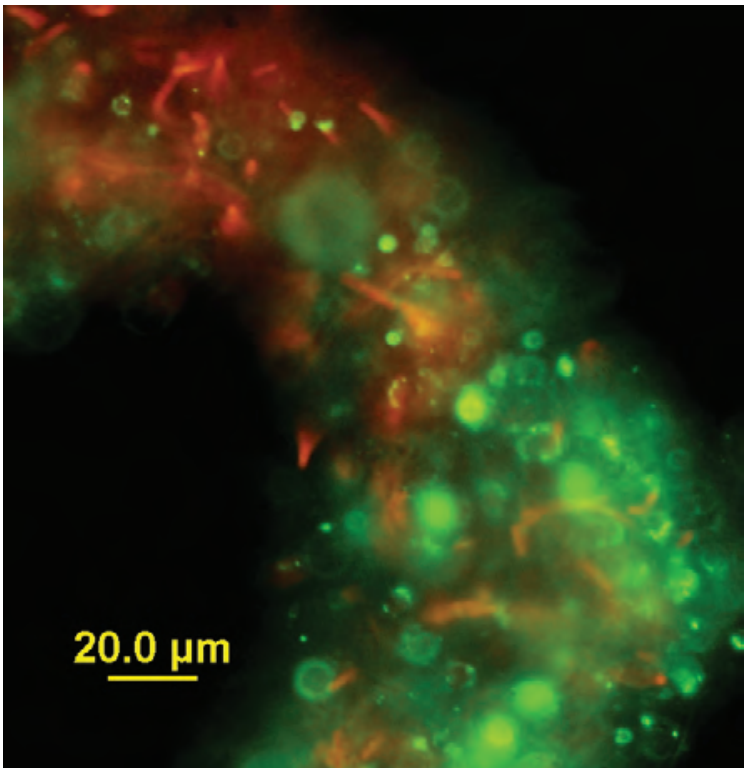

Sytox ${ }^{\circledR}$ green

\section{Sonicated at 10 percent power}

Figure 136. Iron Gate Reservoir, OR (8/25/2009). LM-Microcystis aeruginosa. FITC-a red color dominates the cells; orange filaments are cyanobacterial epiphyte. Sytox ${ }^{\circledR}$ green-stain did penetrate the cell membrane; some cells bright green. LM - differential interference contrast microscopy; FITC - epifluorescent microscopy; Sytox ${ }^{\circledR}$ green - epifluorescent microscopy in conjunction with the nucleic acid stain Sytox ${ }^{\circledR}$ green. 


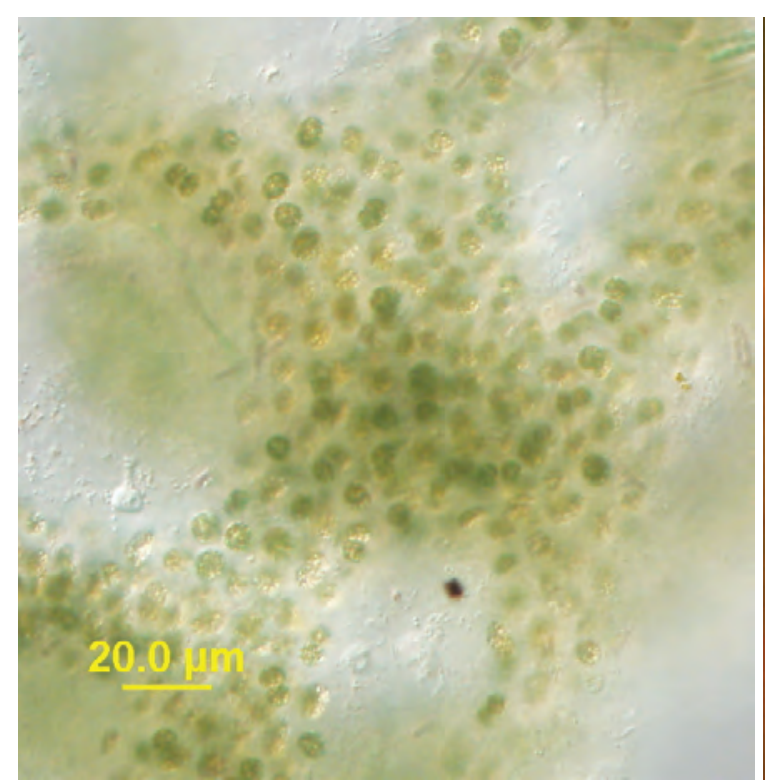

LM

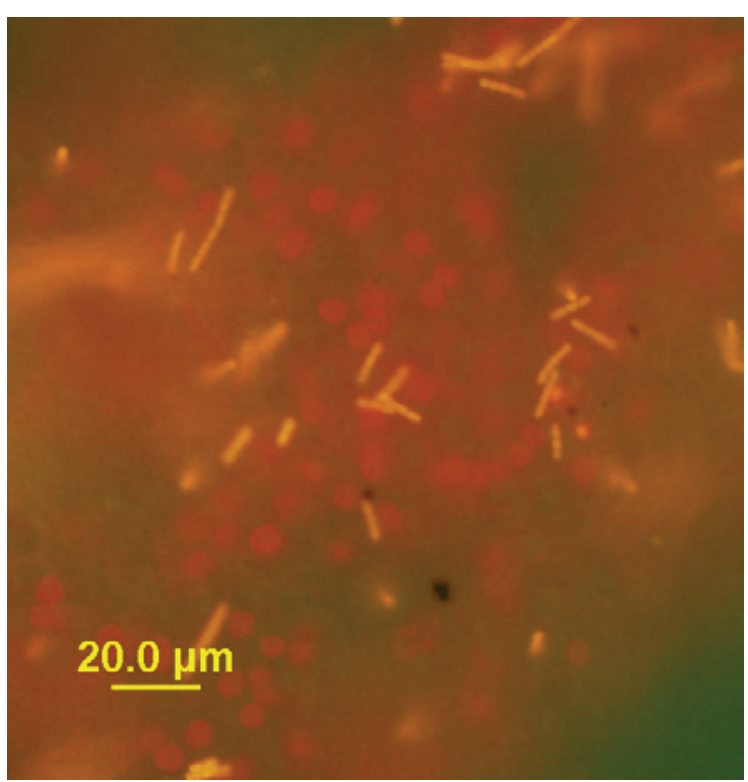

FITC

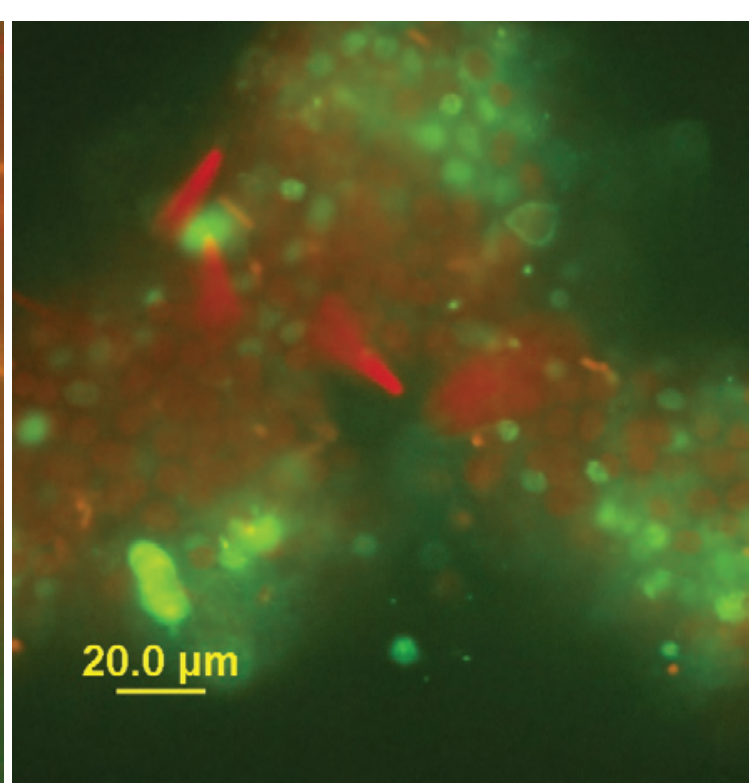

Sytox ${ }^{\circledR}$ green

\section{Sonicated at 35 percent power}

Figure 137. Iron Gate Reservoir, OR (8/25/2009). LM-Microcystis aeruginosa. FITC-a red color dominates the cells; orange filaments are cyanobacterial epiphyte. Sytox ${ }^{\oplus}$ green-stain did penetrate the cell membrane of the peripheral cells; cells bright green. LM - differential interference contrast microscopy; FITC epifluorescent microscopy; Sytox ${ }^{\circledR}$ green - epifluorescent microscopy in conjunction with the nucleic acid stain Sytox ${ }^{\circledast}$ green. 


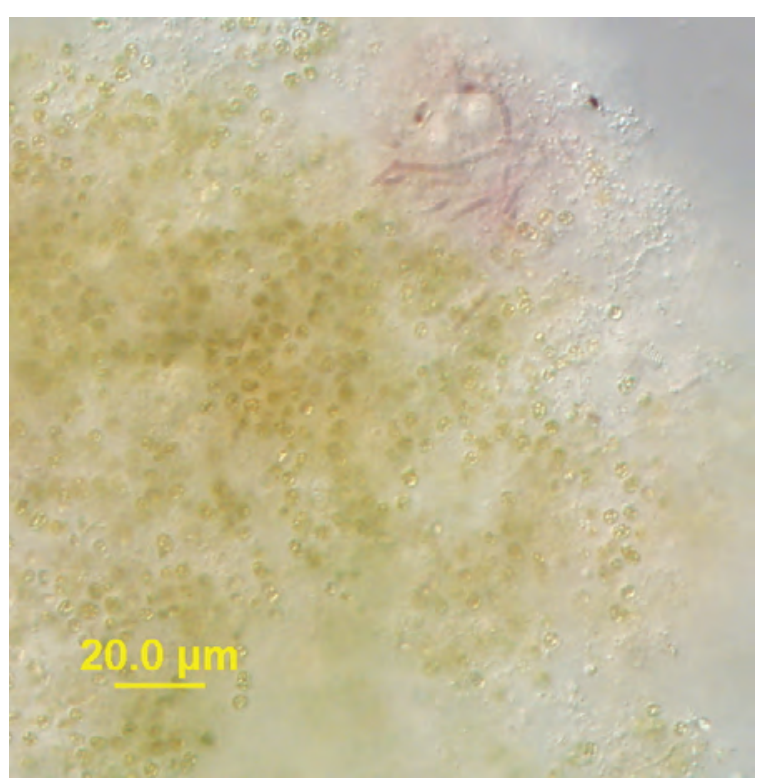

LM

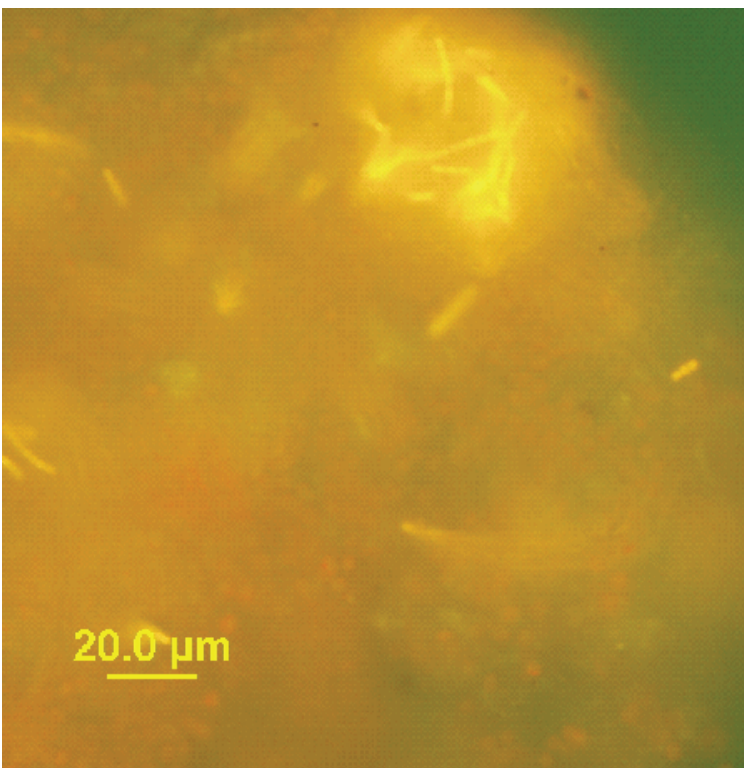

FITC

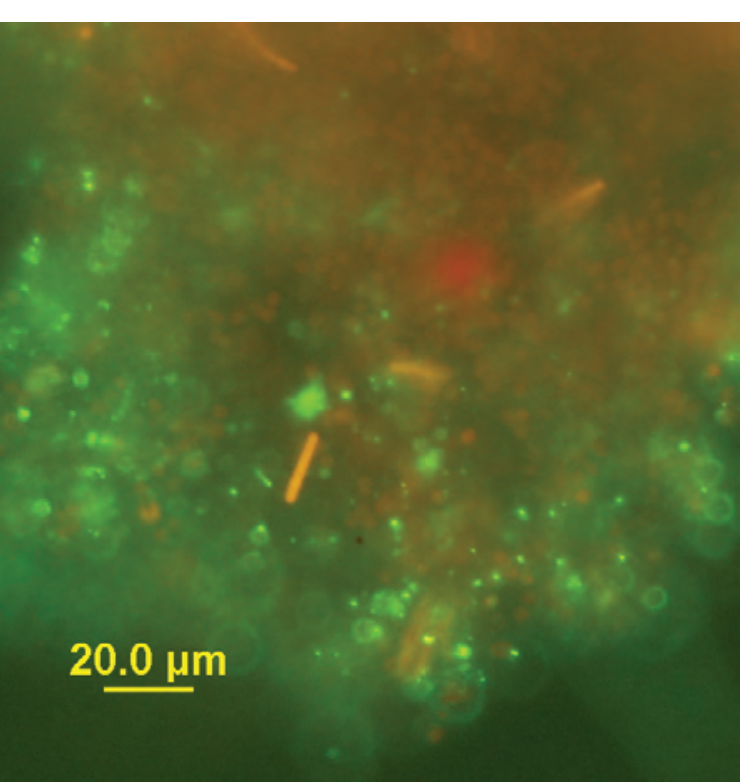

Sytox ${ }^{\circledR}$ green

\section{Sonicated at 70 percent power}

Figure 138. Iron Gate Reservoir, OR (8/25/2009). LM-Microcystis aeruginosa. FITC-a red color dominates the cells; yellow-orange filaments are cyanobacterial epiphyte. Sytox ${ }^{\circledR}$ green-stain did penetrate the cell membrane of the peripheral cells and epiphytic bacterial cells that are bright green. LM - differential interference contrast microscopy; FITC - epifluorescent microscopy; Sytox ${ }^{\circledR}$ green - epifluorescent microscopy in conjunction with the nucleic acid stain Sytox ${ }^{\circledR}$ green. 


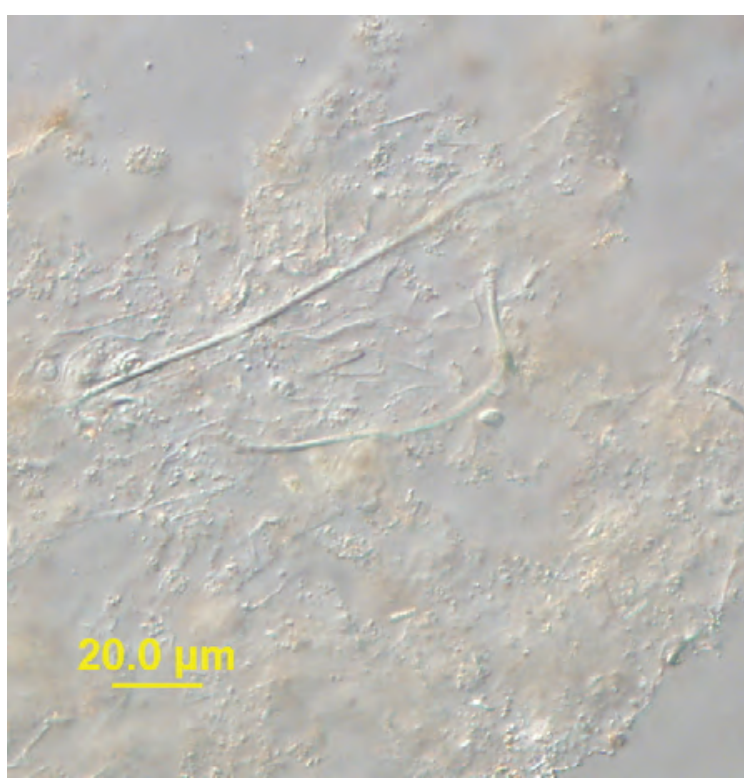

LM

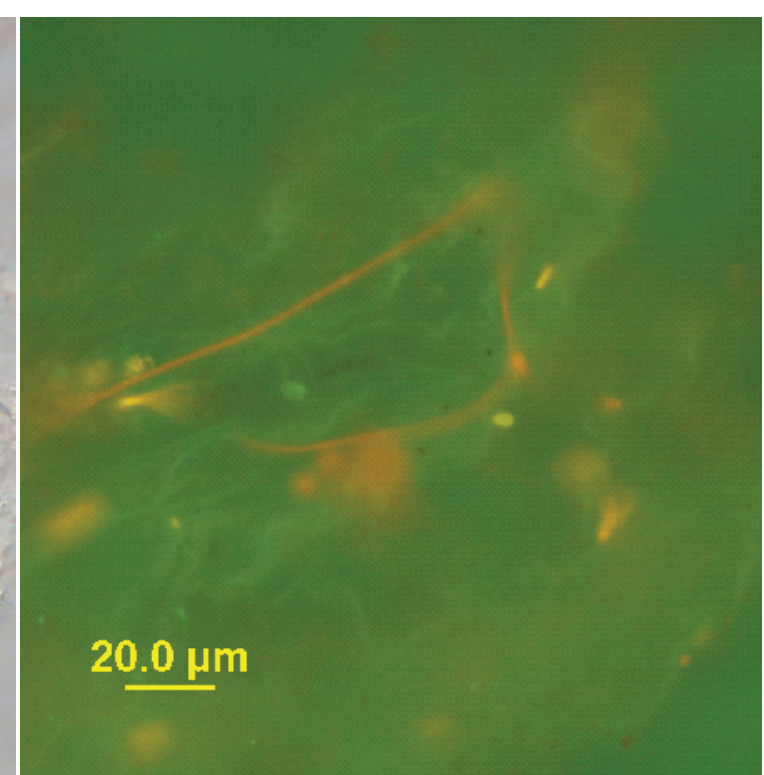

FITC

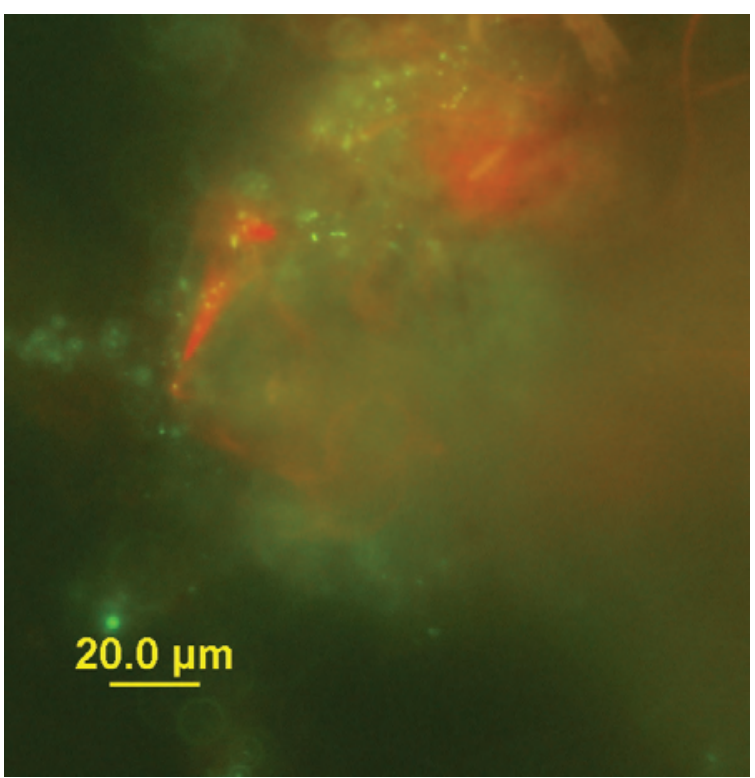

Sytox ${ }^{\circledR}$ green

\section{QuikLyse $^{\mathrm{TM}}-1 \mathrm{x}$}

Figure 139. Iron Gate Reservoir, OR (8/25/2009). LM-Unknown filamentous cyanobacterium. FITC-an orange color dominates the cells. Sytox ${ }^{\circledR}$ green-cannot be determined. LM - differential interference contrast microscopy; FITC - epifluorescent microscopy; Sytox ${ }^{\circledR}$ green - epifluorescent microscopy in conjunction with the nucleic acid stain Sytox ${ }^{\circledR}$ green. 


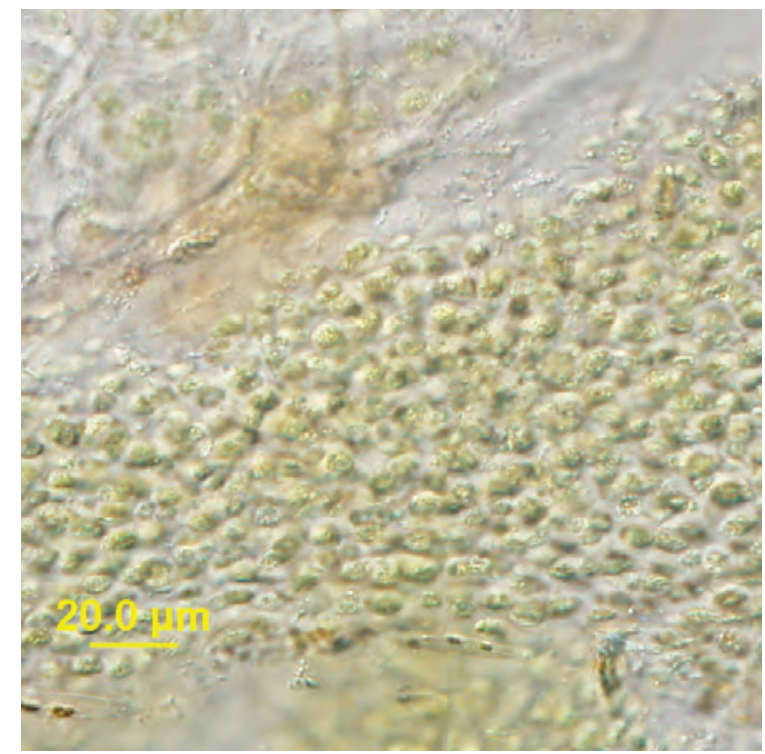

LM

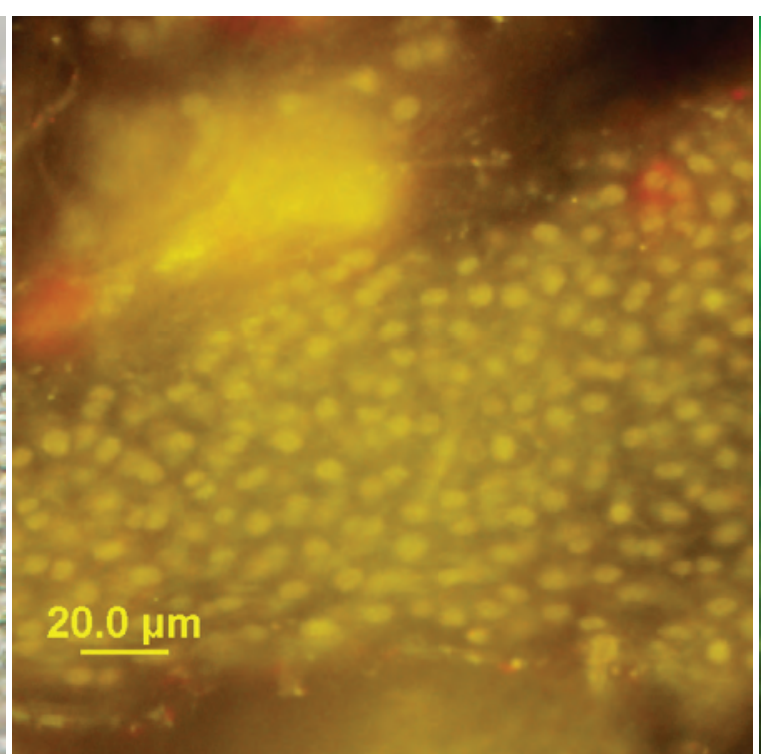

FITC

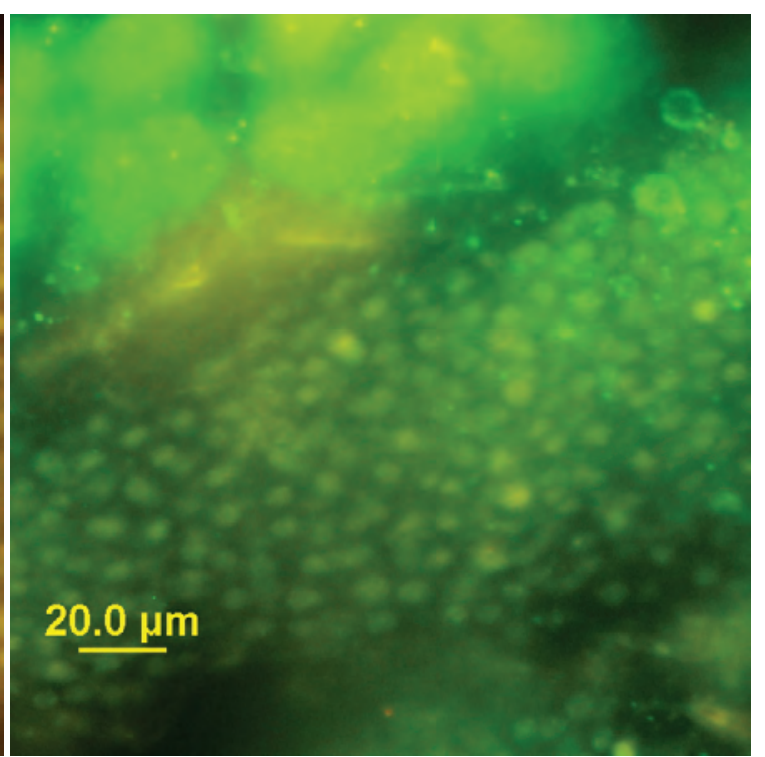

Sytox ${ }^{\circledR}$ green

\section{One freeze-thaw cycle}

Figure 140. Iron Gate Reservoir, OR (8/25/2009). LM-Microcystis aeruginosa. FITC-a yellow color dominates the cells. Sytox ${ }^{\circledR}$ green-stain did penetrate the cell membrane; cells yellow-green. LM - differential interference contrast microscopy; FITC - epifluorescent microscopy; Sytox ${ }^{\circledR}$ green - epifluorescent microscopy in conjunction with the nucleic acid stain Sytox ${ }^{\circledR}$ green. 


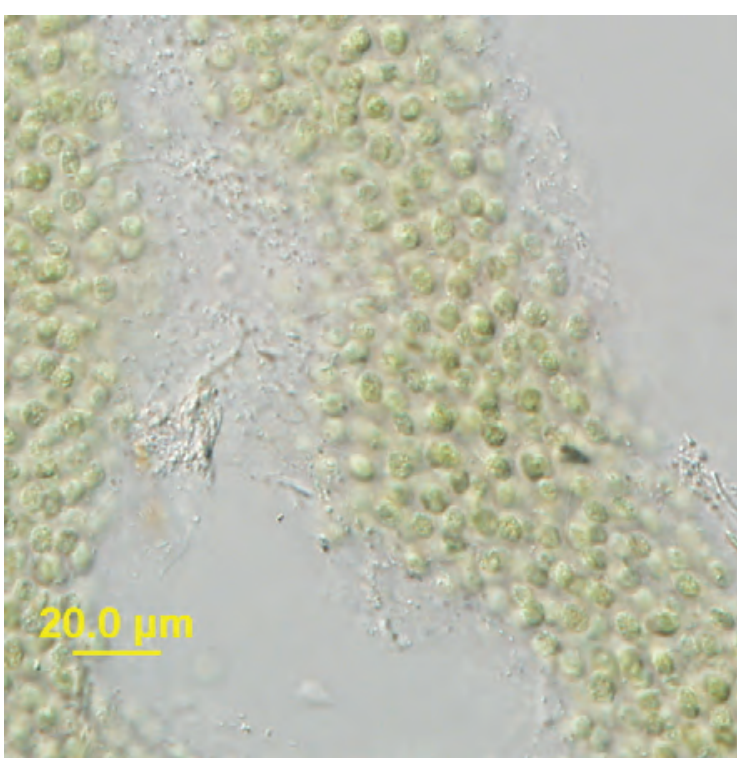

LM

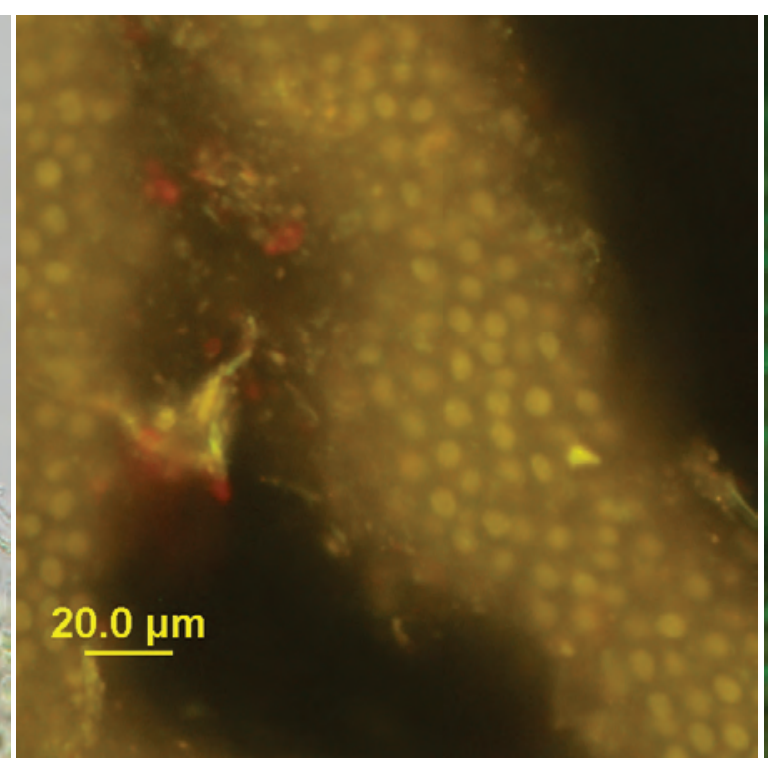

FITC

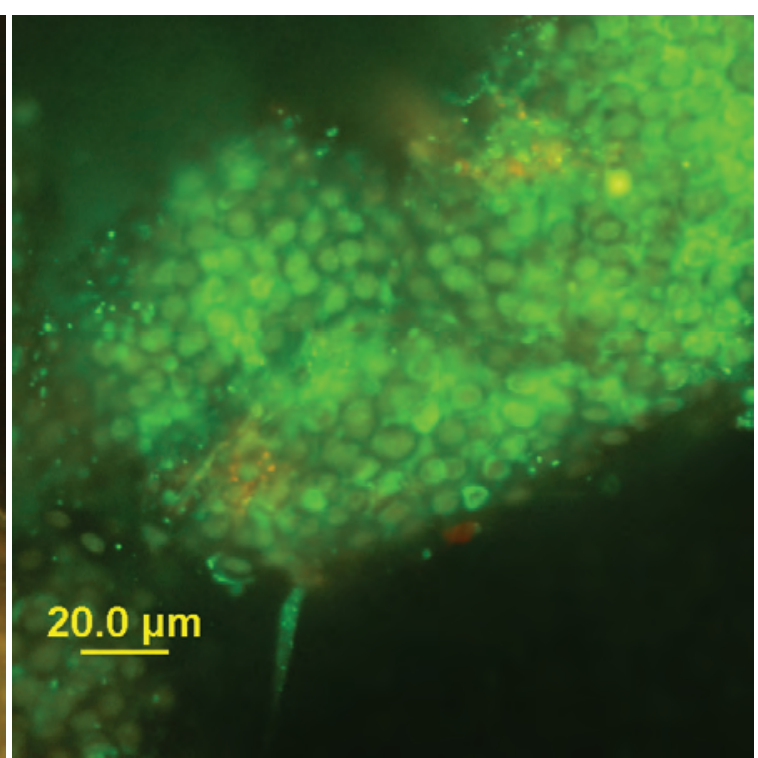

Sytox ${ }^{\circledR}$ green

Two freeze-thaw cycles

Figure 141. Iron Gate Reservoir, OR (8/25/2009). LM-Microcystis aeruginosa. FITC-a yellow-orange color dominates the cells. Sytox ${ }^{\circledR}$ green-stain did penetrate the cell membrane; cells and the mucilage are green. LM - differential interference contrast microscopy; FITC - epifluorescent microscopy; Sytox ${ }^{\circledR}$ green - epifluorescent microscopy in conjunction with the nucleic acid stain Sytox ${ }^{\circledR}$ green. 


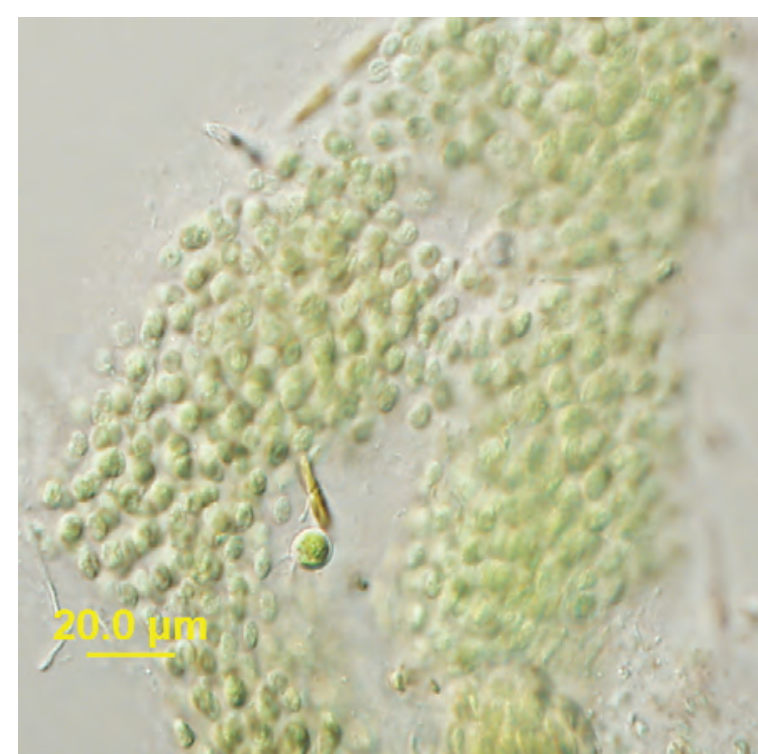

LM

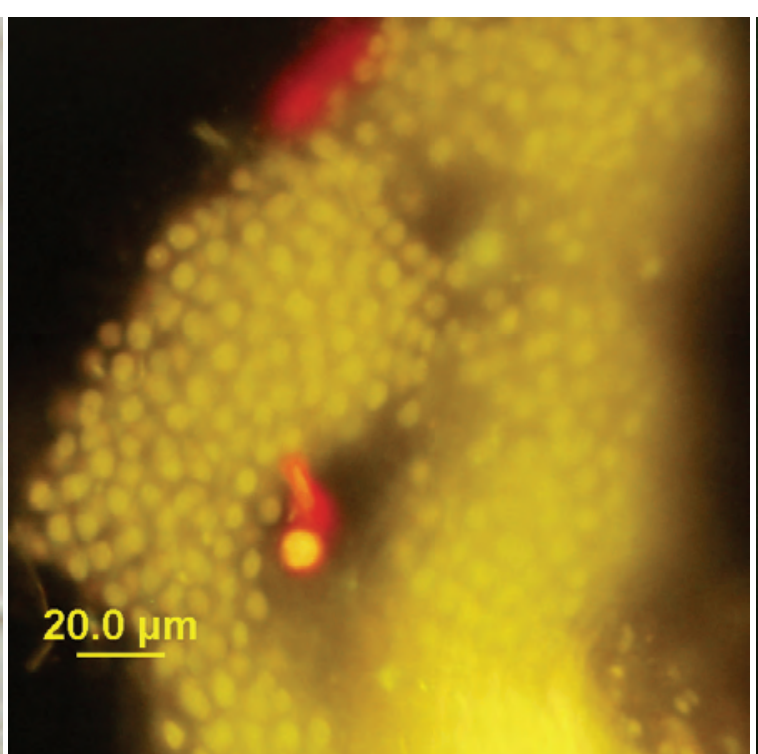

FITC

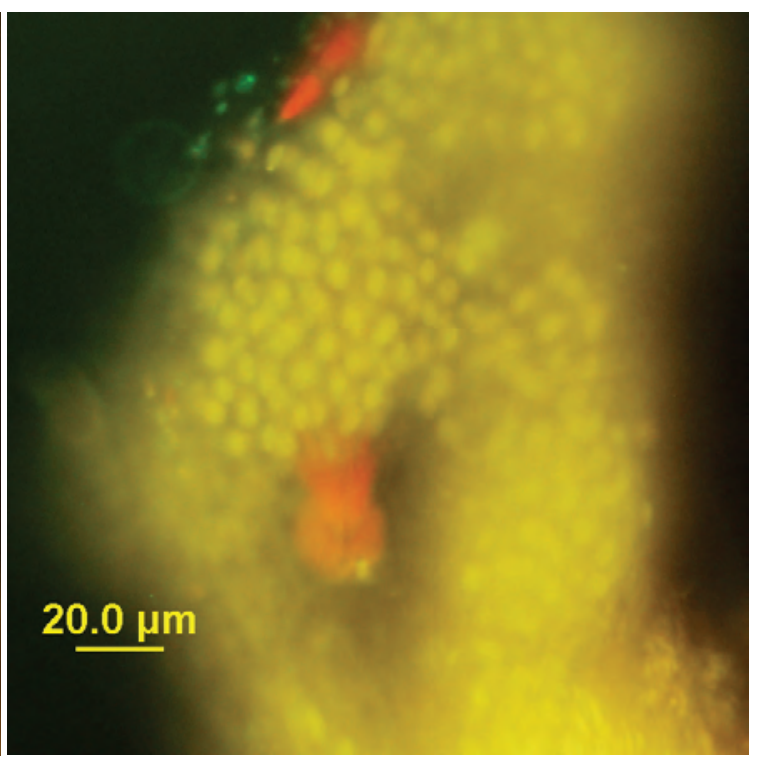

Sytox ${ }^{\circledast}$ green

Three freeze-thaw cycles

Figure 142. Iron Gate Reservoir, OR (8/25/2009). LM-Microcystis aeruginosa. FITC-a yellow color dominates the cells. Sytox ${ }^{\circledR}$ green-stain did not penetrate the cell membrane. LM - differential interference contrast microscopy; FITC - epifluorescent microscopy; Sytox ${ }^{\circledR}$ green - epifluorescent microscopy in conjunction with the nucleic acid stain Sytox ${ }^{\circledR}$ green. 


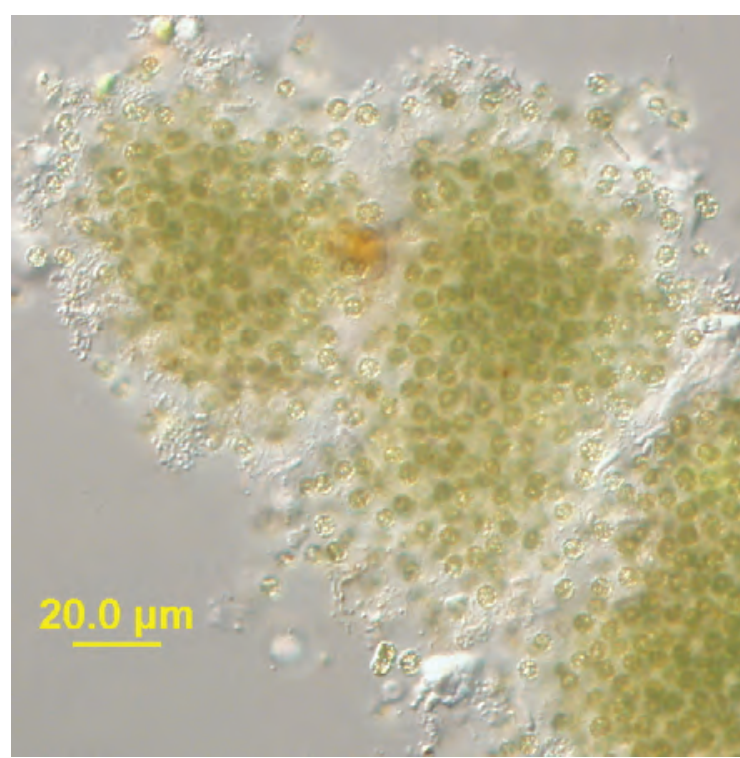

LM

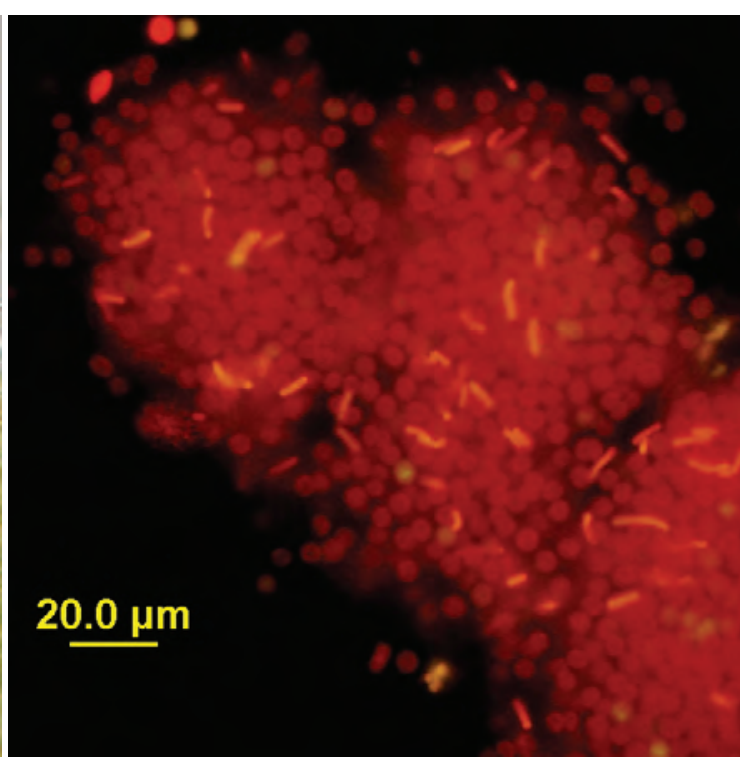

FITC

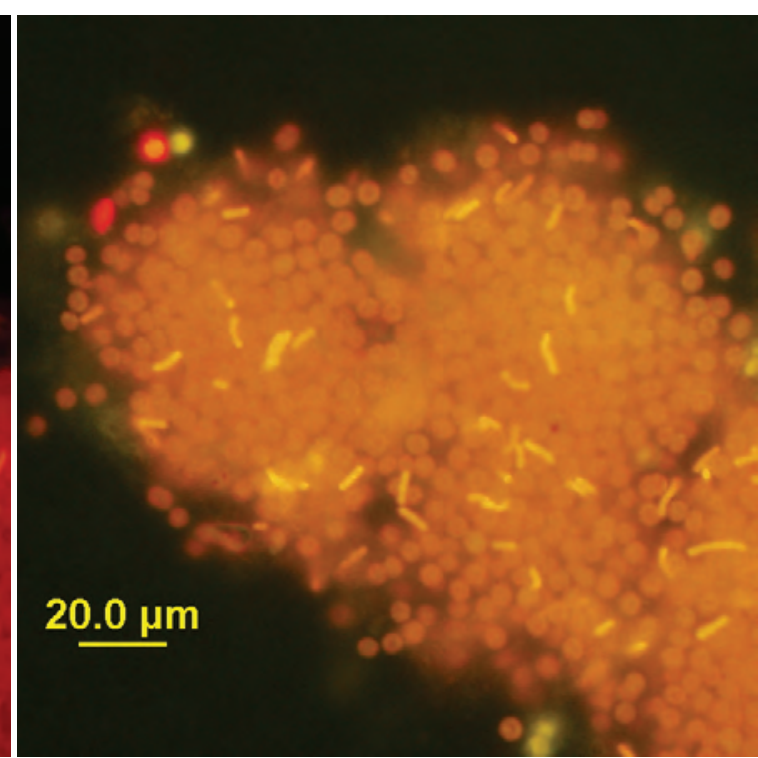

Sytox ${ }^{\circledR}$ green

Control 1

Figure 143. Pinto Lake, CA (9/22/2009). LM-Microcystis aeruginosa. FITC-a red color dominates the cells; orange filaments are cyanobacterial epiphytes. Sytox ${ }^{\circledR}$ green-stain did not penetrate the cell membrane. LM - differential interference contrast microscopy; FITC - epifluorescent microscopy; Sytox ${ }^{\circledR}$ green - epifluorescent microscopy in conjunction with the nucleic acid stain Sytox ${ }^{\circledR}$ green. 


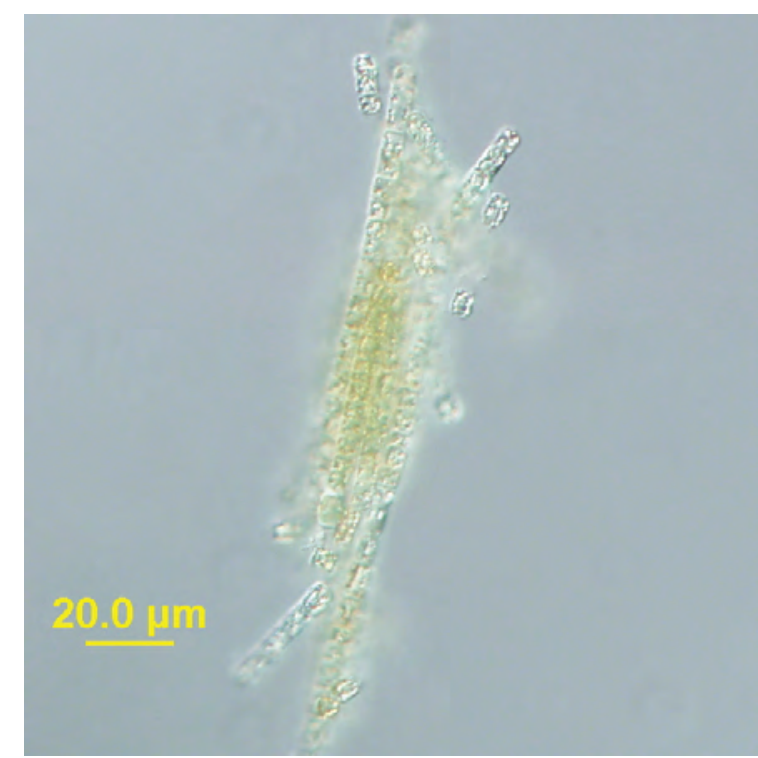

LM

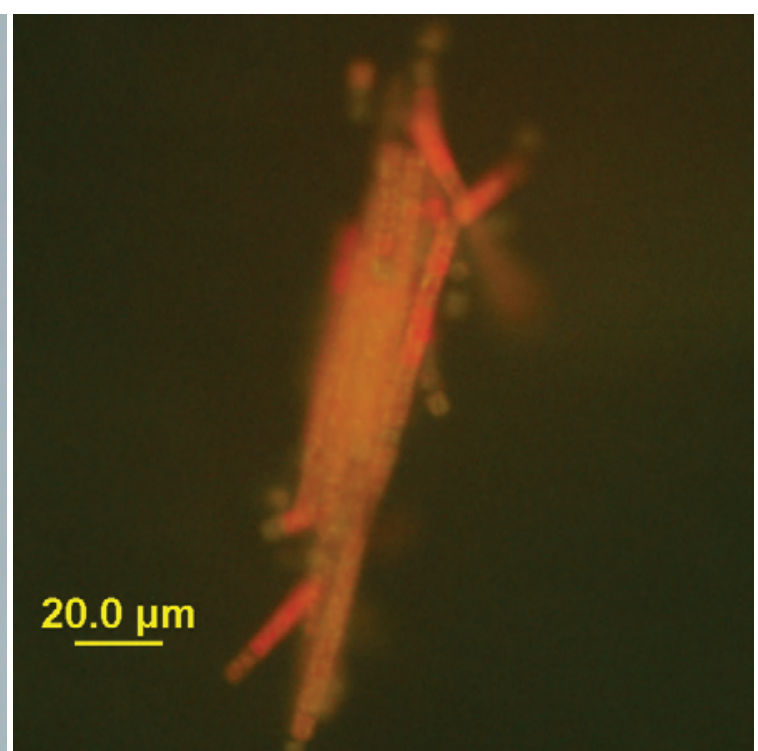

FITC

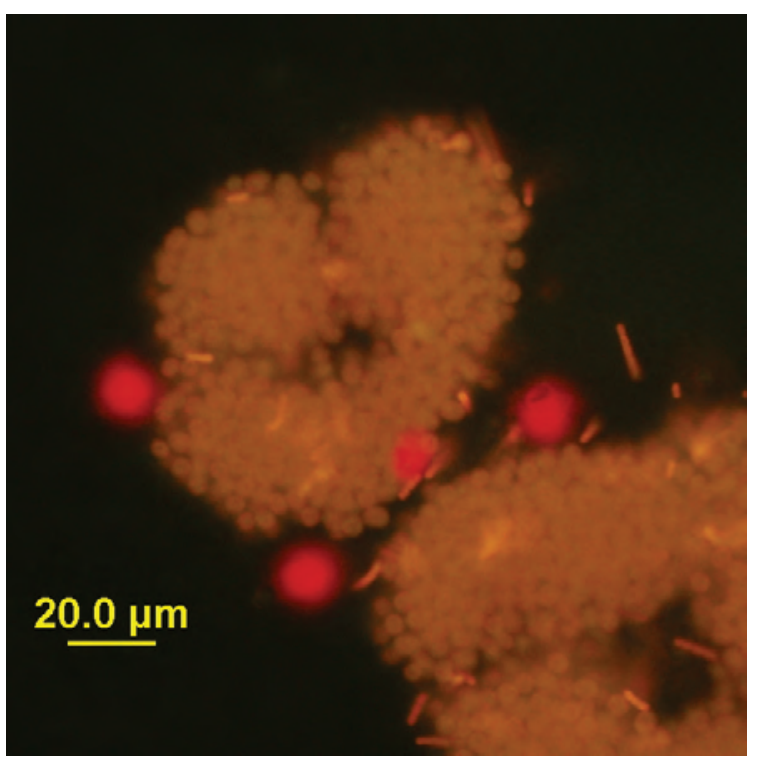

Sytox ${ }^{\circledR}$ green

Control 2

Figure 144. Pinto Lake, CA (9/22/2009). LM- Aphanizomenon flos-aquae. FITC-an orange color dominates the cells. Sytox ${ }^{\circledR}$ green-Microcystis aeruginosa; stain did not penetrate the cell membrane. LM - differential interference contrast microscopy; FITC - epifluorescent microscopy; Sytox ${ }^{\circledR}$ green - epifluorescent microscopy in conjunction with the nucleic acid stain Syto ${ }^{\circledR}$ green. 


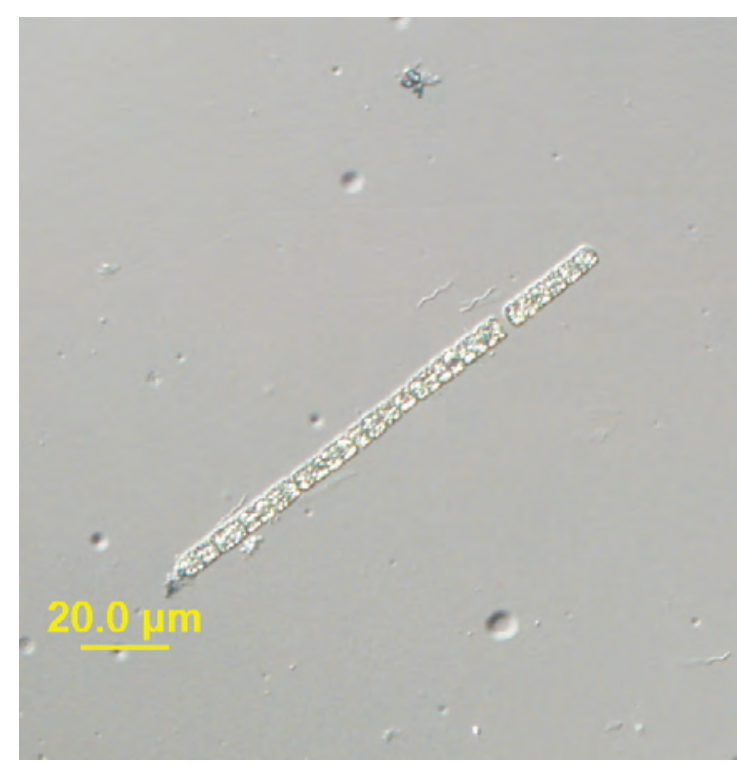

LM

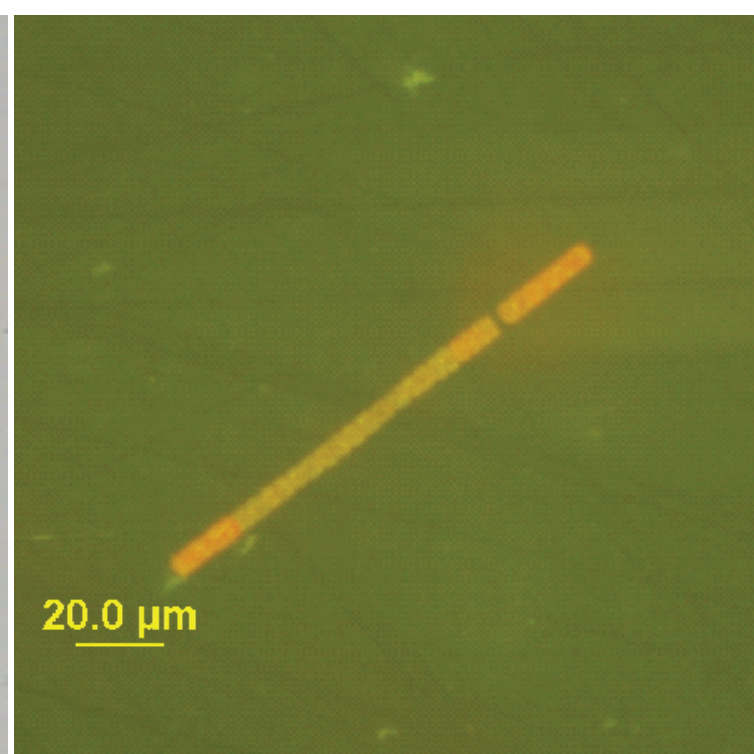

FITC

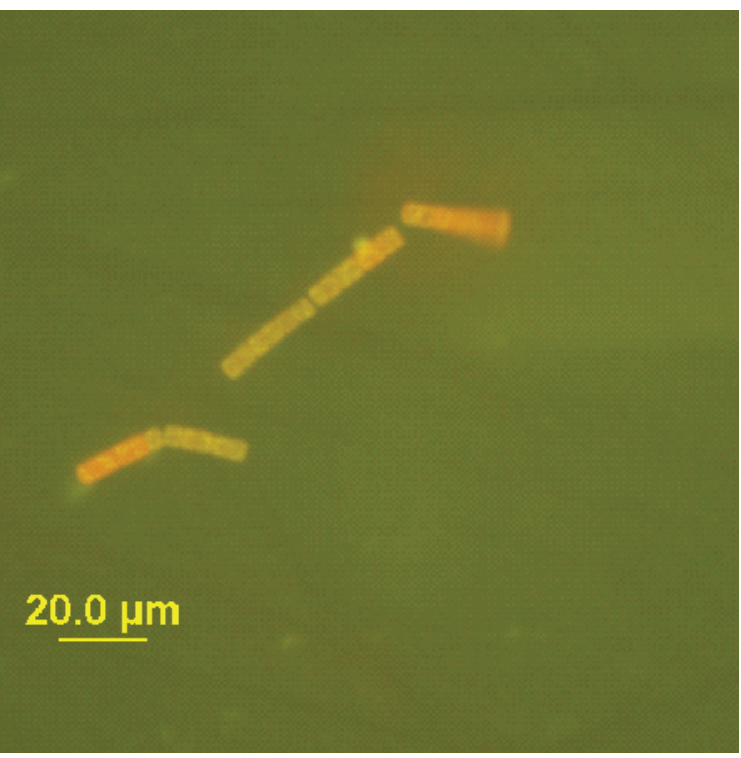

Sytox ${ }^{\circledR}$ green

\section{Control 3}

Figure 145. Pinto Lake, CA (9/22/2009). LM- Aphanizomenon flos-aquae. FITC-an orange color dominates the cells. Sytox ${ }^{\circledast}$ green-stain appears to have penetrated the cell membrane in some cells. LM - differential interference contrast microscopy; FITC - epifluorescent microscopy; Sytox ${ }^{\circledast}$ green - epifluorescent microscopy in conjunction with the nucleic acid stain Sytox ${ }^{\circledR}$ green. 


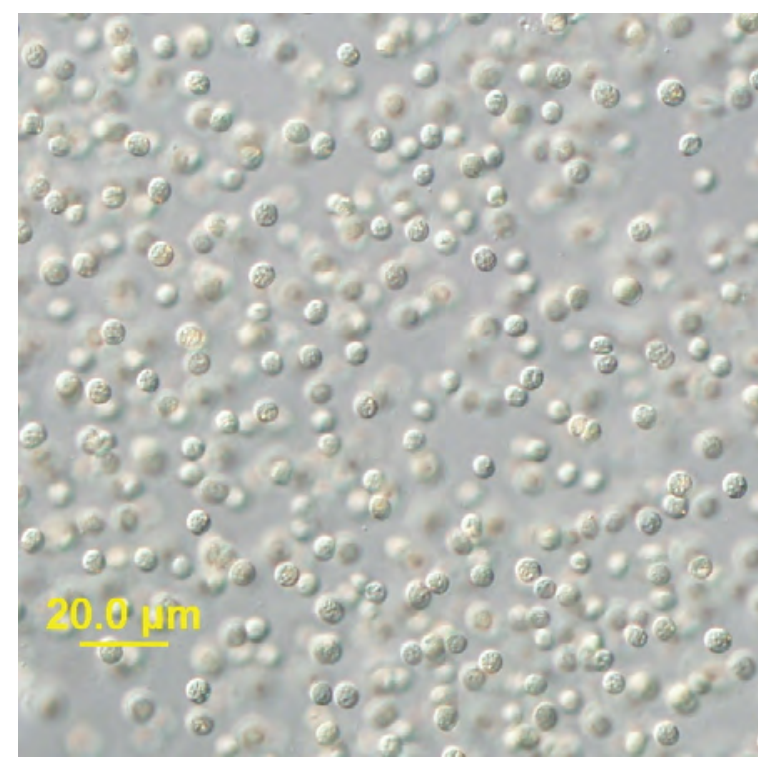

LM

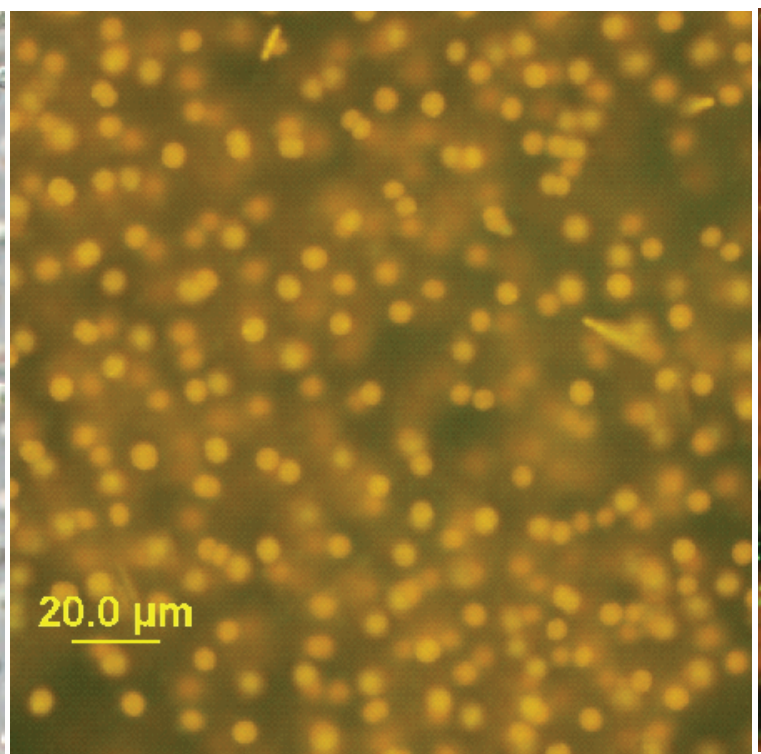

FITC

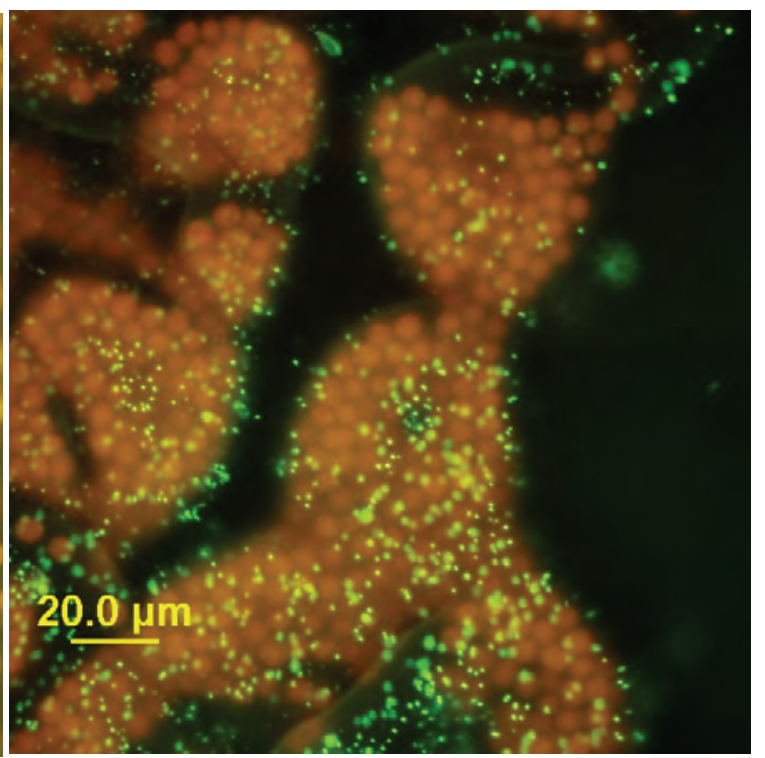

Sytox ${ }^{\circledR}$ green

\section{Boiled for 5 minutes}

Figure 146. Pinto Lake, CA (9/22/2009). LM-Microcystis aeruginosa. FITC-an orange color dominates the cells. Sytox ${ }^{\circledR}$ green-Microcystis wesenbergii-stain did not penetrate the mucilage of the colony; bright green dots are epiphytic bacteria. LM - differential interference contrast microscopy; FITC - epifluorescent microscopy; Sytox ${ }^{\circledast}$ green - epifluorescent microscopy in conjunction with the nucleic acid stain Sytox ${ }^{\circledR}$ green. 


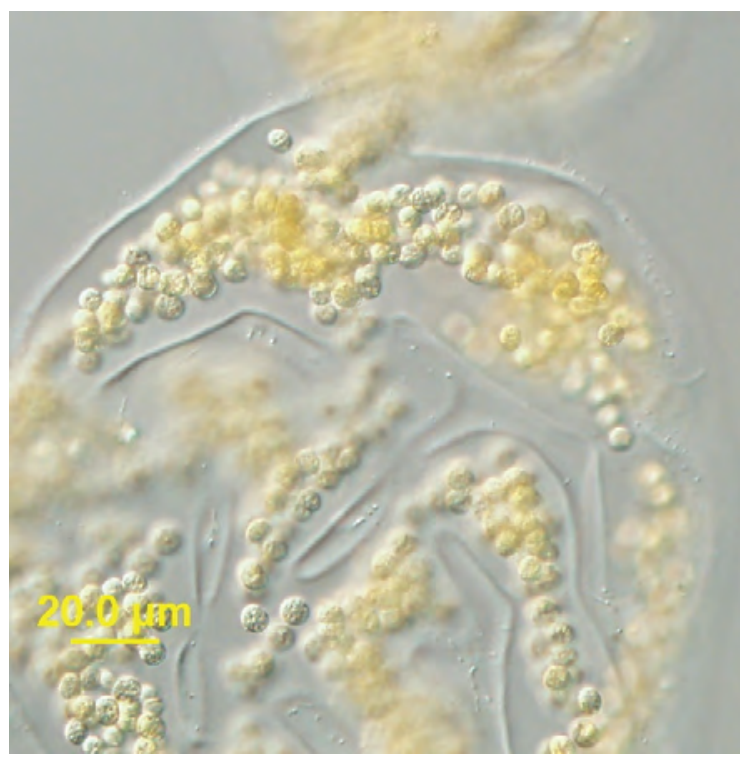

LM

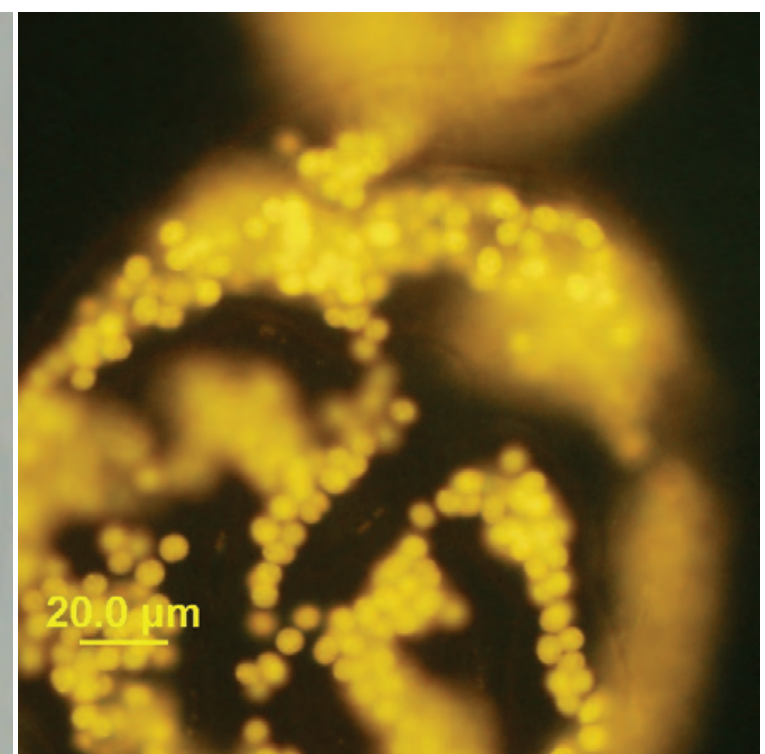

FITC

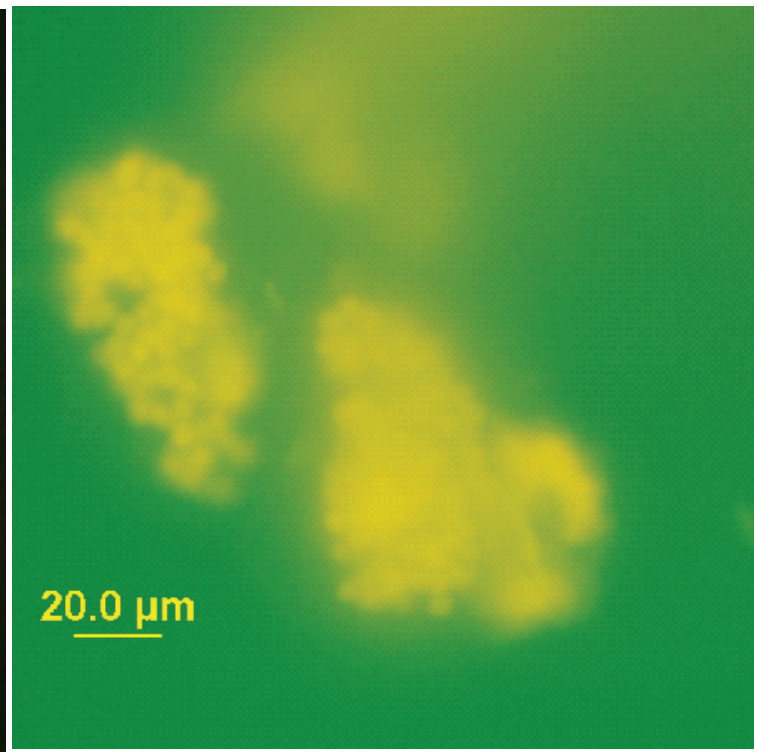

Sytox ${ }^{\circledR}$ green

Boiled for 15 minutes

Figure 147. Pinto Lake, CA (9/22/2009). LM-Microcystis wesenbergii. FITC-a yellow color dominates the cells. Sytox ${ }^{\circledR}$ green-stain did not penetrate the cell membranes. LM - differential interference contrast microscopy; FITC - epifluorescent microscopy; Sytox ${ }^{\circledR}$ green - epifluorescent microscopy in conjunction with the nucleic acid stain Sytox ${ }^{\circledR}$ green. 


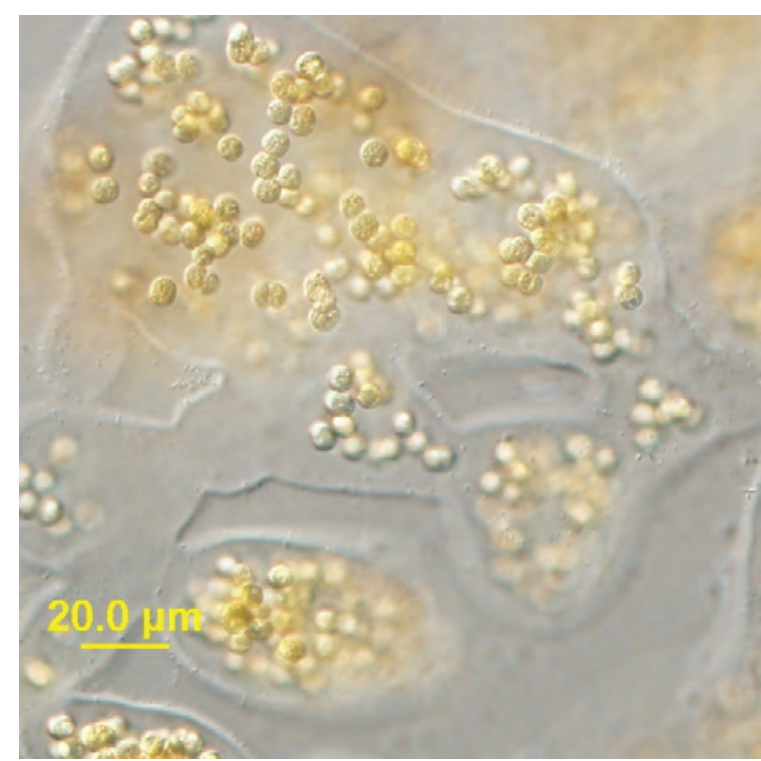

LM

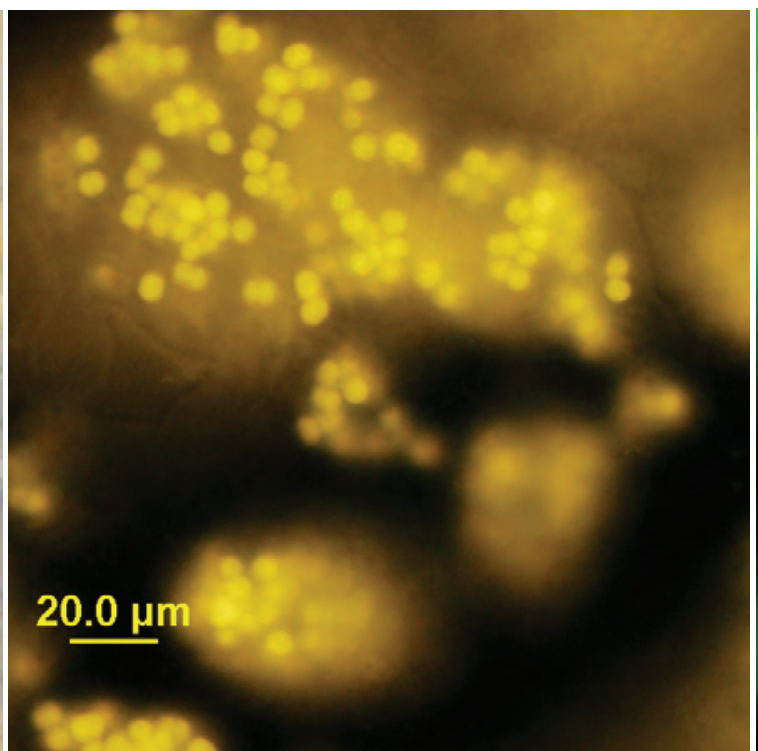

FITC

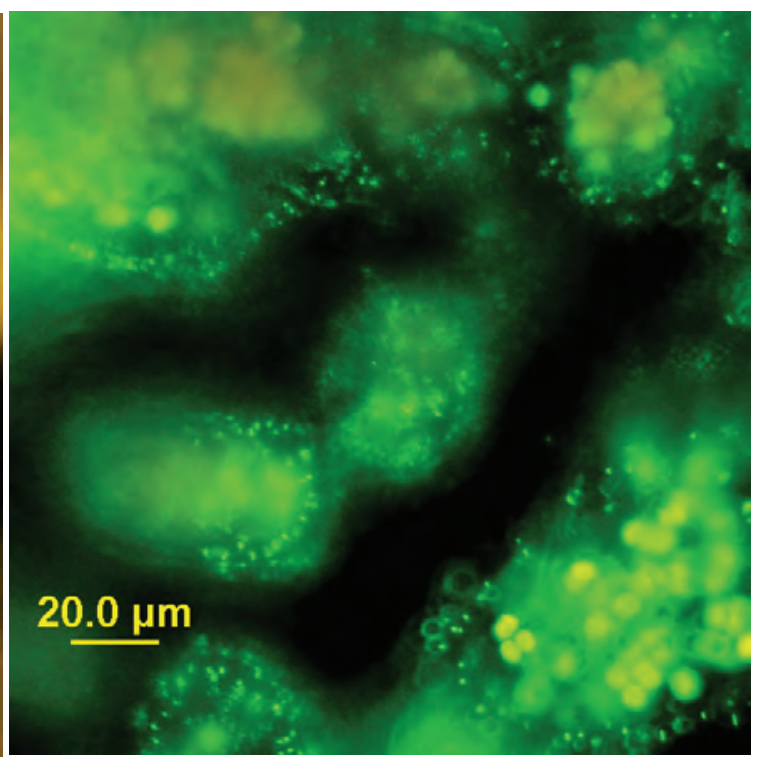

Sytox ${ }^{\circledR}$ green

Boiled for 30 minutes

Figure 148. Pinto Lake, CA (9/22/2009). LM-Microcystis wesenbergii. FITC-a yellow color dominates the cells. Sytox ${ }^{\circledR}$ green-stain did penetrate the mucilaginous cells and the cell membranes; cells bright green. LM - differential interference contrast microscopy; FITC - epifluorescent microscopy; Sytox ${ }^{\circledR}$ green - epifluorescent microscopy in conjunction with the nucleic acid stain Sytox ${ }^{\circledR}$ green. 


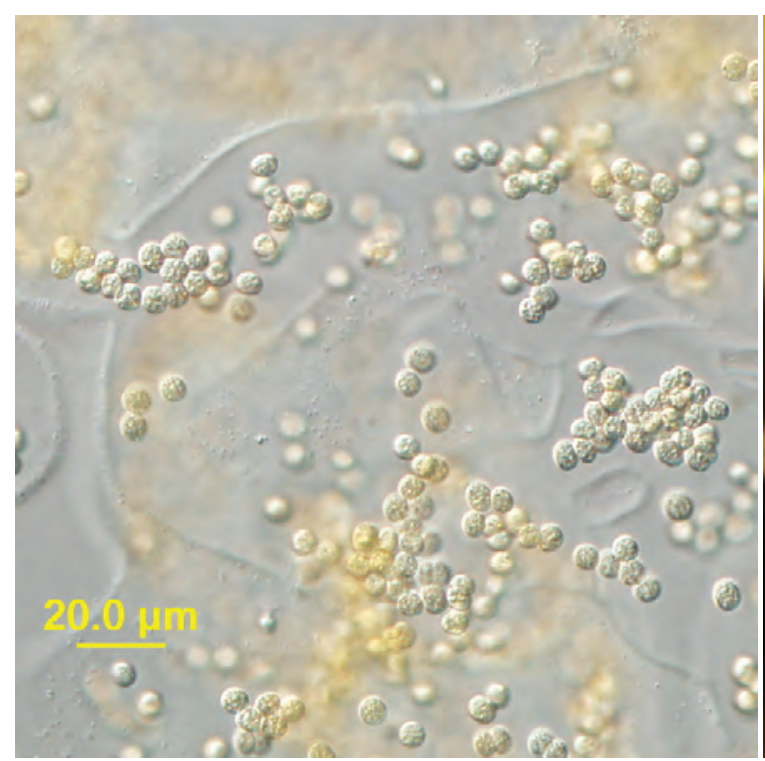

LM

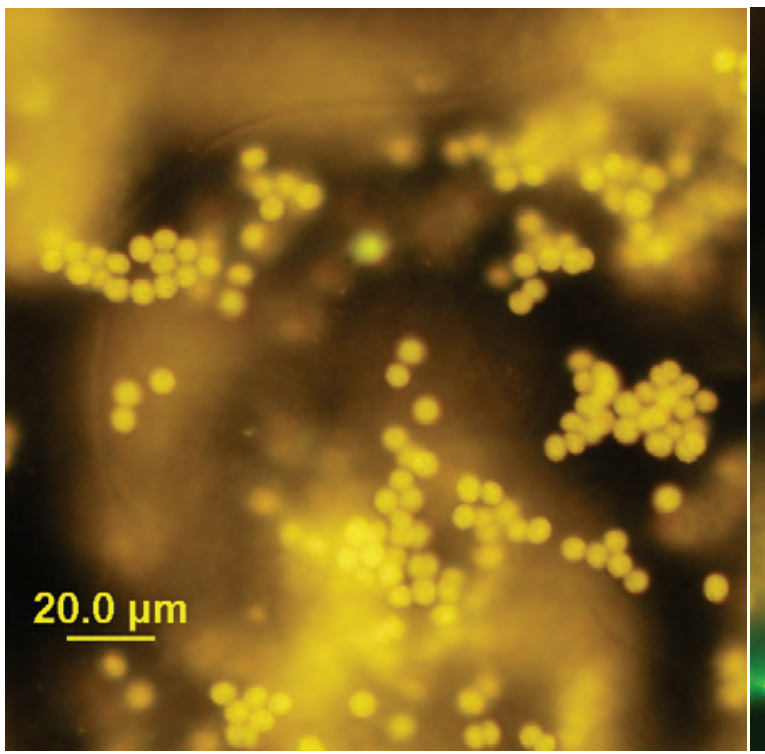

FITC

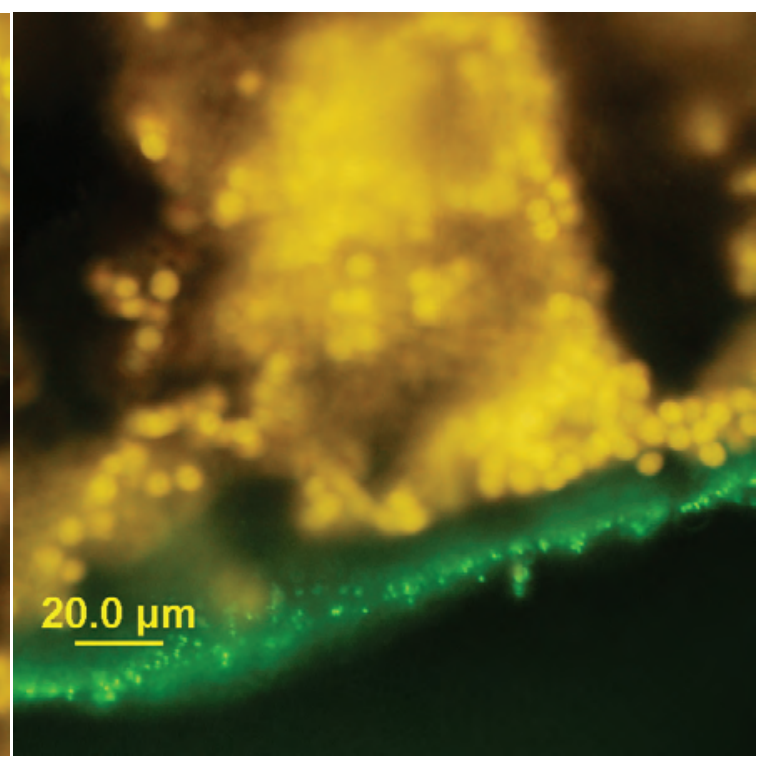

Sytox ${ }^{\circledR}$ green

Autoclaved for 5 minutes

Figure 149. Pinto Lake, CA (9/22/2009). LM-Microcystis wesenbergii. FITC-a yellow color dominates the cells. Sytox ${ }^{\circledR}$ green-stain did not penetrate the mucilage of the colony; bright green dots are epiphytic bacteria and the mucilage appears to have responded to the stain. LM - differential interference contrast microscopy; FITC - epifluorescent microscopy; Sytox ${ }^{\circledR}$ green - epifluorescent microscopy in conjunction with the nucleic acid stain Sytox ${ }^{\circledR}$ green. 


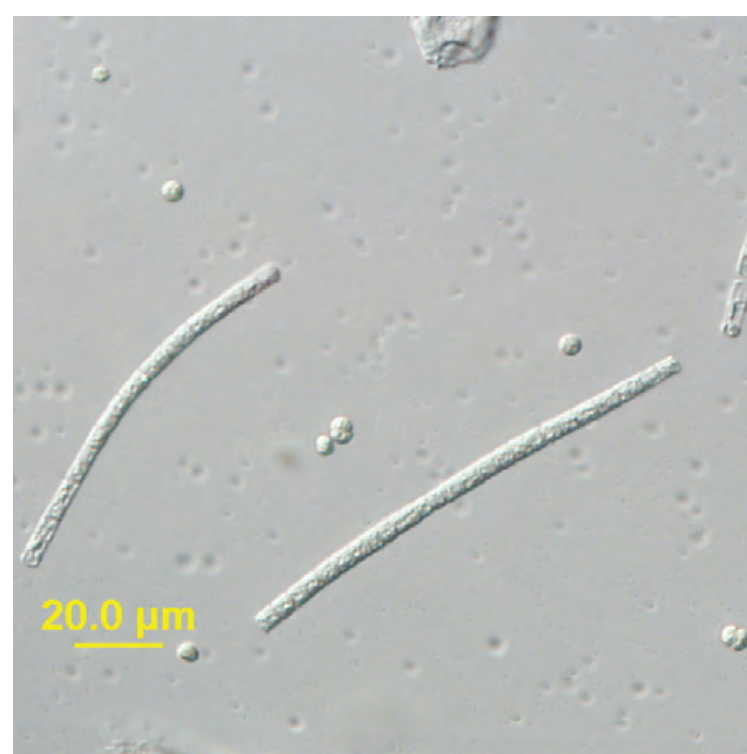

LM

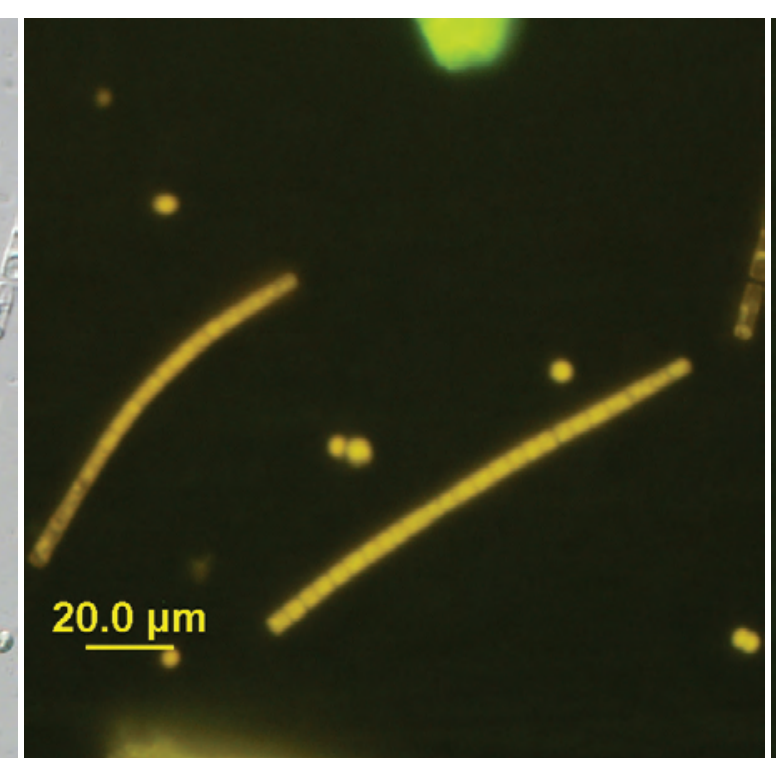

FITC

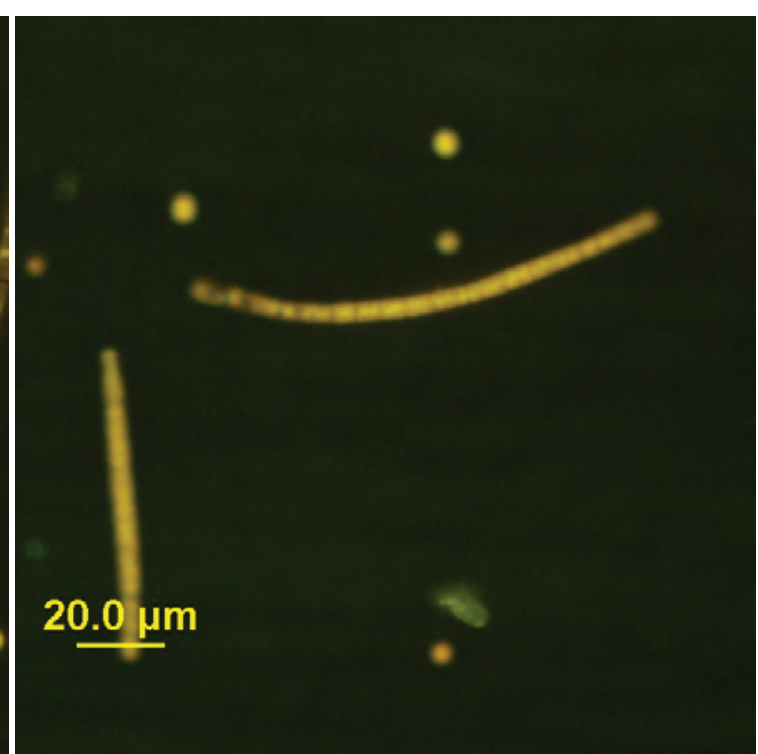

Sytox ${ }^{\circledR}$ green

\section{Autoclaved for 15 minutes}

Figure 150. Pinto Lake, CA (9/22/2009). LM- Aphanizomenon flos-aquae. FITC-a yellow color dominates the cells. Sytox ${ }^{\circledR}$ green-stain did not penetrate the cell membrane. LM - differential interference contrast microscopy; FITC - epifluorescent microscopy; Sytox ${ }^{\circledR}$ green - epifluorescent microscopy in conjunction with the nucleic acid stain Sytox ${ }^{\circledR}$ green. 


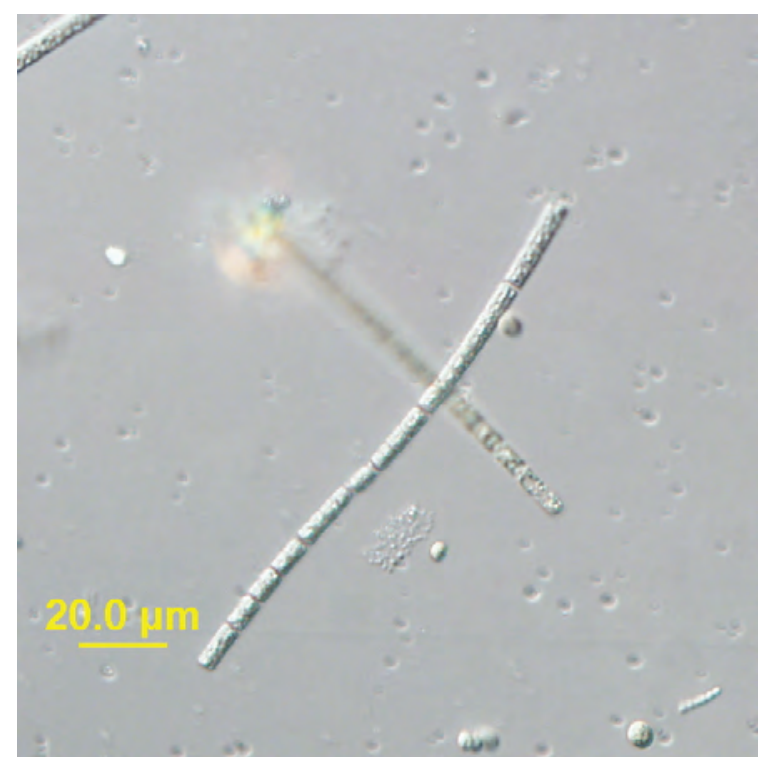

LM

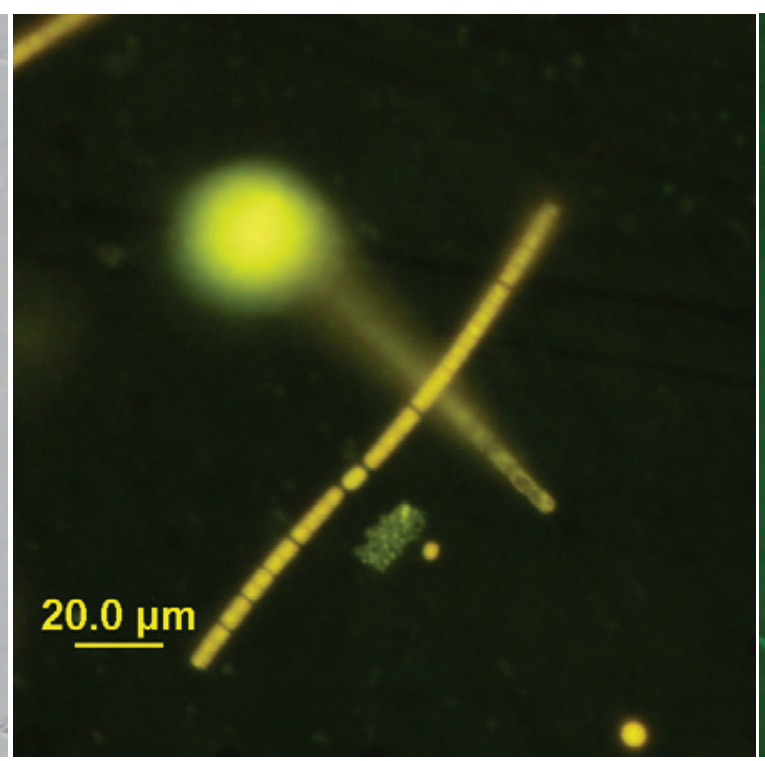

FITC

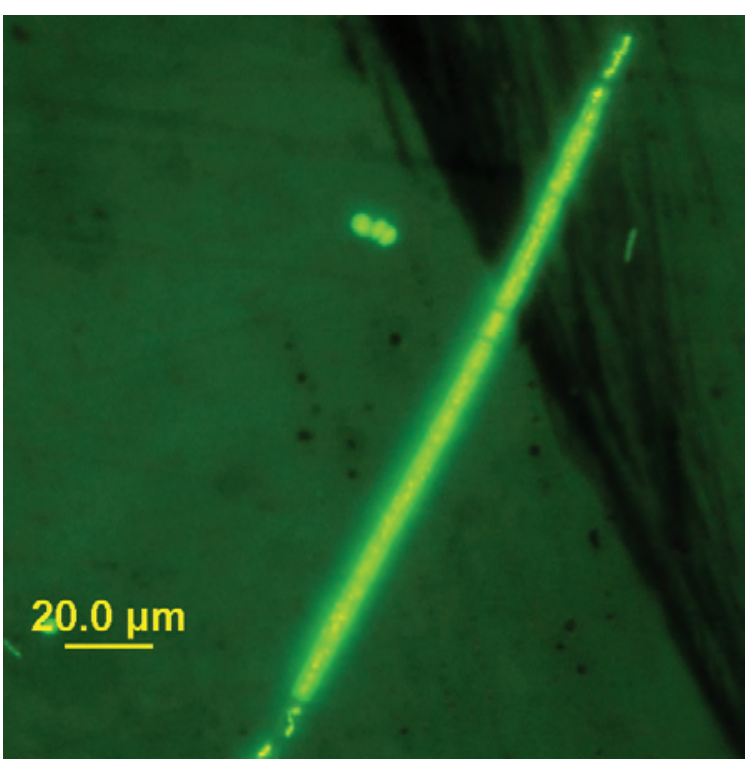

Sytox ${ }^{\circledR}$ green

\section{Autoclaved for 30 minutes}

Figure 151. Pinto Lake, CA (9/22/2009). LM- Aphanizomenon flos-aquae. FITC-a yellow color dominates the cells. Sytox ${ }^{\circledR}$ green-stain did penetrate the cell membrane; cells bright green. LM - differential interference contrast microscopy; FITC - epifluorescent microscopy; Sytox ${ }^{\circledR}$ green - epifluorescent microscopy in conjunction with the nucleic acid stain Sytox ${ }^{\circledR}$ green. 


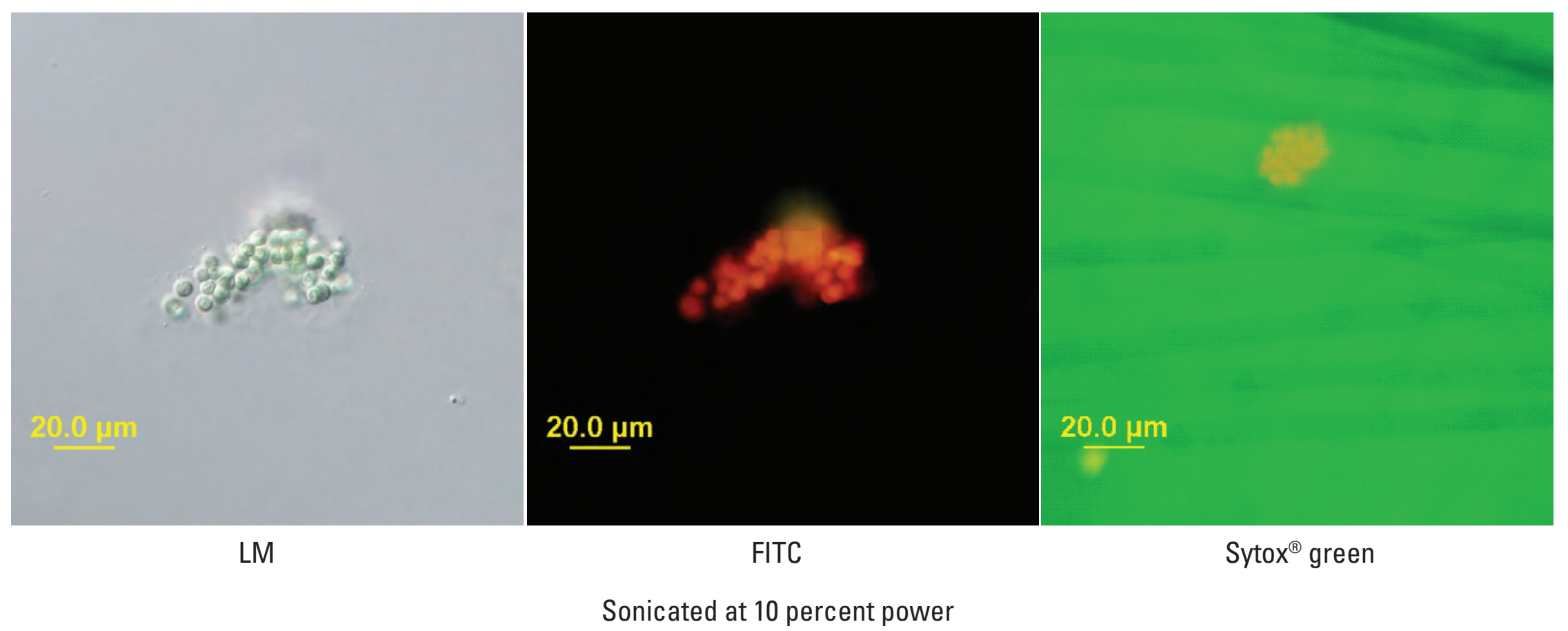

Figure 152. Pinto Lake, CA (9/22/2009). LM-Microcystis sp. FITC-an orange-red color dominates the cells. Sytox ${ }^{\circledR}$ green-stain did not penetrate the mucilage of the colony. LM - differential interference contrast microscopy; FITC - epifluorescent microscopy; Sytox ${ }^{\circledR}$ green - epifluorescent microscopy in conjunction with the nucleic acid stain Sytox ${ }^{\circledR}$ green. Note: No other sonication samples had evidence of cells. 


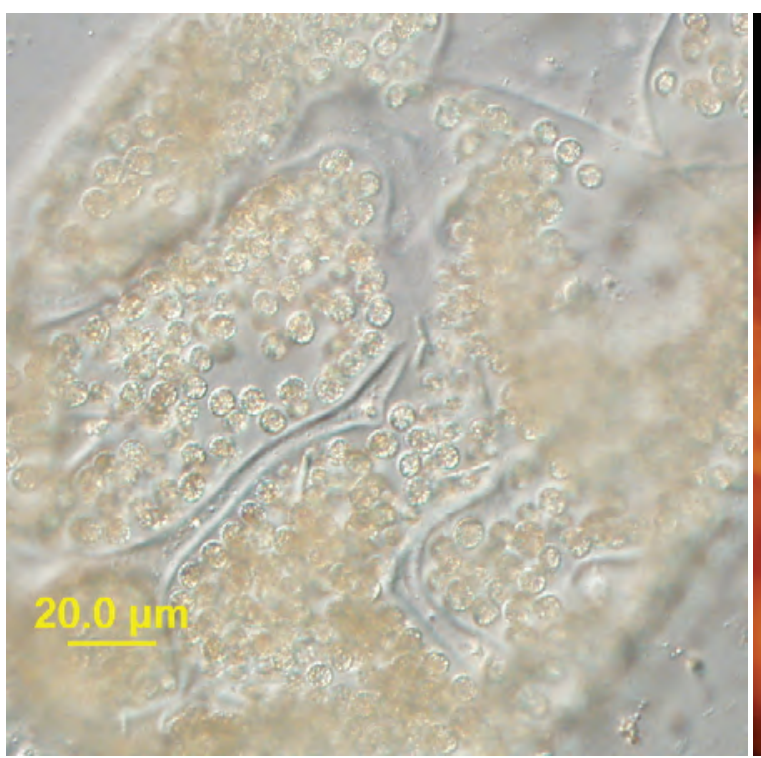

LM

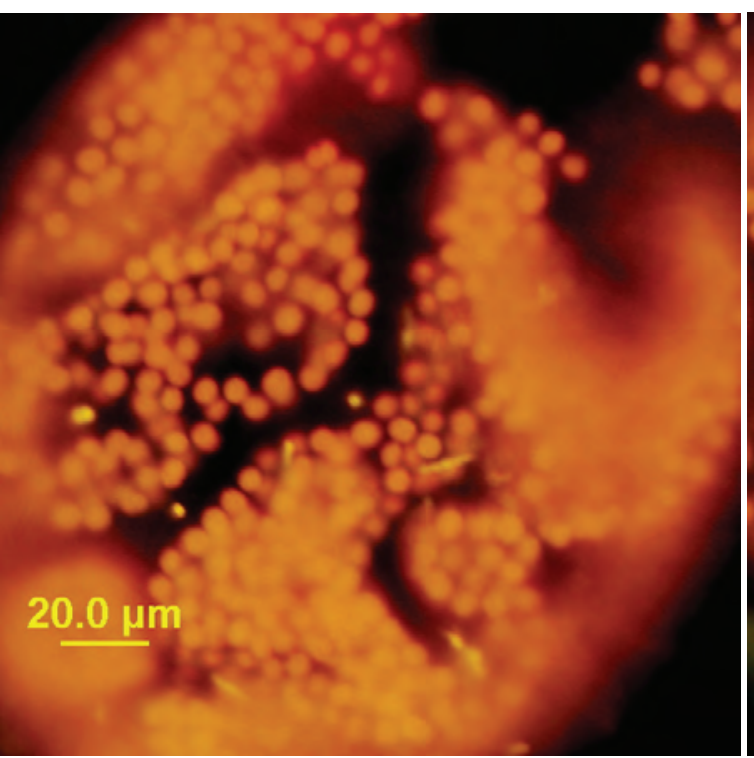

FITC

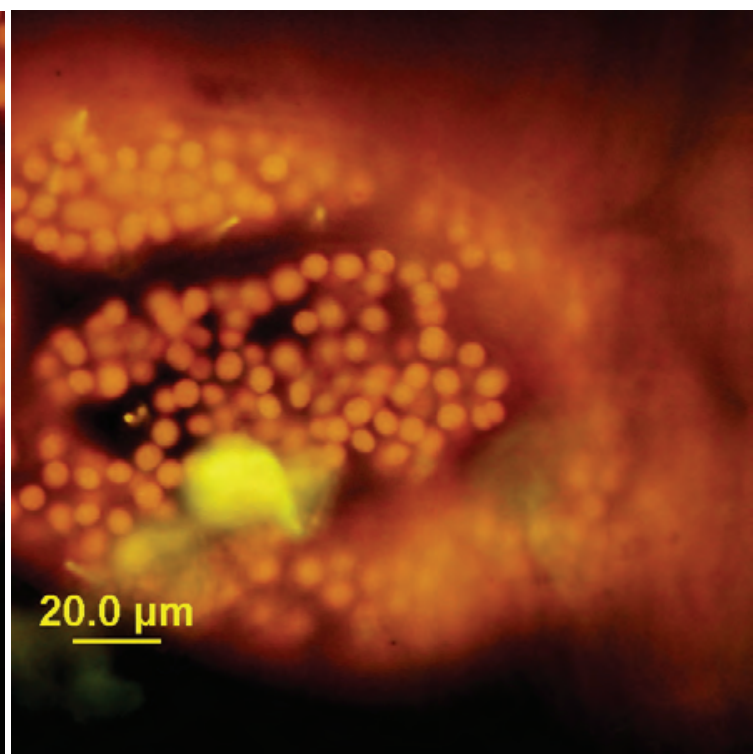

Sytox ${ }^{\circledR}$ green

QuikLyse $\mathrm{TM}^{\mathrm{T}}-1 \mathrm{x}$

Figure 153. Pinto Lake, CA (9/22/2009). LM-Microcystis wesenbergii. FITC-an orange color dominates the cells. Sytox ${ }^{\circledR}$ green-stain did not penetrate the cell membranes. LM - differential interference contrast microscopy; FITC - epifluorescent microscopy; Sytox ${ }^{\circledR}$ green - epifluorescent microscopy in conjunction with the nucleic acid stain Sytox ${ }^{\circledR}$ green. 


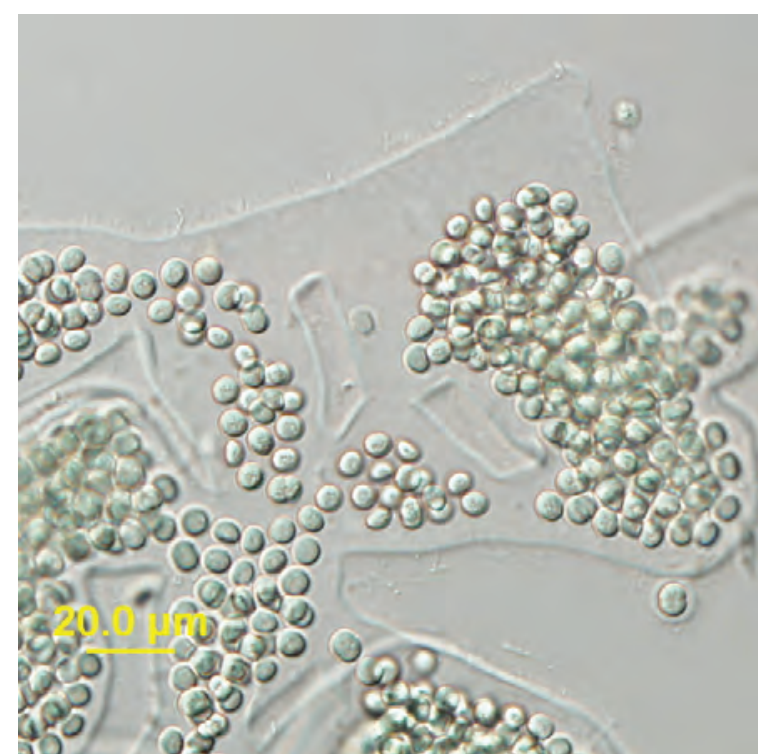

LM

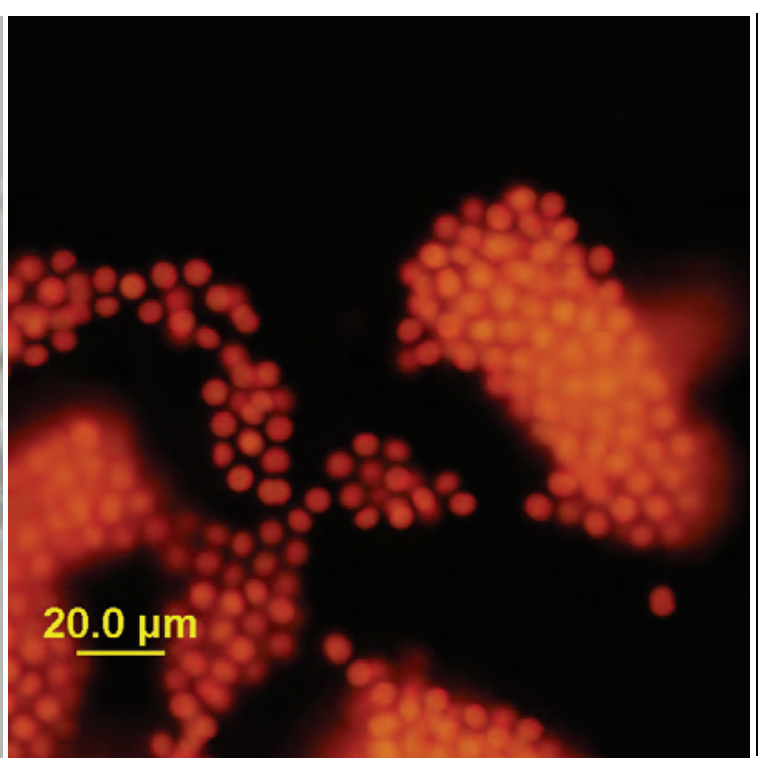

FITC

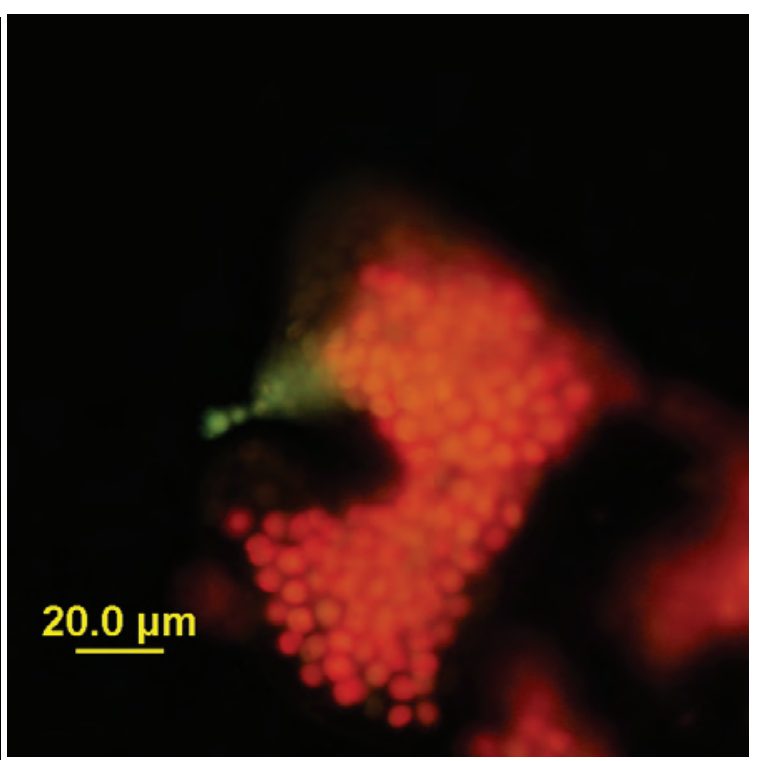

Sytox ${ }^{\circledR}$ green

\section{One freeze-thaw cycle}

Figure 154. Pinto Lake, CA (9/22/2009). LM-Microcystis wesenbergii. FITC-an orange-red color dominates the cells. Sytox ${ }^{\circledR}$ green-stain did not penetrate the cell membranes. LM - differential interference contrast microscopy; FITC - epifluorescent microscopy; Sytox ${ }^{\circledR}$ green - epifluorescent microscopy in conjunction with the nucleic acid stain Sytox ${ }^{\circledR}$ green. 


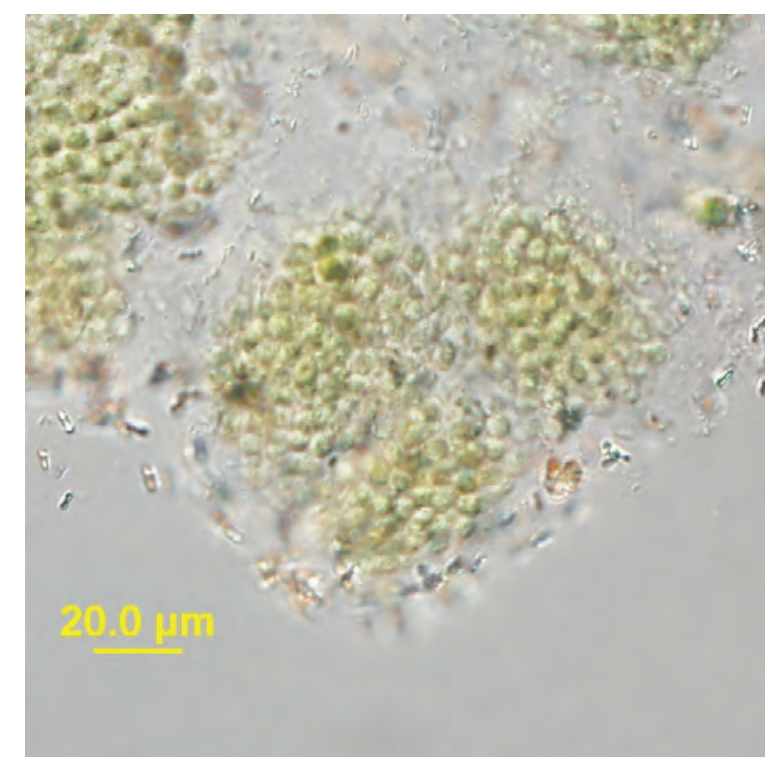

LM

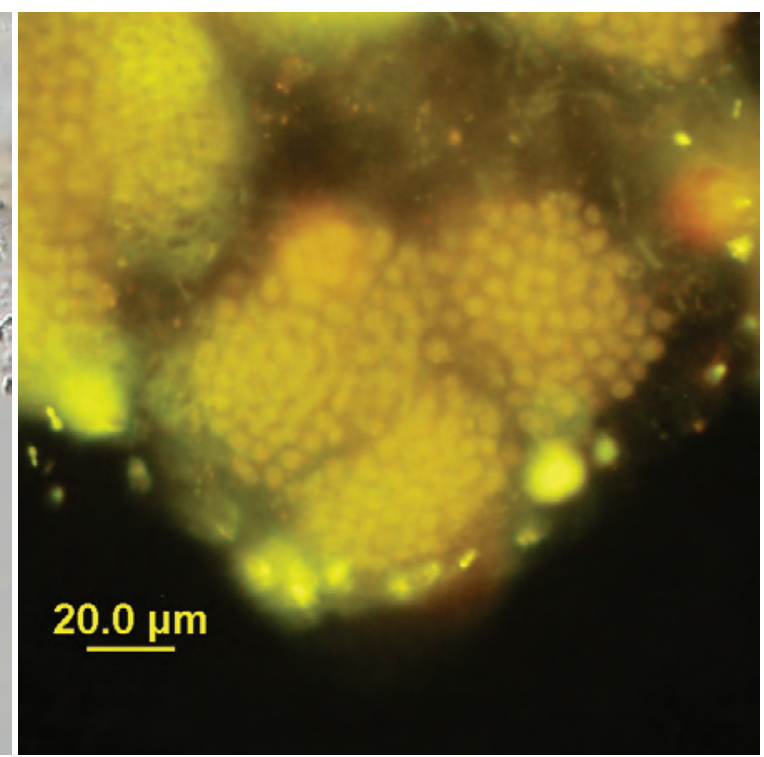

FITC

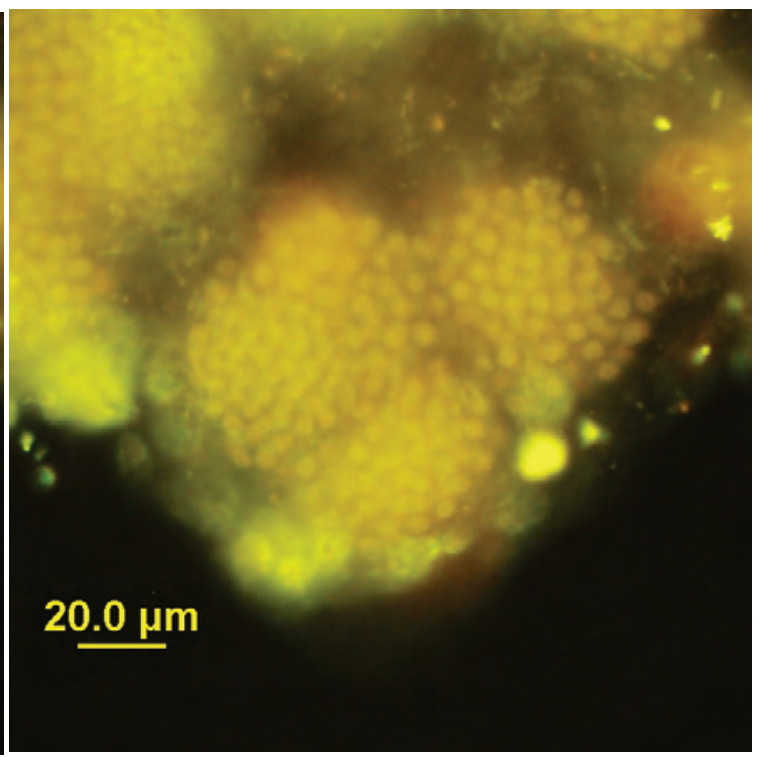

Sytox ${ }^{\circledR}$ green

Two freeze-thaw cycles

Figure 155. Pinto Lake, CA (9/22/2009). LM-Microcystis sp. FITC-a yellow color dominates the cells. Sytox ${ }^{\circledR}$ green-stain did not penetrate the cell membranes. LM differential interference contrast microscopy; FITC - epifluorescent microscopy; Sytox ${ }^{\circledast}$ green - epifluorescent microscopy in conjunction with the nucleic acid stain Sytox ${ }^{\circledR}$ green. 


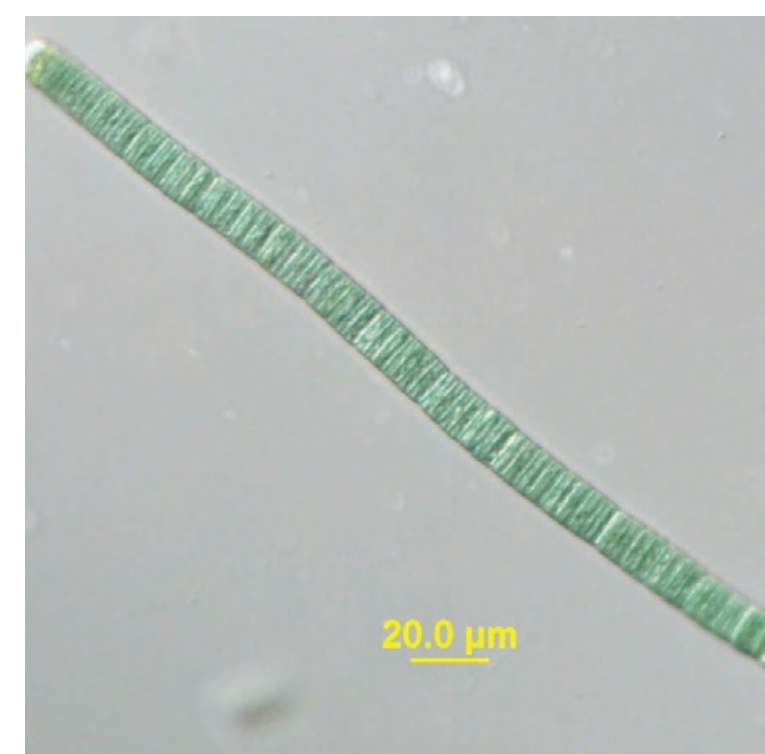

LM

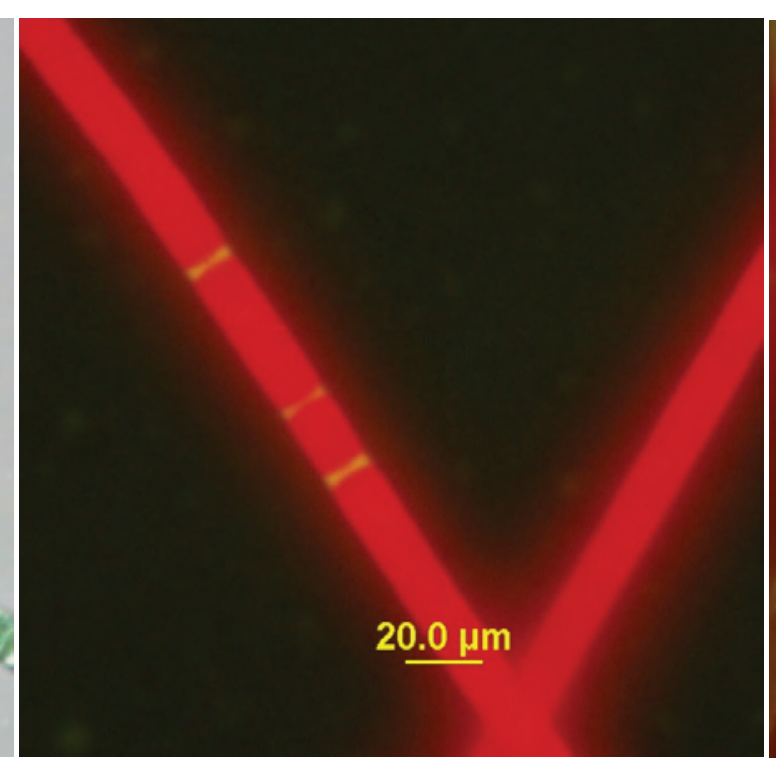

FITC

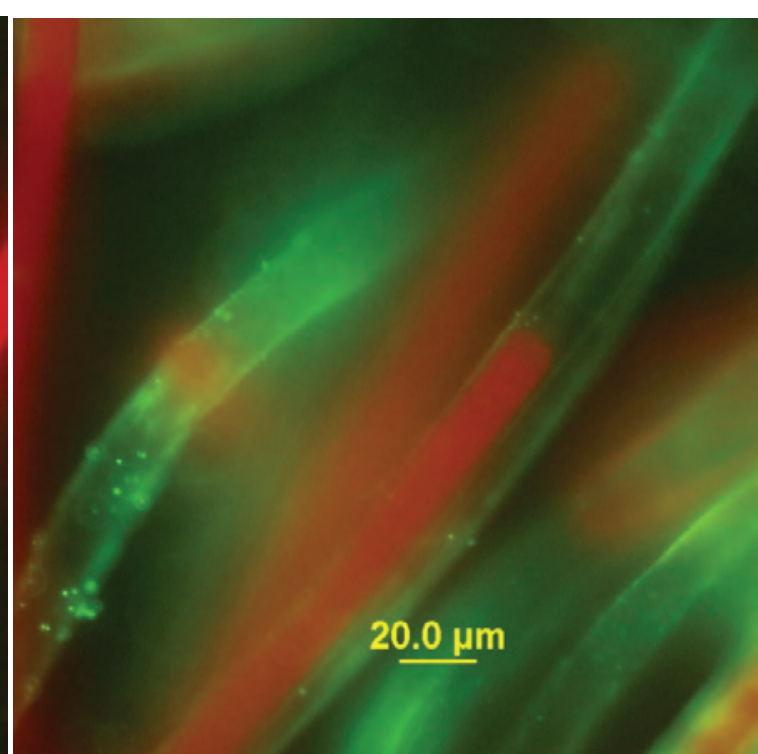

Sytox ${ }^{\circledast}$ green

\section{Control}

Figure 156. Laboratory culture-Lyngbya DVL 1103B. LM-Lyngbya sp. is a filamentous cyanobacteria with a mucilaginous sheath. FITC-a red color dominates the cells. Yellow is the area of filament splitting (separation discs). Sytox ${ }^{\circledR}$ green-stain was picked up by the sheath but not the cells. Bacteria appear as bright green dots on the sheath. LM - differential interference contrast microscopy; FITC - epifluorescent microscopy; Sytox ${ }^{\circledR}$ green - epifluorescent microscopy in conjunction with the nucleic acid stain Sytox ${ }^{\circledR}$ green. 


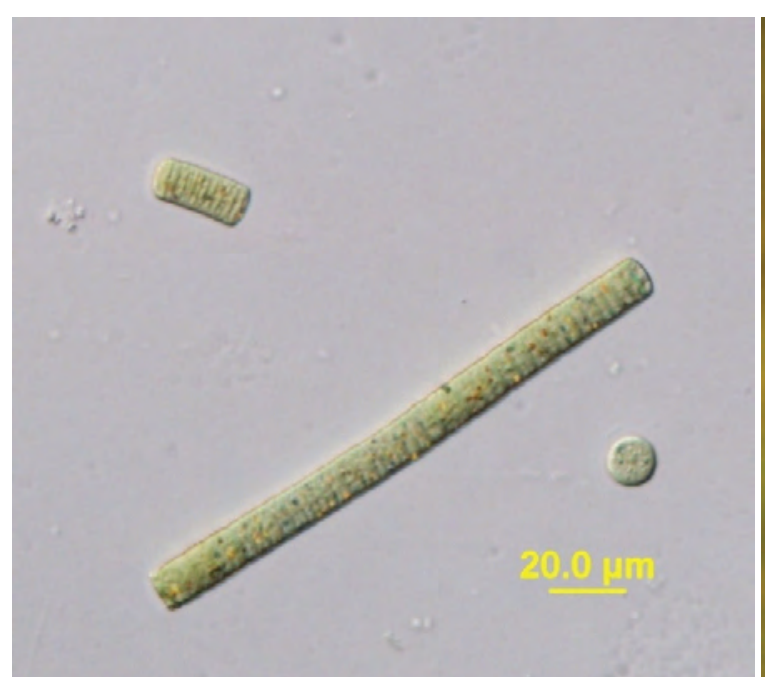

LM

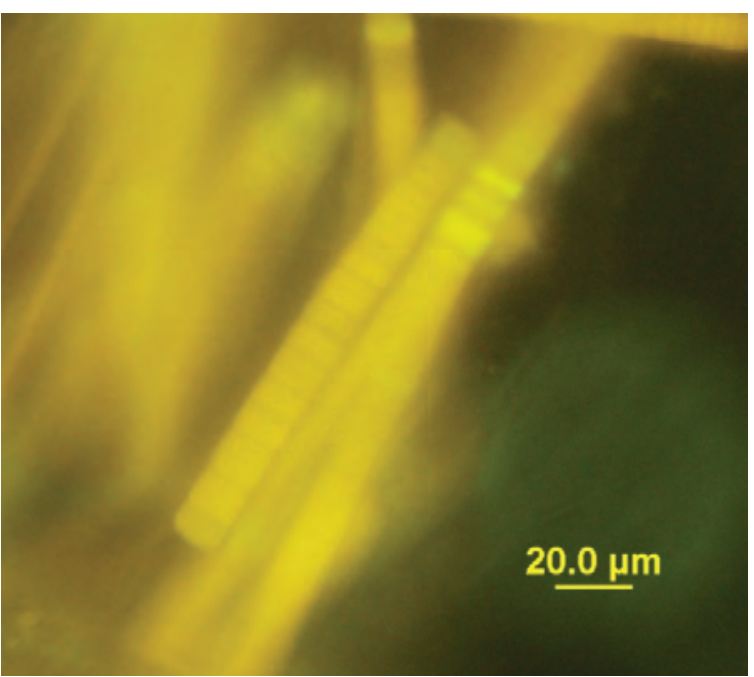

FITC

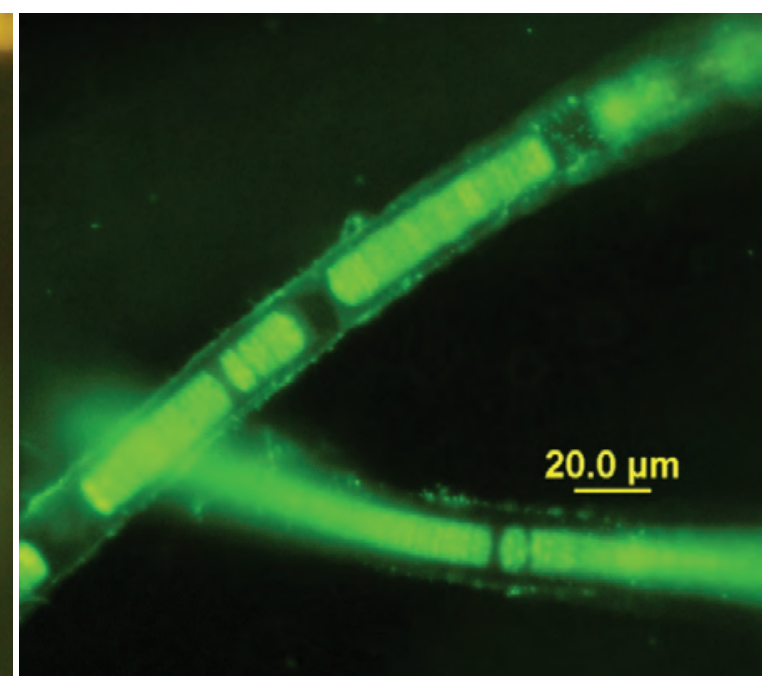

Sytox ${ }^{\circledR}$ green

\section{Boiled for 5 minutes}

Figure 157. Laboratory culture-Lyngbya DVL 1103B. LM-Lyngbya sp. FITC-a yellow color dominates the cells. Sytox ${ }^{\circledR}$ green-stain penetrated, indicating the cell membrane was disrupted. The sheath also picked up the stain. LM - differential interference contrast microscopy; FITC - epifluorescent microscopy; Sytox ${ }^{\circledR}$ green epifluorescent microscopy in conjunction with the nucleic acid stain Sytox ${ }^{\circledast}$ green. 


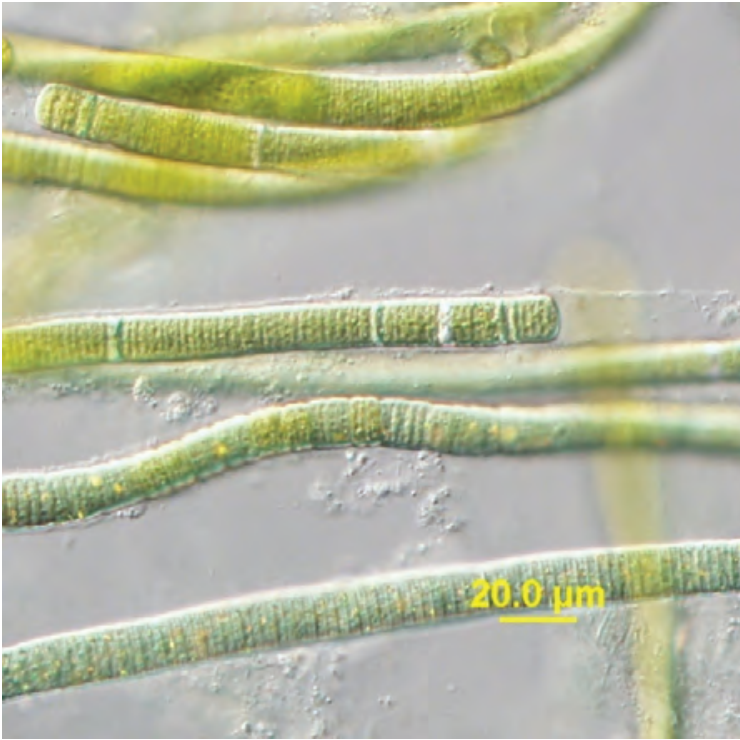

LM

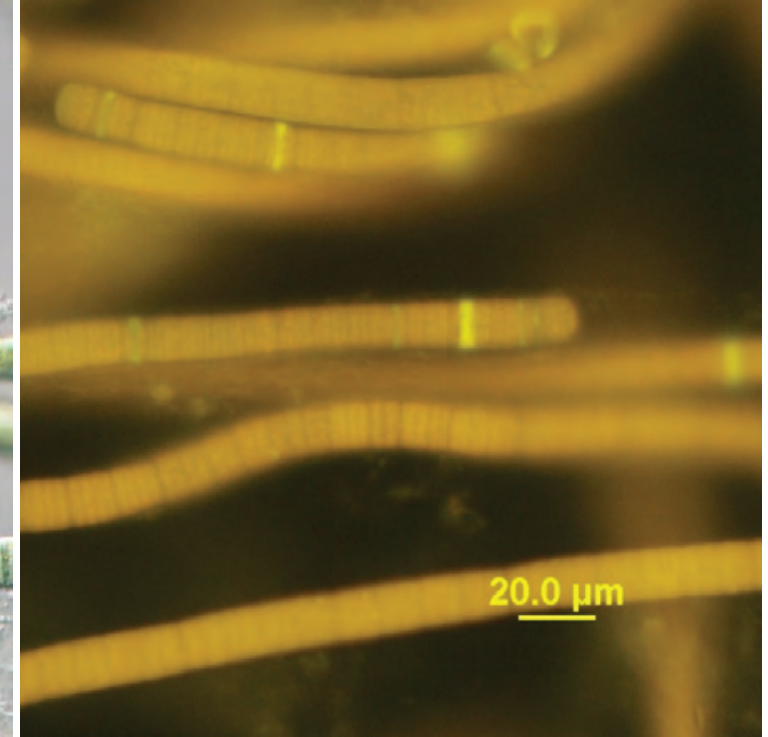

FITC

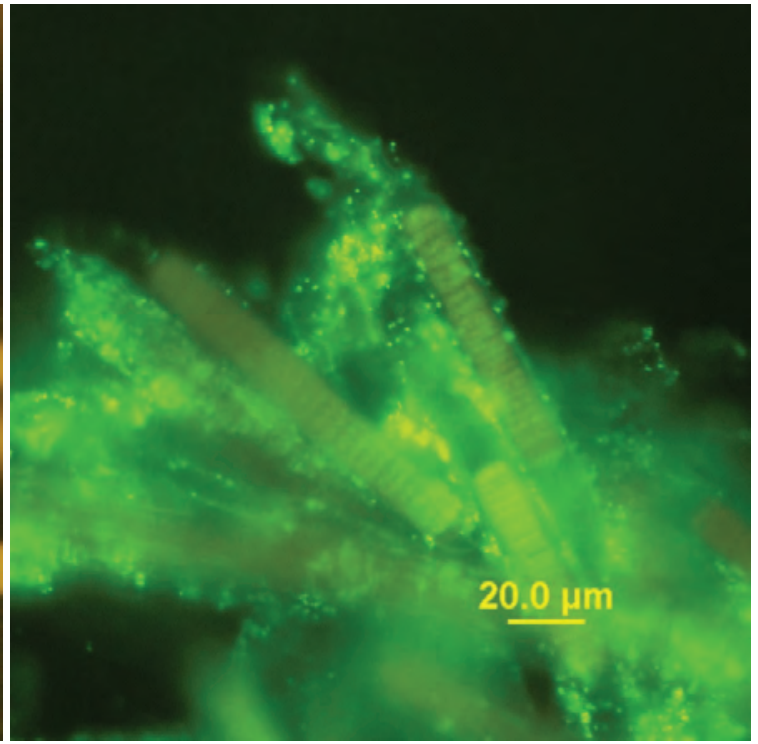

Sytox ${ }^{\circledR}$ green

Boiled for 15 minutes

Figure 158. Laboratory culture-Lyngbya DVL 1103B. LM-Lyngbya sp. FITC-a yellow-orange color dominates the cells. Sytox ${ }^{\circledR}$ green-stain penetrated some cells, indicating the cell membrane was partially disrupted. The sheath also picked up the stain. LM - differential interference contrast microscopy; FITC - epifluorescent microscopy; Sytox ${ }^{\circledR}$ green - epifluorescent microscopy in conjunction with the nucleic acid stain Sytox ${ }^{\circledR}$ green. 


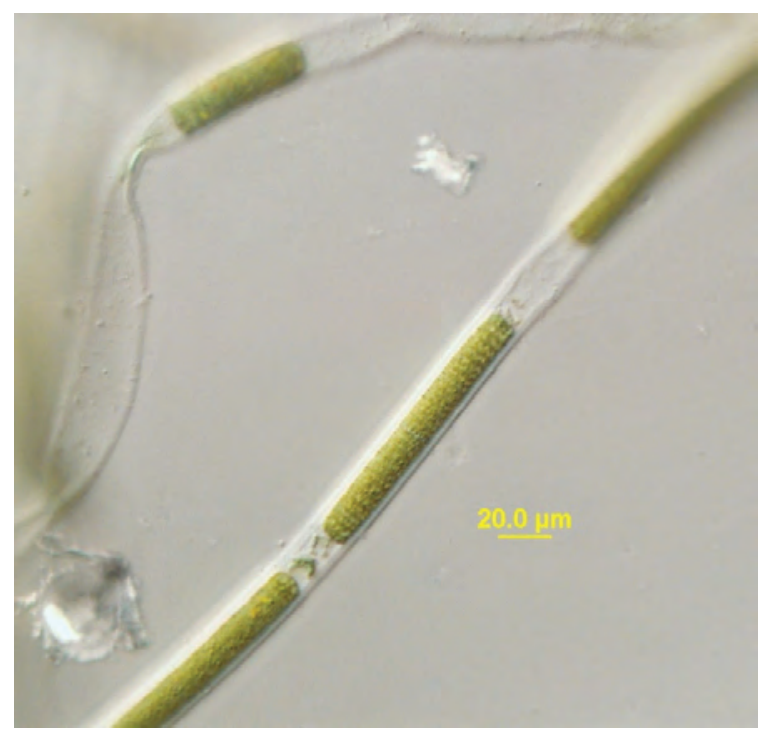

LM

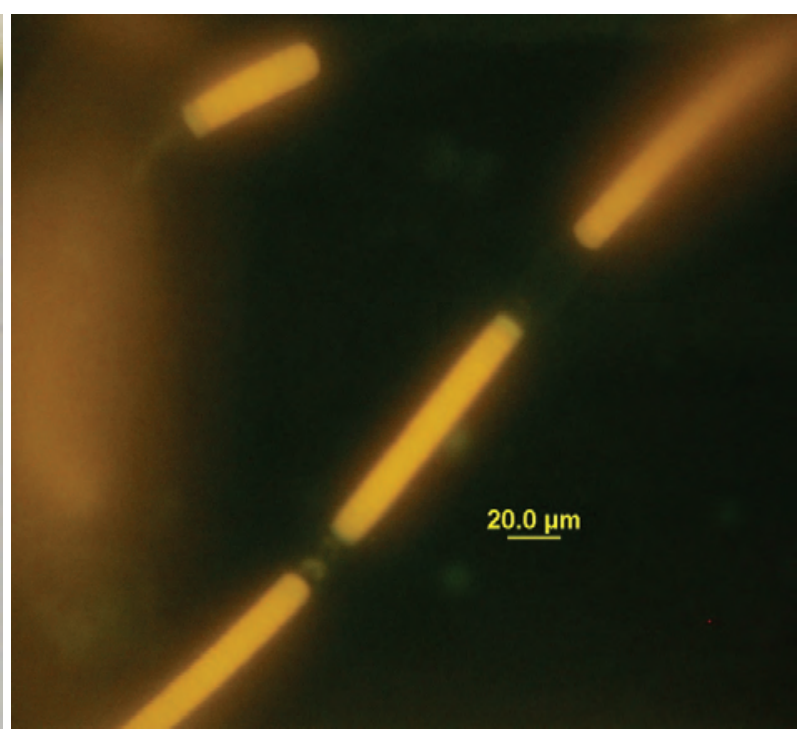

FITC

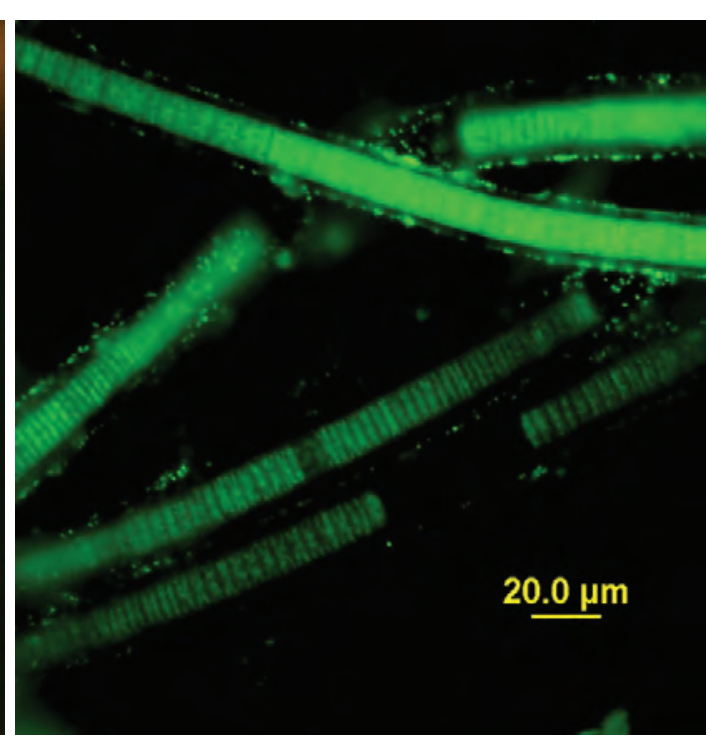

Sytox ${ }^{\circledR}$ green

\section{Boiled for 30 minutes}

Figure 159. Laboratory culture-Lyngbya DVL 1103B. LM-Lyngbya sp. FITC-an orange color dominates the cells. Sytox ${ }^{\circledR}$ green-stain penetrated, indicating the cell membrane was disrupted. The sheath also picked up the stain. LM - differential interference contrast microscopy; FITC - epifluorescent microscopy; Sytox ${ }^{\oplus}$ green epifluorescent microscopy in conjunction with the nucleic acid stain Sytox ${ }^{\circledast}$ green. 


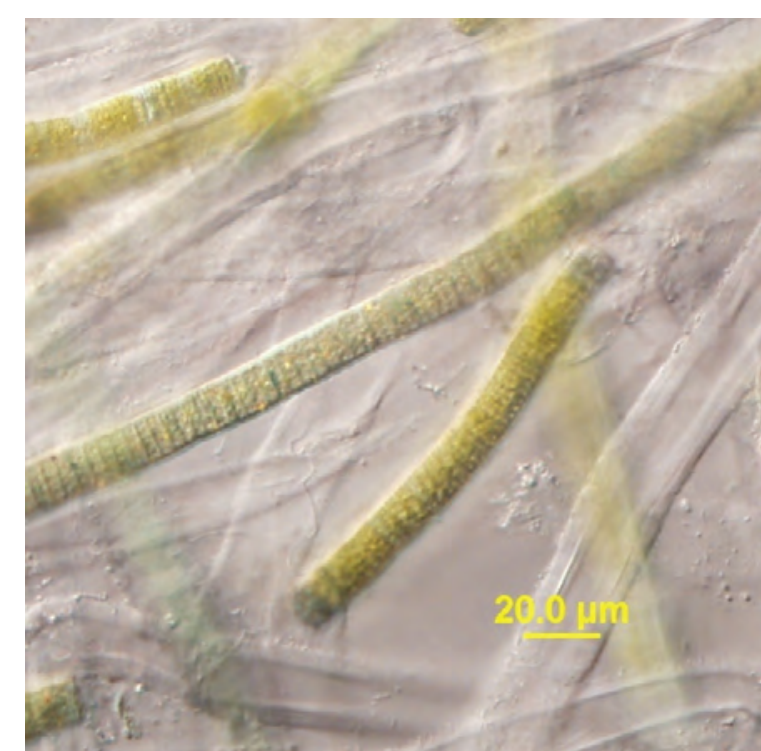

LM

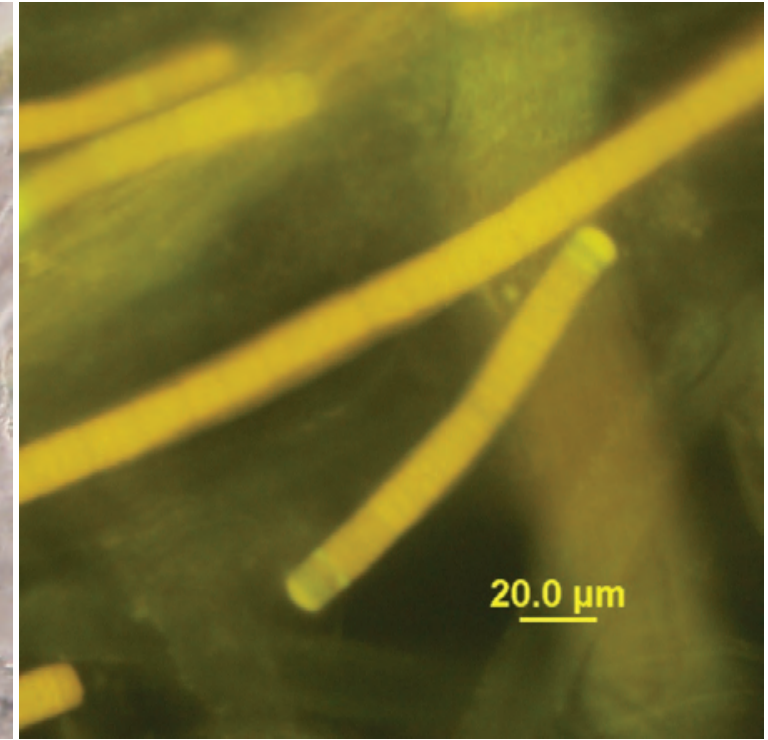

FITC

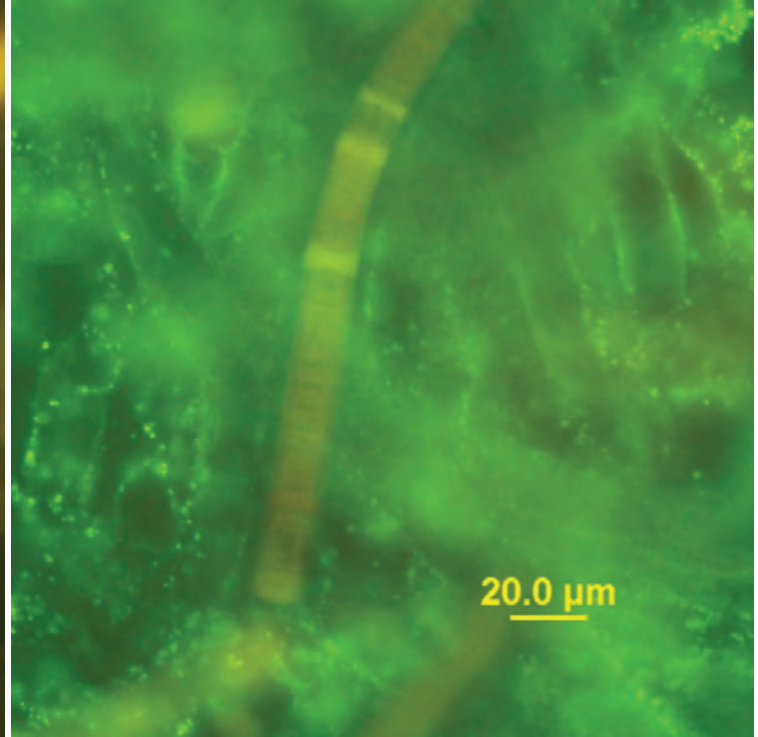

Sytox ${ }^{\circledR}$ green

Autoclaved for 5 minutes

Figure 160. Laboratory culture-Lyngbya DVL 1103B. LM-Lyngbya sp. FITC-a yellow-orange color dominates the cells. Sytox ${ }^{\circledR}$ green-stain did not penetrate, indicating the cell membrane was not disrupted. The sheath also picked up the stain. LM - differential interference contrast microscopy; FITC - epifluorescent microscopy;

Syto ${ }^{\circledR}$ green - epifluorescent microscopy in conjunction with the nucleic acid stain Sytox ${ }^{\circledR}$ green. 


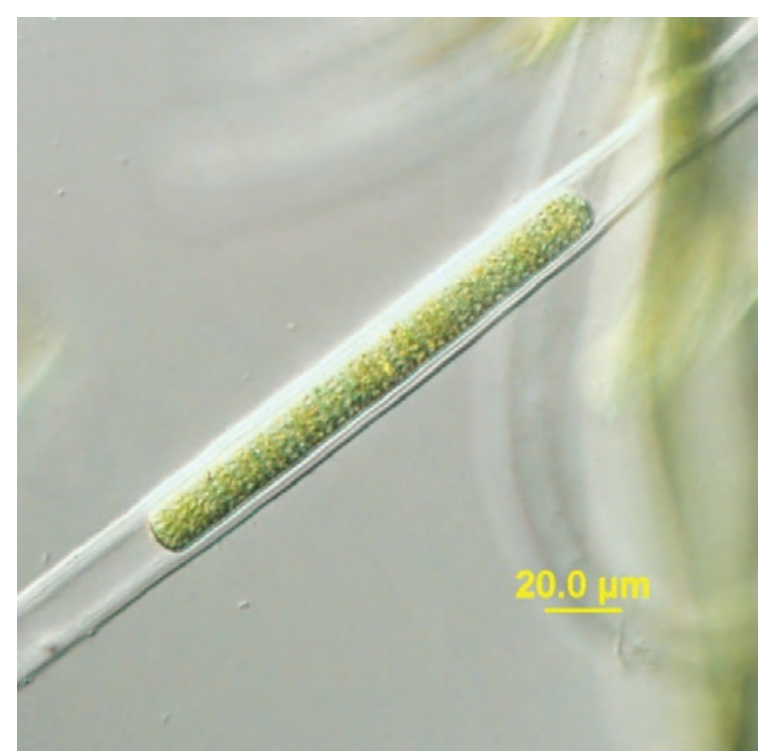

LM

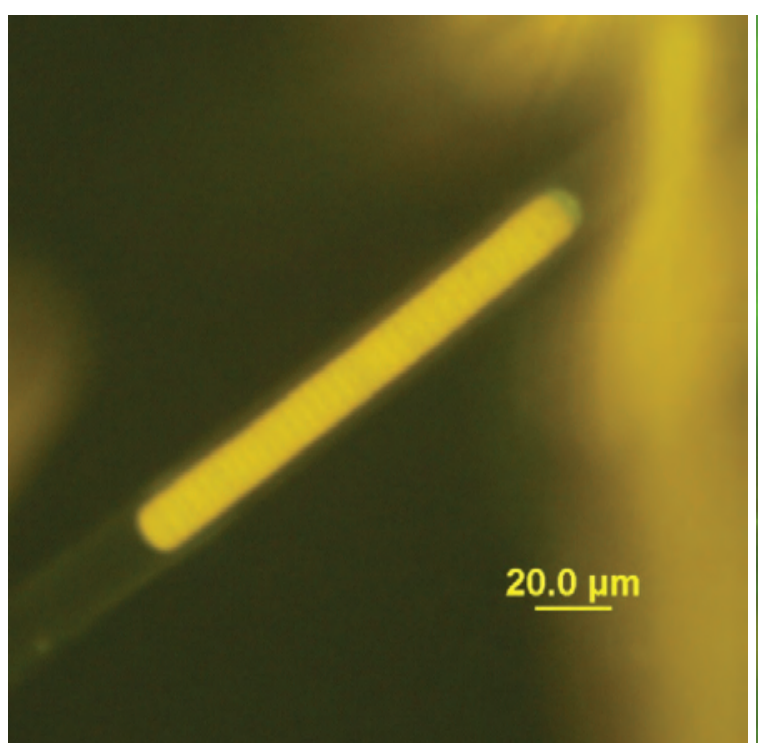

FITC

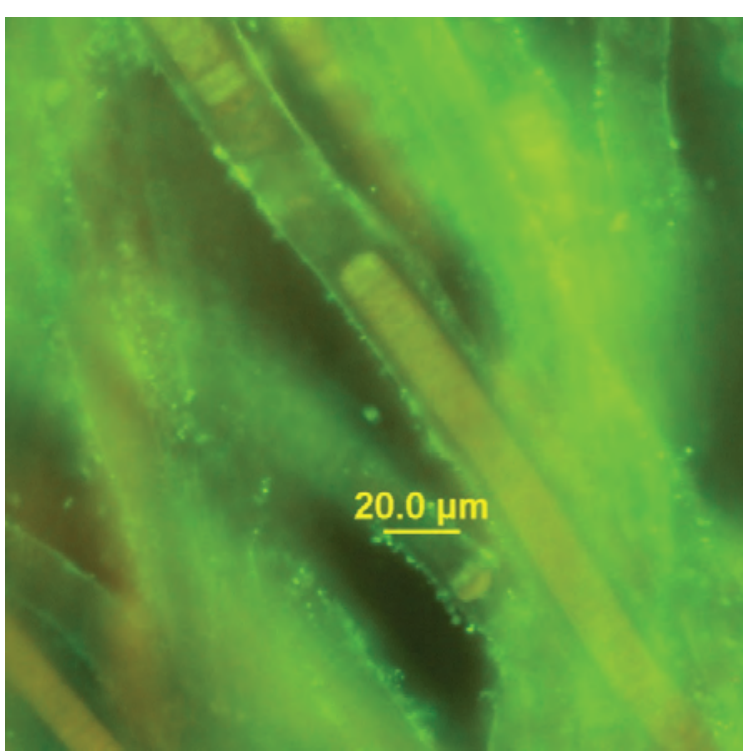

Sytox ${ }^{\circledR}$ green

\section{Autoclaved for 15 minutes}

Figure 161. Laboratory culture-Lyngbya DVL 1103B. LM-Lyngbya sp. FITC-a yellow color dominates the cells. Sytox ${ }^{\circledR}$ green-stain did penetrate to some extent, indicating the cell membrane was disrupted. The sheath also picked up the stain. LM - differential interference contrast microscopy; FITC - epifluorescent microscopy; Sytox ${ }^{\circledR}$ green - epifluorescent microscopy in conjunction with the nucleic acid stain Sytox ${ }^{\circledR}$ green. 


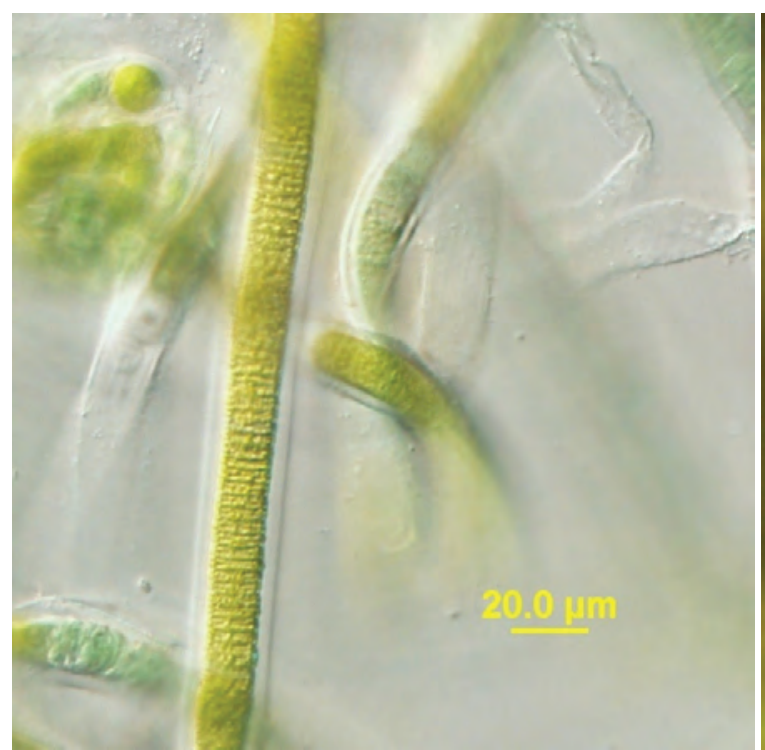

LM

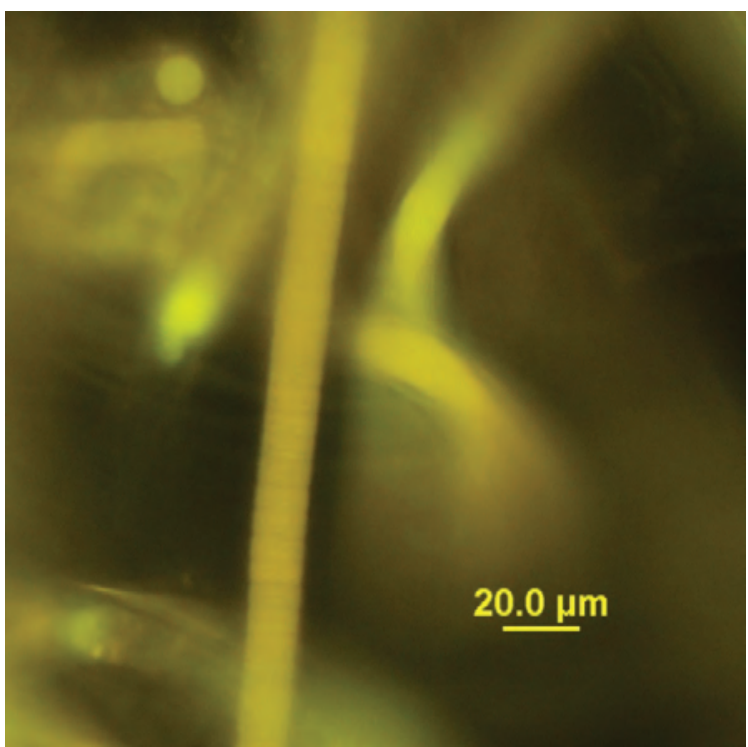

FITC

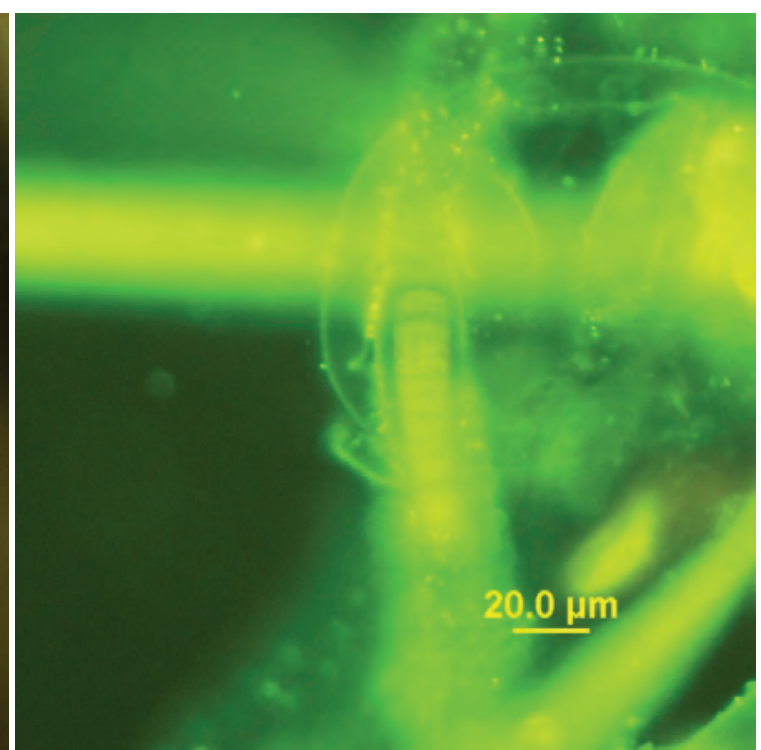

Sytox ${ }^{\circledR}$ green

Autoclaved for 30 minutes

Figure 162. Laboratory culture-Lyngbya DVL 1103B. LM-Lyngbya sp. FITC-a yellow color dominates the cells. Sytox ${ }^{\circledR}$ green-stain did not penetrate, indicating the cell membrane was not disrupted. The sheath also picked up the stain. LM - differential interference contrast microscopy; FITC - epifluorescent microscopy; Sytox ${ }^{\circledR}$ green - epifluorescent microscopy in conjunction with the nucleic acid stain Sytox ${ }^{\circledR}$ green. 


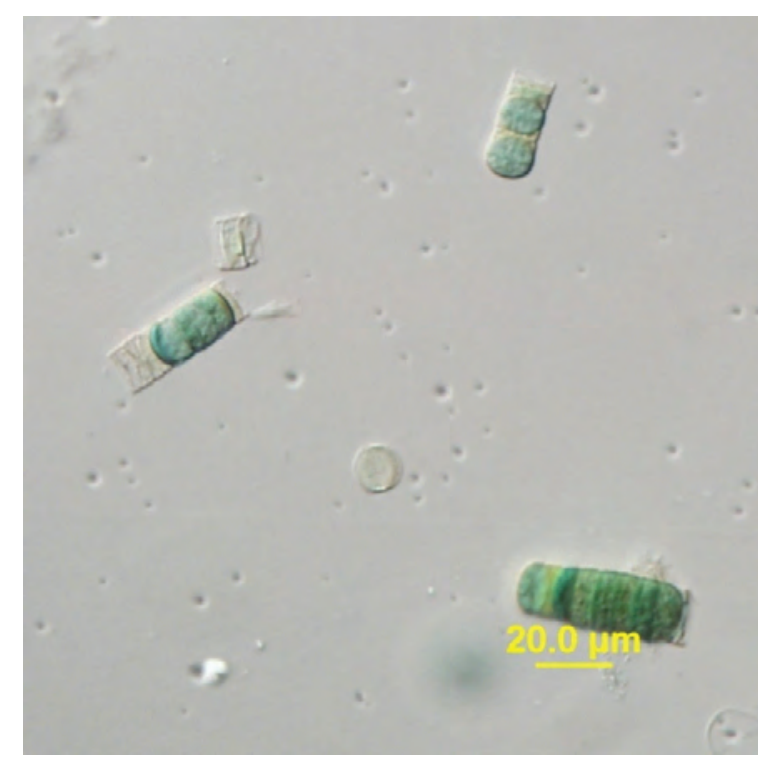

LM

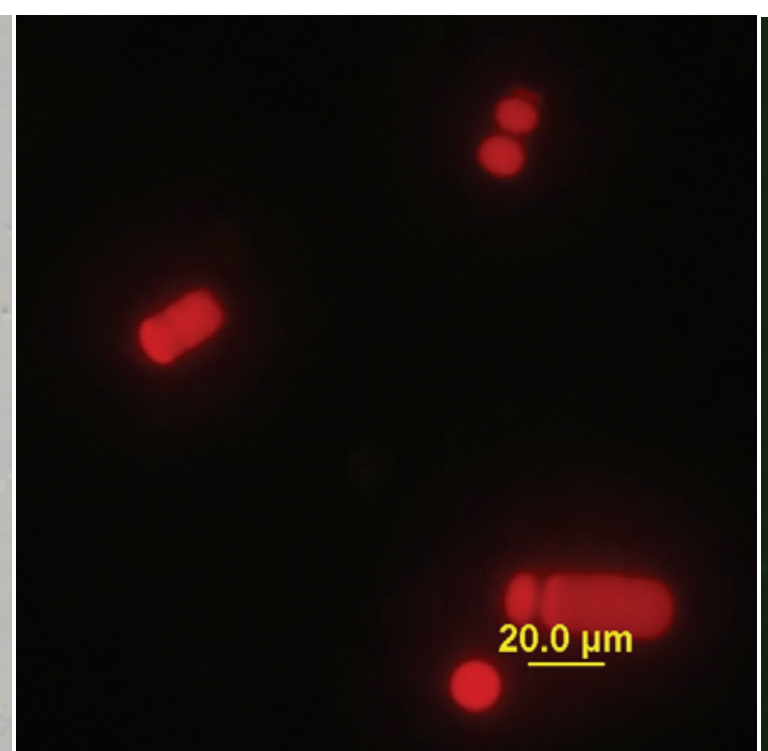

FITC

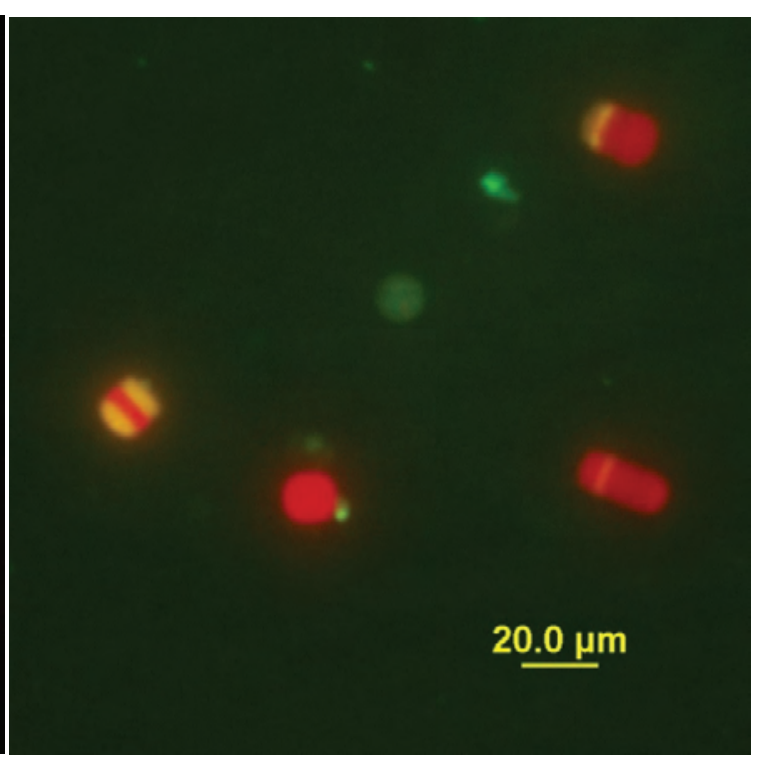

Sytox ${ }^{\circledR}$ green

\section{Sonication at 10 percent power}

Figure 163. Laboratory culture-Lyngbya DVL 1103B. LM-Lyngbya sp. Note: the filaments were fragmented. FITC-a red color dominates the cells. Sytox ${ }^{\circledR}$ green-stain did not penetrate, indicating the cell membrane was not disrupted. LM - differential interference contrast microscopy; FITC - epifluorescent microscopy; Sytox ${ }^{\circledR}$ green - epifluorescent microscopy in conjunction with the nucleic acid stain Sytox ${ }^{\oplus}$ green. 


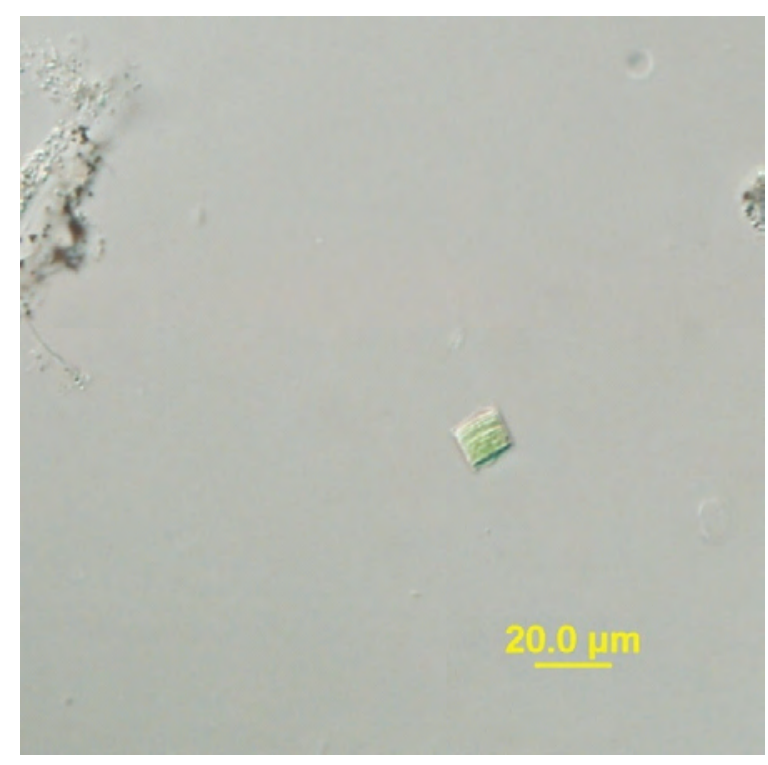

LM

\section{Sonication at 35 percent power}

Figure 164. Laboratory culture-Lyngbya DVL 1103B.

LM-Lyngbya sp. Note: only a few fragments were found and no material for FITC or Sytox ${ }^{\circledR}$ green. LM - differentia interference contrast microscopy; FITC - epifluorescent microscopy; Sytox ${ }^{\circledR}$ green - epifluorescent microscopy in conjunction with the nucleic acid stain Sytox ${ }^{\circledR}$ green. 


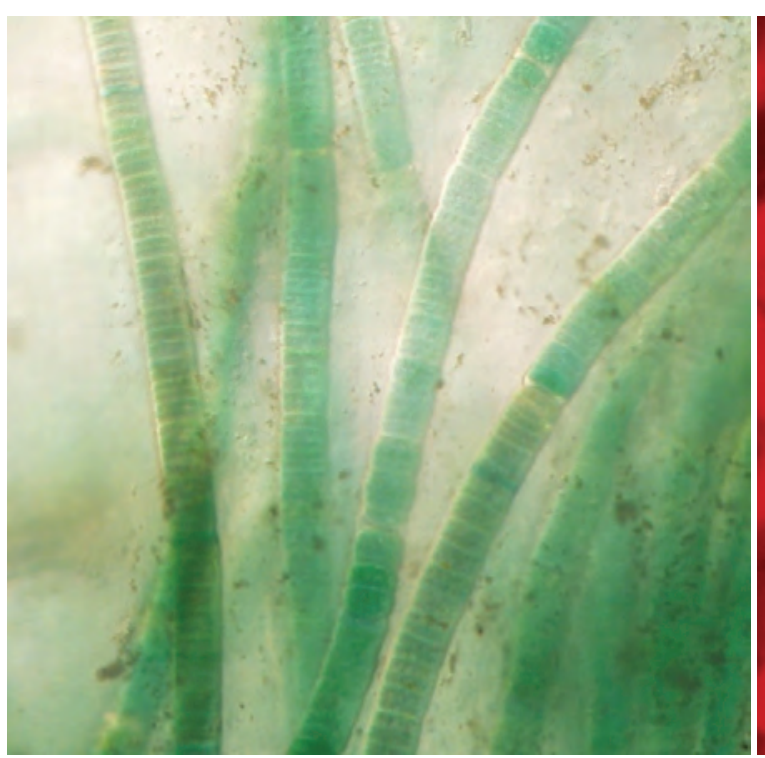

LM

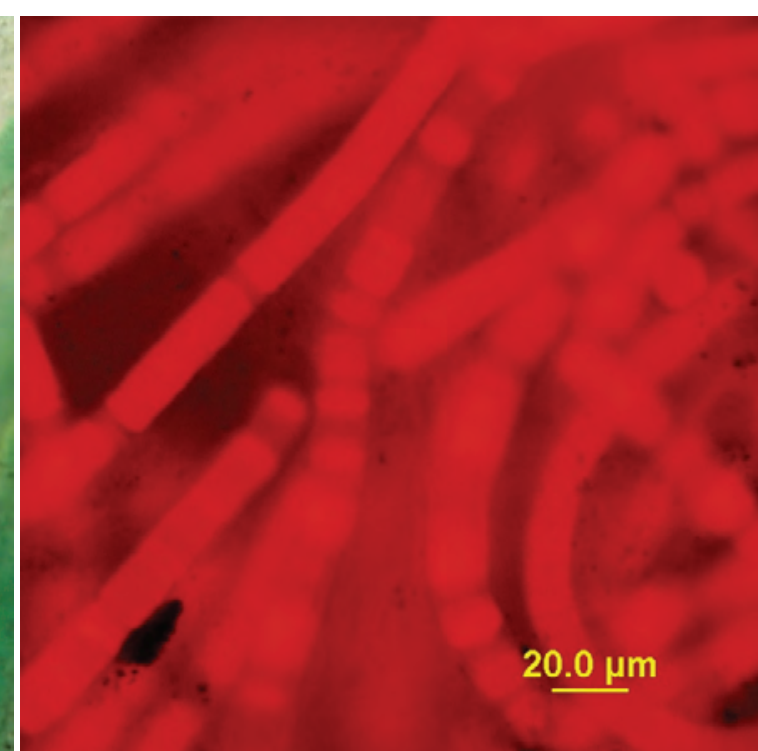

FITC

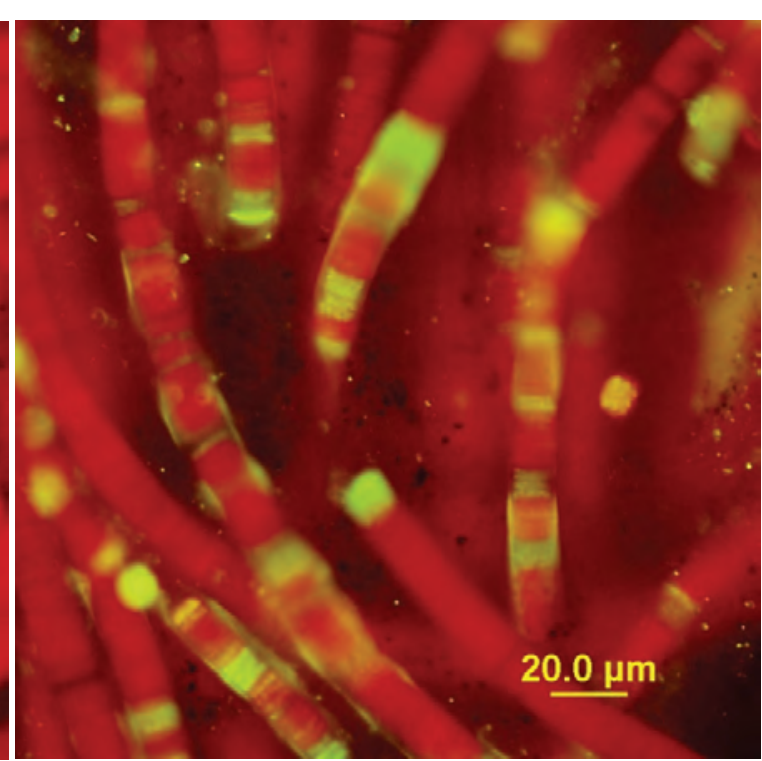

Sytox ${ }^{\circledR}$ green

\section{QuikLyse ${ }^{\mathrm{TM}}-1 \mathrm{x}$}

Figure 165. Laboratory culture-Lyngbya DVL 1103B. LM-Lyngbya sp. FITC-a red color dominates the cells. Sytox ${ }^{\circledR}$ green-stain was picked up by a few cells in each filament and the tips of each filament. LM - differential interference contrast microscopy; FITC - epifluorescent microscopy; Sytox ${ }^{\circledR}$ green - epifluorescent microscopy in conjunction with the nucleic acid stain Sytox ${ }^{\circledR}$ green. 


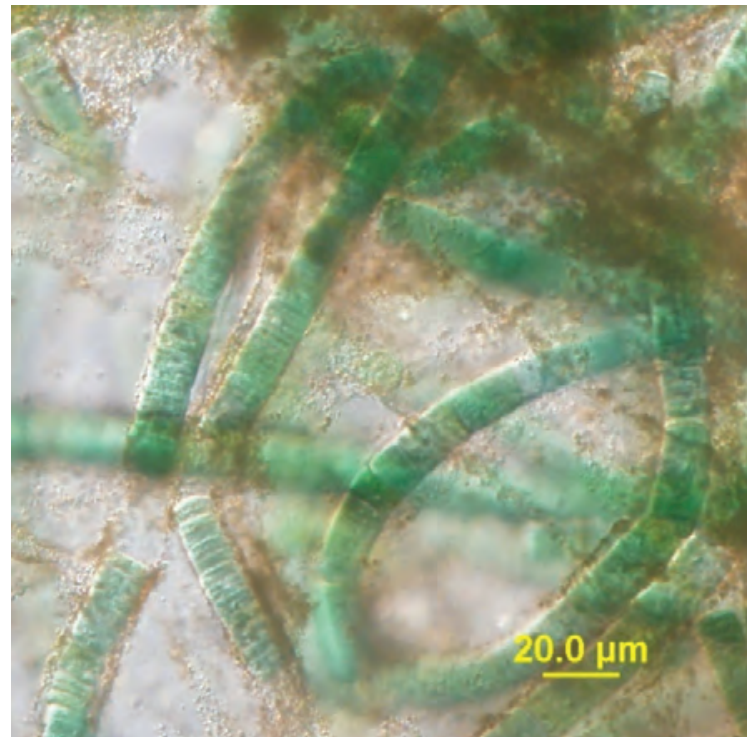

LM

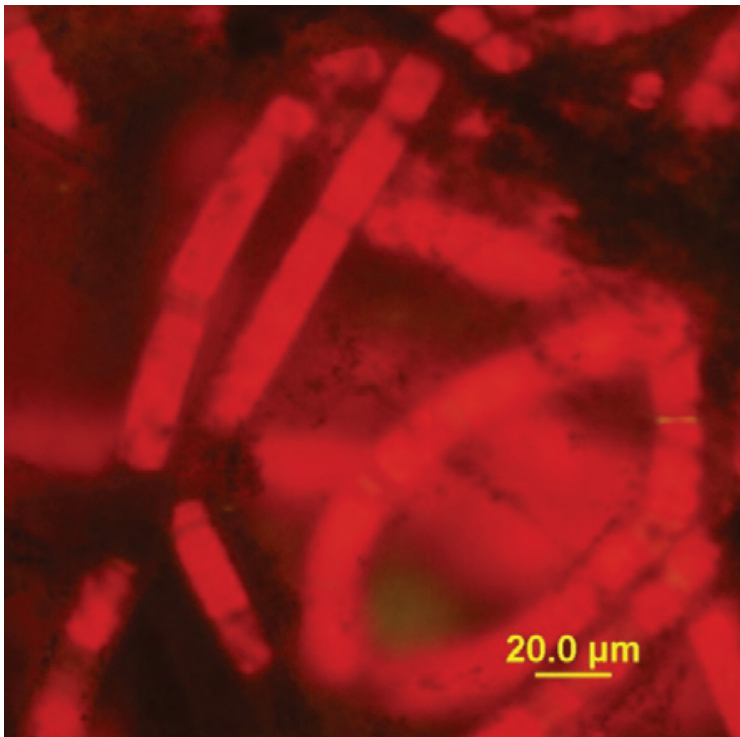

FITC

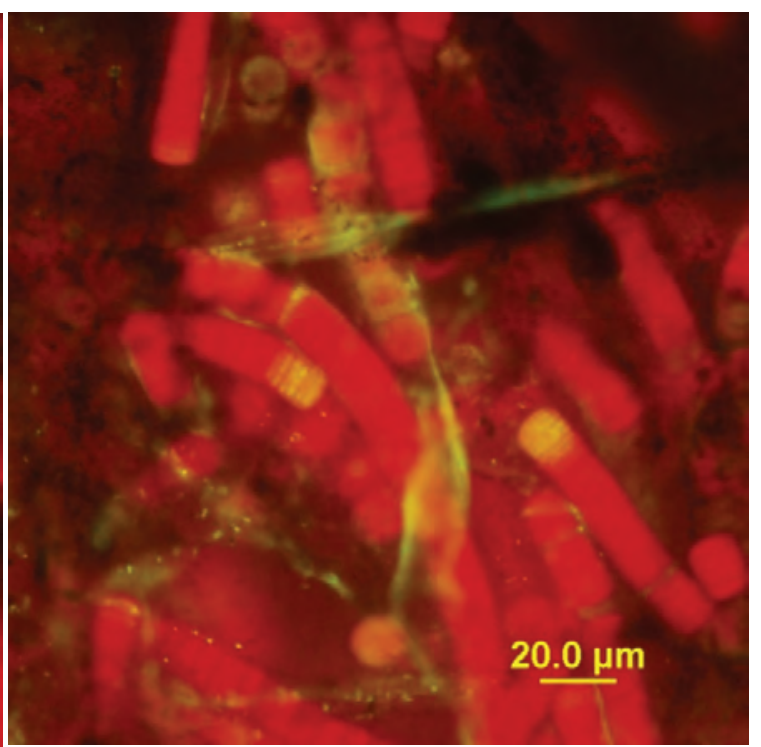

Sytox ${ }^{\circledR}$ green

\section{QuikLyse $^{\mathrm{TM}}-2 \mathrm{x}$}

Figure 166. Laboratory culture-Lyngbya DVL 1103B. LM-Lyngbya sp. FITC-a red color dominates the cells. Sytox ${ }^{\circledR}$ green-stain was picked up by a few cells in each filament and the tips of each filament. LM - differential interference contrast microscopy; FITC - epifluorescent microscopy; Sytox ${ }^{\circledR}$ green - epifluorescent microscopy in conjunction with the nucleic acid stain Syto ${ }^{\circledR}$ green. 


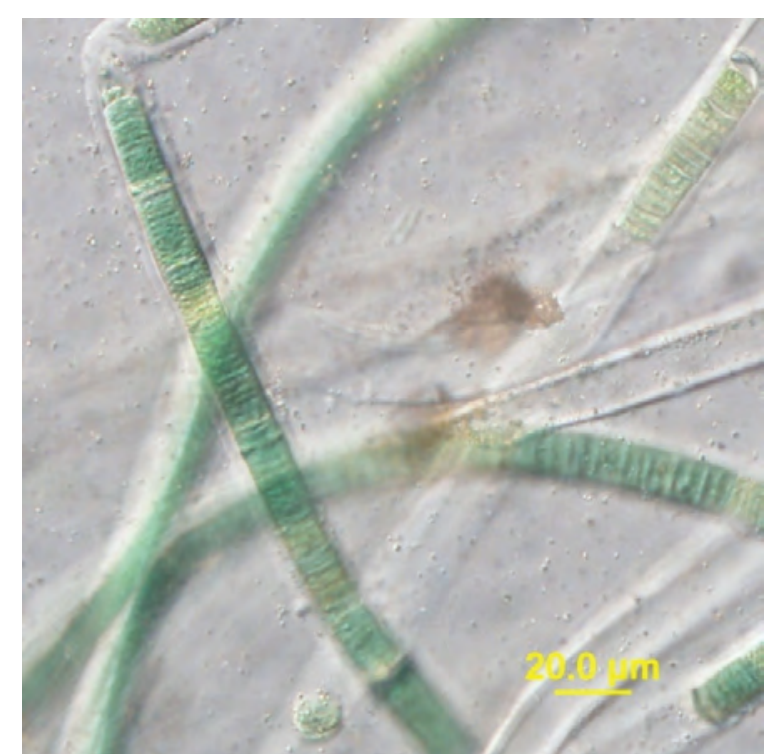

LM

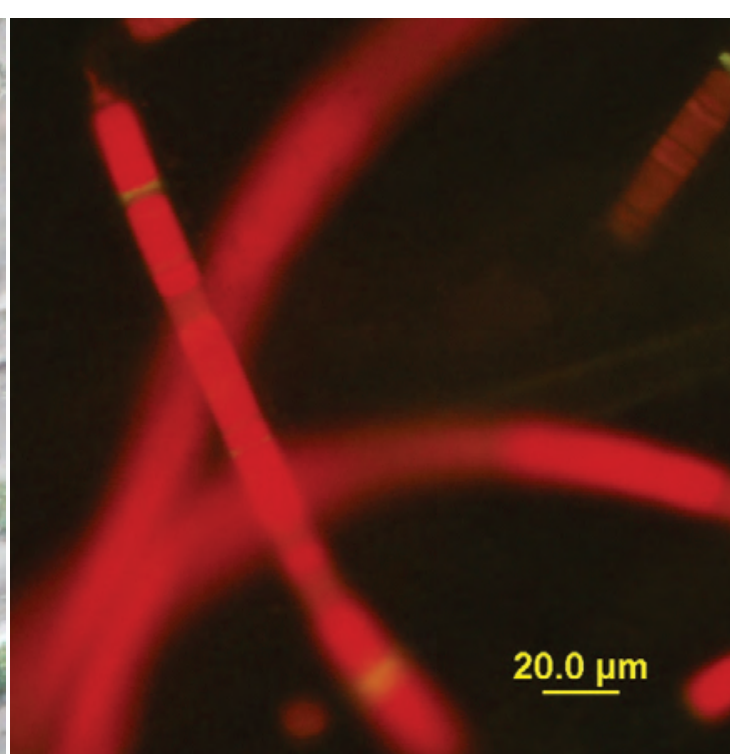

FITC

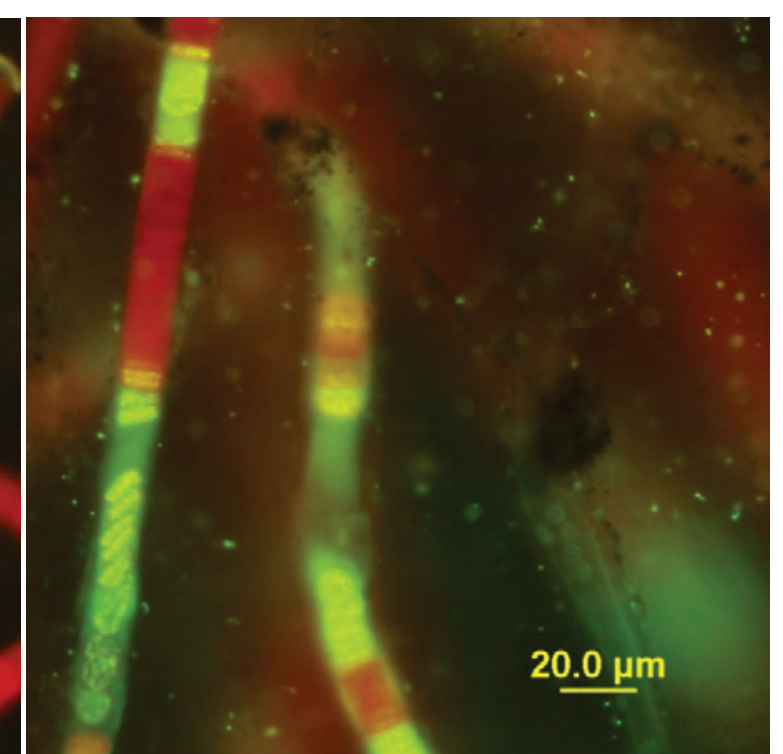

Sytox ${ }^{\circledR}$ green

QuikLyse ${ }^{\text {TM }}-3 x$

Figure 167. Laboratory culture-Lyngbya DVL 1103B. LM-Lyngbya sp. FITC-a red color dominates the cells. Sytox ${ }^{\circledR}$ green-stain was picked up by a few cells in each filament. LM - differential interference contrast microscopy; FITC - epifluorescent microscopy; Sytox ${ }^{\circledR}$ green - epifluorescent microscopy in conjunction with the nucleic acid stain Sytox ${ }^{\circledR}$ green. 


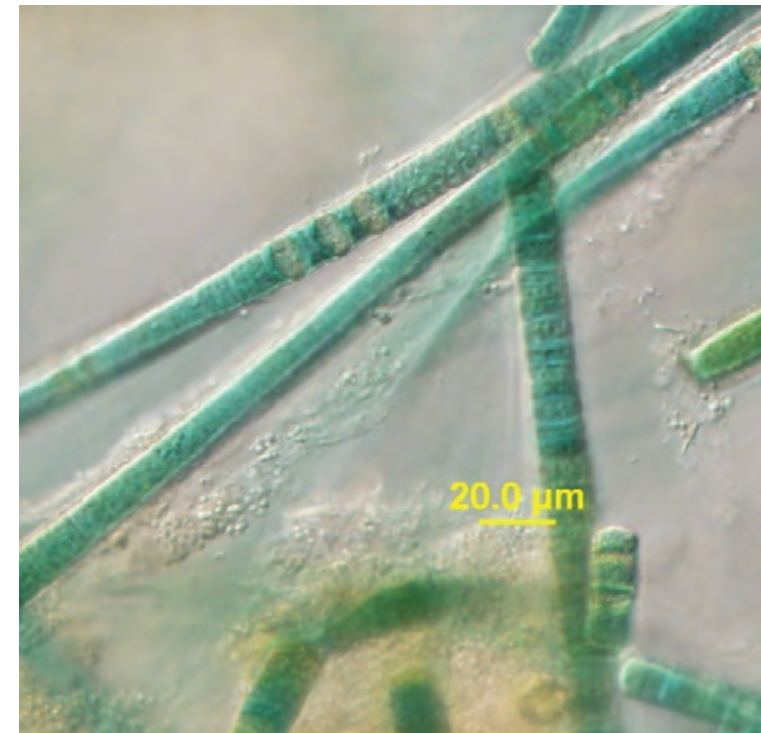

LM

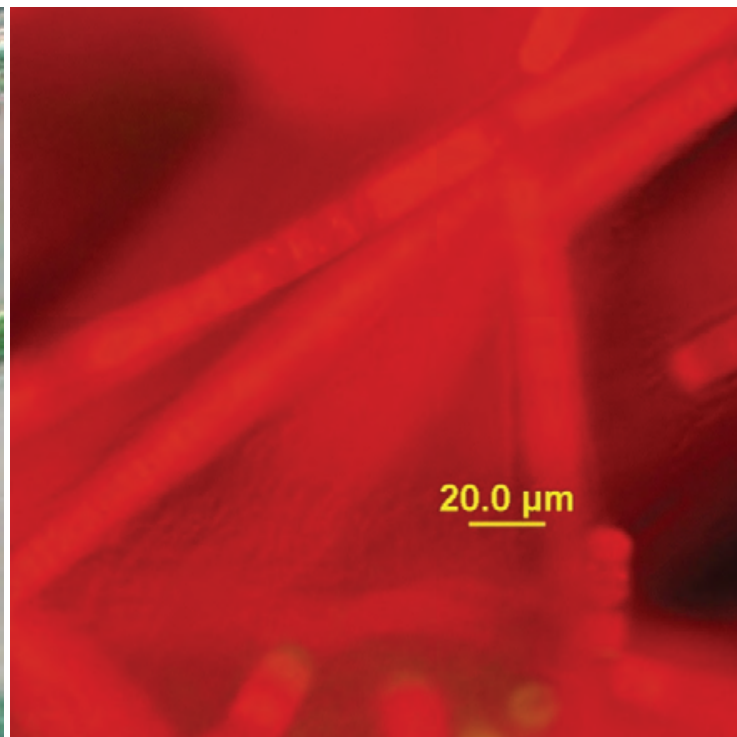

FITC

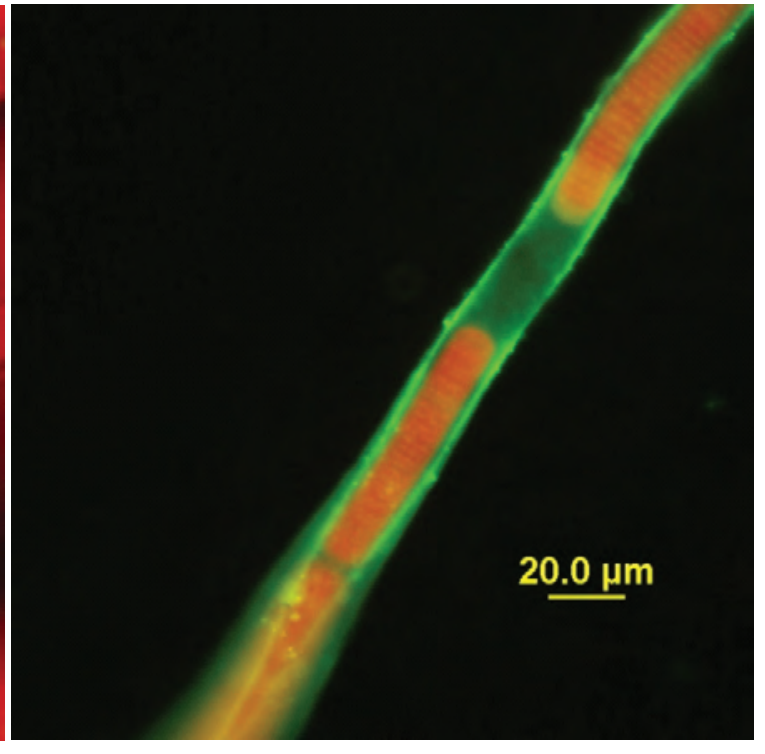

Sytox ${ }^{\circledast}$ green

\section{One freeze-thaw cycle}

Figure 168. Laboratory culture-Lyngbya DVL 1103B. LM-Lyngbya sp. Note: the color is dominated by phycocyanin. FITC-a red color dominates the cells. Sytox ${ }^{\circledR}$ green-stain was picked up by the sheath but not the cells. LM - differential interference contrast microscopy; FITC - epifluorescent microscopy; Sytox ${ }^{\circledR}$ green epifluorescent microscopy in conjunction with the nucleic acid stain Sytox ${ }^{\circledR}$ green. 


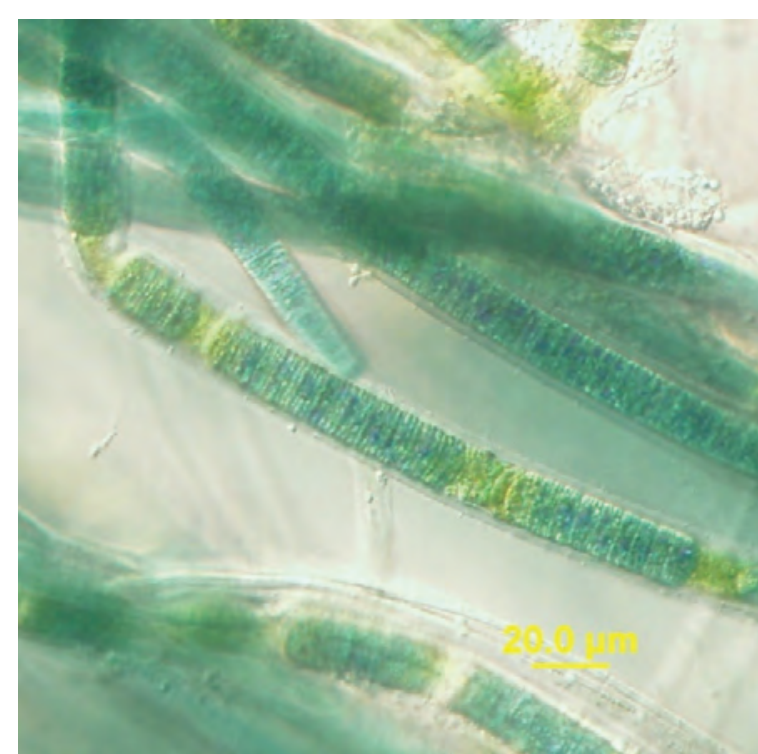

LM

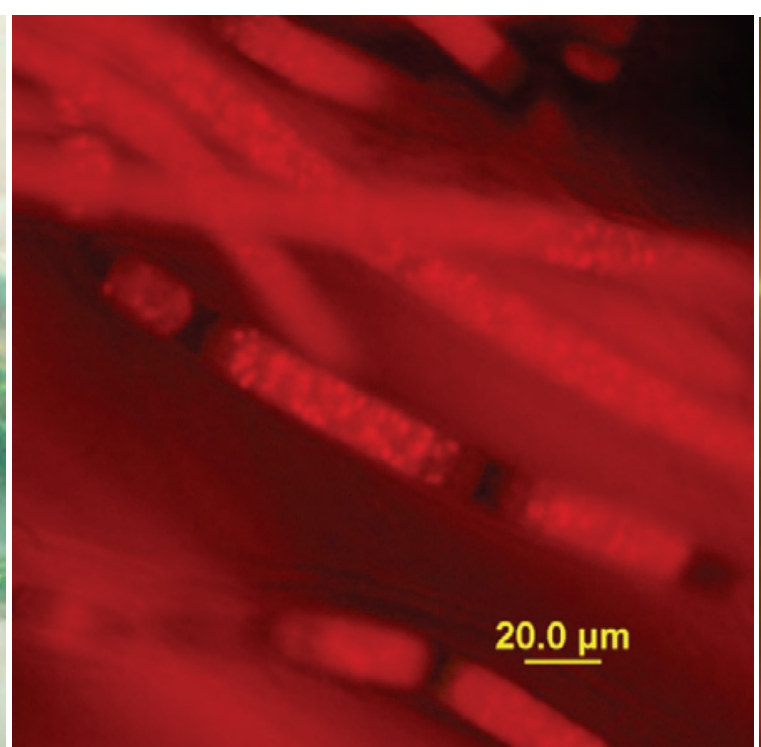

FITC

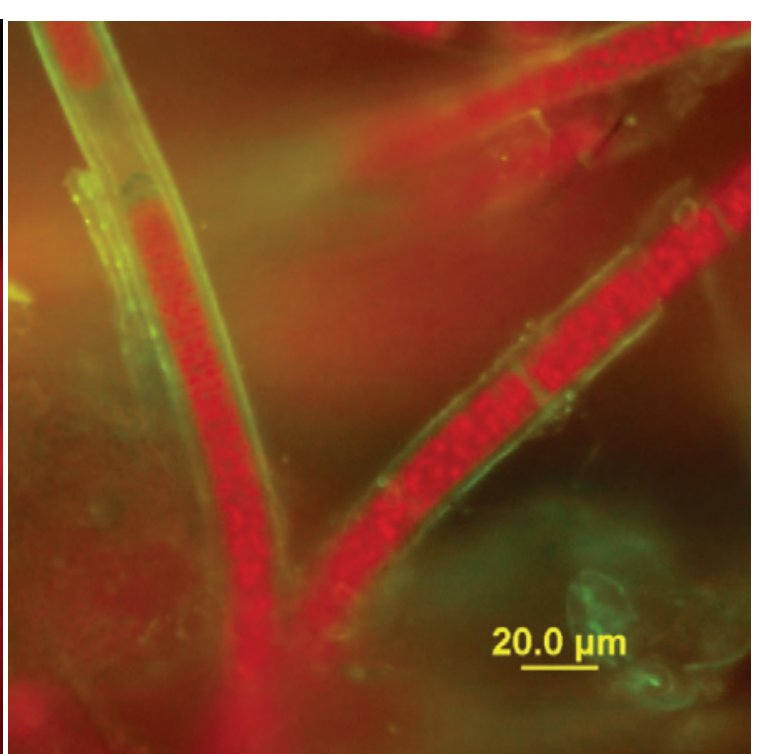

Sytox ${ }^{\circledR}$ green

Two freeze-thaw cycles

Figure 169. Laboratory culture-Lyngbya DVL 1103B. LM-Lyngbya sp. FITC-a red color dominates the cells. Note: cellular material appears to clump into particles. Sytox ${ }^{\circledR}$ green-stain was picked up by the sheath but not the cells. LM - differential interference contrast microscopy; FITC - epifluorescent microscopy; Sytox ${ }^{\circledR}$ green epifluorescent microscopy in conjunction with the nucleic acid stain Sytox ${ }^{\circledR}$ green. 


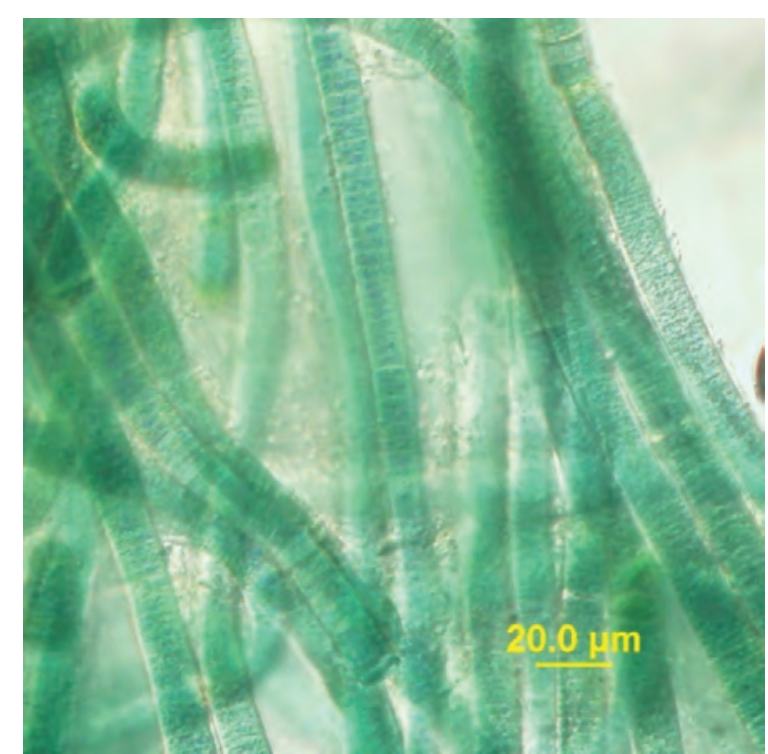

LM

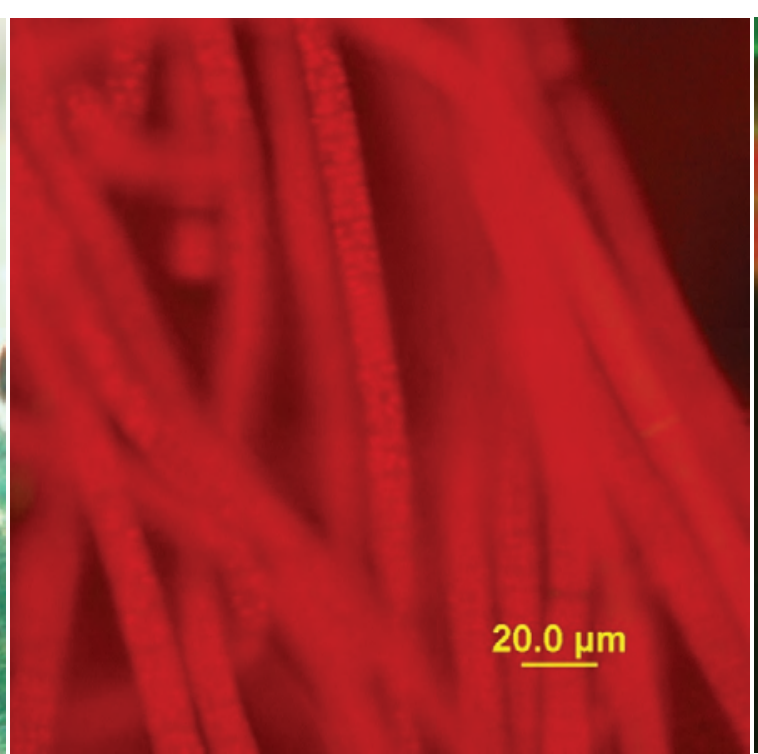

FITC

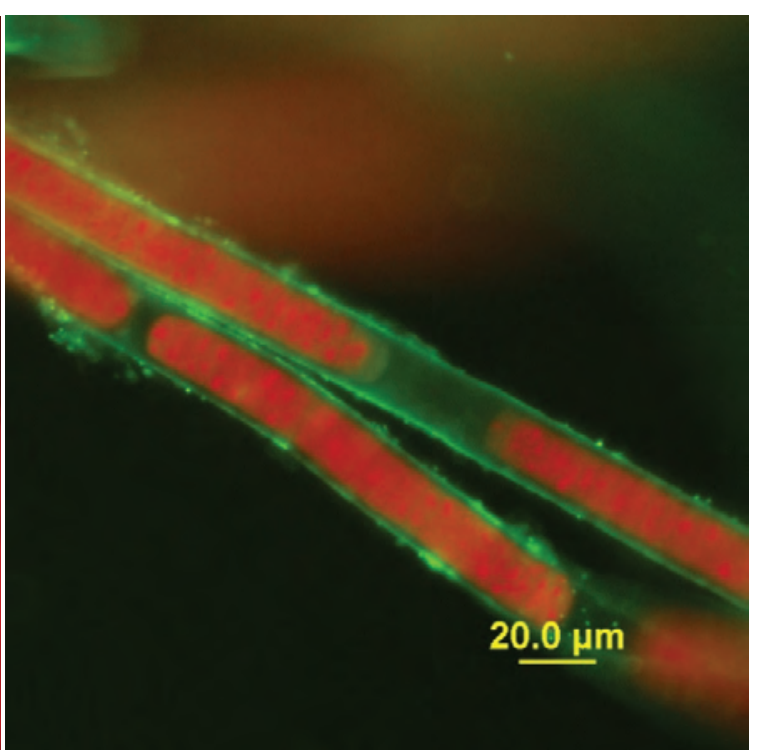

Sytox ${ }^{\circledR}$ green

Three freeze-thaw cycles

Figure 170. Laboratory culture-Lyngbya DVL 1103B. LM-Lyngbya sp. FITC-a red color dominates the cells. Note: cellular material appears to clump into particles Sytox ${ }^{\circledR}$ green-stain was picked up by the sheath but not the cells. LM - differential interference contrast microscopy; FITC - epifluorescent microscopy; Sytox ${ }^{\circledR}$ green - epifluorescent microscopy in conjunction with the nucleic acid stain Syto ${ }^{\circledR}$ green. 


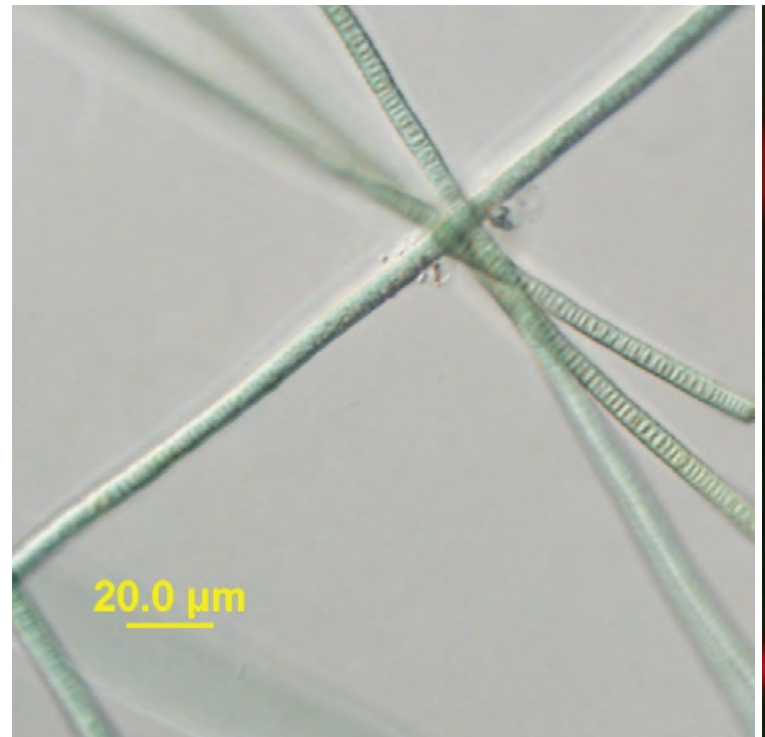

LM

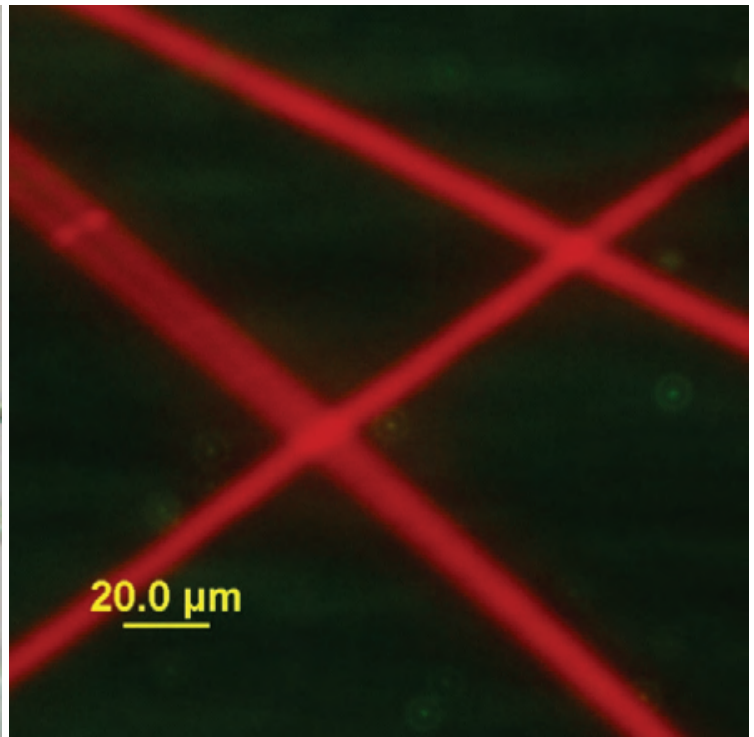

FITC

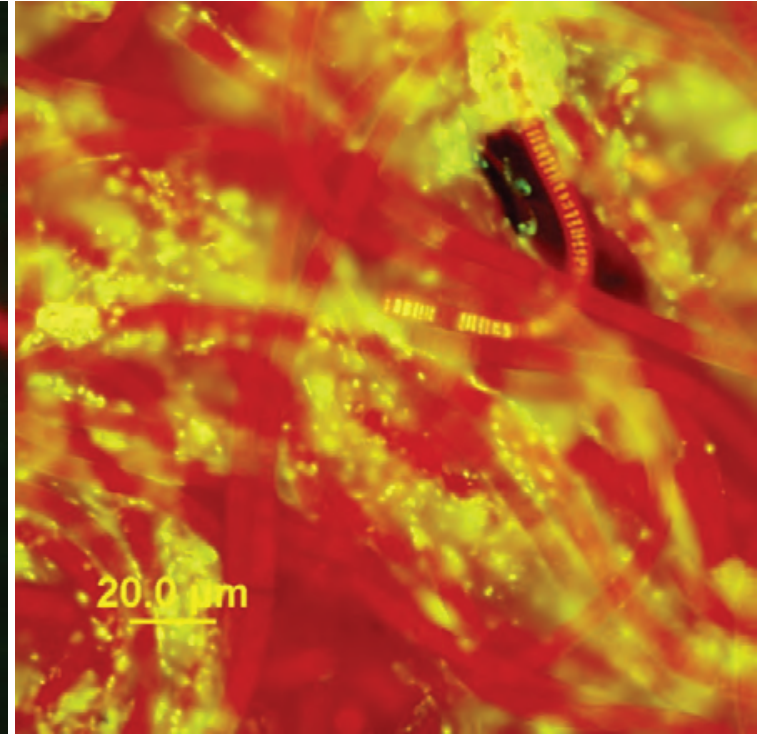

Sytox ${ }^{\circledR}$ green

\section{Control}

Figure 171. Laboratory culture-Phormidium DVL 706A. LM-Phormidium sp. is a filamentous cyanobacterium which may have a thin, mucilaginous sheath. Some species have no sheath. FITC-a red color dominates the cells. Sytox ${ }^{\circledR}$ green-stain was picked up by the extracellular matrix and a few cells. These cultures were not controlled for age; each culture has a mix of filaments that range from actively dividing to senescence. Bacteria appear as bright green dots on the mucilage. LM differential interference contrast microscopy; FITC - epifluorescent microscopy; Sytox ${ }^{\circledR}$ green - epifluorescent microscopy in conjunction with the nucleic acid stain Sytox ${ }^{\circledast}$ green. 


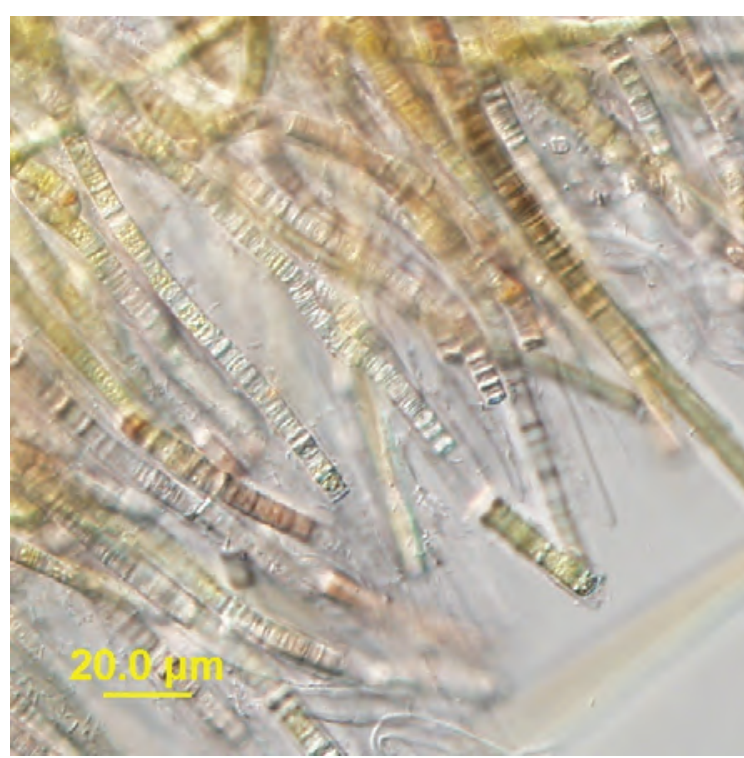

LM

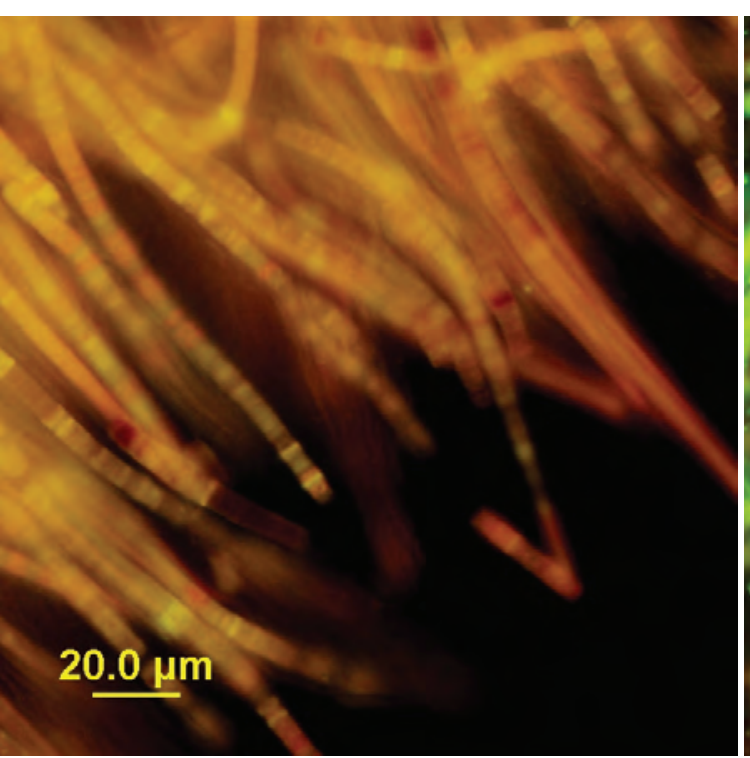

FITC

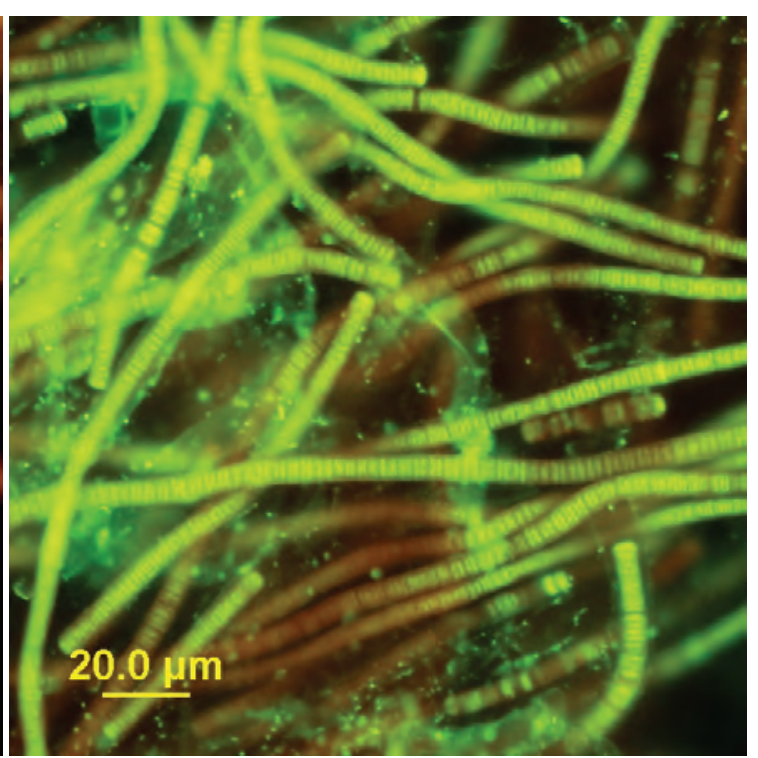

Sytox ${ }^{\circledR}$ green

\section{Boiled for 5 minutes}

Figure 172. Laboratory culture-Phormidium DVL 706A. LM-Phormidium sp. FITC-an orange color dominates the cells. Sytox ${ }^{\circledR}$ green-stain penetrated, indicating the cell membrane was disrupted; bright green cells. Some of the filaments did not have any cells that stained, or only had some of the cells in the filament that stained. LM - differential interference contrast microscopy; FITC - epifluorescent microscopy; Sytox ${ }^{\circledR}$ green - epifluorescent microscopy in conjunction with the nucleic acid stain Sytox ${ }^{\circledR}$ green. 


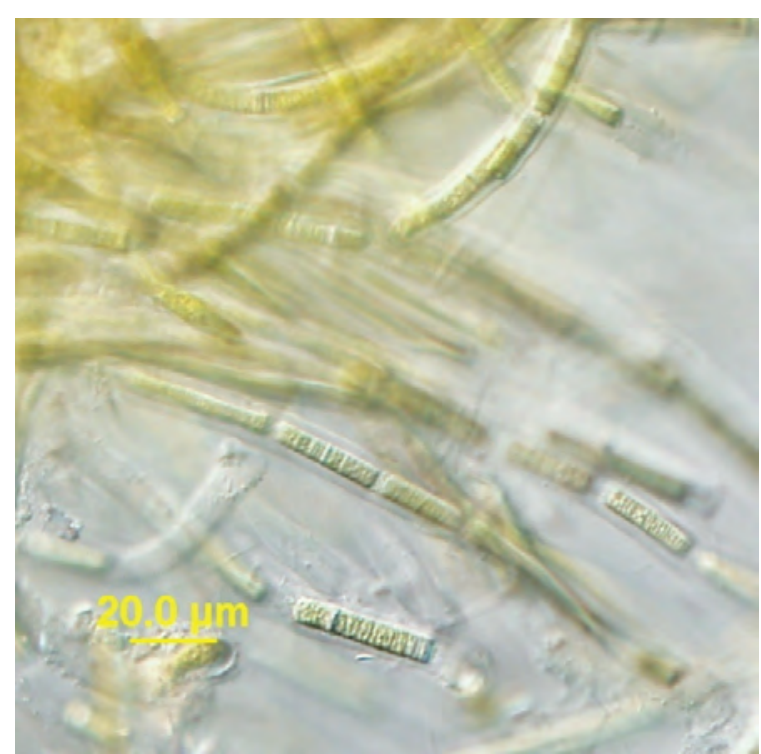

LM

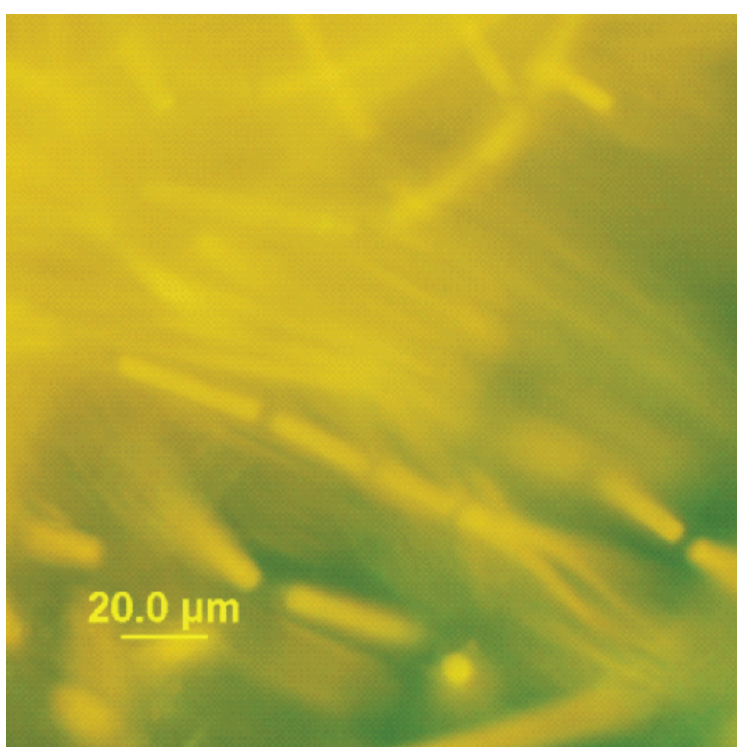

FITC

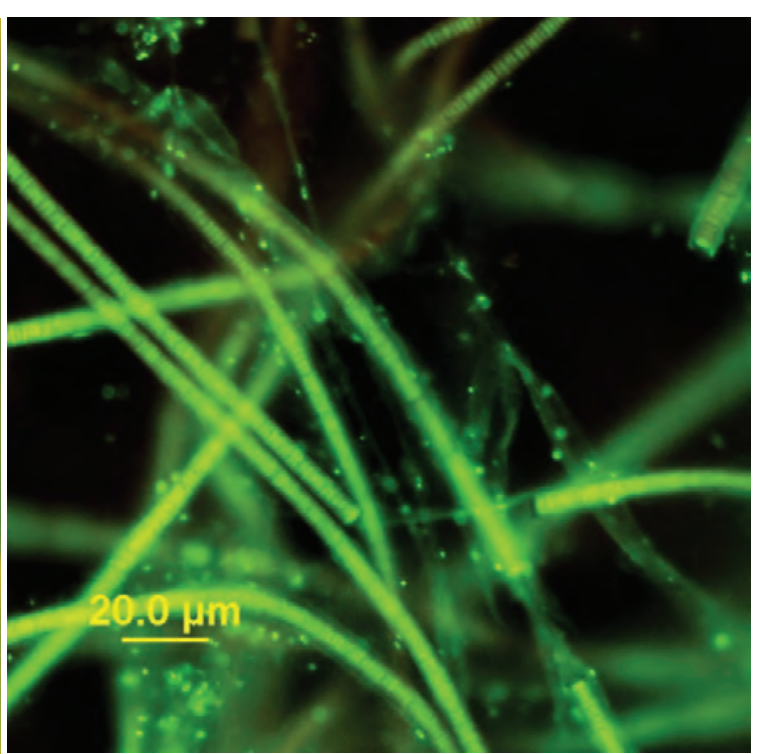

Sytox ${ }^{\circledR}$ green

\section{Boiled for 15 minutes}

Figure 173. Laboratory culture-Phormidium DVL 706A. LM-Phormidium sp. FITC-a yellow-orange color dominates the cells. Sytox ${ }^{\circledR}$ green-stain penetrated, indicating the cell membrane was disrupted; bright green cells. Some of the filaments did not have any cells that stained, or only had some of the cells in the filament that stained. LM - differential interference contrast microscopy; FITC - epifluorescent microscopy; Sytox ${ }^{\circledR}$ green - epifluorescent microscopy in conjunction with the nucleic acid stain Sytox ${ }^{\circledR}$ green. 


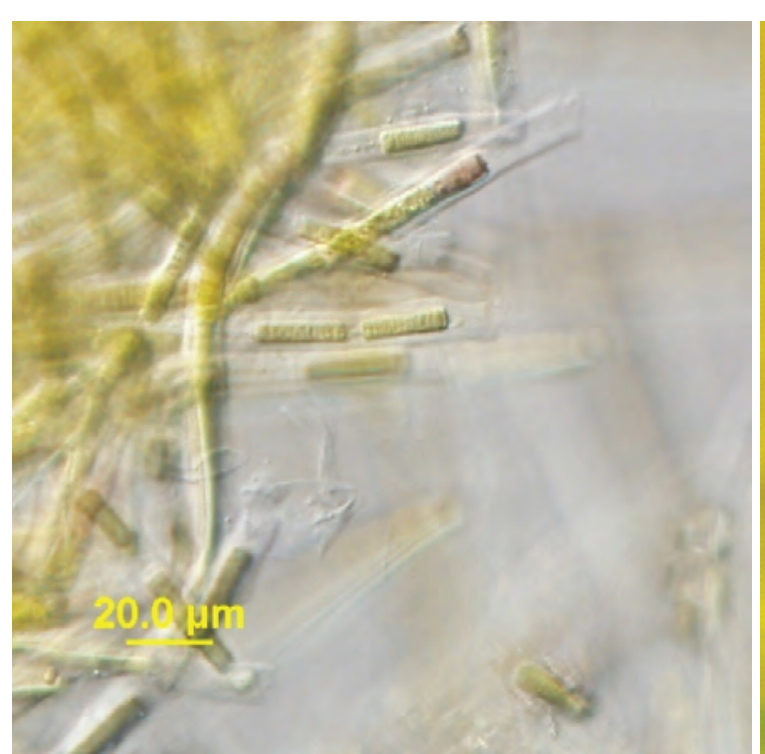

LM

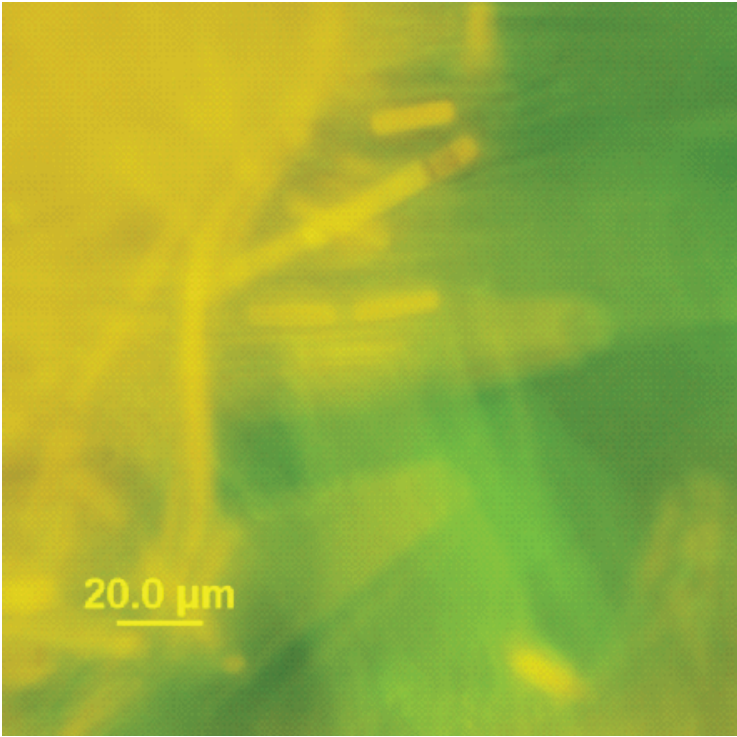

FITC

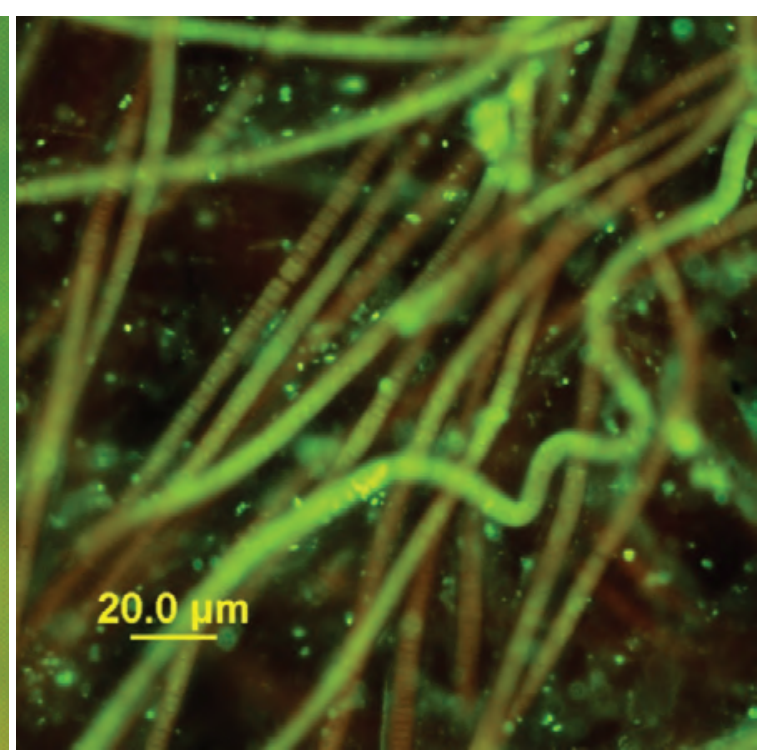

Sytox ${ }^{\circledR}$ green

Boiled for 30 minutes

Figure 174. Laboratory culture-Phormidium DVL 706A. LM-Phormidium sp. FITC-a yellow-orange color dominates the cells. Sytox ${ }^{\circledR}$ green-stain penetrated, indicating the cell membrane was disrupted; bright green cells. Some of the filaments did not have any cells that stained, or only had some of the cells in the filament that stained. LM - differential interference contrast microscopy; FITC - epifluorescent microscopy; Sytox ${ }^{\circledR}$ green - epifluorescent microscopy in conjunction with the nucleic acid stain Sytox ${ }^{\circledR}$ green. 


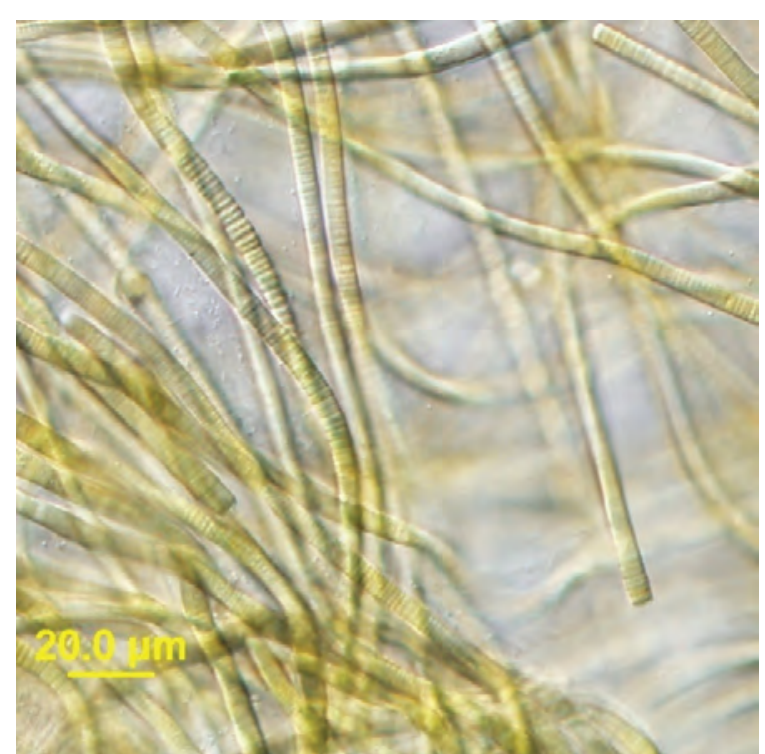

LM

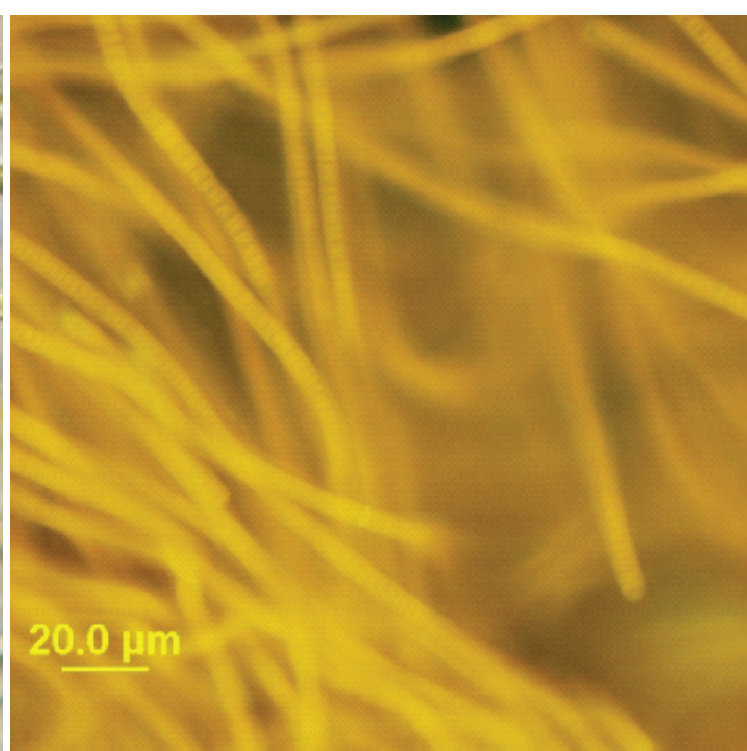

FITC

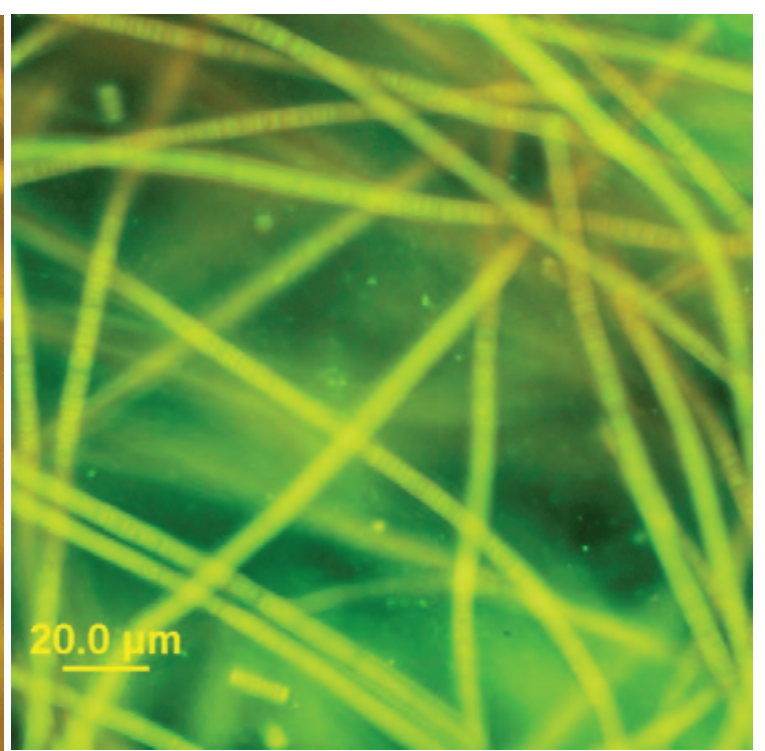

Sytox ${ }^{\circledast}$ green

Autoclaved for 5 minutes

Figure 175. Laboratory culture-Phormidium DVL 706A. LM-Phormidium sp. FITC-a yellow-orange color dominates the cells. Sytox ${ }^{\circledR}$ green-stain penetrated, indicating the cell membrane was disrupted; yellow-green cells. LM - differential interference contrast microscopy; FITC - epifluorescent microscopy; Sytox ${ }^{\circledR}$ green epifluorescent microscopy in conjunction with the nucleic acid stain Sytox ${ }^{\circledR}$ green. 


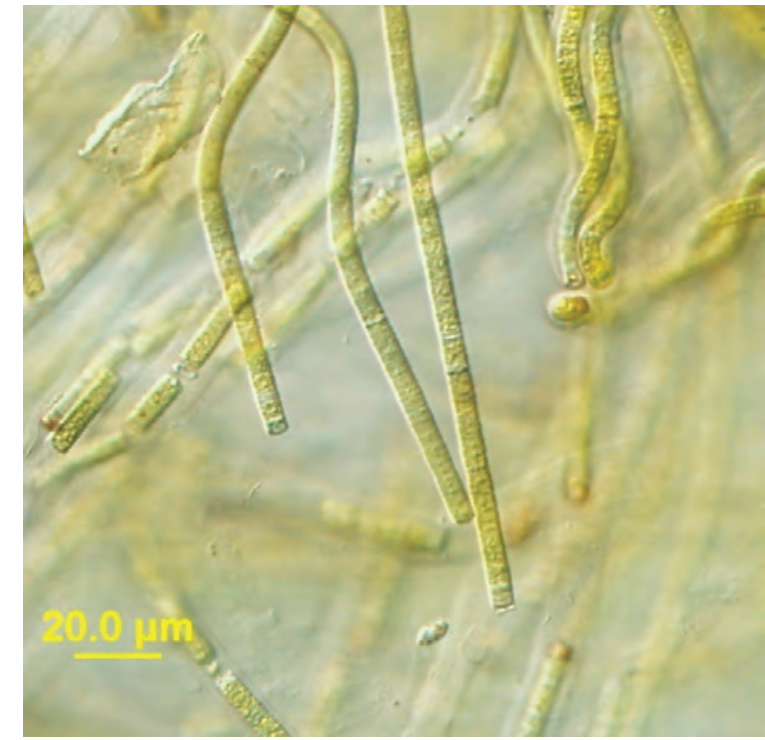

LM

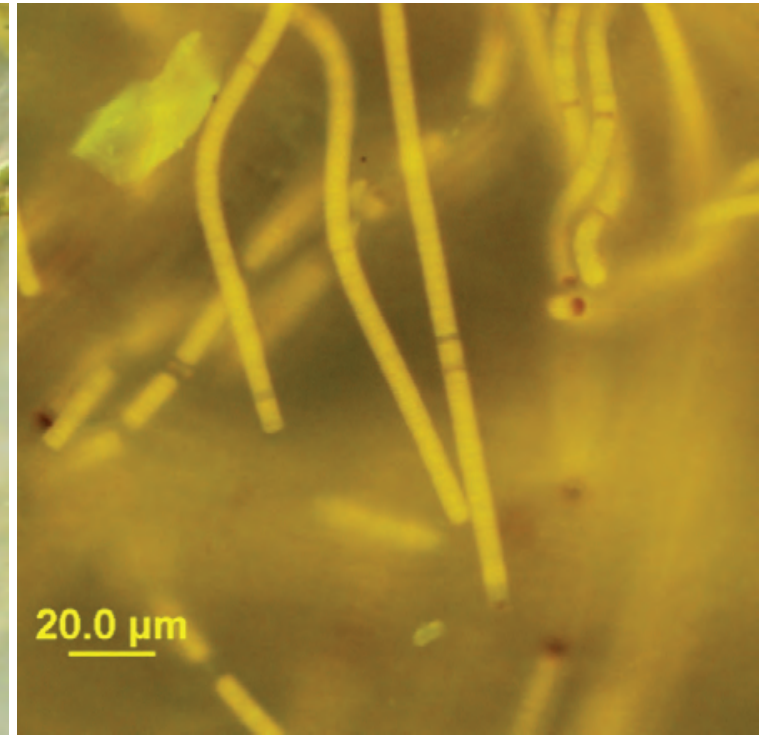

FITC

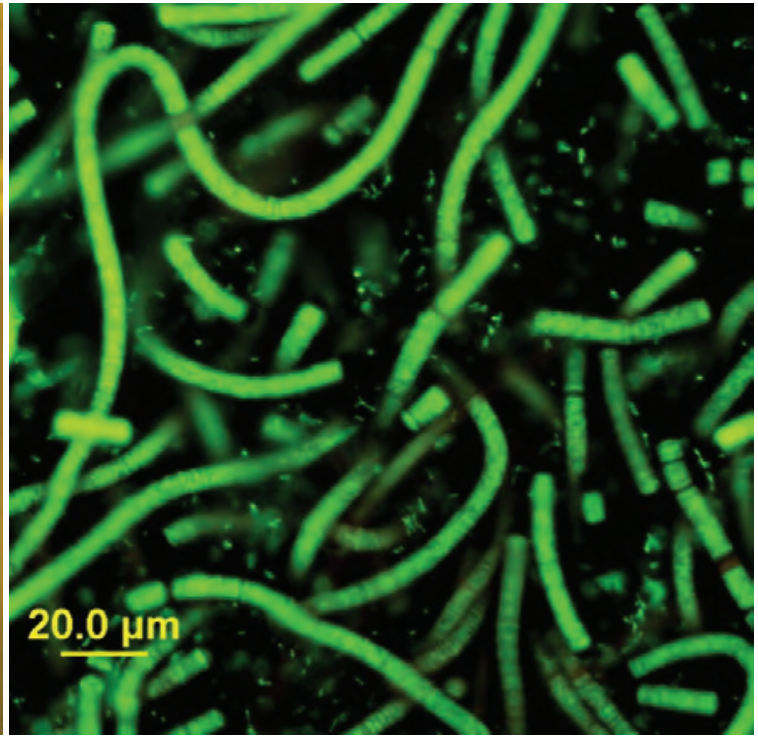

Sytox ${ }^{\circledR}$ green

Autoclaved for 15 minutes

Figure 176. Laboratory culture-Phormidium DVL 706A. LM-Phormidium sp. FITC-a yellow-orange color dominates the cells. Sytox ${ }^{\circledR}$ green-stain penetrated, indicating the cell membrane was disrupted; bright green cells. LM - differential interference contrast microscopy; FITC - epifluorescent microscopy; Sytox ${ }^{\circledR}$ green epifluorescent microscopy in conjunction with the nucleic acid stain Sytox ${ }^{\circledR}$ green. 


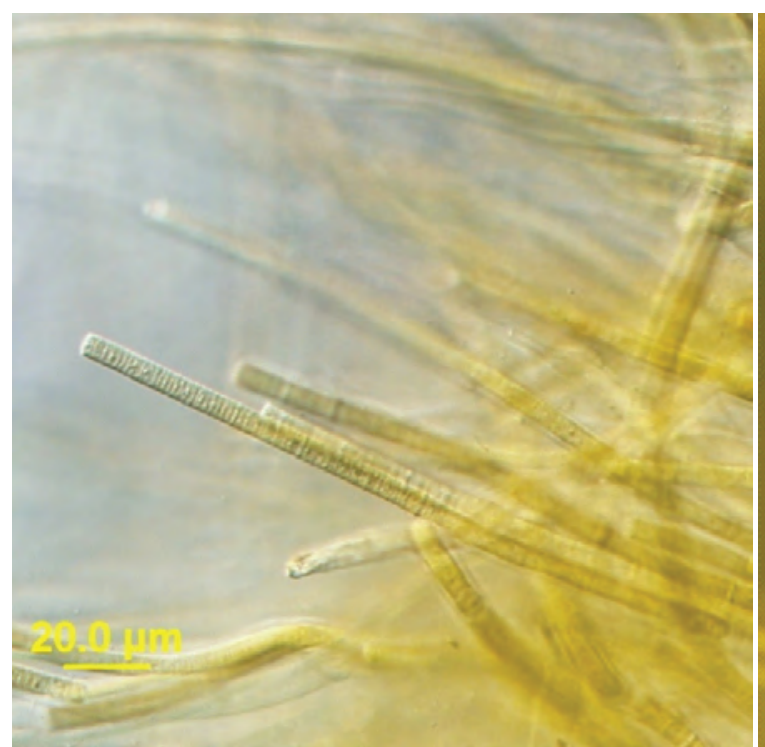

LM

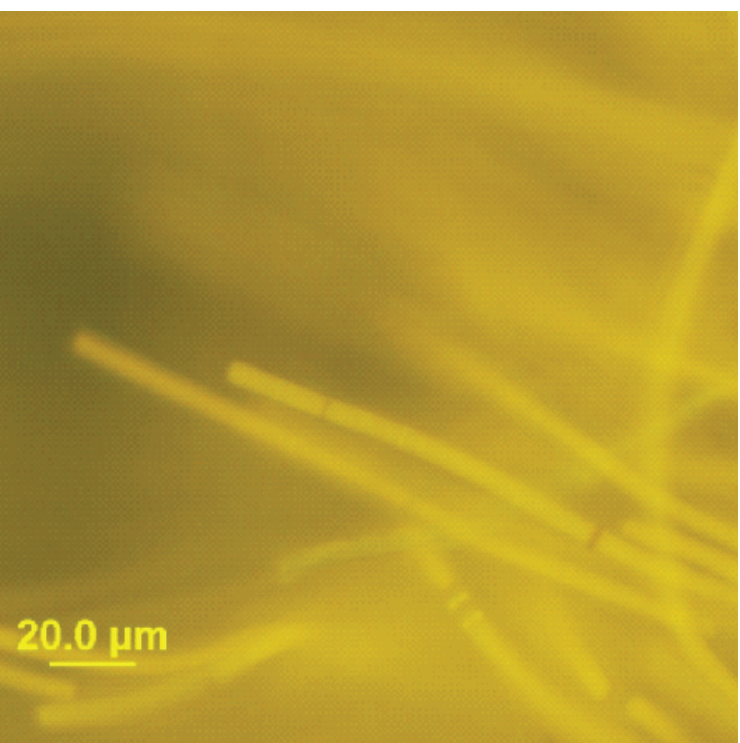

FITC

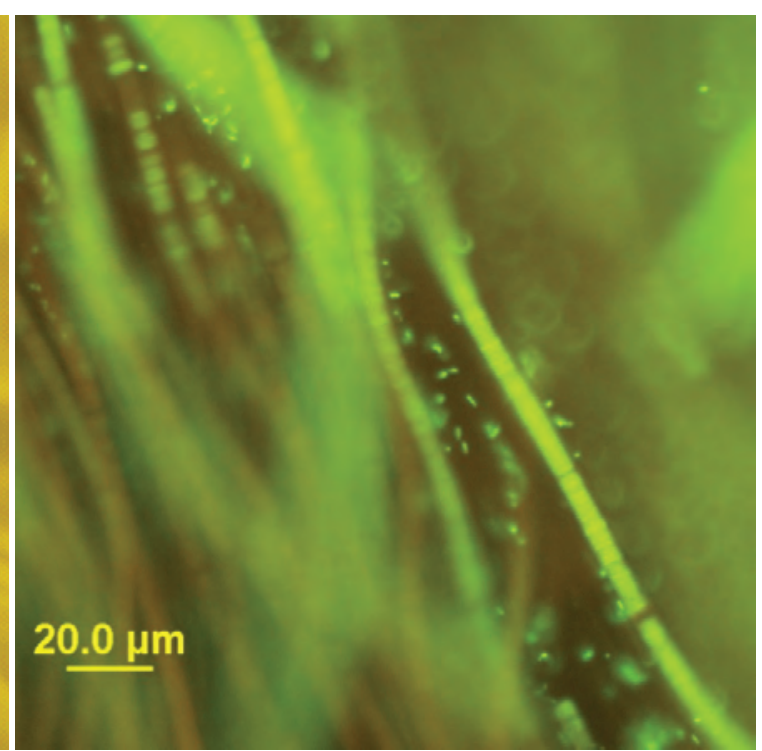

Sytox ${ }^{\circledR}$ green

Autoclaved for 30 minutes

Figure 177. Laboratory culture-Phormidium DVL 706A. LM-Phormidium sp. FITC-a yellow-orange color dominates the cells. Sytox ${ }^{\circledR}$ green-stain penetrated, indicating the cell membrane was disrupted; bright green cells. LM - differential interference contrast microscopy; FITC - epifluorescent microscopy; Sytox ${ }^{\circledR}$ green epifluorescent microscopy in conjunction with the nucleic acid stain Sytox ${ }^{\circledast}$ green. 


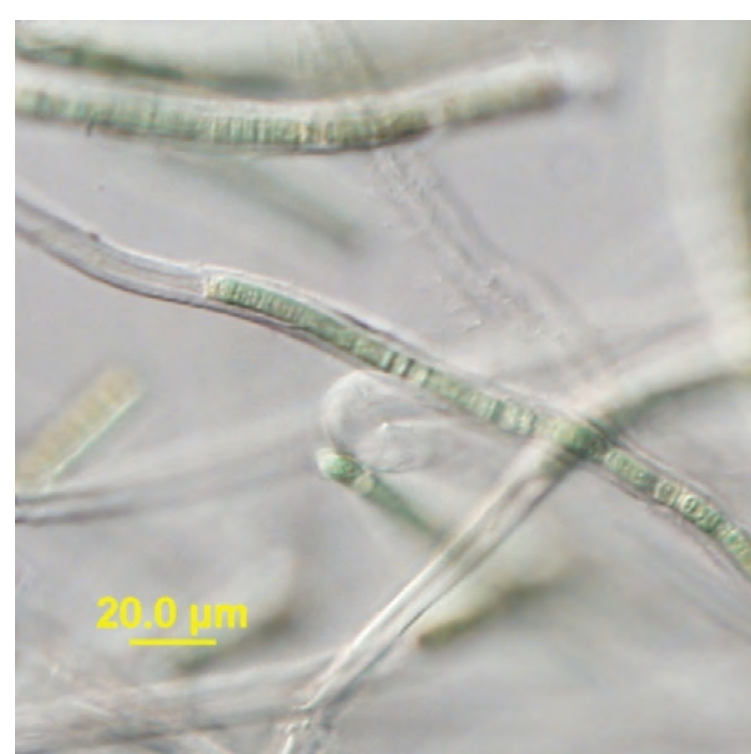

LM

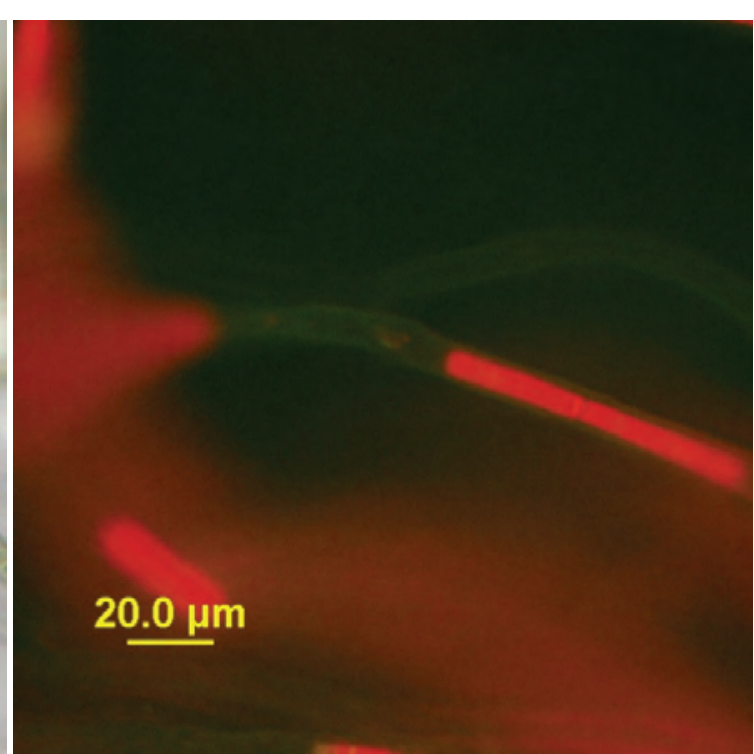

FITC

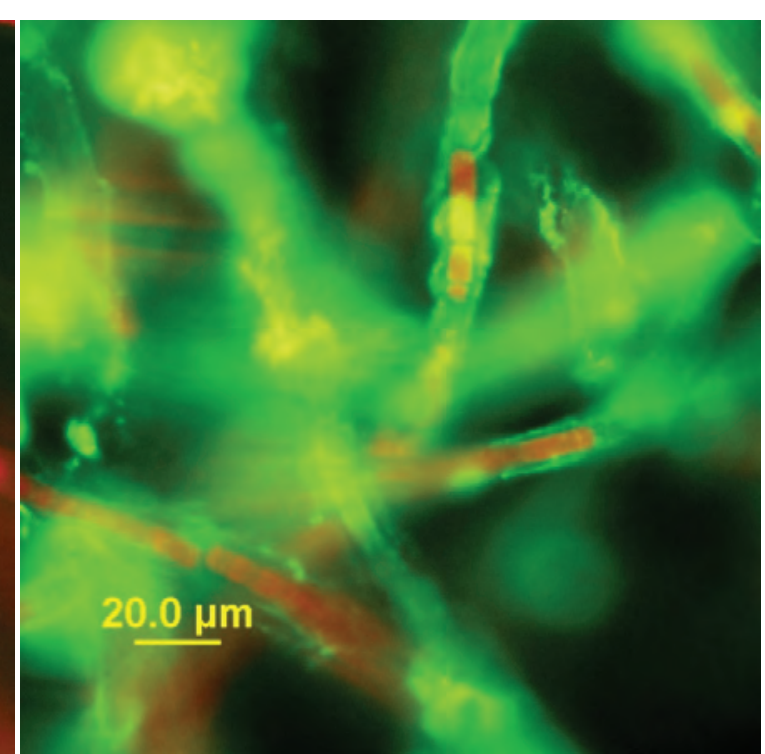

Sytox ${ }^{\circledR}$ green

Sonicated at 10 percent power

Figure 178. Laboratory culture-Phormidium DVL 706A. LM-Phormidium sp. FITC-a red color dominates the cells. Sytox ${ }^{\circledR}$ green-stained the sheath but not the cells.

LM - differential interference contrast microscopy; FITC - epifluorescent microscopy; Sytox ${ }^{\circledR}$ green - epifluorescent microscopy in conjunction with the nucleic acid stain Sytox ${ }^{\circledR}$ green. 


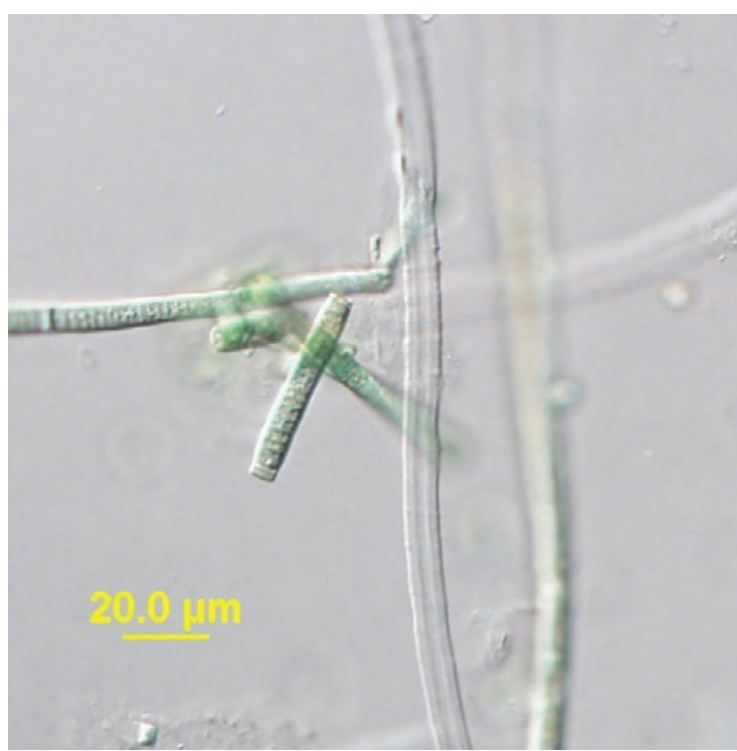

LM

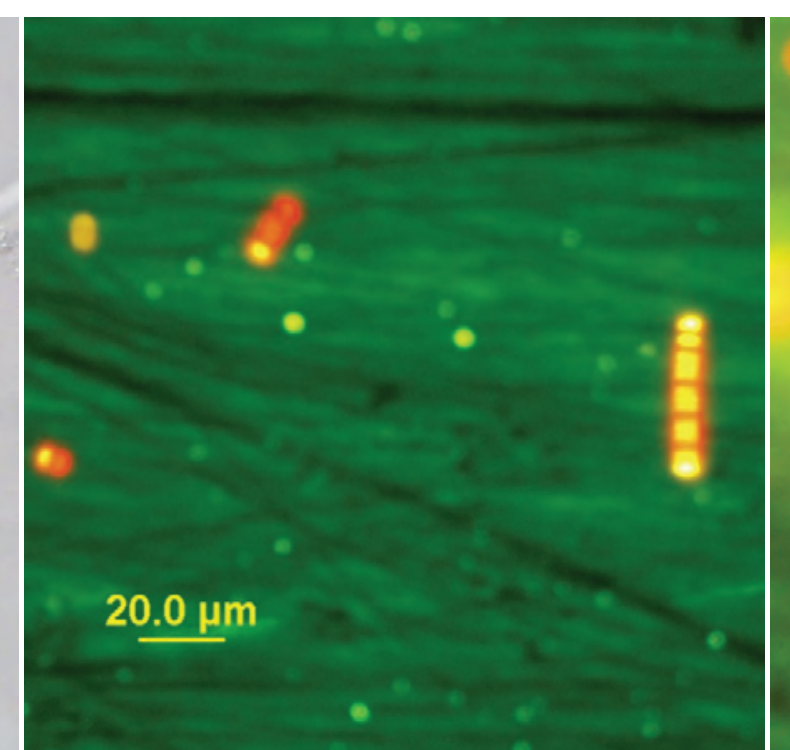

FITC

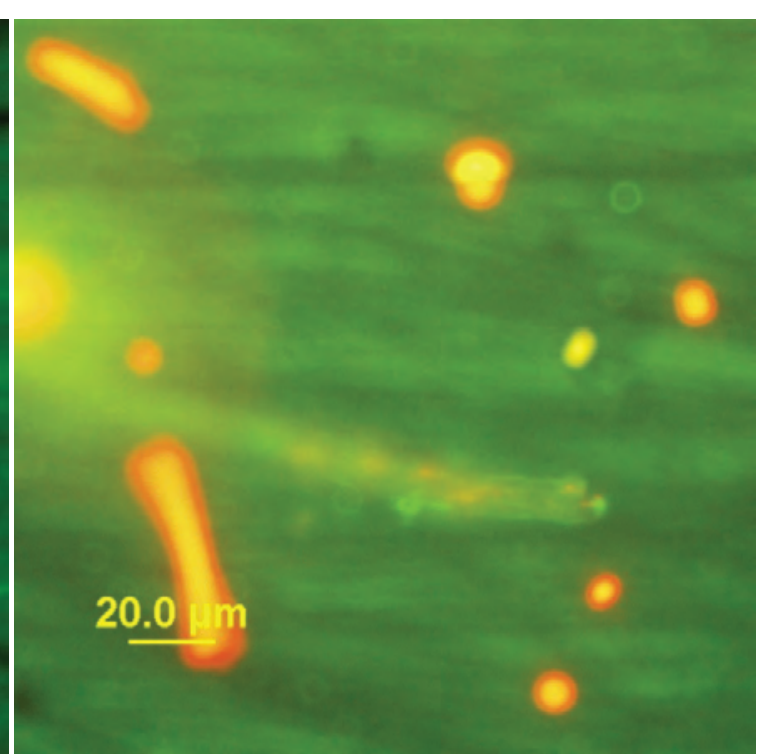

Sytox ${ }^{\circledR}$ green

\section{Sonicated at 35 percent power}

Figure 179. Laboratory culture-Phormidium DVL 706A. LM-Lyngbya sp. Note: the sheath appears to be separated from the cells. FITC-an orange color dominates the cells. Sytox ${ }^{\circledR}$ green-did not penetrate the cells. LM - differential interference contrast microscopy; FITC - epifluorescent microscopy; Sytox ${ }^{\circledR}$ green - epifluorescent microscopy in conjunction with the nucleic acid stain Syto ${ }^{\circledR}$ green. 


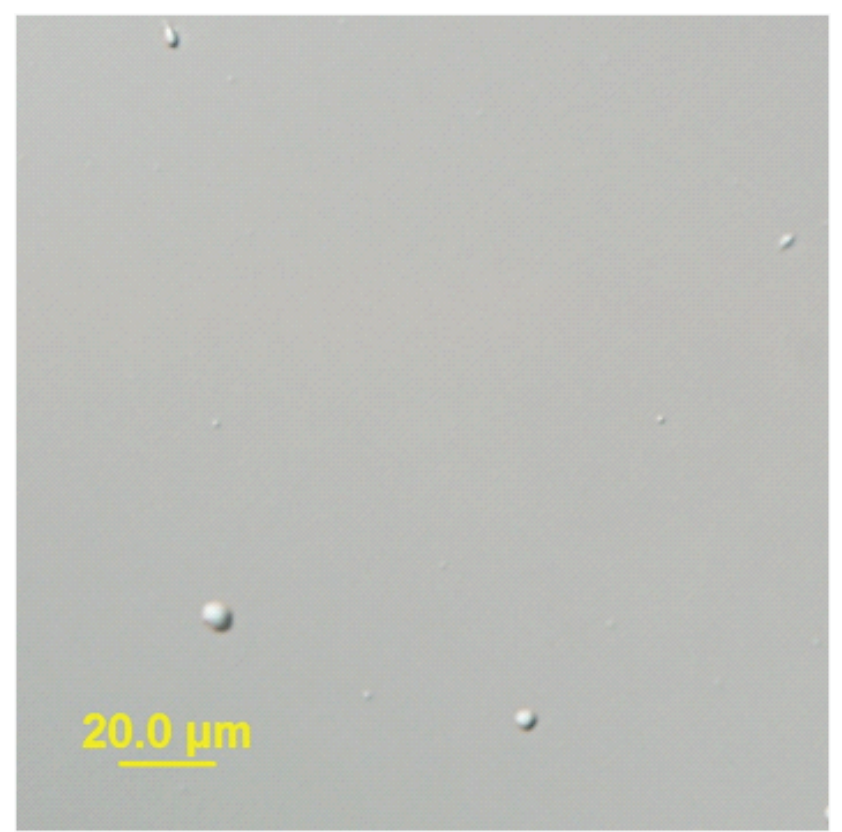

LM-nothing discernable

\section{Sonicated at 70 percent power}

Figure 180. Laboratory culture-Phormidium DVL 706A.

LM-Nothing discernable. LM - differential interference

contrast microscopy; FITC - epifluorescent microscopy;

Sytox ${ }^{\circledR}$ green - epifluorescent microscopy in conjunction

with the nucleic acid stain Sytox ${ }^{\circledR}$ green. 


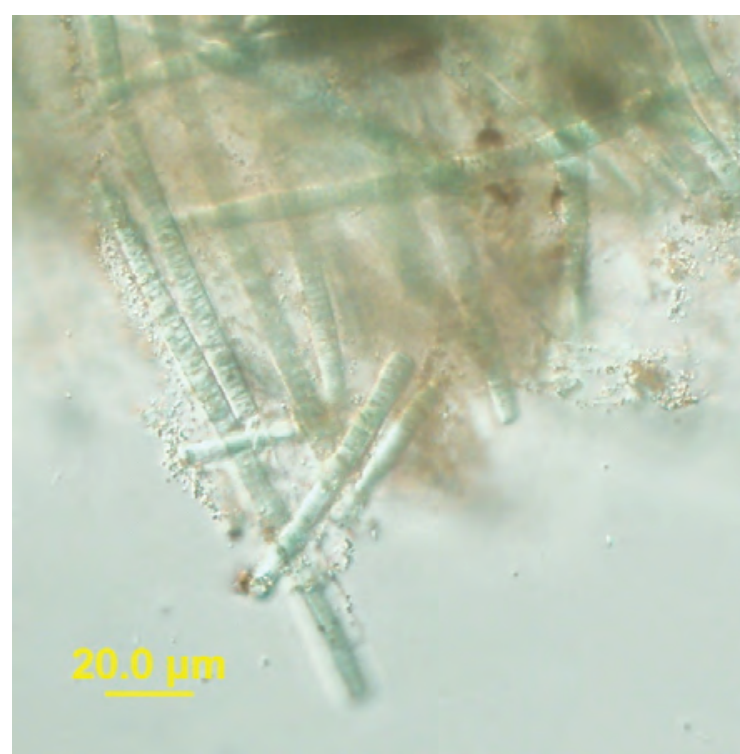

LM

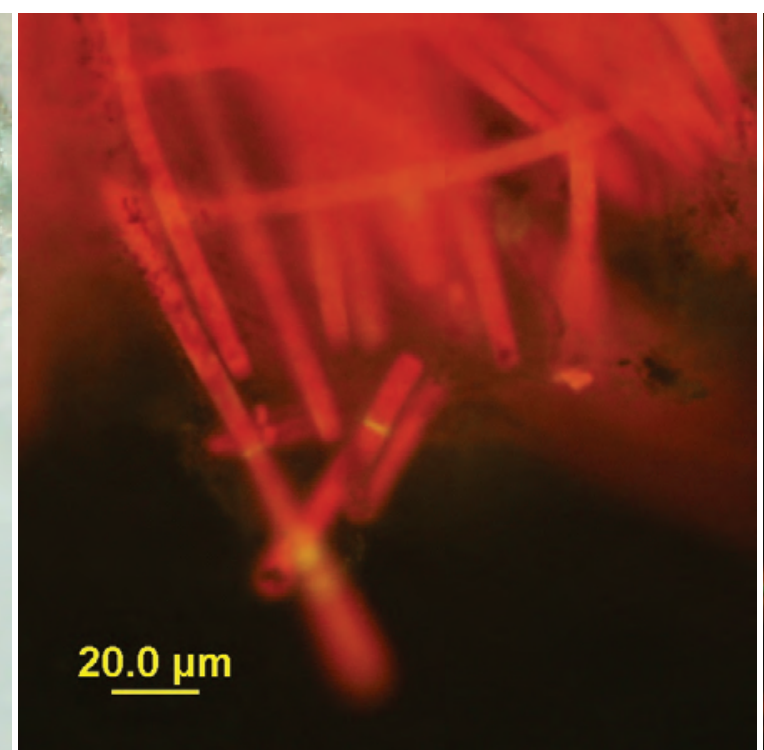

FITC

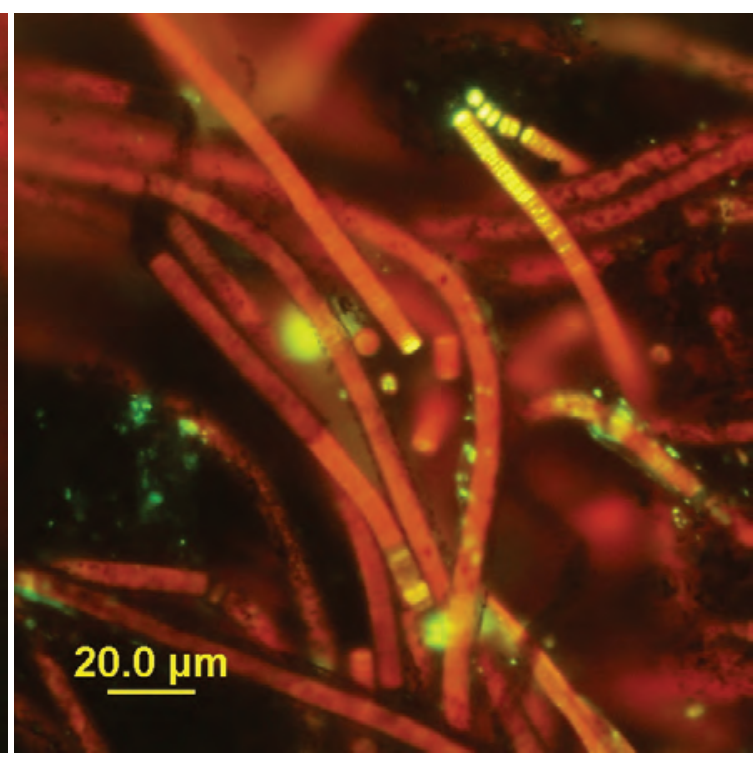

Sytox ${ }^{\circledR}$ green

QuikLyse ${ }^{\mathrm{TM}}-1 \mathrm{x}$

Figure 181. Laboratory culture-Phormidium DVL 706A. LM-Phormidium sp. FITC-a red color dominates the cells. Sytox ${ }^{\circledR}$ green-stain penetrated some cells, indicating the cell membrane was disrupted; bright green cells. Some of the filaments only had some of the cells in the filament that stained. LM - differential interference contrast microscopy; FITC - epifluorescent microscopy; Sytox ${ }^{\circledR}$ green - epifluorescent microscopy in conjunction with the nucleic acid stain Sytox ${ }^{\circledR}$ green. 


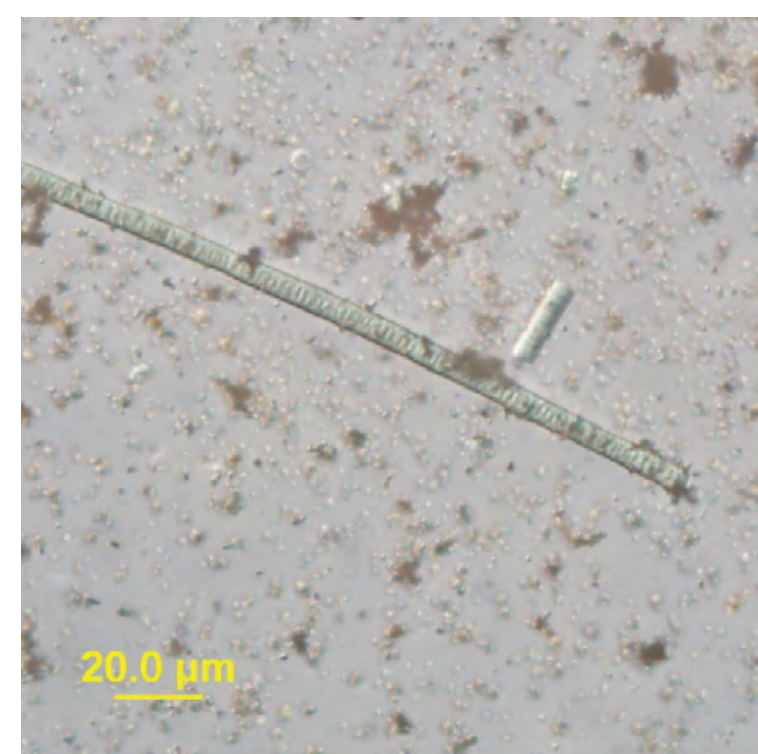

LM

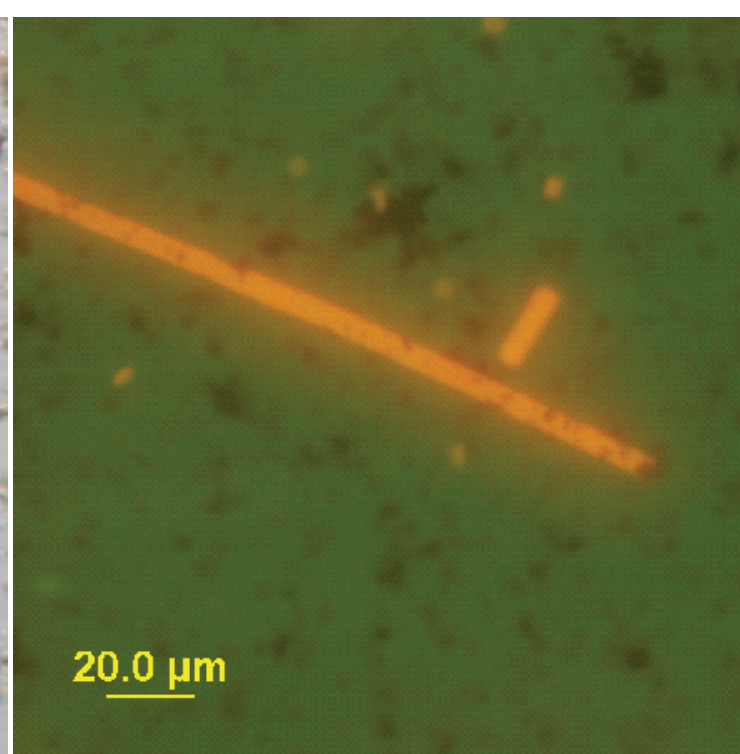

FITC

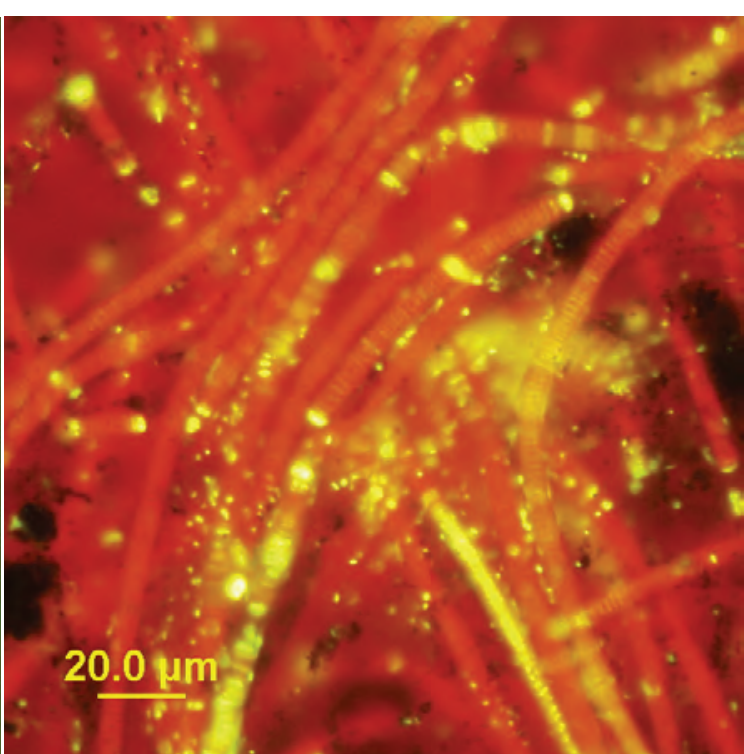

Sytox ${ }^{\circledR}$ green

\section{QuikLyse ${ }^{\mathrm{TM}}-2 \mathrm{x}$}

Figure 182. Laboratory culture-Phormidium DVL 706A. LM-Phormidium sp. FITC-an orange color dominates the cells. Sytox ${ }^{\circledR}$ green-stain penetrated some cells, indicating the cell membrane was disrupted; bright green cells. Some of the filaments only had some of the cells in the filament that stained. LM - differential interference contrast microscopy; FITC - epifluorescent microscopy; Sytox ${ }^{\circledR}$ green - epifluorescent microscopy in conjunction with the nucleic acid stain Sytox ${ }^{\circledR}$ green. 


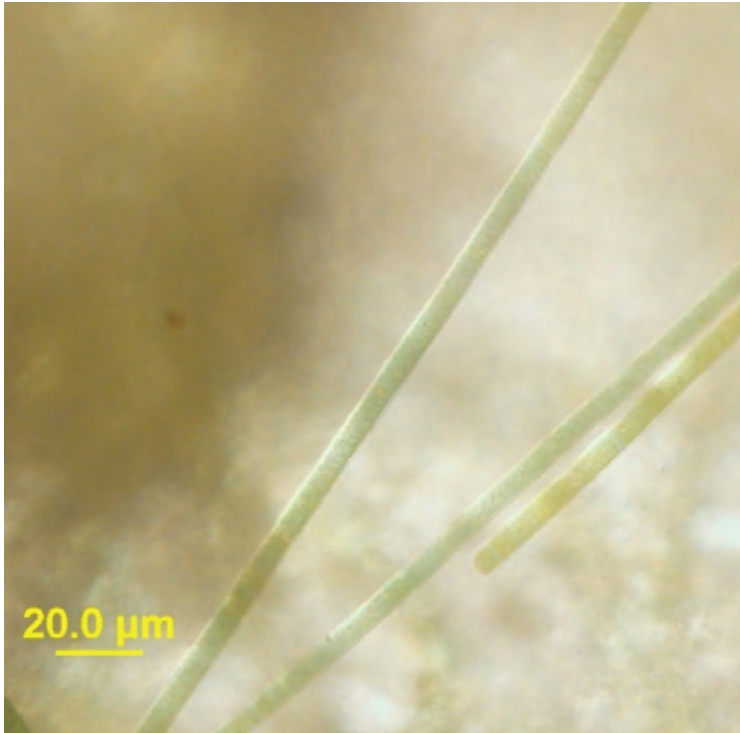

LM

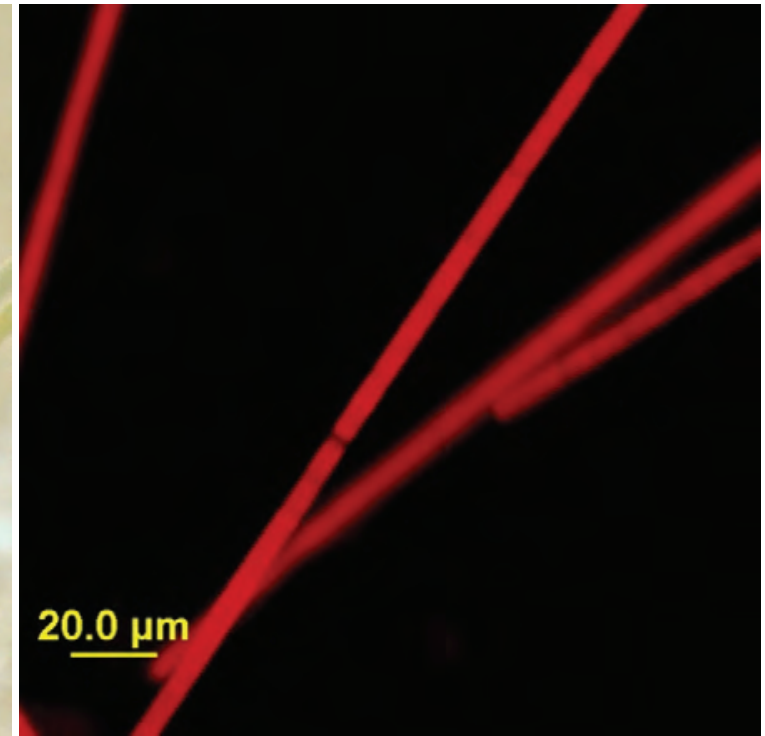

FITC

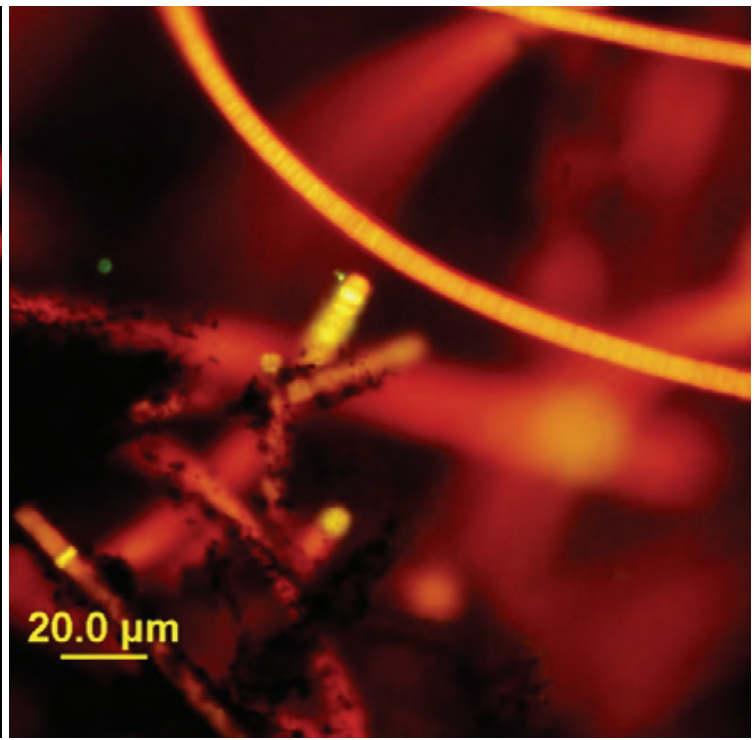

Sytox ${ }^{\circledR}$ green

\section{QuikLyse ${ }^{\mathrm{TM}}-3 \mathrm{x}$}

Figure 183. Laboratory culture-Phormidium DVL 706A. LM-Phormidium sp. FITC-a red color dominates the cells. Sytox ${ }^{\circledR}$ green-stain penetrated some cells, indicating the cell membrane was disrupted; bright green cells. Some of the filaments only had some of the cells in the filament that stained. LM - differential interference contrast microscopy; FITC - epifluorescent microscopy; Sytox ${ }^{\circledR}$ green - epifluorescent microscopy in conjunction with the nucleic acid stain Sytox ${ }^{\circledR}$ green. 


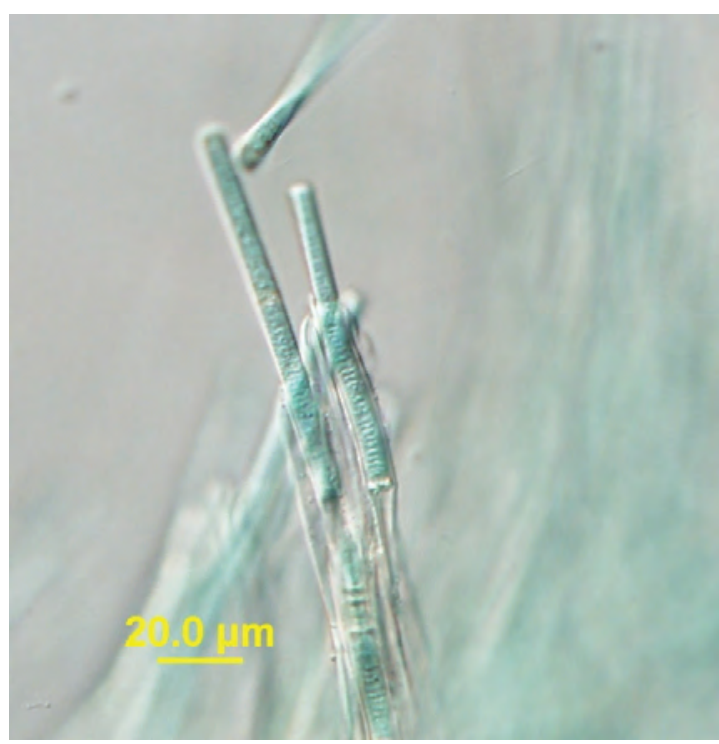

LM

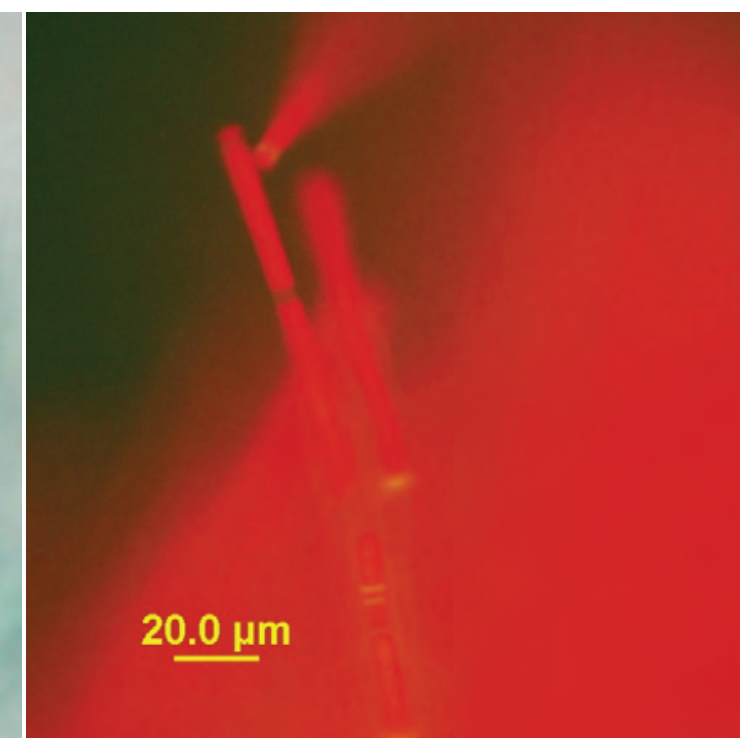

FITC

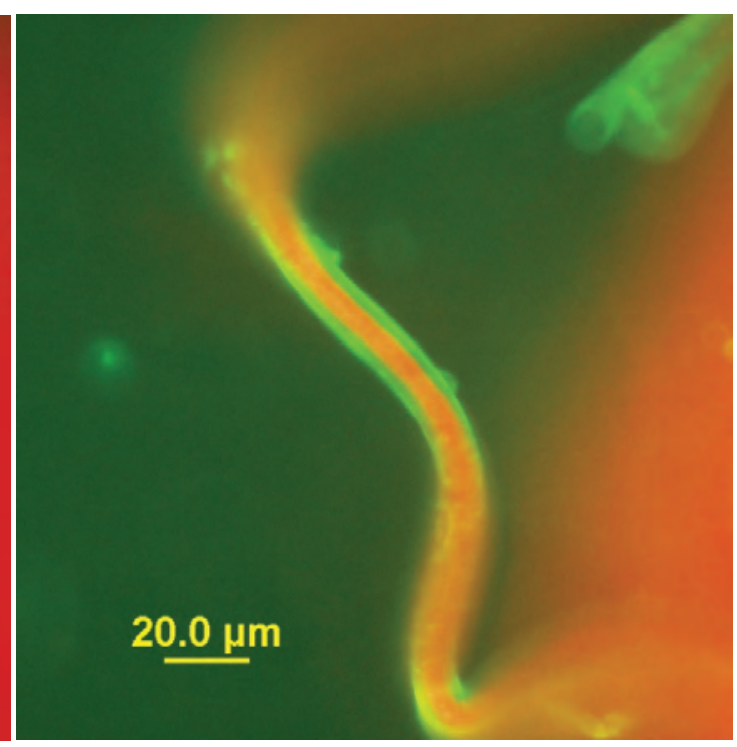

Sytox ${ }^{\circledR}$ green

\section{One freeze-thaw cycle}

Figure 184. Laboratory culture-Phormidium DVL 706A. LM-Phormidium sp. FITC-a red color dominates the cells. Sytox ${ }^{\circledR}$ green-stain was picked up by the sheath but not the cells. LM - differential interference contrast microscopy; FITC - epifluorescent microscopy; Sytox ${ }^{\circledR}$ green - epifluorescent microscopy in conjunction with the nucleic acid stain Sytox ${ }^{\circledR}$ green 


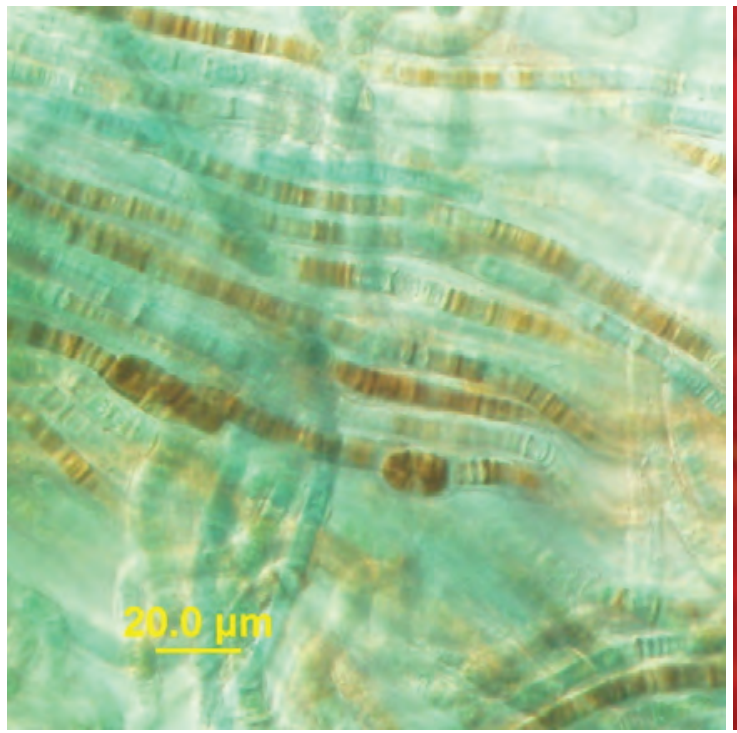

LM

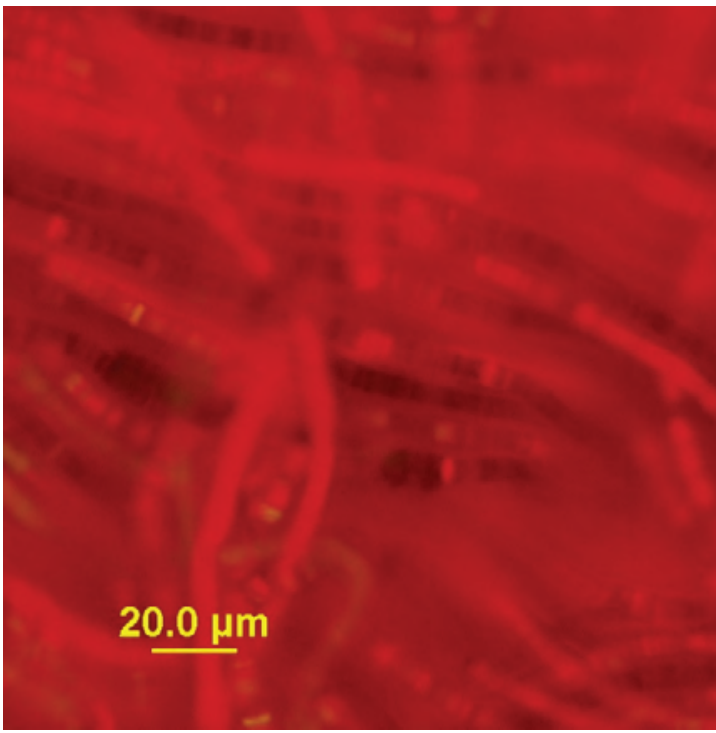

FITC

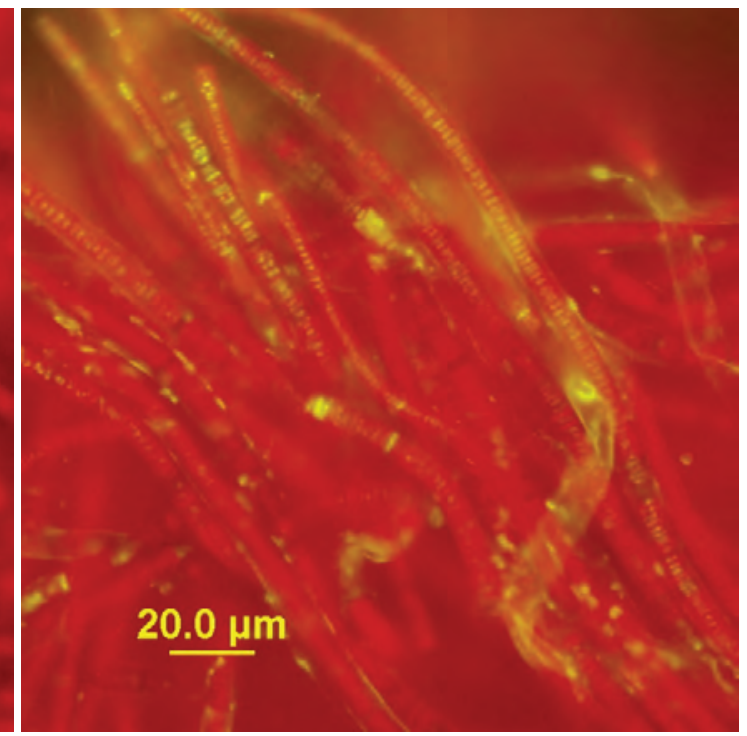

Sytox ${ }^{\circledR}$ green

\section{Two freeze-thaw cycles}

Figure 185. Laboratory culture-Phormidium DVL 706A. LM-Phormidium sp. FITC-a red color dominates the cells. Sytox ${ }^{\circledR}$ green-stain penetrated some cells, indicating the cell membrane was disrupted; bright green cells. Some of the filaments only had some of the cells in the filament that stained. LM - differential interference contrast microscopy; FITC - epifluorescent microscopy; Sytox ${ }^{\circledast}$ green - epifluorescent microscopy in conjunction with the nucleic acid stain Sytox ${ }^{\circledR}$ green. 


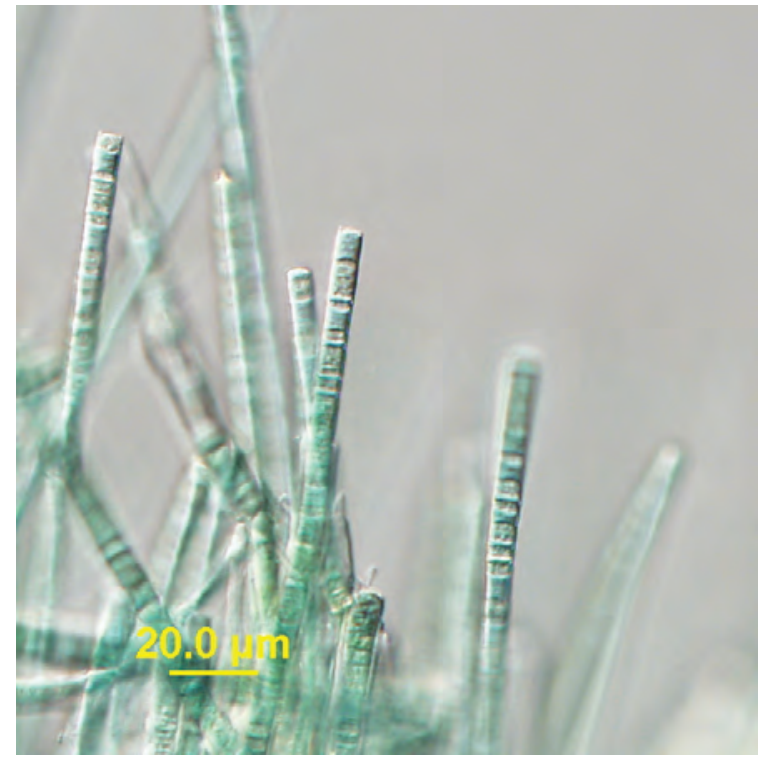

LM

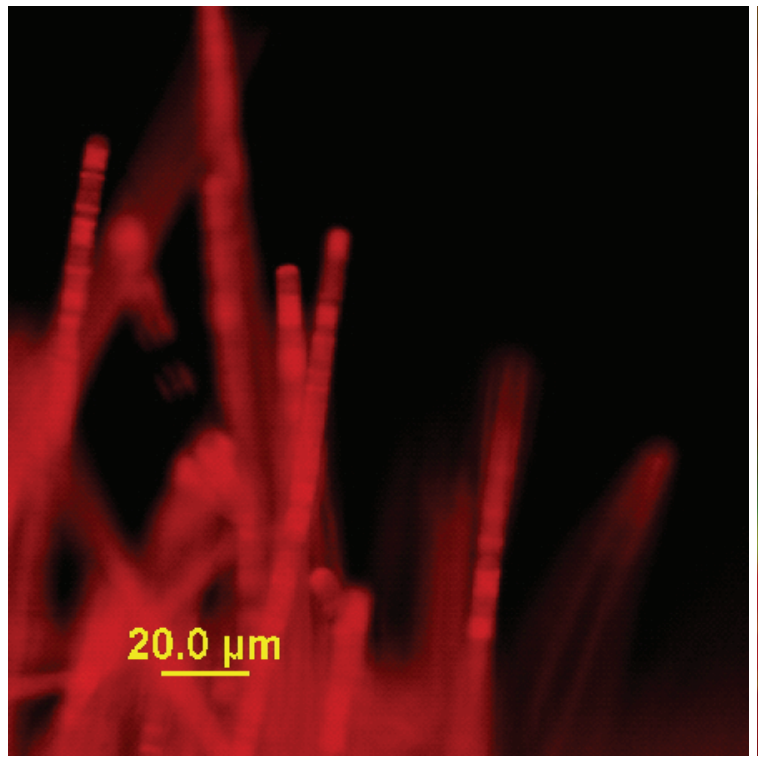

FITC

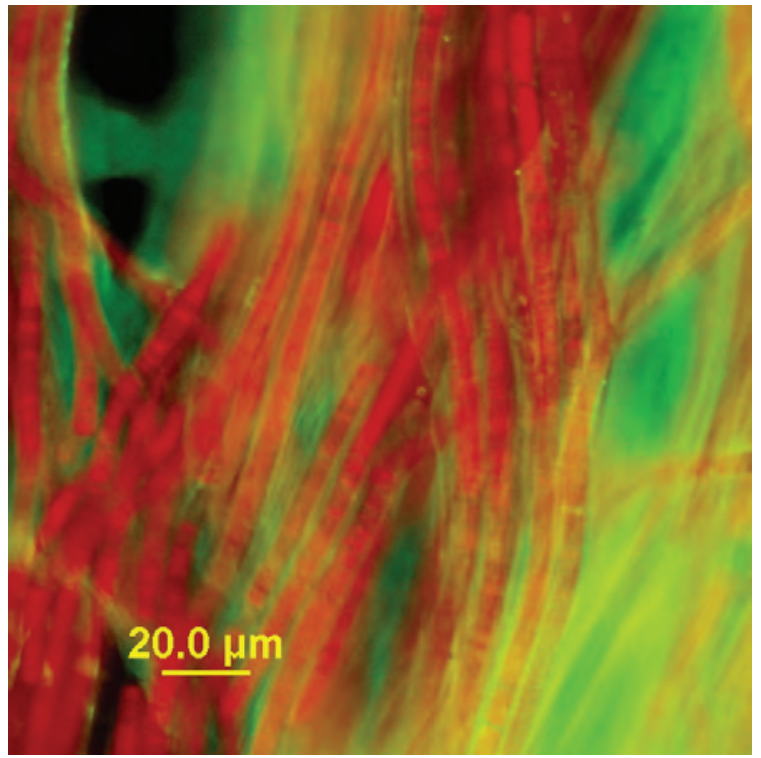

Sytox ${ }^{\circledR}$ green

Three freeze-thaw cycles

Figure 186. Laboratory culture-Phormidium DVL 706A. LM-Phormidium sp. FITC-a red color dominates the cells. Sytox ${ }^{\circledR}$ green-stain was picked up by the sheath but not the cells. LM - differential interference contrast microscopy; FITC - epifluorescent microscopy; Sytox ${ }^{\circledR}$ green - epifluorescent microscopy in conjunction with the nucleic acid stain Sytox ${ }^{\circledR}$ green. 
Table 4. Summary of observations compiled from digital microphotographs of multiple cyanobacteria dominated samples exposed to five different cell-y techniques.

[CA, California; FL, Florida; IA, Iowa; OH, Ohio; OR, Oregon; St., Saint; FITC, epifluorescence microscopy; \%, percent; $\mathrm{x}$, when used after a number indicates the number of times a treatment was conducted (for example, $2 \mathrm{x}$ represents 2 times); min, minutes]

\begin{tabular}{|c|c|c|c|c|}
\hline & & Physical observation & FITC color & Sytox ${ }^{\circledR}$ green \\
\hline \multicolumn{5}{|c|}{ Cassidy Lake, WA (10/12/2009)1 } \\
\hline \multirow[t]{3}{*}{ Control } & 1 & intact & red & no staining \\
\hline & 2 & intact & yellow-orange & no staining \\
\hline & 3 & intact & yellow-orange & no staining \\
\hline \multirow[t]{3}{*}{ Boiled } & $5 \mathrm{~min}$ & single cells & yellow-orange & bright green \\
\hline & $15 \mathrm{~min}$ & single cells & yellow-orange & bright green \\
\hline & $30 \mathrm{~min}$ & colonies degraded & yellow & no staining \\
\hline \multirow[t]{3}{*}{ Autoclaved } & $5 \mathrm{~min}$ & colonies degraded & orange & no staining \\
\hline & $15 \mathrm{~min}$ & single cells & yellow-orange & no staining \\
\hline & $30 \mathrm{~min}$ & single cells & yellow-orange & bright green \\
\hline \multirow[t]{3}{*}{ Sonicated } & $10 \%$ & intact & red & no staining \\
\hline & $35 \%$ & colonies degraded & red-orange & no staining \\
\hline & $70 \%$ & single cells & orange & no staining \\
\hline \multirow[t]{3}{*}{ QuikLyse $^{\mathrm{TM}}$} & $1 x$ & no sample & no sample & no sample \\
\hline & $2 \mathrm{x}$ & no sample & no sample & no sample \\
\hline & $3 x$ & no sample & no sample & no sample \\
\hline \multirow[t]{3}{*}{ Freeze-thaw } & $1 x$ & single cells & no data & bright green \\
\hline & $2 \mathrm{x}$ & no sample & no sample & no sample \\
\hline & $3 x$ & single cells & red-orange & bright green \\
\hline \multicolumn{5}{|c|}{ Spring Lake, CA (8/21/2009)1 } \\
\hline \multirow[t]{3}{*}{ Control } & 1 & intact & orange & no staining \\
\hline & 2 & intact & yellow-orange & no staining \\
\hline & 3 & intact & yellow-orange & no staining \\
\hline \multirow[t]{3}{*}{ Boiled } & $5 \mathrm{~min}$ & colonies degraded & orange & no data \\
\hline & $15 \mathrm{~min}$ & single cells & orange & bright green \\
\hline & $30 \mathrm{~min}$ & single cells & orange & bright green \\
\hline \multirow[t]{3}{*}{ Autoclaved } & $5 \mathrm{~min}$ & single cells & orange & bright green \\
\hline & $15 \mathrm{~min}$ & colonies degraded & orange & bright green \\
\hline & $30 \mathrm{~min}$ & colonies degraded & yellow-orange & bright green \\
\hline \multirow[t]{3}{*}{ Sonicated } & $10 \%$ & intact & orange & no staining \\
\hline & $35 \%$ & colonies degraded & orange & no staining \\
\hline & $70 \%$ & single cells & orange & no staining \\
\hline \multirow[t]{3}{*}{ QuikLyse $^{\mathrm{TM}}$} & $1 x$ & single cells & yellow & bright green \\
\hline & $2 \mathrm{x}$ & intact & yellow & no staining \\
\hline & $3 x$ & no sample & no sample & no sample \\
\hline \multirow[t]{3}{*}{ Freeze-thaw } & $1 \mathrm{x}$ & colonies degraded & yellow & no staining \\
\hline & $2 \mathrm{x}$ & colonies degraded & yellow & no staining \\
\hline & $3 x$ & intact & orange & no staining \\
\hline
\end{tabular}


Table 4. Summary of observations compiled from digital microphotographs of multiple cyanobacteria dominated samples exposed to five different cell-y techniques.-Continued

[CA, California; FL, Florida; IA, Iowa; OH, Ohio; OR, Oregon; St., Saint; FITC, epifluorescence microscopy; \%, percent; $\mathrm{x}$, when used after a number indicates the number of times a treatment was conducted (for example, $2 \mathrm{x}$ represents 2 times); min, minutes]

\begin{tabular}{|c|c|c|c|c|}
\hline & & Physical observation & FITC color & Sytox ${ }^{\circledR}$ green \\
\hline \multicolumn{5}{|c|}{ Blackhawk Lake, IA (8/26/2009)1 } \\
\hline Control & 1 & intact & red & no staining \\
\hline \multirow{5}{*}{ Boiled } & 2 & intact & red-orange & no data \\
\hline & 3 & intact & red-orange & no staining \\
\hline & $5 \mathrm{~min}$ & intact & red-orange & no staining \\
\hline & $15 \mathrm{~min}$ & no sample & no sample & no sample \\
\hline & $30 \mathrm{~min}$ & intact & yellow-orange & no staining \\
\hline \multirow[t]{3}{*}{ Autoclaved } & $5 \min$ & intact & orange & bright green \\
\hline & $15 \mathrm{~min}$ & intact & orange & no staining \\
\hline & $30 \mathrm{~min}$ & intact & yellow-orange & partial \\
\hline \multirow[t]{3}{*}{ Sonicated } & $10 \%$ & intact & red-orange & no staining \\
\hline & $35 \%$ & filaments fragmented & yellow & no staining \\
\hline & $70 \%$ & cells destroyed & no data & no data \\
\hline \multirow[t]{3}{*}{ QuikLyse $^{\mathrm{TM}}$} & $1 \mathrm{x}$ & intact & orange & bright green \\
\hline & $2 \mathrm{x}$ & no sample & no sample & no sample \\
\hline & $3 x$ & no sample & no sample & no sample \\
\hline \multirow[t]{3}{*}{ Freeze-thaw } & $1 \mathrm{x}$ & intact & red-orange & no staining \\
\hline & $2 x$ & colonies degraded & yellow & no staining \\
\hline & $3 x$ & intact & yellow & no staining \\
\hline \multicolumn{5}{|c|}{ Copco Reservoir, CA (9/10/2009)1 } \\
\hline \multirow[t]{3}{*}{ Control } & 1 & intact & orange & no staining \\
\hline & 2 & intact & red-orange & no staining \\
\hline & 3 & intact & orange & no staining \\
\hline \multirow[t]{3}{*}{ Boiled } & $5 \mathrm{~min}$ & intact & yellow & sheath only \\
\hline & $15 \min$ & intact & yellow & sheath only \\
\hline & $30 \mathrm{~min}$ & colonies degraded & yellow & sheath only \\
\hline \multirow[t]{3}{*}{ Autoclaved } & $5 \mathrm{~min}$ & colonies degraded & orange & partial \\
\hline & $15 \mathrm{~min}$ & no sample & no sample & no sample \\
\hline & $30 \mathrm{~min}$ & no sample & no sample & no sample \\
\hline \multirow[t]{3}{*}{ Sonicated } & $10 \%$ & intact & red & no staining \\
\hline & $35 \%$ & intact & red-orange & no staining \\
\hline & $70 \%$ & intact & orange & sheath only \\
\hline \multirow[t]{3}{*}{ QuikLyse $^{\mathrm{TM}}$} & $1 x$ & intact & red-orange & sheath only \\
\hline & $2 x$ & no sample & no sample & no sample \\
\hline & $3 x$ & no sample & no sample & no sample \\
\hline \multirow[t]{3}{*}{ Freeze-thaw } & $1 \mathrm{x}$ & intact & orange & sheath only \\
\hline & $2 x$ & colonies degraded & orange & sheath only \\
\hline & $3 x$ & colonies degraded & yellow-orange & no staining \\
\hline
\end{tabular}


Table 4. Summary of observations compiled from digital microphotographs of multiple cyanobacteria dominated samples exposed to five different cell-y techniques.-Continued

[CA, California; FL, Florida; IA, Iowa; OH, Ohio; OR, Oregon; St., Saint; FITC, epifluorescence microscopy; \%, percent; $\mathrm{x}$, when used after a number indicates the number of times a treatment was conducted (for example, $2 \mathrm{x}$ represents 2 times); min, minutes]

\begin{tabular}{|c|c|c|c|c|}
\hline & & Physical observation & FITC color & Sytox ${ }^{\circledR}$ green \\
\hline \multicolumn{5}{|c|}{ Grand Lake (Lake St. Mary), OH (7/20/2009)1 } \\
\hline \multirow[t]{3}{*}{ Control } & 1 & intact & orange & no staining \\
\hline & 2 & intact & orange & no staining \\
\hline & 3 & intact & orange & no staining \\
\hline \multirow[t]{3}{*}{ Boiled } & $5 \mathrm{~min}$ & intact & orange & no staining \\
\hline & $15 \mathrm{~min}$ & intact & orange & no staining \\
\hline & $30 \mathrm{~min}$ & intact & orange & bright green \\
\hline \multirow[t]{3}{*}{ Autoclaved } & $5 \mathrm{~min}$ & intact & orange & partial \\
\hline & $15 \mathrm{~min}$ & intact & orange & partial \\
\hline & $30 \mathrm{~min}$ & no data & orange & no staining \\
\hline \multirow[t]{3}{*}{ Sonicated } & $10 \%$ & intact & red & no staining \\
\hline & $35 \%$ & filaments fragmented & orange & no staining \\
\hline & $70 \%$ & cells destroyed & no data & no data \\
\hline \multirow[t]{3}{*}{ QuikLyse $^{\mathrm{TM}}$} & $1 x$ & intact & yellow-orange & bright green \\
\hline & $2 \mathrm{x}$ & intact & red & bright green \\
\hline & $3 x$ & no sample & no sample & no sample \\
\hline \multirow[t]{3}{*}{ Freeze-thaw } & $1 x$ & intact & orange & no data \\
\hline & $2 \mathrm{x}$ & colonies degraded & orange & bright green \\
\hline & $3 x$ & intact & orange & no staining \\
\hline \multicolumn{5}{|c|}{ Grand Lake (Lake St. Mary), OH (9/15/2009) ${ }^{1}$} \\
\hline \multirow[t]{3}{*}{ Control } & 1 & intact & orange & no staining \\
\hline & 2 & intact & orange & no staining \\
\hline & 3 & intact & orange & no staining \\
\hline \multirow[t]{3}{*}{ Boiled } & $5 \mathrm{~min}$ & intact & orange & bright green \\
\hline & $15 \mathrm{~min}$ & intact & orange & no staining \\
\hline & $30 \mathrm{~min}$ & intact & orange & partial \\
\hline \multirow[t]{3}{*}{ Autoclaved } & $5 \mathrm{~min}$ & intact & orange & no staining \\
\hline & $15 \mathrm{~min}$ & intact & yellow & partial \\
\hline & $30 \mathrm{~min}$ & intact & yellow & bright green \\
\hline \multirow[t]{3}{*}{ Sonicated } & $10 \%$ & intact & orange & no staining \\
\hline & $35 \%$ & intact & red & no staining \\
\hline & $70 \%$ & cells destroyed & no data & no data \\
\hline \multirow[t]{3}{*}{ QuikLyse $^{\mathrm{TM}}$} & $1 x$ & intact & orange & no staining \\
\hline & $2 \mathrm{x}$ & no sample & no sample & no sample \\
\hline & $3 x$ & no sample & no sample & no sample \\
\hline \multirow[t]{3}{*}{ Freeze-thaw } & $1 \mathrm{x}$ & colonies degraded & orange & no staining \\
\hline & $2 \mathrm{x}$ & colonies degraded & orange & no staining \\
\hline & $3 x$ & colonies degraded & orange & no data \\
\hline
\end{tabular}


Table 4. Summary of observations compiled from digital microphotographs of multiple cyanobacteria dominated samples exposed to five different cell-y techniques. - Continued

[CA, California; FL, Florida; IA, Iowa; OH, Ohio; OR, Oregon; St., Saint; FITC, epifluorescence microscopy; \%, percent; $\mathrm{x}$, when used after a number indicates the number of times a treatment was conducted (for example, $2 \mathrm{x}$ represents 2 times); min, minutes]

\begin{tabular}{|c|c|c|c|c|}
\hline & & Physical observation & FITC color & Sytox ${ }^{\circledR}$ green \\
\hline \multicolumn{5}{|c|}{ St. John's River, Jacksonville, FL (7/28/2009)1 } \\
\hline \multirow[t]{3}{*}{ Control } & 1 & intact & red & no staining \\
\hline & 2 & intact & red & no staining \\
\hline & 3 & intact & red & no staining \\
\hline \multirow[t]{3}{*}{ Boiled } & $5 \min$ & colonies degraded & orange & bright green \\
\hline & $15 \mathrm{~min}$ & single cells & orange & bright green \\
\hline & $30 \mathrm{~min}$ & single cells & orange & bright green \\
\hline \multirow[t]{3}{*}{ Autoclaved } & $5 \min$ & colonies degraded & orange & bright green \\
\hline & $15 \mathrm{~min}$ & colonies degraded & yellow & partial \\
\hline & $30 \mathrm{~min}$ & no sample & no sample & no sample \\
\hline \multirow[t]{3}{*}{ Sonicated } & $10 \%$ & intact & red & no staining \\
\hline & $35 \%$ & intact & orange & no staining \\
\hline & $70 \%$ & cells destroyed & no data & no data \\
\hline \multirow[t]{3}{*}{ QuikLyse $^{\mathrm{TM}}$} & $1 \mathrm{x}$ & intact & red & no staining \\
\hline & $2 \mathrm{x}$ & intact & red & partial \\
\hline & $3 x$ & no sample & no sample & no sample \\
\hline \multirow[t]{3}{*}{ Freeze-thaw } & $1 x$ & colonies degraded & yellow-orange & partial \\
\hline & $2 \mathrm{x}$ & colonies degraded & yellow-orange & partial \\
\hline & $3 x$ & colonies degraded & yellow-orange & no data \\
\hline \multicolumn{5}{|c|}{ Upper Klamath Lake, OR (8/21/2009)1 } \\
\hline \multirow[t]{3}{*}{ Control } & 1 & intact & yellow-orange & no data \\
\hline & 2 & intact & red-orange & sheath only \\
\hline & 3 & filaments degraded & red & partial \\
\hline \multirow[t]{3}{*}{ Boiled } & $5 \mathrm{~min}$ & colonies degraded & yellow-orange & no staining \\
\hline & $15 \mathrm{~min}$ & intact & orange & partial \\
\hline & $30 \mathrm{~min}$ & intact & no data & bright green \\
\hline \multirow[t]{3}{*}{ Autoclaved } & $5 \mathrm{~min}$ & intact & orange & bright green \\
\hline & $15 \mathrm{~min}$ & intact & yellow & partial \\
\hline & $30 \mathrm{~min}$ & intact & yellow & partial \\
\hline \multirow[t]{3}{*}{ Sonicated } & $10 \%$ & intact & red-orange & sheath only \\
\hline & $35 \%$ & single cells & no data & no data \\
\hline & $70 \%$ & cells destroyed & no data & no data \\
\hline \multirow[t]{3}{*}{ QuikLyse $^{\mathrm{TM}}$} & $1 x$ & intact & orange & partial \\
\hline & $2 \mathrm{x}$ & no sample & no sample & no sample \\
\hline & $3 x$ & no sample & no sample & no sample \\
\hline \multirow[t]{3}{*}{ Freeze-thaw } & $1 \mathrm{x}$ & filaments degraded & no data & no data \\
\hline & $2 \mathrm{x}$ & no sample & no sample & no sample \\
\hline & $3 x$ & intact & yellow & bright green \\
\hline
\end{tabular}


Table 4. Summary of observations compiled from digital microphotographs of multiple cyanobacteria dominated samples exposed to five different cell-y techniques.-Continued

[CA, California; FL, Florida; IA, Iowa; OH, Ohio; OR, Oregon; St., Saint; FITC, epifluorescence microscopy; \%, percent; $\mathrm{x}$, when used after a number indicates the number of times a treatment was conducted (for example, $2 \mathrm{x}$ represents 2 times); min, minutes]

\begin{tabular}{|c|c|c|c|c|}
\hline & & Physical observatio & FITC color & Sytox ${ }^{\circledR}$ green \\
\hline \multicolumn{5}{|c|}{ Klamath River, OR (8/21/2009) ${ }^{1}$} \\
\hline \multirow[t]{3}{*}{ Control } & 1 & no sample & no sample & no sample \\
\hline & 2 & no sample & no sample & no sample \\
\hline & 3 & no sample & no sample & no sample \\
\hline \multirow[t]{3}{*}{ Boiled } & $5 \mathrm{~min}$ & no sample & no sample & no sample \\
\hline & $15 \mathrm{~min}$ & no sample & no sample & no sample \\
\hline & $30 \mathrm{~min}$ & no sample & no sample & no sample \\
\hline \multirow[t]{3}{*}{ Autoclaved } & $5 \mathrm{~min}$ & no sample & no sample & no sample \\
\hline & $15 \mathrm{~min}$ & no sample & no sample & no sample \\
\hline & $30 \mathrm{~min}$ & no sample & no sample & no sample \\
\hline \multirow[t]{3}{*}{ Sonicated } & $10 \%$ & no sample & no sample & no sample \\
\hline & $35 \%$ & no sample & no sample & no sample \\
\hline & $70 \%$ & no sample & no sample & no sample \\
\hline \multirow[t]{3}{*}{ QuikLyse $^{\mathrm{TM}}$} & $1 \mathrm{x}$ & no sample & no sample & no sample \\
\hline & $2 x$ & no sample & no sample & no sample \\
\hline & $3 x$ & no sample & no sample & no sample \\
\hline \multirow[t]{3}{*}{ Freeze-thaw } & $1 x$ & colonies degraded & yellow & no staining \\
\hline & $2 \mathrm{x}$ & colonies degraded & yellow & no staining \\
\hline & $3 x$ & colonies degraded & yellow & partial \\
\hline \multicolumn{5}{|c|}{ Iron Gate Reservoir, OR (8/25/2009)1 } \\
\hline \multirow[t]{3}{*}{ Control } & 1 & intact & red & no staining \\
\hline & 2 & intact & red & no staining \\
\hline & 3 & no sample & no sample & no sample \\
\hline \multirow[t]{3}{*}{ Boiled } & $5 \mathrm{~min}$ & colonies degraded & orange & bright green \\
\hline & $15 \mathrm{~min}$ & single cells & orange & bright green \\
\hline & $30 \mathrm{~min}$ & single cells & orange & bright green \\
\hline \multirow[t]{3}{*}{ Autoclaved } & $5 \mathrm{~min}$ & single cells & yellow-orange & bright green \\
\hline & $15 \min$ & single cells & yellow-orange & no data \\
\hline & $30 \mathrm{~min}$ & single cells & yellow-orange & bright green \\
\hline \multirow[t]{3}{*}{ Sonicated } & $10 \%$ & colonies degraded & red & partial \\
\hline & $35 \%$ & colonies degraded & red & partial \\
\hline & $70 \%$ & colonies degraded & orange & partial \\
\hline \multirow[t]{3}{*}{ QuikLyse $^{\mathrm{TM}}$} & $1 \mathrm{x}$ & colonies degraded & orange & no data \\
\hline & $2 \mathrm{x}$ & no sample & no sample & no sample \\
\hline & $3 x$ & no sample & no sample & no sample \\
\hline \multirow[t]{3}{*}{ Freeze-thaw } & $1 x$ & colonies degraded & yellow-orange & partial \\
\hline & $2 \mathrm{x}$ & colonies degraded & yellow-orange & bright green \\
\hline & $3 x$ & colonies degraded & yellow & no staining \\
\hline
\end{tabular}


Table 4. Summary of observations compiled from digital microphotographs of multiple cyanobacteria dominated samples exposed to five different cell-y techniques. - Continued

[CA, California; FL, Florida; IA, Iowa; OH, Ohio; OR, Oregon; St., Saint; FITC, epifluorescence microscopy; \%, percent; $\mathrm{x}$, when used after a number indicates the number of times a treatment was conducted (for example, $2 \mathrm{x}$ represents 2 times); min, minutes]

\begin{tabular}{|c|c|c|c|c|}
\hline & & Physical observation & FITC color & Sytox ${ }^{\circledR}$ green \\
\hline \multicolumn{5}{|c|}{ Pinto Lake, CA (9/22/2009)1 } \\
\hline \multirow[t]{3}{*}{ Control } & 1 & intact & red & no staining \\
\hline & 2 & filaments degraded & orange & no staining \\
\hline & 3 & intact & orange & no staining \\
\hline \multirow[t]{3}{*}{ Boiled } & $5 \mathrm{~min}$ & colonies degraded & orange & no staining \\
\hline & $15 \mathrm{~min}$ & colonies degraded & yellow & no staining \\
\hline & $30 \mathrm{~min}$ & colonies degraded & yellow & bright green \\
\hline \multirow[t]{3}{*}{ Autoclaved } & $5 \mathrm{~min}$ & colonies degraded & yellow & sheath only \\
\hline & $15 \mathrm{~min}$ & intact & yellow & no staining \\
\hline & $30 \mathrm{~min}$ & intact & yellow & bright green \\
\hline \multirow[t]{3}{*}{ Sonicated } & $10 \%$ & colonies degraded & red-orange & no staining \\
\hline & $35 \%$ & cells destroyed & no data & no data \\
\hline & $70 \%$ & cells destroyed & no data & no data \\
\hline \multirow[t]{3}{*}{ QuikLyse $^{\mathrm{TM}}$} & $1 \mathrm{x}$ & intact & orange & no staining \\
\hline & $2 \mathrm{x}$ & no sample & no sample & no sample \\
\hline & $3 x$ & no sample & no sample & no sample \\
\hline \multirow[t]{3}{*}{ Freeze-thaw } & $1 \mathrm{x}$ & colonies degraded & red & no staining \\
\hline & $2 \mathrm{x}$ & colonies degraded & yellow & no staining \\
\hline & $3 x$ & no sample & no sample & no sample \\
\hline \multicolumn{5}{|c|}{ Laboratory Culture- Lyngbya² sp. DVL 1103B } \\
\hline \multirow[t]{3}{*}{ Control } & 1 & intact & red & sheath only \\
\hline & 2 & no sample & no sample & no sample \\
\hline & 3 & no sample & no sample & no sample \\
\hline \multirow[t]{3}{*}{ Boiled } & $5 \mathrm{~min}$ & filaments degraded & yellow & bright green \\
\hline & $15 \mathrm{~min}$ & filaments degraded & yellow-orange & partial \\
\hline & $30 \mathrm{~min}$ & filaments degraded & yellow-orange & bright green \\
\hline \multirow[t]{3}{*}{ Autoclaved } & $5 \mathrm{~min}$ & filaments degraded & yellow-orange & sheath only \\
\hline & $15 \min$ & filaments degraded & yellow-orange & partial \\
\hline & $30 \mathrm{~min}$ & filaments degraded & yellow-orange & partial \\
\hline \multirow[t]{3}{*}{ Sonicated } & $10 \%$ & filaments fragmented & red & no staining \\
\hline & $35 \%$ & filaments fragmented & no data & no data \\
\hline & $70 \%$ & no sample & no sample & no sample \\
\hline \multirow[t]{3}{*}{ QuikLyse $^{\mathrm{TM}}$} & $1 \mathrm{x}$ & intact & red & partial \\
\hline & $2 \mathrm{x}$ & intact & red & partial \\
\hline & $3 x$ & intact & red & partial \\
\hline \multirow[t]{3}{*}{ Freeze-thaw } & $1 \mathrm{x}$ & intact & red & sheath only \\
\hline & $2 \mathrm{x}$ & intact & red & sheath only \\
\hline & $3 x$ & intact & red & sheath only \\
\hline
\end{tabular}


Table 4. Summary of observations compiled from digital microphotographs of multiple cyanobacteria dominated samples exposed to five different cell-y techniques. - Continued

[CA, California; FL, Florida; IA, Iowa; OH, Ohio; OR, Oregon; St., Saint; FITC, epifluorescence microscopy; \%, percent; $\mathrm{x}$, when used after a number indicates the number of times a treatment was conducted (for example, $2 \mathrm{x}$ represents 2 times); min, minutes]

\begin{tabular}{|c|c|c|c|c|}
\hline & & Physical observation & FITC color & Sytox ${ }^{\circledR}$ green \\
\hline \multicolumn{5}{|c|}{ Laboratory Culture- Phormidium² sp. DVL 706A } \\
\hline \multirow[t]{3}{*}{ Control } & 1 & intact & red & partial \\
\hline & 2 & no sample & no sample & no sample \\
\hline & 3 & no sample & no sample & no sample \\
\hline \multirow[t]{3}{*}{ Boiled } & $5 \mathrm{~min}$ & filaments degraded & yellow-orange & bright green \\
\hline & $15 \mathrm{~min}$ & filaments degraded & yellow-orange & bright green \\
\hline & $30 \mathrm{~min}$ & filaments degraded & yellow-orange & bright green \\
\hline \multirow[t]{3}{*}{ Autoclaved } & $5 \mathrm{~min}$ & intact & yellow-orange & bright green \\
\hline & $15 \mathrm{~min}$ & intact & yellow-orange & bright green \\
\hline & $30 \mathrm{~min}$ & intact & yellow-orange & bright green \\
\hline \multirow[t]{3}{*}{ Sonicated } & $10 \%$ & filaments degraded & red & sheath only \\
\hline & $35 \%$ & filaments degraded & orange & no staining \\
\hline & $70 \%$ & cells destroyed & no data & no data \\
\hline \multirow[t]{3}{*}{ QuikLyse $^{\mathrm{TM}}$} & $1 x$ & intact & red & partial \\
\hline & $2 x$ & intact & orange & partial \\
\hline & $3 x$ & intact & red & partial \\
\hline \multirow[t]{3}{*}{ Freeze-thaw } & $1 x$ & filaments degraded & red & sheath only \\
\hline & $2 \mathrm{x}$ & filaments degraded & red & partial \\
\hline & $3 x$ & filaments degraded & red & sheath only \\
\hline
\end{tabular}

${ }^{1}$ Sample collection date noted parenthetically after each sample location.

${ }^{2}$ Lyngya DVL 1103B and Phormidium DVL 706A are cultures transferred from original samples acquired in study by Izaguirre and Taylor, 2004. 

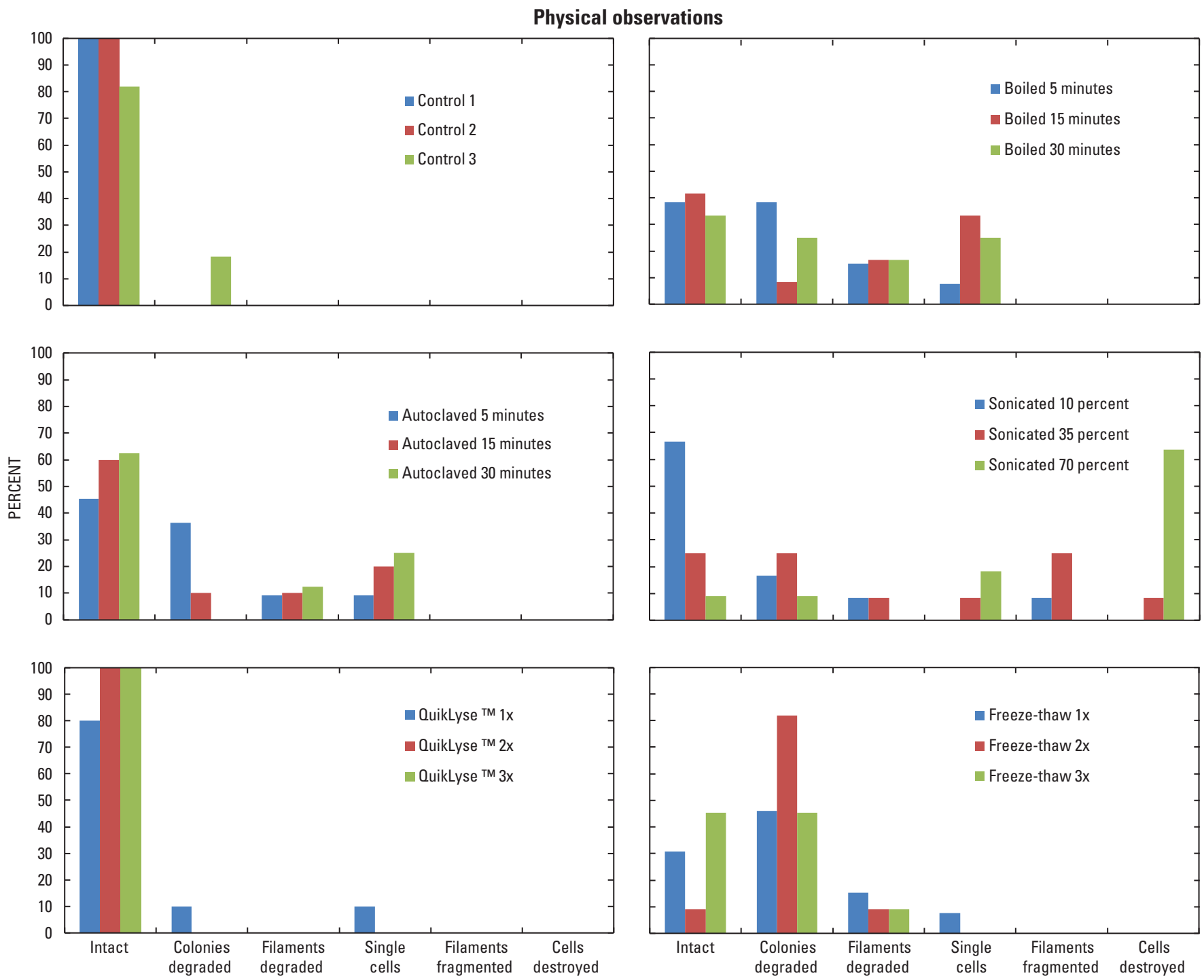

Figure 187. Summary of physical observation of cyanobacterial cell condition, epifluorescent microscopy (FITC), and epifluorescent microscopy in conjunction with the nucleic acid stain Syto ${ }^{\circledast}$ green (Sytox ${ }^{\circledast}$ green staining) as a percentage of the total when results of all environmental samples are combined within each cell-lysis treatment. 

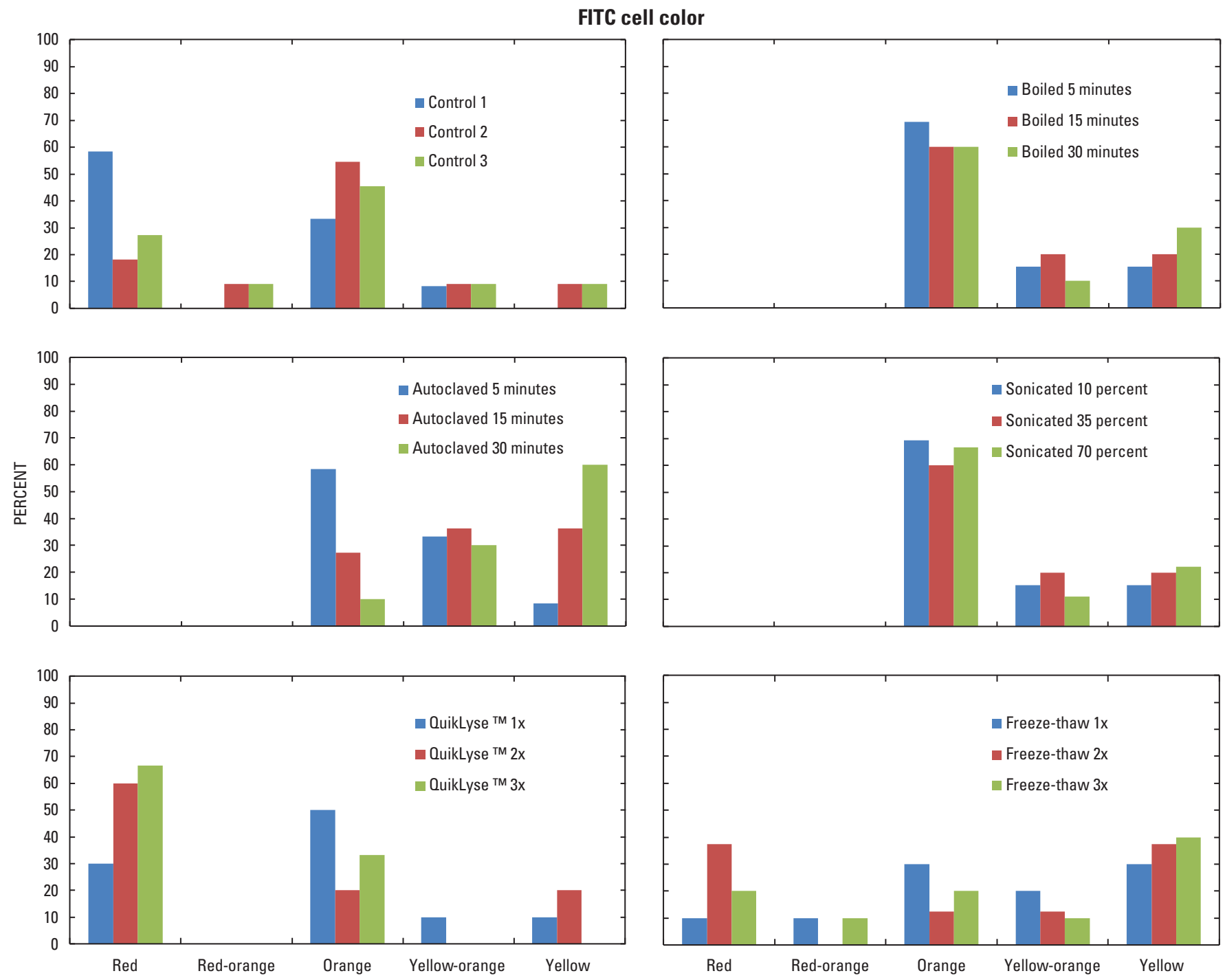

Figure 187. Summary of physical observation of cyanobacterial cell condition, epifluorescent microscopy (FITC), and epifluorescent microscopy in conjunction with the nucleic acid stain Sytox ${ }^{\circledR}$ green (Syto ${ }^{\circledR}$ green staining) as a percentage of the total when results of all environmental samples are combined within each cell-lysis treatment.-Continued 

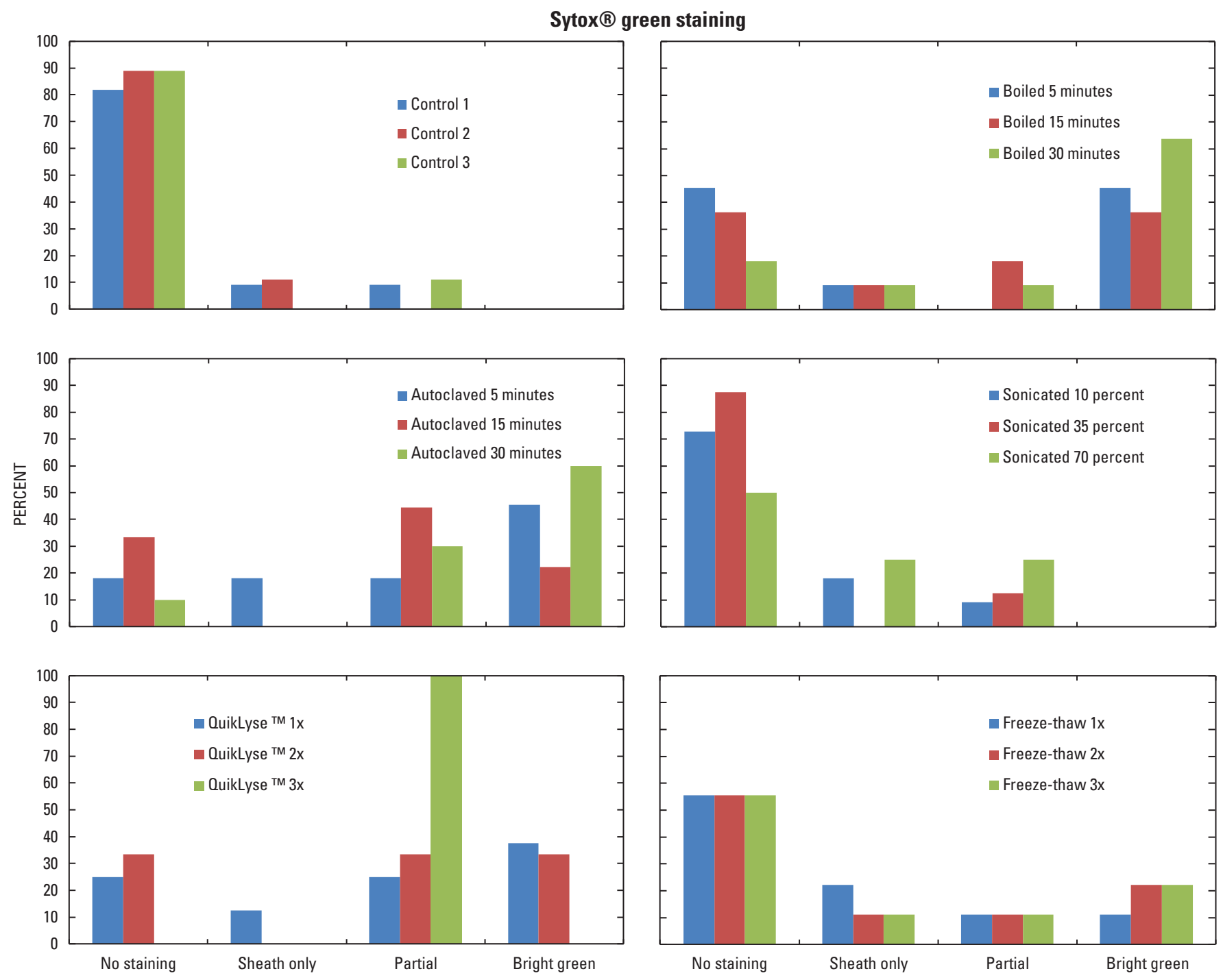

Figure 187. Summary of physical observation of cyanobacterial cell condition, epifluorescent microscopy (FITC), and epifluorescent microscopy in conjunction with the nucleic acid stain Sytox ${ }^{\circledast}$ green (Syto ${ }^{\circledast}$ green staining) as a percentage of the total when results of all environmental samples are combined within each cell-lysis treatment.-Continued 


\section{Results}

A summary of digital photomicrographs made for a given site as a function of cell-lysis technique and treatment level is represented in table 3. Digital photomicrographs of cyanobacteria are shown in figures 1 through 186 separated by site location. Images of a given cyanobacteria genus within a sample were collected by light microscopy (LM), epifluorescence (FITC), and Sytox ${ }^{\circledR}$ green stained cells by epifluorescence (Sytox ${ }^{\circledR}$ green) where complete cell destruction did not occur. A summary of observations made independent of cyanobacterial species for each sample site as a function of cell-lysis technique, treatment level and microscopic imaging technique used is represented in table 4 at the end of this report. Information in table 4 is illustrated in figure 187 by visually using bar charts independent of cyanobacteria species.

In order to summarize the results of the observed changes in the cyanobacteria because of cell lysis in all of the digital microphotographs, a simple tabulation of the observations was compiled as illustrated in figure 187. Data was categorized on the basis of physical changes to the colonies or filaments observed by LM, changes in the color of the cells observed with epifluorescent microscopy FITC, and the observations after staining with Sytox ${ }^{\circledR}$ green also observed by FITC. The observations were gathered across all treatments and all samples when possible and displayed as percentage of the total available for any given treatment.

The physical changes were subcategorized into: 1) intact; 2) colonies degraded; 3) filaments degraded; 4) single cells; 5) filaments fragmented; and 6) cells destroyed. The first subcategory, intact, indicated no change from the controls; subcategories 2 and 3 indicate that the samples, which contained either filaments or colonies of cyanobacteria, were partially degraded relative to subcategory 1 , but not as severely degraded as subcategory 4 to 6 . The degradation of a colony to individual cells or fragmented filaments would be less disruptive than the destruction of the cells (subcategory 6).

The epifluorescent color was subcategorized into: 1) red; 2) red-orange; 3 ) orange; 4) yellow-orange; and 5) yellow. Subcategory 1 and 2, are the expected colors of chlorophyll fluorescence for this setting on the microscope; subcategories 3 to 5 are indicative of degraded chlorophyll.

The Sytox ${ }^{\circledR}$ green observations were subcategorized into: 1) no staining; 2) sheath only; 3 ) partial (staining); and 4) bright green (staining). Subcategory 1 indicated that the cell membrane was intact and excluded the stain. Subcategory 2 appears to be a non-specific staining phenomenon that is unrelated to the treatments or extracellular genetic material. Subcategory 3 indicates that some of the cells in a treatment were stained, which indicates that the cell membrane was penetrated, while others did not. Subcategory 4 clearly indicated that cells had completely lost cell membrane integrity and stained bright green.

Control samples (table 4, figure 187) show predominately intact colonies and filaments on the basis of light microscopy, evaluation by FITC shows a distribution of cell health on the basis of red fluorescence (that is, chlorophyll), and Sytox ${ }^{\circledR}$ green staining did not reveal that genetic material was leaking from cells overall. Green fluorescence was observed in sheath material of some filamentous cyanobacteria. It is not not known from this work whether this is indicative of genetic material present in the sheath or non-specific binding to other molecules.

Of the five techniques, sonication (at 70 percent) was most effective at complete cell destruction while QuikLyse ${ }^{\mathrm{TM}}$ was least effective compared to control samples. Generally, as sonication power was increased between the three treatment levels, the percentage of cells destroyed increased. FITC results indicated that chlorophyll was degraded at all treatment levels (e.g. lack of red fluorescence). In contrast, physical observations (light microscopy) revealed little difference between control samples and those treated by QuikLyse ${ }^{\mathrm{TM}}$, however an increased number of single cells was observed after treatment indicating degradation of some colonial and filamentous cyanobacteria. Red fluorescence (that is, chlorophyll) as measured by FITC was diminished compared to controls indicating a greater proportion of chlorophyll was degraded by QuikLyse ${ }^{\mathrm{TM}}$, however increasing QuikLyse ${ }^{\mathrm{TM}}$ concentrations used above manufacturer recommendations (e.g. $2 \mathrm{x}$ and $3 \mathrm{x}$ treatment levels) did not further diminish red fluorescence in FITC results. Sytox ${ }^{\circledR}$ green staining did show more genetic material was released at the $3 x$ treatment level though.

Autoclaving, boiling, and sequential freeze-thaw were moderately effective in physical destruction of colonies and filaments. Sequential freeze-thaw treatment appeared to have a greater or equal percentage of degraded colonies autoclaving or boiling, while sequential freeze-thaw revealed less degradation of chlorophyll. Sequential freeze-thaw also had the lowest percentage of Sytox ${ }^{\circledR}$ green staining compared to autoclaving or boiling treatments.

\section{Acknowledgments}

Funding for this study was provided by U.S. Geological Survey Toxic Substances Program and EPA DW-14-92285401. The authors are appreciative of sample collection assistance from Tim Wilheite, U.S. EPA; Linda Merchant-Masonbrink, OH EPA; Summer Burdick, Jared Botcher, and Bill Neumann, US Geological Survey; and Marisa Burghdoff, Snohomish Co. Surface Water Management. 


\section{References Cited}

Abraxis, LLC, 2008, QuikLyse ${ }^{\mathrm{TM}}$ cell lysis for microcystin/ nodularins ELISA microtiter plate: Product No. 529911QL, accessed May 2008 at http://www.abraxiskits.com/moreinfo/ PN529911USER.pdf.

Chorus, I., and Bartram, J., eds., 1999, Toxic cyanobacteria in water: London, WHO, E\&FN Spon, 416 p.

Google Earth 5.1, Image@2010 Digital Globe, (c) Google, accessed on $7 / 09 / 2010$.

Hindák, F., 2006, Three planktonic cyanophytes producing water blooms in Western Slovakia: Czech Phycology, Olomouc, v. 6, p. 59-67.

Izaguirre, G. and Taylor, W.D., 2004, A guide to geosmin- and MIB-producing cyanobacteria in the United States: Water Science \& Technology v. 49, no. 9, p. 19-24.
Loftin, K.A., Meyer, M.T., Rubio, F., Kamp, L., Humphries, E., Whereat, E., 2008, Comparison of two cell lysis procedures for recovery of microcystins in waters samples from Silver Lake in Dover, Delaware with microcystin producing cyanobacterial accumulations: USGS Open-File Report 2008-1341, 9 p.

Van Den Hoek, C., Mann, D.G., and Jahns, H.M., 1995, Algae, An introduction to phycology, Cambridge University Press, New York, Chap. 2.

Wehr, J.D., Sheath, R.G., eds, 2003, Freshwater algae of North America ecology and classification, A volume in the aquatic ecology series, Academic Press, Amsterdam, Chap. 3 and 4.

Zimmerman, W.J. and Rosen, B.H., 1992, Cyanobiont diversity within and among cycads of one field site: Canadian Journal of Microbiology, v. 38, no. 12, p. 1,324-1,328. 
Publishing support provided by:

Rolla Publishing Service Center

For additional information concerning this publication, contact:

Director, USGS Kansas Water Science Center

4821 Quail Crest Place, Lawrence, KS (785) 842-9909

Or visit the Kansas Water Science Center Web Site at:

http://ks.water.usgs.gov 



\section{$\frac{\mathbb{3}}{3}$}

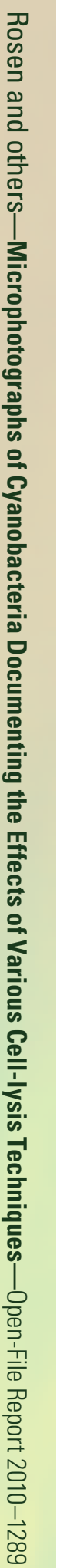


